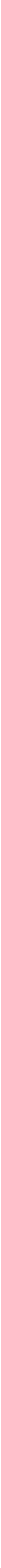

Luiz de Lucca Neto

Orientadora: Mônica Junqueira de

Camargo 


\title{
Instituto Butantan, Plano de Ação e as disputas institucionais de planejamento (1959-1981)
}

\author{
Dissertação apresentada à Faculdade de Arquitetura e Urbanismo da \\ Universidade de São Paulo para obtenção do título de Mestre em Arquitetura e \\ Urbanismo.
}

Área de concentração: História e Fundamentos da Arquitetura e do Urbanismo.

Orientadora: Prof. Dra. Mônica Junqueira de Camargo

Exemplar revisado e alterado em relação à versão original, sob responsabilidade do autor e anuência da orientadora. A versão original, em formato digital, ficará arquivada na Biblioteca da Faculdade. 
Autorizo a reprodução e divulgação total ou parcial deste trabalho, por qualquer meio convencional ou eletrônico, para fins de estudo e pesquisa, desde que citada a fonte.

E-mail do autor: luiz.lucca.neto@usp.br; luiz.delucca@outlook.com

Catalogação na Publicação

Serviço Técnico de Biblioteca

Faculdade de Arquitetura e Urbanismo da Universidade de São Paulo

Lucca Neto, Luiz de

Instituto Butantan, Plano de Ação e as disputas

institucionais de planejamento (1959-1981) / Luiz de Lucca

Neto; orientadora Mônica Junqueira de Camargo. - São Paulo, 2021 .

$330 \mathrm{p}$.

Dissertação (Mestrado) - Faculdade de Arquitetura e Urbanismo da Universidade de São Paulo. Área de

concentração: História e Fundamentos da Arquitetura e do Urbanismo.

1. Instituto Butantan. 2. Plano de ação do Governo do Estado. 3. Cidade Universitária. 4. Planejamento. I.

Camargo, Mônica Junqueira de, orient. II. Título.

Elaborada eletronicamente através do formulário disponível em: <http://www.fau.usp.br/fichacatalografica/>

Imagem da capa: representação do conjunto de edifícios projetados no Plano Geral de 1963 para o Instituto Butantan. Autor: Luiz de Lucca Neto. 
Nome: LUCCA NETO, Luiz de

Título: Instituto Butantan, Plano de Ação e as disputas institucionais de planejamento (1959-

1981)

Dissertação apresentada à Faculdade de Arquitetura e

Urbanismo da Universidade de São Paulo para obtenção do título de Mestre em Arquitetura e Urbanismo.

Aprovado em: 14 de Junho de 2021.

Banca Examinadora

Profa. Dra. Mônica Junqueira de Camargo (Orientadora)

Instituição: Faculdade de Arquitetura e Urbanismo (FAU USP)

Julgamento: aprovado

Prof. Dr. Miguel Antonio Buzzar

Instituição: Instituto de Arquitetura e Urbanismo (IAU USP)

Julgamento: aprovado

Profa. Dra. Suzana Cesar Gouveia Fernandes

Instituição: Instituto Butantan

Julgamento: aprovado 

Ao fortalecimento e democratização das instituições públicas de pesquisa no Brasil 



\section{Agradecimentos}

Agradeço a todos que contribuíram para o desenvolvimento deste trabalho, mesmo que indiretamente, sobretudo diante do contexto da pandemia em que vivemos desde o início de 2020, no qual o apoio destas pessoas foi imprescindível.

Neste sentido, agradeço à minha orientadora Professora Mônica Junqueira de Camargo, que há pouco mais de três anos me recebeu com enorme atenção e esteve presente em cada momento desta trajetória, sendo fundamental para o meu amadurecimento como pesquisador.

Agradeço ao Professor Miguel Buzzar e à Professora Nilce Aravecchia-Bottas pelas observações feitas na qualificação mas, também, pela disposição com a qual sempre me atenderam em diversas ocasiões.

À Suzana Fernandes, agradeço pela oportunidade de trabalhar com o acervo de projetos do Instituto Butantan, fazendo com que esta pesquisa tivesse um início. Do mesmo modo agradeço a todos os queridos colegas com quem trabalhei no antigo Núcleo de Documentação do Instituto Butantan, em especial à Graziela Oliveira, que me atendeu nas consultas ao arquivo durante esta pesquisa, e ao querido amigo e também pesquisador Caio Vargas Jatene, quando trabalhamos na identificação dos mais de 1200 itens do acervo de projetos do Instituto. Ao arquiteto Sérgio de Simone pelas conversas e pelo conhecimento emprestado.

Aos trabalhadores da Biblioteca da FAUUSP, que mesmo durante a pandemia não pouparam esforços para a manutenção das pesquisas.

Ao arquiteto Anderson Luiz Félix de Sá, pelas conversas e questões compartilhadas e pela originalidade de sua pesquisa, que pavimentou e tornou muito mais fácil o desenvolvimento deste trabalho. Também agradeço ao arquiteto Jacob Goldemberg pelo depoimento inspirador de quem viveu e ajudou a construir um país vibrante, no qual o papel dos arquitetos foi crucial e que nos incentiva a imaginar outras realidades.

À minha companheira e também pesquisadora Luiza Veronese Lacava pelas discussões acadêmicas e não acadêmicas, e pelo incentivo constante.

Aos meus pais Luiz e Lia e à minha irmã Angélica pelo apoio incondicional. 



\section{Resumo}

Instituto Butantan, Plano de Ação e as disputas institucionais de planejamento (19591981)

No ano de 1959, o recém-empossado Governador de São Paulo Carlos Alberto de Carvalho Pinto, esteve no Instituto Butantan para anunciar o seu Plano de Ação e os investimentos para a construção de novos edifícios e infraestruturas para o conjunto do Instituto. O Plano de Ação do Governo do Estado (PAGE), ocorreu em um momento de expansão das políticas de desenvolvimento nacional e de afirmação mundial da arquitetura moderna brasileira com a construção da nova capital do país.

Em São Paulo, uma das frentes do Plano foi responsável por iniciar a construção da Cidade Universitária da Universidade de São Paulo, em três quartos da área cujo Instituto Butantan havia sido instalado em 1899. Diante deste extraordinário episódio de planejamento moderno, o Instituto foi integrado à Universidade através de um convênio entre as duas partes, que estabeleceu o planejamento conjunto e a vinculação urbanística das duas instituições, assim como o desenvolvimento de novos edifícios modernos para a já tradicional instituição, mas que não chegaram a ser construídos.

Para esta dissertação foram identificadas e analisadas 1342 pranchas de projetos referentes ao Instituto, dos acervos do Instituto Butantan e da Faculdade de Arquitetura e Urbanismo da USP, dos quais 1045 compreendem o período do convênio com o Escritório Técnico da Cidade Universitária, até a década de 1980. Para o Instituto Butantan, o advento do Plano de Ação significou um impulso institucional e uma oportunidade de atualização de sua infraestrutura, segundo os pressupostos da arquitetura moderna. Em contrapartida, significou a ameaça de perda de autonomia e de sua subordinação ao planejamento da Universidade de São Paulo. Esta pesquisa aborda o impacto do PAGE para o campus do Instituto e o seu desdobramento para o planejamento do conjunto arquitetônico nas décadas seguintes, compreendendo a atuação dos arquitetos modernos no Instituto Butantan como uma frente frustrada do Plano, mas que influenciou decisivamente a conformação contemporânea do conjunto tombado em 1981.

Palavras-chave: Instituto Butantan, Plano de Ação, Cidade Universitária. 



\section{Abstract}

Instituto Butantan, Action Plan and the institutional disputes about planning (19591981)

In 1959, the newly installed Governor of São Paulo Carlos Alberto de Carvalho Pinto, was at the Instituto Butantan to announce its Action Plan and investments for the construction of new buildings and infrastructure for the Institute as a whole. The State Government Action Plan (PAGE) took place at a time of expansion of national development policies and a worldwide affirmation of modern Brazilian architecture with the construction of the country's new capital.

In São Paulo, one of the Plan's fronts was responsible for starting the construction of the University City of the University of São Paulo, in three quarters of the area whose Butantan Institute had been installed in 1899. Faced with this extraordinary episode of modern planning, the Institute was integrated into the University through an agreement between the two parties, which established the joint planning and urban linkage of the two institutions, as well as the development of new modern buildings for the already traditional institution, but they were never built.

For this dissertation, 1342 project boards related to the Institute were identified and analyzed, in the collections of the Instituto Butantan and the Faculty of Architecture and Urbanism at USP, of which 1045 comprise the period of the agreement with the Technical Office of the University City, until the 1980s. For the Instituto Butantan, the advent of the Action Plan meant an institutional impulse and an opportunity to update its infrastructure, according to the assumptions of modern architecture. On the other hand, it meant the threat of loss of autonomy and subordination to the University of São Paulo. This research addresses the impact of PAGE on the Institute's campus and its unfolding for the planning of the architectural ensemble in the following decades, understanding the performance of modern architects at the Butantan Institute as a frustrated front of the Plan, but which decisively influenced the contemporary conformation of the set listed in 1981.

KEY-WoRDs: Instituto Butantan, Action Plan, University City. 



\section{Lista de Ilustrações}

Figura 1: Instituto Butantan, imagem aérea, sem data. Centro de Memória/IB...............p.34

Figura 2: Fotografia do Edifício Vital Brazil, sem data. Centro de Memória/IB..................p.36

Figura 3: Reportagem do Jornal O Estado de São Paulo sobre o Instituto Butantan, 1914.

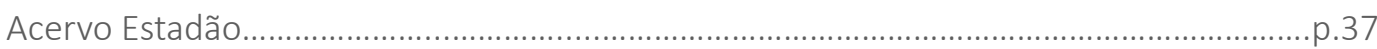

Figura 4: Fotografia do Prédio Novo, década de 1950. Centro de Memória/IB................p.38

Figura 5: Mapa de localização da região do Butantan em 1916. Secretaria de Estado de

Economia e Planejamento. Instituto Geográfico e Cartográfico - IGC...............................p.41

Figura 6: Instituto Butantan em 1917. Centro de Memória/IB..........................................p.42

Figura 7: Foto aérea do Instituto Butantan e da Cidade Universitária. Centro de

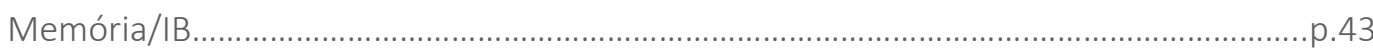

Figura 8: Planta do Instituto Butantan,1930. Arquivo do Estado......................................... 45

Figura 9: Carta do diretor Eduardo Vaz, 1949. Centro de Memória/IB................................42

Figura 10: Imagem aérea do Instituto Butantan, década de 1970. Centro de

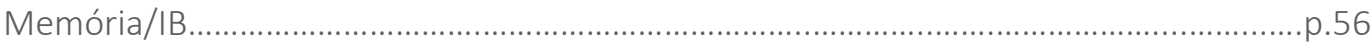

Figura 11: Projeto para o prédio da residência do diretor, 1931. Centro de Memória/IB........p.57

Figura 12: Planta dos dois pavimentos da residência do diretor, 1931. Centro de Memória/IB. ..p.58

Figura 13: Planta de pontos e instalações elétricas, 1928. Centro de Memória/IB...................p.59

Figura 14: Fotografia da Cocheiras Gêmea, sem data. Centro de Memória/IB.................p.60

Figura 15: Planta da Cavalariça/ Cocheira, década de 1920. Centro de Memória/IB.......p.60

Figura 16: Ilustração da fachada do Prédio Novo, sem data. Centro de Memória/IB.........6.62

Figura 17: Fotografia do projeto do Prédio Novo, sem data. Centro de Memória/IB........p.62

Figura 18: Projeto de uma residência rural, 1940. Centro de Memória/IB.........................p.63

Figura 19: Série de mapas do Instituto Butantan, 1989. Centro de Memória/IB..............p.64

Figura 20: Plano de implantação para a Universidade de São Paulo, 1943. Centro de

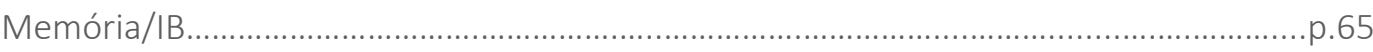

Figura 21: Fotografia do Edifício da recepção de serpentes, década de 1960. Centro de Memória/IB.

Figura 22: Projeto museográfico para o Museu Biológico do Instituto Butantan, 2000.

Centro de Memória/IB.

Figura 23: Projeto museográfico para o Museu Biológico do Instituto Butantan, 2000.

Centro de Memória/IB..

Figura 24: Elevação simplificada do Edifício Vital Brazil, 1999. Centro de Memória/IB...p.70

Figura 25: Desenho do Pavilhão Mourisco da Fiocruz, 1908. DAD/Fiocruz..

.p.70

Figura 26: Página da Revista América apresentando os projetos para o Setor Biológico e Instituto Butantan, 1962. Revista América, no2, 1962

Figura 27: Foto da maquete parcial do Setor Biológico e do Setor do Instituto Butantan, 1962. Revista América, n으, 1962

Figura 28: Planta da Fazenda de Manguinhos, 1908. DAD/Fiocruz....................................p. 82

Figura 29: Mapa do Instituto Butantan no bairro, 2017. Geosampa, edição nossa...........p.83 
Figura 30: Plano Geral do Instituto Butantan, 1961. Centro de Memória/IB......

Figura 31: Fotografia do Pavilhão Arthur Neiva, campus da Fiocruz, década de 1940.

DAD/Fiocruz.

Figura 32: Fotografia do Edifício de História e Geografia da USP em construção, década de 1960. Arquivo Coesf......

p.100

Figura 33: Foto aérea da construção do Conjunto Residencial da USP, 1964. Revista Acrópole, nํ303 p.104

Figura 34: Projeto de uma cadeira para o Conjunto Residencial do Instituto Butantan.

Centro de Memória/IB p.109

Figura 35: Carimbo de projeto do PAGE para o Instituto Butantan, 1962. Centro de Memória/IB

Figura 36: Carimbo rasurado de projeto do PAGE para o Instituto Butantan, 1962. Centro de Memória/IB.

Figura 37: Diagrama de composição do acervo cartográfico do Centro de Memória/IB.

Autoria nossa. p.113

Figura 38: Gráfico percentual de projetos construídos em relação ao acervo acervo cartográfico do Centro de Memória/IB. Autoria nossa.

Figura 39: Diagrama dos projetos relacionados ao Plano de Ação no acervo cartográfico do Centro de Memória/IB. Autoria nossa...... p.116

Figura 40: Detalhe de prancha de projeto. Centro de Memória/IB. p.119

Figura 41: Diagrama de pranchas de projeto no acervo cartográfico do Centro de Memória/IB. Autoria nossa...... p.120

Figura 42: Plano de implantação da Cidade Universitária, 1963. SEF/USP. p.127

Figura 43: Perspectiva do Edifício da Produção, 1963. Centro de Memória/IB. p.129

Figura 44: Elevação do Conjunto Residencial, 1963. Centro de Memória/IB.... .p.131

Figura 45: Perspectiva do Conjunto Residencial, 1963. Centro de Memória/IB. p.131

Figura 46: Corte do Edifício de Pesquisa, 1961. Centro de Memória/IB..... p.133

Figura 47: Planta tipo do Edifício de Pesquisa, 1961. Centro de Memória/IB. .p.133

Figura 48: Corte do Edifício de Vírus e Genética, 1961. Centro de Memória/IB. p.135

Figura 49: Planta do Edifício de Vírus e Genética, 1961. Centro de Memória/IB. p.135

Figura 50: Organogramas de planejamento do IB, 1961. Centro de Memória/IB..........p.137 Figura 51: Organograma de planejamento da Produção do IB, 1961. Centro de Memória/IB...... p.137

Figura 52: Perspectiva do Hospital, 1962. Centro de Memória/IB p.139

Figura 53: Detalhe das esquadrias do Hospital, 1962. Centro de Memória/IB. .p.139

Figura 54: Levantamento do Pavilhão Lemos Monteiro, 1959. Centro de Memória/IB.......

Figura 55: Fachada da Biblioteca e Auditório do IB, 1961. Centro de Memória/IB........p.143 Figura 56: Elevações da Biblioteca do Setor Biológico da USP, 1961. Centro de Memória/IB.

Figura 57: Plano Geral do Instituto Butantan, 1961. Centro de Memória/IB..... p. 145

Figura 58: Plano Geral do Instituto Butantan, 1966. Centro de Memória/IB. .p.145 
Figura 59: Perspectiva do Restaurante do IB, 1962. Centro de Memória/IB .p. 147

Figura 60: Elevações do Restaurante do IB, 1962. Centro de Memória/IB .p.147

Figura 61: Implantação da Igreja do Setor Residencial, 1964. Centro de Memória/IB..p.149 Figura 62: Elevação da Igreja, 1964. Centro de Memória/IB .p.149

Figura 63: Prancha do Prédio da Administração, 1962. Centro de Memória/IB.............p.151

Figura 64: Planta do Prédio da Administração, 1962. Centro de Memória/IB................p.151

Figura 65: Perspectiva do Edifício do Museu,1962. Biblioteca FAUUSP........................p.153

Figura 66: Elevação e cortes do Edifício do Museu, 1962. Biblioteca FAUUSP.................p.153

Figura 67: Corte e Elevação dos Macacários do IB, 1962. Centro de Memória/IB.........p.155

Figura 68: Abrigos dos Macacários do IB, 1962. Centro de Memória/IB.......................p.155

Figura 69: Perspectiva do Edifício de Serviços do IB, 1962. Centro de Memória/IB.......p.157

Figura 70: Implantação dos Pavilhões de Serviços do IB, 1962. Centro de Memória/IB.... p.157

Figura 71: Corte e elevação do Biotério do IB, 1962. Biblioteca FAUUSP...... .p.159

Figura 72: Implantação do Biotério do IB, 1962. Biblioteca FAUUSP...... p.159

Figura 73: Estudos de implantação para o IB, 1959. Centro de Memória/IB. .p.171

Figura 74: Plano de Implantação da Cidade Universitária, 1962. Revista América, nํ2, 1962. .p. 173

Figura 75: Plano de implantação da Cidade Universitária, 1963. SEF/USP. p.173

Figura 76: Plano geral do Instituto Butantan, 1962. Centro de Memória/IB p.174

Figura 77: Plano geral do Instituto Butantan, 1962. Centro de Memória/IB p. 175

Figura 78: Plano geral do Instituto Butantan, 1962. Centro de Memória/IB p.176

Figura 79: Plano geral do Instituto Butantan, 1963. Biblioteca FAUUSP...... p.177

Figura 80: Biotério de Criação do IB, 1966. Revista Acrópole, no 331. p.179

Figura 81: Plano geral do Instituto Butantan, 1965. Revista Acrópole, no 331. p.180

Figura 82: Desenho de localização do Edifício da Produção. Autoria nossa. .p.181

Figura 83: Perspectiva Edifício da Produção, 1962. Centro de Memória/IB ..p.182

Figura 84: Perspectiva Edifício da Produção, 1963. Centro de Memória/IB..... ..p.183

Figura 85: Planta Edifício da Produção, 1963. Centro de Memória/IB ..p.184

Figura 86: Detalhe Edifício da Produção, 1963. Centro de Memória/IB...... p.184

Figura 87: Maquete e Corte do Edifício da Produção, 1966. Revista Acrópole, no 331.p.185 Figura 88: Desenho de localização do Edifício de Serviços. Autoria nossa..... p.186

Figura 89: Perspectiva do Edifício de Serviços, 1962. Biblioteca FAUUSP...... .p.187

Figura 90: Fachada e corte do Edifício de Serviços, 1962. Biblioteca FAUUSP. p.187

Figura 91: Implantação do Edifício de Serviços, 1962. Centro de Memória/IB. ..p.188

Figura 92: Maquete digital do Edifício de Serviços. Autoria nossa..... p.189 Figura 93: Planta do Edifício de Serviços, 1962. Biblioteca FAUUSP. .p.190

Figura 94: Desenho de localização do Conjunto Residencial. Autoria nossa..... ..p.191 Figura 95: Fotografias da Casa do Diretor e de uma casa rural do IB, 1931 e sem data. Centro de Memória/IB...... 
Figura 96: Maquete do Conjunto Residencial da USP, 1962. Revista América, no22, 1962. p.194

Figura 97: Implantação do Conjunto Residencial do IB, 1963. Centro de Memória/IB e SÁ, 2019 . .p.196

Figura 98: Detalhe de caixilho do Conjunto Residencial, 1963. Centro de Memória/IB

Figura 99: Planta e elevações do Conjunto Residencial do IB, 1963. Centro de Memória/IB...... p.198

Figura 100: Fachada, corte e planta do Conjunto Residencial do IB, 1963. Centro de Memória/IB. p.198

Figura 101: Fotografia do Conjunto Residencial do IB. Centro de Memória/IB .p.199

Figura 102: Fotografia do Conjunto Residencial do IB. Centro de Memória/IB. .p.199

Figura 103: Fotografia do Conjunto Residencial do IB, 2019. Foto do autor. .p.199

Figura 104: Planta do Centro Social do IB, 1966. Centro de Memória/IB .p.200

Figura 105: Fotografia do Conjunto Residencial do IB, 2019. Foto do autor. .p.201

Figura 106: Desenho de localização do Edifício de Pesquisa. Autoria nossa. .p.202

Figura 107: Planta do Edifício de Pesquisa do IB, 1966. Revista Acrópole, no 331........p.203

Figura 108: Perspectiva do Edifício de Pesquisa do IB. Centro de Memória/IB..............p.204

Figura 109: Detalhe do Edifício de Pesquisa do IB. Centro de Memória/IB....................p.205

Figura 110: Planta e elevação do Edifício de Pesquisa do IB. Centro de Memória/IB....p.206 Figura 111: Implantação dos edifícios do Setor de Pesquisa do IB. Centro de Memória/IB...... .p.207

Figura 112: Desenho de localização do Edifício de Vírus e Genética. Autoria nossa......p.208 Figura 113: Fotografia do Edifício de História e Geografia da USP, sem data. Arquivo Coesf.

Figura 114: Perspectiva do Edifício de Vírus e Genética do IB, 1966. Revista Acrópole, no 331.

Figura 115: Corte do Edifício de Vírus e Genética do IB, 1966. Revista Acrópole, no 331.......

Figura 116: Fachadas do Edifício de Vírus e Genética do IB, 1961. Centro de Memória/IB.

Figura 117: Implantação do Edifício de Vírus e Genética do IB, 1961. Centro de Memória/IB......

Figura 118: Planta dos pavimentos do Edifício de Vírus e Genética do IB, 1961. Centro de Memória/IB......

Figura 119: Detalhe do Edifício de Vírus e Genética do IB, 1961. Centro de Memória/IB p. 215

Figura 120: Desenho de localização do Edifício da Administração. Autoria nossa p. 217

Figura 121: Fotografia de maquete do Edifício da Administração, 1962. Centro de Memória/IB

Figura 122: Perspectiva do Edifício da Administração, 1962. Biblioteca FAUUSP. p. 218

Figura 123: Plantas e cortes do Edifício da Administração, 1966. Revista Acrópole, no 
Figura 124: Desenho de localização do Edifício do Museu. Autoria nossa. p. 222

Figura 125: Fotografia de Theodore Roosevelt no Instituto Butantan, 1913. Biblioteca do Congresso dos EUA.

Figura 126: Fotografia do Governador Carvalho Pinto no Instituto Butantan, 1959. Centro de Memória/IB. p. 224

Figura 127: Perspectiva do projeto para o Museu do IB, 1962. Centro de Memória/IB... .p.226

Figura 128: Perspectiva do projeto para o Museu do IB, 1962. Biblioteca FAUUSP........p.227 Figura 129: Elevação e cortes do projeto para o Museu do IB, 1962. Biblioteca FAUUSP.

Figura 130: Planta do projeto para o Museu do IB, 1962. Biblioteca FAUUSP ..p. 228

Figura 131: Projeto de placa de obra do PLADI, 1965. Centro de Memória/IB. ..p. 250

Figura 132: Plano geral do Instituto Butantan, 1965. Centro de Memória/IB p. 253 Figura 133: Fotografias do Edifício de Almoxarifados e Serviços do IB, década de $1970 .$. p.255

Figura 134: Fotografia de edifícios para a produção, 1968. Centro de Memória/IB......p.256 Figura 135: Edifícios "gêmeos" para lavanderia e depósito, sem data. Centro de Memória/IB...... p. 257

Figura 136: Corte do edifício da lavanderia do IB, 1966. Centro de Memória/IB. .p. 257 Figura 137: Fotografia dos pavilhões da produção do IB, década de 1970. Centro de Memória/IB...... p.259

Figura 138: Fotografia recente dos pavilhões da produção, 2017. Anderson Luiz Félix de Sá. .p. 259

Figura 139: Fotografias do antigo restaurante e do atual Museu de Microbiologia do IB.

Centro de Memória/IB.. p. 260

Figura 140: Imagens aéreas do Instituto Butantan de 2004 e 2017. Geosampa............p.261

Figura 141: Fotografia do Museu Biológico do IB. Centro de Memória/IB.. p.263

Figura 142: Fotografia da fachada lateral do Museu Bilógico do IB. Centro de Memória/IB. p. 265

Figura 143: Fotografias da Cocheira Central e da arquiteta Lina Bo Bardi em visita ao edifício, sem data. Acervo Instituto Bardi... p.267

Figura 144: Desenhos de lina Bo Bardi para o Museu do IB, 1965. FERRAZ,1993_.........p.267 Figura 145: Pátio da Cocheira Central do IB, década de 1920. Centro de Memória/IB.p.268 Figura 146: Ilustração dos expositores do Museu, 1965. Acervo Instituto Bardi............ 269 Figura 147: Perspectiva do projeto para o Centro Estadual de Cultura e Civismo, 1973. Acervo Jorge Wilheim. .p. 272

Figura 148: Fotografia do Museu Histórico do IB em construção, 1980. Centro de Memória/IB.

Figura 149: Fotografias do antigo restaurante do IB, sem data. Centro de Memória/IB e escritório mk27. 
Figura 151: Fotografias do Museu de Microbiologia do IB. Foto do autor. p.289

Figura 152: Fotografias da praça posterior e entrada do Museu de Microbiologia.

Escritório MK27. p.293 


\section{Lista de Abreviaturas e Siglas}

Al-5: Ato Institucional no 5

Condephaat: Conselho de Defesa do Patrimônio Histórico, Arqueológico, Artístico e Turístico

CM-IB: Centro de Memória do Instituto Butantan

COC: Casa de Oswaldo Cruz

COESF: Coordenadoria do Espaço Físico da USP

CUASO: Cidade Universitária Armando de Salles Oliveira

DOP: Departamento de Obras Públicas

ENBA: Escola Nacional e Belas Artes

FAU USP: Faculdade de Arquitetura e Urbanismo da Universidade de São Paulo

FAU UFRJ: Faculdade de Arquitetura e Urbanismo da Universidade Federal do Rio de Janeiro

FCCUASO: Fundo de Construção para a Cidade Universitária Armando de Salles Oliveira

Fiocruz: Fundação Oswaldo Cruz

FNA: Faculdade Nacional de Arquitetura, atual FAU UFRJ

IAB: Instituto de Arquitetos do Brasil

IB: Instituto Butantan

IPESP: Instituto de Previdência do Estado de São Paulo

IPHAN: Instituto do Patrimônio Histórico e Artístico Nacional

JUC: Juventude Universitária Católica

MMB: Museu de Microbiologia do Instituto Butantan

PAGE: Plano de Ação do Governo do Estado

PCB: Partido Comunista do Brasil (até 1960, e Partido Comunista Brasileiro após esta data)

PDC: Partido Democrata Cristão

PSP: Partido Social Progressista

PTN: Partido Trabalhista Nacional

PLADI: Plano de Desenvolvimento Integrado

SAGAMCS: Sociedade para Análise Gráfica e Mecanográfica Aplicada aos Complexos Sociais

SEADE: Fundação Sistema Estadual de Análise de Dados

SEF: Superintendência de Espaço Físico da Universidade de São Paulo 
SPHAN: Serviço do Patrimônio Histórico e Artístico Nacional (Atual IPHAN)

SESC: Serviço Social do Comércio

UDN: União Democrática Nacional

USP: Universidade de São Paulo 


\section{Sumário}

Introdução

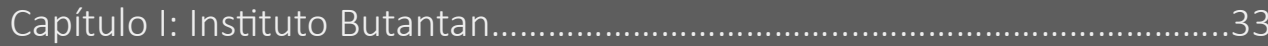

1.1. A formação do Instituto Butantan e do seu conjunto arquitetônico......34

1.1.1. O Instituto no bairro do Butantã: a USP e as origens da disputa..........39

1.1.2. O Centro de Memória do Instituto Butantan.

1.2. Considerações sobre os arquivos de arquitetura e urbanismo................48

1.2.1. A atualidade da questão dos acervos arquitetônicos............................52

1.2.2. O Acervo Cartográfico do Centro de Memória......................................54

1.3. Fontes primárias e a pesquisa em história da arquitetura........................72

1.3.1. Documentos de uma arquitetura não construída: o Instituto Butantan e o Plano de Ação..

1.4. Panorama dos centros de pesquisa em microbiologia entre os séculos $\mathrm{XIX}$ e XX

1.4.1. O Instituto Butantan como centro de pesquisa moderno. 
Capítulo II: Plano De Ação.

2.1. Estado desenvolvimento e arquitetura moderna no âmbito do Plano de Ação.

2.1.1. Estado e plano moderno no Brasil.

2.1.2. A experiência do Plano de Ação e a transformação pela arquitetura.

2.2. O acervo de projetos do Plano de Ação e as particularidades do documento arquitetônico

2.2.1. Uma proposta de organização dos projetos do Plano de Ação para o Instituto Butantan.

2.2.2. Quantificação e composição dos projetos relativos ao Plano de Ação.

2.3 Inventário dos projetos no recorte estabelecido: 1959-1966

2.3.1. Relação das fichas dos projetos inventariados .126

2.3.2. Fichas dos projetos .128

2.4. A dimensão espacial do planejamento: os edifícios modernos e a sua inserção nos planos urbanísticos..

2.4.1. Planejamento moderno e Instituto tradicional.

2.4.2. Representação do plano de 1963: contraste entre os novos e antigos edifícios.......

2.5 Análise de alguns dos projetos do PAGE para o Instituto 170

2.5.1. Planos urbanísticos e de ocupação......................................................170

2.5.2. Edifício da Produção. 181

2.5.3. Edifício dos Serviços 186

2.5.4. Conjunto ou Núcleo Residencial 191

2.5.5. Edifício de Pesquisa. 202

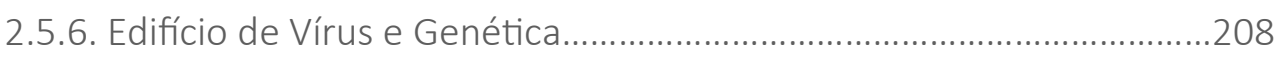

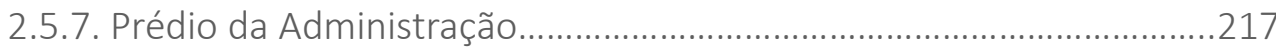

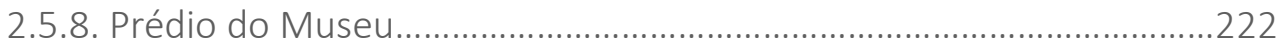


Capítulo III: Disputas institucionais de planejamento...................................231

3.1. Da euforia desenvolvimentista à crise do projeto moderno..................232

3.1.1. Mudanças no planejamento da Cidade Universitária.........................237

3.1.2. Desventuras modernas no Instituto Butantan.....................................243

3.2. Desdobramentos do Plano de Ação no Instituto Butantan.....................248

3.2.1. O PLADI de Ademar de Barros...............................................................249

3.2.2. O escritório de projetos do Instituto Butantan e os edifícios modulares em consonância com a Cidade Universitária....................................................251

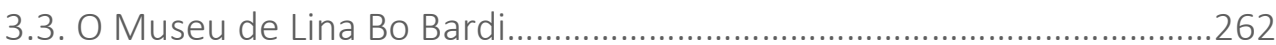

3.4. Das disputas institucionais ao processo de tombamento......................269

3.4.1. A escalada das disputas e o recurso ao passado...................................271

3.4.2. Tombamento e o fim do convênio com a USP.....................................274

3.4.3. A questão do moderno como patrimônio...............................................278

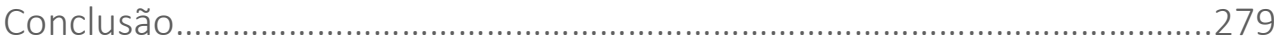

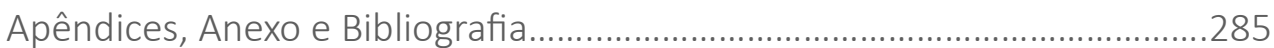

Apêndice I. Manifestação do Contemporâneo no conjunto arquitetônico do

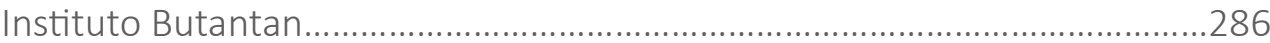

Apêndice II. Entrevista com o arquiteto Jacob Goldemberg.........................294

Anexo I. Carta de Luiz Augusto Ribeiro do Valle à Lina Bo Bardi, 1958........320

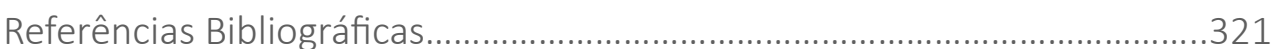

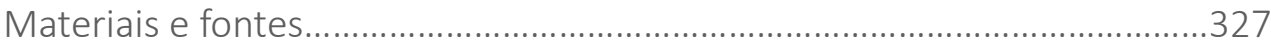



Introdução 
Os planos modernos para o Instituto Butantan no quadro das pesquisas do Plano de Ação em São paulo

Desde a consolidação dos estudos em história da arquitetura e do urbanismo no Brasil, amparados pelo desenvolvimento da pesquisa acadêmica e pela afirmação dos cursos de pós-graduação entre fins dos anos 1970 e nos anos 1980, a arquitetura moderna centrada em São Paulo, em meados do século XX, foi identificada por alguns autores como um movimento, nos moldes de uma escola de arquitetura, assim como foi identificada pela historiografia a chamada escola carioca. Por sua vez, a definição de uma escola paulista de arquitetura teria se dado pela reunião de um grupo de arquitetos modernos depois da emancipação dos cursos de arquitetura no final da década de 1940, especialmente na Faculdade de Arquitetura e Urbanismo da USP, possibilitando a construção de um espaço comum à profissão, de debate e proposição de uma renovação estética da arquitetura:

O debate se concentrou sobretudo na FAU-USP, embora alguns dos seus jovens expoentes tenham se formado no Mackenzie, (Mendes da Rocha, Millan, Mello Saraiva). Mas foi sob o carisma de Vilanova Artigas, que esses jovens ingressaram na FAU como professores, e sua liderança se estendia também ao IAB-SP, criando a oportunidade para a consolidação da Escola Paulista. $\mathrm{O}$ vínculo desses arquitetos, protagonistas da renovação estética, com a docência na FAU-USP certamente contribuiu para o amadurecimento dos princípios, proporcionando desdobramentos que até hoje são discutidos nessa instituição. (CAMARGO, 2019, p.07)

A reconhecida tese de Yves Bruand Arquitetura Contemporânea no Brasil, defendida em 1975 na França e publicada no Brasil somente em 1981, contribuiu para esta ideia de conjunção da arquitetura moderna brasileira sob duas principais correntes: a carioca e a paulista. De modo geral, tornaram-se hegemônicas na historiografia algumas denominações que remetem a esta arquitetura praticada em São Paulo, como apontou Mônica Junqueira de Camargo (2019, p.05): “Arquitetura paulista/ escola paulista/ linha paulista/ projeto paulista/ brutalismo paulista/ escola brutalista paulista são algumas das expressões encontradas, às vezes colocadas entre aspas, sugerindo um sentido figurado ou uma dúvida sobre a pertinência da expressão." 
De todo modo, a interpretação sobre o movimento moderno em São Paulo se limitou a ideia de uma arquitetura local munida de uma estética própria, responsável por conformar uma escola. Esta interpretação focada na análise de um conjunto de elementos estéticos e formais comuns, fez com que estas arquiteturas fossem, de forma recorrente, compreendidas de modo isolado e em seu aspecto autoral, no que pese a dimensão coletiva e a pretensão social destas obras. Ou seja, a vinculação destes profissionais e destas arquiteturas como um grupo, reunidos sob uma mesma cultura arquitetônica, se deu pela proximidade de atuação, pelo compartilhamento de ideias e do mesmo ambiente de ensino e debate, pela dimensão formal e material destes edifícios mas, nem sempre pelo reconhecimento destas arquiteturas como parte de um plano. Um plano inserido no contexto de um Brasil entre o Estado Novo e o regime civil-militar.

Enquanto a aproximação política entre os arquitetos cariocas e o Estado Novo, materializados pela construção do Ministério da Educação e Saúde Pública no Rio de Janeiro em 1936, foi, por vezes, objeto central - inclusive de crítica - na historiografia sobre a arquitetura brasileira, sobretudo na atuação de Oscar Niemeyer nos governos de Juscelino Kubitschek, a arquitetura produzida em São Paulo permaneceu associada a obras individualizadas. Em outras palavras, as notáveis arquiteturas públicas produzidas neste ambiente, que tornaram-se hegemônicas sob a alcunha de escola paulista, raramente foram identificadas como parte da atuação consciente e deliberada destes profissionais no interior das instâncias políticas e de poder formalizadas pelo Estado.

No que pese a difusão destas obras da arquitetura paulista, a sua compreensão como elementos de um mesmo processo somente foram possíveis com as recentes pesquisas desenvolvidas sobre o Plano de Ação do Governo do Estado em São Paulo, durante o Governo de Carlos Alberto de Carvalho Pinto. Iniciadas por Miguel Buzzar e Mônica Junqueira de Camargo (2016), as pesquisas sobre o Plano de Ação em São Paulo permitiram que estas obras arquitetônicas, antes pensadas exclusivamente na trajetória individual destes profissionais, fossem compreendidas como parte de um 
complexo e amplo plano de desenvolvimento em escala regional, no qual a arquitetura e os arquitetos desempenharam um papel central e decisivo.

De outro modo, podemos afirmar que a arquitetura moderna paulista não se explica somente pela inventividade intelectual e talento projetual de seus expoentes qualidades comumente associadas, por exemplo, à Vilanova Artigas, quem reuniu estes arquitetos - mas por uma dimensão conjuntural que possibilitou a atuação destes profissionais em uma escala inédita:

\begin{abstract}
A ampla difusão das ideias de Artigas deveu-se a um contexto muito favorável propiciado sobretudo por três fatores: a estreita relação do brutalismo com certa tradição construtiva característica da produção paulista; o Plano de Ação do Governo Carvalho Pinto 1959-1963 que abriu uma oportunidade ímpar de produção aos arquitetos paulistas e a Artigas em particular, que teve o privilégio de projetar uma Faculdade de Arquitetura, e a reestruturação acadêmica promovida pela Universidade de São Paulo nessa mesma época, que estimulou a reflexão de um novo ensino, simultaneamente à criação de uma nova sede. (CAMARGO, 2015, p.136-137)
\end{abstract}

Reunidos sob a figura de Vilanova Artigas no Instituto de Arquitetos do Brasil, os cerca de 160 profissionais contratados pelo Plano de Ação entre 1959 e 1960 puderam desenvolver mais de mil projetos públicos, distribuídos por 275 cidades de todo o estado de São Paulo. A escala e o período destinado à execução do Plano, restrito aos quatro anos do governo de Carvalho Pinto, demonstram a magnitude destes esforços ao reunir uma miríade de edifícios emblemáticos, construídos em diversos locais do estado, sob o mesmo plano. Nem sempre privilegiada pela análise arquitetônica, a elucidação desta conjuntura fornece à arquitetura uma dimensão política dos atores, pela capacidade de fazer convergir interesses díspares em torno de um projeto de desenvolvimento regional, colocado no âmbito das políticas de desenvolvimento nacional.

O PAGE se constituiu como um amplo plano de modernização e desenvolvimento do estado de São Paulo, inserido no ambiente das políticas e planos desenvolvimentistas do período no Brasil e América Latina mas, de modo particular, enfatizando princípios nem sempre comuns ao processo de desenvolvimento verificado 
nos países periféricos. Estes princípios eram fundados na ideia de desenvolvimento econômico em consonância com o desenvolvimento humano e com o bem-estar social.

A existência do PAGE no contexto das políticas de bem-estar social após a Segunda Guerra e das políticas de desenvolvimento na América Latina e na periferia do capitalismo, apontam um sentido comum para o papel do estado como promotor das políticas públicas. Sobretudo, na posição de agente principal do desenvolvimento econômico, papel este que era assumido pelos Estados Nacionais de todo o mundo e, no Brasil, pelo Governo Federal através do Plano de Metas.

Evidentemente, que uma política keynesiana, quando não opera os determinantes macroeconômicos afeitos a política federal e não estadual, tem seus limites. Mas o sentido do Plano fica evidente em função dessa opção. Ou seja, o recurso poupado pelo Estado através do IPESP tinha necessariamente que ser investido para "criar a capacidade de criar casas, estradas e assim por diante", como previa Keynes. Os investimentos gerariam a procura por emprego e novos recursos capitalizados através de impostos que também seriam gerados. A discussão sobre os fundamentos keynesianos do PAGE escapam aos objetivos do trabalho, mas é notável perceber que nele, mais do que um Plano de porte estadual se fazia presente. (BUZZAR, CAMARGO et al., 2016 p.104).

O sentido do Plano de Ação passava por posicionar o estado de São Paulo diante dos projetos de desenvolvimento nacional, ao extrapolar os limites regionais das políticas de desenvolvimento colocadas pelo governo estadual. Neste sentido que Mônica Junqueira de Camargo (2019, p.09) vai afirmar que o Plano de Ação era a "Brasília" dos arquitetos paulistas, ao se apresentar como oportunidade de realização de suas propostas e de afirmação nacional de sua arquitetura. Não obstante, estes arquitetos estavam a construir, não a "Brasília Paulista" mas, o próprio país, cuja arquitetura fornecia os espaços de uma nova sociabilidade. Uma sociabilidade moderna, como descrevem Fernando Novais e João Manuel Cardoso de Mello (1998).

A analogia com a construção de Brasília é, sem dúvida, inevitável. Apesar do PAGE, como vimos, não ter alcançado o espaço privilegiado que a nova capital do país ocupou na historiografia, é provável que, ao menos em relação aos números, o Plano de Ação em São Paulo supere a quantidade de obras e profissionais envolvidos ${ }^{1}$ no 
fenômeno arquitetônico que se tornou a capital brasileira. Além dos cerca de mil projetos contratados pelo Plano através do IPESP, dos quais parte significativa foi construída, outros diversos projetos estão sendo encontrados e inventariados com o avanço de novas pesquisas, apontando para uma dimensão ainda a ser definida da amplitude que teve o Plano de Ação.

Pesquisas desenvolvidas ao longo das últimas quase duas décadas, têm aprofundado as diversas frentes que constituíram a atuação do PAGE em São Paulo no âmbito dos planos de desenvolvimento e modernização. Entre estas podemos citar o importante trabalho de Maria Tereza Regina Leme de Barros Cordido (2007), sobre a arquitetura forense desenvolvida através do Plano, que pôde dar sentido e coesão à significativa produção de fóruns e edifícios de justiça por arquitetos modernos por todo o estado no período. Do mesmo modo, as pesquisas sobre a arquitetura dos edifícios escolares produzidas pelo PAGE e IPESP, de André Augusto de Almeida Alves (2008 e 2016) e de Angélica Irene da Costa (2014), contribuíram para a compreensão de uma tipologia arquitetônica que propôs a renovação pedagógica a partir da própria arquitetura. $^{2}$

A pesquisa apresentada por esta dissertação constitui parte destes esforços e busca contribuir com a elucidação de uma das frentes do PAGE durante a construção da Cidade Universitária da USP a partir de 1959: a atuação de um corpo de arquitetos no planejamento do Instituto Butantan, vizinho do campus da USP, que constituiu uma

edifícios à Oscar Niemeyer, aquela altura um arquiteto já reconhecido pelas suas obras, em São Paulo a produção PAGE foi pulverizada, articulada por um órgão de classe, o IAB, possibilitando, inclusive, a atuação de jovens arquitetos que desenvolviam seus primeiros projetos públicos.

2 Como quase toda arquitetura produzida pelos arquitetos do Plano de Ação, a arquitetura escolar trazia uma proposta de renovação do ensino, rompia com certas estruturas convencionais desta tipologia propondo um projeto de formação - e de transformação - da sociedade através dos espaços projetados pelos arquitetos modernos. A aplicação destes pressupostos desenvolvidos pela arquitetura escolar do Plano de Ação aparece, de forma integral, no edifício da FAU-USP projetado por Vilanova Artigas e Carlos Cascaldi, no qual ensino e espaço estão plenamente integrados. O mesmo ocorre na arquitetura forense que, entre diversos edifícios paradigmáticos, está sintetizada no projeto do arquiteto Fábio Penteado para o fórum de Araras, que rompe com a organização tradicional e hierárquica dos edifícios de justiça ao propor uma grande praça pública, coberta e acessível. Nestes exemplos, a arquitetura assume - ou ao menos pretende assumir-, por meio do plano, a vanguarda da transformação e da organização da sociedade. Como veremos, este padrão também se verifica para os edifícios da saúde e pesquisa desenvolvidos para o Instituto Butantan. 
frente profícua na produção de inúmeros projetos de edifícios modernos e planos de urbanização. Caracterizado por um programa de reformulação radical do campus do Instituto, marcado pela preexistência de tipologias tradicionais, este episódio se distingue como uma frente de atuação marcada por particularidades e exceções em relação ao que se conhece da produção arquitetônica do PAGE como um todo.

Sabemos que parte minoritária, porém considerável dos projetos feitos pelos arquitetos do Plano de Ação não foi construída, por razões diversas, como em alguns casos da construção da própria Cidade Universitária da Universidade de São Paulo, na qual projetos emblemáticos não foram executados. ${ }^{3}$ Enquanto este episódio está bem narrado por pesquisas sobre o campus da USP (CABRAL, 2018), a ingerência do PAGE no Instituto Butantan não seria conhecida caso não fossem preservados os materiais que documentam este vasto empreendimento de modernização.

Uma segunda particularidade, se refere às especificidades do espaço de intervenção apresentado aos arquitetos, do qual desconhecemos paralelos no Plano de Ação. Neste sentido, a arquitetura moderna no Brasil, que se viu diante da tarefa de formar a nação e de construir o espaço urbano diante do predomínio do vazio e do arcaico (TELLES, 2010), não vai se confrontar com a dimensão da preexistência como condição para a realização do plano moderno. Em geral, esta também é a condição com a qual vão se defrontar boa parte dos arquitetos do PAGE para a elaboração de suas propostas, a serem implantadas em pequenas cidades do interior do estado no início da década de 1960, em condições quase rurais e com a existência de poucas infraestruturas.

Em contrapartida, o "vazio" com o qual se depararam os arquitetos modernos na construção de muitas das obras do PAGE, inclusive da Cidade Universitária, não se verificava no campus do Instituto Butantan nos primeiros anos da década de 1960,

3 Entre os projetos para o chamado "Corredor das Humanas" foram construídos apenas o edifício dos departamentos de História e Geografia (Eduardo Corona) e da FAU (Vilanova Artigas e Carlos Cascaldi). Os demais projetos, para o departamento de Filosofia e Sociologia (Paulo Mendes da Rocha), Letras (Carlos Milan), Geologia (Pedro Paulo de Melo Saraiva) e Matemática (Joaquim Guedes), não foram executados. 


\section{Introdução}

nesta altura detentor de um conjunto arquitetônico consolidado. Esta particularidade do tradicional campus de pesquisa, instalado desde o final do século XIX na região, vai revelar uma aparente tensão entre um patrimônio construído, fundamental para a história do Instituto e os anseios pela sua modernização.

Ao mesmo tempo, para os arquitetos atuantes no planejamento das obras da Cidade Universitária a partir de 1959, o campus de pesquisa e produção de imunobiológicos do Instituto se apresentou como uma exímia oportunidade de ampliação da sua atuação, cujo espaço representava cerca de um quarto da área destinada à Universidade de São Paulo. Embora consolidado, este espaço era constituído por grandes áreas não ocupadas, e seus edifícios históricos, construídos nas primeiras décadas do século $X X$, não condiziam com as necessidades de expansão do Instituto.

Esta conjuntura, inaugura um cenário complexo, de enorme inventividade arquitetônica e, também, de disputas políticas pelo controle e pelo sentido do planejamento, ilustrando a dimensão da vanguarda que caracterizou a arquitetura moderna e do Plano de Ação. De forma simultânea, este episódio da arquitetura moderna, verificado em São Paulo, demonstra a sua amplitude na manifestação de culturas e linguagens arquitetônicas diversas, na atuação de arquitetos vindos de diversas partes do país, extrapolando os limites regionais e conformando uma rica experiência: a utopia de um país moderno.

As atividades desempenhadas para esta pesquisa se constituíram por frentes diversas e complementares, sendo uma das frentes principais definida pela pesquisa em arquivos históricos. Neste sentido, o trabalho se fundamenta pela análise de fontes primárias, pela organização e sistematização de projetos de arquitetura, levantamento de revistas e publicações sobre estes projetos, assim como pela revisão e atualização bibliográfica e aprofundamento historiográfico sobre o tema do Plano de Ação e do conjunto arquitetônico do Instituto Butantan. 
No que se refere aos esforços de busca e análise das fontes primárias, que se desempenhou ao longo das visitas feitas ao arquivo histórico do Centro de Memória do Instituto Butantan, do Instituto Bardi e da biblioteca da FAU-USP, foram levantadas, além dos projetos, fotografias que remetem à história do conjunto arquitetônico do Instituto desde o começo do século XX e à atuação do PAGE. Foram encontradas imagens de maquetes e perspectivas dos edifícios projetados, além de fotografias do Instituto e de edifícios construídos a partir da segunda metade da década de 1960.

Os esforços concentrados nas análises dos documentos textuais ${ }^{4}$ se pautaram pelo recorte temporal que vai do ano de 1955 até 1981. Através destes, procurou-se analisar a situação administrativa e da infraestrutura do Instituto até o ano de 1959, data de anúncio do Plano de Ação pelo governo de Carvalho Pinto, o que possibilitou o aprofundamento sobre a questão da relevância e do impacto do Plano para a infraestrutura do campus, assim como da sua recepção pela comunidade científica e pelo corpo diretor.

Ainda sobre o levantamento de documentos e fontes, como fontes secundárias, foram encontradas publicações que abarcam a tríade que compõe o tema da pesquisa: Instituto Butantan, Plano de Ação e Cidade Universitária. Estas publicações apresentam os projetos para as duas instituições no período do Plano, de 1959 a 1963, nas revistas América (no2, 1962) e Acrópole (no 331, 1966).

De característica teórica e metodológica, a pesquisa esteve também apoiada pela revisão bibliográfica, no aprofundamento sobre a bibliografia do Plano de Ação e sobre a história da arquitetura moderna brasileira e paulista. Esta fase esteve amplamente amparada pelas disciplinas cursadas no curso de mestrado, por discussões com professores e colegas e participação em grupos de pesquisa.

4 Este trabalho focou a análise dos Relatórios Anuais do Instituto, documentos de caráter administrativo produzidos pelos setores de atividades e pela direção da instituição que abordam os aspectos relativos à produção, pesquisa, administração, infraestrutura e eventos relevantes ocorridos ao longo do ano. 
As dificuldades que surgiram durante este processo de investigação estão muito associadas ao volume do material que originou a pesquisa. Foram analisadas todas as 1210 pranchas de projeto que compõem o acervo pesquisado e que correspondem a mais de um século de história do conjunto arquitetônico do Instituto. Deste modo, a delimitação do recorte da pesquisa e dos projetos a serem inventariados e pesquisados constituiu o maior desafio enfrentado, dado o volume do material e a inexistência de pesquisas sobre o Plano de Ação no Instituto Butantan. ${ }^{5}$

A redação do texto está estruturada em quatro capítulos que compõem a dissertação. De modo geral, os capítulos são organizados por três eixos: o conjunto arquitetônico do Instituto e seu acervo de projetos, o advento do Plano de Ação e os projetos desenvolvidos para o campus do Instituto, seus desdobramentos e a relação com a Cidade Universitária. Junto do tema abordado pela pesquisa, são apresentados os documentos inéditos que compõem o acervo estudado, destacando-se a sua relevância para a compreensão deste episódio da arquitetura moderna em São Paulo, assim como o seu potencial para futuras investigações.

A partir deste primeiro esforço de síntese dos documentos primários, o texto se encaminha para um aprofundamento sobre os projetos modernos desenvolvidos pelo Plano de Ação. O objetivo é compreender o impacto desta atuação para os rumos do planejamento do Instituto Butantan, os conflitos suscitados por este evento. Constituindo um movimento de aproximação com as pesquisas consolidadas sobre o tema, busca-se conferir a relação desta frente com a atuação mais ampla do PAGE, por sua vez, inserido-a na produção da arquitetura moderna paulista.

Seguindo este percurso, o primeiro capítulo é constituído por três seções e apresenta o acervo pesquisado e sua inserção na história do conjunto arquitetônico do

5 Como mencionamos, a única pesquisa acadêmica existente sobre a história do conjunto arquitetônico do Instituto é atribuída à dissertação de mestrado do arquiteto Anderson Luiz Félix de Sá, concluída em 2019 na FAU USP, e que foca os edifícios tombados existentes e o seu processo de preservação. Trata-se, portanto, de um campo de pesquisa recente e de grande potencial para futuras investigações. 
Instituto Butantan. Assim, este capítulo introduz esta história da formação do campus como patrimônio histórico e arquitetônico (SÁ, 2019), percorrendo os documentos que compõem o Arquivo Histórico do Centro de Memória da Instituição, partindo dos aspectos mais gerais até a composição do Acervo Cartográfico, seção responsável pela guarda dos projetos arquitetônicos desenvolvidos ao longo de mais de um século. Busca-se evidenciar a disparidade entre este arquivo de projetos e a paisagem construída do Instituto Butantan demonstrando, em um mesmo movimento, a relevância destes documentos e a necessidade de preservação desta arquitetura que a primeira vista não se materializou.

A segunda parte constitui o capítulo central, eixo fundamental e estruturante da dissertação. Entramos na atuação do PAGE na formulação do planejamento do Instituto e no aprofundamento das relações com a Universidade de São Paulo durante a construção da Cidade Universitária. Portanto, mais que reconstituir este emaranhado de relações e conflitos que se estabeleceu entre estas entidades, o capítulo almeja organizar e produzir conhecimento sobre estes documentos referentes ao Plano de Ação no Butantan. Para isto, parte do Plano como política do Estado de São Paulo para o desenvolvimento regional, inserido no quadro das políticas desenvolvimentistas nacionais do período, para então adentrar os projetos para o campus do Instituto, mantidos em seu Acervo Cartográfico. Através desta síntese, tanto bibliográfica quanto documental, apresenta-se um inventário destes projetos e o mapeamento do Plano para o Instituto, localizando e organizando estas frentes de atuação de diversos arquitetos e delimitando a sua relação espacial com a construção do campus da USP.

O capítulo terceiro é reservado aos aspectos que conformam os desdobramentos da atuação do Plano de Ação para o campus do Instituto durante as duas décadas seguintes, entre 1963 e 1981, data de encerramento do governo Carvalho Pinto e o ano do tombamento do conjunto arquitetônico do Instituto Butantan pelo Condephaat. ${ }^{6}$ Este recorte é introduzido por uma revisão historiográfica

6 Através da resolução SC 35/81 o Instituto teve tombados, pelo CONDEPHAAT, o seu conjunto de edifícios e entorno. 
sobre o quadro da arquitetura moderna em São Paulo e da formação da escola paulista de arquitetura, cujas análises têm marginalizado a influência do Plano de Ação para consolidação desta vertente da arquitetura moderna brasileira. Segue-se com a investigação acerca dos projetos modernos desenvolvidos para o Instituto após o período de 1959 a 1963 através do PLADI, ${ }^{7}$ seguido de outros eventos importantes como a atuação da Arquiteta Lina Bo Bardi em projeto para o museu do Instituto, o próprio tombamento em 1981 como reflexo da disputa estabelecida com a USP e o projeto do arquiteto Marcio Kogan para outro Museu em 2002, edifício contemporâneo que reverbera a conformação de uma cultura construtiva moderna durante o período estudado.

A parte final está reservada às considerações acerca da dimensão do Plano de Ação do Governo do Estado para o planejamento do Instituto Butantan e da sua inserção na história da arquitetura moderna paulista. Numa via de mão dupla, pretende-se discutir o alcance e os impasses da correlação entre a política de desenvolvimento e o instituto de pesquisa.

7 Plano de Desenvolvimento Integrado, lançado pelo Governador Ademar de Barros que assume o Governo do Estado após a administração de Carvalho Pinto e o grande sucesso do Plano de Ação. Neste momento os arquitetos contratados pelo Escritório Técnico da Cidade Universitária, passam a atuar em escritório próprio no Instituto Butantan. 
Capítulo 1. Instituto Butantan 


\subsection{A formação do Instituto Butantan e do seu conjunto arquitetônico}

O Instituto Butantan tem sua origem vinculada ao ano de 1898 , quando um surto de peste bubônica se alastrou pelo porto de Santos, atingindo as exportações do café produzido no interior paulista e isolando a cidade litorânea, tão importante para a manutenção da economia cafeeira que impulsionou o desenvolvimento paulista. Como forma de controle e reestabelecimento da ordem econômica afetada pela epidemia, o governo do Estado de São Paulo sustentou a criação de um laboratório, ligado ao Instituto Bacteriológico, para a produção de soro antipestoso.

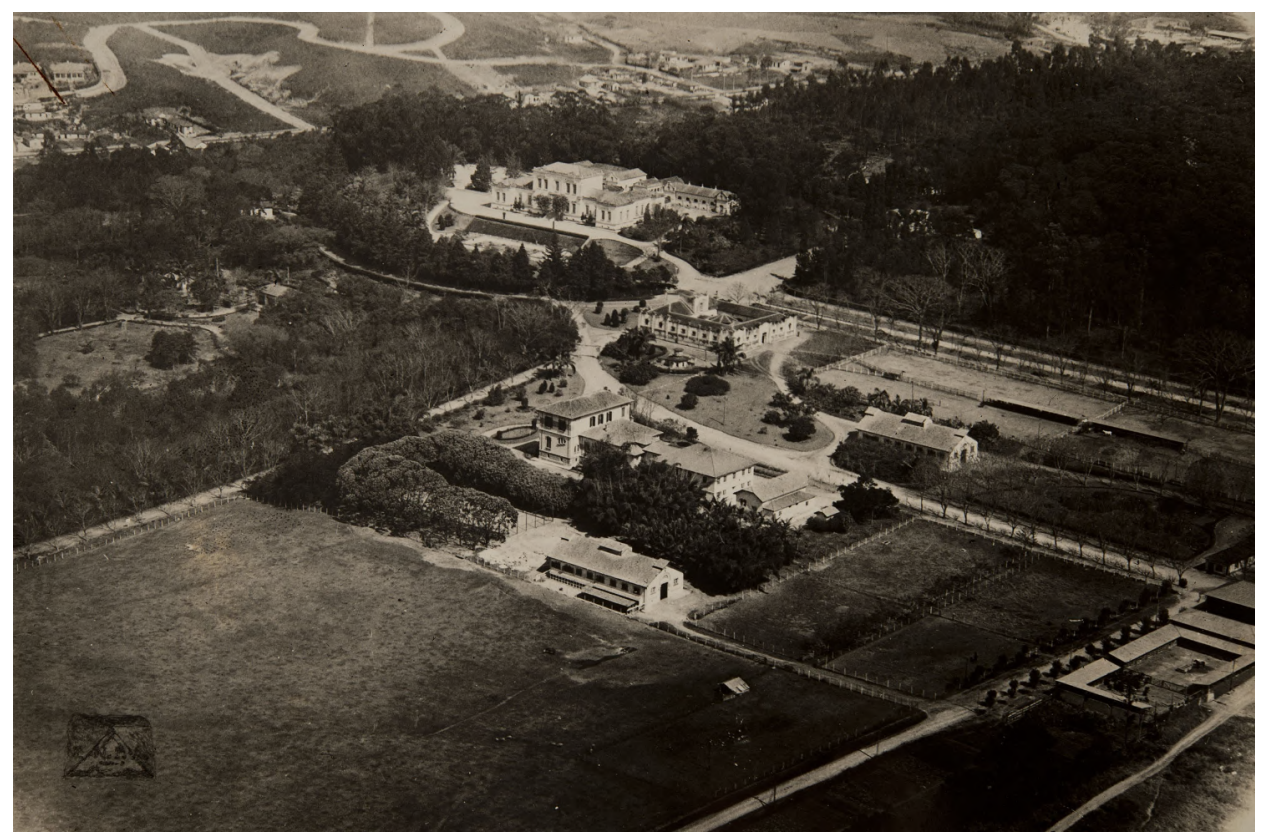

Figura 1: Imagem aérea do primeiro conjunto de edifícios instalados no Instituto Butantan. Ao fundo se percebe a ocupação ainda dispersa do atual bairro do Butantã, sem data, provavelmente dos anos 1920. Fonte: IB_ICO_009358, Centro de Memória/IB.

As questões de salubridade e higiene urbana, deflagradas pelo processo de urbanização nos séculos XIX e XX, suscitaram extensos embates acerca do protagonismo do estado na saúde pública e no planejamento das cidades em acelerada expansão. Neste processo, surgiram diversas instituições de pesquisa biomédica e produção de vacinas pelo país, antes mesmo da República em 1889. O historiador Luiz Antonio Teixeira (2006, p.110-111) relembra que o próprio Instituto Butantan, órgão público fundado pelo governo paulista, viu o médico Vital Brazil, seu diretor e fundador, deixar a direção da entidade em 1919 para fundar uma instituição privada no 
Rio de Janeiro, junto de outros pesquisadores.

Estas divisões marcaram o desenvolvimento da instituição, ao menos, até meados do século XX, em uma disputa pelo espaço de atuação com outras entidades, públicas e privadas. De todo modo, o Instituto Butantan superou as crises das primeiras décadas até a sua afirmação, tornando-se fundamental ao desenvolvimento paulista. Esta superação das crises e cisões internas, demonstram a centralidade alcançada pelo Butantan nas questões sanitárias, pois "São Paulo não podia parar e o Butantan era fundamental para que ela andasse" (Ibid., p.111).

As transformações pelas quais passava a sociedade brasileira nestas décadas contribuiu para o surgimento de centros de pesquisa e de produção de imunobiológicos. A existência destas instituições esteve atrelada ao processo de urbanização que amplificava o surgimento de novas doenças contagiosas. Esta questão se colocava nas reformas urbanas promovidas nas cidades europeias durante o século XIX e se manifestava no Brasil já na primeira década do século $X X$, através da reforma urbana promovida por Pereira Passos na cidade do Rio de Janeiro, ${ }^{8}$ consolidando o sanitarista Oswaldo Cruz à frente deste processo. Em São Paulo, o surto de peste bubônica na cidade de Santos possibilitou a ascensão pública do jovem médico Vital Brazil, quem conduziu as pesquisas para produção de soro antipestoso instalando-se na capital do estado.

Em pouco tempo o laboratório organizado para o combate à peste bubônica foi transferido para a região do atual bairro do Butantã, na zona oeste de São Paulo. Naquela época, uma fazenda afastada da cidade e lugar propício ao desenvolvimento deste tipo atividade, que causava enorme desconfiança por parte da população urbana do município que se contava aos 270 mil habitantes já na primeira década do século XX (SEVCENKO, 1992, p.108). Neste primeiro momento, são construídas, ainda que de forma modesta e provisória, as primeiras instalações para a pesquisa e produção de

8 Este episódio é analisado pelo historiador Nicolau Sevcenko no livro A Revolta da Vacina: mentes insanas em corpos rebeldes (2010), no qual a reforma urbana do Rio de Janeiro e a vacinação em massa contra a varíola são apresentados como eventos de um mesmo processo: de racionalização urbana e controle dos corpos sob o desenvolvimento capitalista. 
vacinas do laboratório, sendo também aproveitados os edifícios já existentes na antiga fazenda, como a atual Casa Vital Brazil, construída na segunda metade do século XIX.

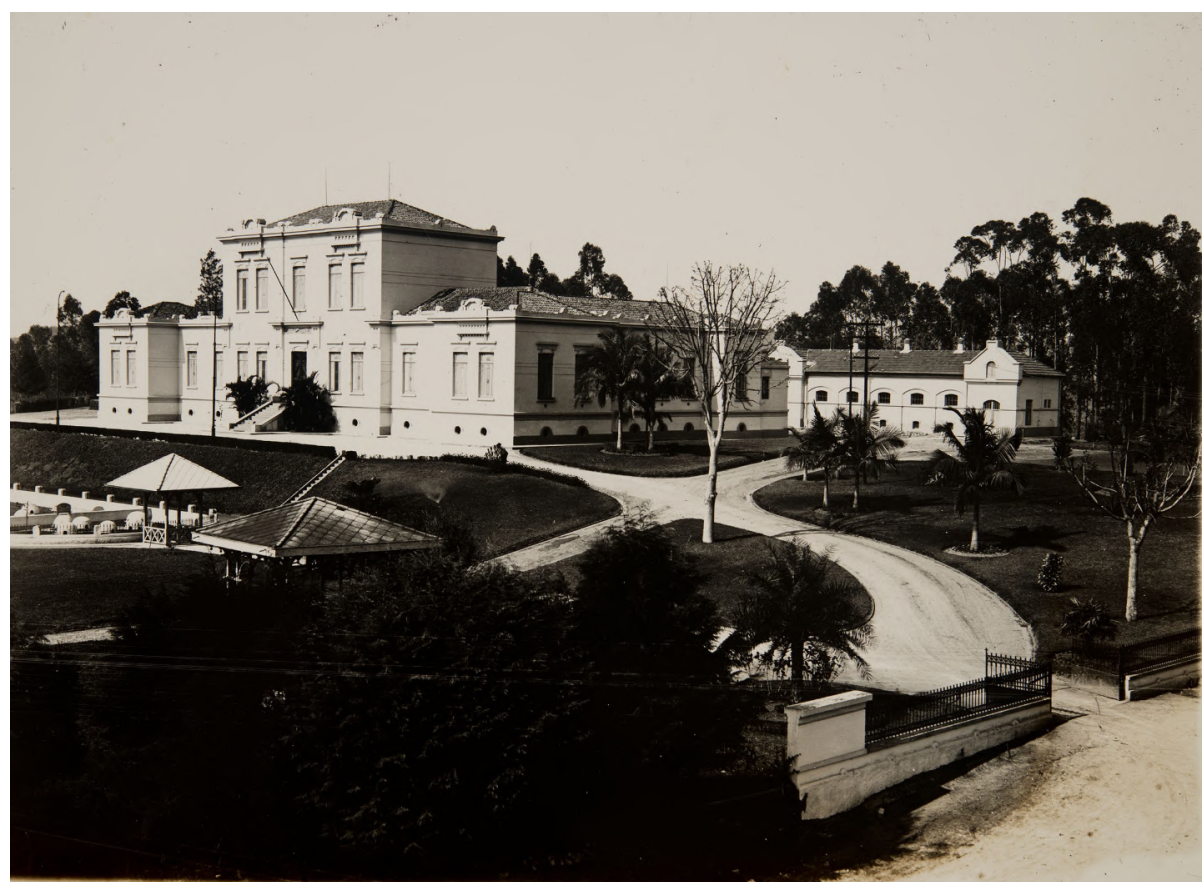

Figura 2: Fotografia do Edifício Vital Brazil, primeiro grande prédio construído no Instituto Butantan. A sua frente está localizado o serpentário e ao fundo o antigo Conjunto da Cocheira enfermaria construído em 1901. Fonte: IB_ICO_008926, Centro de Memória/IB.

Na primeira década do século XX, no ano de 1901, é concluída a construção dos dois pavilhões principais do conjunto projetado em 1899 pelo arquiteto belga, emigrado para São Paulo em 1896, Victor Désiré Clément Andrigo, ${ }^{9}$ destinado ao conjunto de cocheiras e enfermaria para animais, cuja construção ficou a cargo do engenheiro Augusto Fomm, que trabalhara em outras obras iniciais para o Instituto. Situado logo à sua frente, em 1914, é inaugurado o primeiro edifício de grande magnitude da Instituição (Figura 2), projetado pelo engenheiro arquiteto Mauro Álvaro de Souza Camargo, formado pela Escola Politécnica de São Paulo, atual Escola Politécnica da USP, foi convidado a atuar no Instituto em 1910, tendo atuação destacada em sua construção durante as primeiras décadas. Ocupando uma posição de

9 Nascido em 1869, Andrigo teria emigrado para São Paulo em 1896 para trabalhar na "Commissão Technica de Melhoramentos da Intendência de Obras do Município de S. Paulo", onde também atuou no projeto para o Hospital Colônia do Guapira, no bairro do Jaçanã, atual Hospital São Luiz Gonzaga. Também foi nomeado cônsul da Bélgica na cidade de São Paulo. 
destaque, em uma cota alta do terreno, o Prédio Central (atual edifício Vital Brazil) representava a importância que a Instituição passava a adquirir para a saúde pública paulista.

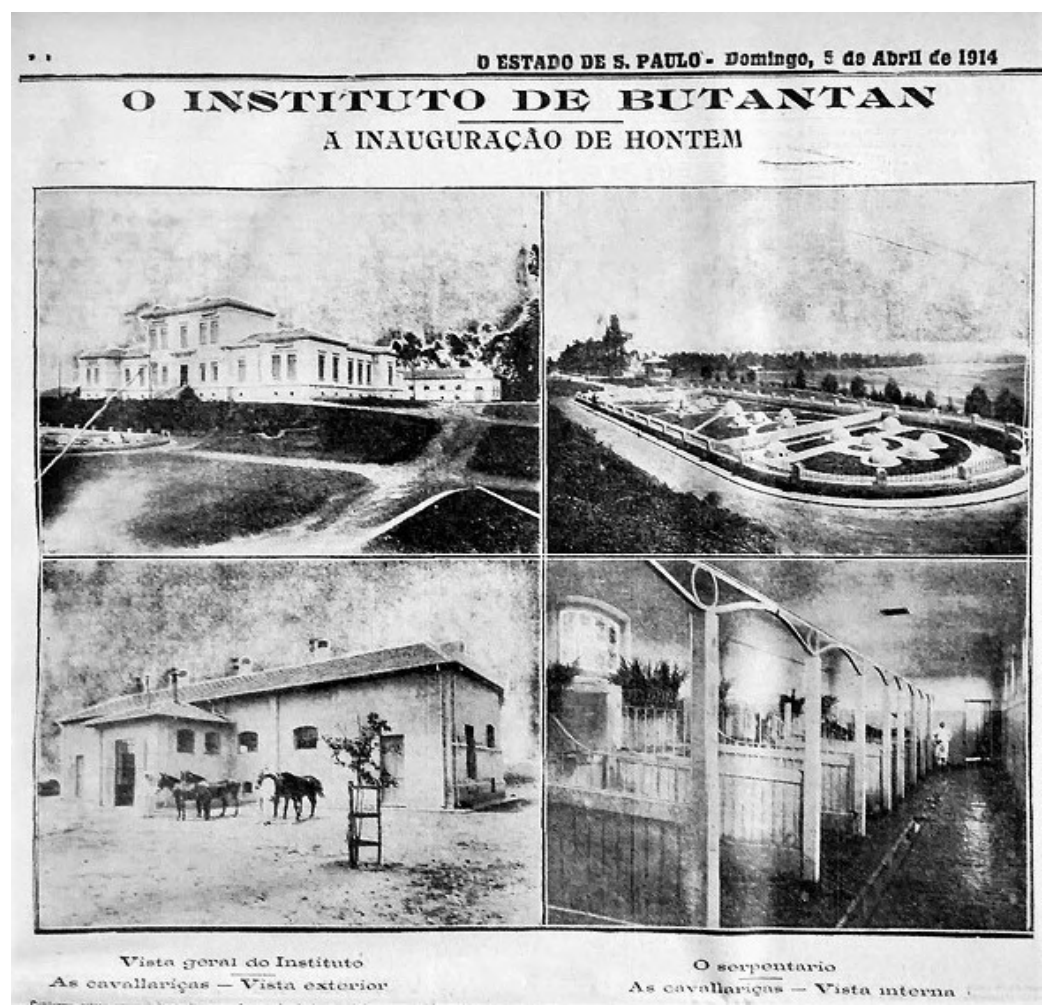

Figura 3: Reportagem do Jornal O Estado de São Paulo sobre a inauguração dos novos edifícios do Instituto Butantan, 5 de Abril de 1914. Fonte: Acervo Estadão.

Há uma intensa atividade construtiva nestas primeiras décadas de existência, revelando um esforço constante de ampliação e desenvolvimento, assim como de afirmação da imagem da Instituição através de seus edifícios. Estes esforços iniciais de ampliação de sua estrutura física estão amparados pela adoção da arquitetura como elemento simbólico, capaz de projetar a imagem do Instituto Butantan, diante das querelas envolvendo outras entidades atuantes na produção de imunobiológicos. É possível afirmar que a arquitetura destes edifícios dava forma a uma instituição que se pretendia moderna e afinada com as mais avançadas técnicas científicas, ajudando a construir um imaginário em torno do Instituto Butantan ao longo do século.

Outros importantes edifícios são construídos ainda na década de 1910, como o prédio da cocheira, também projetado por Mauro Álvaro, assim como o Prédio Central 
de 1914. Nos anos 1920 é inaugurado o Pavilhão Lemos Monteiro, executado sob supervisão do Departamento de Obras Públicas do Estado, cuja autoria é conferida ao engenheiro politécnico Francisco Godoy M. e Costa. Nos anos 1930, o então diretor Afrânio do Amaral, constrói uma residência para abrigar o diretor e sua família, quando do seu regresso dos Estados Unidos para assumir o Instituto, passagem esta que viria a influenciar a escolha do estilo da construção (DE SIMONE, 2018, no prelo), cujo projeto também havia sido desenvolvido por Mauro Álvaro.

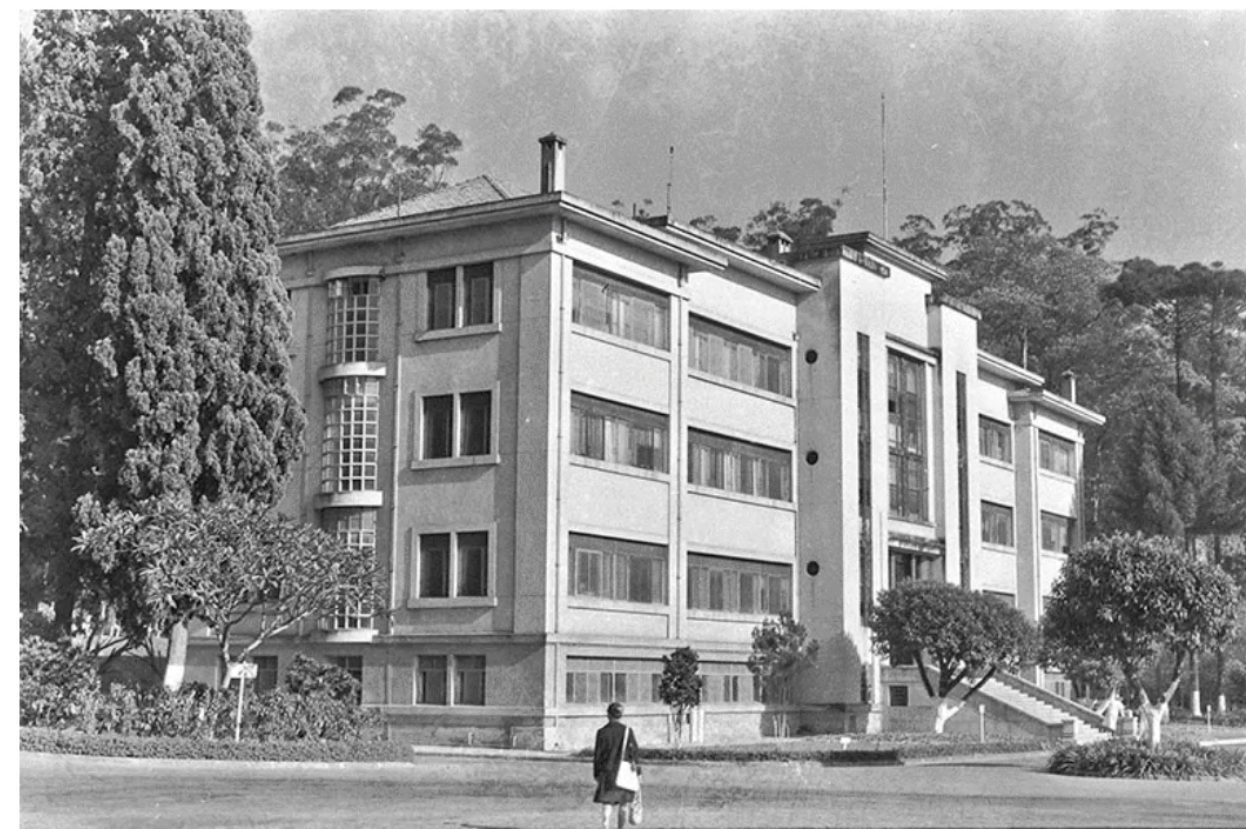

Figura 4: Fotografia do Prédio Novo na década de 1950. Fonte: IB_ICO_001196,Centro de Memória/IB.

Ao final dos anos de 1930, passado o período inicial de construção dos primeiros e principais edifícios do conjunto arquitetônico da instituição, é planejada a realização de um novo edifício adequado à expansão das atividades de pesquisa e produção, iniciado durante a direção de Jayme Arcoverde de Albuquerque Cavalcanti. Ainda inserido no período das "Construções Institucionais", entre 1910 e 1941, como definido por Anderson de Sá em sua proposta de periodização para o conjunto arquitetônico do Instituto (2019 p.247), o edifício foi projetado para receber os laboratórios de pesquisa do Butantan, sendo chamado pelo nome de Prédio Novo (Figura 4), em referência a suas características modernas em relação aos edifícios anteriores e existentes. 
A pesquisa que caracterizou o Instituto Butantan, desde as investigações pioneiras de Vital Brazil, se tornava fundamental ao jovem Instituto que ganhava projeção internacional naquele momento, principalmente durante a atuação do médico e herpetólogo Afrânio do Amaral. ${ }^{10}$ Entre 1928 e 1938, em sua segunda e mais significativa passagem como diretor do Instituto Butantan, Afrânio do Amaral empreendeu um notável esforço de internacionalização do instituto, contratando renomados pesquisadores estrangeiros que se viram diante das tensões da Europa a princípio da Segunda Guerra Mundial (TEIXEIRA, 2006, p.111-112).

\subsubsection{O Instituto no bairro do Butantã: a USP e as origens da disputa}

O Instituto Butantan é hoje o principal centro de produção de imunobiológicos do país e, ao lado da Fiocruz no Rio de Janeiro, internacionalmente prestigiado e reconhecido em sua atuação na pesquisa em biologia e biomedicina e também no campo da cultura, acumulando grande importância pelo seu patrimônio edificado e seus museus. Localizado próximo à margem do rio Pinheiros, na zona oeste da cidade de São Paulo, seu campus de pesquisa e produção é vizinho da Cidade Universitária Armando de Salles Oliveira, o primeiro e mais antigo campus da Universidade de São Paulo.

As duas instituições ocupam a área da atinga Fazenda Butantan, adquirida pelo governo paulista no final do século XIX para a instalação do Instituto que, em 1941, ${ }^{11}$ cedeu pouco mais de três quartos da sua área original para a implantação do campus da Universidade de São Paulo, criada sete anos antes, em 1934. A fundação do Instituto Butantan em 1901, quando se torna um órgão autônomo em relação ao

10 Afrânio do Amaral teve em sua trajetória uma importante vivência internacional que contribuiu para uma profícua relação com pesquisadores e instituições de diversas partes do Brasil e do mundo. Tendo se doutorado na Universidade de Harvard, nos Estados Unidos, o herpetólogo tornou-se internacionalmente conhecido, chegando a ser capa da revista estadunidense Time, no ano de 1929. Na capa da edição 28 de janeiro daquele ano, Afrânio aparece segurando uma serpente que remetia ao trabalho desenvolvido no Instituto Butantan.

11 O decreto 12.401, de 16 de dezembro de 1941 desmembrou a área pertencente à antiga Fazenda Butantan destinando $80 \%$ à construção da Cidade Universitária da USP e mantendo os outros $20 \%$ para o campus do Instituto. 
Instituto Bacteriológico de São Paulo, deu início à formação de uma paisagem construída que tornou-se elemento simbólico da cidade.

Essa notoriedade foi constituída ao longo de uma história rica em conquistas, mas também em controvérsias, tendo como pano de fundo material seu conjunto arquitetônico, urbanístico e paisagístico que, além de registrar os avanços e mudanças dessas atividades científicas, também constitui um registro de diversas expressões técnicas, construtivas e estéticas de projetistas e construtores do século XIX até hoje. Como um palimpsesto, esse espaço, com seus edifícios, vias e praças se tornou, inevitavelmente, um repositório de memórias de diversos matizes (histórico, político, científico, biográfico, social e arquitetônico) e de diversas épocas. (SÁ, 2019, p.15)

O atual bairro do Butantã manteve-se, até as primeiras décadas do século passado, afastado das regiões mais urbanizadas. No período colonial, a região permaneceu pouco habitada, ocupada por propriedades rurais cuja a presença é, até hoje, expressa pelas edificações coloniais preservadas em áreas próximas ao rio Pinheiros, que registram a presença de bandeirantes e jesuítas. É somente na passagem para o século $X X$, na esteira do crescimento urbano, que tem início a transformação da paisagem predominantemente rural. A partir da implantação do Instituto Butantan em 1901 e, posteriormente, da Cidade Universitária e dos primeiros loteamentos, como o promovido pela Companhia City nos anos 1930, o bairro passa gradativamente a ser urbanizado. Apesar da chegada da cidade neste período, o Butantã permaneceu por mais algumas décadas como um bairro pouco ocupado, com a presença de vilas dispersas, de acesso restrito pela dificuldade de transposição do rio e marcado por uma paisagem natural que, em parte, se preserva atualmente.

Por, ao menos, quatro décadas, o campus de pesquisa e de produção de soros e vacinas do Instituto Butantan reinou absoluto no atual bairro que carrega o mesmo nome. ${ }^{12}$ A sua implantação na região durante o final do século XIX, esteve amparada pela busca de um local adequado para este tipo de instalação, orientando-se pelas características específicas de tal atividade, que requeria grandes espaços para abrigar animais e laboratórios, assim como pela desconfiança que suscitava para a população

12 A origem do nome "Butantan" remete ao período colonial, a Fazenda na qual se instalou o Instituto adotava o mesmo nome, que foi herdado pelo bairro na grafia de "Butantã", cujo nome é de origem indígena e significa "terra dura". 
urbana.

Assim, seria necessário encontrar um local para tal produção, que deveria ter como características a capacidade de abrigar animais para inoculação (sobretudo cavalos), edifícios de laboratórios, e localização preferencialmente periférica, distante do centro urbano, uma vez que ainda existia certo receio e desconhecimento em relação à manipulação de microrganismos. Em clima de urgência, o governo identificou na capital que a chamada Fazenda Butantan atendia a esses requisitos. (SÁ, 2019, p.51)

Desta forma implantou-se, na então Fazenda Butantan, uma área alagadiça próxima às margens do rio Pinheiros (Figura 5), os laboratórios para a produção de vacinas e soros antipestosos para o combate à peste bubônica. Distante cerca de 9 quilômetros do centro da cidade, e pouco menos das áreas e bairros adjacentes ao centro, ${ }^{13}$ a fazenda, adquirida em 1899 pelo governo de São Paulo, abrangia uma vasta área de 4 milhões de metros quadrados em uma região marcadamente rural.

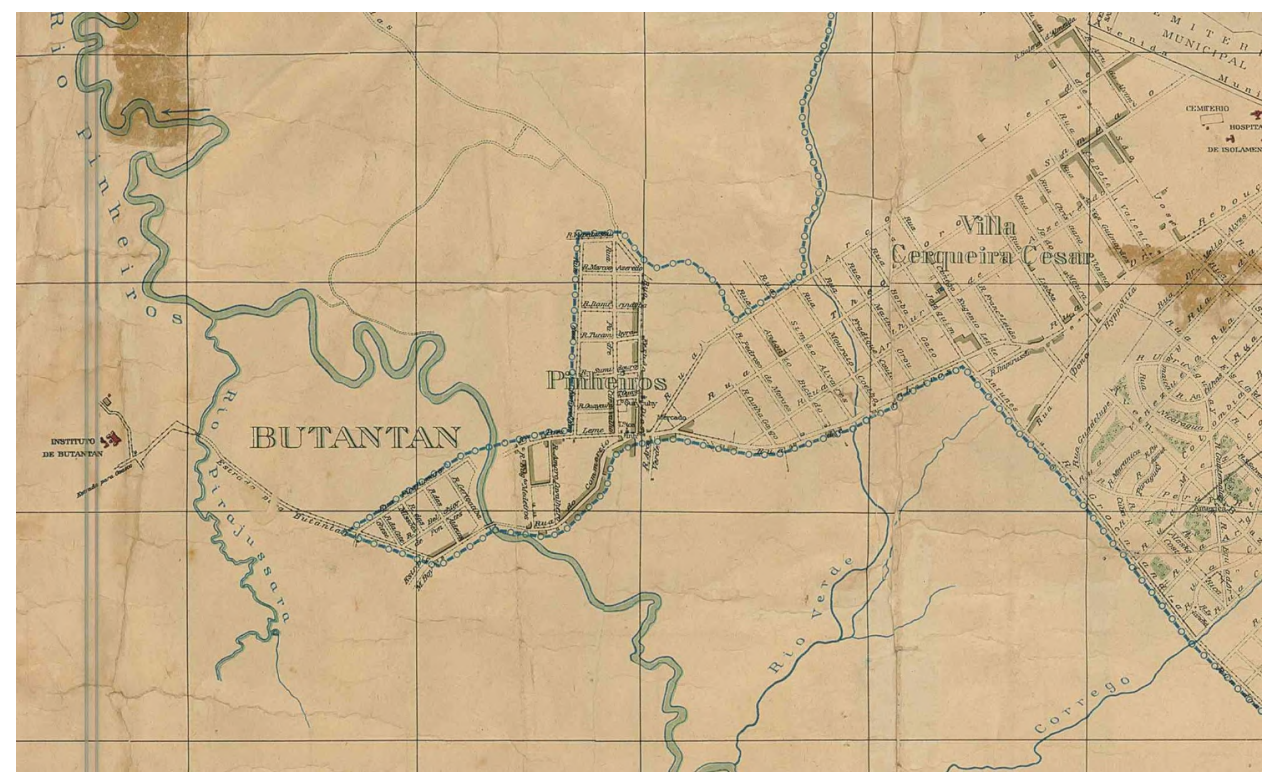

Figura 5: Mapa de 1916 com a implantação do Instituto próximo ao Rio Pinheiros e ao Rio Pirajussara Mirim. O Instituto se encontra na parte esquerda do mapa, ao final da última via representada. Fonte: Secretaria de Estado de Economia e Planejamento. Instituto Geográfico e Cartográfico - IGC. Acervo - Tombo: 1355, 1176 e 1356,.

O local era adequado a um instituto de pesquisa e de produção de vacinas,

13 Os 9 quilômetros entre o edifício Vital Brazil, próxima à entrada do Instituto, até o centro do distrito da Sé, caem para aproximadamente 4,5 quilômetros até a Rua João Moura, no bairro de pinheiros, uma das últimas ruas na área urbanizada da região oeste vista no mapa da cidade de 1887. Ou seja, a distância entre qualquer ponto da área urbanizada e a Fazenda Butantan, variava entre estes dois valores ao final do século XIX. 
visto que este deveria estar à margem da extensão urbana, embora, não totalmente afastado. Sua função estava necessariamente interligada com a manutenção da vida na cidade, com a higiene e a salubridade dos espaços urbanos, que estão na ordem do processo de urbanização e de regulação das cidades modernas.

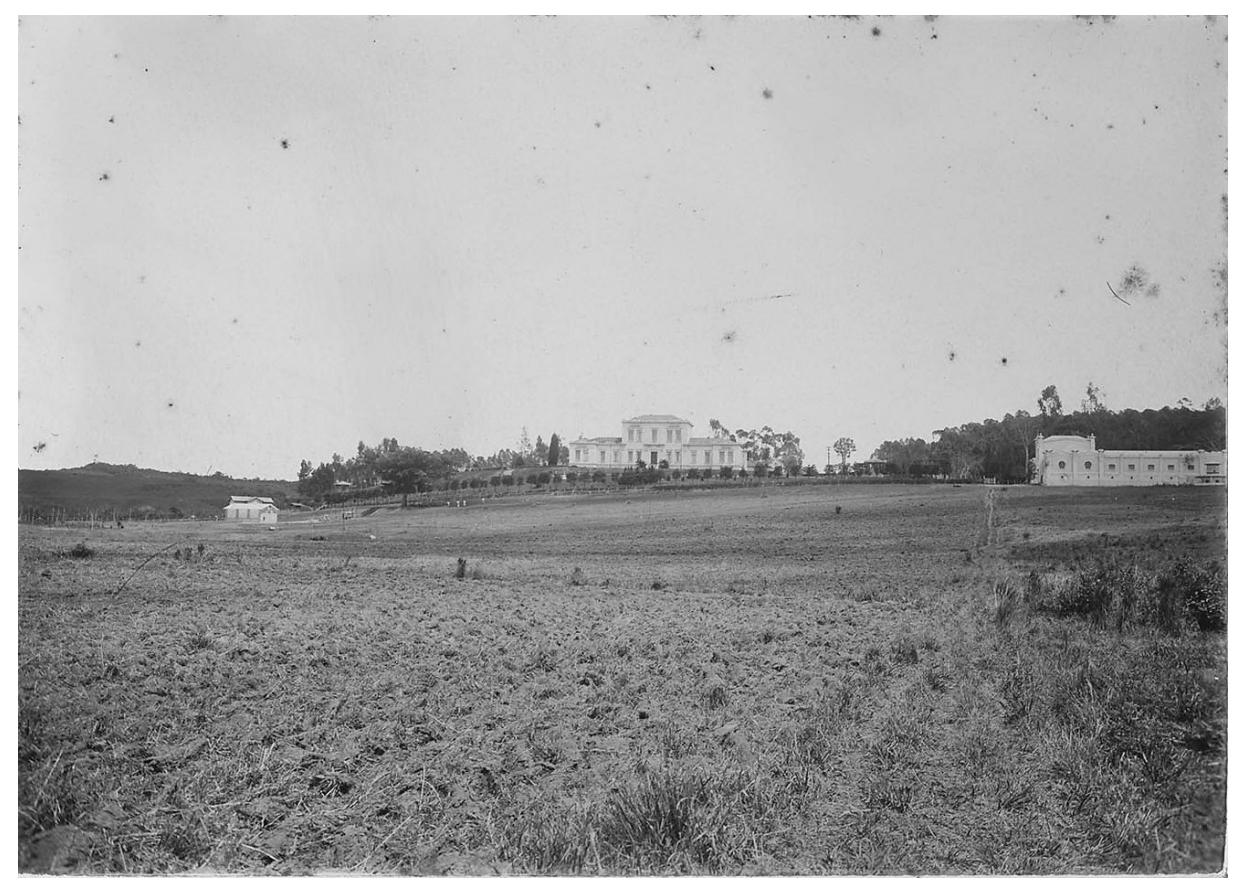

Figura 6: Imagem de 1917 dos primeiros edifícios construídos no Instituto contrastando com a paisagem rural predominante. Fonte: IB_ICO_011498a, Centro de Memória/IB.

Visto atualmente, a imponência do conjunto arquitetônico do Instituto Butantan pode ocultar a precariedade inicial que o caracterizou durante a sua implantação nos primeiros anos do século XX. Mesmo que comprovada a sua centralidade para a manutenção da salubridade urbana, no contexto da acelerada expansão de São Paulo, os meios para a sua instalação não estiveram à altura de tal importância. Originado sob o contexto de expansão da epidemia deflagrada em Santos e que ameaçava se espalhar para as cidades próximas, a implantação do então Instituto Serumtherápico se deu através de recursos escassos, com uma equipe composta por apenas 12 pessoas que se empenharam na adaptação das estruturas existentes da fazenda.

Apesar da limitação imposta durante os primeiros anos, a produção do soro 
antipestoso foi bem-sucedida e em 1902 a epidemia havia sido debelada, concedendo reputação à recém-fundada instituição (SÁ, 2019, p.52). O sucesso obtido logo no início, permitiu ao então diretor Vital Brazil galgar novos patamares para o Instituto, reivindicando ao governo do Estado investimentos para a ampliação de sua estrutura. Neste sentido, as pesquisas sobre ofidismo e a produção de soros antiofídicos, inauguradas por iniciativa de Vital Brazil, também se mostraram estratégicas para o prestígio institucional (IBAÑEZ, WEN, FERNANDES, 2005, p.125).

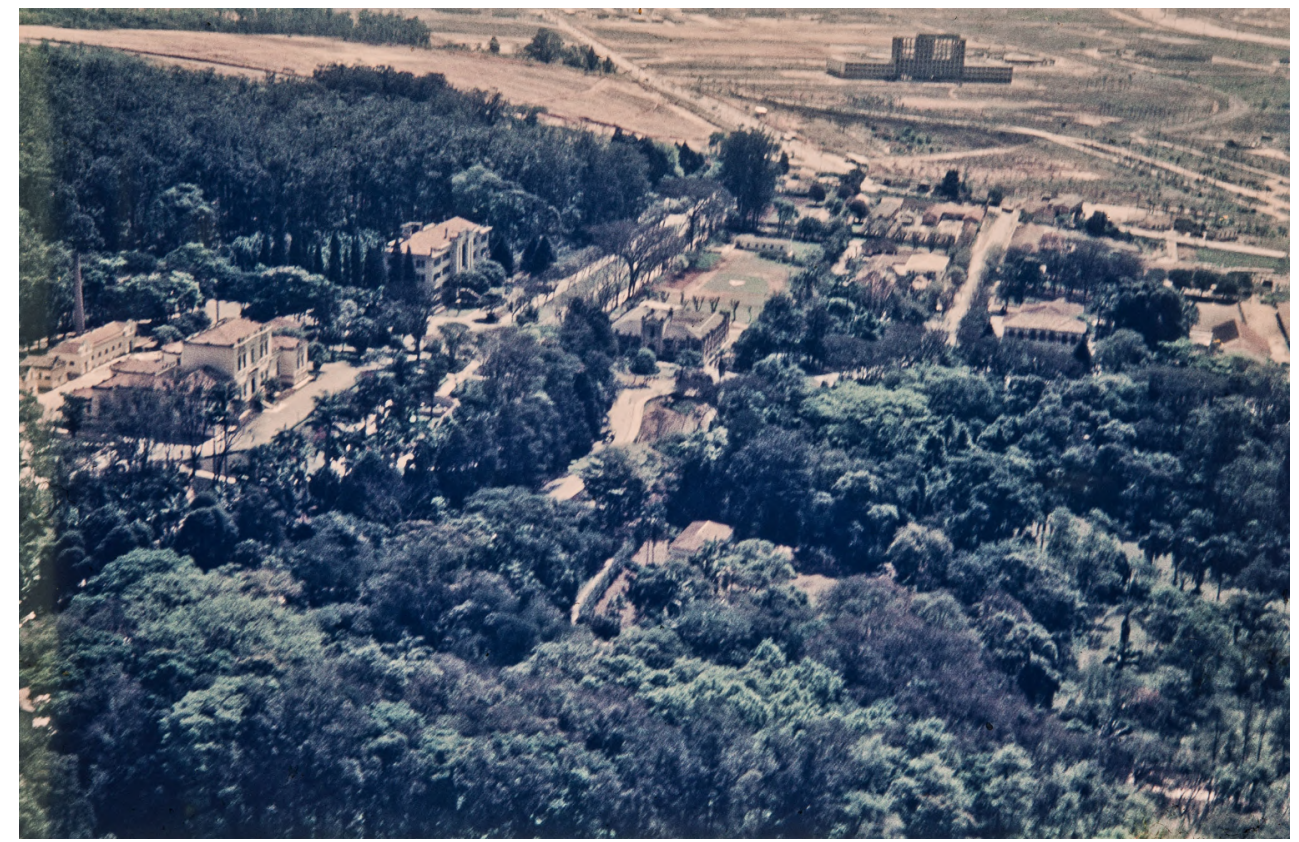

Figura 7: Instituto Butantan com a Cidade Universitária ao fundo durante os anos 1950, onde se vê isolado o edifício da reitoria. Fonte: IB_ICO_000672, Centro de Memória/IB.

Embora fosse notável o desenvolvimento da instituição durante as primeiras décadas, com a construção de seus principais edifícios, ampliação de suas instalações e das áreas de atuação, este processo de desenvolvimento do espaço físico careceu de um planejamento definido à priori, que pudesse regular a sua expansão. Deste modo, a implantação dos primeiros edifícios que conformaram o conjunto arquitetônico inicial respeitou a ordenação de um eixo (Figura 7), ligando a Casa Sede da fazenda ao Prédio Central, principal edifício do Instituto (SÁ, 2019, p.52). Ao longo deste elemento de interligação foram implantados os demais edifícios, marcados por pequenas variações e deslocamentos em relação ao eixo principal, de acordo com o programa ou 
a topografia do terreno.

Nestas primeiras décadas o crescimento do Instituto Butantan se deu através de uma espécie de sobreposição: de estilos arquitetônicos e edifícios dispostos no terreno conforme as necessidades de ampliação e de acordo com os recursos investidos pelo Estado. Esta característica acabou também por definir um planejamento fragmentado, composto por camadas, por edifícios construídos em momentos distintos e definidos por arquiteturas variadas.

No início dos anos 1950 já estão estabelecidos alguns dos núcleos urbanos que hoje compõem o distrito do Butantã e regiões próximas. A ocupação do bairro por residências unifamiliares, segundo o modelo de loteamento das cidades jardins, conforma nestas regiões uma característica de suburbanização e uma ocupação residencial que transplanta o limite natural definido pelo rio. As décadas de 1940 e 1950, são determinantes para a urbanização do bairro, conduzindo um processo iniciado com a implantação do Instituto e seguido pela implantação da Cidade Universitária da USP. Juntos, os campi das duas instituições ajudaram a promover a expansão da cidade no sentido oeste e o desenvolvimento da região.

Contudo, o impulso representado pela definição do local a ser implantado o campus da USP não foi imediato, o plano para a Cidade Universitária ainda levaria ao menos duas décadas até a sua consolidação. Desta forma, após a fundação da Universidade de São Paulo em 1934, e estabelecida a sua localização em área contígua e de propriedade do Instituto Butantan pelo decreto de 1941, são desenvolvidos diversos planos para a construção do seu campus. Estes planos permaneceram no papel e poucos edifícios foram construídos para a acomodação dos departamentos universitários, que ainda eram mantidos dispersos na região do centro da cidade.

O Campus da Universidade de São Paulo, que vinha se arrastando desde a década de 1940, com mais de dez planos concebidos e nenhum totalmente realizado, teve seu maior impulso com o PAGE, quando a Universidade passava por profundas mudanças estruturais.

[...] Muitos desses projetos contratados são referências para cultura arquitetônica, como o setor residencial de Eduardo Knesse de Mello; o Centro Esportivo - CEPE de Ícaro de Castro Mello; as Escolas de Minas e 
Petróleo. Mesmo os não executados, como o Centro Cultural de Oswaldo Arthur Bratke; o Centro de Convivência Social de Rino Levi; e os projetos para os edifícios do Setor das Humanas, que constituíram as propostas mais inovadoras. (CAMARGO, 2019, p.11-12)

Apesar da extensa lista de planos desenvolvidos para a criação da Cidade Universitária, uma dezena de planos segundo Mônica Junqueira de Camargo (2019, p.11), é somente no ano de 1959, através do Plano de Ação do Governo do Estado, no governo de Carlos Alberto Alves de Carvalho Pinto, que tem início a construção do campus que se conhece atualmente. Até esta data, o local permaneceu praticamente desocupado, com a presença de poucos edifícios dispersos pela extensa área, vizinha ao Instituto. Há, neste aspecto, um curioso contraste com o Instituto Butantan (Figura 8), detentor de um conjunto arquitetônico consolidado.

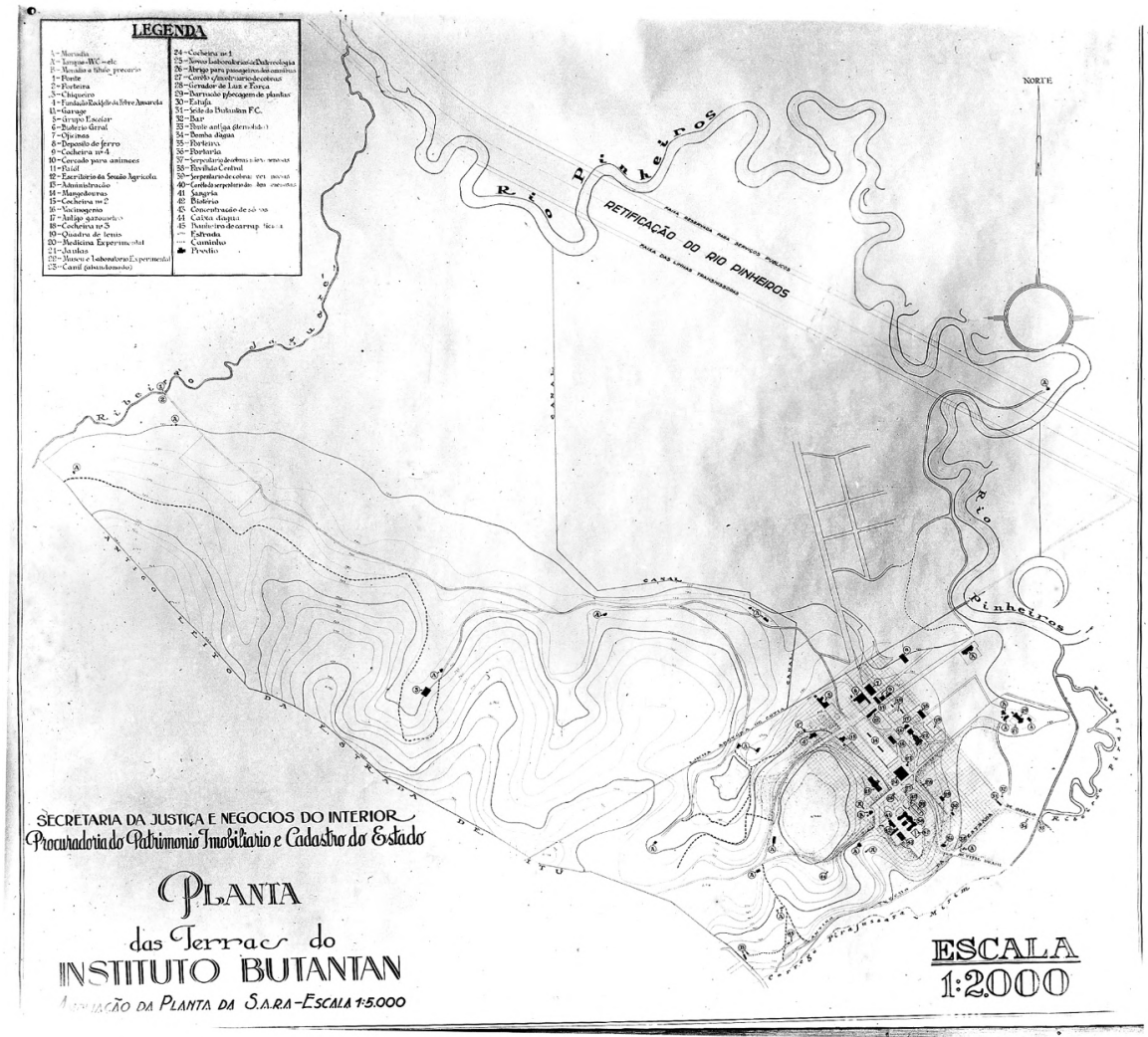

Figura 8: Planta do Instituto Butantan no ano de 1930: na parte inferior direita, em figura fundo, estão localizados os edifícios que compõem o conjunto; na parte superior a área que foi destinada à implantação da Cidade Universitária da Universidade de São Paulo. Fonte: Arquivo do Estado.

Idealizado na esteira dos planos desenvolvimentistas dos anos 1950, o Plano de Ação possibilitou a realização da Cidade Universitária Armando de Salles Oliveira, ao 
mesmo tempo em que se apresentou ao Instituto Butantan como oportunidade de expansão de suas estruturas e ampliação de sua capacidade física. Após quase seis décadas de sua fundação, seus edifícios eram vistos como insuficientes pela direção e pelos pesquisadores do Instituto, que constantemente comunicavam à diretoria a situação precária dos laboratórios. Em 1956, Helio Belluomini, responsável pelo Laboratório de Ofiologia, descreveu a situação do prédio e de suas instalações:

\footnotetext{
O Laboratório de Ofiologia está situado no velho prédio da sede da antiga Fazenda Butantan e suas instalações são extremamente precárias, não oferecendo condições mínimas para abrigar Laboratórios e muito menos a Coleção de Ofídios, extremamente pesada, conservada em álcool e depositada em salas assoalhadas que, além de instalações elétricas primitivas, apresentam inúmeras goteiras por ocasião das chuvas. (Relatório Anual, 1956, fl. 2).
}

Logo, os investimentos do Plano de Ação viriam a sanar deficiências de infraestrutura que se apresentavam como condição ao desenvolvimento do renomado centro de pesquisa. Além disso, a construção da Universidade, em área contígua, delimitada pelo decreto de 1941, era fruto de esforços coletivos, compartilhados pelos pesquisadores do Butantan, para os quais, a sua criação compactuava com a vocação científica do Instituto que, por fim, se fortaleceria com a atuação dos novos profissionais formados na USP. Em 1959, a definitiva implantação da Cidade Universitária acrescenta novos elementos à histórica relação com a USP, tornando-se um aspecto importante para o planejamento do Instituto Butantan e que permanece até hoje.

\subsubsection{O Centro de Memória do Instituto Butantan}

Buscamos apresentar, até este ponto, uma breve história da formação do Instituto Butantan e de seus principais edifícios que compõem o conjunto arquitetônico tombado em 1981, na esfera de preservação estadual, pelo Condephaat. Esta trajetória construtiva definida pelas primeiras décadas está, em boa parte, documentada pelos arquivos do Centro de Memória do Butantan, que guardam uma extensa documentação sobre a história do Instituto que completa 120 anos em 2021. 
Responsável pela guarda de seus documentos históricos, o Centro preserva fontes primárias em suportes diversos. Entre os itens de seus acervos estão mais de 17.000 fotografias, em diversos formatos, referentes à história institucional; relatórios anuais produzidos desde os primeiros anos de sua fundação, cartas (Figura 9) e documentos pessoais de seus diretores e pesquisadores, compondo o acervo textual; e, constituindo parte do acervo cartográfico, estão 1210 itens, entre mapas e projetos arquitetônicos, referentes à construção e ao planejamento do conjunto do Instituto ao longo de mais de um século.

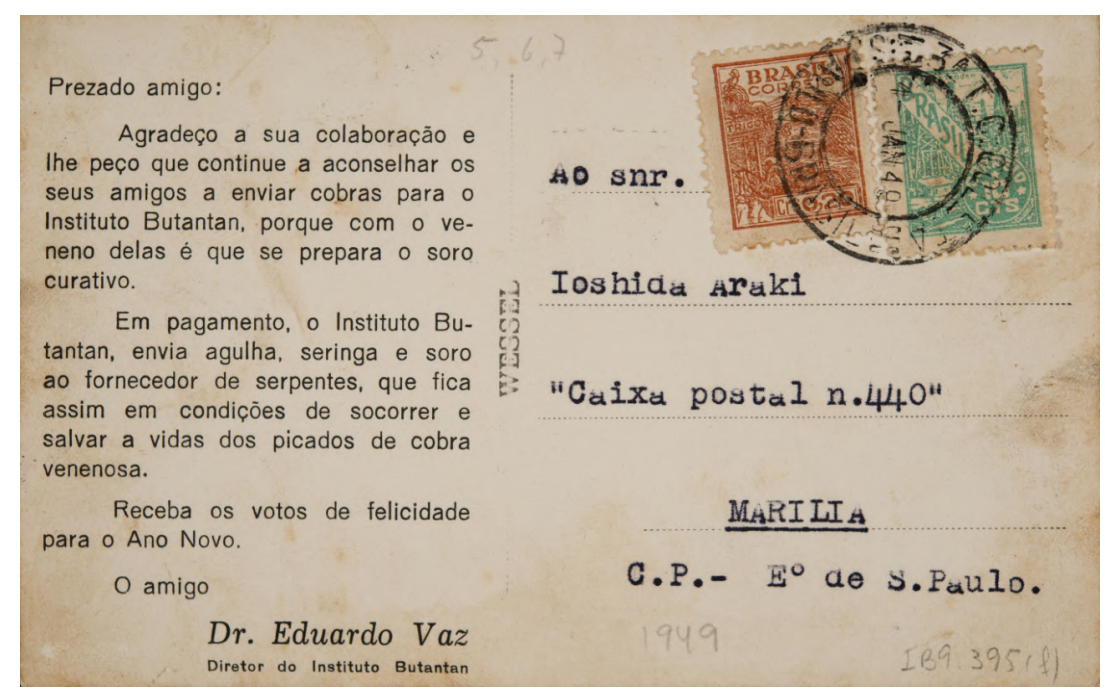

Figura 9: Carta do diretor Eduardo Vaz em agradecimento pelo envio de serpentes para a produção de soro no Instituto Butantan, 1949. Fonte: IB_ICO_008923, Centro de Memória/IB.

Além desta documentação textual e iconográfica, o arquivo guarda um importante material sonoro e audiovisual significativo da história da saúde pública de São Paulo, além de desenhos, coleções de gravuras e estudos de autoria de diversos de seus pesquisadores, compondo parte do acervo iconográfico. Desde o ano de 2019, quando foi elevado ao status de Centro de Memória, incorpora em seu acervo mais de 2.000 itens da coleção museológica, destinada à guarda dos artefatos expostos nos museus do Instituto Butantan, principalmente, no Museu Histórico.

Ao longo desta trajetória, os profissionais do Centro de Memória contribuíram decisivamente para a guarda, preservação e difusão da história do Instituto Butantan e 
da saúde pública no estado de São Paulo. Desde a sua fundação em 2010, como Núcleo de Documentação, é também responsável pela publicação de pesquisas e investigações históricas no campo da saúde pública, da história da ciência e do patrimônio cultural. Neste sentido, tem se consolidado como centro de pesquisa e de apoio a pesquisadores em diversas áreas de conhecimento promovendo, além da guarda de acervos e da pesquisa histórica, a realização de oficinas e eventos acadêmicos e oferecendo cursos voltados à museologia e à preservação do patrimônio cultural da saúde, inseridos no programa de especialização do Instituto Butantan.

\subsection{Considerações sobre os arquivos de arquitetura e urbanismo}

Recentemente, a discussão sobre os arquivos de arquitetura voltou a ter espaço significativo no debate público brasileiro. Esta relevância foi motivada por casos específicos, como a doação feita pelo arquiteto Paulo Mendes da Rocha, de seu próprio acervo, para uma instituição portuguesa, mas também pela preocupação com os rumos da cultura no país, com o desmonte das políticas públicas do setor e o enfraquecimento de órgãos e instituições de preservação. ${ }^{14} \mathrm{Em}$ carta aberta divulgada em Setembro de 2020, o Instituto de Arquitetos do Brasil defende a necessidade de constituição de uma política voltada aos acervos de arquitetura no Brasil, mencionando a preocupação com "a situação crítica que vigora no país em relação às políticas culturais, sob ataque constante e com estrangulamento de verbas" (IAB, 2020).

Todavia, não se trata de uma discussão inédita, nem mesmo recente. No que se refere ao patrimônio moderno brasileiro, a preservação de acervos de arquitetura e

14 As constantes nomeações de profissionais não capacitados aos cargos técnicos do IPHAN pelo atual Governo Federal (desde 2019), assim como o rebaixamento do Ministério da Cultura à condição de Secretaria Especial, subordinada ao Ministério do Turismo, são alguns exemplos do estado atual da cultura no Brasil. A própria condição designada à cultura como esfera complementar do turismo demonstra tal reducionismo, restringindo-a como mero artifício econômico. Esta situação, também se reproduz nas esferas regionais de preservação com a desestruturação do conselho técnico do Condephaat que se manifestou, por exemplo, na demolição da arquibancada popular do Estádio do Pacaembu, conhecida como "Tobogã", para a instalação de um complexo hoteleiro e, mais recentemente (2020), na recusa pelo tombamento do Conjunto Esportivo do Ibirapuera em favor da construção de um empreendimento imobiliário no local. 
urbanismo é debatida, ao menos, desde o período da redemocratização, durante os anos oitenta. Naquele momento, a sedimentação do movimento moderno e a perspectiva de abertura democrática inauguravam um novo cenário, no qual a arquitetura moderna brasileira passava a ser vista e percebida como parte da história, e novos caminhos eram debatidos por arquitetos e intelectuais brasileiros. Esta conjuntura somente foi possível com a institucionalização da pesquisa acadêmica no país e a consolidação de revistas especializadas sobre arquitetura (GUERRA, 2010, p.11-12), que constituíram as bases de uma retomada da arquitetura moderna como tema de investigação.

Este movimento de retomada do passado se relaciona a uma forma específica de percepção do tempo que passa a vigorar nas últimas décadas do século $X X$. Multiplicam-se, por diversas partes do mundo, os museus e instituições dedicadas à preservação do patrimônio e da documentação histórica, e se intensificam os processos de renovação dos centros históricos urbanos, em uma espécie de museificação das cidades. Diversos autores identificaram estes sintomas do período sob a ideia de patrimonialização ou da ascensão do patrimônio.

O historiador francês François Hartog (2013) aponta, no último quartel do século, a passagem para um novo regime de historicidade amparado pela experiência do passado, que na França se confunde com o bicentenário da Revolução Francesa, em 1989. Assim, se a categoria do "futurismo" definiu boa parte da experiência do tempo no século $X X$, esta cede espaço ao presentismo na medida em que vai se decantando o processo de modernização. Há uma retração da expectativa de redenção da humanidade pelo progresso técnico, tão comum ao ideário do século.

As décadas finais do breve século XX, como definiu Eric Hobsbawm (1995), são repletas de episódios, eventos históricos, que marcaram o encerramento ou a realização de um ciclo histórico, a exemplo do bicentenário da Revolução Francesa de 1789, comemorado em 1989, como mencionou François Hartog (2013). A queda do muro de Berlim no ano seguinte, em 1889, e o fim da União Soviética em 1991, por exemplo, encerrando a experiência socialista, são datas que ajudaram a conformar esta 
ideia de conclusão, de encerramento do regime moderno ou, ao menos, de sua crise (Ibid., p.136). O mesmo pode ser percebido na história brasileira que, para a sua arquitetura, tem nestas mesmas décadas um momento de revisão do seu passado próximo, em um contexto de transição para a democracia, cujo ano de 1988 contém um caráter simbólico.

Embora importantes, estas formas de experienciar o tempo guardam suas especificidades para o caso brasileiro e latino-americano. Por aqui, as aparentes contradições na ideia de vanguarda e modernidade - no Brasil e na América Latina como um todo - subvertem a lógica de funcionamento das vanguardas europeias. Neste sentido, Adrián Gorelik (2005) vai caracterizá-las como “Vanguardas Adjetivadas", que se voltam ao passado para construir o futuro nacional, formalizando o primeiro grande movimento para a preservação e, principalmente, para a construção da noção de patrimônio cultural que, no caso brasileiro, será pautado pela criação do SPHAN durante o Estado Novo, em 1937.

A partir desse ponto de vista, poder-se-ia dizer que o ciclo vanguardista na América Latina supos uma combinação diferente e contemporânea daquela que se produzia na Europa: entre um passado imaginável e um futuro disponível. Não se podia propor a tabula rasa porque o problema local por excelência era a tabula rasa: na América Latina não havia um passado clássico sólido para se aproveitar e reciclar, mas um "vazio" a preencher, o que explica o salto sem mediações por cima da história até os mitos de origem, para se inventar um passado comum para uma comunidade nacional que necessitava dele para se formar. (GORELIK, 2005, p.51-52)

Sem dúvida, o episódio das vanguardas modernas no Brasil pode ser visto como inaugural, e ao mesmo tempo transformador, da forma como se condicionou a importância do patrimônio histórico e cultural na sociedade brasileira. Percebe-se um modo distinto de apropriação do tempo, habilmente operada pelos intelectuais modernos para a construção nacional, que se alterna entre passado e futuro.

Outros episódios da história brasileira tornaram-se fundamentais como iniciativas de preservação do patrimônio nacional. As iniciativas mais específicas de preservação de documentos arquitetônicos podem ser considerada mais tardias, acompanhando a institucionalização do campo profissional e a consolidação do ensino 
nas escolas de arquitetura no país. Sem a intenção de identificar as ações originais, podemos mencionar arquivos importantes que se constituíram a partir da segunda metade do século $X X$, voltados à preservação e difusão de acervos de arquitetura e urbanismo.

Entre estes acervos mais recentes, surgidos na segunda metade do século $X X$, estão a Biblioteca da FAU USP, na cidade de São Paulo, e o Núcleo de Pesquisa e Documentação (NPD) da FAU UFRJ, na cidade do Rio de Janeiro. A primeira constituiuse a partir da década de 1960, abrigando acervos de diversos arquitetos, muitos professores da instituição, que ajudaram a conferir à Biblioteca da Faculdade uma importante posição como instituição de referência na guarda e pesquisa de acervos de arquitetura. O segundo, também ligado a uma universidade pública e ao ensino de arquitetura e urbanismo, é organizado aproximadamente duas décadas depois, no ano de 1982, constituindo, junto da Biblioteca da FAU USP, um dos principais arquivos voltados à preservação de acervos de arquitetura e urbanismo no Brasil e no mundo.

Estes arquivos voltados a uma categoria específica de documentação, no caso os documentos de arquitetura e urbanismo, se formaram a partir do fortalecimento da ideia de preservação dos documentos históricos e de projetos de arquitetura e da consolidação da pesquisa em nível de pós-graduação no país, como já mencionamos. Também é relevante destacar a condição histórica do país a partir das décadas de 1960 e 1970, quando a experiência moderna brasileira passava a acumular décadas de história. Tornava-se história mesmo que ainda se mantivesse como prática, realidade do cotidiano da profissão. Nas últimas décadas do século $X X$, o peso desta história vai se acumulando e consolidando o seu processo de decantação; o modernismo é convertido em tema de debate e objeto de pesquisa histórica.

Não é incoerente, portanto, que parte significativa dos acervos das instituições arquivísticas voltadas para a preservação de documentos de arquitetura no país, sejam compostos por materiais que remontam à arquitetura e aos arquitetos modernos. Neste sentido, também não são raros os acervos que vão sendo "descobertos", apontando para uma importante massa documental em processo de identificação e 
catalogação que, em alguns casos, não se encontra depositada em instituições especializadas para o seu acondicionamento, mas guardada por familiares dos arquitetos ou dispersa em locais desconhecidos. Estes documentos, base material para pesquisas históricas, mas também para o ensino nas escolas de arquitetura, são fundamentais para a complementação, a revisão e a diversificação da história da arquitetura e do urbanismo, construindo novas possibilidades de compreensão do processo histórico.

\subsubsection{A atualidade da questão dos acervos arquitetônicos}

Atualmente, a discussão sobre os arquivos de arquitetura e urbanismo voltam a ganhar importância e a ter centralidade por motivos diversos. Em um primeiro aspecto, as novas tecnologias da informação têm impactado de forma decisiva na organização arquivística. Assim, a possibilidade de digitalização de documentos, por exemplo, ampliam progressivamente o seu potencial de difusão, tornando-os acessíveis a pesquisadores e ao público em geral em diversas partes do mundo. Este fenômeno foi possível com a expansão do acesso à internet nas últimas décadas, atrelada a internacionalização acadêmica e à valorização dos acervos arquitetônicos, que têm recebido atenção exclusiva em exposições dedicadas à arquitetura por todo o mundo, sendo cultuados como objeto artístico.

Neste sentido, se a arquitetura está no edifício construído, tem sido deflagrado um caminho inverso, de valorização do processo criativo e de resgate da produção documental de personagens importantes da arquitetura do século passado. No Brasil, podemos destacar nas últimas três décadas o surgimento de novos acervos autorais de arquitetura, assim como a publicação de livros de caráter biográficos sobre determinados arquitetos e a organização de exposições, que se alimentam dos documentos destes novos acervos.

Para citar alguns destes casos temos, no início dos anos noventa, a fundação do Instituto Bardi, buscando preservar a obra da arquiteta Lina Bo e de Pietro Maria Bardi. 
Mais recentemente, entre outras iniciativas surgidas no período, destacamos: a organização do acervo do arquiteto Fabio Penteado, as chamadas "ocupações" organizadas pelo Itaú Cultural em São Paulo, que nesta década contemplaram as obras dos arquitetos Flávio Império, Vilanova Artigas, Paulo Mendes da Rocha e Gregori Warchavchik, além da exposição Infinito Vão, sobre a arquitetura moderna brasileira, ocorrida entre 2018 e 2019 na Casa da Arquitetura, em Portugal (FERRAZ, 2019). ${ }^{15}$

Na mesma medida, esta valorização dos acervos de arquitetura pelo mundo tem confluído para um cenário de acirramento e de intensificação das disputas pelos acervos autorais de arquitetos consagrados. Embora a expatriação de objetos de importância histórica e cultural não configure um fenômeno contemporâneo, visto que a pilhagem de artefatos históricos e arqueológicos na história moderna foi um fator decisivo para a montagem de muitas instituições museológicas europeias, a discussão tem ganhado novos contornos a partir de acontecimentos recentes.

Dito isto, esta dissertação, cuja base material se apoia na pesquisa em arquivos públicos, não poderia deixar de discutir a querela surgida em torno da recente doação feita pelo arquiteto Paulo Mendes da Rocha de seu acervo, para a mesma Casa da Arquitetura em Portugal. Nos cabe acrescentar que neste ambiente de disputa, cujas instituições privadas situadas principalmente em países europeus largam a frente, os objetos e documentos de valor cultural têm obtido um novo status que os coloca como agentes de valorização local. Projetos museográficos e expositivos, pensados como elementos centrais na reabilitação ou na inserção de certos espaços em um circuito global de uma economia da cultura, capazes de intensificar o turismo e alçar determinada região a um novo patamar, dando visibilidade ao mecenato contemporâneo que financia tais iniciativas, frequentemente ligadas a instituições financeiras.

Neste sentido, há uma subversão da função arquivística, que perde o seu espaço de guarda e difusão dos documentos históricos para a produção de

15 Exposição "Infinito vão - 90 anos de arquitetura brasileira", Casa da Arquitectura - Centro Português de Arquitectura, Matosinhos, 28 de setembro de 2018 a 28 de abril de 2019. Comissariado geral Nuno Sampaio. Curadoria Fernando Serapião e Guilherme Wisnik. 
conhecimento e preservação da memória. As fontes primarias, base da pesquisa em história, tornam-se ativos financeiros inseridos num circuito de valorização através de grandes e espetaculares exposições de alcance global.

Neste novo contexto, convém relembrar a centralidade dos documentos históricos para as sociedades humanas que, segundo Jaques Le Goff (1990, p.548), representam o poder das sociedades do passado sobre a memória do futuro. Neste sentido, acrescentamos, na atual conjuntura a importância da preservação documental e das instituições arquivísticas se voltam para a questão da soberania das sociedades, do seu direito de preservação da própria cultura como forma de perpetuação da memória coletiva. Além de guardar fontes materiais do passado, preservar esta memória é, fomentar uma cultura autônoma diante da acelerada difusão de informações na era digital.

\subsubsection{O Acervo Cartográfico do Centro de Memória}

De fato, o que sobrevive não é o conjunto daquilo que existiu no passado, mas uma escolha efetuada quer pelas forças que operam no desenvolvimento temporal do mundo e da humanidade, quer pelos que se dedicam à ciência do passado e do tempo que passa, os historiadores. (LE GOFF, 1990, p.535)

Nesta passagem de sua importante crítica dos documentos, presente no livro História e Memória (1990), o célebre historiador francês Jacques Le Goff sintetizou, de forma precisa, o caráter complexo das fontes documentais para o ofício do historiador. Abordando a oposição entre documento e monumento, Le Goff argumenta que os vestígios do passado não são elementos absolutos da história, como se constituíssem artefatos preservados no tempo que representariam integralmente os eventos históricos. Pelo contrário, pouco há de acaso na perpetuação destes materiais. São fruto da escolha consciente daqueles que nos antecederam, preservados e constituídos pelas forças que atuaram no tempo. Neste sentido, o historiador é apresentado como um destes atores que operam a seleção dos vestígios que vão fundamentar a análise histórica. 
Esta perspectiva crítica das fontes históricas, material que constitui e constituiu a base do ofício dos historiadores, está amplamente vinculada à renovação documental proposta desde a primeira geração dos historiadores da Escola dos Annale que, como vimos anteriormente, defenderam a ampliação da noção de documento. Esta renovação, da qual Le Goff faz parte, coloca em xeque a noção de neutralidade e imparcialidade dos documentos, onde a função do historiador estaria apenas em resgatá-los para, em consequência, reconstituir o passado, cujo documento aparece como prova de sua existência.

Em última instância, esta crítica ao documento, coloca em evidência como este é carregado de intenções, de esforços pela preservação de uma determinada cultura ou grupo em detrimento de outros, como elemento de sua perpetuação no tempo. Pela sua intencionalidade, o documento, material selecionado pelo historiador, se aproxima do monumento, herança do passado que se manifesta, por exemplo, na arquitetura (LE GOFF, 1990, p.536). ${ }^{16}$

Embora a preocupação de Jacques Le Goff quanto ao caráter ambivalente dos documentos históricos esteja, sobretudo, depositada nos estudos da história medieval, pela qual o seu trabalho é amplamente conhecido, estas questões servem a todos os historiadores e pesquisadores que trabalham com fontes primárias. Deste modo, esta condição do documento nos permite introduzir uma questão central para o objeto desta pesquisa, na medida em que esta se apoia sob uma significativa e relevante massa documental relacionada à arquitetura, mas que, não diretamente, se desdobra sobre o espaço construído.

Algumas questões permearam esta pesquisa desde o princípio, quando foram feitas as primeiras aproximações com o acervo cartográfico do arquivo do Centro de Memória. A primeira destas questões corresponde a uma expectativa não confirmada: a de que os documentos de arquitetura guardados no acervo se referiam ao conjunto construído do Instituto Butantan. Ora, na medida em que se trata de um conjunto

16 Como exemplos de monumento, Jacques Le Goff menciona o arco do triunfo, o pórtico ou coluna, elementos comemorativos intencionalmente erigidos como forma de preservação da memória de um evento relevante para determinada sociedade. 
arquitetônico (Figura 10) de grande relevância como patrimônio histórico e arquitetônico, com edifícios centenários, esperava-se que os projetos destes edifícios fizessem parte do acervo institucional. De fato, alguns destes projetos estão presentes no acervo, todavia, constituem uma parte surpreendentemente minoritária, como veremos no capítulo 2 .

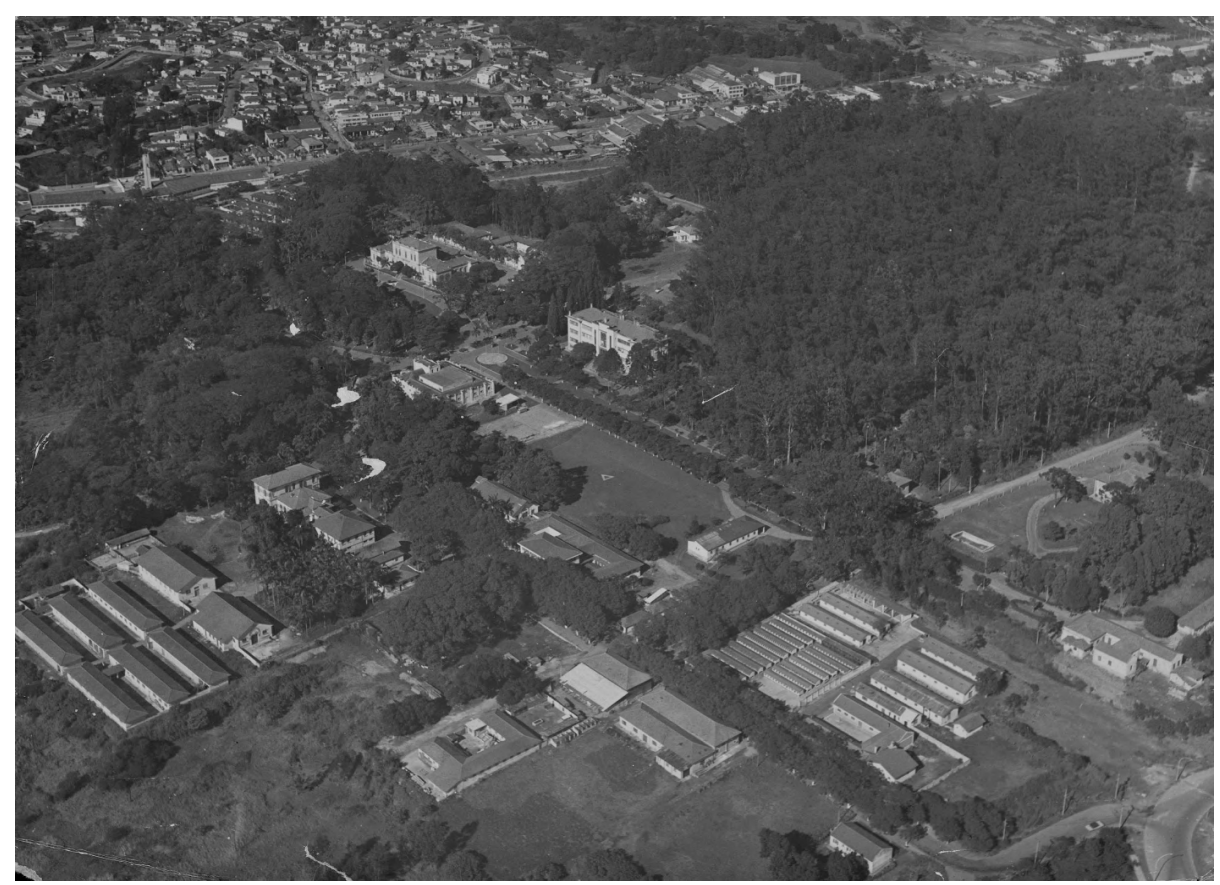

Figura 10: Imagem aérea do eixo turístico do Instituto Butantan, onde estão a maior parte dos edifícios históricos tombados, sem data, provavelmente da década de 1970. Fonte: IB_ICO_008923, Centro de Memória/IB.

Uma segunda questão que surgiu neste processo foi a inquietação ao se deparar com a grande quantidade de projetos de arquitetura moderna, desconhecidos em sua maioria, produzidos para o Instituto Butantan ao longo da década de 1960, que não haviam sido construídos, como se estes documentos "clamassem" pela sua divulgação e publicização. Esta discrepância entre os projetos e o conjunto existente nos fez imaginar uma situação hipotética, na qual um historiador do futuro que se defrontasse com estes documentos pudesse imaginar um centro de pesquisa composto por uma arquitetura moderna e arrojada, em contraste com os prédios históricos existentes.

Do mesmo modo, a existência destes documentos nos alertou para a 
necessidade de resgate de uma história que não se manifesta na paisagem que o Instituto Butantan transmite aos seus milhares de visitantes; ${ }^{17}$ a imagem do Instituto tradicional montado nas primeiras décadas do século XX, cujos edifícios históricos são os protagonistas do setor turístico. De certo modo, as centenas de documentos que registram os projetos de modernização ensaiados nos anos 1960, confrontam a imagem oficial que o conjunto arquitetônico tombado imprime.

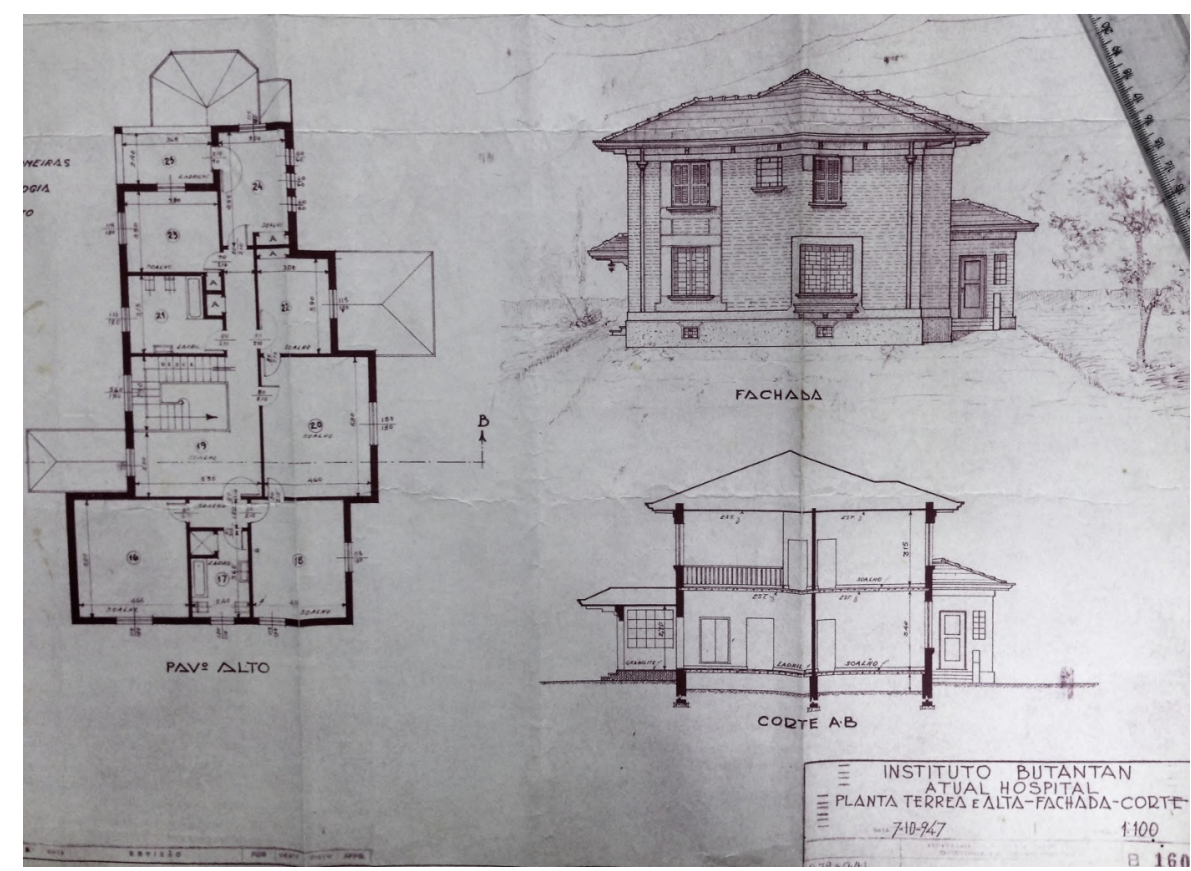

Figura 11: Projeto para o prédio da residência do diretor, atual Casa de Afrânio do Amaral, projeto do engenheiro arquiteto Mauro Álvaro de 1931. Fonte: prancha 50.28, Centro de Memória/IB.

Em suma, objeto central desta pesquisa, os projetos modernos desenvolvidos através do Plano de Ação a partir de 1959 estão largamente documentados no acervo cartográfico. Todavia, o conjunto do acervo guarda uma infinidade e enorme variedade de projetos desenvolvidos ao longo de mais de 120 anos de história institucional, desenvolvidos por muitos profissionais, arquitetos e engenheiros, que planejaram estes espaços segundo as mais avançadas técnicas e formas arquitetônicas, representando o progresso do Instituto e do estado de São Paulo (SÁ, 2019, p.248).

17 Segundo o Relatório Anual do Instituto Butantan do ano de 2018, somente as exposições de longa duração, sediadas nos três museus da instituição, receberam 288.434 visitantes ao longo do ano, mesmo com fechamento do Museu Biológico para reformas e com a suspensão das atividades em dias de jogos do Brasil na Copa do Mundo que ocorreu naquele ano. 


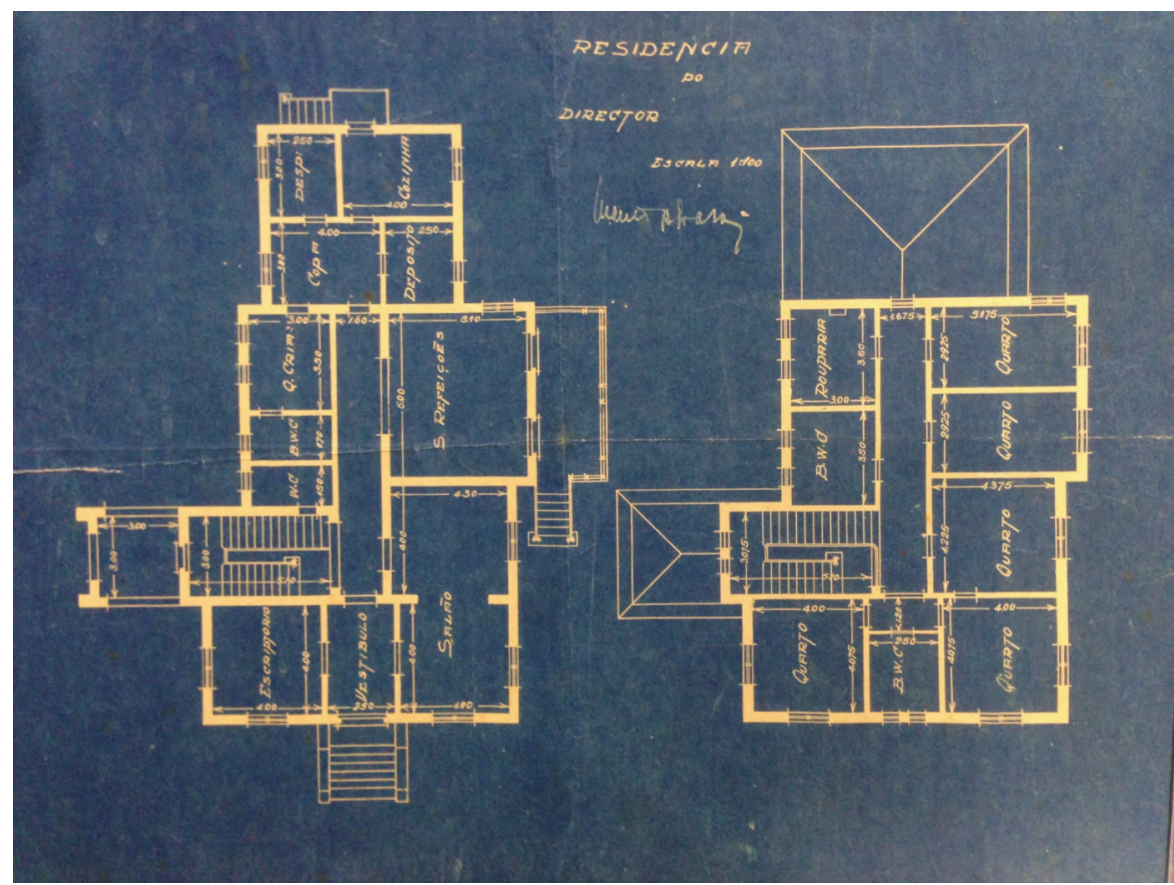

Figura 12: Planta dos dois pavimentos da residência do diretor, projeto do engenheiro arquiteto Mauro Álvaro, 1931. Fonte: prancha 50.29, Centro de Memória do IB.

Projetos de boa parte dos edifícios históricos, construídos nas primeiras quatro décadas do Instituto estão guardados no acervo. Por exemplo, a casa construída pelo então diretor Afrânio do Amaral (Figuras 11 e 12), durante a sua segunda passagem pela direção do Instituto (1928-1938) é um dos importantes prédios do conjunto que está representado no acervo. Projetado pelo engenheiro arquiteto Mauro Álvaro, que elaborou outros prédios do Instituto nestas primeiras décadas ${ }^{18}$, o edifício foi planejado como residência do diretor e da sua família, que não possuíam uma residência no local, sendo obrigados a se deslocar diariamente para o centro da cidade, distante alguns quilômetros da Fazenda Butantan.

O edifício Vital Brazil, principal e primeiro projeto de grande porte construído no período das "Construções Institucionais" do Butantan, em um momento no qual se acelerou a ocupação e a expansão do Instituto (SÁ, 2019, p.247), apresenta uma prédio mais representativo e frequentemente vinculado à imagem do Instituto Butantan. Também projetou o serpentário, localizado à frente deste, o Prédio da Cocheira dos anos 1910, onde se encontra o Museu Biológico, e o edifício anexo à residência do diretor, onde hoje se encontra a creche dos funcionários do Instituto. 
documentação particular no acervo do Centro de Memória. Curiosamente, são poucos os itens do acervo que se referem ao mais significativo edifício institucional, adotado e representado como imagem do Butantan desde a sua inauguração, há mais de um século. Um dos poucos projetos conservados é uma planta de instalações elétricas (Figura 13) datada de 1928, produzida pela São Paulo Tramway, Light and Power Company, registrando a implantação de uma infraestrutura de energia elétrica na região afastada do centro urbanizado.

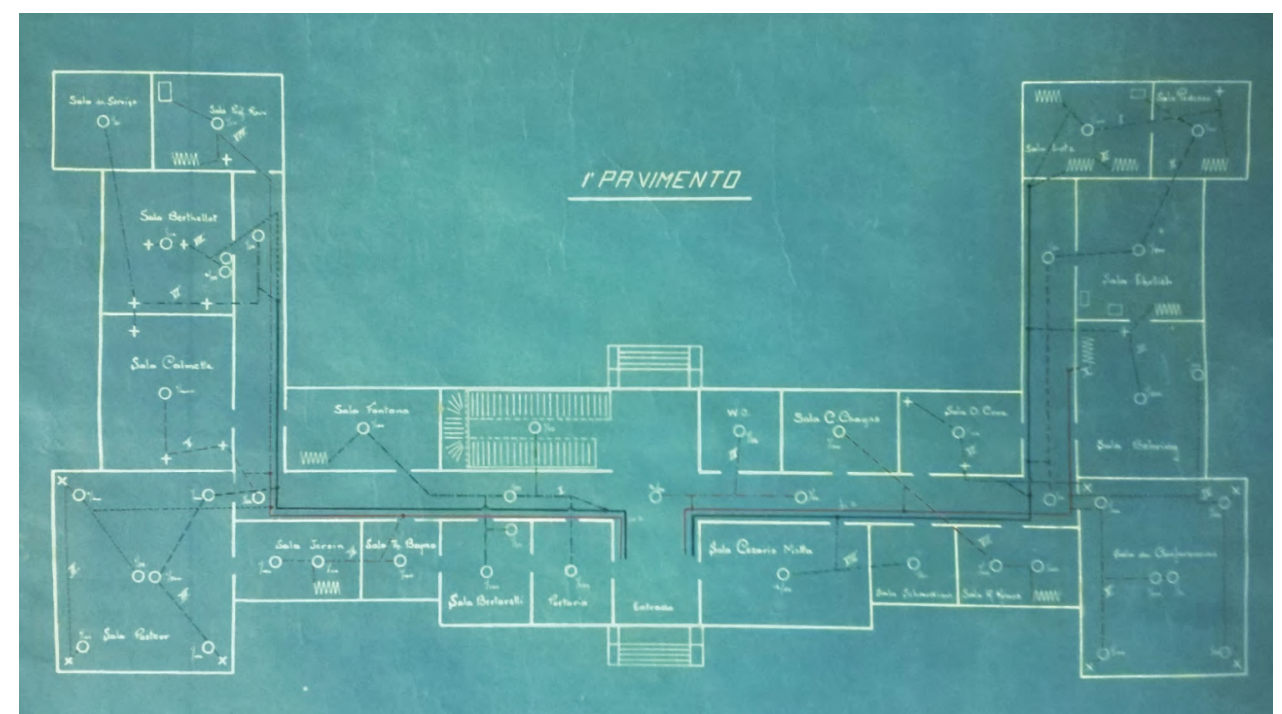

Figura 13: Planta de pontos e instalações elétricas do 1ㅇ pavimento do Edifício Vital Brazil pela S. P. T. L. \& P. Co., 1928. Fonte: prancha 24.12, Centro de Memória do IB.

Outro interessante, porém, menos conhecido projeto deste período que está documentado no acervo é da Cocheira-biotério, ou prédio da cavalariça, segundo o projeto existente no acervo (Figuras 14 e 15). De autoria desconhecida, o edifício construído na década de 1920, ficou popularmente conhecido como "Cara de Cavalo", por ser designado como cocheira-enfermaria para os animais da Escola de Veterinária ${ }^{19}$ e, principalmente, pelos elementos que adornam a fachada do prédio indicando a sua função. Estes adornos da fachada são constituídos por três relevos no formato de cabeças de animais (uma de boi e duas de cavalo) posicionadas na entrada principal do edifício. Um segundo edifício idêntico foi construído, sem os adornos da fachada.

19 Em 1917, criou-se no Instituto Butantan uma Escola de Veterinária que motivou a construção do Pavilhão Lemos Monteiro. A iniciativa, no entanto, não foi bem recebida por Vital Brazil pelas questões relacionadas à presença de animais doentes em uma instituição dedicada à produção de imunobiológicos. Sobre o edifício da Escola de Veterinária ver SÁ (2019, p.160). 


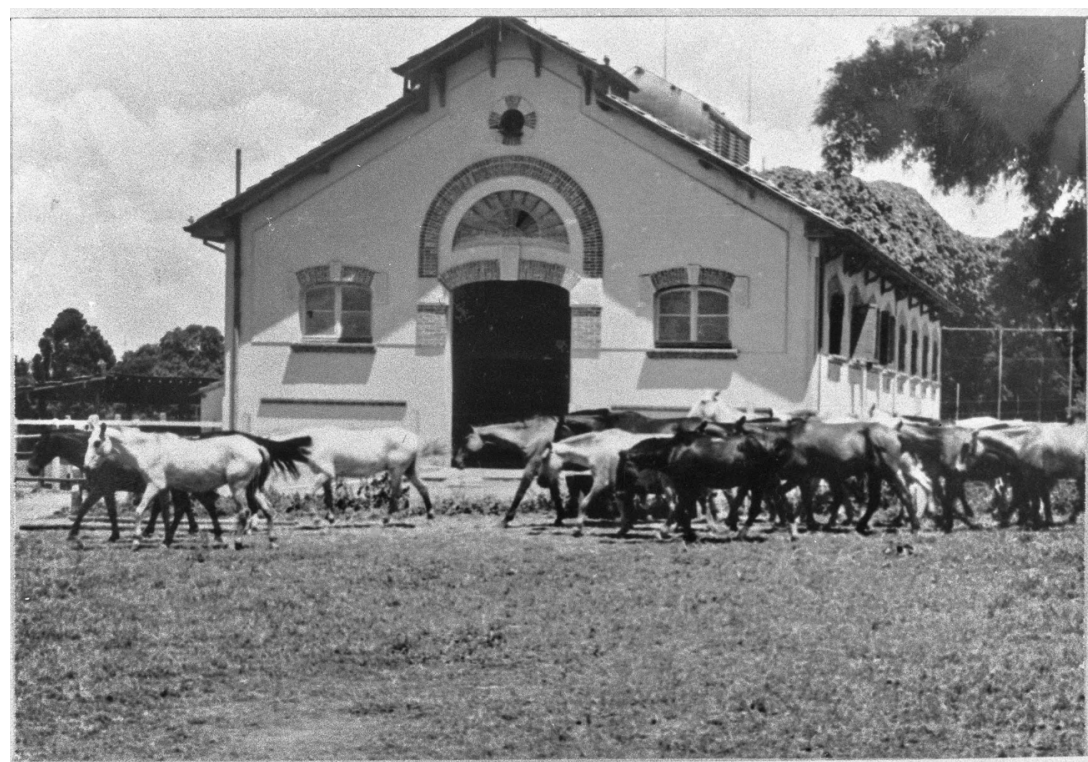

Figura 14: Cocheira gêmea, construída sem os relevos no arco de tijolos acima da entrada, data desconhecida. Fonte: IB_ICO_003378, Centro de Memória/IB.

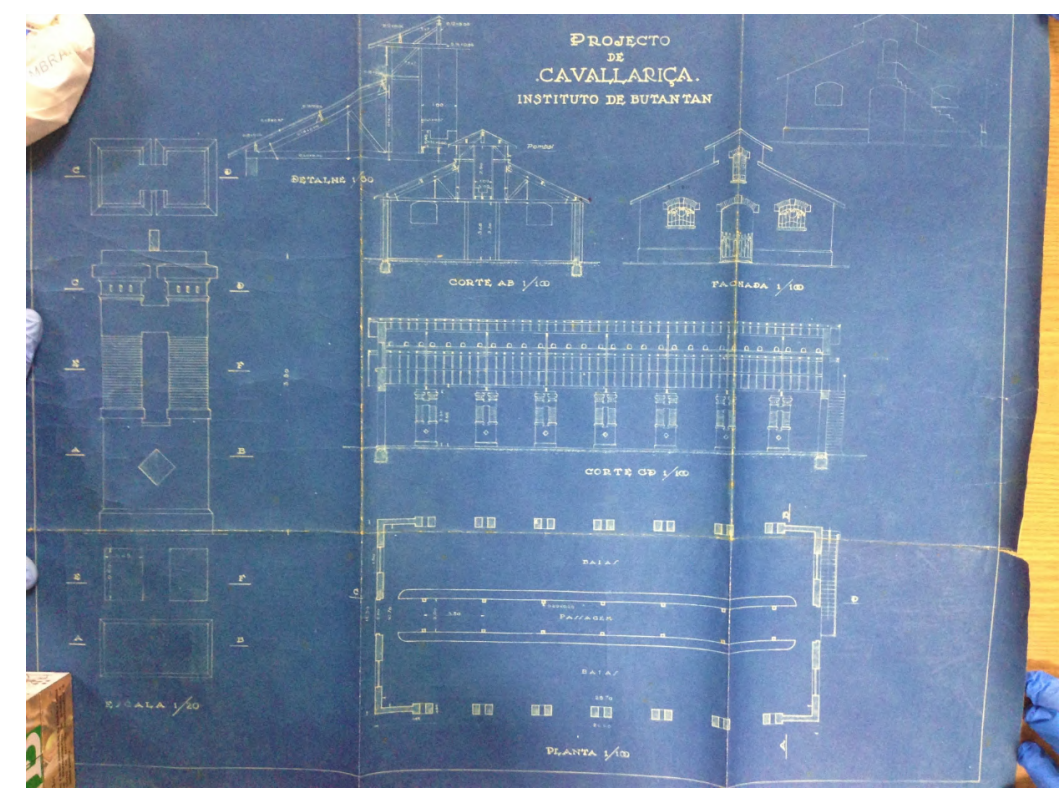

Figura 15: Projeto para o prédio da cavalariça, conhecido como "Cara de Cavalo", década de 1920. Fonte: prancha 51.01, Centro de Memória/IB.

A forma e a estrutura do edifício são simples e convencionais, mas reforçam uma simbologia importante para o Instituto. Sua estrutura é feita em alvenaria autoportante servindo de sustentação para as tesouras de madeira de "duas águas" que apoiam o telhado (MONTEIRO, 2017, p. 28), por sua vez, se divide em dois níveis, criando uma espécie de lanternim, uma abertura para a iluminação e ventilação em 
sua parte mais alta, algo bastante comum em tipologias fabris e de estábulos para animais. A antiga cavalariça está posicionada ao lado do amplo espaço aberto que servia como área de pastagem, atualmente adotado como espaço de recreação e heliponto, num ponto central do eixo turístico do Instituto.

O edifício conhecido como "Prédio Novo", iniciado em 1938 para receber os laboratórios de pesquisa e produção que se tornou um dos mais importantes e reconhecidos edifícios do eixo turístico do Butantan, também marca o encerramento do período que pode ser denominado como o das "construções institucionais", seguindo a periodização proposta por Anderson de Sá (2019). Este período, definido entre 1910 e 1941, é marcado pela expansão e consolidação do Butantan, quando é montada a estrutura edilícia, viária e paisagística que confere um sentido e uma organização urbanística ao conjunto disperso e de aspecto rural predominante (Ibid., p.247-248). Segundo Anderson Luiz Félix de Sá:

\footnotetext{
Em termos de linguagem arquitetônica, este edifício pode ser considerado o marco do final da fase ligada às expressões do início do século XX no campus, sendo a única construção de vulto a adotar o Art Déco, e possivelmente esse seja um dos motivos pelos quais o apelido "Prédio Novo" tenha sido adotado, pelo contraste que surgia em relação aos primeiros edifícios do núcleo histórico. Esse contraste ainda é percebido quando se percorre o conjunto, já que o prédio mantém as principais características externas, ainda que tenha sofrido alterações. (SÁ, 2019, p.193)
}

Embora seja o prédio mais recente dentre os que compõem o conjunto de edifícios históricos, o projeto completo do "Prédio Novo" construído pelos engenheiros politécnicos Francisco Azevedo e Francisco Palma Travassos não consta no acervo, onde se encontram somente algumas plantas e materiais gráficos. $\mathrm{O}$ acervo de fotografias do Centro de Memória guarda alguns materiais relacionados ao edifício, como as plantas dos seus quatro pavimentos e uma interessante ilustração da fachada (Figuras 16 e 17). As fotografias são os mais importantes registros da construção do edifício nos anos 1940, guardados no acervo estão fotos do prédio em obras, dos seus interiores e do evento de sua inauguração. 


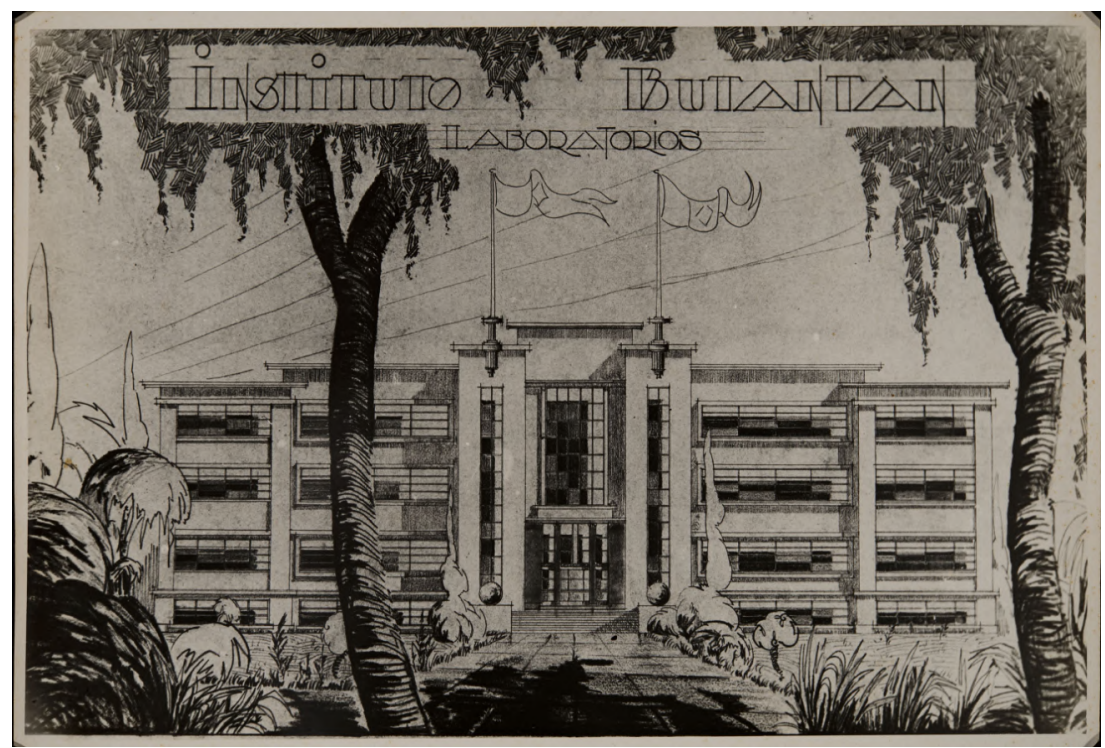

Figura 16: Ilustração da fachada do Prédio Novo. Fonte: IB_ICO_008488, Centro de Memória/IB.

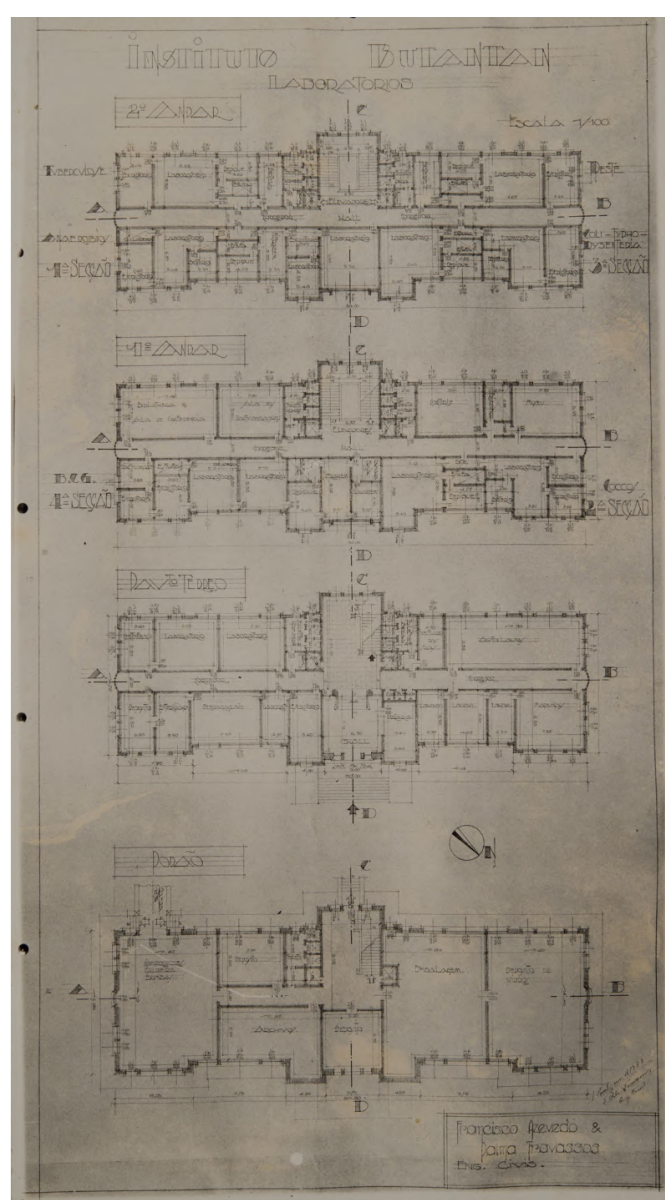

Figura 17: Fotografia do projeto dos pavimentos tipo do edifício conhecido como Prédio Novo, construído entre 1938 e 1945. Fonte: IB_ICO_008479, Centro de Memória/IB. 
Resumidamente, excluídos os projetos modernos do período do Plano de Ação e do convênio com a construção da Cidade Universitária, que vai até o ano de 1981, a composição do acervo cartográfico é caracterizada por estas descontinuidades, guardando fragmentos de projetos dos edifícios que conformam o conjunto arquitetônico do Butantan. No entanto, o acervo não é formado somente por projetos autorais de edifícios simbólicos para a instituição. É interessante notar que muitos projetos datados destas primeiras décadas são "projetos padrão" (Figura 18), produzidos por órgãos do estado para a construção de infraestruturas comuns em ambientes rurais.

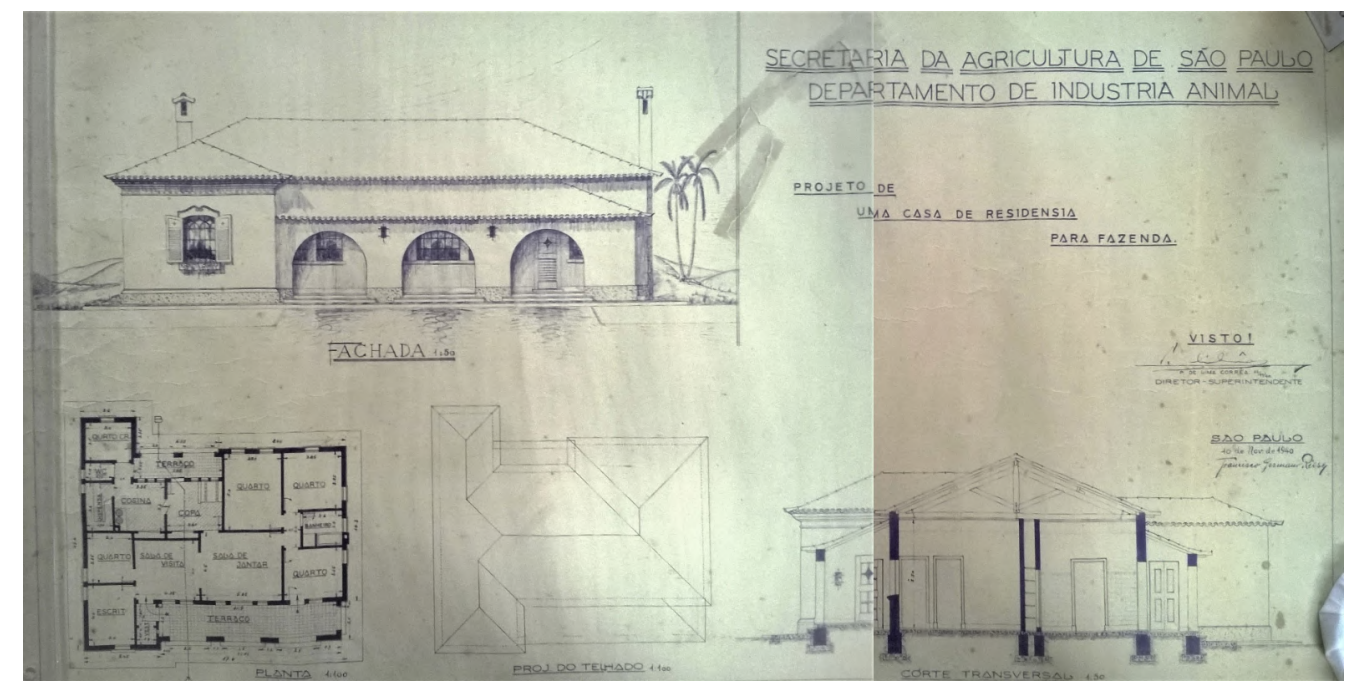

Figura 18: Projeto de uma residência para fazenda produzido pela Secretaria da Agricultura de São Paulo, 1940. Fonte: prancha 41.29, Centro de Memória/IB.

São projetos para silos, currais, abrigos para animais, e todo tipo de edificação rural e para fazendas, como estábulos e cavalariças, casa para colonos e residências. São projetos produzidos por órgãos ligados ao governo estadual e federal, como a Secretaria da Agricultura de São Paulo e do Ministério da Agricultura, que possuíam departamentos próprios para o desenvolvimento de projetos para instituições públicas, e que faziam circular estes desenhos padronizados para a construção em áreas rurais.

Outra categoria de projetos presentes no acervo é a de mapas e planos urbanísticos. Constam no acervo planos para o campus do Instituto Butantan que registram a sua ocupação física inicial nas primeiras décadas de sua implantação, 
passando pela sua expansão ao longo do século $X X$, até planos mais recentes que se relacionam com a as iniciativas pela preservação do conjunto e com a elaboração do plano diretor do campus. Uma série de seis mapas (Figura 19) registra o desenvolvimento dos espaços do campus entre 1901, ano de sua efetiva implantação na fazenda Butantan, até o ano de 1989 quando o seu conjunto já havia sido tombado pelo Condephaat.

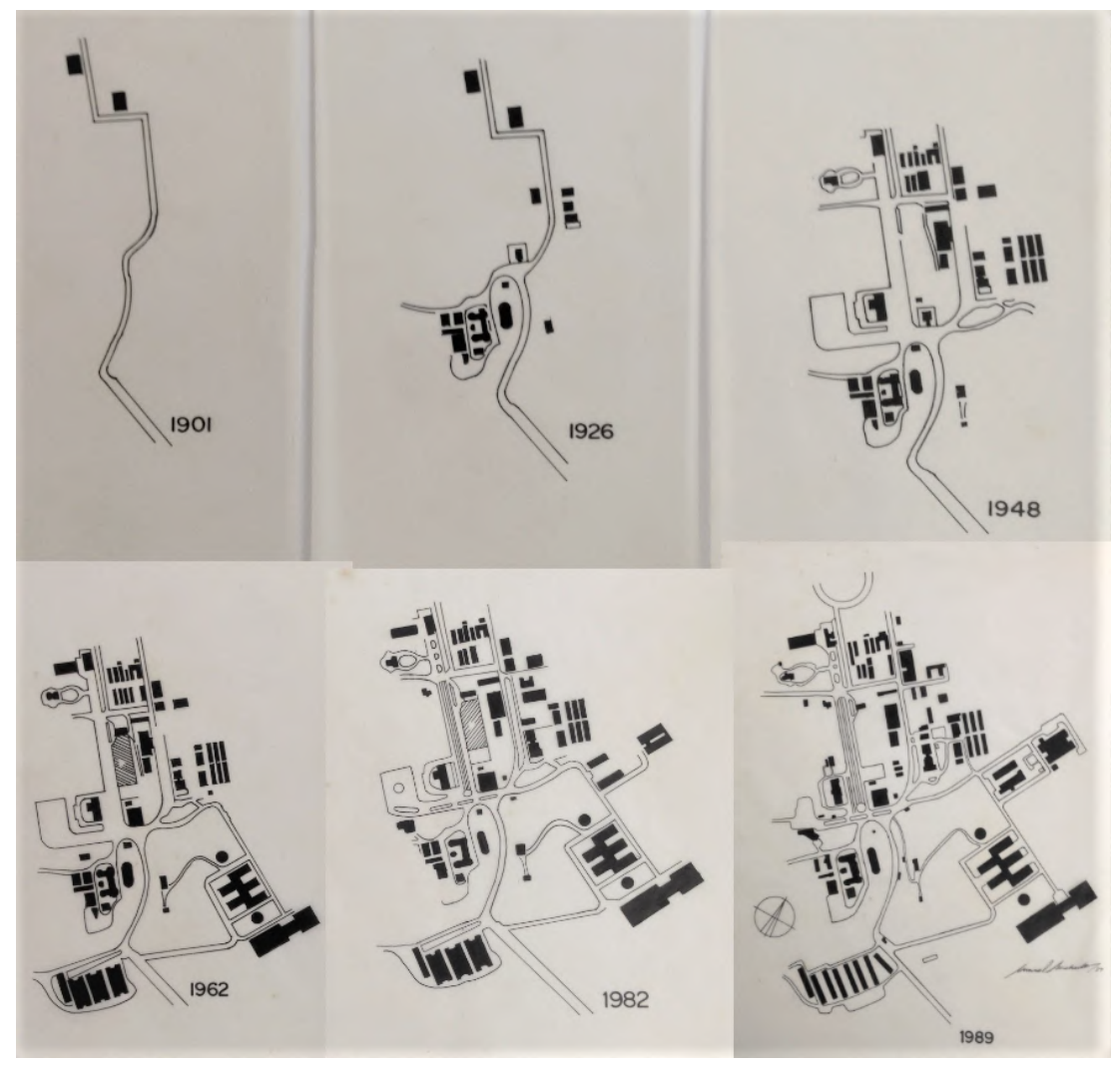

Figura 19: Série de seis mapas tipo figura fundo apresentando a evolução da ocupação territorial do Instituto Butantan ao longo do século XX, caneta sobre papel vegetal, Samuel Machado, 1989. Fonte: dossiê 59.12, Centro de Memória/IB.

Não estão claras as intenções nem o contexto de elaboração destes mapas do tipo figura fundo, desenhados a mão sobre papel vegetal e assinados por Samuel Machado no ano de 1989. De toda forma, esta série de mapas nos mostra alguns aspectos que talvez fossem relevantes para o autor no momento de sua elaboração. Por exemplo, colocados lado a lado, como expostos na Figura 19, os desenhos nos mostram a formação de um núcleo que se expande até a década de 1940 e parece consolidado no mapa de 1962, sofrendo pequenas adições e alterações nos mapas 
seguintes, ao menos considerado o seu núcleo central. Isto se deve por motivos diversos, mas que se relacionam com a consolidação do núcleo central do conjunto a partir da década de 1940, que vai se aprofundar com esforços pela sua patrimonialização nas décadas seguintes até 1981. Não por acaso este período coincide com os anos do Plano de Ação, que legaram ao Butantan um convênio de duas décadas com a Cidade Universitária.

O primeiro mapa da série, do ano de 1901, nos mostra o ponto de partida da ocupação territorial e a situação precária do início das atividades do Instituto. Neste momento, ocupou-se a casa sede da antiga fazenda, atualmente denominada Casa Vital Brazil, também conhecida como Casa Rosa, além de um segundo prédio, inicialmente utilizado de forma improvisada como laboratório, que foi reconstruído em 1981 para a instalação do Museu Histórico. A comparação dos mapas de 1926 e 1948 nos mostra a organização viária do campus, com a construção da alameda principal que se tornou o eixo do núcleo histórico do Instituto Butantan.

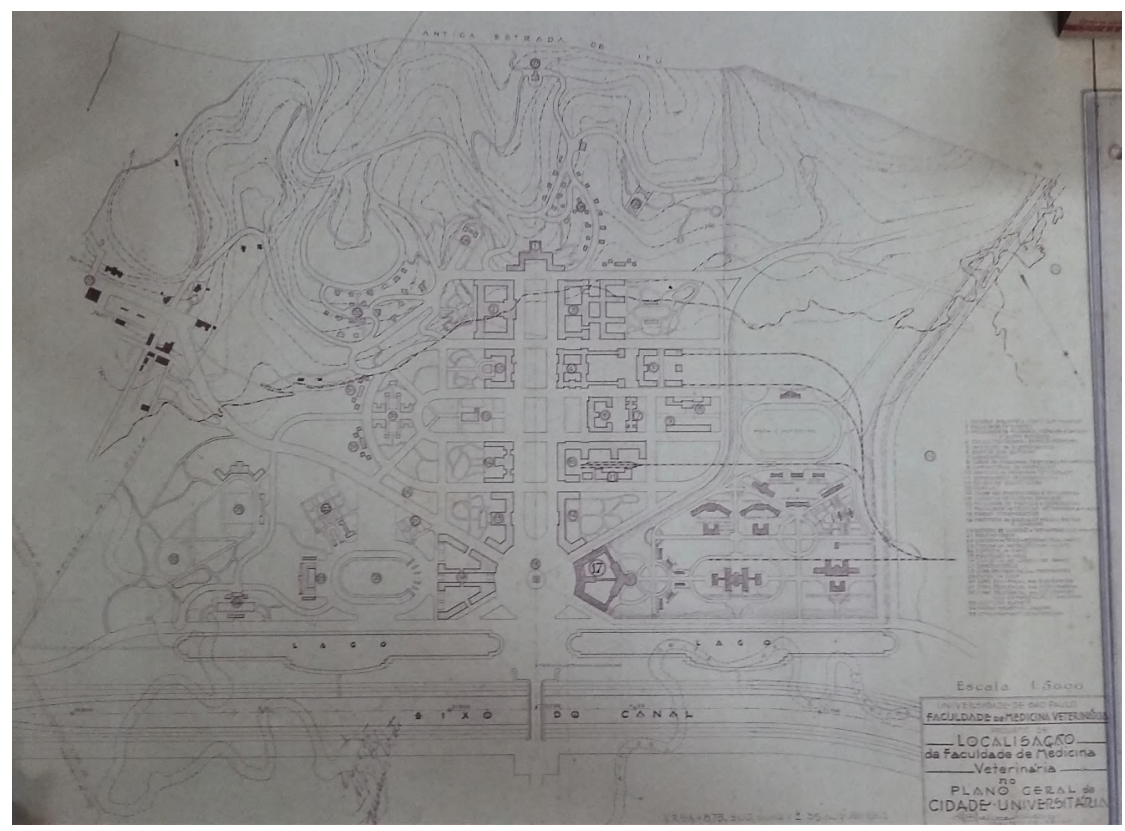

Figura 20: Plano de implantação da Universidade de São Paulo com indicação dos edifícios do Instituto Butantan na parte superior esquerda, 1943. Fonte: prancha 5.07, Centro de Memória/IB.

Entre outros, também estão preservados no acervo cartográfico, mapas de São Paulo e da porção oeste da cidade que, provavelmente, ajudaram a embasar as 
iniciativas de planejamento do campus localizado próximo às áreas alagadiças do rio Pinheiros, cuja retificação teve início em 1928. Do mesmo modo, a situação territorial tornou-se uma questão relevante para o Instituto a partir do desmembramento de três quartos de sua área para a criação do campus da USP em 1941.

Neste contexto, com frequência os planos desenvolvidos para a Cidade Universitária a partir de 1941 levavam em conta o campus do Instituto Butantan. Alguns destes projetos, que registram as ideias e intenções de ocupação de um território muito pouco urbanizado, no qual o Butantan aparece a frente deste processo, estão documentados no acervo do Centro de Memória. Um dos primeiros planos para a USP (Figura 20), datado de 1943, propõe a integração das duas instituições e de seus campi através de uma via que liga o eixo principal do Butantan ao eixo universitário.

No final da década de 1940 o modernismo se afirmava como uma realidade para a arquitetura e para os arquitetos brasileiros, em uma conjuntura favorável ao desenvolvimento da arquitetura moderna no país que, naquele momento, se apoiava majoritariamente sobre a matriz corbusiana do movimento internacional. Neste mesmo cenário, que confere reconhecimento mundial à arquitetura de Oscar Niemeyer, o Instituto Butantan constrói um dos poucos edifícios modernos de seu conjunto e o único que se vincula à arquitetura carioca. ${ }^{20}$

Desenvolvido pelos arquitetos Helio Duarte e Ernest Mange o edifício (Figura 21), inaugurado em 1952, era destinado à recepção de serpentes para a extração de venenos, já que era muito comum que animais peçonhentos capturados por todas as regiões do estado e do país fossem enviados ao Butantan que, inclusive, fomentava campanhas de recepção de animais para a produção de soros. Conforme Anderson de Sá, o pequeno edifício:

[...] veio trazer uma corrente arquitetônica até então distante do que era

20 O primeiro edifício de feições modernistas construído no Butantan foi o Pavilhão Vital Brazil, inaugurado em 1948. Ainda que incipientes, suas características principais remontam à arquitetura de Frank Lloyd Wright, sendo originalmente composto por um único volume coberto por um telhado de quatro águas, e que foi descaracterizado por uma série de ampliações que quadruplicaram o seu tamanho inicial. Ver MONTEIRO (2017, p.30). 
feito no campus, com elementos característicos do modernismo, como a estrutura aparente, formas depuradamente geométricas e os grandes panos de vidro, desmaterializando a volumetria. Essa combinação de planos inclinados, pilares esbeltos e revestimentos vincula essa arquitetura muito mais à escola carioca da Arquitetura Moderna. (SÁ, 2019, p.203)

Neste sentido, o autor acrescenta (Ibid., p.204) que o campus de Manguinhos da Fundação Oswaldo Cruz, no Rio de Janeiro - instituição coirmã do Butantan fundada em 1900 pelo médico sanitarista Oswaldo Cruz - já possuía em seu conjunto de edifícios um exemplar moderno: o Pavilhão Arthur Neiva, projetado pelo arquiteto Jorge Ferreira e inaugurado em 1951. O edifício modernista da instituição carioca, vinculada ao governo federal, possui dimensões muito maiores que a do pequeno exemplar moderno do Butantan mas que, por sua vez, demonstra um certo esforço de atualização da instituição paulista ao passo do desenvolvimento da linguagem arquitetônica da época. O projeto está conservado no acervo cartográfico do Centro de Memória do Instituto Butantan, embora a condição de sua reprodução fotográfica seja limitada pelo seu estado de conservação.

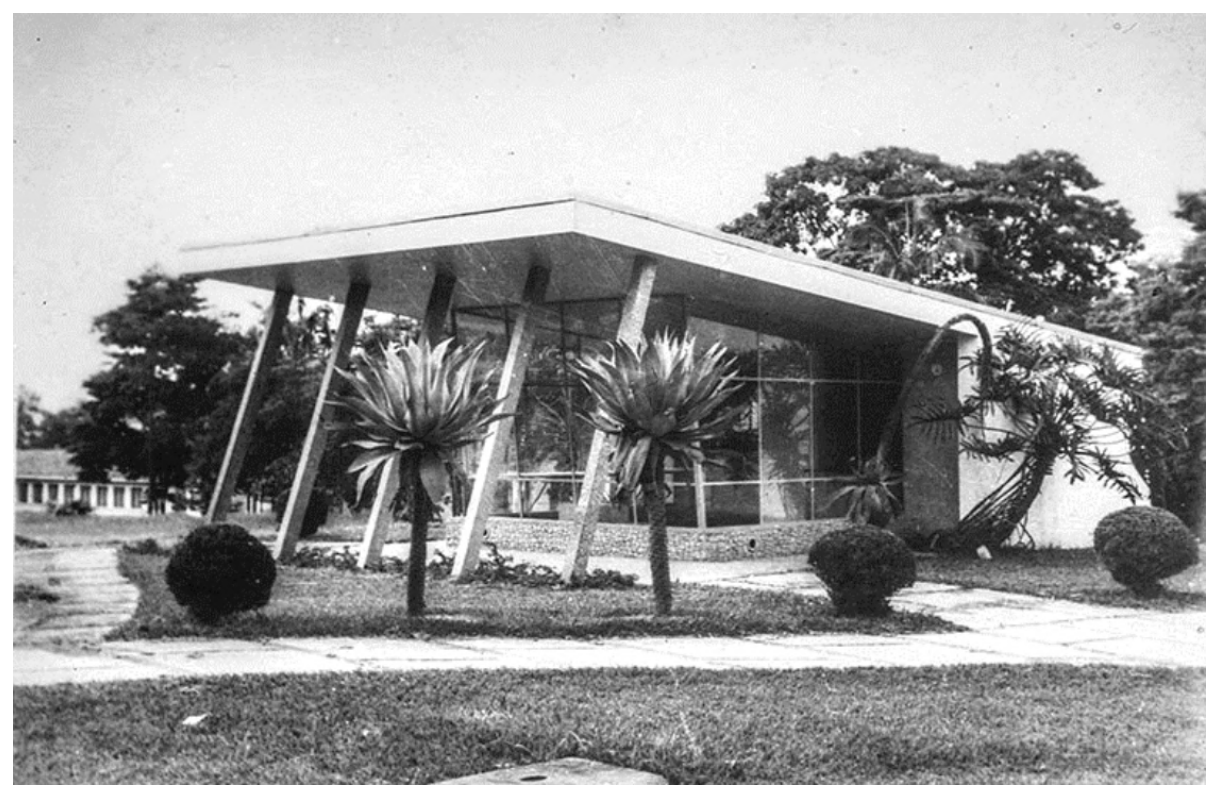

Figura 21: Fotografia do Edifício da recepção de serpentes inaugurado em 1952 e que passou por uma restauração recente, foto da década de 1960. Fonte:

IB_ICO_000425, Centro de Memória/IB.

Comentamos até aqui alguns dos principais projetos existentes no acervo do Centro de Memória e que documentam parte fundamental da história construtiva do 
Instituto Butantan até a década de 1950. Comentamos também que os projetos do Plano de Ação, que inauguram um novo contexto para o planejamento do campus, constituem a maior parte deste acervo. Este período é o objeto privilegiado desta dissertação no capítulo 2.

Também compõem o acervo projetos mais recentes, além da série de mapas apresentados na Figura 19, datados do ano de 1989. Alguns destes documentos remetem ao projeto museográfico desenvolvido para o Museu Biológico do Instituto no ano de 2000 (Figura 22), que ocupa o edifício da Cocheira Central concluído na segunda metade da década de 1910, cujo projeto é atribuído ao engenheiro-arquiteto Mauro Álvaro. O edifício passou por diversas modificações desde a sua inauguração, sendo a mais significativa a que foi feita para a sua transformação definitiva em museu e auditório em 1966, feito pelo arquiteto Osmar Mammini, durante o convênio com o FCCUASO. Esta reforma decisiva do edifício, inclusive, sucedeu um projeto desenvolvido pela arquiteta Lina Bo Bardi em 1965, do qual trataremos mais adiante nesta dissertação, no capítulo 3.

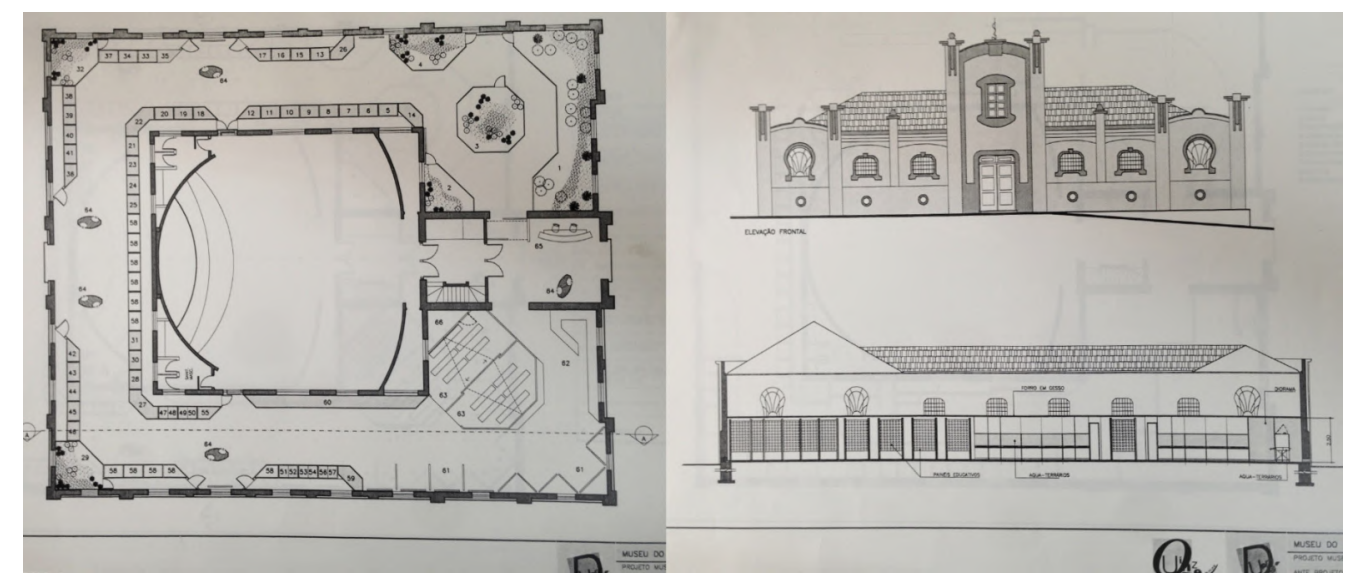

Figura 22: Planta, fachada e corte do projeto museográfico para o Museu Biológico do Instituto Butantan, arquiteto Nelson Dupré, 2000. Fonte: dossiê 60.04, Centro de Memória/IB.

Quanto aos documentos que registram todas estas alterações, estão guardados no acervo o projeto de conversão do edifício em Museu Biológico por Osmar Mammini, de 1966, e o projeto museográfico desenvolvido em 2000 pelo arquiteto Nelson Dupré. Trata-se de um projeto museográfico pouco usual, destinado à exposição de animais 
vivos, da fauna brasileira e de regiões distintas do mundo. Deste modo, a exposição emula o ambiente natural destes animais que são, além das serpentes, aranhas, escorpiões, lagartos, peixes e insetos. O projeto museográfico desenvolvido há duas décadas ainda pode ser visto na atual configuração do Museu, que passou por reformas estruturais no ano de 2018.

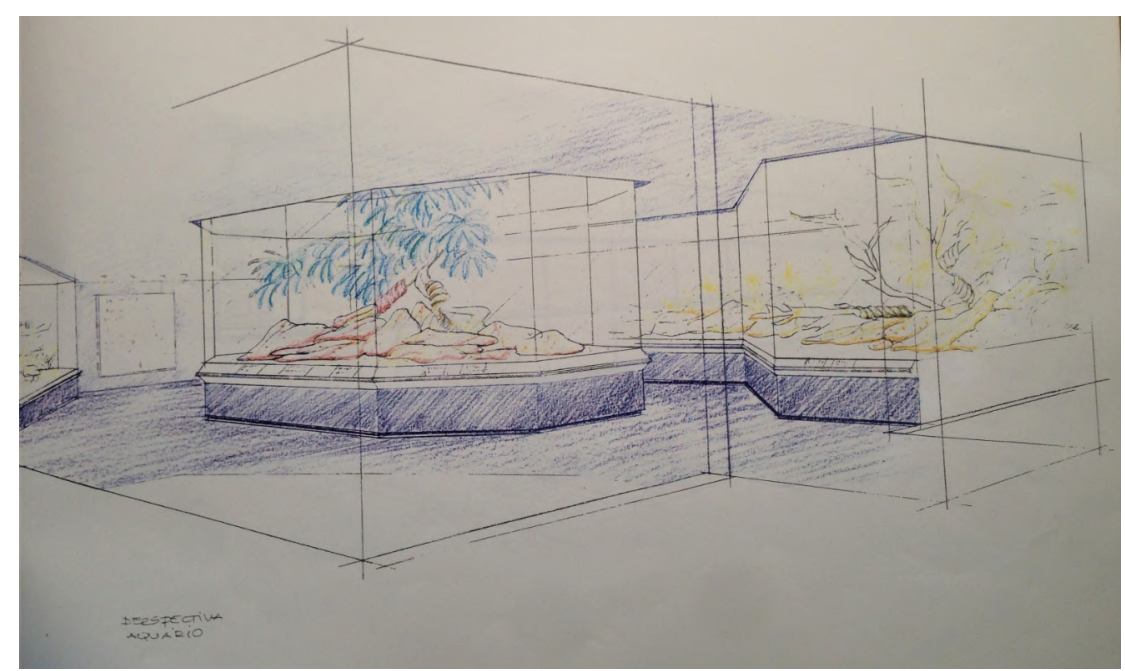

Figura 23: Perspectiva dos aquários para a exposição dos animais do Museu Biológico do Instituto Butantan, arquiteto Nelson Dupré, 2000. Fonte: dossiê 60.04, Centro de Memória/ IB.

Por fim, ainda considerando o material recente que compõe o acervo, existe um conjunto de desenhos do Museu Biológico e do Edifício Vital Brazil (Figura 24), também conhecido como Prédio Central ou Prédio da Biblioteca, composto por plantas e elevações destes edifícios históricos, que demonstram a rica variedade desta documentação. Não são projetos arquitetônicos completos, mas desenhos que retratam as características principais dos edifícios. Datados de 1999, entre outros usos, possivelmente serviram para o uso em logotipos e materiais publicitários e de divulgação do Instituto Butantan e da Fundação Butantan ${ }^{21}$ que, por algum tempo, usou a elevação deste prédio como símbolo da entidade.

A associação da arquitetura de seus edifícios simbólicos à imagem da instituição tornou-se um recurso adotado a partir da patrimonialização destes edifícios em 1981, mas que esteve presente desde o início da formação do Butantan. Esta prática também

21 A fundação Butantan é uma entidade privada e sem fins lucrativos, criada em 1989 para apoiar as atividades desempenhadas pelo Instituto. 
aparece em instituições centenárias criadas no mesmo período, como o uso da arquitetura do Castelo Mourisco, principal edifício do campus de Manguinhos (Figura 25), no logotipo da Fiocruz.

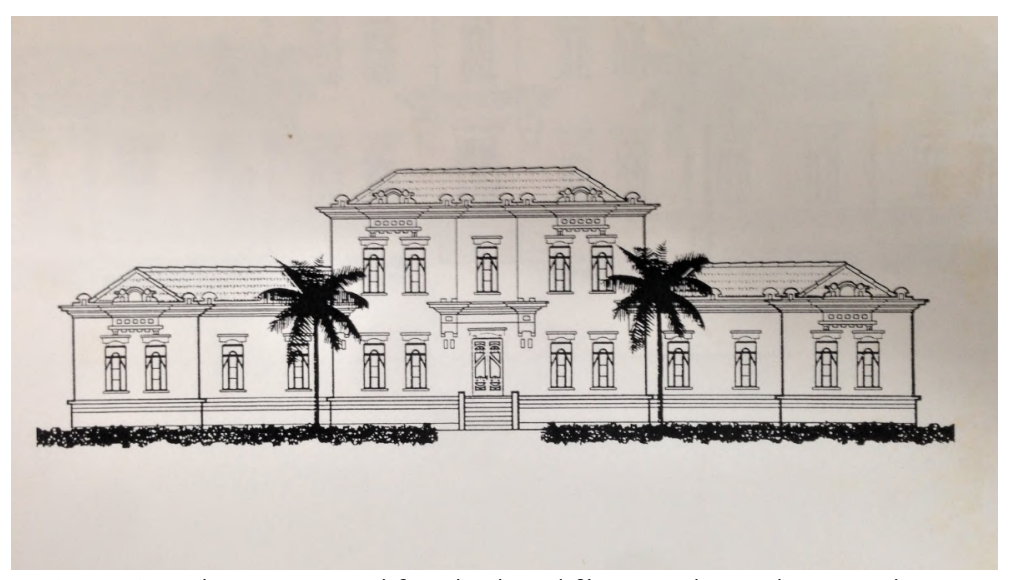

Figura 24: Elevação simplificada do Edifício Vital Brazil, parte de um conjunto de materiais gráficos relacionados ao edifício e ao prédio do Museu Biológico, 1999. Fonte: dossiê 60.04, Centro de Memória/IB.

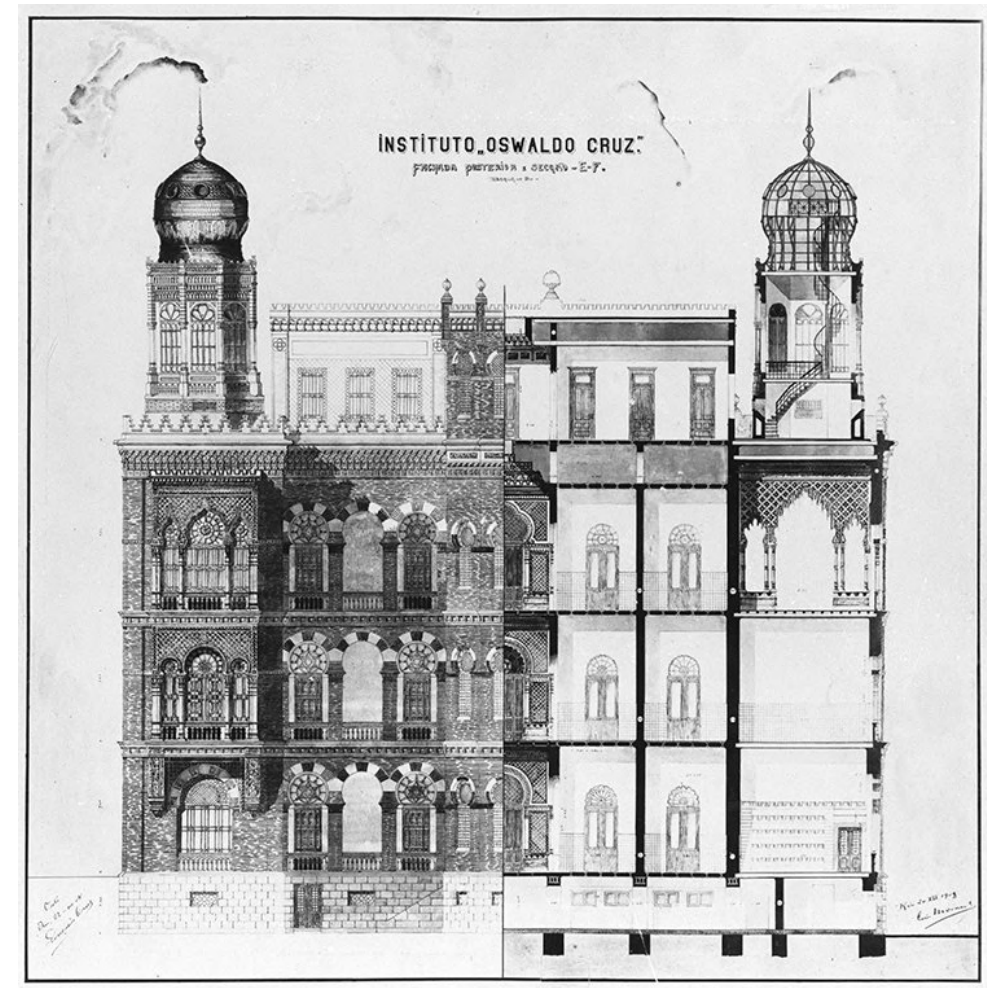

Figura 25: Desenho de 1908 do Pavilhão Mourisco, principal edifício do campus de Manguinhos da Fiocruz, iniciado em 1905 e concluído em 1918. A "silhueta" formada pela elevação do edifício é utilizada no logotipo da instituição. Fonte: Departamento de Arquivo e Documentação (DAD) / Fiocruz. 
Procuramos esboçar, nesta parte do primeiro capítulo, uma visão geral dos projetos, mapas, planos e desenhos, que compõem o acervo cartográfico do Centro de Memória do Instituto Butantan e que não estão incluídos no recorte temporal dos projetos do Plano de Ação. Embora não sejam o objeto central desta pesquisa, estes projetos constituem uma parte relevante do acervo e, diferentemente dos projetos do PAGE, são caracterizados por uma enorme variedade de temas, conformando um material de significativo valor para muitas pesquisas que versam sobre a história urbana e da urbanização de São Paulo, da arquitetura e do patrimônio histórico da saúde, extrapolando as pesquisas sobre o conjunto arquitetônico do Instituto Butantan.

O potencial destes documentos para outras pesquisas passa pela conservação do acervo de cerca de 1210 itens, entre pranchas, dossiês e séries de documentos, que têm sido cuidadosamente conservados, restaurados e difundidos pela equipe do Centro de Memória ao longo da última década. Estes esforços incluem planos de digitalização para a difusão do acervo e iniciativas para a adequação e qualificação dos espaços de acondicionamento destes materiais. Esta dissertação, também pretende contribuir para o fortalecimento destas ações de preservação e difusão, em uma tentativa de dar coesão a esta massa documental difusa.

Quanto ao seu estado de conservação, os documentos estão, de modo geral, em boas condições. Embora alguns itens estejam em um estado mais preocupante e propício à perda de informações, ainda são passíveis de recuperação e reparos que diminuam o processo de deterioração em curso antes da reunião destes materiais pelo Centro de Memória. Isto se deve pela condição destes projetos que estiveram, por décadas, acondicionados nos departamentos e laboratórios do Instituto em condições não adequadas.

As investigações que se apoiem sobre o acervo devem também estar atentas a algo que expomos reiteradamente neste texto: que não se trata de um acervo de projetos dos edifícios do Instituto Butantan, mas de documentos acumulados por aqueles que participaram deste processo. São documentos que também contam a 
história construtiva do Instituto, mas não exatamente aquela que é apresentada pelo seu conjunto de edificações históricas. Discorrem sobre uma conjunção de fatores e eventos sobrepostos, desencadeados ao logo do processo histórico, que configuram a forma e a paisagem atuais do campus do Butantan.

Como veremos a seguir, com os projetos do Plano de Ação, estes eventos nem sempre se complementaram de forma harmônica. Muitas vezes se desenvolveram de forma conflituosa, fragmentada e não linear, revelando projetos distintos para o Instituto Butantan.

\subsection{Fontes primárias e a pesquisa em história da arquitetura}

São diversas as pesquisas e os pesquisadores que abordaram, no recorte da história da ciência e da saúde pública, as instituições de pesquisa e de produção de imunobiológicos desde as últimas décadas do século XIX, quando se desenvolvia a microbiologia e se verificava o aumento das populações urbanas. No Brasil, o Instituto Butantan em são Paulo e a Fundação Oswaldo Cruz no Rio de Janeiro, instituições centenárias e centrais para o desenvolvimento da saúde pública no país, ocuparam lugar privilegiado nas pesquisas voltadas à história das instituições de pesquisa em saúde.

Nesta dissertação nos apoiamos em alguns destes autores que se debruçaram sobre estas instituições pioneiras e, principalmente, nas obras que tratam sobre a história do Instituto Butantan. Entre eles, podemos mencionar o trabalho dos historiadores Jaime Larry Benchimol (1993) e Luiz Antonio Teixeira (1993 e 2006), ambos pesquisadores da Casa de Oswaldo Cruz, da Fundação Oswaldo Cruz, que se dedicaram aos estudos comparativos entre esta Fundação e o Instituto Butantan. Por sua vez, mencionamos o trabalho conjunto de três autores, os médicos Fan Hui Wen e Nelson Ibañez, coordenador do Laboratório de História da Ciência do Instituto Butantan, e a historiadora e diretora do Centro de Memória da mesma instituição Suzana Cesar Gouveia Fernandes (2005), responsáveis pela construção desta história 
institucional.

Estes e outros autores contribuíram para a construção de uma história do Instituto Butantan, abarcando seus embates políticos internos, as trajetórias de sua formação e os esforços de consolidação, a atuação de seus pesquisadores e trabalhadores, as relações entre estes institutos públicos e o Estado no Brasil ao longo do século XX. Neste caso, a despeito da existência destas relevantes pesquisas que abordam a sua história e importância como centro de pesquisa e de desenvolvimento científico, são minoritárias aquelas que têm como objeto de investigação o seu conjunto arquitetônico e sua inserção na história urbana e da arquitetura da cidade de São Paulo. Assim como sua relação com o próprio bairro do Butantã, no qual a sua ocupação de caráter inaugural na região impulsionou a expansão do bairro no eixo oeste da cidade.

Neste sentido, um dos poucos trabalhos de fôlego que se dedicaram exclusivamente à dimensão espacial do conjunto arquitetônico do Instituto Butantan foi realizado pelo arquiteto e urbanista Anderson Luiz Félix de Sá (2019). Em sua dissertação de mestrado, intitulada "Preservação do patrimônio arquitetônico no Instituto Butantan", defendida em 2019 na Faculdade de Arquitetura e Urbanismo da USP, o pesquisador estuda o patrimônio edificado e as políticas de preservação do conjunto do Instituto, composto por edifícios construídos, majoritariamente, até a década de 1940. Deste modo, avança até as décadas mais recentes no que diz respeito às estratégias de preservação e os conflitos estabelecidos com outros episódios relativos à construção do espaço físico da instituição

No nosso caso, a pesquisa apresentada por esta dissertação se concentra sobre os projetos do Plano de Ação do Governo do Estado desenvolvidos para o Instituto Butantan durante a construção da vizinha Cidade Universitária da USP, a partir de 1959, e está amparada por estas iniciativas anteriores. Todavia, o eixo de análise deste trabalho se estende a um episódio decisivo para a história do conjunto arquitetônico 
do Instituto, ilustrando as disputas internas pela autonomia e pelo planejamento da instituição na década de 1960, na esteira dos planos de modernização.

A rara existência de estudos específicos sobre a arquitetura do Butantan, ao longo de toda a sua história mas, principalmente, no período após a década de 1940, se explica pelo caráter inédito dos documentos guardados pelo Centro de Memória. Trata-se, no geral, de materiais pouco divulgados e conhecidos pela sociedade e pela comunidade científica. Esta quantidade significativa de documentos acumulados ao longo de mais de um século de existência da instituição só começou a passar por um projeto de identificação e organização no ano de 2010 através da criação do Núcleo de Documentação do Instituto Butantan. Nesta data, o órgão passava a ser responsável pelo gerenciamento e difusão dos diversos acervos institucionais, dando início à organização desta massa documental.

Dada a originalidade destes documentos, o campo de pesquisa que se desenha, além de amplo, pode ser fundamental para a compreensão de uma parte significativamente importante da história da cidade de São Paulo, que se apresenta no conjunto arquitetônico do Instituto das mais diversas formas, através do patrimônio centenário que ali se constituiu.

\subsubsection{Documentos de uma arquitetura não construída: o Instituto Butantan e o Plano} de Ação

Esta pesquisa intitulada "Instituto Butantan, Plano de Ação e as disputas institucionais de planejamento, 1959-1981" parte de um acervo consolidado e pouco investigado, tendo como proposta o estudo dos projetos arquitetônicos desenvolvidos pelo Plano de Ação do Governo do Estado para o Butantan na década de 1960.

Estes projetos compõem a maior parte das 1210 pranchas do Acervo Cartográfico do Centro de Memória do Instituto Butantan. Deste total, cerca de 913 itens se referem ao período do convênio entre o Butantan e a Universidade de São Paulo, firmado em 1961, no contexto das obras inauguradas pelo Plano de Ação na 
Cidade Universitária. Além destes documentos, foram analisadas outras 132 pranchas de projetos do PAGE para o Instituto, que se encontram na Biblioteca da FAU USP, totalizando 1045 itens, cuja maioria data da década de 1960.

Estes projetos que, em geral, se encontram bem conservados, representam arquiteturas não construídas em sua maioria. São propostas de novos edifícios, planos urbanísticos de reformulação total, projetos estruturais e de execução, desenvolvidos para o campus do Instituto Butantan em convênio com o Fundo de Construção para a Cidade Universitária da USP, através do Plano de Ação do Governo do Estado de São Paulo, nos anos de 1959 a 1963. Em contraste com a paisagem edificada predominante no campus do Instituto, estas arquiteturas manifestam propostas radicais de reformulação, nitidamente vinculadas a uma linguagem moderna, especificamente àquela que se tornou conhecida como a vertente paulista da arquitetura moderna brasileira.

Partindo destes elementos, a pesquisa se concentra em avaliar os aspectos, os impactos e os desdobramentos da atuação do PAGE no Instituto Butantan a partir da construção do campus da Universidade de São Paulo, entendendo seus efeitos para o planejamento da Instituição nos anos seguintes. Para atingir tal objetivo, partimos da organização e avaliação destas fontes primárias, de modo a compreender e difundir este material pouco conhecido, relacionando-o com a implantação do campus da USP a partir de 1959, e com a historiografia da arquitetura moderna em São Paulo. Neste curso, verificamos que a ação dos arquitetos do PAGE no Instituto Butantan pode representar uma possível exceção ao êxito alcançado pelo plano no estado de São Paulo que, embora não materializada, deixou vestígios pouco visíveis, mas determinantes para o planejamento do campus nas décadas seguintes.

O sucesso internacional da arquitetura brasileira durante a metade do século XX, coroada com a construção de Brasília e que animava os debates arquitetônicos pelo mundo, constituindo o quadro hegemônico da arquitetura canonizada como a vertente carioca do modernismo brasileiro e que teve o estado como o seu grande promotor, acabava por colocar São Paulo à margem de toda esta repercussão. O Plano de Ação do 
Governo Carvalho Pinto será, então, um ponto chave para a virada construtiva por qual passará todo o estado a partir de 1959, responsável por efetivar uma cultura construtiva moderna em detrimento da arquitetura padronizada e de orientação eclética ou neocolonial produzida pelo DOP. Esta, embora não expressiva da totalidade dos edifícios produzidos pelo órgão, refletia certa resistência à adoção dos pressupostos modernos nos edifícios públicos desenvolvidos pelo Estado (BUZZAR, CAMARGO e CORDIDO, 2016, p. 03).

O início da construção da Cidade Universitária pelo Plano de Ação, surge como ponto determinante e inaugural de um novo momento para o planejamento e expansão do campus do Instituto. A partir do ano de 1959, quando é consolidada a implantação do campus da USP, se estabelece um conflito inicialmente simbólico mas que terá grande relevância para as décadas seguintes: a tradicional Instituição de saúde pública, detentora de um patrimônio edificado consolidado e associado à sua imagem, receberá no espaço que pertencia a sua fazenda até 1941, a construção de um grande campus universitário segundo os moldes modernos.

Embora o impacto do enorme canteiro de obras que se iniciava no campus vizinho não se verifique inicialmente, os planos de intervenção do PAGE não tardariam a se estender ao Instituto. As queixas proferidas pela direção quanto à insuficiência dos espaços físicos e da sua incompatibilidade com o renome internacional da Instituição, dariam lugar ao tom eufórico com os investimentos vultuosos possibilitados pelo Plano, que possibilitariam a inserção do Instituto no mais alto nível das grandes instituições de pesquisa, condizentes com a reputação que, não somente seus diretores, mas, a própria comunidade científica internacional lhe conferia. ${ }^{22}$

22 Já nas décadas de 1920 e 1930, o Instituto desfrutava de considerável reconhecimento internacional. Como comentamos no item 1.1 deste capítulo, o médico Afrânio do Amaral, diretor de 1919 até 1921 e de 1928 até 1938, empreendeu considerável esforço de expansão e divulgação do Butantan no exterior, sendo contemplado na capa da revista estadunidense Time, no ano de 1929. Afrânio também promoveu a construção de novos edifícios no campus, entre eles uma casa para uso do diretor e de sua família, que diariamente fazia o longo trajeto do centro da cidade à fazenda. Hoje o edifício é utilizado como sede administrativa e da direção, tendo sido nomeado Casa Afrânio do Amaral em 2018. 


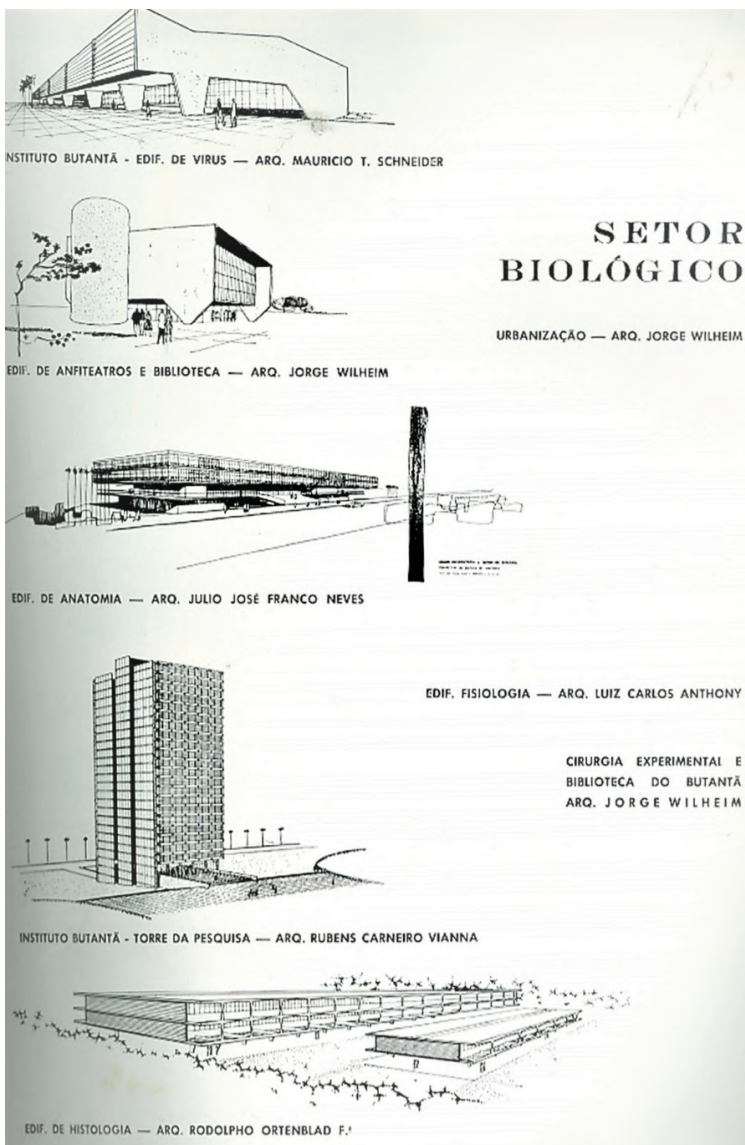

Figura 26: Página da Revista América apresentando os projetos dos novos edifícios para o Setor Biológico e o Setor do Instituto Butantan da CUASO. Entre eles três edifícios para o IBu, de Maurício Tuck Schneider, Jorge Wilhein e Rubens Carneiro Vianna. Fonte: Revista América, ano 7, n2, 1962, sem página.
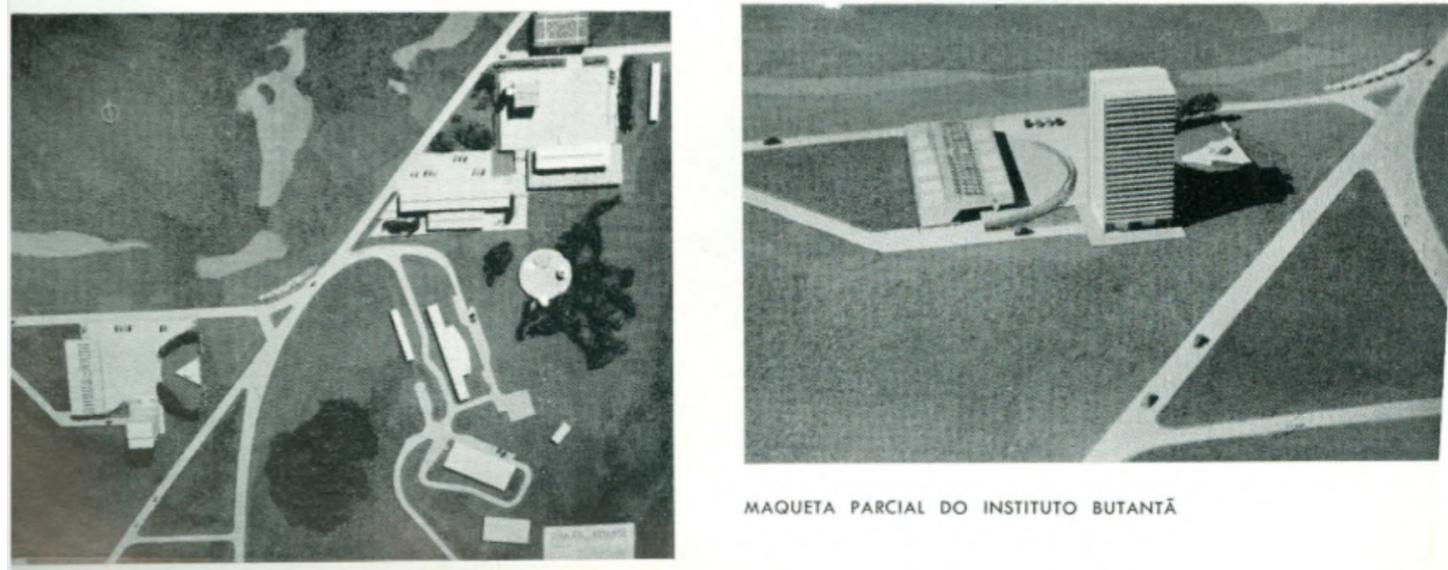

MAQUETA PARCIAL DO INSTITUTO BUTANTA

Figura 27: Maquete parcial do Setor Biológico da Cidade Universitária e do setor do Instituto Butantan que estavam integrados. Fonte: Revista América, ano 7, no22, 1962, sem página. 
No ano de 1959, já no primeiro ano de seu governo, o Governador Carvalho Pinto faz uma visita à instituição. Na oportunidade são anunciados quatro novos edifícios: para o setor de produção, o setor de pesquisa, um novo edifício para o biotério e um para a biblioteca. O espaço cedido pelo governador ao Instituto rende elogios por parte do diretor Flávio Ribeiro da Fonseca (1956-1963), pela primazia do Plano de Ação, do qual destaca o "aspecto até então inédito em São Paulo, de governar com um plano previamente traçado" (Relatório Anual, 1959, fl. 07).

Prontamente, a direção se encarregou de apresentar um plano que viabilizasse os investimentos na reestruturação do Instituto. O Arquiteto Rubens Carneiro Vianna, formado pela Escola Politécnica em 1939, é colocado à disposição para atuação exclusiva no planejamento e para a formulação de um inédito plano diretor para o campus, que carecia de tal organização nas seis décadas de sua existência. Estas intenções de reorganização do campus era algo que já se cogitava, ao menos, desde 1953, quando atuou no Instituto Carlos Alberto Cerqueira Lemos, arquiteto formado no Mackenzie em 1950, professor da FAUUSP e diretor do escritório de Niemeyer em São Paulo, na mesma década. Para a formulação deste plano geral se estabelece um convênio com o FCCUASO que se encarregará, através do seu escritório técnico, da formulação dos projetos para o Butantan e de um zoneamento que organizasse as áreas e os seus setores de atividade. Um concurso é realizado para a formulação das propostas.

Articulados, os esforços resultaram em diversas propostas de novos edifícios e planos de reformulação radical para o campus do Instituto, segundo critérios urbanísticos modernos já colocados em prática na construção da Cidade Universitária. Os esforços pela autonomia institucional manifestos pela diretoria, antes mesmo da criação do PAGE, se somam ao receio de que o Instituto fosse anexado à Universidade de São Paulo, tornando-se uma de suas unidades. A euforia modernizante cede espaço à cautela já no primeiro ano do Plano de Carvalho Pinto. 
Responsável pelo desenvolvimento de mais de mil projetos de novos edifícios e infraestruturas, distribuídos por mais de duzentas cidades do interior paulista, além da capital, e elaborados por cerca de 160 arquitetos diretamente contratados (CAMARGO, 2016, p. 165), o Plano de Ação se caracterizou pela urgência com que avançou na execução de suas metas e pelo sucesso de seu planejamento. Para o Instituto, esta urgência significará a entrega do planejamento do campus para o corpo técnico que já atuava na construção da Cidade Universitária, motivando o aumento do receio quanto à espoliação de sua autonomia e o acirramento das disputas territoriais com a Universidade pelo controle do planejamento.

\subsection{Panorama dos centros de pesquisa em microbiologia entre os séculos $\mathrm{XIX}$ e XX}

Em sua pesquisa de mestrado, o arquiteto e urbanista Anderson Luiz Félix de Sá (2019, p.22), cujo trabalho tem sido fundamental para esta dissertação, ${ }^{23}$ desenvolve a questão das instituiç̧̃es precursoras no campo da microbiologia e que se inserem no mesmo contexto da formação do Instituto Butantan em São Paulo. Sabe-se que tanto o Butantan quanto a Fiocruz, no Rio de Janeiro, se formaram em um cenário de crescimento populacional urbano na passagem dos séculos XIX e XX, que tornavam frequente a disseminação de doenças transmissíveis, ocasionando crises epidêmicas como a da febre amarela, da varíola e da própria peste bubônica, que motivou a criação do Instituto Butantan pelo Estado de São Paulo, tarefa encarregada ao médico Vital Brazil.

Neste contexto, os avanços da microbiologia, que tornaram possíveis as pesquisas voltadas a estas e outras doenças transmissíveis, contribuíram para o surgimento destas instituições que passaram a trabalhar no controle das doenças epidêmicas de modo a prevenir o seu alastramento e, consequentemente, a

23 O seu trabalho inaugural sobre o conjunto arquitetônico do Instituto Butantan, tem nos oferecido uma base e um ponto de partida para uma questão tão ampla quanto a da arquitetura centenária desta instituição de pesquisa e saúde. Deste modo, a sua pesquisa que se concentra na questão da preservação do conjunto arquitetônico construído, majoritariamente, na primeira metade do século XX, nos permite avançar para a situação do conjunto na segunda metade do mesmo século, com maior foco nos projetos do Plano de Ação a partir de 1959. 
imprevisibilidade econômica e social que acarretavam estas crises sanitárias. Nicolau Sevcenko mostrou como as questões sanitárias, urbanas e sociais estavam entrelaçadas e tornavam-se urgentes para o controle, inclusive social, da situação na capital brasileira durante a Primeira República:

A cidade era foco endêmico de uma infinidade de moléstias: febre amarela, febre tifóide, impaludismo, varíola, peste bubônica, tuberculose, dentre outras. Destas, a febre amarela e a varíola eram as que ceifavam o maior número de vidas. A febre amarela, em particular, manifestava toda a sua violência para com estrangeiros e migrantes de outros estados. Sua fama era internacional, sendo o Rio de Janeiro conhecido no exterior, por sua causa, como "o túmulo dos estrangeiros". Por isso, as tripulações e passageiros nem se atreviam a descer dos navios quando estes chegavam no porto: permaneciam a uma distância prudente, evitando qualquer contágio. (SEVCENKO, 2010 p.63)

Em São Paulo, a emergência de uma crise sanitária também aparecia no litoral do estado, na cidade de Santos, dada a sua condição de cidade portuária. Neste sentido, embora não fosse a primeira instituição do tipo na capital paulista, sendo precedida, por exemplo, pelo Instituto Bacteriológico - com o qual manteve vínculos iniciais até atingir a sua autonomia em $1901^{24}$-, entre outras instituições deste tipo, o Butantan surgiu como uma das iniciativas do estado para controlar a crise que ameaçava São Paulo, em paralelo com a inciativa promovida pelo Governo Federal:

\begin{abstract}
Seu surgimento, em 1900, foi consequência de um surto de peste bubônica no Porto de Santos em 1899. Para combatê-lo, o governo do Estado convocou o médico Vital Brasil (1865-1950), pesquisador do Instituto Bacteriológico. Em Santos, ele encontraria o médico Oswaldo Cruz, enviado pelo governo federal para a mesma função que Vital cumpria no Estado de São Paulo. Do encontro dos dois nasceria uma parceria, importante para criação e desenvolvimento dos dois institutos que em pouco tempo surgiriam. ${ }^{25}$ (TEIXEIRA, 2016, p.165-166)
\end{abstract}

As instituições criadas pelos dois médicos sanitaristas, Vital Brazil e Oswaldo Cruz, compartilharam uma origem comum e que partiam de experiências prévias e

24 O Instituto coordenado por Vital Brazil foi concebido inicialmente como um laboratório ligado ao Instituto Bacteriológico de São Paulo, dirigido à época pelo médico Adolfo Lutz. Debelada a crise da peste bubônica em Santos, o laboratório de Vital Brazil, instalado na Fazenda Butantan, ganhou autonomia, sendo denominado Instituto Serumtherápico em 1901. Posteriormente viria a se chamar Instituto Butantan, pela relação histórica com o bairro.

25 A data de criação do Instituto Butantan é adotada com algumas divergências pela bibliografia sobre o assunto. Isto se deve pela sequência de eventos e datas importantes para a sua constituição. De todo modo, o ano oficial de sua fundação é 1901, quando se emancipa do Instituto Bacteriológico. 
semelhantes como a do Instituto Pasteur, fundado em Paris em 1887. Seu fundador e primeiro diretor, o cientista francês Louis Pasteur, tornou-se conhecido pela criação da vacina antirrábica em 1885 e do método da pasteurização de alimentos, que leva o seu nome. As experiências de controle epidemiológico conduzidas pelo Estado no Rio de Janeiro e em São Paulo, que se desdobravam no controle urbano e social, reproduziam intenções que estavam na base da fundação do Instituto Pasteur, na França, e que se relacionavam ao colonialismo europeu:

Rapidamente o combate às epidemias através da microbiologia pasteuriana se tornou não apenas uma questão científica ou humanitária, mas estratégica do ponto de vista econômico, uma vez que as trocas comerciais entre a Europa, suas colônias, e os países recém independentes envolviam também o inevitável contato com doenças infecciosas autóctones das Américas, África e Ásia. (SÁ, 2019, p.22)

Deste modo, a criação destas instituições implicou no desenvolvimento de um novo tipo de programa arquitetônico e urbanístico definido pelo campus de pesquisa, que passava a abrigar atividades de pesquisa e produção farmacológica. A emergência desta nova tipologia arquitetônica não significa que instituições deste tipo fossem inéditas, todavia, estas eram, até então, “ligadas aos hospitais, administrados pela Igreja, com configurações físicas advindas dos mosteiros e claustros" (Ibid., p.23).

Uma característica que marcou a constituição destas estruturas, foi a implantação de edifícios pavilhonares organizados em um campus, conformando um conjunto a partir de uma lógica de salubridade que respeitasse as atividades e separações de seu programa que, muitas vezes, lidava com pacientes e doenças infecciosas. Neste sentido, era também fundamental o distanciamento do conjunto em relação aos centros urbanos ou áreas densamente povoadas. Isto se dava tanto pela característica das atividades desempenhadas, quanto pela desconfiança e receio que estas suscitavam em parte da população pela possibilidade de contágio.

No caso do Instituto Butantan, estas características também estavam associadas à existência de diversas espécies de animais que apoiavam boa parte das pesquisas e da produção de fármacos. Além dos cavalos, utilizados para a inoculação e produção sorológica, o Instituto realizou, desde os seus primeiros anos, pesquisas sobre ofidismo 
que o tornaram famoso pelo trabalho com serpentes. Assim, além dos estábulos, cocheiras e cavalariças, destinados à acomodação de equinos, os serpentários e, em seguida, os biotérios para a criação de animais foram, e ainda são, tipologias arquitetônicas recorrentes no campus de pesquisa da instituição.

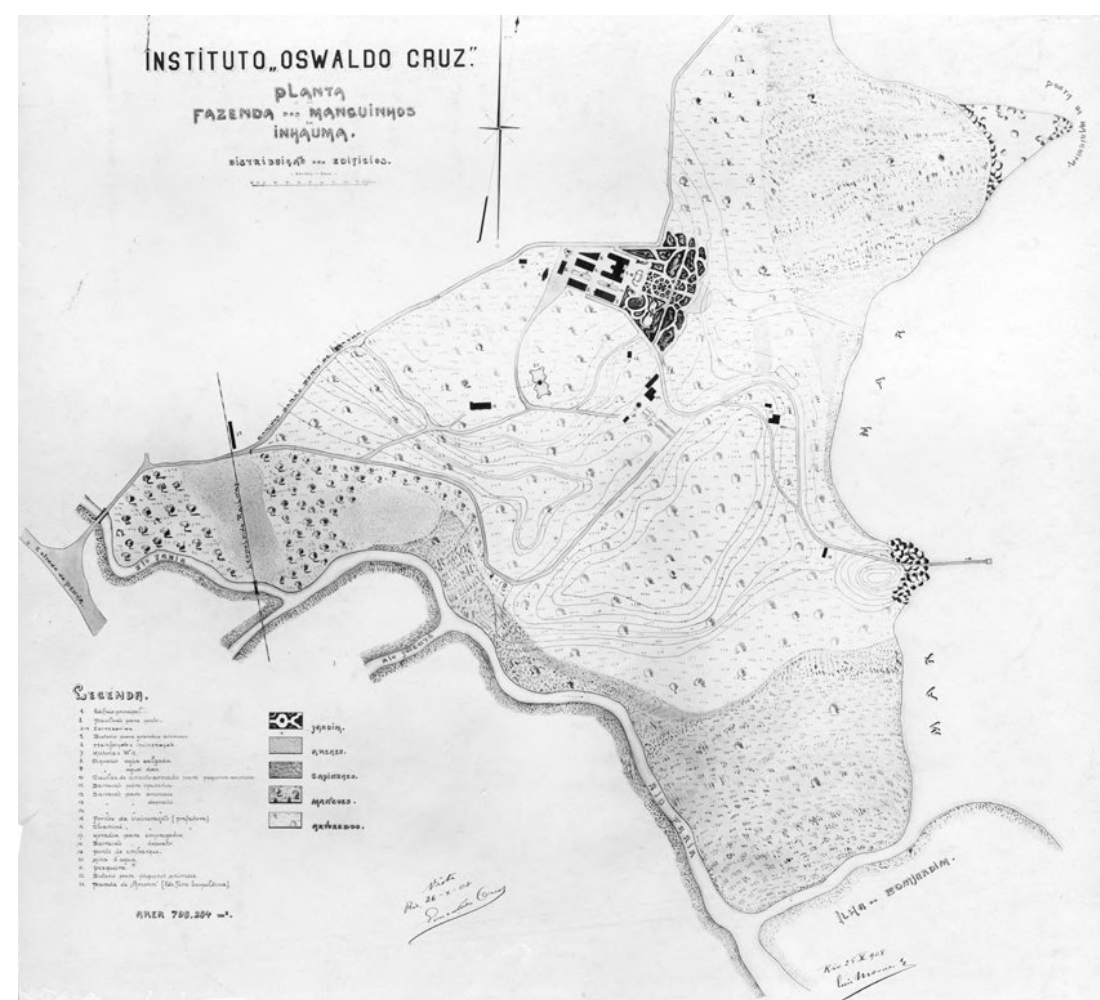

Figura 28: Planta da Fazenda de Manguinhos com a implantação do Pavilhão Mourisco, 1908. Percebe-se uma preocupação com a implantação dos seus edifícios de modo que apresentem uma coesão no território ainda não ocupado, conformando um conjunto. Fonte: Departamento de Arquivo e Documentação (DAD) / Fiocruz.

Por sua vez, o campus de Manguinhos, da Fundação Oswaldo Cruz (Figura 28) também apresenta características próximas, uma vez que compartilha com o Instituto Butantan as mesmas origens relacionadas ao surto de peste bubônica em fins do século XIX. Instalou-se assim, no início do século XX, em uma fazenda na então capital federal, com o objetivo de combater a peste que ameaçava avançar sobre os grandes centros urbanos próximos. O local escolhido para a sua implantação, assim como o laboratório de Vital Brazil instalado na Fazenda Butantan em São Paulo, era afastado da região central da cidade do Rio de Janeiro, conhecido como Fazenda Manguinhos. 
Hoje, as duas instituições, localizadas em São Paulo e no Rio de Janeiro respectivamente, primeira e quarta cidades mais populosas da América Latina -, estão inseridas na malha urbana das duas cidades, que as incorporou na medida em que foi se expandindo ao longo das décadas. A acelerada urbanização brasileira em meados do século XX, fez com que os campi de pesquisa e produção do Butantan e da Fiocruz ficassem, literalmente, rodeados, como se constituíssem enclaves urbanos.

\subsubsection{O Instituto Butantan como centro de pesquisa moderno}

Diante desta nova condição de equipamento inserido na cidade (Figura 29), muito distinta das primeiras décadas, são desenvolvidos os projetos para a modernização do Butantan, inaugurando um novo momento para o conjunto marcado por uma tipologia arquitetônica do final do século anterior. Estes planos de modernização conformam uma nova tipologia, que inserem o campus do Instituto no contexto dos centros de pesquisa modernos, construídos a partir do pós-guerra.

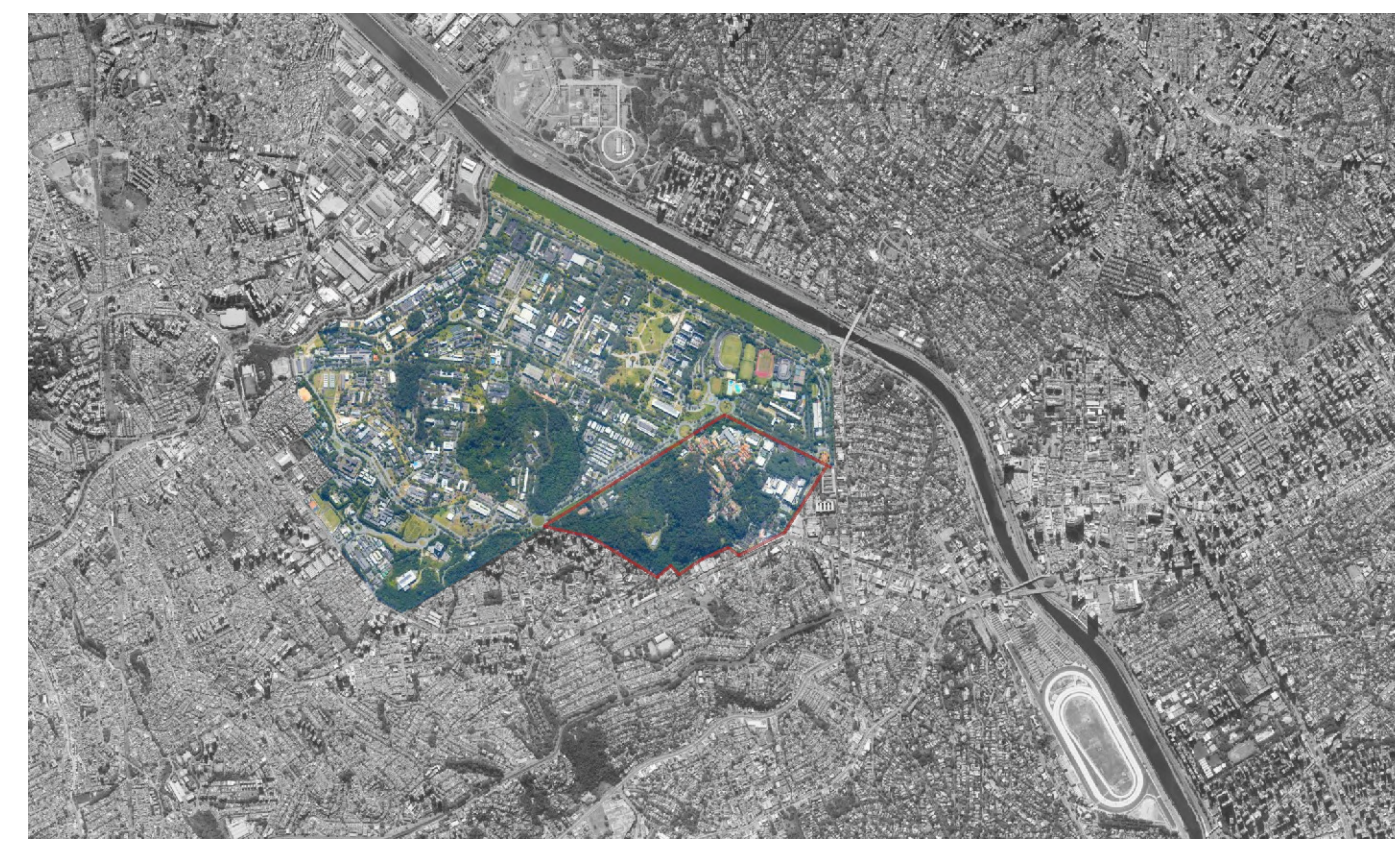

Figura 29: Conformação atual do Instituto Butantan e da Cidade Universitária da USP na região oeste da cidade de São Paulo: cidade e centro de pesquisa constituem um mesmo espaço,embora apresentem formas distintas de ocupação do território. Fonte: Geosampa, Prefeitura Municipal de São Paulo, 2017, edição nossa. 
Falamos aqui de algumas estruturas arquitetônicas, construídas em meados do século XX, principalmente a partir da década de 1960 e que se tornaram muito importantes na história da arquitetura. Este reconhecimento se deve, também, por uma perceptível sedimentação do modernismo nos países centrais, com a emergência de obras críticas e de arquiteturas que transitavam entre a modernidade e a pósmodernidade, esta ainda não reconhecida como tal. Em maior ou menor grau, estas obras renunciavam ao rigor funcional e à racionalidade estabelecidas pelo modernismo.

Esta capacidade de se deslocar dos elementos formais do modernismo em direção a uma experimentação estética que não temia o recurso ao histórico, foi acentuada na obra do arquiteto estadunidense Robert Venturi. Em seu manifesto crítico ao Movimento Moderno, Venturi (2004) se opõe as ideias de abstração e universalidade que permearam a arquitetura até meados do século $X X$, chegando a identificar na cultura de massas uma potência negligenciada pelos arquitetos e defendendo a ultilização dos elementos históricos de forma alegórica e irônica ao purismo modernista. Neste mesmo período, também como contraponto à relação do modernismo com a história, ainda que de forma distinta, esta dimensão aparece na obra do arquiteto italiano Aldo Rossi (2001), que apontou a incompatibilidade entre o projeto moderno e as cidades históricas italianas. Neste sentido, em sua teoria, buscou a reconciliação da arquitetura com os elementos urbanos preexistentes, conservando certos aspectos da modernidade em conjunto com preocupações de caráter histórico, pautando a ideia de lugar e da memória coletiva das cidades.

Guardadas suas diferenças, as obras teóricas e arquitetônicas de Venturi e Rossi compartilham a retomada das referências históricas como recurso simbólico da arquitetura, assim como a cidade tradicional é revalorizada, em detrimento dos esforços de renovação colocados pela arquitetura moderna. Embora a noção de tradição para os autores esteja amparada por vivências distintas, a partir dos Estados Unidos e da Itália, ambos manifestam a preocupação com a ideia do vínculo da arquitetura com o seu contexto, assim como retomam o uso das técnicas tradicionais e 
das formas geométricas na composição dos edifícios.

Teorizados, sobretudo, ao longo da década de 1960, alguns destes aspectos podem ser vistos de forma precoce na arquitetura de Louis Isador Kahn, com quem Venturi trabalhou no início da carreira. No ambiente em que são gestadas as teorias que questionaram os paradigmas da modernidade, Kahn desenvolveu projetos que avançavam em direção a uma maior diversificação formal do repertório modernista. Neste sentido, a obra de Kahn foi precursora e representativa de um momento de crise e de transição na arquitetura.

Louis I. Kahn inicia a fase mais importante de sua carreira na década de 50, na qual o modernismo começa a sofrer pesadas críticas, e alguns autores dão inicio a especulações na criação de novas teorias arquitetônicas. A partir desse período Kahn tenta reproduzir em sua obra temas discutidos acerca de aspectos históricos ou presentes no passado, como a monumentalidade, forma, ordem, luz, etc. Sem deixar de reconhecer o modernismo como sistema compositivo completo, e externando alguns aspectos históricos como geradores de relações formais em seus projetos e obras, Kahn obteve o reconhecimento de modernos e de antimodernos, e provou que o passado pode servir como base de novas explorações, como repertório válido, sem que se caia no ridículo do historicismo. (PALERMO, 2006)

É neste contexto que Louis Kahn vai desenvolver alguns de seus principais projetos, entre eles edifícios e conjuntos para instituições científicas e de pesquisa, de arte e cultura e universidades. Seu primeiro projeto de maior importância foi o Centro de Arte da Universidade de Yale, onde era professor, cujo edifício finalizado em 1953 é conhecido pela laje nervurada em concreto que forma uma malha triangular. No que pese a planta do edifício que remete a uma organização clássica, o edifício preserva um aspecto moderno, com elementos puros, panos de vidro compondo as fachadas e ênfase estrutural dada pelo concreto armado, aspecto enfatizado pelo brutalismo durante o pós-guerra.

Em 1957, o arquiteto inicia o projeto para o conjunto de edifícios dos Laboratórios de Pesquisa Médica Richards, no campus da Universidade da Pensilvânia na Filadélfia, onde também havia se graduado. É um dos seus primeiros projetos no qual aparece a proposta de hierarquização entre espaços servidos e servidores. Deste modo, o edifício é definido por um conjunto de torres nas quais se situam os 
laboratórios (espaços servidos), que são rodeados por infraestruturas (espaços servidores) como escadas, elevadores e dutos de ventilação que liberam a parte central das torres, onde se desenvolve o programa. A estrutura vertical do edifício também é marcada por esta separação, constituída por pilares de concreto situados no perímetro das torres.

A partir do projeto para o conjunto de laboratórios, Louis Kahn vai desenvolver outras importantes propostas para edifícios institucionais, centros de pesquisa e de arte nos Estados Unidos e em diversas partes do mundo, aplicando e desenvolvendo a ideia de separação entre espaços de serviço/ servidores e servidos. ${ }^{26}$ Entre 1959 e 1966 o arquiteto desenvolveu um de seus mais importantes e paradigmáticos projetos para o Instituto Salk, situado em La Jolla na Califórnia.

Fundado pelo médico e epidemiologista Jonas Edward Salk, o Instituto dedicado à pesquisa biológica se encontra em uma posição privilegiada da paisagem no litoral oeste dos Estados Unidos, voltado para o Oceano Pacífico. Desta proximidade com o mar, Louis Kahn extraiu uma perspectiva que parte da organização axial e simétrica dos edifícios, de modo que estes conformam, em seu eixo, um pátio central que organiza o conjunto voltando-se ao mar. Como em muitos outros projetos do arquiteto, a disposição simétrica do conjunto se assemelha a uma ordem clássica e monumental, comportando no pátio um simbólico curso d’água.

O Instituto Salk para Pesquisas Biológicas tornou-se um dos projetos mais enigmáticos e singulares do século XX. O conjunto de edifícios dispostos no território sob uma ordenação clássica, se assemelha a um espaço de retiro e reclusão, quase espiritual e religioso. Comentando algumas das obras monumentais ${ }^{27}$ de Kahn feitas neste período, Vincent Scully (2001, p.10) afirma que [...] "cada um daqueles grupos de edifícios era, de um modo ou de outro, uma ruína romana, uma ruína que triunfava especificamente sobre o Estilo Internacional através da subordinação do vidro ou da

26 Apesar do nome, os espaços de serviço propostos por Louis Kahn, não definiam uma separação social, no sentido de separar trabalhadores e usuários do edifício, mas eram espaços projetados para a organização das infraestruturas do edifício.

27 Especificamente o Instituto Salk para Pesquisas Biológicas, o Instituto Indiano de Administração e o Capitólio de Daca, ou Assembleia Nacional de Bangladesh. 
sua total eliminação". ${ }^{28}$ Ao mesmo tempo, no Instituto Salk, a sua estrutura, os materiais e a racionalidade dos espaços se antecipam ao desenvolvimento tecnológico que, frequentemente, tornam as instalações de centros de pesquisa de ponta rapidamente obsoletas.

Curiosamente, o intervalo do desenvolvimento e execução do projeto para o Instituto Salk, entre 1959 e 1965, coincide com o período do Plano de Ação e dos projetos para a modernização do Instituto Butantan. Nestes projetos, aparecem certas preocupações que são, ao mesmo tempo, comuns a outros centros de pesquisa do período e específicas do contexto da arquitetura brasileira nas décadas de 1950 e 1960. Assim, a dimensão urbana destes novos espaços, em oposição ao caráter rural do conjunto histórico do Butantan, parece ser uma questão importante.

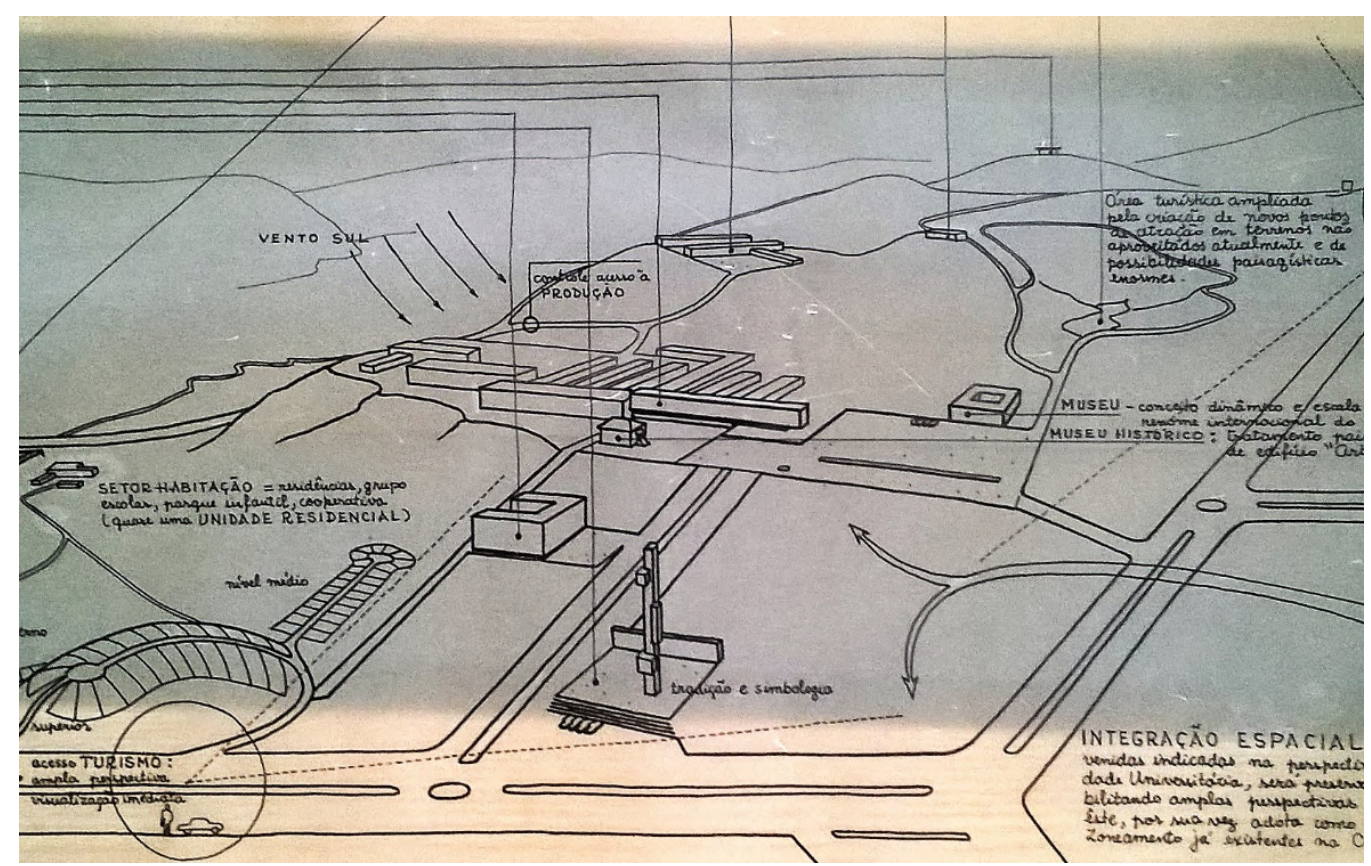

Figura 30: Ilustração do plano geral proposto pelos arquitetos Leo Quanji Nishikawa e Sergio Atrigliano, em 1961. Há uma praça monumental no eixo que conecta a USP ao Instituto Butantan, onde se lê a inscrição "tradição e simbologia". Fonte: prancha 40.11, Centro de Memória do IB.

Do mesmo modo, por mais que os arquitetos paulistas se negassem a recorrer a determinados artifícios simbólicos e monumentais da arquitetura, estes aparecem como recurso que evoca o desenvolvimento do país e o avanço da ciência. Estes 
elementos estão nos edifícios e no plano da Cidade Universitária e também aparecem nos projetos para o Instituto Butantan das mais diversas maneiras. A proposição de eixos monumentais, praças e espaços coletivos, a ideia de que a nova arquitetura (moderna) também deveria representar a tradição e os símbolos da Instituição, além da preocupação com a disposição dos edifícios na paisagem, são aspectos que definem o plano geral de 1961 para o Instituto, feito pelos arquitetos Léo Quanji Nishikawa, formado na FAU USP nos anos 1950, e Sergio Atrigliano, afirmando uma preocupação com a dimensão representativa da arquitetura do Instituto Butantan como centro de pesquisa.

Nos parece que uma referência para estes planos de modernização do Butantan, capitaneados por estes arquitetos em São Paulo, se estabelecia na crítica e na adoção de certos aspectos simbólicos, também presentes na monumentalidade de Brasília, a grande obra moderna do país naquele momento e que, não obstante, permeou o imaginário dos próprios arquitetos, como comentou em entrevista Jacob Goldemberg (ver Apêndice II). Algo já mencionado por Mônica Junqueira de Camargo (2019, p.09) sobre o significado do PAGE para os arquitetos paulistas, no contexto da construção da capital brasileira pelo Plano de Metas. ${ }^{29}$ Assim, estes projetos dialogam com a modernidade da nova capital, seja negando ou reafirmando certos pressupostos da arquitetura monumental de Niemeyer.

Outro aspecto que nos parece interessante é a estratégia adotada por Louis Kahn na separação dos espaços segundo critérios funcionais, entre espaços servidores e servidos, e que se mostrou essencial para edifícios de centros de pesquisa. No Butantan, este recurso aparece, não necessariamente de forma idêntica à utilizada por Kahn, no Edifício de Pesquisa e de laboratórios do arquiteto Rubens Carneiro Vianna, em 1961. Em uma variação do mesmo princípio de separação, o recurso também está

29 Esta ideia nos parece importante para compreender a dimensão monumental destes projetos do Plano de Ação para a Cidade Universitária e Instituto Butantan, pois compartilham certos elementos de uma monumentalidade moderna. Cabe ressaltar que, enquanto a arquitetura da Nova Capital era obra de Oscar Niemeyer, em São Paulo predominava uma maior heterogeneidade de formas e soluções da linguagem moderna, fruto da reunião de muitos arquitetos que projetaram estas obras. Abordaremos novamente estas questões no capítulo a seguir. 
presente no Edifício de Vírus e Genética do arquiteto Maurício Tuck Schneider, feito no mesmo ano, que cria uma "rua interna" de serviços que atende os laboratórios de pesquisa, assim como fez Oscar Niemeyer eu seu projeto para o Edifício Central da Universidade de Brasília, também desenvolvido no início dos anos 1960.

Uma característica particular dos projetos modernos para o Instituto Butantan está relacionada com a preexistência de edifícios de relevância histórica para a instituição. Neste sentido, novamente, a Fiocruz se assemelha ao Butantan, na medida em que o seu campus também recebeu projetos de vulto para a construção de arquiteturas modernas a partir dos anos 1940.

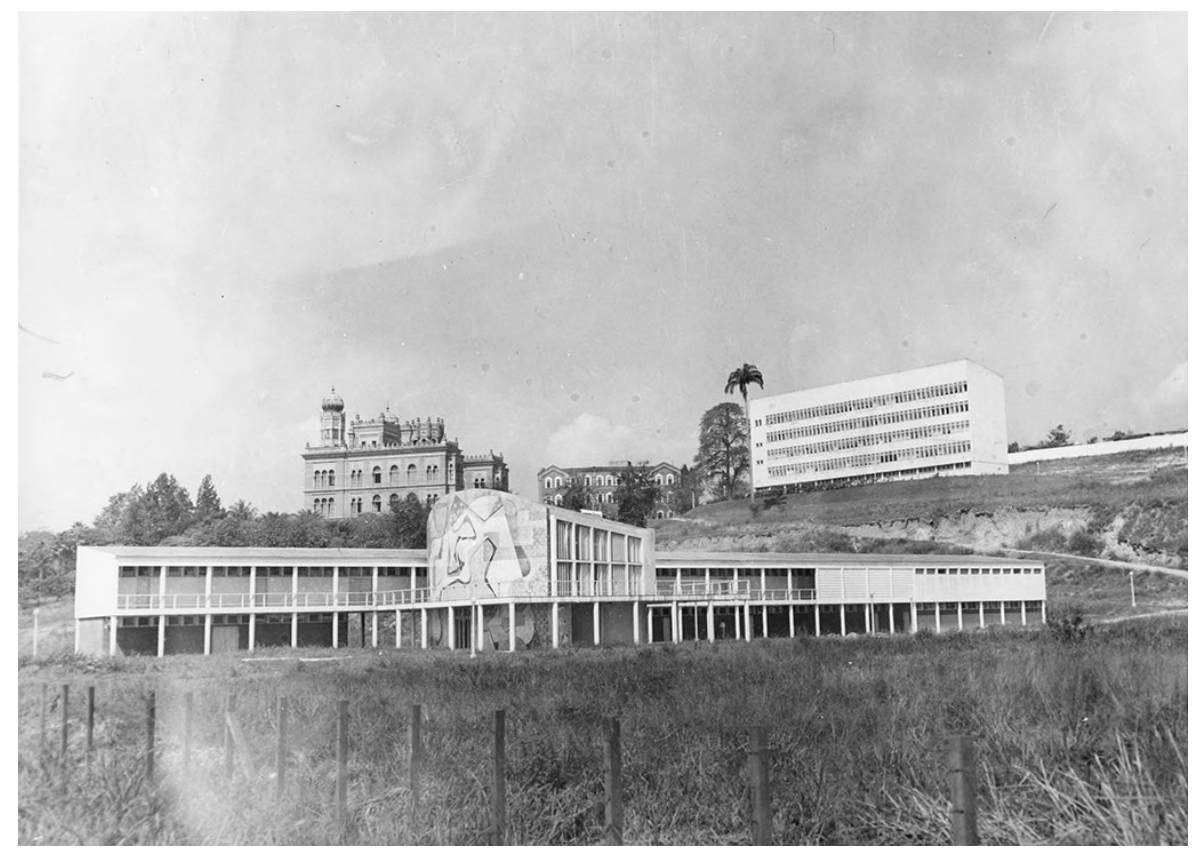

Figura 31: Pavilhão Arthur Neiva, projeto do arquiteto Jorge Ferreira, construído na década de 1940, cujo painel de azulejos do auditório é de autoria de Roberto Burle Marx. Ao fundo, do lado esquerdo, vê-se o Pavilhão Mourisco, concluído em 1918. Fonte: Departamento de Arquivo e Documentação (DAD) / Fiocruz.

Em Manguinhos estes projetos construídos ajudaram a conformar um conjunto variado de exemplares arquitetônicos, cuja presença do modernismo é bastante significativa (Figura 31). ${ }^{30}$ No Instituto Butantan, a presença de exemplares modernos é reduzida, limitada à existência do pequeno prédio da recepção de animais (Figura 21) e

30 A Casa de Oswaldo Cruz, unidade da Fiocruz dedicada à preservação da memória institucional, inclusive, se refere ao conjunto de edifícios modernistas como "Núcleo Modernista". 
do Pavilhão Vital Brazil, cuja relevância como obra moderna é pouco significativa. ${ }^{31}$

Todavia, como veremos nos capítulos a seguir, outros edifícios de arquitetura moderna foram construídos durante as duas décadas do convênio com o FCCUASO, entre 1961 e 1981. Estas construções, no entanto, nunca se firmaram na paisagem do Instituto Butantan, tendo sido demolidas ou descaracterizadas por reformas para abrigar outros programas. O mesmo tem acontecido com o Conjunto Residencial, do arquiteto Mário Rosa Soares, formado em 1960 pela Universidade Mackenzie e integrante do escritório técnico do FCCUASO, autor do único edifício de grande relevância construído no período do Plano de Ação, entre 1959 e 1963, e um dos poucos remanescentes do Instituto Butantan como centro de pesquisa moderno.

31 Como nos referimos no capítulo 1.2.2, o Pavilhão passou por diversas alterações e expansões desde a sua construção em 1948, e sua arquitetura original é pouco relevante se comparada ao conjunto dos edifícios históricos. 
Capítulo 2. Plano de Ação 


\subsection{Estado desenvolvimento e arquitetura moderna no âmbito do Plano de Ação}

Referindo-se às origens do desenvolvimento do modernismo arquitetônico na América Latina, Adrian Gorelik (2005) situa o Estado como agente central na realização do plano da vanguarda nas primeiras décadas do século XX. É na vanguarda arquitetônica que se verificarão, de forma efetiva, os pressupostos gestados pelas manifestações artísticas nas décadas anteriores. Esta confluência representada pela associação entre Estado e Arquitetura determina, para o caso da América Latina, uma contradição que marcará a trajetória do modernismo por aqui, em oposição aquele que se configurava nos países centrais.

No vácuo de uma tradição consolidada e de um passado comum, o modernismo na periferia vai se vincular ao Estado na construção de uma identidade nacional, de uma reorganização do passado que viabilize a modernidade. $O$ pensamento da vanguarda Latino Americana, fundado na própria dinâmica do seu processo histórico particular, será caracterizado pela contradição entre estes pressupostos nostálgicos e o caráter radical de rompimento com o passado, comum à vanguarda europeia.

Os movimentos de vanguarda ensaiados na periferia estarão, assim, constituídos por particularidades e contradições inerentes à sua formação e contexto, de modo que se voltarão ao passado para a construção de uma história comum e nacional, reorganizando a sociedade em vista ao progresso futuro. Esta singularidade acaba por destacar uma de suas principais contradições: configura-se com uma vanguarda passadista, que se apoia no passado para organizar um futuro nacional mas, para isso, parte de um movimento de caráter universal e internacionalista como o Movimento Moderno.

Esta contradição, exposta no discurso moderno construído nos países periféricos, cujos movimentos são definidos como Vanguardas Adjetivadas por Gorelik (Ibid., p. 16), foi elemento central e constituinte de boa parte da história da arquitetura brasileira nas décadas marcadas pelo nacional desenvolvimentismo. Por vezes, esta arquitetura esteve condenada pelas análises de críticos estrangeiros que acusavam a incompatibilidade desta produção singular, concebida na periferia, com os postulados 
modernos gestados no centro. ${ }^{32}$ Por outro lado, esta mesma produção, tornou-se responsável pelo despertar de uma nova potência da arquitetura moderna, não desenvolvida no centro do sistema capitalista, particularmente na Europa, onde tiveram origem as incursões modernas contra a arquitetura antiga e acadêmica.

Por sua natureza contraditória, a vanguarda latino-americana se depara com um contexto no qual a necessidade de se construir uma sociedade - num ambiente arraigado pelo atraso e pela sujeição ao passado colonial - se mostra muito mais urgente do que aquela que se colocava aos arquitetos modernos na Europa, cuja renovação radical e a libertação das amarras históricas, que obstruíam o desenvolvimento da disciplina e da própria cidade industrial nascente, despontavam como prioridade.

Em outras palavras, na periferia, a vanguarda se pautava pela edificação de uma sociedade fragmentada e em processo de construção. Neste sentido, manifestava-se como proposta construtiva, não apenas destrutiva, em um ambiente incompatível com renovações radicais ou de tábula rasa, vista a condição de sociedade rural e não industrializada. Esta característica será entendida como uma tradição do pensamento brasileiro e latino-americano no século XX, como a potência que emerge de sua própria contradição.

[...] a vanguarda descobre que o território americano é o âmbito de radicação do mais arcaico, mas, por isso mesmo, é o lugar onde o novo pode emergir puro, e que nessa potencialidade construtiva esconde-se a tão ansiada 'especificidade' cultural. Nessa dupla cara da identidade, explica-se tanto o recurso à Nostalgia como ao Plano, o modo com que a vanguarda busca potencializar as 'vantagens do atraso' com as 'vantagens do moderno'. (GORELIK, p.26)

As ideias provenientes do centro, que na periferia pareciam se situar fora de contexto e alheias a esta realidade social, são adotadas como ferramentas de desenvolvimento, onde o moderno se manifesta como possibilidade de construção da nacionalidade. A arquitetura moderna é materializada como instrumento

32 Nos referimos aqui às críticas desferidas por Max Bill à arquitetura moderna brasileira, principalmente em sua vertente dita carioca, suscitando reações vindas de Lúcio Costa em defesa de Niemeyer e de sua arquitetura, acusada pelos críticos estrangeiros como formalista e socialmente descompromissada. 
imprescindível à emancipação nacional, à inversão da lógica do sistema na qual predomina a submissão econômica e cultural ao centro. O progresso moderno será para estas sociedades, ao menos neste momento, a via de inserção no mundo 'civilizado', capitalista, urbano e industrial, de superação do atraso e do subdesenvolvimento, legados pela herança colonial.

Neste sentido, é na periferia, nas franjas do sistema capitalista, que o modernismo se efetiva e é através da ação do Estado que toma forma sua materialização. No Brasil do início do século XX, marcado pelo distanciamento de uma tradição autóctone, determinado pela sua formação colonial e pela independência recente singularizado pelo dirigismo da metrópole, de predominância do vazio mas, também, de latente necessidade construtiva, o modernismo encontrará contexto adequado à sua máxima potencialidade. Tais condições, reunidas no país, demonstrariam uma disposição para o florescimento da modernidade (TELLES, 2010, p.24.), que se beneficiará de um nascente Estado de âmbito centralizador e modernizante a partir dos anos 1930.

Sabe-se que tal conjuntura proporcionou ambiente ideal para a expansão e concretização, sem precedentes, do modernismo arquitetônico na América Latina permitindo, novamente de modo contrário ao que se verificava na Europa, uma produção em outra escala, de grandes edifícios públicos - como o Ministério da Educação e Saúde Pública no Rio de Janeiro - até cidades inteiras, uma nova capital como Brasília. Ganha força a relação entre arquitetura e estado que poucas vezes se manifestou nos países centrais, privilegiada a dimensão simbólica que representava estas intervenções na periferia. Adrián Gorelik (2005, p.28) destaca este movimento na periferia do capitalismo como um esforço na criação de um mercado onde predominava a fragmentação territorial e cultural. Era o Estado assumindo a vanguarda da modernização capitalista.

No Brasil, Carlos Alberto Ferreira Martins (1988) retoma a questão da origem da modernidade para entender como se deu a construção do discurso moderno no contexto brasileiro, compreendendo a formação de uma intelligentsia como ponto de 
partida para tal processo. A existência de uma elite caracterizada pelo domínio intelectual começa a ser gestada anteriormente ao Estado Novo e dará os meios para a realização do projeto moderno. Esta elite, mesmo que consciente da miséria social brasileira, munida de anseios vanguardistas e portadora de um plano de construção de uma nação moderna, careceria de um projeto de transformação social ${ }^{33}$ e terá, no governo autoritário e centralizador, a possibilidade de construção da identidade nacional contida em seu projeto moderno. Estas contradições tipificariam uma modernização de tipo conservadora, conformando uma característica do processo de modernização e desenvolvimento nas periferias do sistema, um outro paradoxo das vanguardas na América Latina.

Luciano Martins indica que, ao contrário do que fez a força da intelligentsia russa, os intelectuais brasileiros, mesmo os mais lúcidos denunciadores da miséria moral e material do país, são incapazes de superar em seu discurso o domínio da crítica moral, frequentemente confusa "os protestos e perplexidades não chegam a se converter em um projeto de transformação da sociedade". (MARTINS, 2010, p.281)

No que se refere a esta característica, essencial da arquitetura latino-americana, a Argentina passará por processo semelhante na conformação de sua vanguarda nos anos 1920 e 1930. Guardadas algumas distinções em relação ao cenário brasileiro, como a "tardia" articulação da vanguarda com o estado, o caso argentino constitui-se como uma "modernização dentro da modernização", num processo levado a cabo pela elite social portenha, que buscava se legitimar no quadro da perda de sua hegemonia cultural. Conformava-se, assim, uma modernização também de aspecto conservador, responsável por configurar a Buenos Aires moderna. Mais uma vez, não se objetivava combater padrões consolidados, como se propunham as vanguardas europeias, mas forjar uma identidade condutora do processo modernizante, unindo-se, nas décadas

33 Esta particularidade mobilizada por Carlos Martins, da ausência de um projeto de transformação social no plano da vanguarda brasileira, deve ser pensada no quadro das intensas transformações pelas quais passava o mundo no início do século XX. Deve-se ter em vista o processo de expansão e acirramento dos nacionalismos europeus durante a Primeira Guerra Mundial e, principalmente, os acontecimentos revolucionários que inauguraram a perspectiva real de uma transformação da condição humana sob o capitalismo, circunstância estabelecida pela Revolução Russa de 1917. Neste sentido, considerada a condição subdesenvolvida do capitalismo brasileiro, portanto próxima do contexto da Rússia Czarista pré-revolucionária, a modernização do Brasil se dará optando pela manutenção de certas estruturas arcaicas. 
seguintes, aos anseios do Estado nacional emergente (GORELIK,2005).

Retomando as contradições imanentes à modernização brasileira, esta elite intelectual, ou intelligentsia (MARTINS, 1988), mostrou-se capaz de projetar uma ideia de nação audaciosa e radical, considerado o ambiente social no qual estas ideias foram gestadas. Este ambiente, estritamente dependente das condições impostas pela sua formação colonial, era marcado por uma estrutura social na qual as elites, apesar da concretização do processo de independência, ainda se distinguiam pela adoção de hábitos europeus responsáveis por reforçar a estratificação social (BUZZAR, 2014, p.108) e no qual, de fato, inexistia um projeto de nação emancipada da órbita europeia.

Martins se aproxima de Gorelik quanto às particularidades da realização do plano moderno no Brasil. O propósito de construção da nacionalidade fará com que esta elite intelectual brasileira se arranje numa espécie de duplo movimento: universal e localista. Este movimento, busca se adequar ao avanço moderno, alinhando-se ao sistema internacional, ao mesmo tempo em que pretende se diferenciar, afirmando suas próprias identidades locais e voltando-se, para isto, à descoberta do país. Havia a necessidade de afirmação de uma independência política diante do imperialismo internacional, assim como de unificação política e econômica de um território fragmentado em vista da vulnerabilidade provocada pelo iminente colapso de sua coesão social (MARTINS, 1988, p.121).

O que congregará todos estes elementos será a constituição de uma identidade nacional como projeto, pensada como resposta e solução às instabilidades internas. A educação constituirá elemento-chave da política estatal, responsável por dar coesão ao corpo social em iminente colapso, assim como constituir um público para a obra modernista, o que somente será possível através da ação do Estado em associação com tal elite intelectual detentora do projeto.

Esta associação não se resolve através da sujeição desta elite intelectual, ou da chamada intelligentsia, ao poder estatal por meio da cooptação, mas deve ser entendida como plano que se viabiliza no estado modernizador. 0 projeto modernista 
age através do estado e, quando institucionalizado, se propõe à superação do atraso econômico e a arrancar o país do atraso cultural. Neste sentido, a ação educacional deve criar cidadãos e modernizar as elites. Enquanto na Europa os regimes autoritários perseguiam as vanguardas e barravam o avanço do Movimento Moderno, no Brasil o plano modernista se aproxima do Estado para sua realização.

É a autoatribuída tarefa de construção da identidade nacional que orienta o projeto modernista a pensar e propor a ação cultural como política cultural. Por isso, pelo menos tanto quanto pela locação repressiva e controladora do varguismo, o Estado será no Brasil, do pós 1930, não apenas o árbitro, mas o promotor privilegiado da produção cultural. (MARTINS, 1988, p.126).

\subsubsection{Estado e plano moderno no Brasil}

Deflagrado o primeiro impulso do desenvolvimento nacional durante o Estado Novo, tal modelo permanecerá, ao menos até a dispersão do neoliberalismo pelo mundo a partir dos anos 1970, constituindo o eixo fundamental das políticas econômicas dos governos brasileiros. Um esforço de superação do atraso e da dependência que ainda se sustenta durante boa parte da ditadura civil-militar no país. A arquitetura de Oscar Niemeyer tornou-se a representação deste processo de construção nacional. Amparado por Lucio Costa, a partir da década de 1930, e consagrado por Juscelino Kubistchek nas décadas seguintes, até a construção da nova capital, Niemeyer foi capaz de se colocar como o representante oficial dos governos que buscavam em sua arquitetura a representação do progresso do país.

Este ambiente de expansão econômica e intensa urbanização do país, marcado pela centralização das ações de desenvolvimento pelo Estado nacional, impulsionou arquiteturas como as de Niemeyer, produzindo a concretização e expansão da modernidade sem precedentes no território brasileiro, atingindo o seu ponto máximo com a construção da cidade de Brasília. A indústria da construção civil, assimilada como potente frente de desenvolvimento econômico que permitia a incorporação da massa de trabalhadores brasileiros, cuja formação era menos ou pouco qualificada, fortaleceu a relação entre arquitetura e estado e formou mercados num território de capitalismo até então insípido. 
Tamanha realização alcançada pela modernidade no Brasil em seu auge, nas décadas de 1950 e 1960, está, como vimos, permeada pelos esforços inaugurais de construção de uma nacionalidade, cujos intelectuais modernistas desempenharam nas décadas de 1920 e 1930 na agência do Estado como meio fundamental para a realização do plano moderno no país. Ao fim do Estado Novo, em 1945, e após o retorno de Vargas, eleito em 1951 e de seu suicídio em 1954, permanece a voga desenvolvimentista como mote das políticas desempenhadas pelo estado e que vai nortear o pensamento arquitetônico moderno brasileiro, também, ao longo da segunda metade do século XX.

A mais conhecida e fundamental política desenvolvimentista dos anos pósVargas, o Plano de Metas de Juscelino Kubitschek, teve como símbolo de sua materialização a construção da cidade de Brasília. A nova capital representava, ao mesmo tempo, a concretização do Estado Nacional, a interiorização e o alcance da coesão de um país fragmentado e disperso, arcaico e dependente. A universalidade da arquitetura moderna europeia vai se constituir no Brasil na chave da particularidade (TELLES, 2010, p.25-26), que incorpora elementos de uma "brasilidade" como afirmação de uma modernidade própria.

Neste sentido, a Brasília de meados dos anos 1950 materializava o impulso dado pelas vanguardas dos anos 1930, intelectuais e Estado, que atingiam a consumação do plano moderno na construção da nova capital, legitimamente brasileira, coroando uma arquitetura de símbolos nacionais que viabilizava a aparente inclusão do Brasil nos círculos dos países de capitalismo avançado.

Entre 1950 e 1979, a sensação dos brasileiros, ou de grande parte dos brasileiros, era a de que faltava dar uns poucos passos para finalmente nos tornarmos uma nação moderna. Esse alegre otimismo, só contrariado em alguns rápidos momentos, foi mudando sua forma. Na década de 1950, alguns imaginavam até que estaríamos assistindo ao nascimento de uma nova civilização nos trópicos, que combinava a incorporação das conquistas materiais do capitalismo com a persistência dos traços de caráter que nos singularizavam como povo: a cordialidade, a criatividade, a tolerância. (NOVAIS e MELLO, 1998, p.560)

No que pese todas as limitações impostas em um país de capitalismo insípido e incompleto em sua formação, como aquele que caracterizava a Primeira República, 
tamanha realização alcançada pelo plano moderno no Brasil, a ponto de ser definida por um de seus principais artificies como um milagre, ${ }^{34}$ fez surgir nos anos 1950 um modelo aparentemente imbatível para a solução das mazelas do atraso social e econômico determinados pela formação histórica do país.

As políticas desenvolvimentistas que tiveram na arquitetura, através dos arquitetos modernos, a possibilidade de materialização e formalização de seus pressupostos, se estendem aos governos de todo o mundo, segundo as condições locais de desenvolvimento, originando novos surtos de modernização tardia pelos anos 1960. Este processo pode ser concebido como tardio, não pela noção de atraso em relação aos países centrais, mas como um estágio do desenvolvimento capitalista nos países periféricos, que vislumbraram na modernização a oportunidade de superação da condição de subdesenvolvimento legada pela organização global do sistema capitalista.

O desenvolvimento planejado e produzido pelo Estado nacional era, principalmente após as crises de 1929 e da Segunda Guerra, a única forma que se apresentava aos países do chamado "Terceiro Mundo", no contexto da Guerra Fria, para que superassem o atraso econômico e social que se estabelecia em comparação ao "Primeiro Mundo". Segundo Eric Hobsbawm (1995, p.350), esta condição se afirmava na medida em que nenhum destes países acreditava na possibilidade de se atingir este desenvolvimento por meio do mercado mundial capitalista ou da empresa privada interna, desenvolvida espontaneamente. ${ }^{35}$

Voltando ao Brasil, o contexto das políticas de desenvolvimento nacionais, pautadas pelo Plano de Metas, também se verificam nos planos regionais de desenvolvimento, em meados do século XX. Em São Paulo, o Plano de Ação do Governo do Estado, inaugurado pelo Governo Carvalho Pinto, iniciou uma nova rodada de construção em massa de edifícios e infraestruturas modernas, em um Estado que havia

34 Em referência ao ensaio "Muita construção, alguma arquitetura e um Milagre" escrito por Lucio Costa em 1951.

35 Enquanto alguns países da periferia se engajavam em seus processos de modernização e desenvolvimento do capitalismo nacional, outros se voltavam para o modelo comunista soviético para a superação de sua condição arcaica e atrasada. Neste sentido, o modelo socialista (não necessariamente soviético), também, serviu aos países recém-independentes que pretendiam ultrapassar o subdesenvolvimento econômico e a persistência da condição agrária. 
perdido a hegemonia política para o Varguismo e acompanhava, a passos largos, o predomínio de uma arquitetura moderna brasileira de origem carioca, que ganhava projeção internacional.

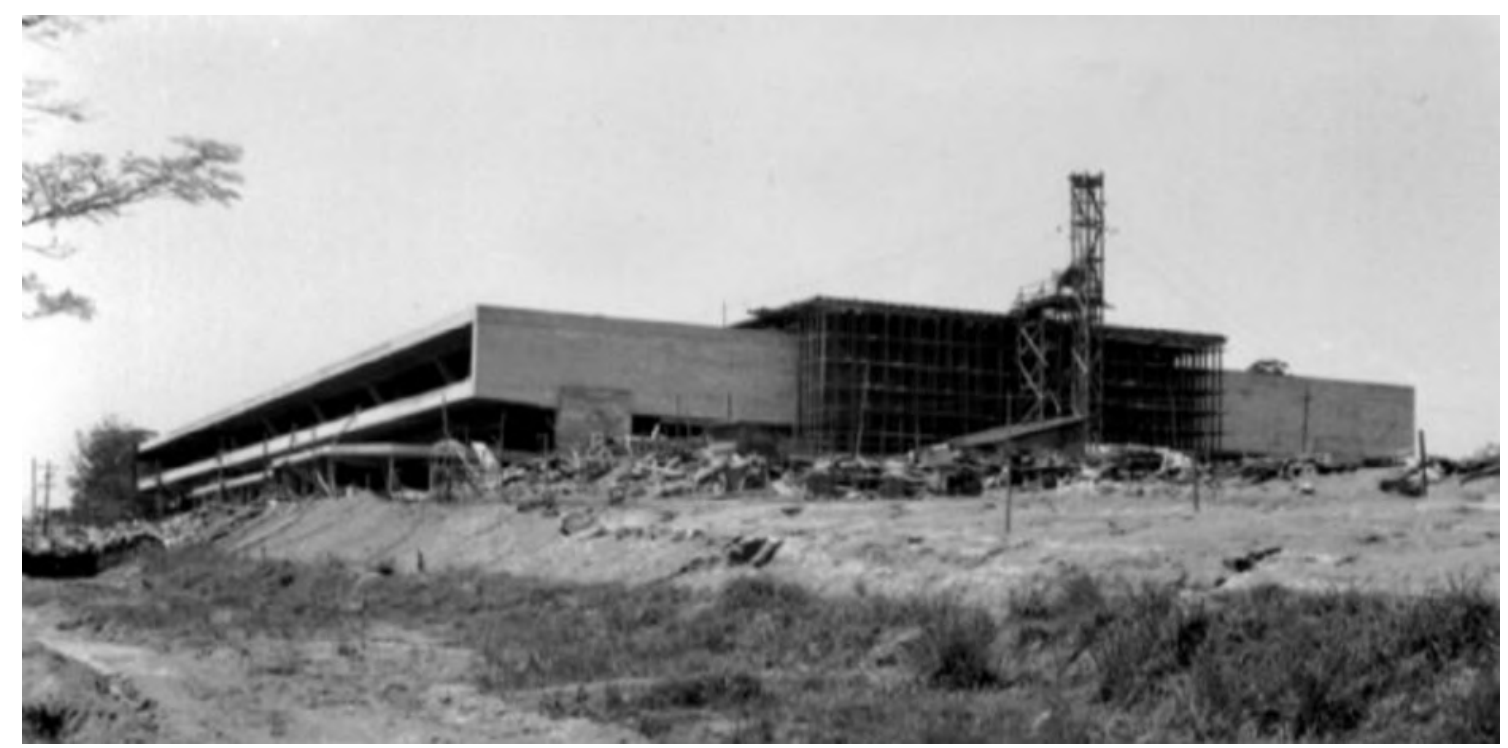

Figura 32: Construção do edifício dos departamentos de História e Geografia da USP, uma das obras do PAGE na Cidade Universitária, projeto do Arquiteto Eduardo Corona. Fonte: Arquivo COESF. Disponível em: <https://www.arquivo.arq.br/faculdade-de-historia-e-geografia-da-usp?lightbox=image_12dn >, acesso em: 05/03/2020.

Apesar da primazia, o Plano de Metas de JK é contemporâneo ao Plano de Ação em São Paulo e reforça a noção de que, em certo aspecto, este constitui uma tentativa de reposicionamento do estado de São Paulo diante do cenário nacional após décadas de hegemonia política Getulista e de um certo atraso estético da arquitetura pública praticada, até aquele momento, pelos órgãos do Estado paulista.

O PAGE, em que pese a linguagem eclética consolidada no Estado, funcionou como uma espécie de mecanismo que tornou o Estado permeável ao modernismo. A não adoção da linguagem moderna, no quadro de sucesso internacional e nacional da arquitetura moderna brasileira, com os projetos modernos de Brasília, tanto arquitetônicos como urbanístico, já em curso, certamente, trazia questionamentos inúmeros. (BUZZAR et al., p.162)

Longe de resolver tal disputa acerca do PAGE como resposta ou não ao triunfo da arquitetura de vertente carioca naquele momento, e que surge na historiografia recente sobre o Plano de Ação (CAMARGO, 2016, p.164), cabe aqui destacar a intersecção temporal entre os dois planos e afirmar a prevalência do planejamento orçamentário como elemento inédito destas políticas de desenvolvimento. Planejadas 
através de metas e orçamentos previamente definidos, estas ações viabilizaram a intervenção massiva do estado na infraestrutura pública em um curto período de quatro anos de governo.

Em São Paulo, as pesquisas sobre o Plano de Ação do Governo do Estado deram respostas ao que se imaginava como manifestações individualizadas de determinados arquitetos modernos paulistas, ${ }^{36}$ tendo Vilanova Artigas espaço privilegiado pela historiografia. A numerosa construção de edifícios de linguagem moderna, neste período no estado de São Paulo, foi possibilitada pela atuação e mediação direta e intencional do Estado, assim como definido por Adrián Gorelik (2005) e Carlos Martins (1988 e 2010) em seus estudos sobre a constituição do modernismo na América Latina e no Brasil, como ator privilegiado da produção da cultura na sociedade.

Além de se situar na esteira do sucesso das políticas de desenvolvimento à época, que alcançaram através da arquitetura uma parcela importante de visibilidade, o Plano de Ação em São Paulo se vinculou à herança do planejamento da Sociedade de Análises Gráficas e Mecanográficas Aplicadas aos Complexos Sociais, as SAGMACS, fundada pelo padre francês Louis-Joseph Lebret e que contribuiu para a formação de quadros importantes ao planejamento urbano no país, segundo os princípios do Mouvement Économie et Humanisme. Durante seu processo de formação intelectual Lebret, que visitou diversos países latino-americanos, tendo visitado São Paulo no ano de 1947, se vinculou aos estudos da teoria marxista, influente na formulação do conceito de Economia Humana (ROLDAN, 2012, p.35).

As SAGMACS tiveram papel importante na formulação de políticas de planejamento em São Paulo e no Brasil, até a reviravolta política ocasionada pelo golpe civil-militar de 1964. Alinhado às políticas de desenvolvimento do período, orientadas pelo planejamento público de grande alcance e escala, o PAGE foi responsável pelo

36 Por diversas vezes as obras modernas construídas por meio do Plano de Ação foram entendidas como manifestações isoladas, ou meramente autorais, e a construção historiográfica da chamada escola paulista entendida fora do âmbito de sua promoção pelos arquitetos modernos no interior das instâncias do estado. Todavia, é importante acrescentar que, embora a esta arquitetura seja atribuída uma vinculação estética e ideológica, a linguagem da arquitetura produzida pelo Plano de Ação se vincula a um amplo repertório, compartilhado pela arquitetura brasileira e de outros lugares no período. 
desenvolvimento de ao menos mil projetos em todo o Estado de São Paulo, através da contratação de mais de 160 arquitetos organizados em torno do Instituto de Arquitetos do Brasil (IAB-SP) e do arquiteto João Batista Vilanova Artigas. Naturalmente, o Plano se apoiou na arquitetura como representação do progresso técnico moderno e do desenvolvimento ensaiado pela sociedade brasileira naqueles anos, cujo o Estado de São Paulo, até então, não protagonizava (CAMARGO, 2016, p.165).

Considerando somente os investimentos direcionados à construção de novas infraestruturas, o Plano de Ação do Governo do Estado, que permaneceu entre 1959 e 1963 no âmbito do Governo de Carvalho Pinto, foram construídos edifícios públicos em mais de 260 cidades paulistas num significativo processo de interiorização e de ampliação do alcance dos investimentos e da atuação do Estado. Estas construções se dividiam entre fóruns, postos de saúde, escolas e ginásios de todos os níveis, do primário ao ensino superior, e representavam, além da sua dimensão social, a formação de uma imagem de progresso e modernidade materializada através da arquitetura, assim como apontavam para uma significativa transformação no modo de produção da arquitetura pública no estado de São Paulo.

\subsubsection{A experiência do Plano de Ação e a transformação pela arquitetura}

Sabe-se que o Plano de Metas de Juscelino Kubitschek teve na construção da nova capital brasileira, apenas um de seus diversos pontos a serem alcançados, constituindo, portanto, uma de suas metas. Estas estavam subdivididas por setores econômicos que receberiam estímulos ao seu desenvolvimento: os setores de energia, transportes, indústria de base e educação. Mesmo que a construção de Brasília representasse apenas uma das metas estipuladas pelo governo, foi aquela que mais contribuiu para o reconhecimento do plano, justamente pela sua dimensão e pelo caráter simbólico que ocupou na sociedade brasileira. Algo que remetia à constituição de uma nação moderna, um símbolo do país, como pretendeu a vanguarda.

Neste processo, Brasília também esteve associada à consolidação de uma 
indústria nacional da construção civil, origem de grandes empresas ligadas à tecnologia do concreto armado. Esta técnica construtiva permaneceu profundamente atrelada à arquitetura moderna brasileira sendo responsável por definir uma estética própria, uma característica determinante da forma arquitetônica. De modo complementar e nem sempre evidente, a outra face deste processo também retrata aquilo que se verifica no curso da consolidação de um mercado em um ambiente de capitalismo pouco avançado, algo como um "acúmulo primitivo", que constitui as bases para o desenvolvimento e ampliação do capital nas etapas seguintes. ${ }^{37} \mathrm{O}$ Estado assume o papel de promotor do capitalismo numa economia periférica. ${ }^{38}$

Localizado em São Paulo, o Plano de Ação, que teve também na arquitetura um elemento central para a construção de uma imagem de progresso e de modernidade, foi organizado segundo três categorias essenciais, que muito traziam do conceito de Economia e Humanismo defendidos por Lebret: "melhoria das condições do homem", infraestrutura e expansão agrícola.

Alguns autores ${ }^{39}$ ressaltam esta herança humanista e a atuação política e social dos arquitetos envolvidos no plano, como um dos fatores que enaltecem a dimensão social do PAGE em São Paulo. De fato, aproximadamente um terço do total de

37 Evidente que não se trata de uma "acumulação primitiva" nos moldes do conceito teorizado por Karl Marx, na obra "O Capital", mas do seu uso como uma figura de linguagem para ilustrar o processo de desenvolvimento do capitalismo no Brasil. O conceito de Marx se refere ao processo de expropriação que está na origem do modo de produção capitalista e antecede a Revolução Industrial. Na Europa, a expropriação, que caracterizou esta etapa do desenvolvimento capitalista, foi responsável por separar o produtor dos meios de produção na formação do trabalho assalariado; nas colônias, a expropriação pela metrópole ocorreu, entre outros fatores, pelo monopólio mercantil, pelo comércio e manutenção da escravidão e pela expropriação de riquezas que sustentaram o desenvolvimento do capitalismo nos países centrais. No caso do Brasil do século XX, o Estado assumiu a dianteira do desenvolvimento, criando mercados, estruturas empresariais e a divisão do trabalho que permitiu a expansão do capitalismo nacional e as bases do seu processo de industrialização. Vale lembrar que, conforme Marx expôs no capítulo 24 de "O Capital" e em outras obras como "Os despossuídos", as estruturas do estado foram fundamentais para a constituição de mercados e da divisão do trabalho no capitalismo.

38 A questão da materialidade possibilitada pelo concreto armado é importante, pois, será objeto de disputa entre as narrativas das correntes modernas brasileiras quanto ao aspecto social da produção arquitetônica, quando da incorporação da estética brutalista. É também, um ponto relevante para se discutir os limites do discurso progressista destes planos, recheados de aspectos contraditórios que apontam para uma modernização conservadora.

39 Dos quais podemos destacar dois pioneiros sobre as pesquisas do PAGE, a professora Mônica Junqueira de Camargo (2016) e o professor Miguel Antonio Buzzar (2015), que ressaltam a dimensão social dos arquitetos envolvidos no plano. 
investimentos mobilizados foi destinado ao setor denominado "melhoria das condições do homem" e que correspondia as áreas de educação, saúde, cultura e pesquisa, assistência social e saneamento. O reflexo disto foi a construção de inúmeros edifícios escolares, fóruns e postos de saúde pelos municípios do estado, como já citamos, além da criação da Universidade Estadual de Campinas, da Fundação de Amparo à Pesquisa do Estado de São Paulo e do Fundo para a Construção da Cidade Universitária da Universidade de São Paulo, que se arrastava há duas décadas no bairro do Butantã, na zona oeste de São Paulo.

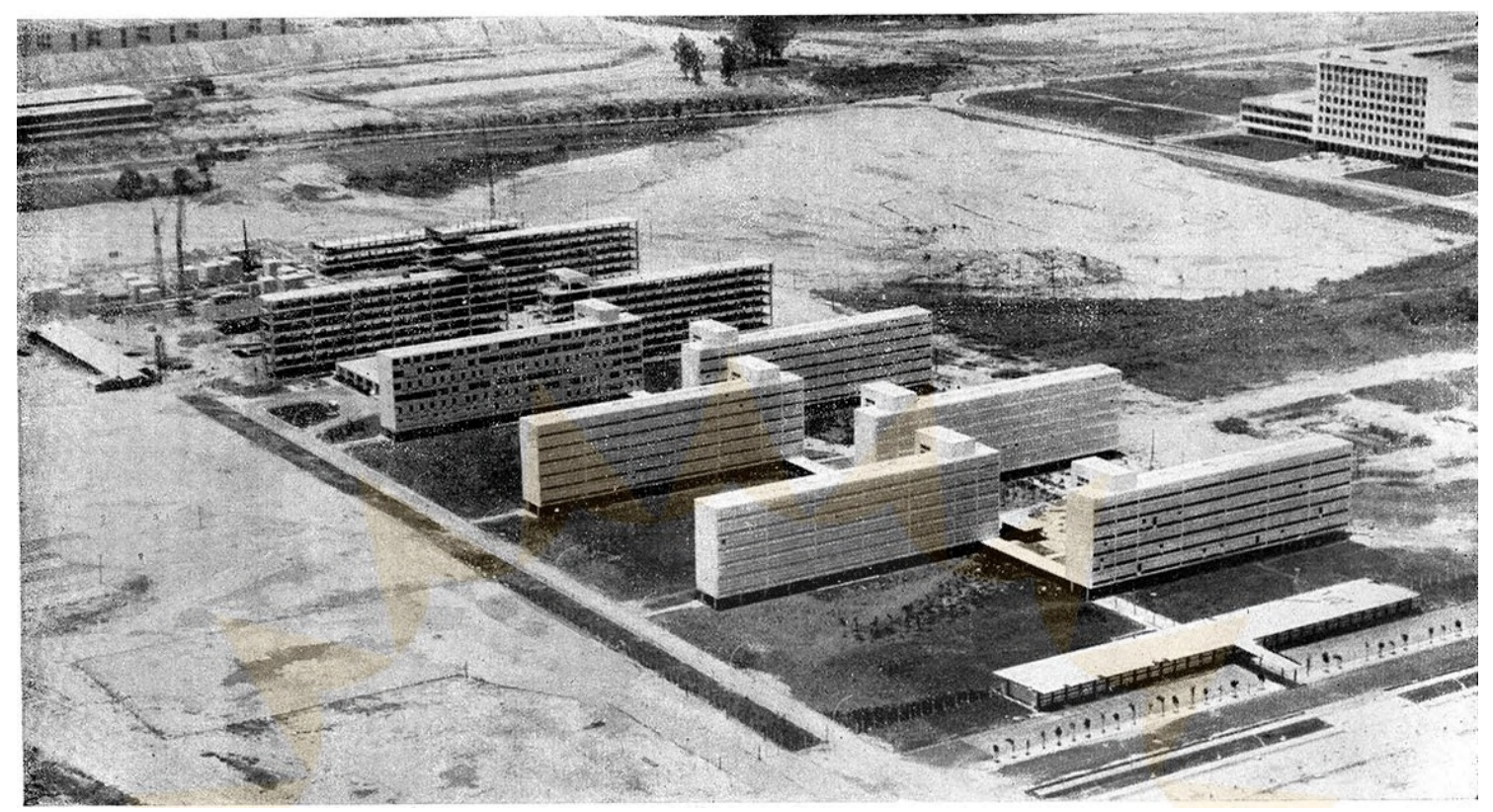

Figura 33: Vista aérea da construção do Conjunto Residencial da Cidade Universitária da USP. Fonte: Revista Acrópole, 1964, ano 26, no 303, p.94.

Malgrado a origem conservadora de Carvalho Pinto, ao mesmo tempo, detentor de certa consciência social, na perspectiva de Plínio de Arruda Sampaio ${ }^{40}$ (CORDIDO, 2007, p.302) $)^{41}$, a afinidade do Governador de São Paulo com a ideia de planejamento, também está presente em Juscelino, como fator fundamental para o sucesso do Plano (ALVES, 2008, p.90). Neste sentido, é surpreendente imaginar o alcance obtido por

40 Plínio de Arruda Sampaio participou junto aos quadros de elaboração do PAGE no Governo de Carvalho Pinto.

41 "E ele era um burguês que não queria mudar fundamentalmente a sociedade, mas acreditava que se organizasse bem o governo e se tivesse um sentimento de generosidade, etc., era possível construir uma sociedade mais justa. Essa era a ideologia do Carvalho Pinto." Plínio Sampaio em entrevista à Cordido (2007, p.302). 
estas políticas e a magnitude dos resultados produzidos, com número significativo de objetivos realizados em um curto período de quatro anos de governo.

Neste breve intervalo, tornaram-se responsáveis pela transformação da cultura construtiva do Estado, principalmente no caso do Plano de Ação, obtendo enorme sucesso no que se refere à consolidação de uma cultura arquitetônica profundamente influentes na arquitetura moderna brasileira. Neste ponto, o planejamento do estado aparece como forma de realização do plano das vanguardas.

Tanto o Plano de Metas quanto o Plano de Ação, guardado o caráter pioneiro do Plano de Juscelino Kubitscheck, - mas que também se desenhava em São Paulo através da atuação de Lebret e do próprio Convênio Escolar na cidade de São Paulo constituem iniciativas de planejamento em escala universal até então pouco recorrente no país. Representam um esforço de superação dos entraves econômicos e sociais ao desenvolvimento, que se verificava no Brasil já nos anos de 1930 e, portanto, pertencentes e herdeiros de uma tradição modernizante de longa duração, centralizada no Estado e que se inicia com Getúlio Vargas.

Para além da complementariedade temporal e da proximidade dos dois planos como políticas de planejamento, gestados em um momento econômico e social de ampla urbanização e industrialização do país, é importante reforçar o cenário de disputa no qual se inscrevem. Tanto a forma política quanto o discurso sobre a arquitetura moderna brasileira permeiam a relação entre os dois planos, representando, ao mesmo tempo, o auge e o início do desgaste da vertente moderna ancorada em Lucio Costa e Oscar Niemeyer, assim como, uma brecha para o deslocamento do modernismo arquitetônico para São Paulo.

De qualquer modo, talvez o que seja possível constatar, são os traços, a permanência, de uma modernização conservadora no Plano de Metas de Juscelino Kubitschek, que parece, em um primeiro momento, herdada do projeto das elites intelectuais no seio do Estado Novo. O projeto da vanguarda não partia de esforços de transformação da sociedade, como evidenciou Carlos Martins (2010), mas da constituição de uma identidade nacional. Podemos conjecturar sobre a construção 
nacional corresponder ou não a um projeto de transformação social, contudo, nos parece que, embora não se coloque como revolucionária, a construção do estado nacional naquele momento se coaduna com os esforços para a transformação da realidade cultural dependente do país.

Já a condição do Brasil e da América latina em meados do século XX se torna mais complexa e evidente neste sentido, pois o projeto de transformação social, embora colocado pelos arquitetos e intelectuais do período, parece convergir de forma mais contraditória com os interesses das elites e do Estado. Portanto, o plano moderno neste momento parece estar mais diretamente em conflito com as intenções de modernização do estado do que na década de 1930, embora o projeto dos arquitetos e intelectuais modernos ainda seja capaz de convergir com estes outros interesses para o desenvolvimento nacional. ${ }^{42}$

No caso de São Paulo, apesar da ênfase na defesa de uma arquitetura socialmente comprometida, que encontrava amparo nos princípios da Economia e Humanismo que fundamentaram o Plano de Ação, também estavam colocados os interesses de projeção política de uma elite local. Esta convergência em torno de um projeto nacional, representado tanto pelo Plano de Metas quanto pelo PAGE vai mostrar o seu esgotamento com o revés de 1964. No Plano de Ação, mais do que uma convergência entre estado e projeto moderno, a arquitetura correspondeu à viabilização do desenvolvimento econômico do estado e de sua interiorização.

\subsection{O acervo de projetos do Plano de Ação e as particularidades do documento arquitetônico}

Para os historiadores positivistas o documento era entendido como um testemunho escrito dos eventos históricos, cujo ofício do historiador estaria em retirar tudo o que este pudesse oferecer. Em consequência, os documentos eram fundamentalmente compostos por fontes textuais. Segundo Jacques Le Goff, há neste entendimento o predomínio do documento sobre o monumento que se verifica,

42 Esta dimensão é muito bem exemplificada pelo posicionamento do Partido Comunista Brasileiro, favorável a uma aliança de classes em torno do projeto nacional, do qual participaram intelectuais como João Batista Vilanova Artigas. 
sobretudo, no final do século $X X$, quando o documento torna-se fundamento do fato histórico e adquire o status de prova. (LE GOFF, 1990, p.536-537).

Portanto, Le Goff vai afirmar que "com a escola positivista o documento triunfa" (Ibid., p.539). O triunfo do documento estava, sobretudo, ligado às fontes textuais, sendo que a sua inexistência ou perda, decretava a extinção dos fatos históricos relacionados. Esta concepção de documento começa a se alterar de forma mais perceptível a partir dos historiadores da Escola dos Annale, que expandem a noção de documento para tudo aquilo que tenha pertencido ou se vinculado ao homem (Ibid., p.540).

Esta ampliação da noção de documento para a história abre um importante precedente. Autoriza o historiador a buscar outros elementos que complementem a documentação tradicional, não se limitando aos documentos oficiais, vinculados ao estado e às instituições existentes ou focados nas grandes personalidades históricas, podendo propor a história a partir de novas perspectivas. Abre-se a possibilidade de que a história resgate povos, culturas e sociedades, cujos documentos oficiais existentes não guardam registro.

Dentro deste processo de dilatação das fontes documentais, podem ser inseridos aqueles documentos que se vinculam ao fazer arquitetônico, que antecipam a materialização do edifício e se relacionam ao processo de concepção e desenvolvimento do projeto. A inclusão de documentos arquitetônicos como elemento do ofício do historiador abre, para além da história da arte, uma nova ramificação ao campo, a da história da arquitetura e das cidades.

Na mesma medida, este alargamento da noção de documentação histórica culminou na explosão documental de meados do século XX. Esta revolução documental, se relaciona com uma outra revolução, de caráter tecnológico, com o advento do computador e das novas tecnologias da informação (LE GOFF, 1990, p.542). Deste modo, foi possível uma ampliação nunca imaginada do processamento de dados que impactou diretamente o campo da história, cujo o enorme aumento da massa 
documental fez com que o historiador passasse a trabalhar com novas formas de interpretar as infindáveis séries de documentos dispostos nos arquivos.

Quanto aos arquivos, como consequência deste processo há um vertiginoso aumento de organismos e instituições dedicadas a preservação de documentos, assim como de profissionais ligados à arquivística. Entre eles os dedicados à preservação de projetos e documentos relacionados à arquitetura e o urbanismo, que configuram um novo rol de arquivos especializados. Os arquivos de arquitetura apresentam características específicas que tornam a preservação documental particularmente mais complexa se comparados a outros tipos de documentos.

[...] no caso dos arquivos de arquitetura soma-se o fato de que as características de suporte físico (diversidade, fragilidade e formato em grandes dimensões), conteúdo informacional (representações gráficas, terminologia e linguagem específica), acessibilidade, diferentes modelos de tratamento e incorporação de novos elementos ao projeto de arquitetura, sabor de inovações e tecnologias desenvolvidas tanto pelo campo da administração como pelo campo da arquitetura ao longo dos séculos XIX e $X X$, traz ainda mais dificuldade à proposição de soluções na organização da massa documental acumulada. (VIANA, 2015, p.127)

Estas características particulares dos documentos arquitetônicos, definidas por uma enorme diversidade e variação, tanto de suporte documental quanto de tipologia, dimensão das pranchas de projeto, inexistência de informações completas, dificuldades de armazenamento e condições de conservação, acabam por impactar diretamente na organização arquivística e na difusão deste tipo de acervo.

\subsubsection{Uma proposta de organização dos projetos do Plano de Ação para o Instituto}

\section{Butantan}

Projetos urbanos e planos de implantação e de zoneamento, projetos para edifícios de pesquisa e de produção de imunobiológicos, museus, hospital, biblioteca, restaurante, conjunto residencial, prédios administrativos e de serviços, projetos de instalações para uma fazenda, biotério para animais, cobris e serpentários, um macacário, projetos de mobiliário e, até mesmo, uma igreja estão entre os planos desenvolvidos para o Instituto Butantan através do PAGE, a partir de 1959, durante a 
construção da Cidade Universitária da USP. Cada um destes programas e tipologias apresentam uma infinidade de outras versões, de anteprojetos, revisões e variações do projeto original, reformulações e atualizações, pranchas de detalhamento e projetos executivos, projetos estruturais desenvolvidos por empresas de engenharia da época, assinados por diversos profissionais envolvidos na concepção de um plano de modernização para o Instituto Butantan.

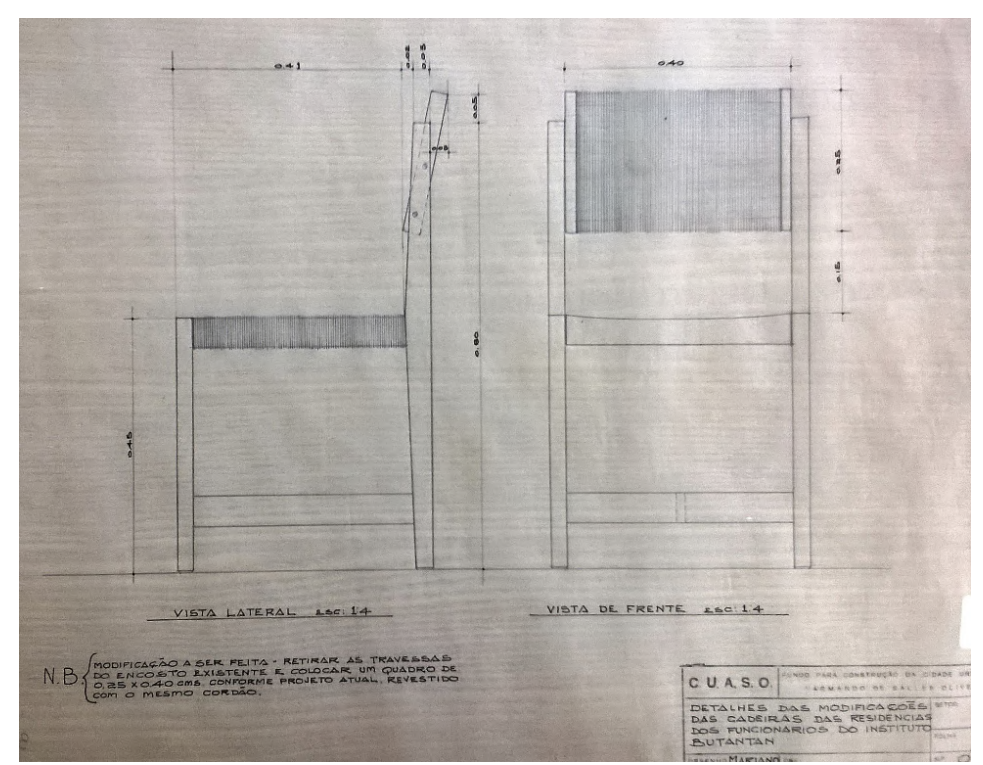

Figura 34: Projeto de uma cadeira para o mobiliário das casas dos funcionários do Conjunto Residencial, projeto do arquiteto Osmar Antonio Mammini. Fonte: prancha 32.21, Centro de Memória/IB.

Atualmente, 1210 itens compõem o Acervo Cartográfico do Instituto Butantan, que recebe doações regulares de novos documentos vindos dos diversos setores, departamentos e laboratórios da Instituição. Entre estes, 913 correspondem ao período de 1959 até 1981, quando vigorou o convênio estabelecido entre Universidade de São Paulo e Instituto Butantan, para o planejamento conjunto dos campi de ambas as instituições, através do Fundo para Construção da Cidade Universitária Armando de Salles Oliveira. ${ }^{43}$ No período que compreende estas pouco mais de duas décadas de

43 Segundo os Relatórios Anuais do Instituto, o convênio é firmado em 1961, entretanto, por causa do Plano de Ação, o compartilhamento técnico para o planejamento ocorria desde 1959. O Fundo para Construção da Cidade Universitária Armando de Salles Oliveira foi instituído no ano de 1960 para a execução das obras de construção e da Cidade Universitária. Nas décadas seguintes passou por modificações tendo o nome alterado para FUNDUSP (Fundo de Construção da Universidade de São Paulo) em 1969, COESF (Coordenadoria do Espaço Físico) em 2002 e SEF (Superintendência do Espaço Físico) em 2012. Desde a sua fundação na década de 1960, o órgão é responsável pela 
convênio, temos 603 itens referentes à atuação direta do Plano de Ação do Governo do Estado no Instituto, compreendendo os quatro anos do governo de Carvalho Pinto, entre 1959 e 1963, que se estendem, ao menos, até 1966, consideradas as revisões de projeto já sob o governo posterior, de Ademar de Barros.

Esta constelação de projetos traz uma enorme complexidade para a sua organização, pelos motivos já mencionados no tópico anterior deste capítulo, e que caracterizam os documentos de arquitetura mas, também, pela própria especifidade dos documentos relativos ao Plano de Ação. Neste sentido, parte considerável destes projetos não faz menção direta ao plano governamental e, em sua maior parte, referem-se apenas ao convênio com a Universidade de São Paulo.

Considerado o cenário de disputa inaugurado com a concessão de parte da área original do Instituto para a construção da Cidade Universitária em 1941, situação que ganha novos contornos a partir de 1959, são comuns pranchas de projetos cujo carimbo do PAGE está rasurado (figura 35 ) e raros os carimbos que estão completos (figura 36). Não é possível afirmar ao certo de que se trata de uma tentativa de apagamento da menção ao Plano, no entanto, esta circunstância é bastante curiosa e ilustrativa da dificuldade de se dimensionar o impacto do Plano para o Instituto Butantan e de seus projetos existentes no acervo.

coordenação das construções e intervenções no espaço físico da Universidade em todos os seus campi. 


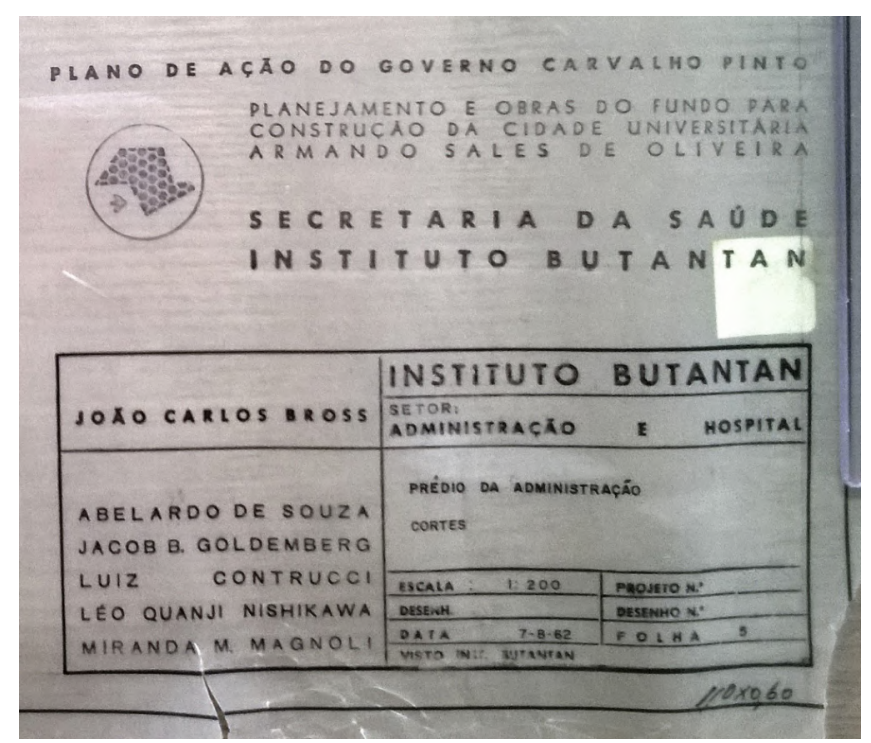

Figura 35: Carimbo de prancha de projeto para o Prédio da Administração do Instituto Butantan, contendo o carimbo e o nome do PAGE. Fonte: item 46.05, Centro de Memória/IB.

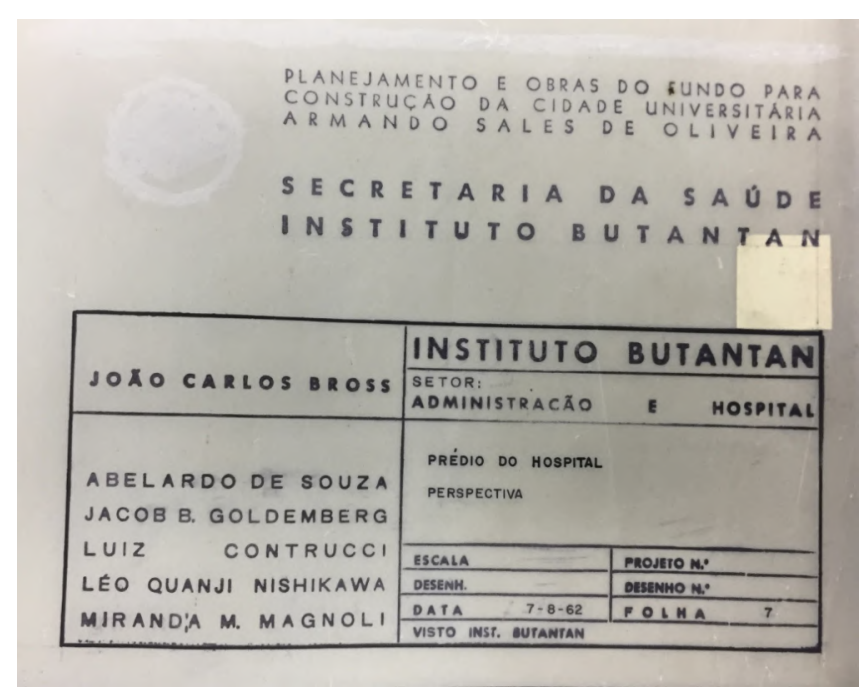

Figura 36: Carimbo de prancha de projeto para o Prédio do Hospital do Instituto Butantan, com nome e carimbo do PAGE rasurados. Fonte: item 21.02, Centro de Memória/IB.

Um segundo ponto importante se refere à considerável quantidade de pranchas não datadas e não assinadas, ou que não fazem menção ao profissional responsável pelo projeto. Neste sentido, para fins de identificação e classificação, conferimos a autoria dos projetos aos autores da primeira versão identificada, que em alguns casos foi sendo desenvolvida por outras equipes ao longo dos anos seguintes. Do mesmo modo a relação dos projetos com o PAGE foi definida pela data e, na ausência desta, 
pela identificação do edifício projetado nos planos gerais para o Instituto, ou nos documentos complementares. Em suma, na ausência de informações determinantes para a interpretação do conjunto do acervo, foi preciso recorrer a outros documentos, textuais, fotográficos, publicações e também aos próprios projetos, além da bibliografia sobre o PAGE, de modo a complementar as informações identificadas nas pranchas.

Identificadas as questões de autoria e vinculação ao plano, foi preciso delimitar o período em que o PAGE se estende como definidor do planejamento do Instituto. Dada as ambições colocadas pelo Plano de Ação, os quatro anos do Governo Carvalho Pinto não foram suficientes para a execução de todos os projetos idealizados durante o tempo do seu governo. Ao todo foram mais de mil obras projetadas em três amplos setores de atuação, além do tempo necessário ao planejamento e desenvolvimento destes projetos e à aprovação do Plano Plurianual de Orçamento na Assembleia Legislativa do Estado (CAMARGO, 2016, p.171). Neste sentido, são comuns casos como do emblemático edifício da FAU USP, projetado por Vilanova Artigas e Carlos Cascaldi em 1961, cuja obra é iniciada somente em 1966, fora do período do governo, sendo concluída em 1969.

Dada esta condição comum no campo da arquitetura, na qual o momento da idealização e o da finalização do edifício podem estar separados por décadas, levou-se em consideração, para a catalogação dos projetos definidos para esta pesquisa, o período que vai até o ano de 1966. Até esta data limite a maior parte dos projetos pensados no período anterior, até 1963 , ainda eram avaliados para execução, sendo desenvolvidos na forma de projetos complementares. Soma-se a esta questão, a prevalência de uma ampla maioria de projetos não construídos entre os identificados no período de 1959 à 1981.

Por fim, a última consideração se refere a dispersão destes documentos pelo acervo. Acondicionados em tubos e pastas, foram identificados e vem sendo recuperados pelos profissionais do Centro de Documentação do Instituto Butantan, mas ainda carecem de uma sistematização. Com o objetivo de contribuir para a organização da totalidade deste acervo, não somente do período estudado por esta 
pesquisa, propomos a disposição destes itens em três grupos principais sendo:

Grupo A. 603 itens relativos aos projetos do PAGE, entre 1959 e 1966;

Grupo B. 310 itens relativos ao período seguinte do convênio entre Instituto Butantan e Universidade de São Paulo, compreendendo projetos a partir de 1967 até 1981.

Grupo C. 297 itens relativos aos demais períodos da história do conjunto, que compreendem projetos recentes e antigos, e que foram construídos em sua maioria.

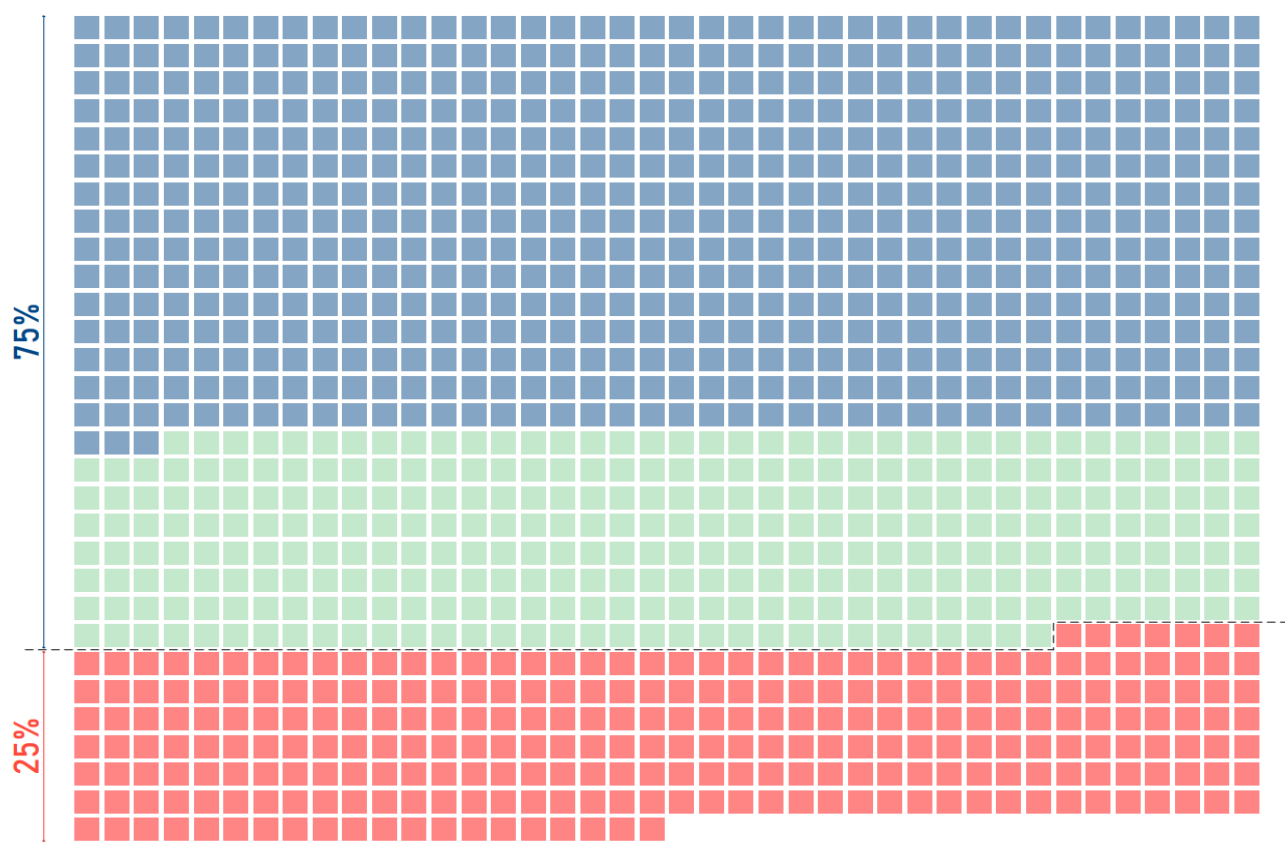

Figura 37: Diagrama de composição do Acervo Cartográfico do Centro de Memória segundo a organização proposta: azul: Grupo A; verde: Grupo B; vermelho: Grupo C. Cada quadrado representa um item identificado do Acervo Cartográfico, compondo 1210 itens no total, cujo Grupo A e B representa os projetos referentes ao convênio com o FCUASO (1959-1981), contabilizando aproximadamente $75 \%$ do acervo, com 913 pranchas de projeto. Fonte: nossa autoria.

A partir desta categorização, demonstrada pelo diagrama acima (Figura 37), os itens referentes ao primeiro grupo podem ser desmembrados por autoria e tipologia. Por exemplo, as pranchas do projeto para o Edifício de Pesquisa, cujo anteprojeto é de 1961 e de autoria do arquiteto Rubens Carneiro Vianna, representando uma quantidade significativa de itens do acervo, podem ser agrupadas, para que sejam mais 
facilmente acessadas. Em seguida, outros projetos assinados pelo mesmo arquiteto, e que aparecem em menor quantidade, podem estar atrelados ao projeto que está mais documentado pela razão da autoria. Temos assim, dentro do Plano de Ação, os projetos acessíveis por autoria e tipologia, dos que estão mais documentados no acervo aos que aparecem em menor quantidade.

Esta estrutura pode ser reproduzida também para o grupo $B$, cuja proximidade com os itens do grupo A é notória, pois constituem parte de um mesmo período inaugurado pela construção da Cidade Universitária, referentes ao processo de modernização do Instituto e no qual são predominantes os projetos não construídos. Apesar das proximidades, cabe a este grupo, uma maior preocupação com as tipologias como eixo norteador, visto que a autoria não está muito clara e poucos arquitetos, trabalhando diretamente no Instituto, são responsáveis pela maior parte dos projetos.

Esta proposta deve ficar mais detalhada com a descrição dos itens do Plano de Ação apresentado no tópico a seguir. Por fim, embora os itens referentes ao grupo $C$ não façam parte do objeto desta dissertação, através do contato possibilitado ao longo desta pesquisa é possível tecer algumas considerações. Neste sentido, a organização destes documentos deve, ao menos em uma primeira aproximação, priorizar a datação pois, tratando-se de projetos de períodos muito distintos, o agrupamento por data parece mais adequado.

Deste modo, é amplamente recomendada a periodização do conjunto construído do Instituto Butantan, proposta pelo arquiteto e pesquisador Anderson Luiz Félix de Sá (2019, p.245-250) em sua dissertação de mestrado intitulada Preservação do patrimônio arquitetônico do Instituto Butantan, defendida no ano de 2019, neste mesmo programa de pós-graduação da Faculdade de Arquitetura e Urbanismo da USP.

\subsubsection{Quantificação e composição dos projetos relativos ao Plano de Ação}

A partir de uma primeira aproximação com estes números temos, em um acervo que se refere à história construtiva de uma instituição com 120 anos: cerca de 
$50 \%$ dos projetos identificados referentes ao período de 1959 a 1966, que se referem principalmente aos projetos do PAGE, além de outros 25\% do período que vai até 1981 . Somados, os dois momentos correspondem a aproximadamente $75 \%$ do acervo, circunscrevendo o período mais amplo do convênio com o FCUASO, firmado em 1961 mas condicionado pelo PAGE em 1959. Em suma, a maioria absoluta dos desenhos guardados pelo acervo foram produzidos em duas décadas, de 1960 e 1970.

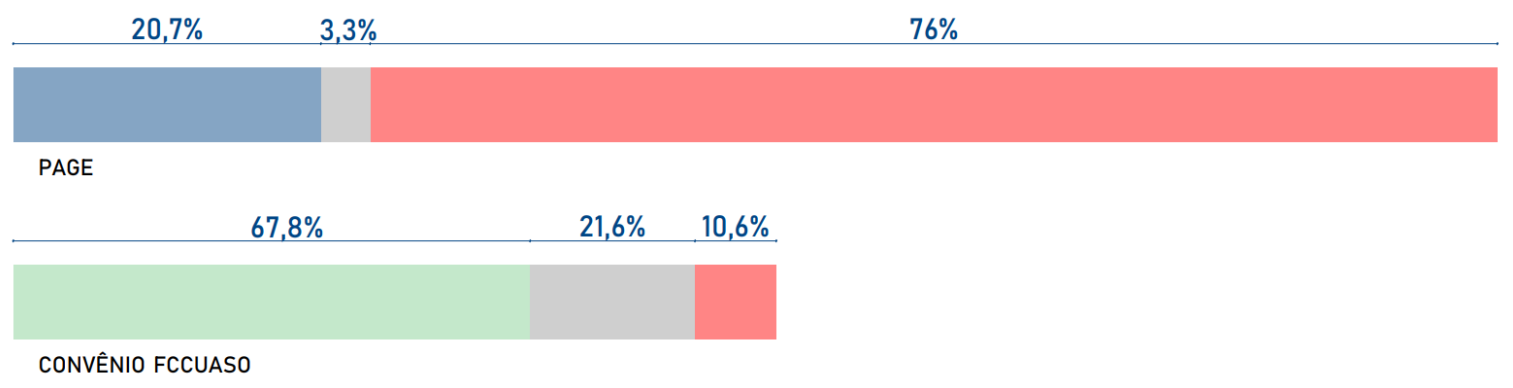

Figura 38: Gráfico do percentual dos desenhos referentes a projetos construídos: em vermelho os não construídos ou parcialmente construídos, em cinza os desenhos sem dados. Barra 1: 603 pranchas referentes ao PAGE; Barra 2: 310 pranchas do convênio com o FCCUASO. Fonte: nossa autoria.

Deste modo, restam outros $25 \%$ para a maior parte da história do conjunto (1899-2021) - quase um século se excluirmos os 22 anos de convênio -, exatamente, 297 itens do conjunto do Acervo Cartográfico. Em contrapartida, cerca de 76\% dos itens referentes ao período do Plano de Ação, tratam de projetos não construídos ou construídos parcialmente. Em suma, a maior parte do acervo é formado por projetos do Plano de Ação, e a maior parte destes projetos não passou da concepção.

Esta primeira constatação deixa uma impressão de disparidade no que se refere à relação entre acervo de projetos e ambiente construído, na medida em que boa parte dos projetos desenvolvidos para o Instituto Butantan, pelo Plano de Ação, não foram executados. De toda maneira, é preciso acrescentar que estes números tratam de itens do acervo e não da quantidade de projetos, assim como os projetos existentes no arquivo do Centro de Memória da Instituição não tratam da totalidade dos eventos relativos à história do conjunto arquitetônico, ${ }^{44}$ embora sejam significativos.

44 Por exemplo, entre os projetos referentes à construção da Cidade Universitária, disponíveis na Biblioteca da FAU USP, também estão alguns projetos para o Instituto Butantan. Trata-se de um material importante, que complementa a documentação existente no arquivo do Instituto. Assim, 


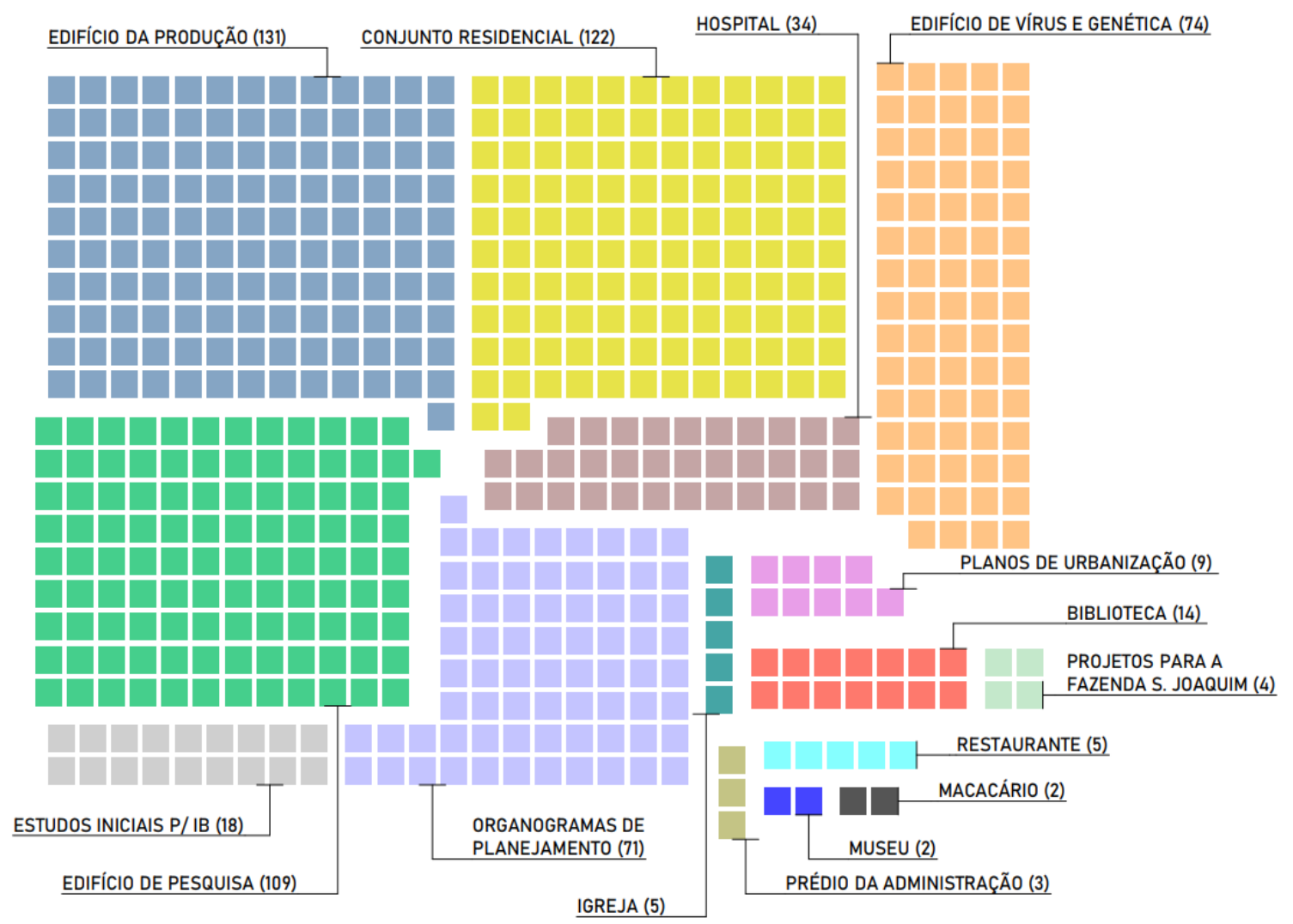

Figura 39: Diagrama dos projetos relacionados ao Plano de Ação identificados no acervo. Cada quadrado representa uma prancha relacionada a um edifício ou equipamento projetado no período, possibilitando a compreensão de cada tipologia na composição total do acervo. A soma de todos é igual à quantidade de itens do Grupo A, referente aos projetos do PAGE e que somam 603 itens conforme representado no diagramas anteriores (Figuras 37 e 38). Fonte: nossa autoria.

Neste sentido, é fundamental a identificação dos projetos, pois, entre os diversos que foram idealizados para o Instituto, no período do Plano de Ação, apenas um foi de fato construído, o Conjunto Residencial projetado pelo arquiteto Mario Rosa Soares, provavelmente em 1963. Assim, por ter sido desenvolvido e construído, o Conjunto Residencial está largamente documentado no acervo, compondo 122 pranchas de projeto. Desta forma representa quase a totalidade dos itens vinculados a projetos construídos no período. Em contrapartida, considerados apenas os edifícios projetados no contexto do Plano de Ação, o Conjunto Residencial representa 1 entre 15

embora esta pesquisa não tenha identificado, é bastante provável que outras partes deste acervo, contendo, talvez, projetos inéditos, ainda não tenham sido encontradas. Esta possibilidade, abre espaço para futuras pesquisas que ampliem a as investigações sobre o Plano de Ação e sobre o período da construção da Cidade Universitária e de suas relações com o Instituto Butantan. 
edifícios que foram identificados. ${ }^{45}$ Ou seja, os projetos não construídos representam quase a totalidade dos edifícios projetados.

Apenas um projeto aparece mais vezes entre os itens do acervo do que o projeto para o Conjunto Residencial, que compõe 122 pranchas. Os planos desenvolvidos para a construção de um edifício para o Setor da Produção constituem cerca de 131 pranchas, compostas por anteprojetos, revisões e reformulações, projetos executivos e um conjunto de pranchas para a execução das fundações e das estruturas em concreto armado protendido, desenvolvido pela empresa Figueiredo Ferraz Consultoria e Engenharia de Projetos, do Engenheiro José Carlos de Figueiredo Ferraz.

O engenheiro, que na Universidade de São Paulo foi professor da Escola Politécnica e da Faculdade de Arquitetura e Urbanismo, tornou-se um dos grandes nomes da arquitetura moderna brasileira. Foi responsável pelo desenvolvimento de edifícios icônicos a partir de meados do século $X X$, cujo projeto arquitetônico tirava partido dos grandes vãos executados em concreto protendido, como o MASP de Lina Bo Bardi e o Edifício da FAU USP de Vilanova Artigas, assim como as estruturas do trecho norte-sul do metrô da cidade, no período em que foi Prefeito de São Paulo entre 1971 e $1973 .{ }^{46}$ O nome de Figueiredo Ferraz vinculou-se à arquitetura moderna, um dos símbolos do desenvolvimento do país e da tecnologia do concreto armado.

Os projetos desenvolvidos para o Edifício da Produção, são de autoria de diversos profissionais, arquitetos e engenheiros, em algumas variações desenvolvidas entre 1962 e 1966. Trata-se de uma das propostas de novos edifícios para o Instituto Butantan que passou por frequentes alterações, o que contribui para explicar a quantidade de documentos vinculados ao projeto que estão disponíveis no acervo. Do mesmo modo, é um projeto bastante completo, que chegou a ser desenvolvido para além da concepção arquitetônica, contendo detalhamento, executivo, estruturas e fundações. Grandes instalações para o setor de produção eram, também, uma

45 Estes 13 projetos representam a quantidade de novas propostas identificadas no acervo e desenvolvidas a partir do Plano de Ação, sendo que os demais projetos tratam de reformas pontuais ou adaptações em edifícios já existentes.

46 À época, durante o Regime Civil-militar, o prefeito era nomeado pelo governo do estado, que na ocasião partiu da escolha do governador Laudo Natel membro do ARENA, o partido do regime. 
demanda importante para a instituição, que carecia deste tipo de infraestrutura necessária às intenções de expansão, expressas por seus dirigentes à época.

O primeiro projeto para o Setor de Produção aparece entre os documentos no ano de 1962, desenvolvido por Jacob Goldemberg, arquiteto formado em 1960 pela FNA, e Luiz Contrucci, engenheiro arquiteto da Escola Politécnica, que fizeram parte de uma equipe de seis profissionais, bastante atuante no instituto nestes anos. Além dos dois arquitetos, trabalharam no Instituto neste período, Abelardo de Souza, arquiteto pela ENBA em 1932 e professor da FAU USP, João Carlos Bross, arquiteto formado em 1956 na Universidade Mackenzie, Léo Quanji Nishikawa, egresso da FAU USP na década de 1950, e Miranda Magnoli, arquiteta paisagista e professora da FAU USP, a partir de $1964 .{ }^{47}$ Ao longo dos anos seguintes o anteprojeto para o Edifício da Produção é desenvolvido, detalhado e, no ano de 1965, passa a ser estudado para a sua implantação no Instituto pelo arquiteto Osmar Antonio Mammini, formado em 1959 no Mackenzie. Em 1966, o escritório do Engenheiro Figueiredo Ferraz desenvolve os projetos de fundações e estrutura para o edifício.

Não existem registros de que algum destes projetos tenha sido construído. As áreas para construção, indicadas nas implantações, previam a demolição de edifícios históricos, ainda hoje existentes, como o Edifício Vital Brazil, inaugurado em 1914, que daria lugar ao Pavilhão de Serviços, também projetado por Goldemberg e Contrucci. Em um dos poucos terrenos livres naquela época, no qual seria implantado o Edifício da Produção, foi construído em 1973, o edifício para o Centro Estadual de Civismo e Cultura, projetado por Jorge Wilheim com a colaboração de Sylvio Sawaya. Posteriormente o prédio se tornou o Paço das Artes onde, desde 2019, estão instalados os escritórios administrativos do Instituto Butantan.

Além do Edifício da Produção e do Conjunto Residencial, outros grandes projetos desenvolvidos, neste período, compartilham certas características em comum. De modo geral, apesar da diversidade de tipologias e programas, estes projetos são

47 Outras informações sobre os arquitetos estão no item 2.5, onde tratamos dos projetos desenvolvidos pelo grupo para o Instituto Butantan. 
definidos por elementos estéticos e formais que remontam à arquitetura moderna produzida na década de 1960 . Vincula-se, sem dúvida, ao período amplamente discutido pela historiografia que é marcado pela produção dos arquitetos associados a João Batista Vilanova Artigas, entre as décadas de 1950 e 1960 em São Paulo, e que tiveram no Plano de Ação do Governo Carvalho Pinto uma oportunidade singular de atuação (CAMARGO, 2015, p.136).

Neste contexto, os edifícios pensados para o Instituto adotam certos elementos que definem o partido arquitetônico, marcados pelo brutalismo e pela estrutura como elemento formal e estético definidor da obra. Não obstante, estes atributos coexistem com outros elementos que caracterizam uma ampla gama de linguagens e soluções.

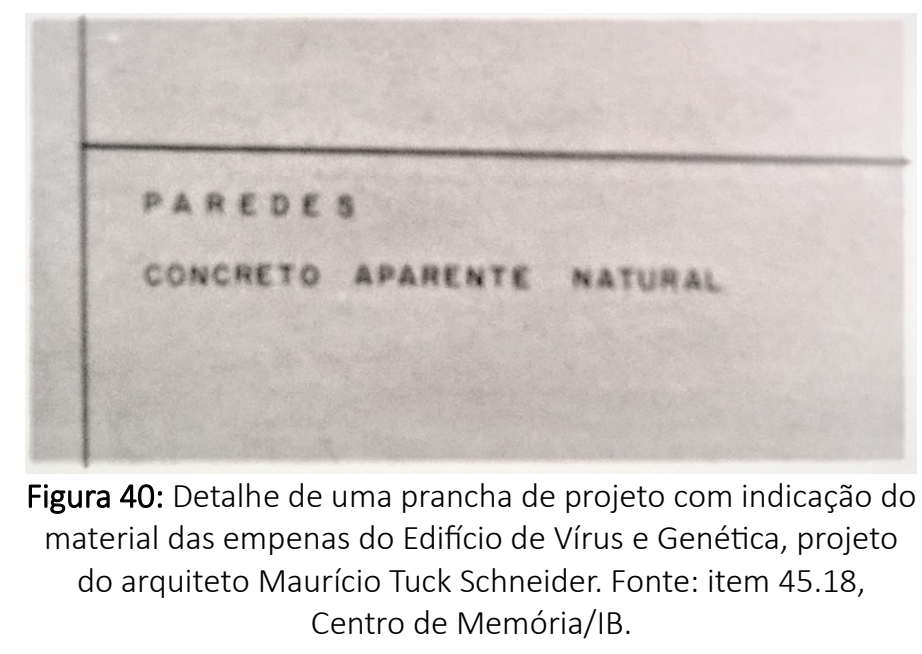

Apesar de não construídos, os projetos indicavam uma certa preocupação com a definição dos materiais na execução dos edifícios (Figura 40), dimensão que aponta para a filiação destes arquitetos, muitos egressos da FAU USP, ao chamado brutalismo, que se tornou muito comum aos arquitetos da época. Todavia, a ênfase aos materiais brutos convive com o concreto pintado ou com painéis de azulejos, com a alvenaria aparente e com os muros de pedra, com referências à arquitetura corbusiana ou ao plano de Brasília; volumes opacos convivendo com planos envidraçados, expressando uma forte cultura arquitetônica comum e, ao mesmo tempo, diversa por parte destes profissionais de São Paulo e de outras partes do país. 


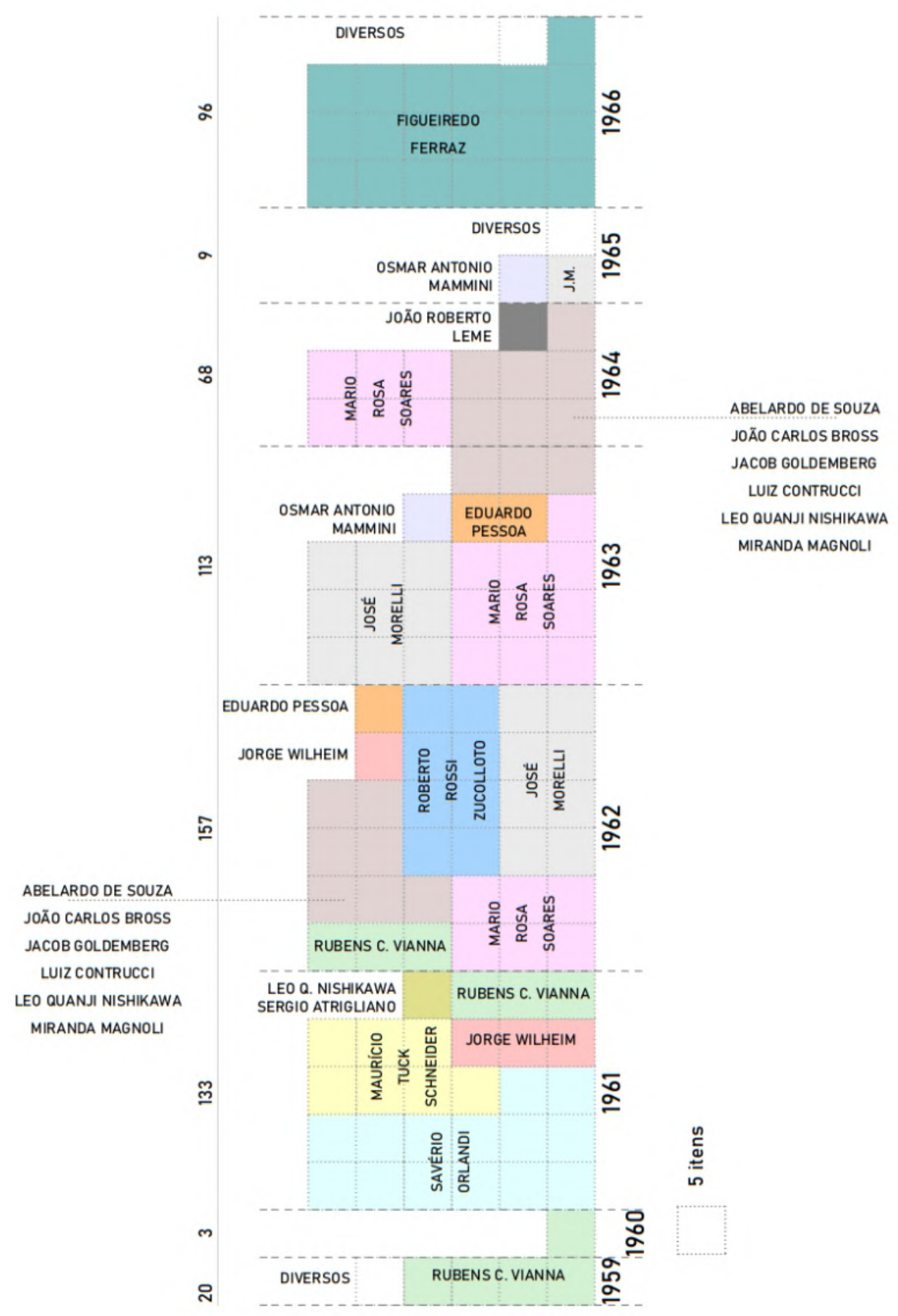

Figura 41: Diagrama de pranchas de projeto no acervo, por ano e por autor. Cada unidade corresponde a até 5 pranchas existentes no acervo, a linha superior apresenta a soma dos itens em um mesmo ano, que está indicado na linha inferior. Fonte: nossa autoria. 
No diagrama apresentado na Figura 41, é possível perceber de forma mais ampla a atuação destes profissionais nos planos para o Instituto Butantan a partir de 1959 , com arquitetos que atuaram de forma mais pontual e outros que tiveram uma atuação mais permanente. Nos primeiros dois anos do PAGE, o arquiteto Rubens Carneiro Vianna produziu, praticamente sozinho, quase todos os projetos feitos no período. Neste momento, eram caracterizados por planos de reforma, alterações e adaptações de edifícios existentes e de acordo com as necessidades mais urgentes apresentadas pelos diretores e pesquisadores da instituição

Com a oficialização do convênio entre o Fundo para a Construção da Cidade Universitária (FCCUASO) e o Instituto, no ano de 1961, há um alargamento na quantidade de projetos e de profissionais atuando para o planejamento do campus do Butantan, que passa a ser compreendido como um dos dezoito setores da Cidade Universitária em construção. Surgem assim os organogramas de planejamento dos setores, desenvolvidos pelo Engenheiro Orlando Savério, responsável pelo planejamento do campus da Universidade.

No mesmo ano estão datados os projetos para o Edifício de Vírus e Genética, do arquiteto Maurício Tuck Schneider e do Edifício para a Biblioteca e Auditórios, projetados por Jorge Wilheim. Estão também os vencedores do concurso para o plano geral do Instituto, Sergio Atrigliano e Leo Quanji Nishikawa. Este último vai compor, nos anos seguintes, o grupo de arquitetos que vai desenvolver os demais projetos para a Instituição, que conformam o plano de 1963. Em 1962 se iniciam os trabalhos dos profissionais que vão desenvolver as estruturas de alguns dos edifícios projetados até esta data, como os Engenheiros Roberto Rossi Zucolloto e José Morelli, além dos primeiros estudos para o Conjunto Residencial do arquiteto Mario Rosa Soares.

São interessantes dois aspectos perceptíveis no diagrama da Figura 41, que apresenta a autoria e a quantidade de pranchas por ano. O primeiro é que o ano de 1961 inicia a concepção dos primeiros e mais significativos projetos, que praticamente se encerram em 1964. O segundo diz respeito à permanência da atuação dos arquitetos ao longo dos anos. Maurício Tuck Schneider e Jorge Wilheim, por exemplo, 
atuam principalmente no ano de 1961, sem que seus projetos prossigam em desenvolvimento nos anos seguintes, embora permaneçam em todos os planos. Wilheim ainda propõe novos desenhos para a Biblioteca em 1962, mas em menor quantidade que no ano anterior.

É provável que este último aspecto tenha diversas motivações, não sabemos ao certo como se deu a relação entre cada um destes arquitetos e a direção do Instituto, ou com o responsável pela admissão das propostas. Jorge Wilheim por exemplo se dividiu entre outros projetos para o PAGE, sendo responsável pelo desenvolvimento do próprio Setor Biológico da Cidade Universitária, ao qual o Instituto Butantan estava integrado. De todo modo, é relevante considerar o fato de que certos projetos foram integralmente desenvolvidos, encontrando-se prontos para a execução das obras, enquanto outros não passaram dos primeiros croquis ou de um projeto básico. ${ }^{48}$

O exemplo do Edifício de Produção, nos ajuda a compreender o emaranhado de planos e atores envolvidos nestes processos de modernização que, assim como em outros diversos projetos elaborados nestes anos, foram marcados por interrupções, desistências e continuidades. A aparente percepção de fracasso do plano no Instituto Butantan - que ao fim e ao cabo não executou praticamente nenhum dos projetos nos leva a compreender este contexto, também, como um esforço dos próprios profissionais atuantes em assegurar a viabilização de suas propostas, diante dos interesses e necessidades colocadas pela direção do Instituto. Não obstante, como veremos, o Plano de Ação impactou decisivamente o planejamento do campus nos anos seguintes, definindo a sua conformação atual.

48 Novamente, como dissemos neste mesmo capítulo, é possível que a identificação de outros documentos dispersos e ainda não encontrados, venha a confirmar, ou talvez acrescentar novas possibilidades de interpretação a este episódio do Plano de Ação, visto que o arquivo do Instituto, possivelmente, detém a maior parte, mas não guarda a totalidade dos projetos desenvolvidos no período. 


\subsection{Inventário de projetos no recorte estabelecido: 1959-1966}

Uma questão que pautou esta pesquisa desde o princípio, foi a da importância de se organizar e difundir estes documentos relativos aos projetos do Plano de Ação, tanto para o desenvolvimento do trabalho quanto para apoiar futuras investigações acerca dos temas relacionados, abertas por esta pesquisa ou que com ela possam se vincular. Esta preocupação se deve pelo pouco conhecimento destes projetos pela comunidade acadêmica e sociedade, como discutimos no Capítulo $1 .^{49}$

Neste sentido, um dos principais objetivos deste trabalho é contribuir para a difusão do acervo de projetos do Centro de Memória do Instituto Butantan, sobretudo daqueles desenvolvidos através do Plano de Ação do Governo do Estado, durante a construção da Cidade Universitária da USP. Esta intenção se desenvolve concomitantemente ao esforço de se produzir conhecimento sobre esta documentação, fornecer um sentido e dar coesão à massa documental dispersa e fragmentada que pôde ser verificada com a identificação das pranchas do acervo. A análise destes projetos, amparada pela bibliografia do Plano de Ação, do Instituto Butantan e da arquitetura moderna brasileira, junto da pesquisa em arquivos e de outras fontes primárias e secundárias, têm ajudado a situar este conjunto de projetos no processo histórico e diante das relações sociais que os produziram.

Também é intenção desta pesquisa abrir espaço para outras investigações, construindo uma base de dados e de informações, apresentando e detalhando as características destes projetos, para que possam contribuir para a pesquisa em história da arquitetura. Do mesmo modo, o breve inventário apresentado a seguir não almeja induzir uma organização do acervo, mas identificar e apresentar alguns dos projetos que o constituem.

49 De modo geral, esta documentação também é pouco conhecida do público do Instituto Butantan. Com exceção dos profissionais que trabalham diretamente na organização e conservação do arquivo do Centro de Memória, o conhecimento sobre este episódio do Plano de Ação no Instituto é reduzido. Esta percepção está amparada nas conversas que realizamos com funcionários e pesquisadores ao longo do desenvolvimento deste trabalho. Do mesmo modo, embora tenha sido fundamental para a consolidação do modernismo em São Paulo, o reconhecimento do Plano de Ação é também reduzido se considerarmos as pesquisas acadêmicas sobre a arquitetura moderna brasileira. 
Neste sentido, a formulação do inventário dos projetos do Plano de Ação, presentes no acervo cartográfico do Centro de Memória do Instituto Butantan, permite uma visão geral e uma maior compreensão das características destes documentos, dos tipos de projetos existentes, do contexto em que foram produzidos e dos atores envolvidos em sua concepção. A organização deste inventário está amparada pela relação de projetos apresentada no subcapítulo anterior 2.2. Os projetos do Plano de Ação no acervo do Instituto Butantan", mais precisamente no tópico 2.2.3. Quantificação e composição dos projetos relativos ao Plano de Ação. Além de contribuir com os objetivos e intenções expostos, este inventário também é central para a escolha dos projetos a serem aprofundados no subcapítulo 2.5 , no qual são analisados os planos e projetos desenvolvidos para o campus do Instituto Butantan nestes anos. Neste sentido, o inventário deve contribuir para a definição dos projetos a serem analisados.

O recorte temporal estabelecido para o inventário dos projetos, entre 1959 e 1966, que extrapola o período do PAGE, delimitado pelo governo de Carlos Alberto de Carvalho Pinto (1959-1963), se justifica pela extensão do prazo de desenvolvimento destes projetos, que também se verifica em diversos edifícios construídos pelo Plano. Assim, mesmo que o governo tenha se encerrado no ano de 1963, quando foi sucedido por Ademar de Barros, muitos projetos desenvolvidos neste período, avançaram a década de 1960 até serem finalizados. ${ }^{50}$ No caso do Instituto Butantan, alguns dos projetos ensaiados nos anos de 1961 e 1962 são desenvolvidos e detalhados nos anos seguintes, cuja maioria das pranchas vai até 1966. A partir desta data, são desenvolvidos outros projetos pelo corpo técnico do Fundo de Construção da Cidade Universitária, cujo convênio com o Instituto permanece até 1981. Este período posterior ao Plano de Ação será aprofundado no terceiro capítulo desta dissertação.

O inventário destes projetos reúne, em fichas, as 603 pranchas identificadas

50 Este é o caso, como haviamos comentado, do edifício da Faculdade de Arquitetura e Urbanismo, projetado por Vilanova Artigas e Carlos Cascaldi em 1961, que fiu concluído em 1968, passando a receber, em 1969, o curso de arquitetura e urbanismo, até então sediado no edifício da FAU Maranhão, quase 6 anos após o fim do Plano de Ação e do Governo de Carvalho Pinto. 
neste período de 1959 até 1966, de acordo com o programa ou tipologia do projeto. Conforme apresentamos na Figura 41 deste capítulo, são relacionados os materiais encontrados no acervo do Centro de Memória e acrescentamos os que foram identificados em outros acervos como o da Biblioteca da FAU USP, que também reúne alguns destes projetos, além de publicações. Desta forma, o inventário poderá funcionar como um catálogo de pesquisa, uma base no qual os projetos podem ser consultados de forma complementar à pesquisa em arquivo.

A ordem de apresentação das fichas corresponde à quantidade de documentos encontrados no acervo do Centro de Memória, conforme apresentado pela figura 39, seguidos pelos documentos encontrados majoritariamente na Biblioteca da FAU USP. Por sua vez, a localização referida nas fichas, está relacionada aos setores do planejamento da Cidade Universitária para o caso dos planos urbanísticos, que pode ser visto no mapa a seguir (Figura 42). Os projetos são localizados nos setores do planejamento do Instituto Butantan, que se organizam da seguinte forma: administração, turismo, serviços, pesquisa, biotérios, produção e residencial. Em suma, o setor 10 da Cidade Universitária se refere ao Instituto Butantan, como parte do campus da USP, enquanto os demais setores correspondem à organização interna do Instituto. 


\subsubsection{Relação das fichas dos projetos inventariados}

\section{Projetos no acervo do Centro de Memória do Instituto Butantan ${ }^{51}$}

Ficha 01: Edifício da Produção

Ficha 02: Conjunto Residencial

Ficha 03: Edifício de Pesquisa

Ficha 04: Edifício de Vírus e Genética

Ficha 05: Organogramas de Planejamento

Ficha 06: Hospital "Vital Brazil"

Ficha 07: Conjunto de estudos iniciais do PAGE para o Instituto Butantan

Ficha 08: Biblioteca e Auditório

Ficha 09: Planos de Urbanização

Ficha 10: Restaurante

Ficha 11: Igreja "Nossa Senhora dos Pobres"

Ficha 12: Prédio da Administração

Ficha 13: Museu

Ficha 14: Macacário

Projetos no acervo da Biblioteca da Faculdade de Arquitetura e Urbanismo da USP

Ficha 15: Pavilhão de Serviços

Ficha 16:Edifício dos Biotérios

51 Embora a maior parte dos desenhos esteja no acervo do Instituto Butantan, alguns destes projetos também podem ser encontrados na Biblioteca da FAUUSP. Estas informações estão registradas nas fichas. 


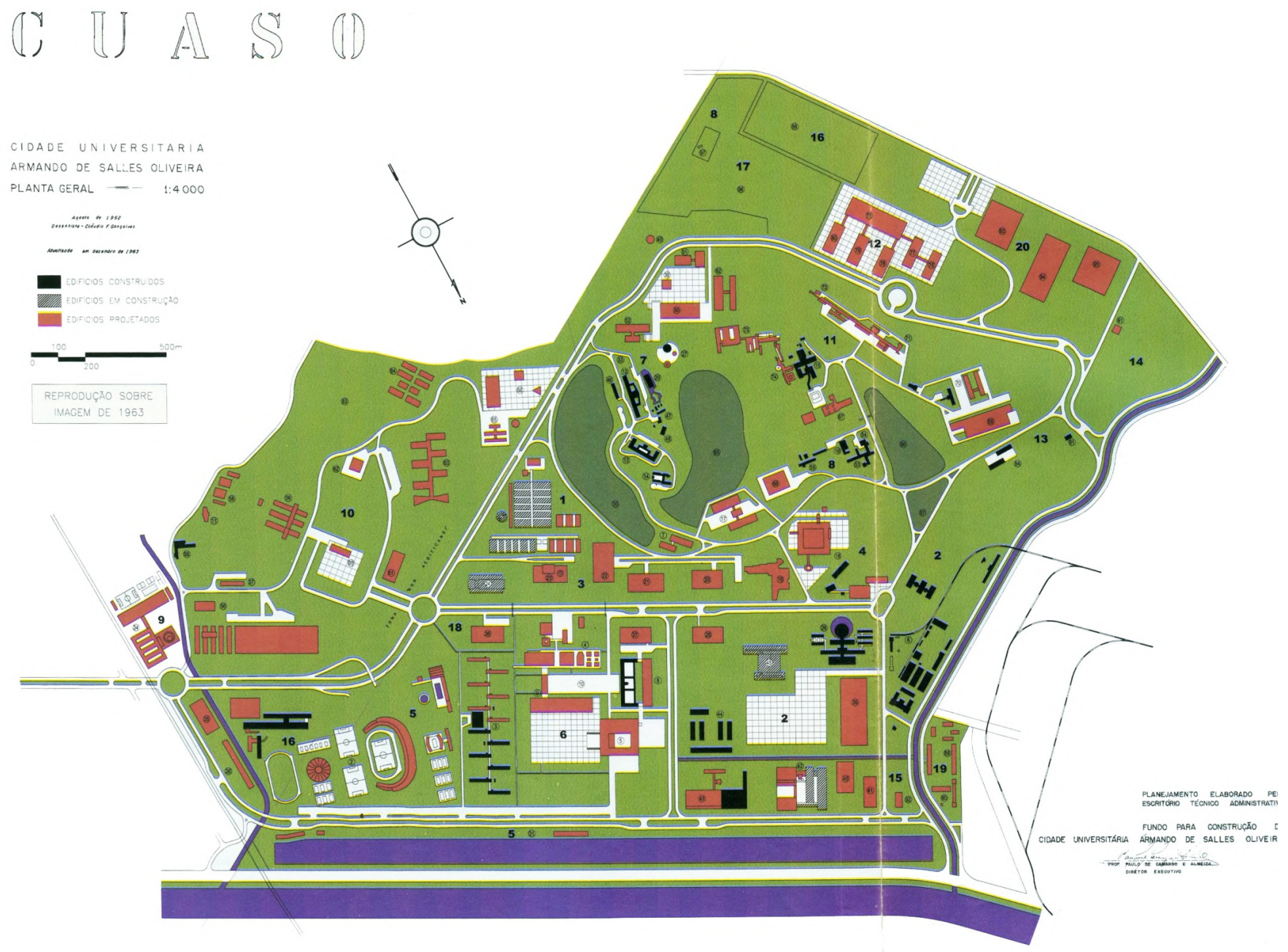

Figura 42: Plano de implantação da Cidade Universitária de 1963: à esquerda, onde se encontra o setor 10, é possível localizar os edifícios projetados para o Instituto Butantan. Fonte: SEF/USP. 


\subsubsection{Fichas dos projetos}

\section{Ficha 01: Edifício da Produção}

\begin{tabular}{|c|c|}
\hline Data & $\begin{array}{l}\text { 1962, } 1963 \text { e } 1964 \text { (projeto de arquitetura); 1965, } 1966 \text { e } 1967 \\
\text { (projeto de estruturas). }\end{array}$ \\
\hline Autoria & $\begin{array}{l}\text { Arquitetura: arquitetos Jacob Goldemberg, Luiz Contrucci, } \\
\text { Abelardo de Souza, João Carlos Broos, Leo Quanji Nishikawa, } \\
\text { Miranda M. Magnoli. }{ }^{52} \\
\text { Estrutura: engenheiro José Carlos de Figueiredo Ferraz. }\end{array}$ \\
\hline Localização & Setor de Produção do Instituto Butantan. \\
\hline Referência & $\begin{array}{l}\text { Consta no plano de implantação da Cidade Universitária de } \\
\text { 1963. }\end{array}$ \\
\hline Status & Não construído. \\
\hline Uso & $\begin{array}{l}\text { Edifícios para a produção de imunobiológicos do Instituto } \\
\text { Butantan. }\end{array}$ \\
\hline Material iconográfico & $\begin{array}{l}\text { Centro de Memória/ Instituto Butantan: } 131 \text { pranchas e } 1 \\
\text { fotografia } \\
\text { Biblioteca da Faculdade de Arquitetura e Urbanismo/USP: } 20 \\
\text { pranchas }^{53}\end{array}$ \\
\hline Publicações & $\begin{array}{l}\text { Revista América, nำ2, 1962, s.p. } \\
\text { Revista Acrópole, no 331, 1966, p.32 e } 33\end{array}$ \\
\hline Desenhos & $\begin{array}{l}\text { Planta baixa, cortes, elevação, implantação, perspectiva, } \\
\text { detalhamento, estrutural. }\end{array}$ \\
\hline
\end{tabular}

\section{Características do projeto}

Implantação: No plano de implantação da Cidade Universitária de 1963, o edifício está situado onde hoje está o centro administrativo do Instituto Butantan, no prédio do antigo Paço das Artes, na Avenida da Universidade.

52 Segundo o arquiteto Jacob Goldemberg, cuja entrevista se encontra no anexo C desta dissertação, os nomes dos seis arquitetos que aparecem nos carimbos dos projetos, incluindo ele, se dividiram para o desenvolvimento dos edifícios para o Instituto Butantan, ficando a cargo dele, Jacob Goldemberg, e do arquiteto Luiz Contrucci, a elaboração dos projetos para os edifícios da produção e de serviços.

53 O acervo do Centro de Memória contém uma prancha referente à localização do Pavilhão de Serviços e outras 130 do Edifício da Produção. A Biblioteca da FAUUSP guarda 7 itens referentes ao Edifício da Produção, 5 do Pavilhão de Serviços e outras 8 que se referem ao Setor de Produção e Serviços, totalizando 20. Por comporem o mesmo setor, os edifícios aparecem juntos em determinadas pranchas. 
Número de pavimentos: Pavilhões de 2 pavimentos com torres de cerca de 10 andares (produção), variando para mais em alguns desenhos e perspectivas.

Sistema construtivo: Estrutura em concreto armado protendido e estrutura prémoldada.

Comentários: $O$ edifício é formado por um conjunto de pavilhões e torres dispostos paralelamente, de modo a permitir futuras ampliações. Os vários blocos estão organizados visando a racionalização dos acessos e fluxos internos. Sua implantação prevista acima do nível da Avenida da Universidade, garante seu destaque na paisagem e uma referência ao pedestre.

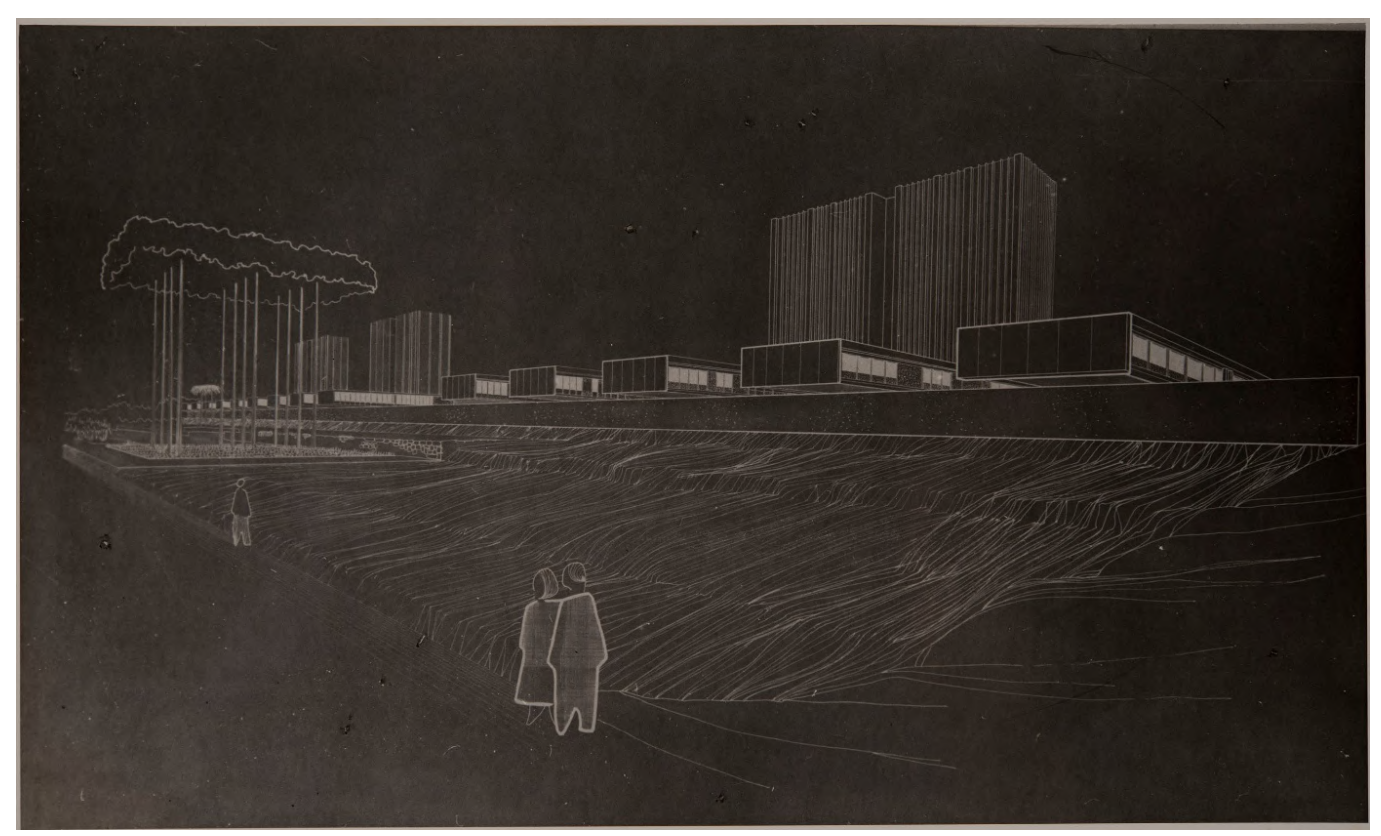

Figura 43: Perspectiva em negativo do edifício da produção, arquitetos Luiz Contrucci e Jacob Goldemberg, 1963. Fonte: IB_ICO_008487, Centro de Memória/IB. 
Ficha 02: Conjunto Residencial

\begin{tabular}{|l|l|}
\hline Data & 1962 a 1966. \\
\hline Autoria & $\begin{array}{l}\text { Arquitetura: arquiteto Mario Rosa Soares; desenvolvimento: } \\
\text { arquiteto Osmar Mammini. } \\
\text { Estrutura: engenheiro Eduardo Pessoa. }\end{array}$ \\
\hline Localização & Setor Residencial do Instituto Butantan. \\
\hline Referência & $\begin{array}{l}\text { Consta no plano de implantação da Cidade Universitária de } \\
1963 .\end{array}$ \\
\hline Status & Construído. \\
\hline Uso & Conjunto de residências para os funcionários do Instituto. \\
\hline Material Iconográfico & $\begin{array}{l}\text { Centro de Memória/ Instituto Butantan: 122 pranchas e 2 } \\
\text { fotografias }\end{array}$ \\
\hline Desenhos & $\begin{array}{l}\text { Planta baixa, cortes, elevação, implantação, perspectiva, } \\
\text { detalhamento, estrutural e mobiliário. }\end{array}$ \\
\hline
\end{tabular}

\section{Características do projeto}

Implantação: o conjunto de cerca de 50 residências está implantado na entrada do Instituto Butantan pela Avenida Vital Brazil e próximo da Avenida Corifeu de Azevedo Marques. No plano de implantação da Cidade Universitária de 1963, o conjunto está situado no mesmo local.

Número de pavimentos: residências térreas.

Sistema construtivo: Estrutura em concreto armado, fechamento em alvenaria aparente e cobertura de "duas águas".

Comentários: As residências são geminadas e estão implantadas frente a frente, em fileiras paralelas e intercaladas por vias de acesso e pelos pátios internos das casas. $\mathrm{O}$ conjunto residencial é o único projeto construído deste período, algumas das casas foram reformadas e hoje abrigam departamentos do Instituto, como o Centro de Memória e o Laboratório de História da Ciência. Com exceção das unidades reformadas o conjunto está bastante deteriorado, apresentando problemas estruturais e dificuldades de acesso às unidades. 


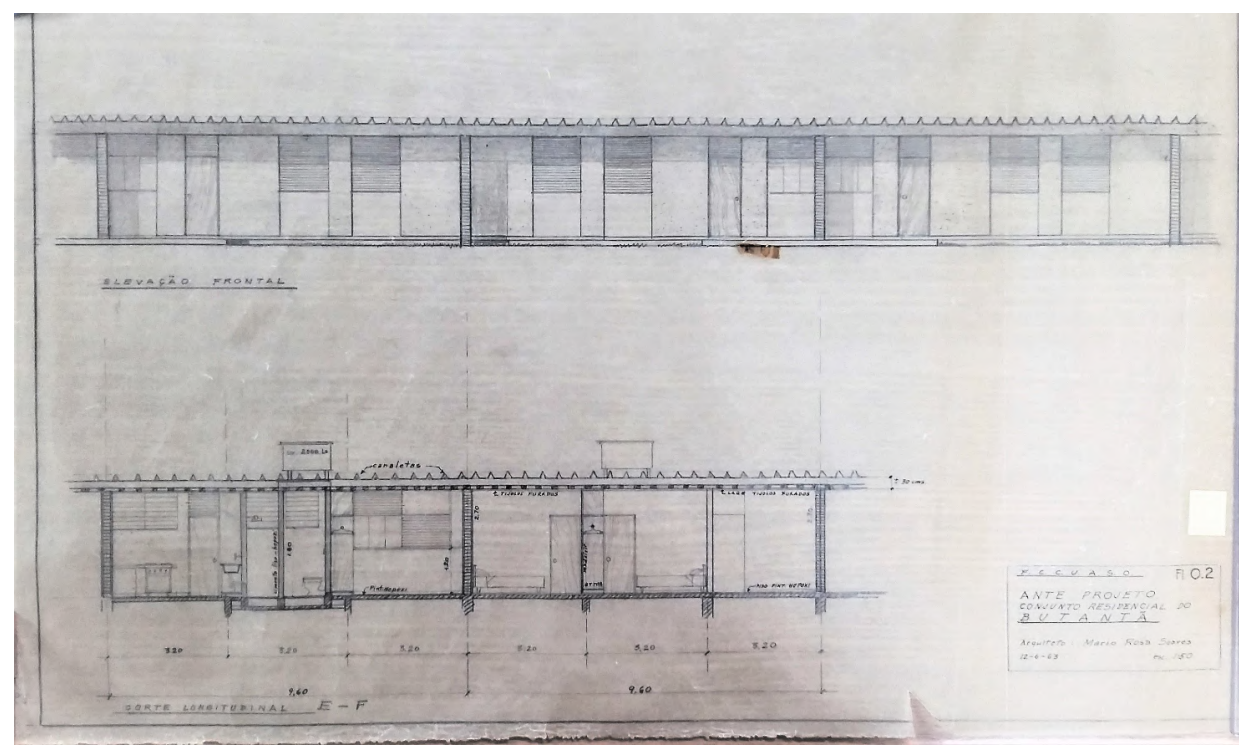

Figura 44: Elevação e corte das residências, arquiteto Mário Rosa Soares, 1963. Fonte: prancha 19.21, Centro de Memória/IB.

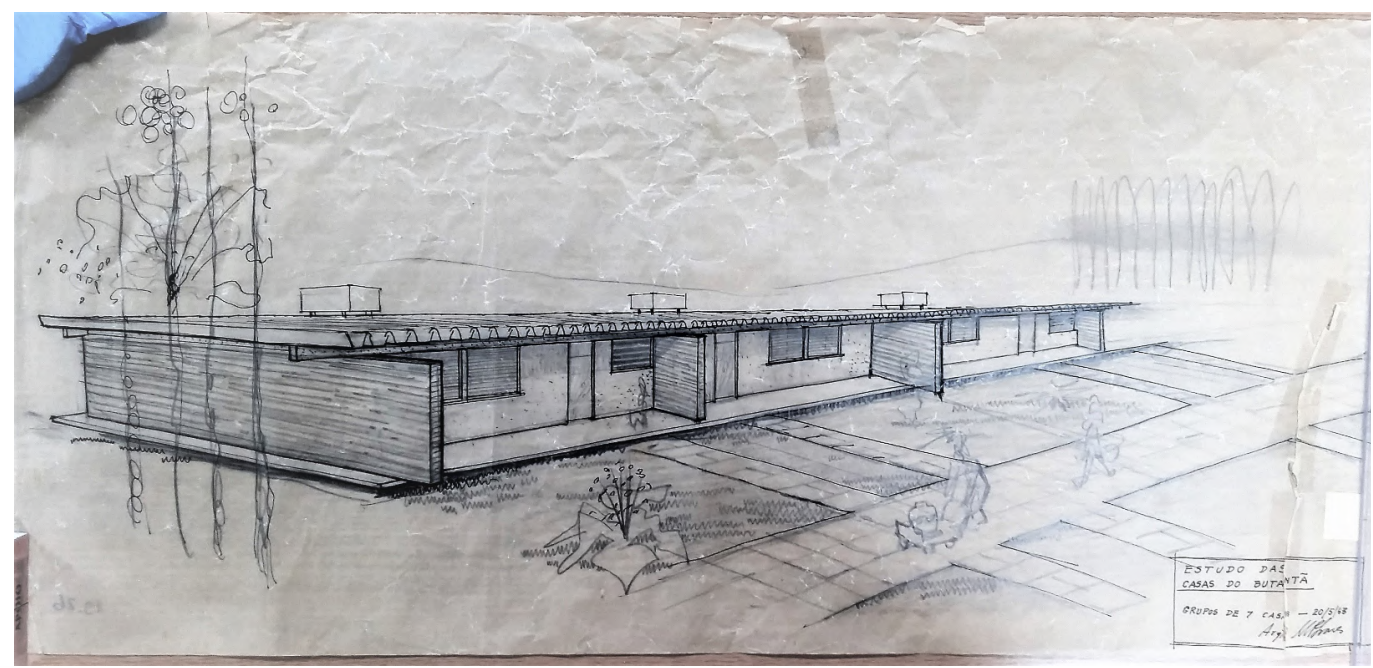

Figura 45: Perspectiva das residências, arquiteto Mário Rosa Soares, 1963. Fonte: prancha 19.26, Centro de Memória/IB. 
Ficha 03: Edifício de Pesquisa

\begin{tabular}{|l|l|}
\hline Data & $\begin{array}{l}1961 \text { (projeto de arquitetura), } 1962 \text { (projeto de arquitetura e } \\
\text { estruturas), 1963 e } 1965 \text { (projeto de estruturas). }\end{array}$ \\
\hline Autoria & $\begin{array}{l}\text { Arquitetura: arquiteto Rubens Carneiro Vianna. } \\
\text { Estrutura: engenheiro José Morelli. }\end{array}$ \\
\hline Localização & Setor de Pesquisa do Instituto Butantan. \\
\hline Referência & $\begin{array}{l}\text { Consta nos planos de implantação da Cidade Universitária de } \\
1961 \text { e 1963. }\end{array}$ \\
\hline Status & Não construído. \\
\hline Uso & Edifício para os laboratórios de pesquisa do Instituto. \\
\hline Material Iconográfico & Centro de Memória/ Instituto Butantan: 109 pranchas \\
\hline Publicações & $\begin{array}{l}\text { Revista América, no2, 1962, s.p. } \\
\text { Revista Acrópole, no 331, 1966, p.38 e 39 }\end{array}$ \\
\hline Desenhos & $\begin{array}{l}\text { Planta baixa, cortes, elevação, implantação, perspectiva, } \\
\text { detalhamento, estrutural e mobiliário. }\end{array}$ \\
\hline
\end{tabular}

\section{Características do projeto}

Implantação: Tanto no plano de 1961 quanto no plano de 1963, o edifício seria implantado em uma esplanada junto do Edifício de Vírus e Genética e de um edifício para o auditório, que conformam uma praça central. O conjunto está localizado na porção oeste do Instituto, próximo à divisa com o campus da Universidade de São Paulo e da Avenida Professor Lineu Prestes.

Número de pavimentos: Edifício vertical com cerca de 20 pavimentos, sendo 2 subsolos abaixo do nível da esplanada. Uma outra versão do projeto possuí 23 pavimentos, sendo um pavimento térreo e um subsolo.

Sistema construtivo: Estrutura em concreto armado protendido, com caixilhos projetados sob medida para os vãos.

Comentários: Entre os projetos desenvolvidos para o Instituto, neste período, é o mais verticalizado, contrapondo o padrão dominante dos edifícios pavilhonares e horizontais dispersos pelo terreno. Provavelmente, é também o edifício mais alto entre os que foram propostos para a Cidade Universitária. 


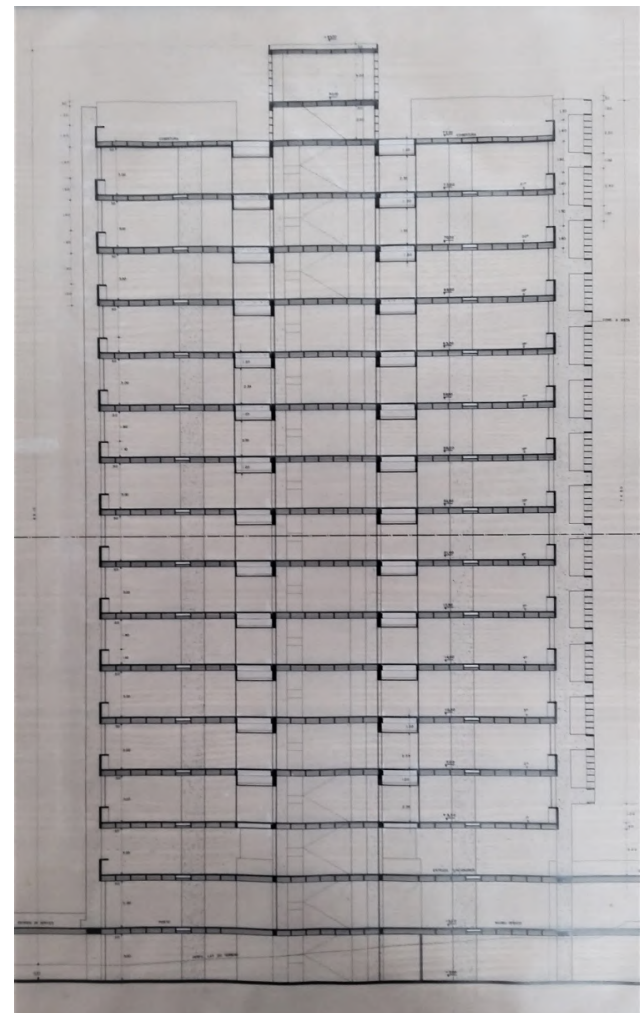

Figura 46: Corte do edifício, Arquiteto Rubens Carneiro Vianna, 1962. Fonte: prancha 19.13, Centro de Memória/ IB.

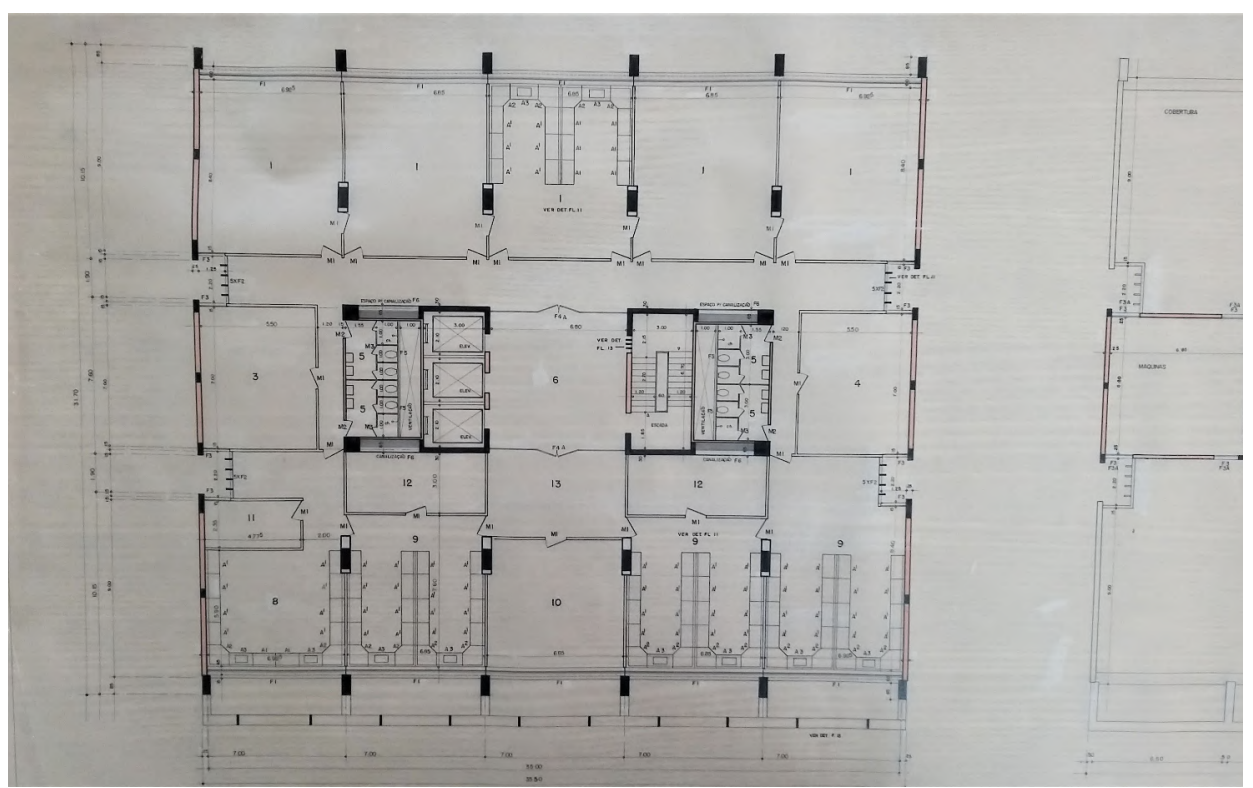

Figura 47: Planta do pavimento tipo, arquiteto Rubens Carneiro Vianna, 1962. Fonte: prancha 19.01, Centro de Memória/IB. 
Ficha 04: Edifício de Vírus e Genética

\begin{tabular}{|l|l|}
\hline Data & 1961 (projeto de arquitetura) e 1962 (projeto de estruturas). \\
\hline Autoria & $\begin{array}{l}\text { Arquitetura: arquiteto Maurício Tuck Schneider. } \\
\text { Estrutura: engenheiro Roberto Rossi Zucollo. }\end{array}$ \\
\hline Localização & Setor de Pesquisa do Instituto Butantan. \\
\hline Referência & $\begin{array}{l}\text { Consta nos planos de implantação da Cidade Universitária de } \\
1961 \text { e 1963. }\end{array}$ \\
\hline Status & Não construído. \\
\hline Uso & $\begin{array}{l}\text { Edifício para os laboratórios dos departamentos de vírus e } \\
\text { genética do Instituto. }\end{array}$ \\
\hline Material Iconográfico & Centro de Memória/ Instituto Butantan: 74 pranchas \\
\hline Publicações & $\begin{array}{l}\text { Revista América, no2, 1962, s.p. } \\
\text { Revista Acrópole, no 331, 1966, p.36 e 37 }\end{array}$ \\
\hline Desenhos & $\begin{array}{l}\text { Planta baixa, cortes, elevação, implantação, detalhamento e } \\
\text { perspectiva. }\end{array}$ \\
\hline
\end{tabular}

\section{Características do projeto}

Implantação: Nos planos de 1961 e de 1963, o edifício está implantado na esplanada que conforma o setor de pesquisa do Instituto, junto do Edifício de Pesquisa e do auditório. Está localizado na porção oeste do Instituto, próximo à divisa com o campus da Universidade de São Paulo e da Avenida Professor Lineu Prestes.

Número de pavimentos: Edifício com 4 pavimentos, sendo 1 subsolo abaixo do nível da esplanada.

Sistema construtivo: Estrutura em concreto armado protendido.

Comentários: Segundo a descrição do projeto na Revista Acrópole (1966, p.36), o edifício é conformado por dois "edifícios distintos", o de vírus e o de genética, sob uma cobertura única. A cobertura é repleta de domus e abriga, além dos dois setores, uma "rua" interna de acesso aos blocos. Duas empenas de concreto armado aparente conformam as fachadas norte e sul, enquanto nas fachadas leste e oeste estão as aberturas dos laboratórios, protegidas por brises horizontais. 


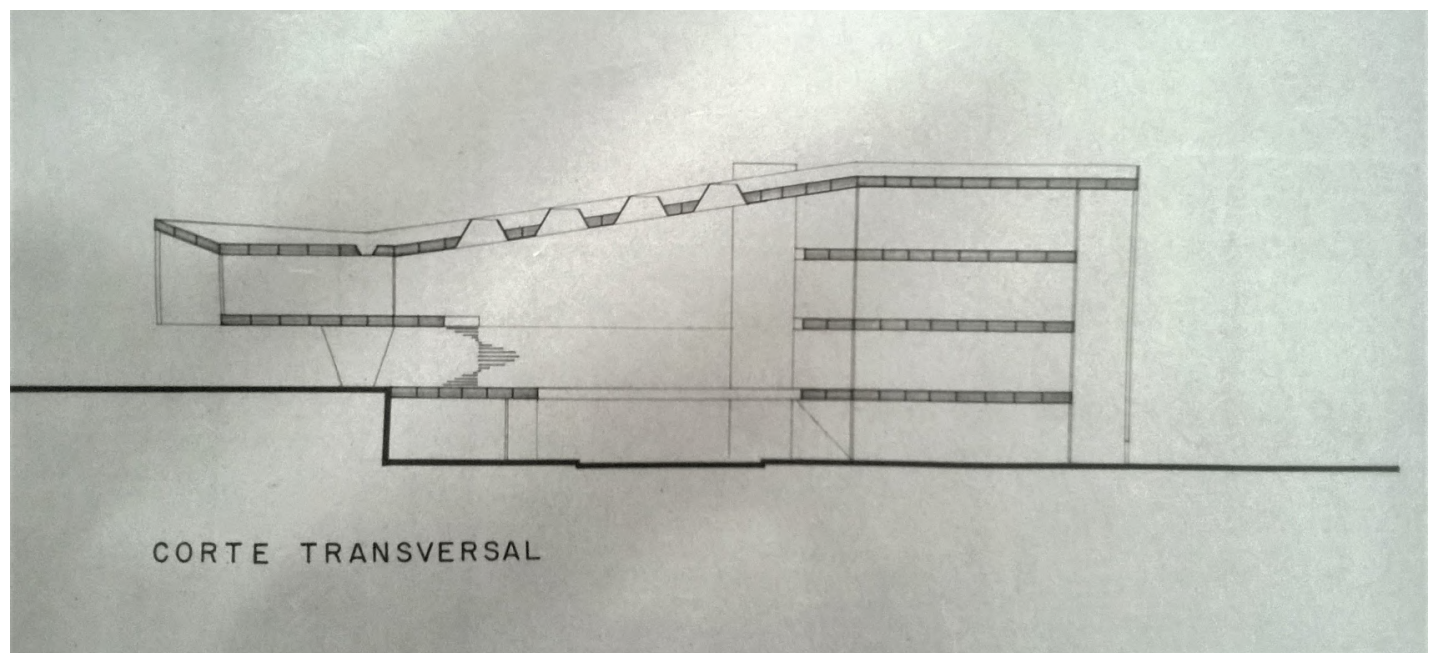

Figura 48: Corte do Edifício de Vírus e Genética, 1961. Fonte: prancha 42.11, Centro de Memória/IB.

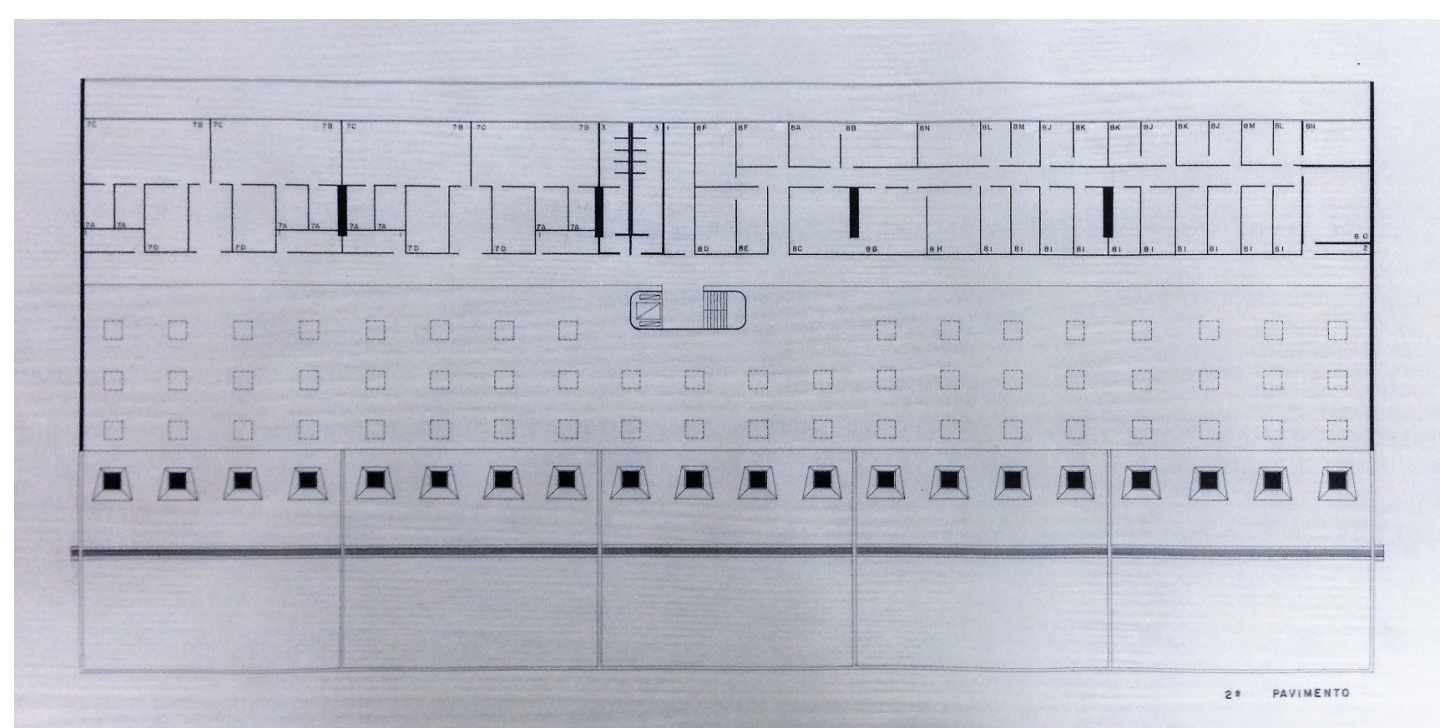

Figura 49: Planta do 2o pavimento, com projeção da cobertura de domus, 1961. Fonte: prancha 48.03, Centro de Memória/IB. 
Ficha 05: Organogramas de planejamento

\begin{tabular}{|c|c|}
\hline Data & 1961. \\
\hline Autoria & Engenheiro Savério Andréa Felice Orlandi. ${ }^{54}$ \\
\hline Localização & Setor 10 do planejamento da Cidade Universitária. \\
\hline Referência & - \\
\hline Status & Parcialmente construído. \\
\hline Uso & $\begin{array}{l}\text { Organogramas de planejamento com programa de } \\
\text { necessidades e estudos preliminares das obras do Instituto } \\
\text { Butantan, divididos por setores. }\end{array}$ \\
\hline Material Iconográfico & $\begin{array}{l}\text { Centro de Memória/ Instituto Butantan: } 71 \text { pranchas } \\
\text { Biblioteca da Faculdade de Arquitetura e Urbanismo/USP: } 28 \\
\text { pranchas }\end{array}$ \\
\hline Desenhos & Organograma. \\
\hline
\end{tabular}

\section{Características do projeto}

Implantação: Cidade Universitária da Universidade de São Paulo e Instituto Butantan. Comentários: os documentos se referem a um conjunto de organogramas de planejamento das obras e projetos para o Instituto. Estes organogramas são divididos por setores e apresentam diretrizes para o planejamento e desenvolvimentos dos edifícios, descrevendo o programa, as áreas, circulação, fluxos e hierarquias. Os setores apresentados pelos documentos são: administração, turismo, serviços, pesquisa, biotérios, produção e residencial, definindo o programa e as áreas do planejamento do Instituto Butantan. 


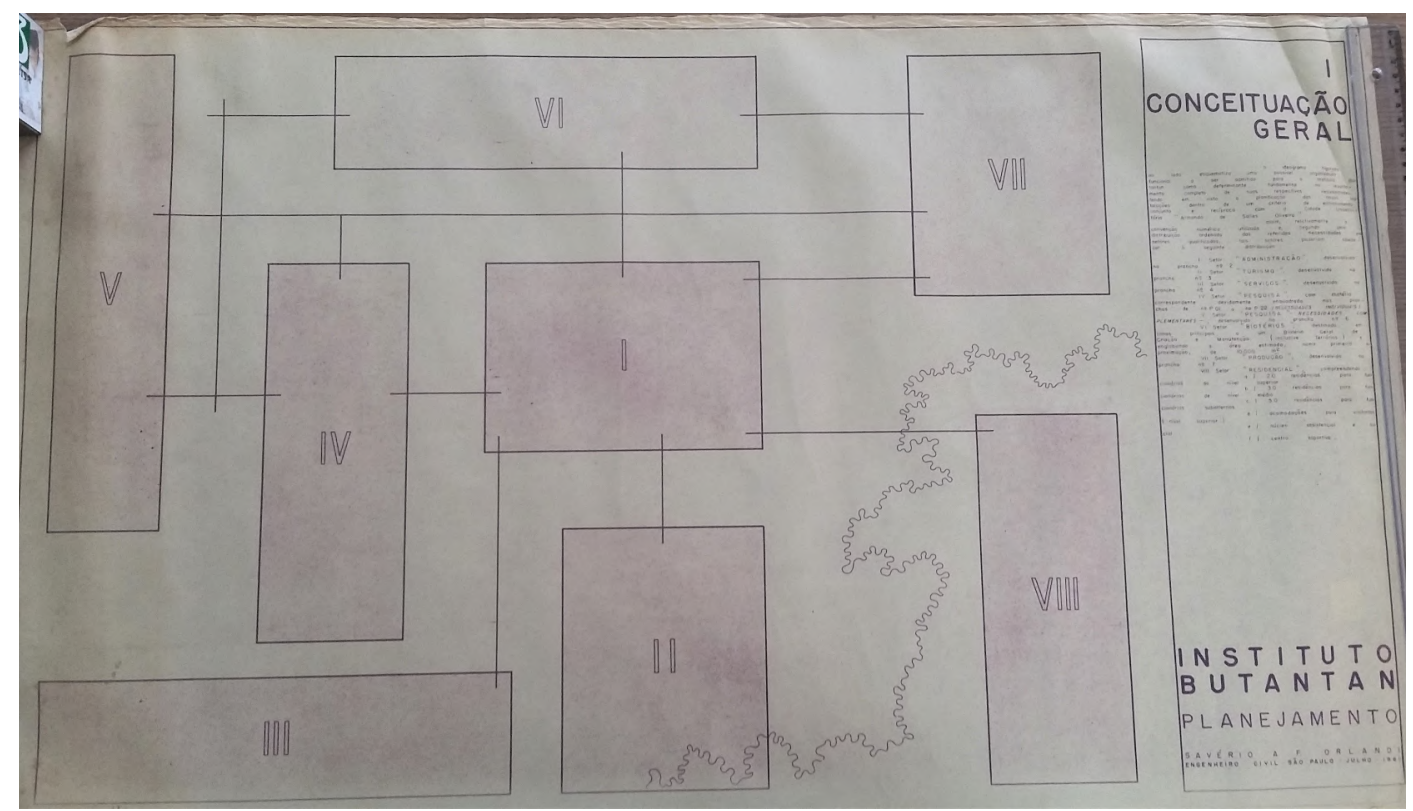

Figura 50: Conceituação geral: organograma de setores para o planejamento do Instituto Butantan, 1961. Fonte: prancha 17.06, Centro de Memória/IB.

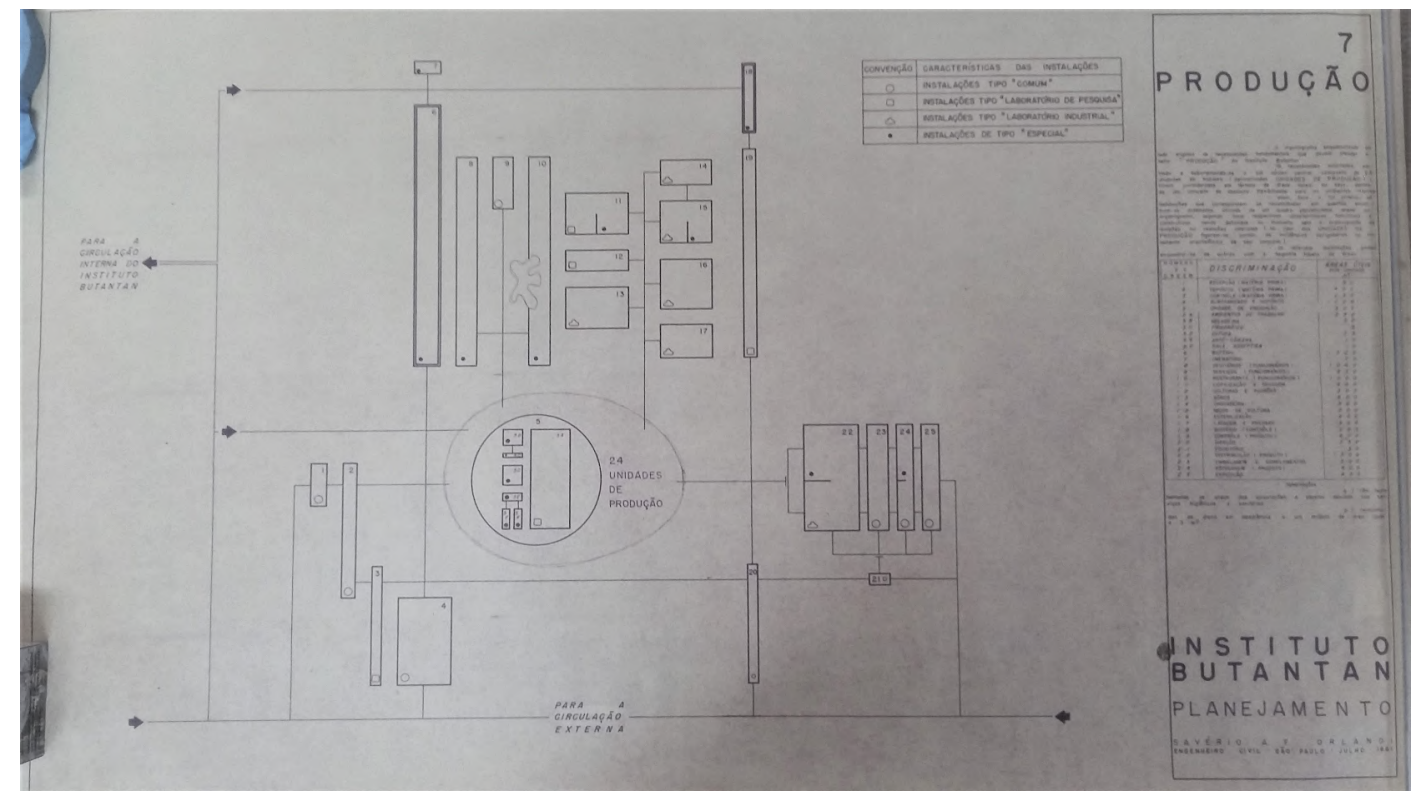

Figura 51: Produção: organograma específico do setor da produção, 1961. Fonte: prancha 17.33, Centro de Memória/IB. 
Ficha 06: Hospital “Vital Brazil”55

\begin{tabular}{|l|l|}
\hline Data & 1962 e 1964. \\
\hline Autoria & $\begin{array}{l}\text { Arquitetura: arquitetos João Carlos Bross, Abelardo de Souza, } \\
\text { Jacob Goldemberg, Luiz Contrucci, Leo Quanji Nishikawa, } \\
\text { Miranda M. Magnoli. }{ }^{56}\end{array}$ \\
\hline Localização & Setor da Administração e Hospital do Instituto Butantan. ${ }^{57}$ \\
\hline Referência & $\begin{array}{l}\text { Consta no plano de implantação da Cidade Universitária de } \\
1963 .\end{array}$ \\
\hline Status & Não construído. \\
\hline Uso & Edifício para o hospital do Instituto. \\
\hline Material Iconográfico & Centro de Memória/ Instituto Butantan: 34 pranchas \\
\hline Desenhos & $\begin{array}{l}\text { Planta baixa, cortes, elevação, implantação, perspectiva, } \\
\text { estrutural e detalhamento. }\end{array}$ \\
\hline
\end{tabular}

\section{Características do projeto}

Implantação: No plano de 1963, o edifício está implantado próximo à esplanada que conforma o setor de pesquisa, na porção oeste do Instituto, ao lado da divisa com o campus da Universidade de São Paulo e da Avenida Professor Lineu Prestes.

Número de pavimentos: Edifício horizontal com único pavimento único.

Sistema construtivo: Estrutura em concreto armado e fechamento composto por peças pré-fabricadas.

Comentários: O projeto para um novo hospital do Instituto Butantan apresenta, como em outros projetos do período, uma organização pavilhonar e que permitiria a expansão do conjunto conforme as necessidades de ampliação das atividades. Deste modo, apesar de alguns detalhamentos do projeto apresentarem uma estrutura moldada em obra, as características do projeto original descrevem elementos

55 Algumas pranchas conferem o nome de Vital Brazil ao Hospital. Possivelmente, o novo edifício seria o substituto do prédio cujo o Hospital do Instituto estava instalado e no qual se encontra atualmente.

56 O nome de João Carlos Bross aparece em destaque nas pranchas indicando-o como autor principal deste projeto. O arquiteto Jacob Goldemberg, em entrevista para o autor, confirma a atuação de Bross em alguns projetos específicos. Ver também a nota 51.

57 Nos carimbos das pranchas para o Hospital, o edifício está classificado no setor denominado "Administração e Hospital". 
modulados, como um edifício pensado para ser executado com peças pré-fabricadas. Com o desenvolvimento do projeto, é possível que tenha se tornado um projeto para um edifício de estrutura mista, ou com elementos pré-fabricados.

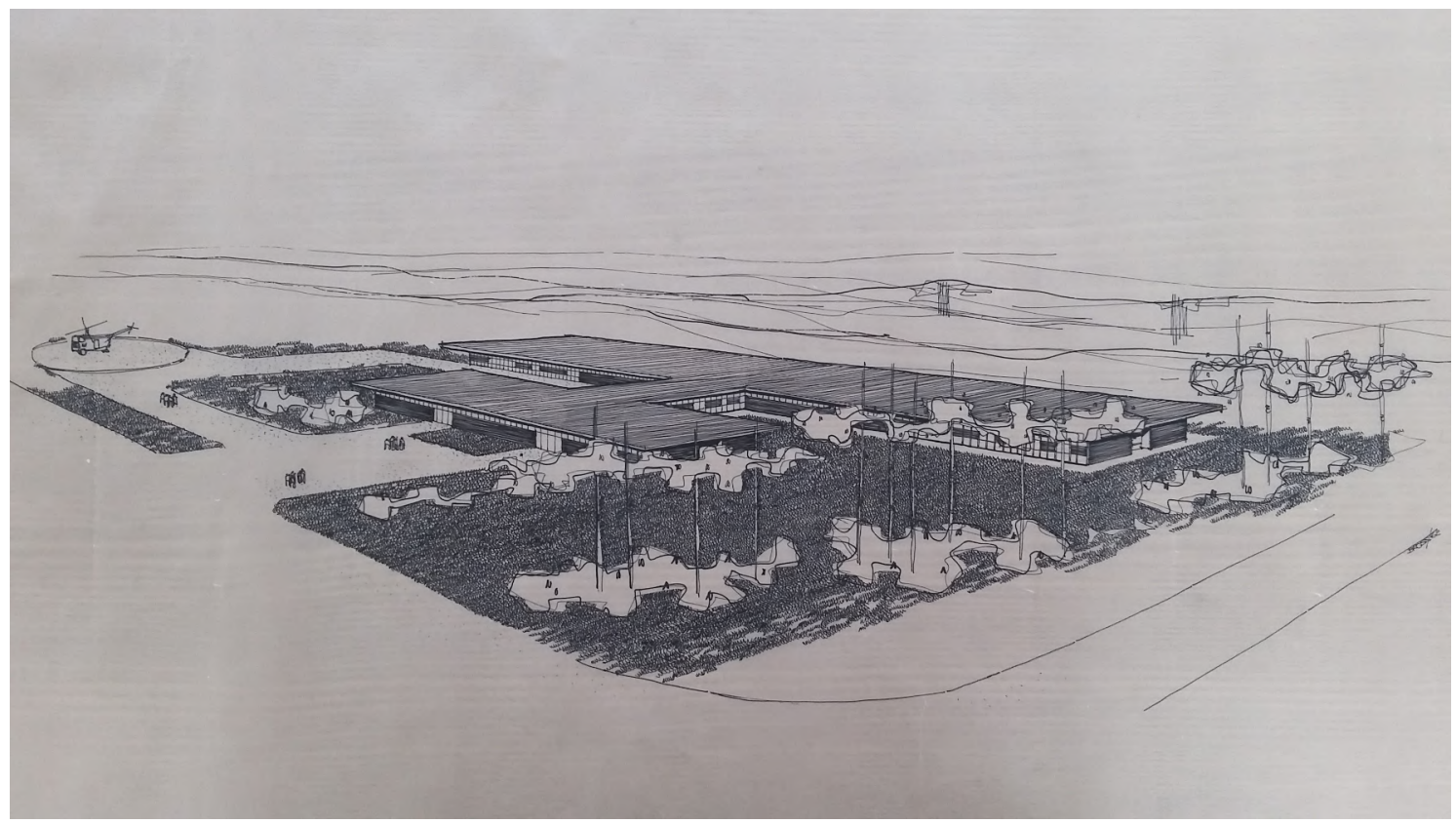

Figura 52: Perspectiva do Hospital, 1962 Fonte: prancha 21.02, Centro de Memória/IB.

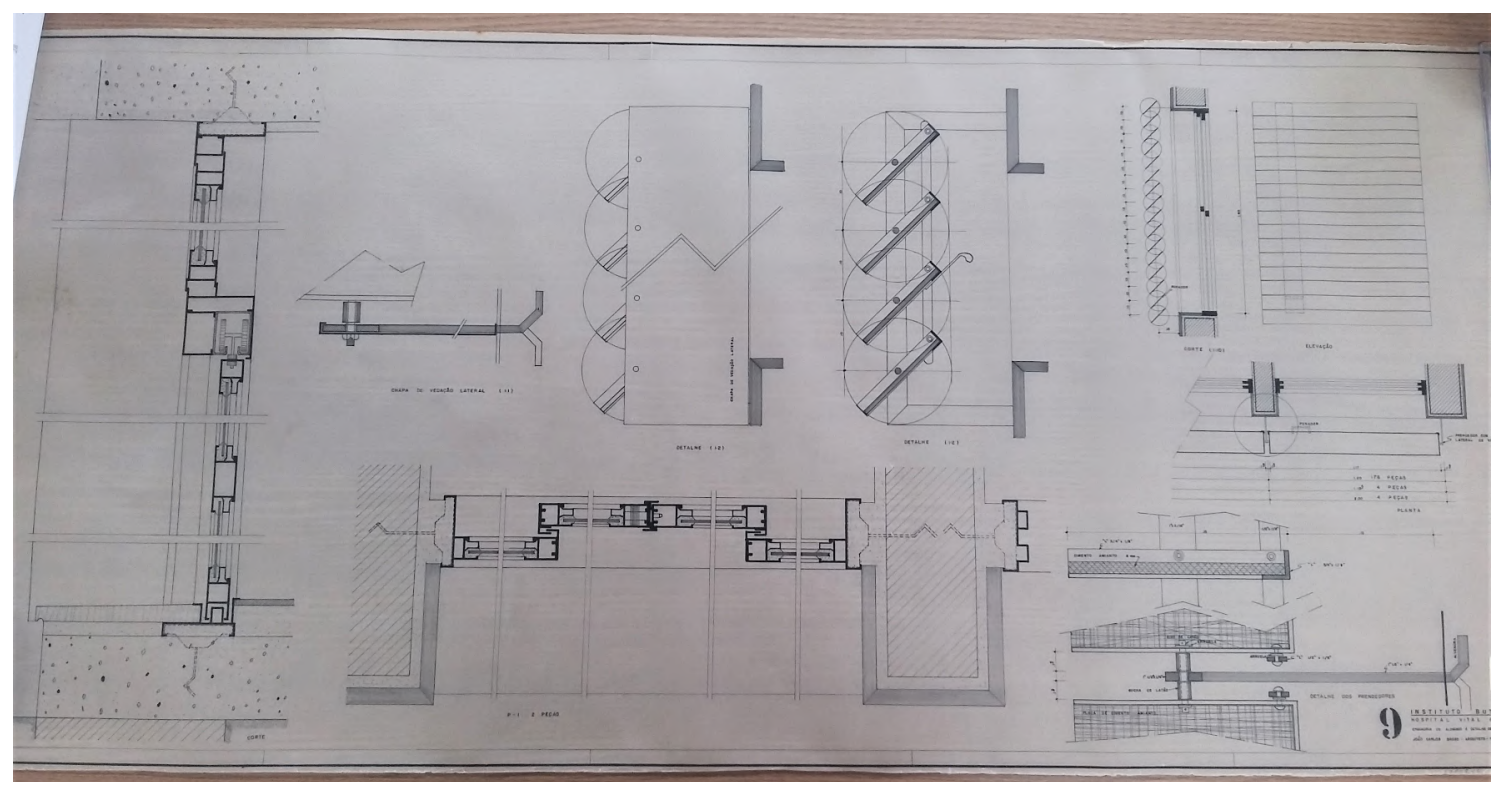

Figura 53: Detalhe das esquadrias e brises do Hospital, 1964. Fonte: prancha 6.05, Centro de Memória/IB. 
Ficha 07: Conjunto de estudos iniciais do PAGE para o Instituto Butantan

\begin{tabular}{|l|l|}
\hline Data & $1959 .^{58}$ \\
\hline Autoria & Arquiteto Rubens Carneiro Vianna. \\
\hline Localização & \multicolumn{1}{|c|}{-} \\
\hline Referência & Parcialmente ou não construídos. ${ }^{59}$ \\
\hline Status & $\begin{array}{l}\text { Projetos diversos de reformas e intervenções nos nos de uso } \\
\text { departamentos do Instituto, em edifícios de } \\
\text { administrativo, da produção, pesquisa, biotérios, entre outros. }\end{array}$ \\
\hline Uso & Centro de Memória/ Instituto Butantan: 18 pranchas ${ }^{60}$ \\
\hline Material Iconográfico & Planta baixa, corte, elevação. \\
\hline Desenhos &
\end{tabular}

\section{Características do projeto}

Implantação: Estes projetos estão situados em edifícios existentes do Instituto, prédio da diretoria (atual Casa de Afrânio do Amaral), o Pavilhão Lemos Monteiro e Hospital Vital Brazil (prédio atual), assim como na Fazenda São Joaquim.

Comentários: Apesar da pouca informação existente sobre estes projetos, que tornam sempre imprecisas as datas e a autoria, é bastante provável que estes desenhos se refiram à atuação do arquiteto Rubens Carneiro Vianna no primeiro ano do Plano de Ação, em 1959. Nesta data o arquiteto passa a atuar no planejamento de novos edifícios a partir da ideia de um plano diretor para o Instituto. São estudos iniciais bastante simples, croquis feitos a mão que deram início aos planos de modernização

58 Muitos destes projetos estão sem data ou sem autoria, contudo, foi possível conferir informações aos desenhos pela reunião dos itens e pelo confrontamento com os documentos administrativos do período. Pelas características dos projetos é possível conferir a autoria à Rubens Carneiro Vianna, porém, não descartamos a atuação do arquiteto Carlos Alberto Cerqueira Lemos, que trabalhou para o Instituto na década de 1950.

59 Não é possível afirmar ao certo quantos destes projetos foram executados, visto que são propostas de reformas e intervenções em edifícios existentes. Seria necessário um estudo minucioso das intervenções feitas nestes edifícios, sendo alguns destes centenários e outros não mais existentes. Todavia, para efeito de classificação dos projetos, é provável que algumas intervenções tenham sido executadas.

60 Outros dois itens também compõem este conjunto de estudos iniciais: o Plano Geral de 1959 e um projeto para a Fazenda São Joaquim, para onde o Instituto Butantan deslocou parte das suas atividades com animais. Optou-se por classificar o Plano de 1959 na ficha dos Planos Urbanísticos. 
da infraestrutura do campus.

Curiosamente, muitos destes projetos estão nomeados com os departamentos e os nomes dos cientistas responsáveis, assim como de suas áreas de atuação ou o nome dos seus laboratórios. Por exemplo: o "Moluscário do Dr. Perez", o "prédio de virusterapia do Dr. Vallejo" ou a "planta do biotério da Dra. Jandyra." Podemos conjecturar sobre estas características imaginando uma proximidade dos cientistas com o arquiteto planejador destas propostas, o que provavelmente procede, mas, principalmente, estes detalhes parecem reafirmar uma intenção, a princípio, menos universal destes planos iniciais, que se pautam pelo levantamento e pela aproximação com o espaço a receber a intervenção.

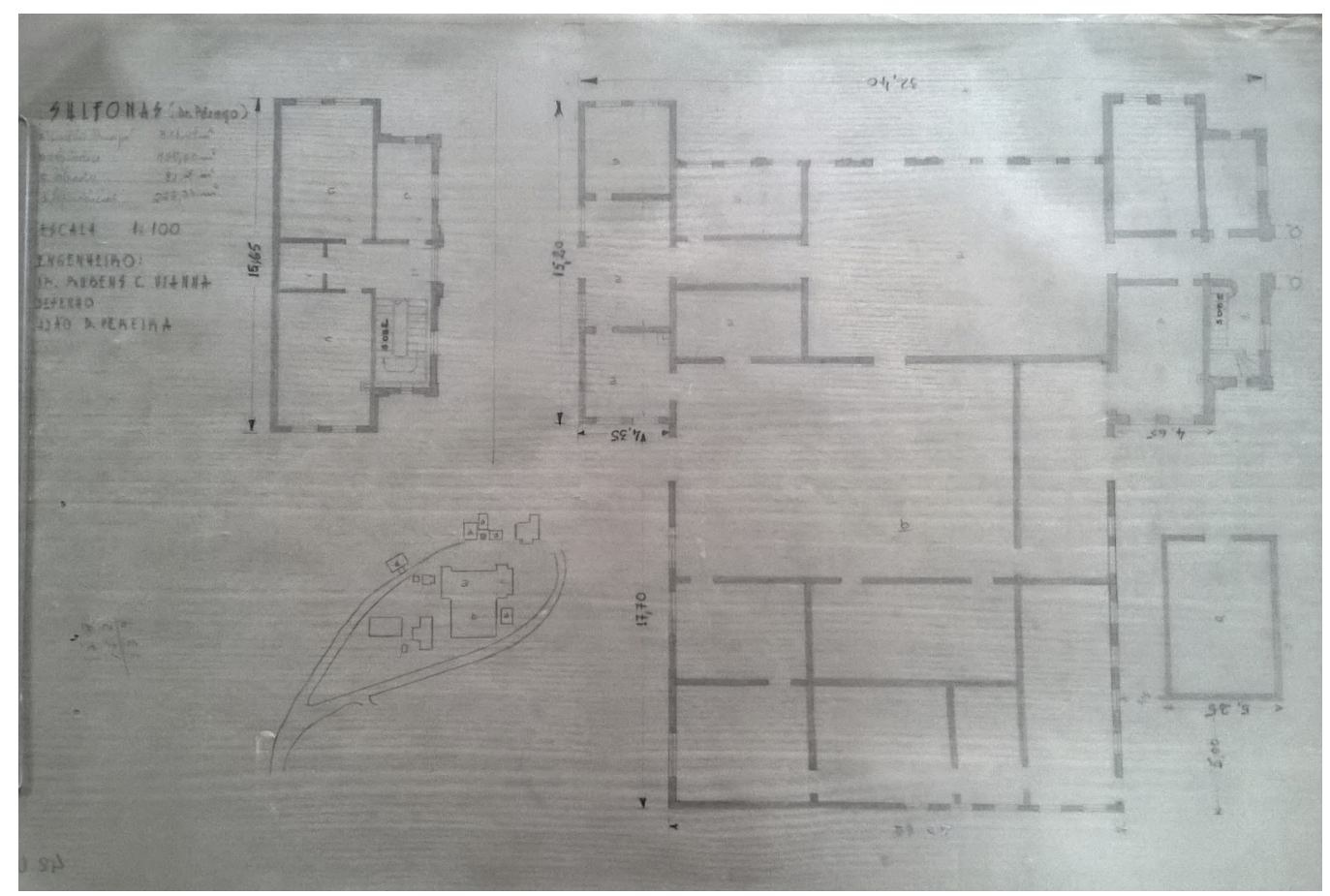

Figura 54: Levantamento do Pavilhão Lemos Monteiro, 1959. Fonte: prancha 42.07, Centro de Memória/IB. 
Ficha 08: Biblioteca e Auditório

\begin{tabular}{|l|l|}
\hline Data & 1961 e 1962. \\
\hline Autoria & Arquiteto Jorge Wilheim. \\
\hline Localização & Setor de pesquisa do Instituto Butantan. \\
\hline Referência & $\begin{array}{l}\text { Consta nos planos de implantação da Cidade Universitária de } \\
1961 \text { e } 1963 .\end{array}$ \\
\hline Status & Não construído. \\
\hline Uso & $\begin{array}{l}\text { Edifício para biblioteca e auditório do Setor de Pesquisa do } \\
\text { Instituto Butantan. }\end{array}$ \\
\hline Material Iconográfico & Centro de Memória/ Instituto Butantan: 14 pranchas \\
\hline Desenhos & $\begin{array}{l}\text { Planta baixa, cortes, elevação, implantação, perspectiva, } \\
\text { estrutural e detalhamento. }\end{array}$ \\
\hline
\end{tabular}

\section{Características do projeto}

Implantação: Nos planos de 1961 e 1963, o edifício está situado na esplanada do setor de pesquisa, localizado na porção oeste do Instituto, ao lado da divisa com o campus da Universidade de São Paulo e da Avenida Professor Lineu Prestes. O segundo projeto faz parte do Setor 7, ou Setor Biológico, da Cidade Universitária.

Número de pavimentos: $O$ projeto a ser implantado no Instituto Butantan é de um edifício de dois pavimentos, cujo térreo apresenta pequenas variações internas de pé direito e um desnível para acomodar o auditório. O outro edifício, provavelmente situado na Cidade Universitária, seria composto pelo térreo mais quatro pavimentos.

Sistema construtivo: Estrutura em concreto armado e fechamento feito por grandes panos de vidro.

Comentários: O projeto para a Biblioteca e Auditórios do Instituto Butantan é constituído por duas lajes "soltas" que conformam uma projeção triangular e abrigam biblioteca e auditório; o segundo pavimento abriga salas de reunião e estudos. $\mathrm{O}$

61 O edifício para a biblioteca e auditório está localizado, nos planos de 1961 e 1963, na esplanada conformada pelo setor de pesquisas. O segundo projeto para uma biblioteca e anfiteatros, também projetado por Jorge Wilheim em 1961, é parte do Setor 10, ou Setor Biológico, da Cidade Universitária, que é integrado ao Instituto Butantan. 
segundo edifício de mesmo programa, é conformado por quatro lajes sobrepostas, apoiadas por empenas estruturais; uma torre cilíndrica de circulação, ao lado do volume principal, que completa o edifício.

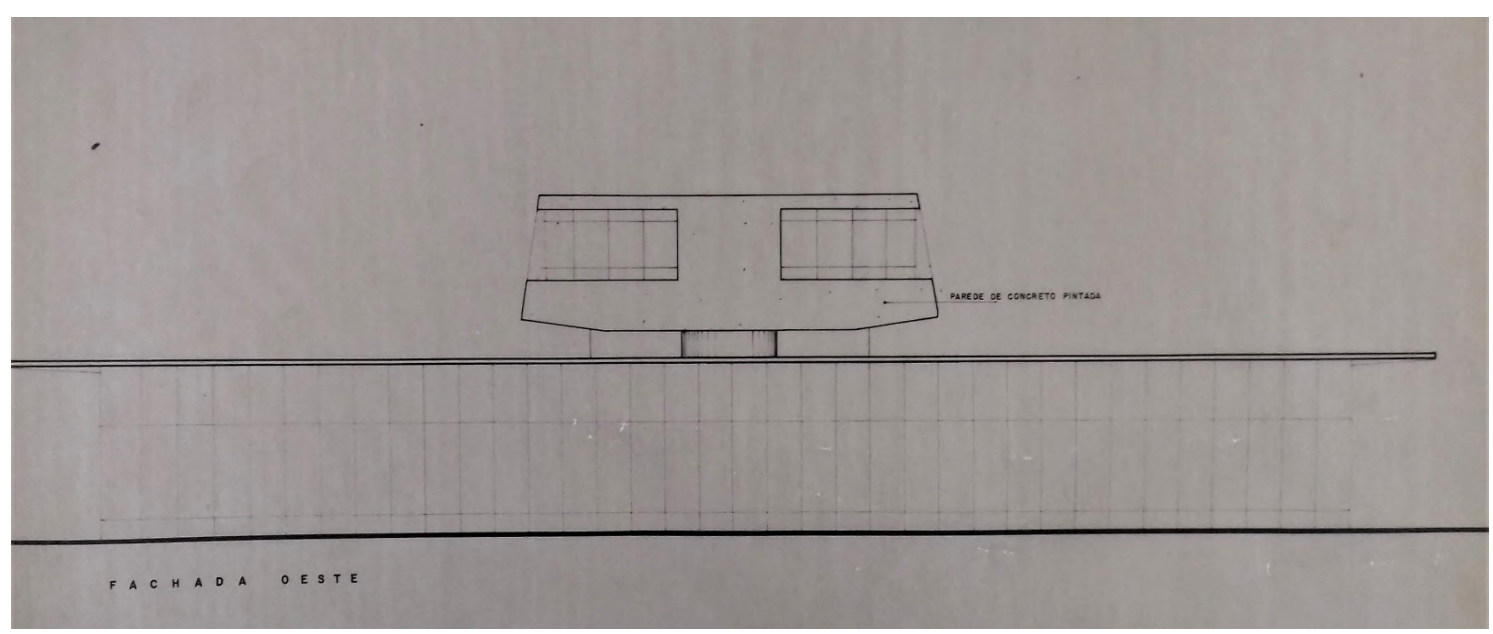

Figura 55: Fachada do edifício para a Biblioteca e Auditório do Instituto Butantan: uma laje extensa com grandes panos de vidro e uma torre acima do térreo, 1961. Fonte: prancha 34.09, Centro de Memória/ IB.

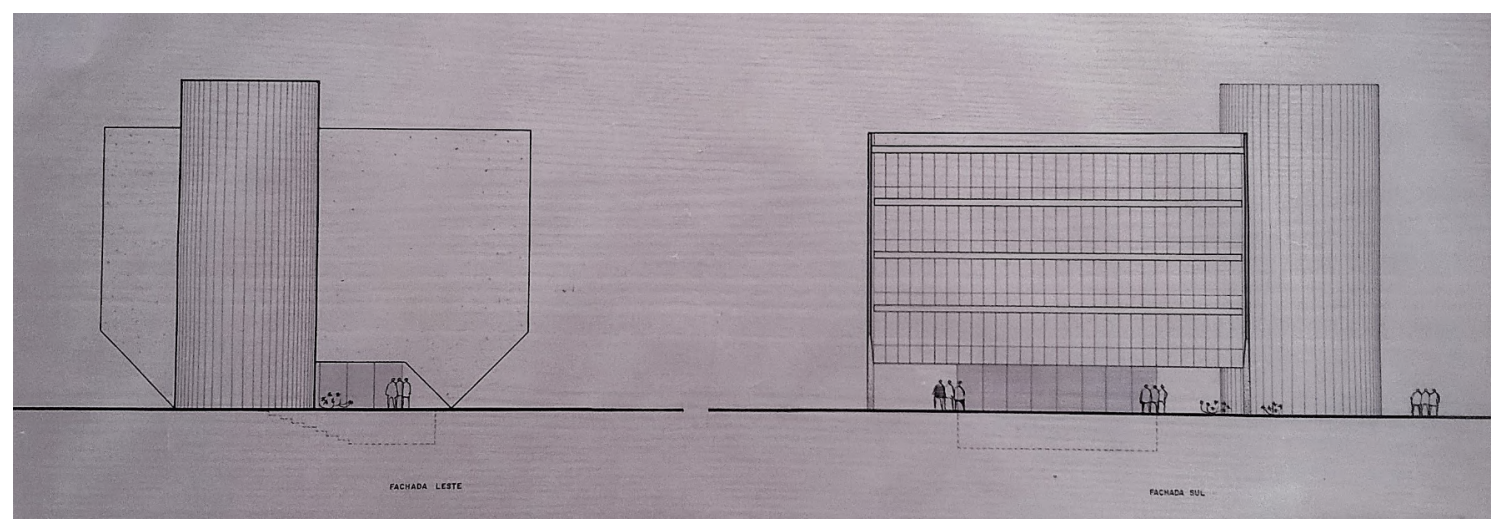

Figura 56: Elevações do edifício para a biblioteca e anfiteatro do Setor Biológico: dois volumes conformam o edifício, 1961. Fonte: prancha 36.10, Centro de Memória/ IB. 
Ficha 09: Planos de Urbanização

\begin{tabular}{|c|c|}
\hline Data & 1959, 1961, 1963, 1965 e 1966. \\
\hline Autoria & $\begin{array}{l}\text { Arquitetos Rubens Carneiro Vianna, Jorge Wilheim, Léo Quanji } \\
\text { Nishikawa e Sergio Atrigliano, Jacob Goldenberg, Luiz } \\
\text { Contrucci, Abelardo de Souza, João Carlos Bross, Miranda M. } \\
\text { Magnoli, Osmar Mammini. }\end{array}$ \\
\hline Localização & Setor 10 do planejamento da Cidade Universitária. \\
\hline Referência & $\begin{array}{l}\text { Correspondem aos planos de implantação da Cidade } \\
\text { Universitária de 1961, } 1963 \text { e de } 1965 \text { e } 1966 \text { para o Instituto } \\
\text { Butantan. }\end{array}$ \\
\hline Status & Parcialmente construídos. \\
\hline Uso & $\begin{array}{l}\text { Plano gerais de zoneamento e implantação de edifícios para o } \\
\text { Instituto Butantan. }\end{array}$ \\
\hline Material Iconográfico & $\begin{array}{l}\text { Centro de Memória/Instituto Butantan: } 9 \text { pranchas } \\
\text { Biblioteca da Faculdade de Arquitetura e Urbanismo/USP: } 3 \\
\text { pranchas }\end{array}$ \\
\hline Publicações & $\begin{array}{l}\text { Revista América, no2, 1962, s.p. } \\
\text { Revista Acrópole, no 331, 1966, p.31 }\end{array}$ \\
\hline Desenhos & Planta baixa, implantação, viário e zoneamento. \\
\hline
\end{tabular}

\section{Características do projeto}

Implantação: Campus do Instituto Butantan.

Comentários: O plano de 1959, de autoria de Rubens Carneiro Vianna, é um esforço inicial de levantamento das condições do Instituto e de situação dos novos edifícios do biotério, pesquisa e produção, propondo algumas alterações na circulação e acesso ao campus. O plano de 1961, de Leo Quanji Nishikawa e Sergio Atrigliano é uma proposta vencedora do concurso para o zoneamento do campus. O plano de 1963 é o desenvolvimento do plano de 1961, com a atuação de Nishikawa e outros arquitetos contratados pelo FCCUASO. O plano de 1965 e 1966 é uma atualização e reformulação feita no período em que atuaram Osmar Mammini e Carlos Henrique Heck como arquitetos do Instituto Butantan. 


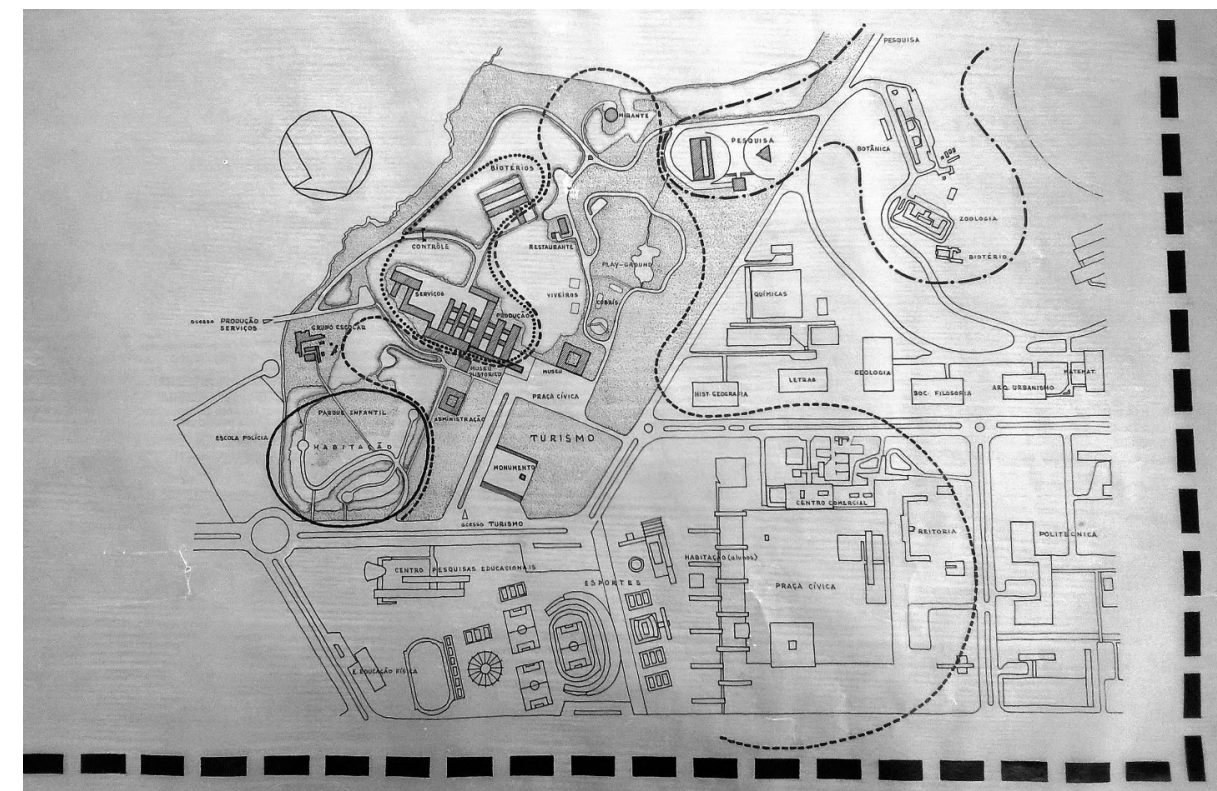

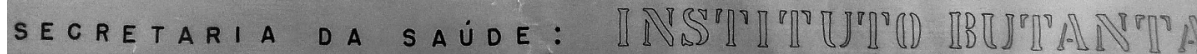

Figura 57: Detalhe do plano de 1961, dos arquitetos Leo Quanji Nishikawa e Sergio Atrigliano. Fonte: prancha 40.11, Centro de Memória/ IB.

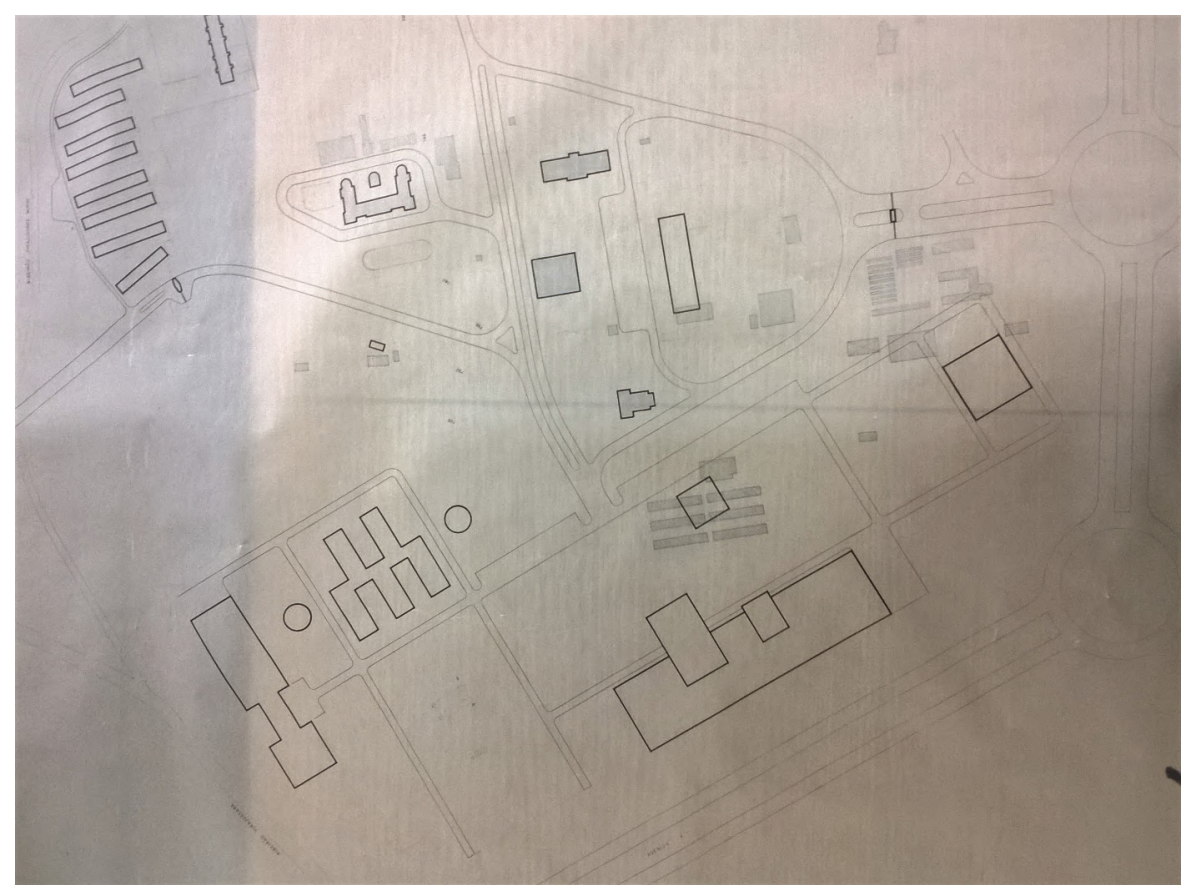

Figura 58: Plano de 1965 e 1966: são efetuadas alterações viárias importantes, conciliadas com a preservação de alguns edifícios históricos. Fonte: prancha 39.01, Centro de Memória/ IB. 
Ficha 10: Restaurante

\begin{tabular}{|l|l|}
\hline Data & 1962. \\
\hline Autoria & $\begin{array}{l}\text { Arquitetos Abelardo de Souza, João Carlos Bross, Jacob B. } \\
\text { Goldenberg, Luiz Contrucci, Leo Quanji Nishikawa, Miranda } \\
\text { Magnoli. }{ }^{62}\end{array}$ \\
\hline Localização & Setor de Turismo do Instituto Butantan. \\
\hline Referência & $\begin{array}{l}\text { Consta nos planos de implantação da Cidade Universitária de } \\
1961 \text { e 1963. No último plano aparece já no formato do } \\
\text { edifício projetado. }\end{array}$ \\
\hline Status & Não construído. \\
\hline Uso & Edifício para o restaurante do Instituto Butantan. \\
\hline Material Iconográfico & $\begin{array}{l}\text { Centro de Memória/ Instituto Butantan: 5 pranchas } \\
\text { Biblioteca da Faculdade de Arquitetura e Urbanismo/USP: } 30 \\
\text { pranchas. }^{63}\end{array}$ \\
\hline Desenhos & Planta baixa, cortes, elevação, perspectiva. \\
\hline
\end{tabular}

\section{Características do projeto}

Implantação: Guardadas pequenas variações, tanto no plano de 1961 quanto no de 1963, o edifício está situado numa posição central da área do Instituto Butantan, no local onde hoje existe uma mata preservada. O edifício estaria implantado próximo ao ponto em que confluem as ruas Emílio Ribas e Adolfo Lutz, vias internas atualmente existentes no campus do Butantan.

Número de pavimentos: $O$ projeto tem cerca de 4 pavimentos, contando com um semienterrado e apresentando pé direito duplo no salão do restaurante.

Sistema construtivo: Estrutura em concreto armado e fechamento feito por grandes panos de vidro e paredes de pedra.

Comentários: O projeto para o Restaurante do Instituto Butantan é constituído por

62 O nome de Abelardo de Souza aparece em destaque nas pranchas de projeto do edifício para o Restaurante, indicando-o como autor principal.

63 É possível que o número de pranchas do projeto para o Restaurante, disponíveis na Biblioteca da FAU USP, seja um pouco maior que 30, visto que a nomeação de alguns dos itens da lista de projetos referentes ao Instituto Butantan não menciona diretamente o edifício. Todos estes projetos fazem parte do acervo do Arquiteto Abelardo de Souza. 
uma grande laje acima do último andar, apoiada por planos triangulares invertidos e um mezanino intermediário, acessível por uma rampa externa. Sua posição na topografia e as aberturas do mezanino, permitem visuais amplas para o Instituto e a cidade.

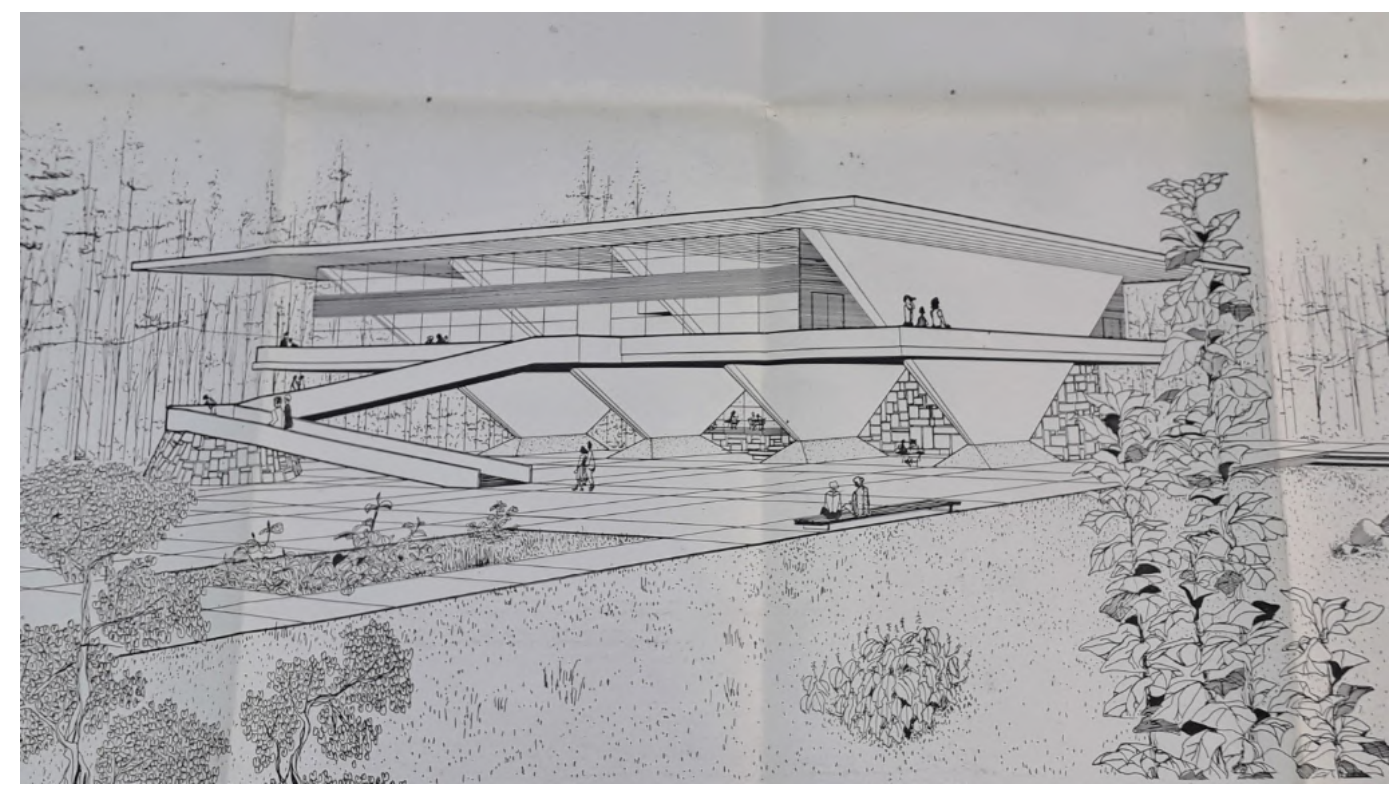

Figura 59: Perspectiva do Restaurante do Instituto Butantan, 1962. Fonte: Fl.44-RestaurantePerspectiva, Biblioteca FAUUSP.

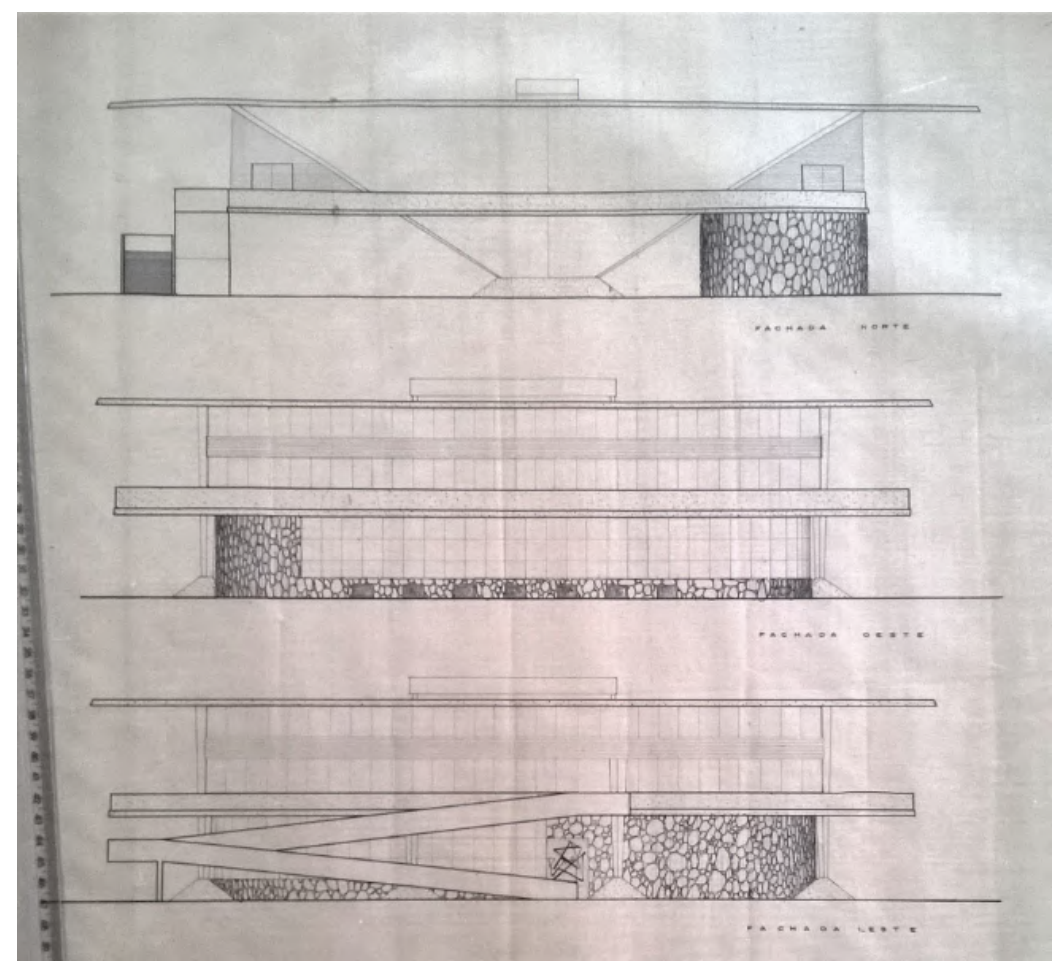

Figura 60: Elevações do Restaurante do Instituto Butantan, 1962. Fonte: prancha 55.08, Centro de Memória/ IB. 
Ficha 11: Igreja "Nossa Senhora dos Pobres" ${ }^{4}$

\begin{tabular}{|l|l|}
\hline Data & 1964. \\
\hline Autoria & Arquiteto João Roberto Leme Simões. \\
\hline Localização & Setor Residencial do Instituto Butantan. ${ }^{65}$ \\
\hline Referência & $\begin{array}{l}\text { Consta no plano de implantação da Cidade Universitária de } \\
1963 .\end{array}$ \\
\hline Status & Não construído. \\
\hline Uso & $\begin{array}{l}\text { Edifício para uma igreja próxima ao conjunto residencial do } \\
\text { Instituto Butantan. }\end{array}$ \\
\hline Material Iconográfico & Centro de Memória/ Instituto Butantan: 5 pranchas \\
\hline Desenhos & Planta baixa, cortes, elevação, implantação. \\
\hline
\end{tabular}

\section{Características do projeto}

Implantação: O edifício seria implantado próximo à entrada do Instituto Butantan pela Avenida Vital Brazil, ao lado do Conjunto Residencial, onde até hoje se encontra a Paróquia Nossa Senhora dos Pobres. O projeto consta no plano de implantação da Cidade Universitária de 1963.

Número de pavimentos: 2 pavimentos, sendo um semienterrado.

Sistema construtivo: Estrutura possivelmente em concreto armado protendido.

Comentários: O projeto para a Igreja parece compor parte do Conjunto Residencial do Instituto Butantan. O edifício é delimitado por grandes planos verticais que, pelas imagens, parecem ser construídos em concreto armado, o acesso ocorre por duas rampas posicionadas nas extremidades do edifício, uma voltada para a Avenida Vital Brazil e outra para o Ribeirão Pirajussara Mirim, onde hoje está a Avenida Corifeu de Azevedo Marques. Um terceiro acesso se encontra no lado oposto ao altar da igreja. O projeto do edifício carece de detalhes sobre a composição dos espaços e da estrutura.

64 O projeto da Igreja está vinculado ao FCCUASO e seria construído em substituição à Igreja de Nossa Senhora dos Pobres, que seria demolida.

65 Apesar de o projeto não especificar o setor no qual seria construída a Igreja, o edifício está localizado próximo ao conjunto residencial do Instituto. 


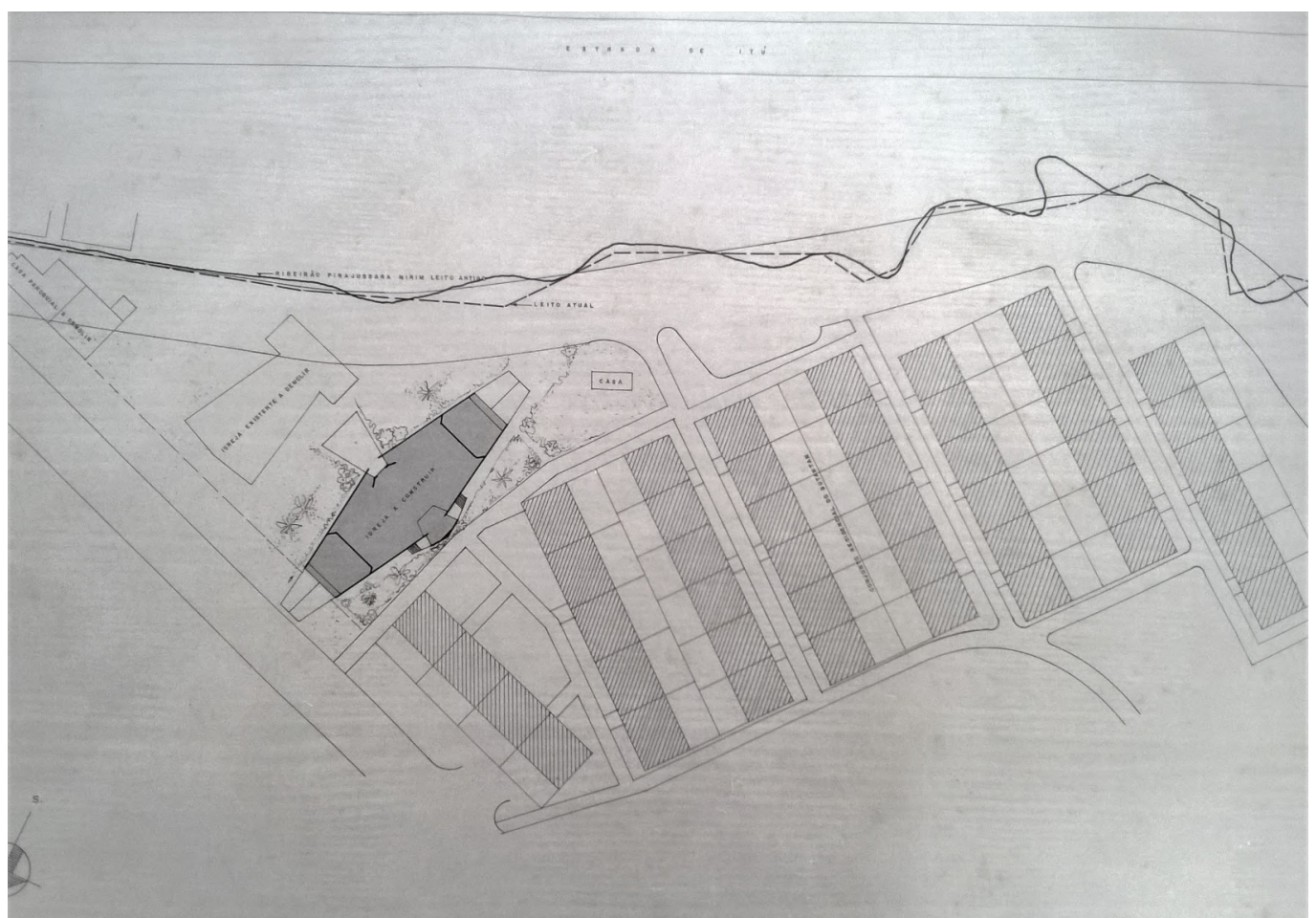

Figura 61: Implantação do edifício próximo ao Conjunto Residencial do Instituto Butantan, 1964 Fonte: prancha 43.09, Centro de Memória/ IB.

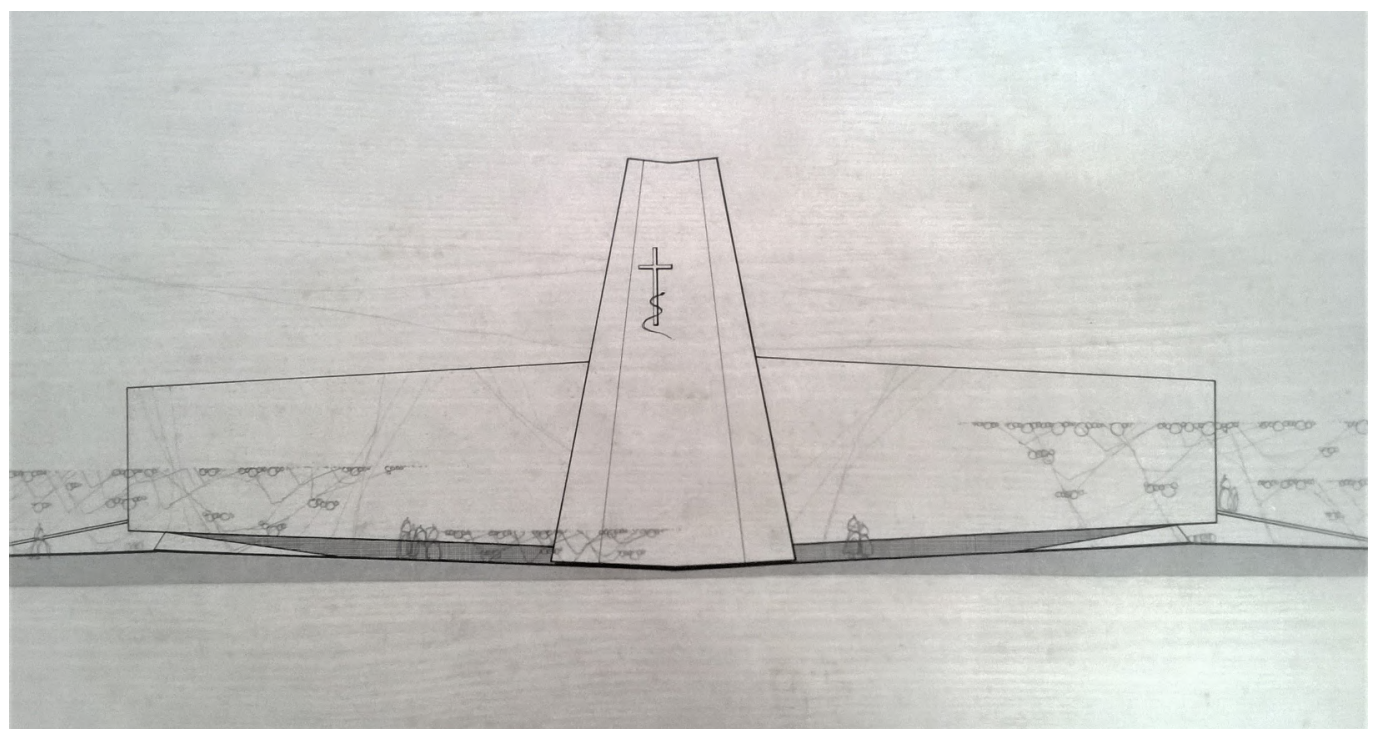

Figura 62: Elevação posterior do edifício para a Igreja, 1964. Fonte: prancha 43.11, Centro de Memória/IB. 
Ficha 12: Edifício da Administração

\begin{tabular}{|l|l|}
\hline Data & 1962. \\
\hline Autoria & $\begin{array}{l}\text { Arquitetos João Carlos Bross, Abelardo de Souza, Jacob B. } \\
\text { Goldenberg, Luiz Contrucci, Leo Quanji Nishikawa, Miranda } \\
\text { Magnoli.66 }\end{array}$ \\
\hline Localização & Setor de Administração e Hospital do Instituto Butantan. \\
\hline Referência & $\begin{array}{l}\text { Consta no plano de implantação da Cidade Universitária de } \\
1963 .\end{array}$ \\
\hline Status & Não construído. \\
\hline Uso & Edifício para a administração do Instituto Butantan. \\
\hline Material Iconográfico & $\begin{array}{l}\text { Centro de Memória/ Instituto Butantan: 3 pranchas e 1 } \\
\text { fotografia } \\
\text { Biblioteca da Faculdade de Arquitetura e Urbanismo/USP: 6 } \\
\text { pranchas. }\end{array}$ \\
\hline Publicações & Revista Acrópole, no 331, 1966, p.40 e 41 \\
\hline Desenhos & Planta baixa, cortes, elevação, perspectiva, implantação. \\
\hline
\end{tabular}

\section{Características do projeto}

Implantação: No plano de 1963 o edifício está localizado em um ponto privilegiado do Instituto, no prolongamento da Avenida Luciano Gualberto, que atravessa a Cidade Universitária da USP.

Número de pavimentos: 2 pavimentos, sendo um subsolo semienterrado.

Sistema construtivo: Estrutura possivelmente em concreto armado protendido.

Comentários: O projeto para o edifício da administração do Instituto Butantan parece, de acordo os planos, ocupar um espaço importante no conjunto, tanto pela sua localização quanto pelo programa. Além da sua função administrativa, o edifício conforma uma ampla praça com espelho d'água, situada em um ponto do campus no qual passam todas as vias de circulação e acesso do Instituto. Sua forma é definida por sucessivos pórticos estruturais cujos apoios são imperceptíveis.

66 O nome de João Carlos Bross aparece em destaque nas pranchas de projeto do edifício da Administração, indicando-o como autor principal. 


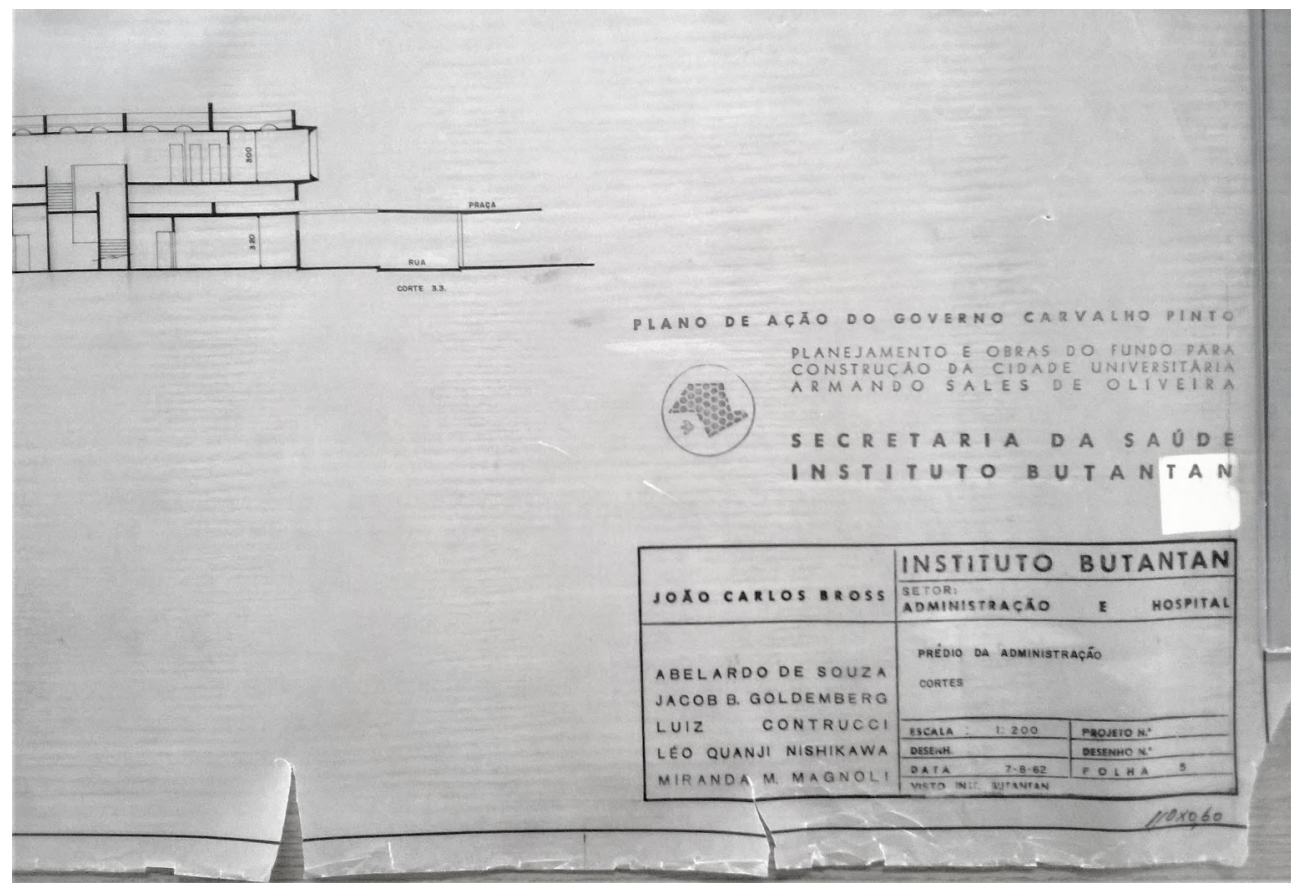

Figura 63: Carimbo do Plano de Ação em uma das pranchas do Prédio da Administração, 1962. Fonte: prancha 46.05, Centro de Memória/IB.

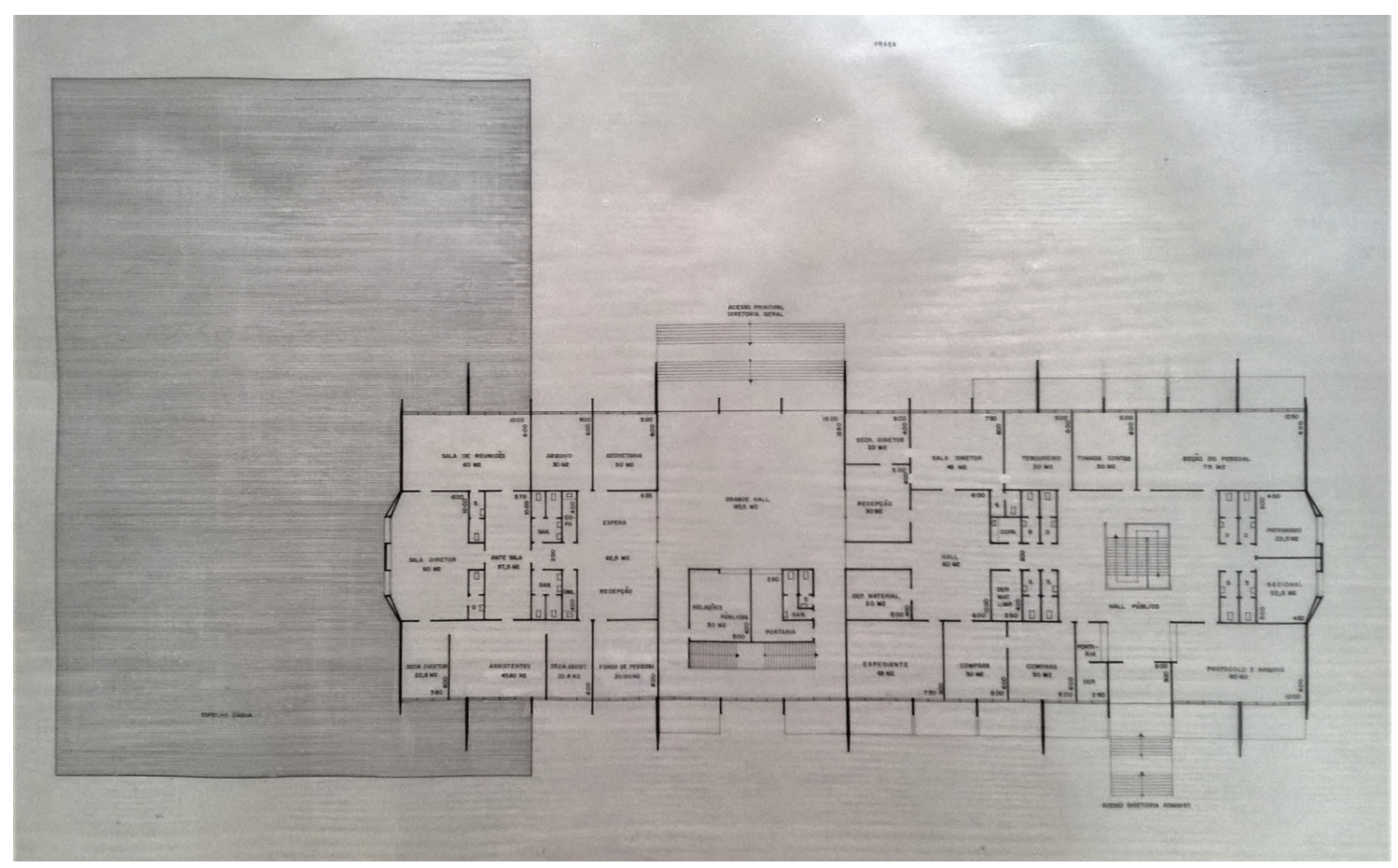

Figura 64: Planta do pavimento acima do nível da praça, 1962. Fonte: prancha 46.01, Centro de Memória/IB. 
Ficha 13: Prédio do Museu

\begin{tabular}{|l|l|}
\hline Data & 1962. \\
\hline Autoria & $\begin{array}{l}\text { Arquitetos Abelardo de Souza, João Carlos Bross, Jacob B. } \\
\text { Goldenberg, Luiz Contrucci, Leo Quanji Nishikawa, Miranda } \\
\text { Magnoli. }{ }^{67}\end{array}$ \\
\hline Localização & Setor de Turismo do Instituto Butantan. \\
\hline Referência & $\begin{array}{l}\text { Consta no plano de implantação da Cidade Universitária de } \\
1963{ }^{68}\end{array}$ \\
\hline Status & Não construído. \\
\hline Uso & Edifício para o museu do Instituto Butantan. \\
\hline Material Iconográfico & $\begin{array}{l}\text { Centro de Memória/ Instituto Butantan: 2 pranchas } \\
\text { Biblioteca da Faculdade de Arquitetura e Urbanismo/USP: 15 } \\
\text { pranchas. }\end{array}$ \\
\hline Desenhos & $\begin{array}{l}\text { Planta baixa, cortes, elevação, perspectiva, estrutura (planta } \\
\text { dos pilares). }\end{array}$ \\
\hline
\end{tabular}

\section{Características do projeto}

Implantação: No plano de 1963 o edifício está localizado na porção oeste do Instituto, próximo ao setor de pesquisa e da Avenida Professor Lineu Prestes, na Cidade Universitária.

Número de pavimentos: Edifício de pavimento único elevado do solo. 0 pé-direito de 7 metros comporta mezaninos nos pavilhões.

Sistema construtivo: Estrutura constituída por pórticos, possivelmente em concreto armado.

Comentários: O projeto para o edifício do Museu do Instituto Butantan é constituído por blocos conectados por um eixo de circulação. Em uma das extremidades deste eixo se encontra um auditório, e o acesso do público é feito por estes dois pontos opostos. Os volumes do edifício são espaçados, constituindo vazios ajardinados. O desenho do projeto indica um curso d'água sobre o qual o edifício se projeta elevado.

67 O nome de Abelardo de Souza aparece em destaque nas pranchas de projeto do Museu, indicando-o
como autor principal.
68 O museu previsto no plano de 1961 está em uma localização diferente e corresponde a outro projeto. 


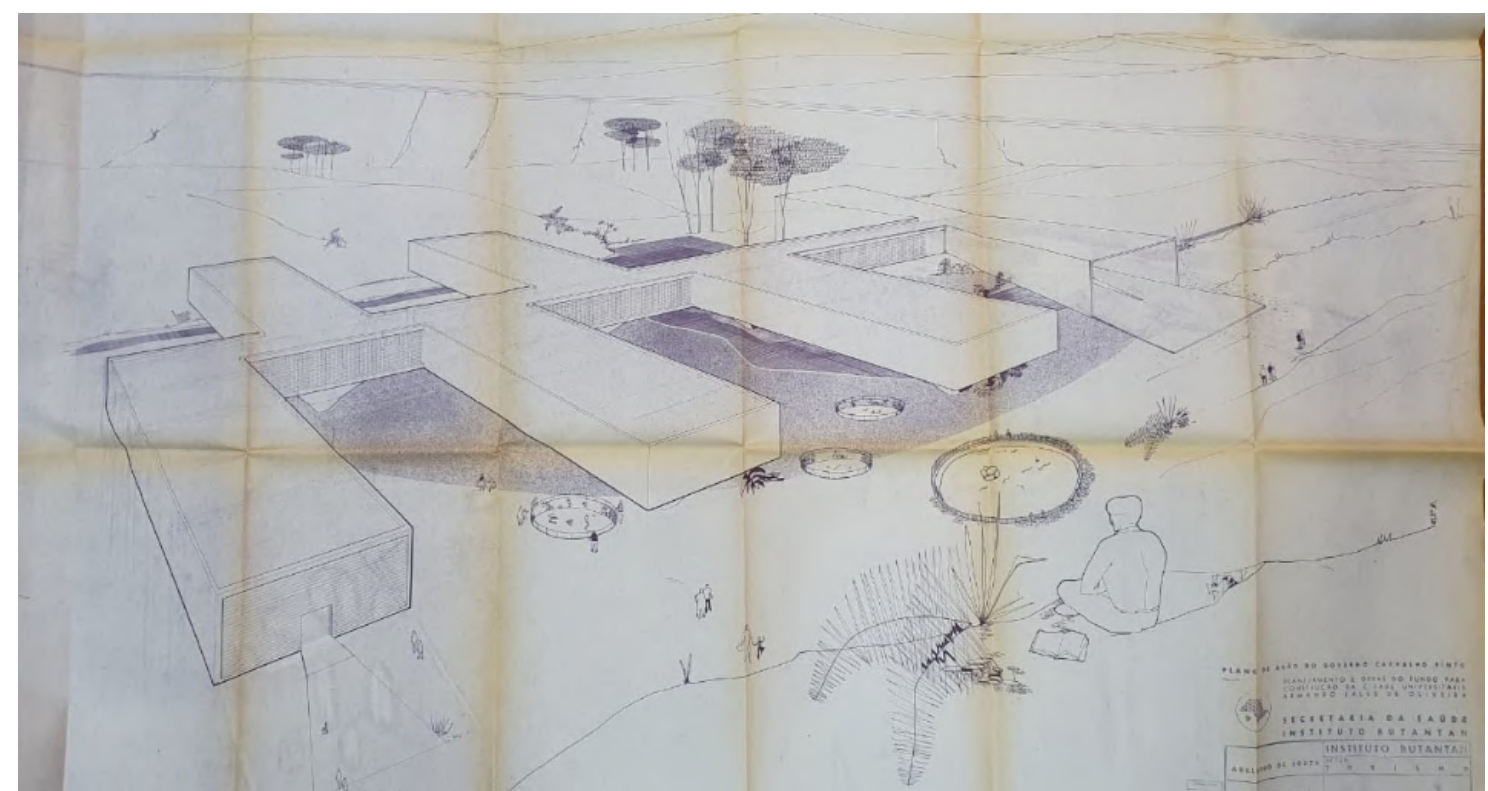

Figura 65: Perspectiva do edifício do Museu sem a projeção dos pórticos estruturais, 1962. Fonte: Fl.11Museu - Perspectiva, Biblioteca FAU/USP.

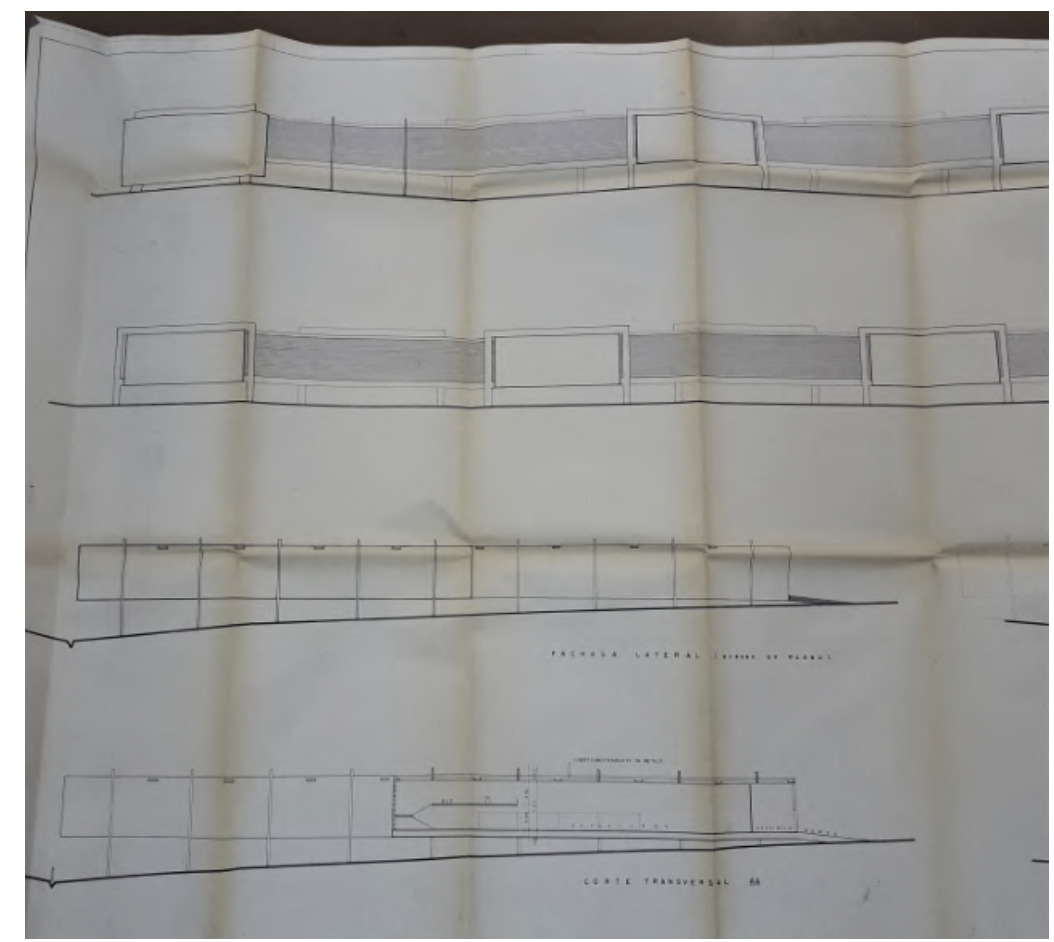

Figura 66: Elevação e cortes do edifício do Museu com a projeção dos pórticos estruturais, 1962. Fonte: Fl.12-Museu- Cortes E Fachadas, Biblioteca FAU/USP. 
Ficha 14: Macacários

\begin{tabular}{|l|l|}
\hline Data & 1962. \\
\hline Autoria & $\begin{array}{l}\text { Arquitetos Abelardo de Souza, João Carlos Bross, Jacob B. } \\
\text { Goldenberg, Luiz Contrucci, Leo Quanji Nishikawa, Miranda } \\
\text { Magnoli. }{ }^{69}\end{array}$ \\
\hline Localização & Setor de Turismo do Instituto Butantan. \\
\hline Referência & $\begin{array}{l}\text { Consta no plano de implantação da Cidade Universitária de } \\
1963 .\end{array}$ \\
\hline Status & Não construído. \\
\hline Uso & $\begin{array}{l}\text { Estrutura para abrigo e exposição de animais do Instituto } \\
\text { Butantan. }\end{array}$ \\
\hline Material Iconográfico & $\begin{array}{l}\text { Centro de Memória/ Instituto Butantan: 2 pranchas } \\
\text { Biblioteca da Faculdade de Arquitetura e Urbanismo/USP: 1 } \\
\text { prancha }\end{array}$ \\
\hline Desenhos & Planta baixa, corte, elevação. \\
\hline
\end{tabular}

\section{Características do projeto}

Implantação: No plano de 1963 o edifício está localizado próximo à Cidade Universitária, no prolongamento da Avenida Professor Luciano Gualberto.

Número de pavimentos: $O$ terreno dos macacários é rebaixado, constituindo um platô para observação dos animais pelos visitantes.

Sistema construtivo: Muros de pedra, abrigos de estrutura metálica e cobertura de chapa metálica ondulada.

Comentários: O projeto para os macacários é conformado por dois espaços retangulares que se acomodam em um corte no terreno em declive, uma plataforma destinada aos visitantes está situado no nível intermediário. Nas duas áreas destinadas aos animais, estão localizados abrigos feitos de estrutura metálica e cobertos por chapas onduladas. Visto do nível da rua, o conjunto forma um comprido volume único, uma espécie de monolito, paralelo às curvas de nível, e que ganha altura conforme avança sobre o terreno em declive.

69 O nome de Abelardo de Souza aparece em destaque nas pranchas de projeto dos Macacários, indicando-o como autor principal. 


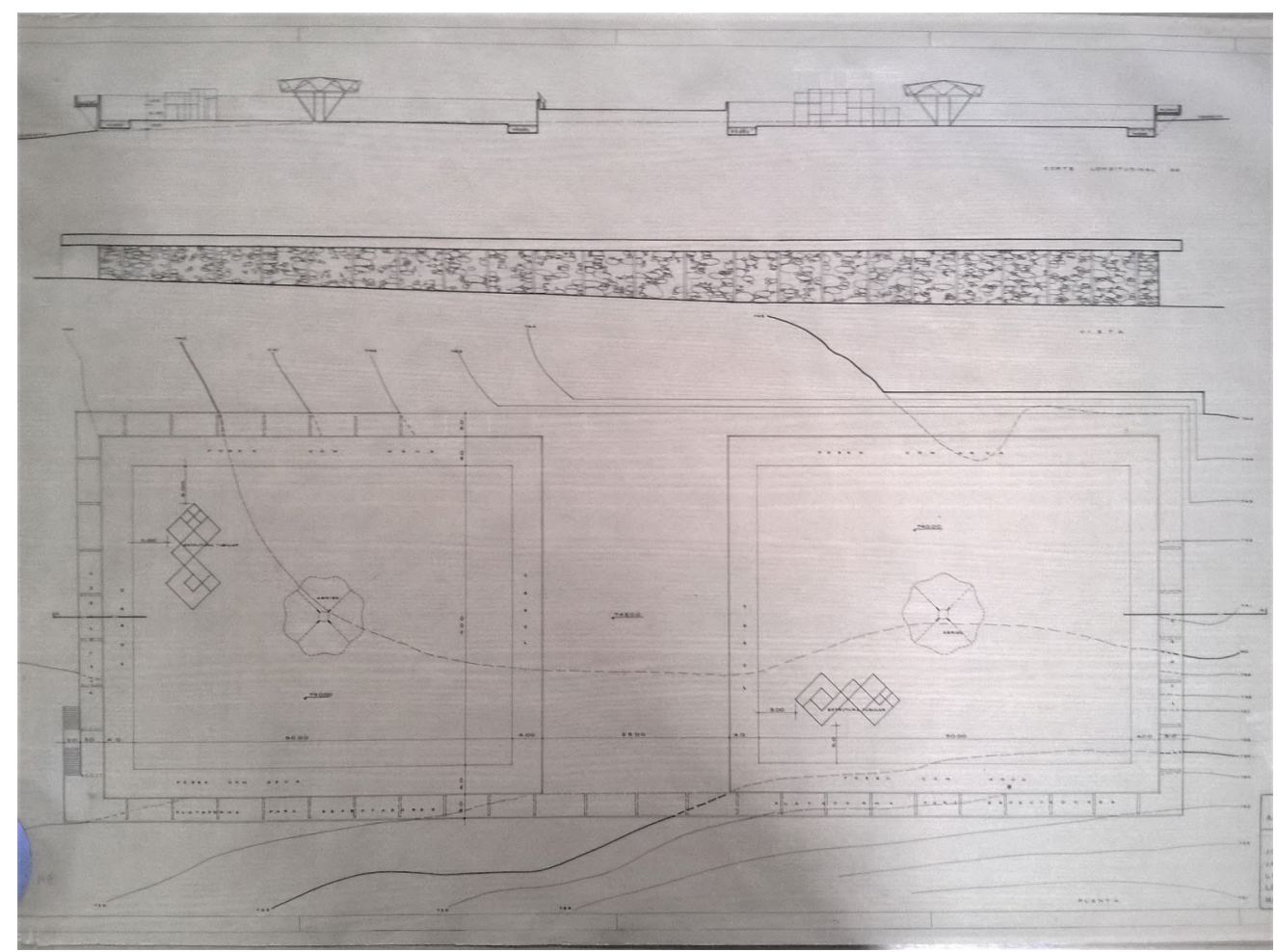

Figura 67: Corte, elevação e planta dos Macacários do Instituto Butantan, 1962. Fonte: prancha 34.06, Centro de Memória/IB.

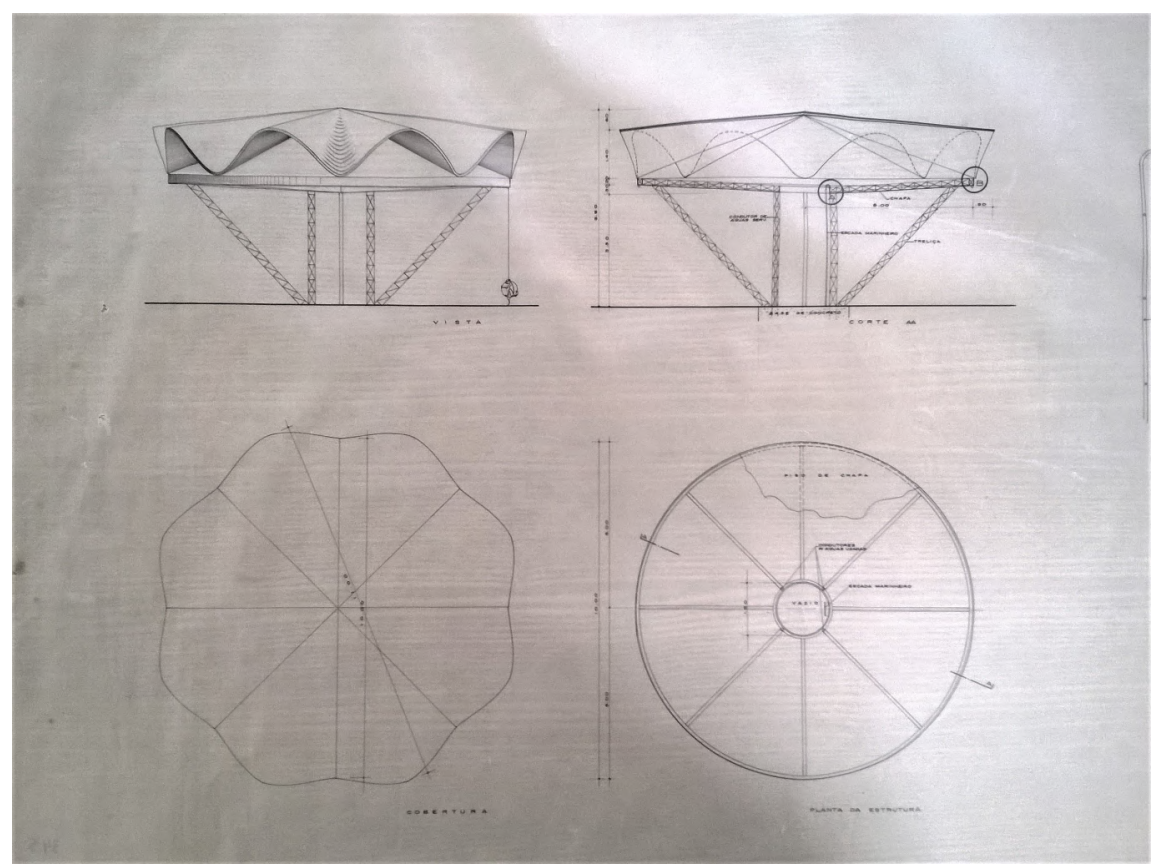

Figura 68: Projeto para os abrigos internos dos Macacários, 1962. Fonte: prancha 34.05, Centro de Memória/IB. 
Ficha 15: Pavilhão de Serviços

\begin{tabular}{|l|l|}
\hline Data & 1962. \\
\hline Autoria & $\begin{array}{l}\text { Arquitetos Jacob Goldemberg, Luiz Contrucci, Abelardo de } \\
\text { Souza, João Carlos Broos, Leo Quanji Nishikawa, Miranda M. } \\
\text { Magnoli. }{ }^{70}\end{array}$ \\
\hline Localização & Setor de Produção do Instituto Butantan. \\
\hline Referência & $\begin{array}{l}\text { Consta no plano de implantação da Cidade Universitária de } \\
1963 .\end{array}$ \\
\hline Status & Não construído. \\
\hline Uso & $\begin{array}{l}\text { Edifícios para os serviços de almoxarifado, depósito, garagem e } \\
\text { escritórios do Instituto Butantan. }\end{array}$ \\
\hline Material Iconográfico & $\begin{array}{l}\text { Biblioteca da Faculdade de Arquitetura e Urbanismo/USP: 20 } \\
\text { pranchas } \\
\text { Centro de Memória/ Instituto Butantan: 1 prancha }\end{array}$ \\
\hline Desenhos & $\begin{array}{l}\text { Planta baixa, cortes, elevação, implantação, perspectiva, } \\
\text { detalhamento. }\end{array}$ \\
\hline
\end{tabular}

\section{Características do projeto}

Implantação: No plano de implantação da Cidade Universitária de 1963 o Pavilhão de Serviços está implantado na atual localização do Edifício Vital Brazil.

Número de pavimentos: 3 pavimentos.

Sistema construtivo: Estrutura em concreto armado protendido.

Comentários: O edifício é formado por extensos pavilhões de dois pavimentos, sobre os quais é sobreposto um bloco perpendicular em balanço, conformando o último andar. Assim como o Edifício da Produção, seu caráter modular previa a expansão dos espaços construídos ao possibilitar o acréscimo de novos módulos/ pavilhões de forma ilimitada. Os pavilhões também estão organizados de modo a organizar os fluxos internos e acessos de veículos.

70 Como nos referimos anteriormente, os arquitetos Jacob Goldemberg e Luiz Contrucci são os autores principais do Edifício da Produção e do Pavilhão de Serviços.

71 Ver nota 51, sobre a composição dos projetos nos acervos do Centro de Memória e da FAU USP. 


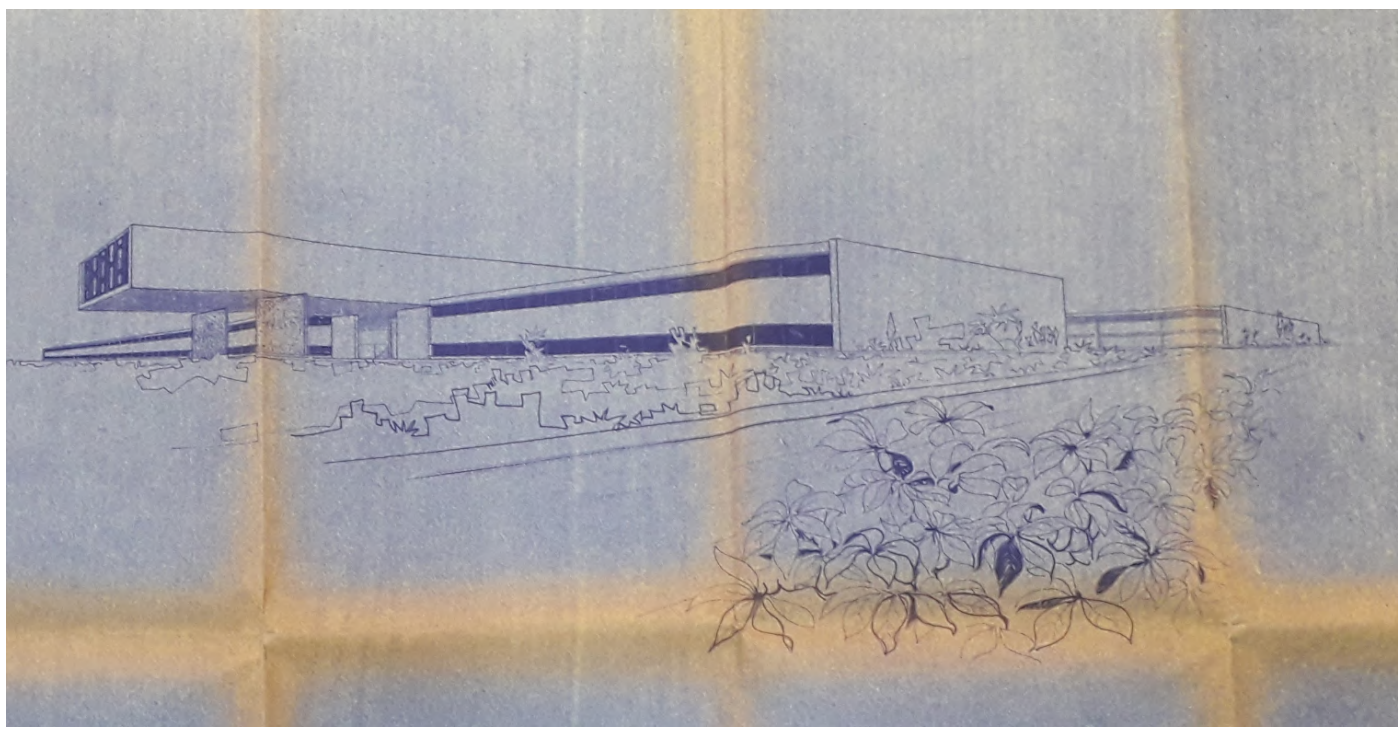

Figura 69: Perspectiva do Edifício de Serviços, 1962. Fonte: Fl.36-Anteprojeto-Serviços, Biblioteca FAU USP.

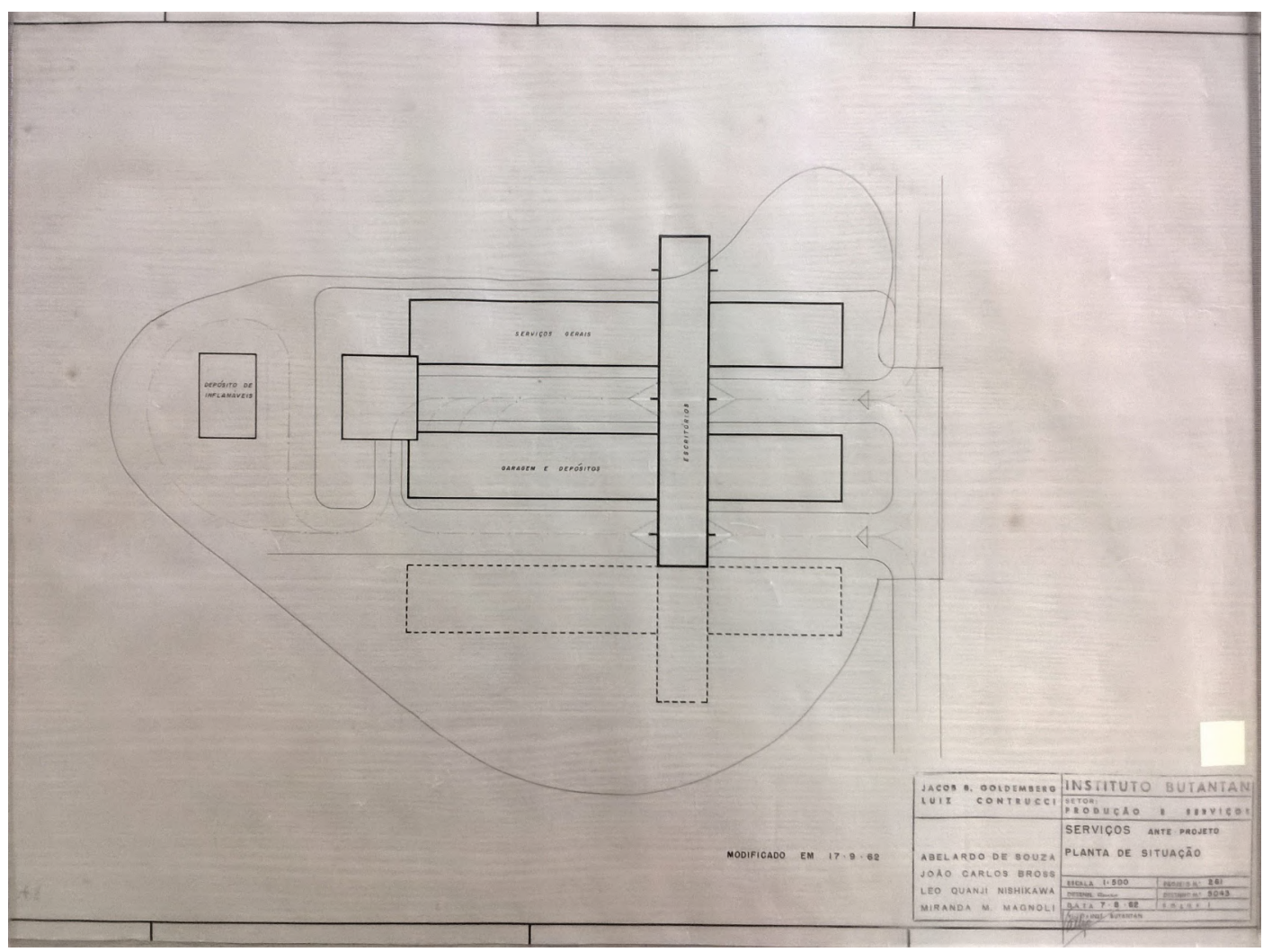

Figura 70: Implantação dos pavilhões com a projeção de expansão do conjunto, 1962. Fonte: prancha 37.01, Centro de Memória/IB. 
Ficha 16: Edifício dos Biotérios

\begin{tabular}{|l|l|}
\hline Data & 1962. \\
\hline Autoria & $\begin{array}{l}\text { Arquitetos Abelardo de Souza, João Carlos Bross, Jacob B. } \\
\text { Goldenberg, Luiz Contrucci, Leo Quanji Nishikawa, Miranda } \\
\text { Magnoli. }{ }^{72}\end{array}$ \\
\hline Localização & Setor dos Biotérios. \\
\hline Referência & $\begin{array}{l}\text { Consta no plano de implantação da Cidade Universitária de } \\
1963 .{ }^{73}\end{array}$ \\
\hline Status & Não construído. \\
\hline Uso & Projeto para os biotérios de animais do Instituto Butantan. \\
\hline Material Iconográfico & $\begin{array}{l}\text { Biblioteca da Faculdade de Arquitetura e Urbanismo/USP: 7 } \\
\text { pranchas }\end{array}$ \\
\hline Desenhos & Planta baixa, corte, elevação. \\
\hline
\end{tabular}

\section{Características do projeto}

Implantação: No plano de 1963 o conjunto do Biotério está localizado na porção mais ao sul do Instituto, próximo à divisa com a Vila Indiana, região do bairro do Butantã vizinha da Cidade Universitária e do Instituto.

Número de pavimentos: Edifício elevado do solo com 2 pavimentos.

Sistema construtivo: Estrutura em concreto armado protendido e cobertura formada por abóbadas.

Comentários: O edifício segue o modelo de pavilhões expansíveis, interligados por um eixo de circulação, comum aos projetos feitos para o Instituto Butantan neste período. Destacam-se as lajes formadas por um sistema de abóbodas e a existência de um outro projeto que parece se tratar de uma proposta para a expansão do núcleo inicial de biotérios.

72 O nome de Abelardo de Souza aparece em destaque nas pranchas de projeto dos Biotérios, indicando-o como autor principal.

73 O biotério previsto no plano de 1961 está em uma localização diferente e corresponde a outro projeto. 


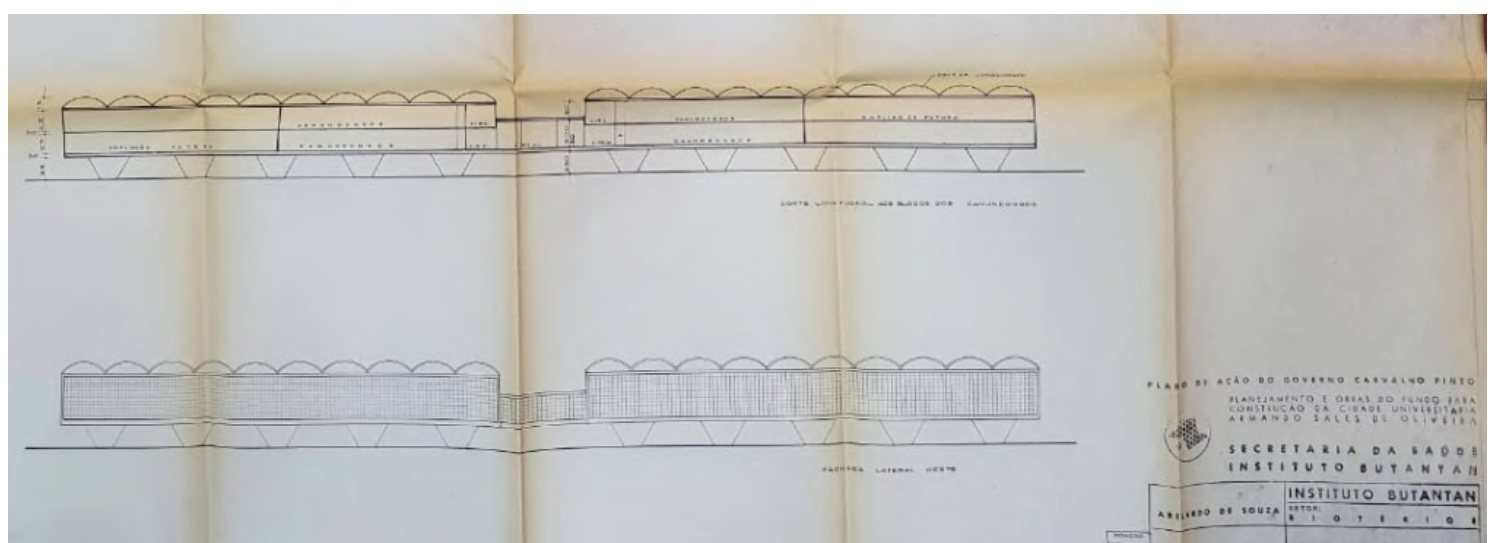

Figura 71: Corte e elevação do Biotério, 1962. Fonte: Fl.22-Biotério- Cortes e Fachadas, Biblioteca FAUUSP.

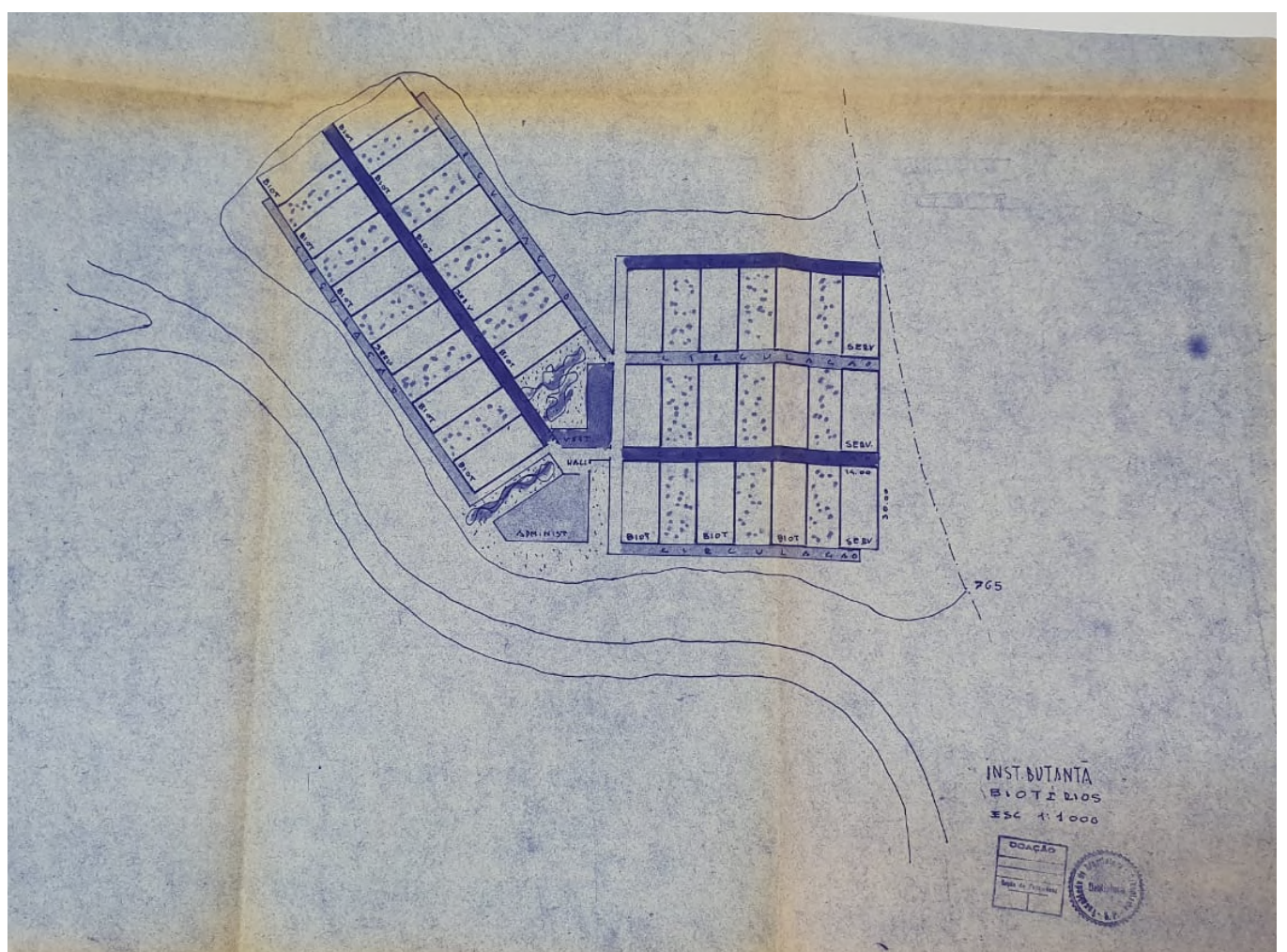

Figura 72: Variação ou plano de expansão do conjunto dos Biotérios, 1962 ou 1963. Fonte: Fl.23Biotério - Planta, Biblioteca FAUUSP. 
2.4. A dimensão espacial do planejamento: os edifícios modernos e a sua inserção nos planos urbanísticos

O processo de identificação e organização destes projetos, nos forneceu uma visão mais apurada sobre o conjunto dos materiais pesquisados, quanto ao volume de trabalhos elaborados no período, à atuação dos arquitetos e de outros profissionais e, sobretudo, da dimensão do Plano de Ação e de seu impacto para o Instituto Butantan nestes primeiros anos da década de 1960. Isto nos permite direcionar a análise destes projetos e avaliar o campo das relações políticas e institucionais no qual o planejamento está inserido, assim como, avaliar a espacialidade e a escala destas estruturas modernas no território.

No que se refere à dimensão destas arquiteturas, analisadas individualmente, é interessante notar o vigoroso ímpeto transformador que estes projetos carregavam, a ponto dos edifícios históricos e preexistentes nem sempre representarem um obstáculo aos novos planos. Os desenhos e documentos do período parecem deixar evidente que a arquitetura moderna era, tanto para os diretores, quanto para os arquitetos, principalmente para estes, algo indiscutível. Assim, para a direção, o impulso moderno era uma oportunidade de expansão, almejando corresponder à reputação internacional do Instituto de saúde e pesquisa. Aos arquitetos, a realização do plano moderno correspondia à construção do país pela arquitetura e, para os mais politicamente engajados, à construção dos espaços de uma nova sociedade brasileira. O moderno condizia com todas estas expectativas e, definitivamente, não estava em discussão, como salientou Plínio de Arruda Sampaio:

[...] Mas era óbvio que tinha que ser moderno, nem se discutia, era uma coisa de senso comum. Era tão hegemônica a idéia e eles todos eram ligados a isso, tinham acabado de sair da arquitetura. Eram todos alunos do Artigas, desse pessoal "craque". Eu me lembro que todo mundo achava muito bonito, nos recebemos muitos elogios. Os prefeitos ficavam contentes, tinha maquete que era bonita. Então eu recebia muitos telegramas, muito obrigado e "tal". (CORDIDO, 2007, p.308).

Se integralmente realizado, o plano poderia ter construído um Instituto muito diferente do que se conhece atualmente, marcado pela paisagem tradicional de seus 
edifícios históricos. Em oposição a este conjunto, os projetos do Plano de Ação conformariam uma paisagem radicalmente diferente talvez somente próxima da paisagem moderna da Cidade Universitária da USP. Neste sentido, compreender estes projetos de forma conjunta, passa por concebê-los como paisagem e como um fragmento do território, inserido na cidade de uma forma completamente diferente da atual.

É visível, nos planos e estudos elaborados entre 1959 e 1966, um momento de euforia com a modernização, seguido de uma certa acomodação destes projetos aos anseios de conservação do conjunto do Instituto Butantan. A partir de 1965 há um arrefecimento das propostas radicais e modernizantes de 1961 e 1963, no que parece um movimento conciliatório entre as intenções colocadas pela arquitetura e pela direção do Instituto. ${ }^{74}$ Neste sentido, as últimas propostas caminham para uma maior preservação do conjunto de edifícios existentes.

O plano de 1961, de Leo Quanji Nishikawa e Sergio Atrigliano, estabelecido por um concurso, apresenta os pressupostos de modernização que serão consolidados no plano de 1963. Este, por sua vez, propõe a demolição de estruturas existentes conciliando-as com a manutenção de alguns edifícios considerados de importância histórica ou relevantes para o funcionamento do Instituto.

Discutiremos estas questões referentes aos planos urbanísticos mais adiante, no item 2.5 deste capítulo. Por enquanto, nos interessa dar forma a estes projetos não construídos, propondo um exercício de imaginação. Assim, optamos por situar estes projetos no plano de 1963, construindo um modelo digital do plano. Identificados os projetos do acervo, este modelo nos permite dar forma e discutir os aspectos urbanos do plano, entendendo os edifícios como conjunto e antecipando a análise individual dos projetos no item $\mathbf{2 . 5}$.

74 Embora mais visíveis por parte dos arquitetos, através dos desenhos e do ambiente de entusiasmo da arquitetura brasileira nas décadas de 1950 e 1960, estas intenções são menos evidentes por parte da direção do Instituto, cuja manifestação quanto aos projetos aparece, somente, por meio de documentos oficiais. Os elogios ao Plano de Carvalho Pinto e ao Governo do Estado de São Paulo nos documentos assinados pelo diretor Flávio Ribeiro da Fonseca em 1959, dão lugar à preocupação com o andamento dos projetos e com a expansão da Cidade Universitária. 


\subsubsection{Planejamento moderno e Instituto tradicional}

Tanto os projetos para edifícios quanto os planos urbanísticos desenvolvidos para o Instituto Butantan entre 1960 e 1963, colocavam em pauta a necessidade de uma unidade no planejamento do campus de pesquisa, que regulasse o seu crescimento de acordo com os seus setores de atividade. Esta intenção, no entanto, não foi inaugurada com o PAGE, mas constituía um desejo antigo, percebido pelos seus administradores com a consolidação do Instituto e manifestado, pelo menos, desde a década de 1950 quando, na direção de Luiz Augusto Ribeiro do Valle ganha força a ideia de se produzir um plano diretor (Relatório Anual IBu, 1960-1961, fl.02). Tal intenção será viabilizada a partir do modelo estabelecido para a construção da Cidade Universitária: eminentemente moderno, funcional e de arquitetura avançada, como a nova capital brasileira que era inaugurada em 1960.

Três episódios aqui tratados são importantes para esta mudança de orientação do planejamento: 1953, quando Carlos Lemos, arquiteto e professor da FAU USP a partir do ano seguinte, inicia os primeiros estudos sobre o conjunto do Instituto para a elaboração de um plano; 1959, ano em que o arquiteto Politécnico Rubens Carneiro Vianna elabora um programa de necessidades e que será, em 1961, adotado como base do concurso de projetos para a elaboração de um plano urbanístico. O resultado deste concurso, já sob o planejamento do Plano de Ação e em cooperação com o FCCUASO, é a formulação de um plano que integra o Instituto Butantan à Cidade Universitária, inserido-o no setor 10 do campus da USP.

Existem poucos documentos que discorrem sobre aspectos mais específicos deste concurso, como ata, composição do juri, equipes participantes e projetos submetidos. Sabemos que a primeira versão do plano escolhido em 1961, para o setor 10, era de autoria da dupla de arquitetos Leo Quanji Nishikawa e Sergio Atrigliano. Estes arquitetos não constam na lista de contratação do PAGE, segundo levantamento feito por Miguel Buzzar (2015, p. 89), tratando-se, provavelmente, de profissionais contratados externamente por meio de sua participação no concurso, já que não compunham o corpo de servidores do FCCUASO. Esta situação era comum durante o 
planejamento da Cidade Universitária, embora os servidores pertencentes ao corpo técnico do órgão tenham desenvolvido a maior parte dos projetos executados (SÁ, 2019, p.65).

Os primeiros edifícios projetados no plano de 1961, implantados nos setores 7 e 10 da Cidade Universitária, correspondentes ao Setor Biológico e ao Instituto Butantan, foram projetados por um grupo de profissionais vinculados ao corpo técnico do FCCUASO. Os projetos para o Butantan, ficaram a cargo dos arquitetos Jorge Wilheim, formado na década de 1950 no Mackenzie e que havia participado do concurso para o Plano Piloto de Brasília em 1956; Maurício Tuck Schneider, o arquiteto Politécnico Rubens Carneiro Vianna e Mário Rosa Soares, formado no Mackenzie em 1960 e que atuou em diversos projetos para a Cidade Universitária sob o FCCUASO. ${ }^{75}$

A partir de 1962, um segundo grupo de arquitetos passa a projetar os demais edifícios do plano de 1961. Ao arquiteto Leo Quanji Nishikawa, estudante da FAU USP nos anos 1950 e um dos autores do primeiro plano, se somam Abelardo de Souza, arquiteto formado na Escola Nacional de Belas Artes no Rio de Janeiro em 1932 e um dos autores do Edifício do IAB de São Paulo; João Carlos Bross, arquiteto carioca formado em 1956 no Mackenzie; Jacob Goldemberg, também carioca e formado em 1960 pela Faculdade Nacional de Arquitetura do Rio de Janeiro; Luiz Contrucci, engenheiro arquiteto Politécnico, formado em 1950; e a arquiteta paisagista Miranda Magnoli que, em 1964, ingressaria na FAU USP como professora auxiliar de Abelardo de Souza.

Estes profissionais vão elaborar os edifícios que não haviam sido contemplados em 1961, ajudando a constituir o Plano de 1963 para o Instituto Butantan. Do primeiro para o segundo plano, são mantidos o Edifício de Pesquisa, o Edifício de Vírus e Genética, e o Prédio da Biblioteca e Auditórios. Assim, com exceção do Conjunto Residencial, de Mario Rosa Soares, todos os outros edifícios do Plano de 1963 são projetados por arquitetos deste segundo grupo.

75 A partir da experiência atuando na USP, Mario Rosa Soares também trabalhou em planos para outras Universidades no país, sendo responsável pelo Plano da Universidade Federal da Paraíba em João Pessoa. 


\section{Capítulo 2. Plano de Ação}

Estes planos para a renovação do Instituto constituíam propostas notáveis, principalmente os de 1961 e 1963, que se complementavam. A importância dada à monumentalização dos espaços, presente nas perspectivas dos principais eixos, nos monumentos e na formulação de espaços cívicos, no uso sofisticado da declividade do terreno, afirmava uma preocupação com a necessidade que se impunha naqueles anos de a arquitetura comunicar certos elementos que remetiam a uma sociedade em acentuado processo de desenvolvimento, na qual se projetava a "possibilidade de construir outro país" (MARTINS, 2010, p.162). Em Brasília, estes elementos evocavam o caráter nacional, o espírito cívico e democrático; no Instituto Butantan e na Universidade de São Paulo a arquitetura exprimia, ao mesmo tempo, o desejo de se desenhar espaços para uma nova sociedade, como pretendiam os arquitetos mais engajados, e a demonstração do poder simbólico do estado modernizador e de suas instituições públicas.

Contemplados, em maior ou menor medida, por grande parte dos projetos desenvolvidos neste período através do Plano de Ação, estes aspectos aparecem de forma central no Plano de 1961, mas estavam limitados pela existência do conjunto arquitetônico tradicional do Instituto. O plano moderno por excelência, que partia do planejamento total e que se verificava na construção da Cidade Universitária, se projetava ao Instituto estabelecendo uma relação conflituosa, na qual o existente deveria ceder espaço ao moderno. Desta forma, a proposta do plano consistia na demolição de todo o conjunto arquitetônico composto por edifícios históricos e construídos nas primeiras décadas da Instituição, preservando somente um único edifício: o prédio da cocheira construído na década de 1910 pelo engenheiro arquiteto Mauro Álvaro, que seria preservado e destinado ao museu histórico. A proposta de "tábula rasa" é amenizada no plano de 1963, com a preservação de alguns edifícios existentes. 


\subsubsection{Representação do Plano de 1963: contraste entre os novos e antigos edifícios}

O plano de 1963 é o resultado de praticamente uma década de esforços dos profissionais atuantes na instituição em produzir um plano para a organização do Instituto. Partia da demanda de preservação do núcleo original em coexistência com a necessidade de se planejar novos espaços para o desenvolvimento das atividades científicas e de produção. Este aspecto é relatado nos documentos institucionais do período, que discorrem sobre o desenvolvimento do plano diretor sob a atuação do arquiteto Rubens Carneiro Vianna, a partir de 1959:

Nesta ocasião, baseado no Plano Diretor, o Arquiteto Rubens Gouveia Carneiro Vianna começou a planejar os edifícios que a atual Diretoria julgava necessários. Esta última orientação estava ligada à determinação governamental de realizar, dentro do Plano de Ação do Govêrno, uma série de obras que redundariam na transformação total do Instituto Butantan, ao mesmo tempo que se aproveitariam os edifícios com valor técnico ou histórico indiscutível. (Relatório Anual IBu, 1961, fl.02)

O trabalho do arquiteto Carlos Alberto Cerqueira Lemos a partir de 1953, seguido do arquiteto Rubens Carneiro Vianna em 1959, durante a diretoria de Flávio da Fonseca, já apresentam a condição de preservação dos edifícios históricos. Neste sentido, esta intenção é enfatizada no convênio com o Fundo de Construção da Cidade Universitária, firmado em 7 de Julho de 1961, no qual ficam expostas as condições para o planejamento conjunto e a integração do Instituto ao campus da USP.

As condições da assinatura do convênio manifestavam a apreensão por parte do Instituto quanto à concessão do planejamento aos profissionais responsáveis pelas obras executadas na USP. Sobretudo, a direção de Flávio da Fonseca, exprimia a sua preocupação quanto a espoliação da área do Instituto, que passava a ser enquadrado no plano urbanístico e na paisagem da Cidade Universitária.

Receiosa de que o entrosamento no Plano para Construção da Cidade Universitária viesse a redundar em cessão,- pelo Instituto Butantan, de área ainda maior à Cidade Universitária, a atual Diretoria do Instituto fêz ênfase, em reuniões e representações, na necessidade de não mais ser o Instituto espoliado em sua propriedade, já tornada pequena pela mutilação até então sofrida. (Relatório Anual IBu, 1961, fl.04) 


\section{Capítulo 2. Plano de Ação}

Evidente que a "mutilação", referida pelo diretor, se trata do decreto de 1941, que resultou na cessão da maior parte do território da Fazenda Butantan para a instalação do campus da USP, fundada sete anos antes. A despeito dos esforços manifestados pelos dirigentes do Instituto Butantan em manter a sua autonomia territorial e institucional, assim como de preservação de parte de seus edifícios históricos, o Plano de 1963 vem reafirmar a transformação da paisagem do Instituto.

Em fevereiro de 1963, no mesmo mês em que Aristides Vallejo-Freire assume a direção do Instituto, é apresentado um relatório geral do FCCUASO para o Butantan. O relatório aponta revisões feitas em relação ao "1a esquema geral" a partir de novos estudos, que resultaram no plano definitivo (Relatório Geral FCCUASO, 1963). Segundo o documento, os estudos almejaram dar uma maior individualidade ao Instituto prevendo, inclusive, a manutenção de alguns dos edifícios existentes.

De todo modo, apesar das revisões feitas pelos profissionais do FCCUASO, que amenizaram a tábula rasa moderna de 1961 ao manter um maior número de edifícios, o Plano de 1963 conforma uma situação inusitada: os novos edifícios não parecem coexistir de forma harmoniosa com os prédios históricos, mas os contrapõe pela escala discrepante. Assim, grandes edifícios formados por torres e extensos pavilhões são implantados em posições muito próximas aos prédios históricos, estabelecendo uma relação um tanto conflituosa e que, em alguns momentos, chega a se sobrepor aos edifícios existentes.

Não parece haver um estudo para a preservação do conjunto existente, apenas são dispostos os novos edifícios de modo a evitar a demolição dos edifícios históricos. O modelo isométrico das páginas 168 e 169, que representa o conjunto projetado em 1963, demonstra a inversão posta pelos edifícios modernos, que parecem diminuir a imponência do conjunto original, ao qual é reservado o lugar de fragmento histórico da tradicional instituição transformada em um centro de pesquisa moderno. 


\section{Os edifícios do Plano de 1963}

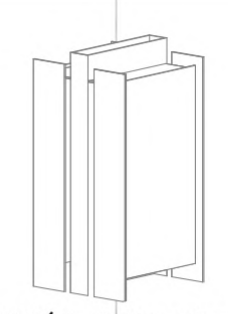

Edifício de Pesquisa

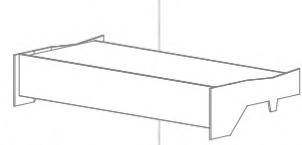

Edifício de Vírus e Gnética

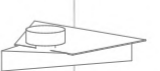

Biblioteca e Auditório

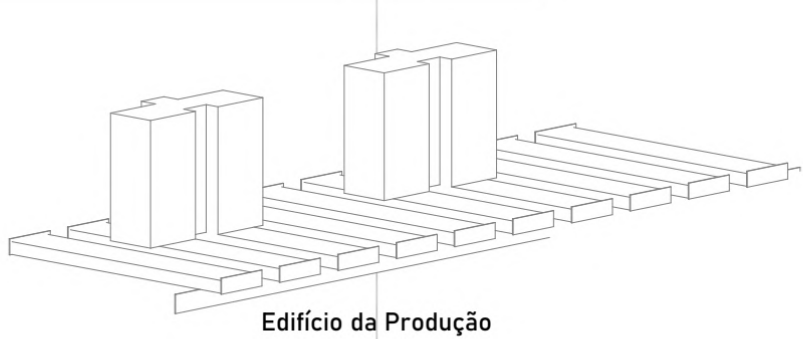

Edifício da Produção

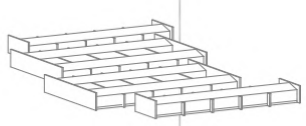

Conjunto Residencial

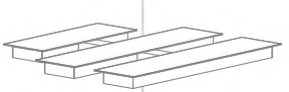

Hospital

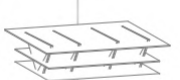

Restaurante

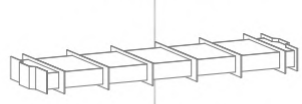

Prédio da Administração

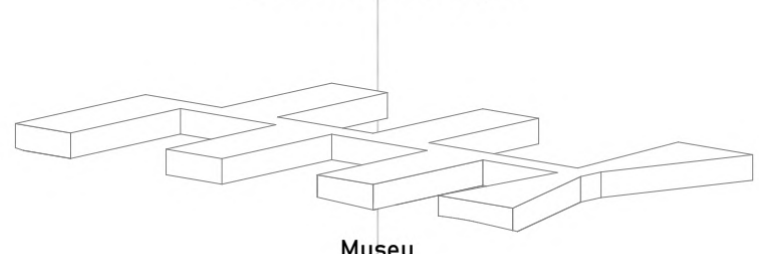

Museu

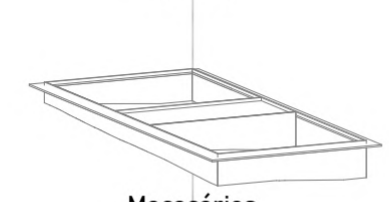

Macacários

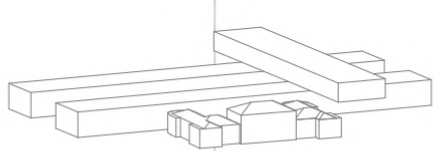

Pavilhão de Serviços

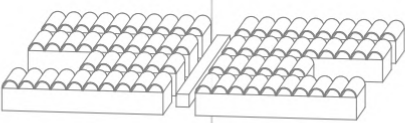

Biotérios 


\section{Os edifícios projetados no Plano de $1963^{76}$}

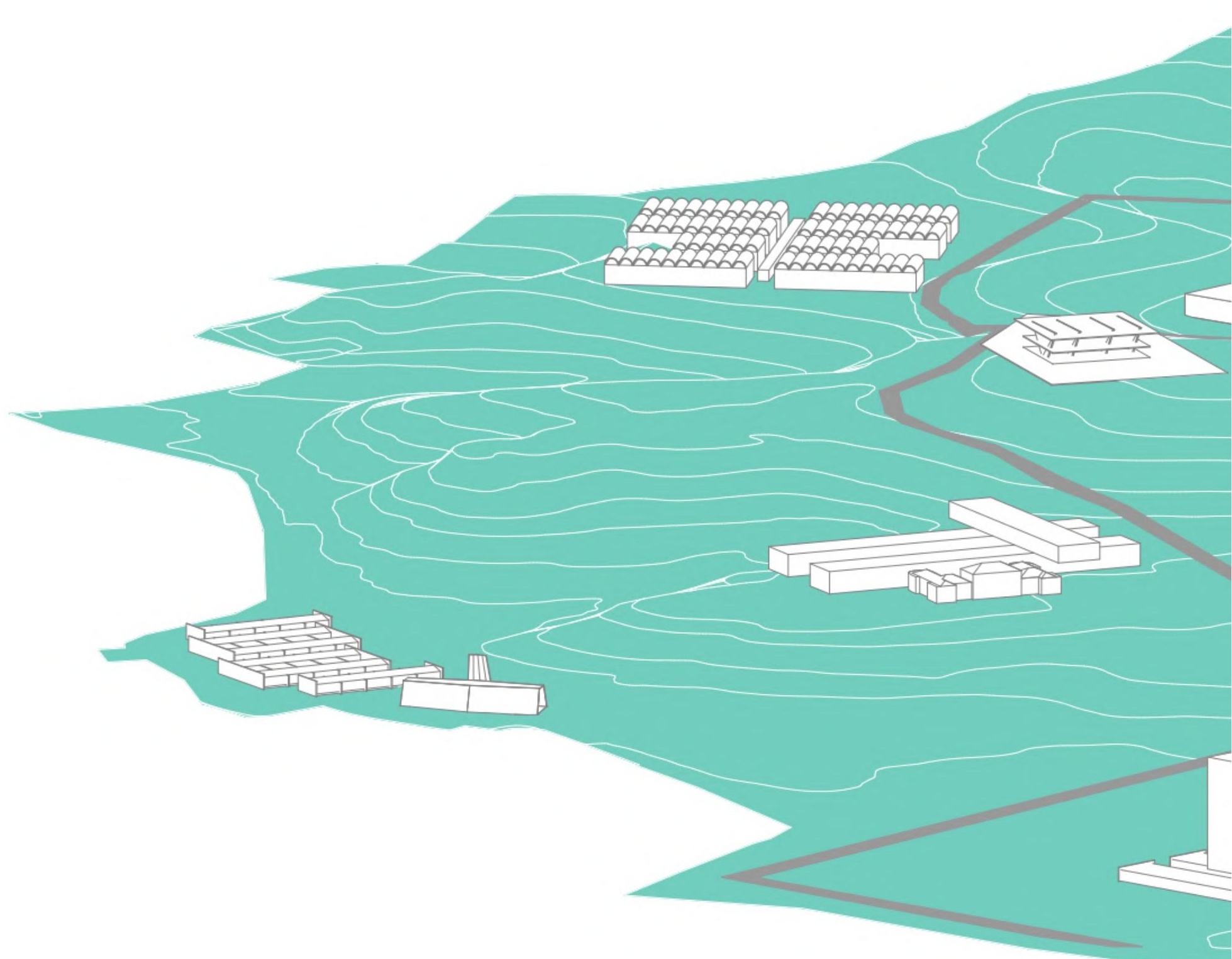

76 O Plano de 1963 não deixa claro quais edifícios históricos seriam preservados, embora alguns deles estejam representados, como o Edifício Vital Brazil (1914), o Prédio Novo (1945) e o Pavilhão Lemos Monteiro (1920), que podem ser vistos nesta perspectiva isométrica. Fonte: desenho do nosso. 


\subsection{Análise de alguns dos projetos do PAGE para o Instituto}

\subsubsection{Planos urbanísticos e de ocupação ${ }^{77}$}

Entre o primeiro ano do Plano de Ação, em 1959, até 1966, são desenvolvidos para o Instituto Butantan, ao menos, 4 planos urbanísticos distintos, por meio dos profissionais contratados pelo Fundo de Construção da Cidade Universitária. Do primeiro ao último plano se desenha um processo de aumento das intenções transformadoras e de modernização do Instituto ao ritmo dos projetos para o campus da USP, cujo ápice é o concurso de 1961. A partir desta data, quando é formalizado o convênio entre as duas instituições, as propostas de modernização total começam a perder força, até atingirem um modelo de conciliação com as intenções de autonomia e de preservação dos edifícios históricos por parte da direção do Instituto.

\section{Estudos de 1959 de Rubens Carneiro Vianna}

Inaugurado pelo Plano de Ação e iniciado antes do convênio de 1961, o plano de 1959 lança as tentativas de adequação das instalações do Instituto Butantan ensaiadas por toda a década de 1950 e finalmente viabilizadas no Governo de Carvalho Pinto. Embora fossem urgentes as necessidades de formulação de um plano diretor para a regulação do campus e a construção de novos edifícios para a ampliação da estrutura física, o estudo elaborado pelo arquiteto Politécnico Rubens Carneiro Vianna ainda é bastante insipiente. Limita-se a um croqui com a situação dos edifícios e vias existentes e com a implantação dos novos edifícios a serem construídos, além de alterações viárias pontuais.

Próximos ao núcleo original do Instituto Butantan, no entorno do eixo principal do campus que liga o Edifício Vital Brazil à Casa Vital Brazil, antiga sede da Fazenda Butantã e atual Rua Roberto Kok, são dispostos os novos edifícios de pesquisa, produção e dos biotérios. O conjunto de residências, outra demanda antiga da instituição, está implantado no vértice formado pela Avenida da Universidade e a linha

77 Para mais informações sobre os documentos referentes aos projetos, consultar a ficha 09 do inventário (subcapítulo 2.3). 
adutora de Cotia, onde hoje se encontra a Avenida Lineu Prestes. No plano não são indicadas demolições, apenas o levantamento das edificações existentes e a serem construídas.

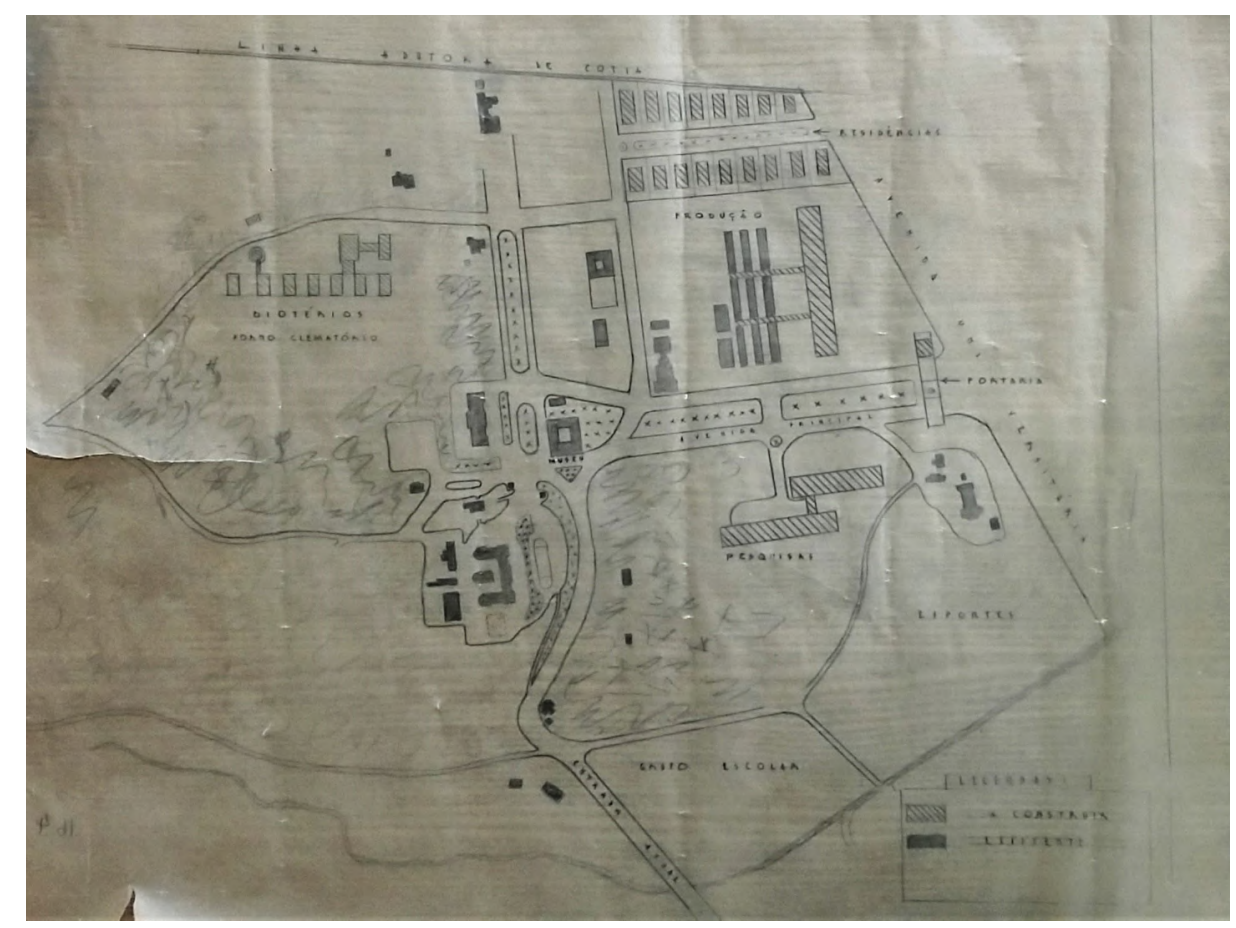

Figura 73: Estudo do arquiteto Rubens Carneiro Vianna para o Instituto Butantan, 1959. Fonte: prancha 16.04, Centro de Memória/IB.

As intervenções propostas pelo estudo do arquiteto Rubens Carneiro Vianna, não chegam a interferir radicalmente no conjunto arquitetônico existente e mantêm a conformação do nucelo original com pequenas alterações viárias e com a indicação dos novos edifícios a serem projetados. A transformação mais significativa é definida pelos novos acessos ao Instituto Butantan. Duas novas vias são projetadas a partir da Avenida da Universidade: uma para o acesso ao conjunto de residências e outra para a entrada principal do Instituto. Esta conforma uma avenida situada no eixo do prédio da cocheira e atual Museu Biológico, na posição onde hoje está a Rua Emílio Ribas, e se conectando com o eixo principal do campus.

No mais, a proposta elaborada por Rubens Carneiro Vianna, parece buscar uma harmonização entre o conjunto de edifícios existentes, compreendidos pela sua importância histórica para a Instituição, com o conjunto de novos edifícios modernos 
demandados pelos pesquisadores, diretores e pela comunidade científica de modo geral, com a qual o arquiteto estabeleceu alguma proximidade durante a elaboração dos estudos para os laboratórios do Butantan no mesmo ano. A manutenção do conjunto existente mantém as edificações concentradas na porção noroeste da área do Instituto e, ao mesmo tempo, as vias e a localização dos novos edifícios projetados propõem uma maior integração e abertura para a Cidade Universitária em início de construção.

\section{Plano de 1961: "tábula rasa" e monumentalidade modernas}

Como vimos anteriormente, o plano urbanístico elaborado pela dupla de arquitetos Leo Quanji Nishikwa e Sergio Atrigliano é resultado de um concurso de projetos para o Plano Geral do Instituto Butantan que, após dois anos de Plano de Ação, era o único setor correspondente ao planejamento da Cidade Universitária que ainda carecia de um plano definido (Figura 74). O plano definido por concurso público, foi estabelecido pelas diretrizes e levantamentos feitos desde 1953 e consolidados em 1959 na atuação do arquiteto Rubens Carneiro Vianna, em contato direto com os cientistas e pesquisadores do Instituto.

As diretrizes do concurso definiram o seguinte programa: zonas destinadas aos setores referentes às atividades de administração, oficinas, biotério, produção industrial, pesquisa, biblioteca e auditório, turismo e residencial. A antiga cavalariça/ cocheira, atual Museu Biológico, deveria ser mantida e reformada para abrigar o museu do Instituto, assim como deveriam ser mantidos, sempre que possível, a paisagem conformada pela topografia e vegetação originais (Relatório Anual IBu, 1961, fl.02-03).

De fato, estas condições previamente colocadas foram as únicas preservadas no plano proposto. Os demais elementos existentes foram repensados e substituídos por estruturas modernas, contendo grandes edifícios de arquitetura arrojada, aos moldes do planejamento da Cidade Universitária. 


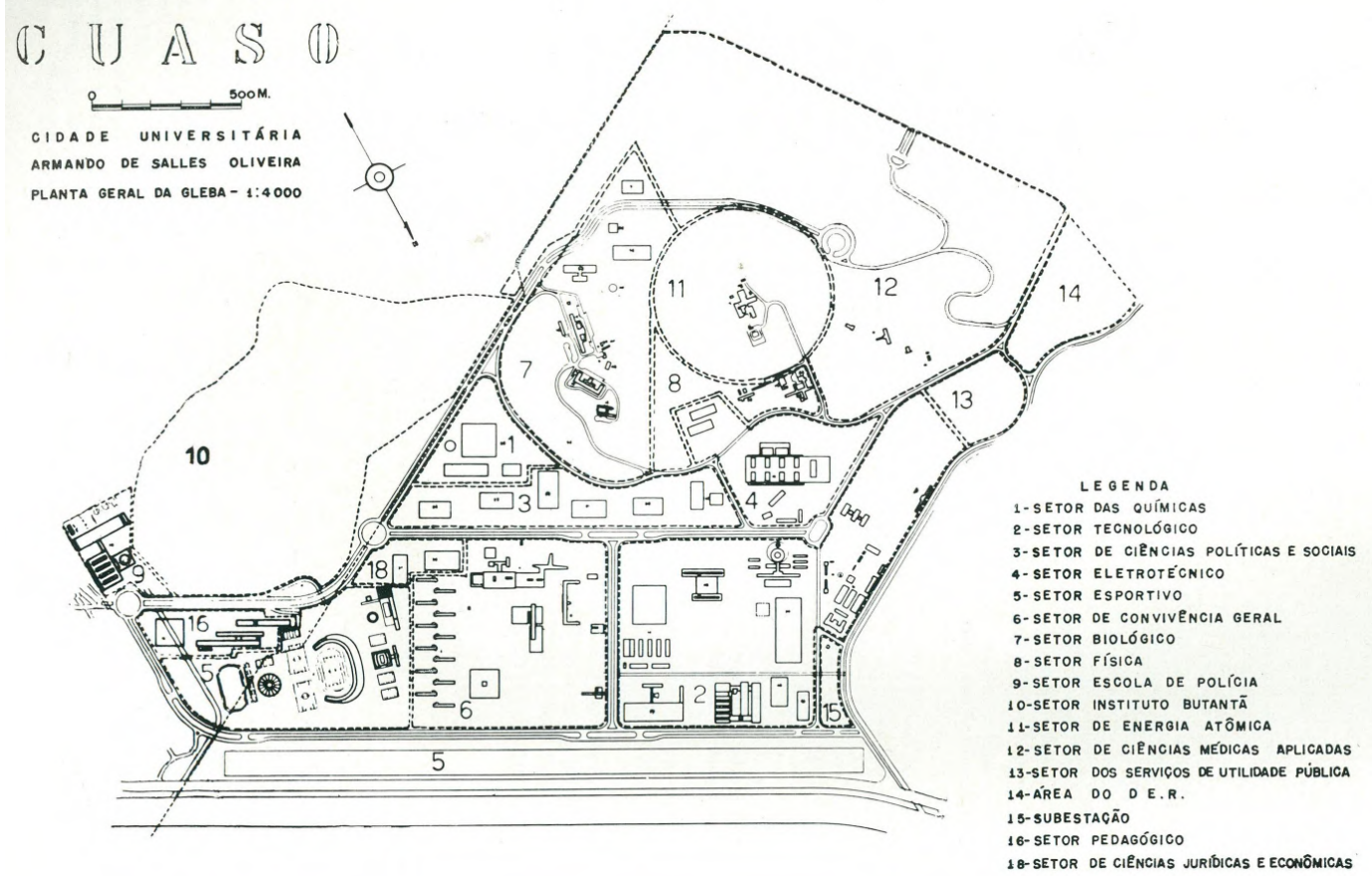

Figura 74: No Plano Geral da Cidade Universitária da USP, publicado pela Revista América em 1962, o Setor do Instituto Butantan é o único que ainda não está definido. Fonte: Revista América, ano 7, no2, 1962, sem página.

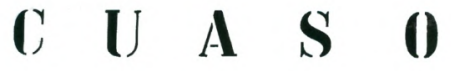

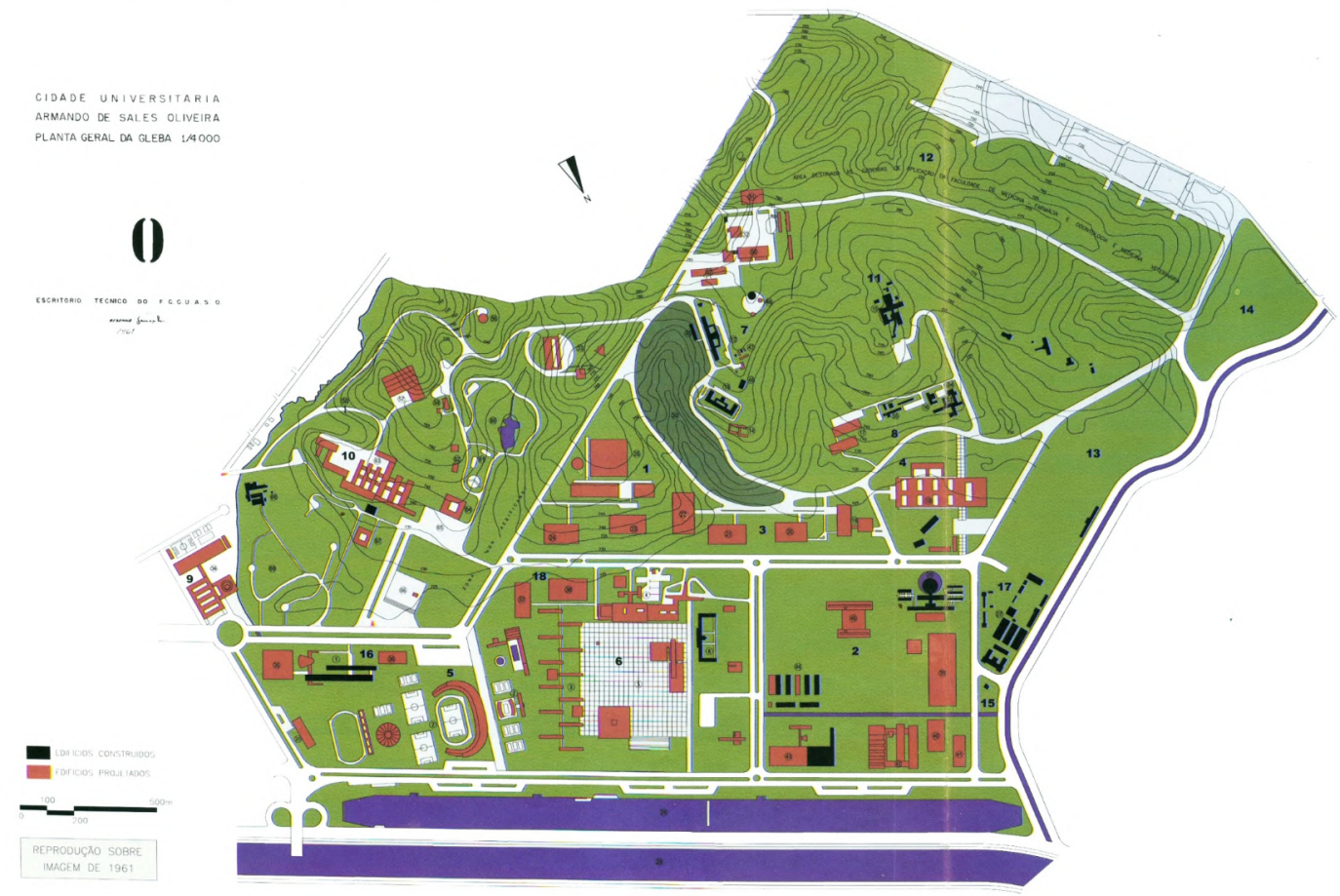

Figura 75: Plano de implantação da Cidade Universitária de 1961, no setor 10 se encontra o Instituto Butantan. Fonte: SEF/USP. 
$\mathrm{Na}$ enorme prancha do projeto são elencadas as condições do conjunto existente, mencionando a falta de uma definição das funções, apresentando edifícios com usos diferentes concentrados em uma área central, cuja circulação é confusa e pouco funcional (Figura 76). Em seguida, são apontadas as deficiências do conjunto existente, composto por "instalações materiais deficientes de valor artístico-cultural discutível" e limitados do potencial paisagístico da área. Por fim, as habitações estão dispersas pela terreno e careciam de requisitos mínimos de higiene (Centro de Memória, prancha 40.11).

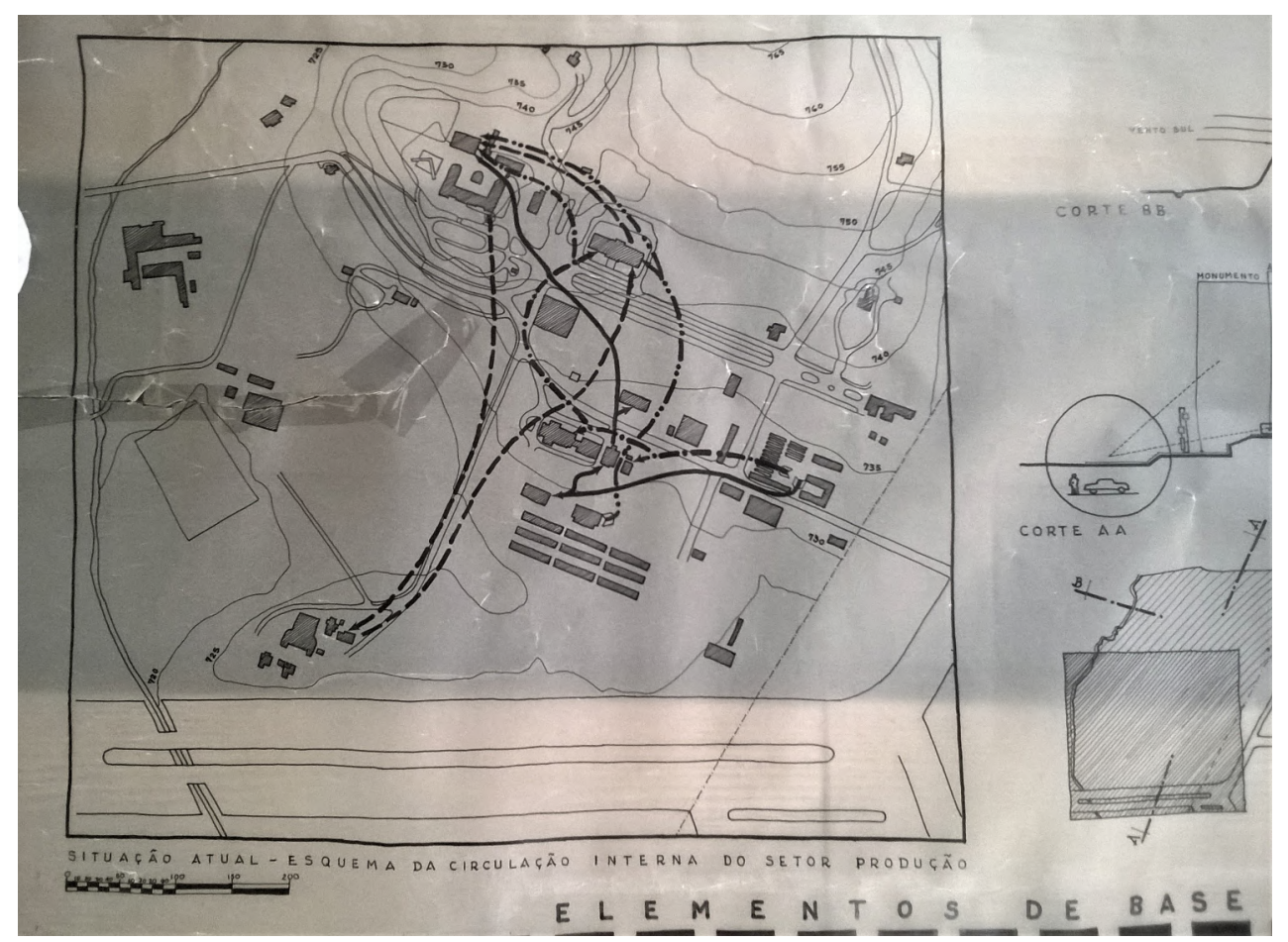

Figura 76: Estudo da situação existente do conjunto do Instituto, no qual predomina uma circulação pouco funcional ou organizada, dada pela heterogeneidade do conjunto, 1962.

Fonte: prancha 40.11, Centro de Memória/IB.

Amparados pela análise da situação do conjunto, os arquitetos propõem a dispersão dos edifícios pelo território segundo suas características funcionais. Neste sentido, pela necessidade de acesso controlado, o conjunto da produção e biotérios é situado na porção mais ao sul do território, próximo ao limite com a Avenida Corifeu de Azevedo Marques. Ao edifício da produção é conferido um caráter simbólico: pela sua dimensão e posição, o prédio se aproxima da região central do campus em um 
ponto de destaque, onde se situa o histórico Edifício Vital Brazil que, consequentemente, seria demolido.

Na porção mais ao leste, próximo ao setor 7, ou Setor Biológico da Cidade Universitária, no limite com a Avenida Lineu Prestes, está a esplanada do conjunto de pesquisa, onde se encontram os edifícios de Vírus e Genética, de Pesquisa e o Prédio da Biblioteca e Auditórios. Na região central, substituindo os principais edifícios existentes e mantendo o edifício destinado ao museu, estaria o setor administrativo e de turismo, onde se encontra uma praça e um grande eixo monumental de acesso ao Instituto (Figura 77).

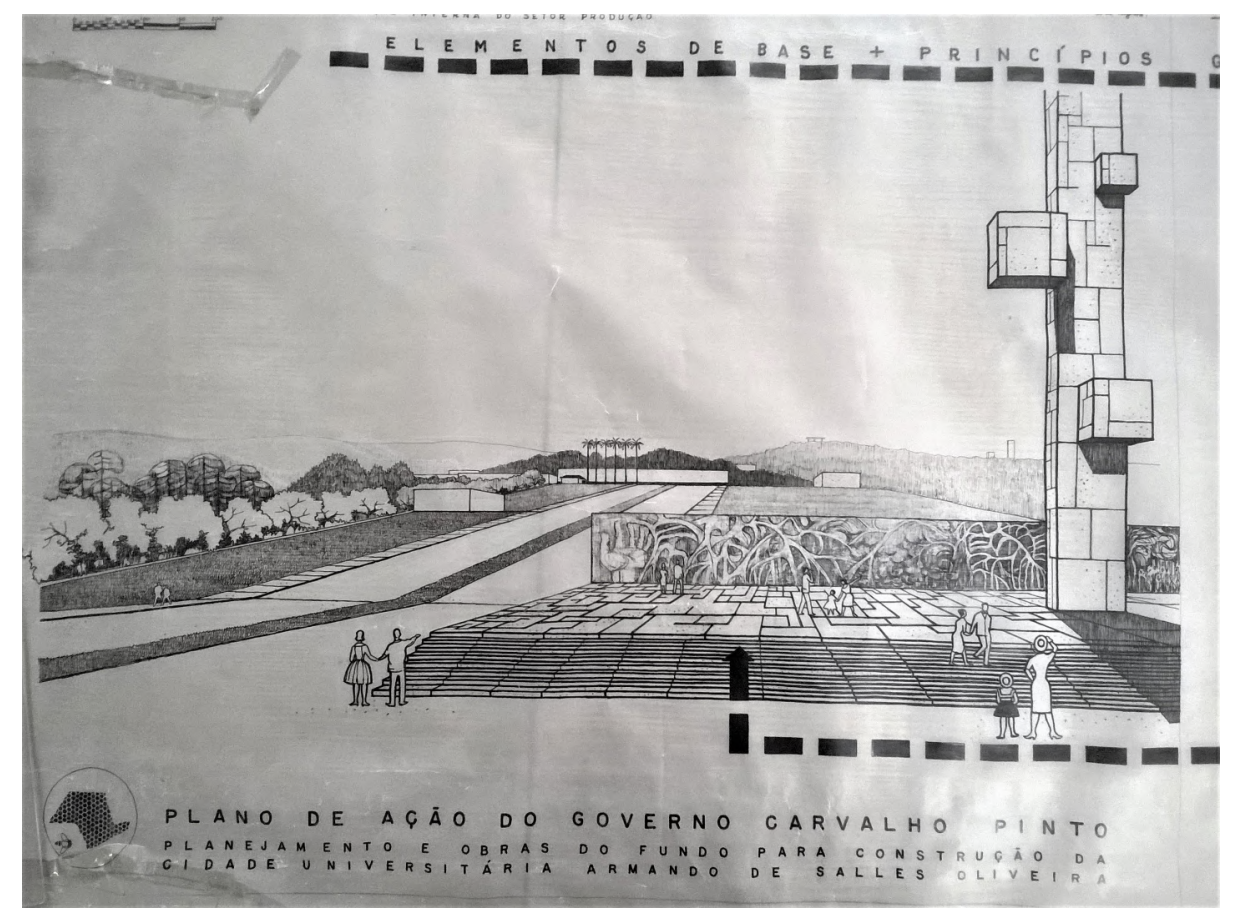

Figura 77: Perspectiva da praça monumental localizada no acesso principal ao Instituto Butantan pela Cidade Universitária, 1961. Fonte: prancha 40.11, Centro de Memória/IB.

Deste modo, o Instituto se integrava de forma definitiva à Cidade Universitária, a partir de uma ocupação menos concentrada e da ampliação do setor de turismo por boa parte do espaço existente. As vias e acessos passavam a ser mais bem definidos, sendo o acesso público voltado para o núcleo central da Cidade Universitária, onde estão o Centro de Práticas Esportivas, o Conjunto Residencial, a Praça Cívica e o 
chamado Corredor das Humanas, eixo articulador do campus da Universidade de São Paulo.

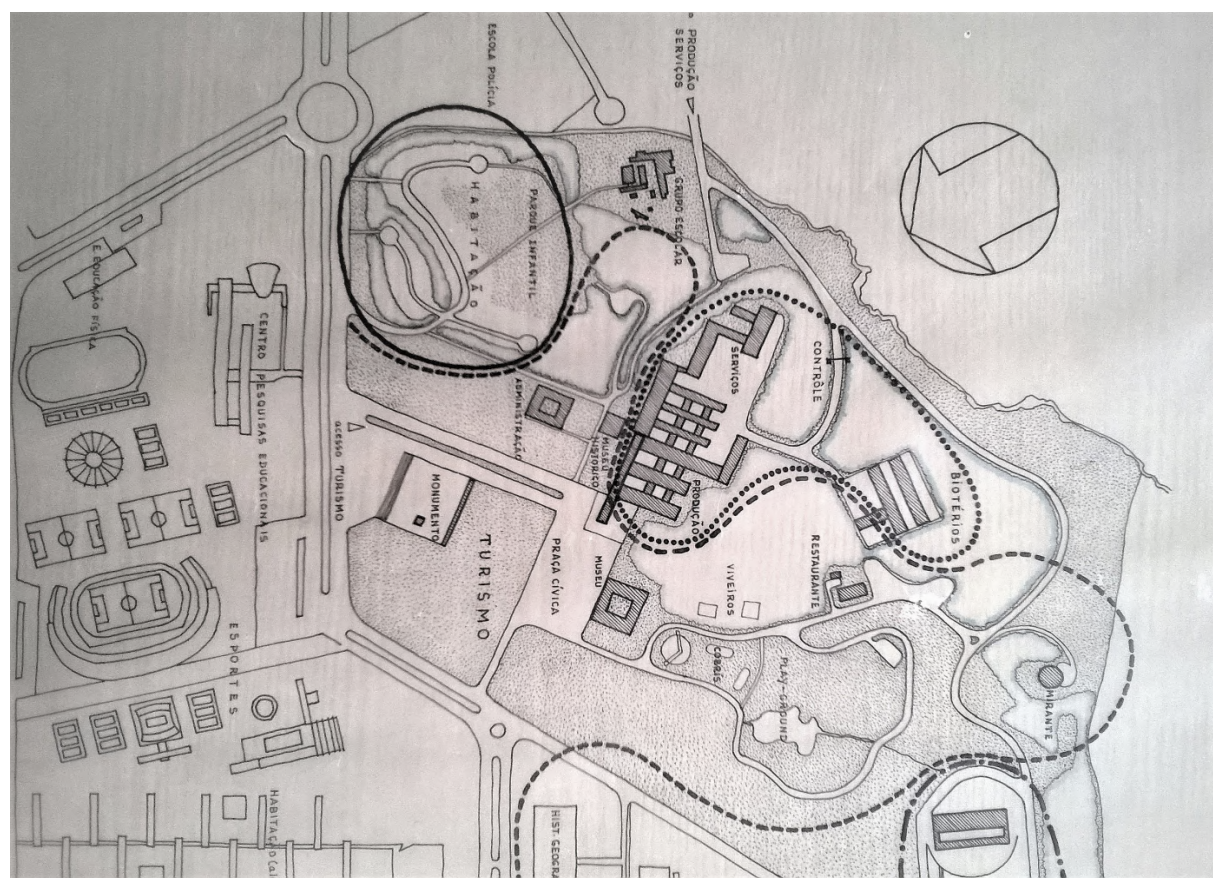

Figura 78: Detalhe da prancha contendo o plano geral do Instituto Butantan no Plano da Cidade Universitária, proposto em concurso pelos arquitetos Leo Quanji Nishikawa e Sergio Atrigliano em 1961. As linhas contínuas e tracejadas demarcam os espaços restritos ou permeáveis, onde o setor de turismo é pensado como parte da área de convivência da Cidade Universitária. Fonte: prancha 40.11, Centro de Memória/IB.

A característica que parece ser determinante neste plano é a da integração paisagística com o campus da USP, na qual a única delimitação é dada por elementos simbólicos, como o monumento e a conformação do paisagismo. Deste modo, a área delimitada pelas avenidas que separam o campus do Butantan da Universidade é reservada, fundamentalmente, para o setor de turismo e de pesquisa, dotados de importância simbólica e monumental, pela característica dos seus edifícios e sua localização. O primeiro abriga uma praça cívica e uma praça monumental, o segundo é formado por uma esplanada que estabelece uma relação direta com o setor biológico universitário. Na entrada da Universidade, pelo atual portão 1, é situado o conjunto residencial do Instituto, pela facilidade de acesso ao bairro. 


\section{Plano de 1963: reconciliação com o conjunto histórico}

Com a assinatura do convênio com o FCCUASO em 1961, no qual a direção do Butantan manifesta as condições de preservação do seu território, fica a cargo dos profissionais do escritório técnico da Universidade a reformulação do plano anterior e o desenvolvimento dos edifícios ainda não projetados. O modelo isométrico, reproduzido nas páginas 168 e 169 desta dissertação, exemplifica a espacialidade do novo plano que apresenta a arquitetura dos edifícios em estágio avançado de desenvolvimento, enquanto o plano anterior definia apenas os prédios do setor de pesquisas, projetados em 1961.

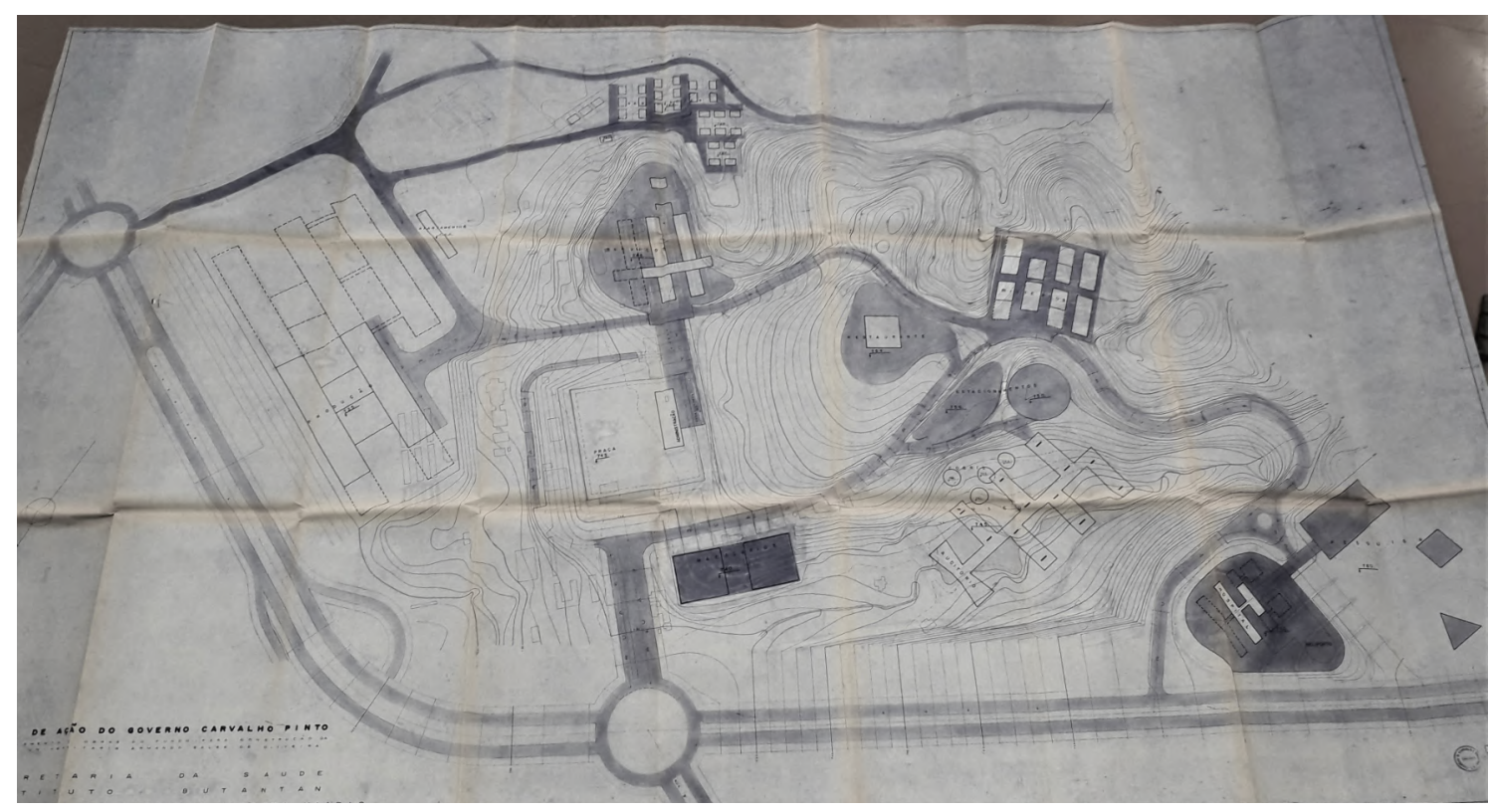

Figura 79: Plano de 1963 para o Instituto Butantan. As avenidas a esquerda e na parte inferior do desenho delimitam a Cidade Universitária. Fonte: Fl.88 A 90-Plano Geral- Zoneamento E Sistema Viário, Biblioteca FAU/USP.

Neste sentido, a característica principal do Plano de 1963 é a continuidade do projeto modernizador, desta vez conciliado com a preservação de parte dos edifícios históricos e a supressão do eixo monumental que conectava o centro de pesquisa à Cidade Universitária. Nesta linha, uma alteração importante trazida pelo Plano de 1963 está na fragmentação do setor turístico. Antes concentrado na área dos edifícios históricos e voltado à Universidade, continua a ocupar uma área parecida, mas é disperso pela extinção da praça monumental que articulava os edifícios do setor. 0 
prédio da administração passa a ocupar a única praça do campus, conformando o "core" institucional pelo qual passam as principais vias e por onde se dá o acesso pela USP.

Ainda assim, com exceção do conjunto residencial, deslocado para a entrada da Avenida Vital Brazil, e do Edifício da Produção, posicionado no alinhamento da Avenida da Universidade, permanece a organização por setores e a posição aproximada dos edifícios em relação ao plano anterior. O museu também passa por mudanças significativas, deixando o prédio que estaria situado na praça cívica, além do Prédio da Cocheira que abrigaria um museu histórico, para receber um projeto próprio, cujo edifício é um dos mais extensos do novo plano.

Não é possível afirmar quais edifícios do conjunto histórico seriam preservados, pois não há um plano de conservação destas estruturas. Ao que tudo indica, alguns dos edifícios mais relevantes do conjunto seriam mantidos, como o Edifício Vital Brazil, de 1914, o Pavilhão Lemos Monteiro, da década de 1920 e o Prédio Novo, de 1945. A preservação dos prédios existentes não parece ser uma grande preocupação deste plano, que busca destacar os novos prédios e a organização dos setores e vias. No mais, persistem os pressupostos de 1961, com alterações pontuais, mas significativas, que tornam o Instituto menos permeável ao modificar os acessos e a configuração original do setor turístico.

\section{Plano de 1965 e 1966: última experiência moderna de planejamento}

A partir do ano de 1964 começam a atuar diretamente no Instituto Butantan os arquitetos Osmar Mammini e Carlos Henrique Heck, contratados por meio do convênio com o FCCUASO. Os dois profissionais passam a revisar os projetos desenvolvidos até esta data e elaboram uma nova atualização dos planos gestados pra o Instituto durante o período do Plano de Ação.

Neste novo plano, os arquitetos mantêm alguns dos projetos desenvolvidos nos anos anteriores e chegam a propor novos edifícios, como o Biotério de Criação (Figura 
80), sem nada ter sido efetivamente construído, com exceção de alguns edifícios do setor da produção e de serviços que seriam iniciados nos últimos anos da década de 1960.

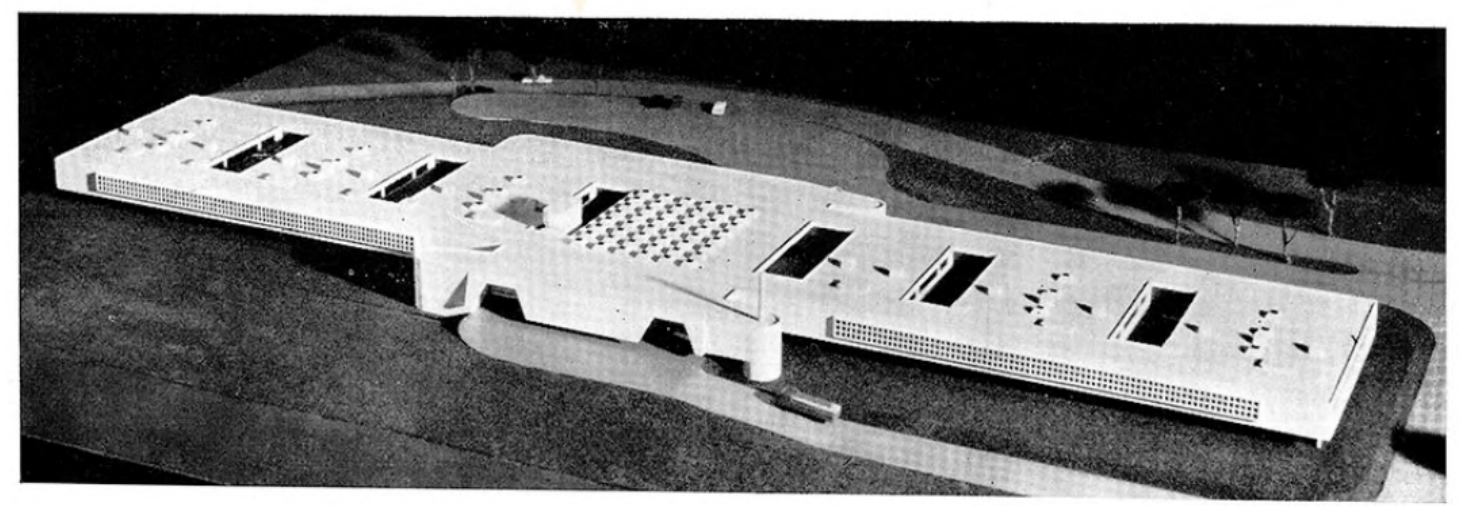

Figura 80: Maquete do Biotério de Criação, projeto dos arquitetos Osmar Antônio Mammini e Carlos Henrique Heck. Fonte: Revista Acrópole, 1966, ano 28, n³31, p. 34.

Existem duas propostas para o plano geral neste período que guardam pequenas diferenças quanto à estrutura viária. A primeira, datada de 1965 (Figura 81), dá continuidade à via Prof. Luciano Gualberto, atravessa a Universidade acessando o Instituto Butantan. A segunda proposta, do ano de 1966 (Figura 58), cria uma separação em "V", em vez de prolongar a Avenida que adentra o Instituto pela Universidade. A diferença entre as duas propostas está no prédio da administração projetado no plano de 1963, que é mantido em 1965 e tem a posição alterada na proposta de 1966. Ao que parece, a intenção de prolongar a avenida que sai da Cidade Universitária pode ter sido negada ou alterada por uma questão prática.

Comparado ao plano de 1963, o plano geral elaborado pelos dois arquitetos entre 1965 e 1966, guarda duas distinções principais. A primeira é o isolamento do núcleo histórico original, local em que é evitada a implantação dos novos edifícios, remanejados para áreas menos ocupadas do Instituto. A segunda característica se refere aos acessos que, mais do que uma distinção em relação aos planos anteriores, parece reiterar as intenções de individualizar o Instituto do campus da USP. Neste sentido, o único acesso pela Universidade parece ser pela entrada da rotatória das 
Avenidas Prof. Luciano Gualberto e Prof. Lineu Prestes, que é a atual via de acesso ao Instituto pela Cidade Universitária.

1 Setor de produção: A) Pesquisas; B) vírus e genética; C) biblioteca; D) hospital; E) heliporto

2 Biotérios de criação

3 Setor residencial: A) Residências de funcionários; B) dências de funcionários; $B$ )
centro sócio-cultural; $\quad$ C) esportes; D) escola

4 Administração

5 Setor de produçāo: A) Edifício da produção; B) bio. tério de inoculados; C) restaurante

6 Setor de serviços: A) Edimoxarifado; B) inflamáveis C) oficinas; D) lavander:a

7 Edifícios a preservar: A) $10^{\circ}$ edificio de laboratórios (1910); B) laboratórios atuais e antiga cocheira (foto acima)

8 Bosques; 9 Área de am pliação; 10 Área reserva. da ao turismo (museu, par. que e restaurante)

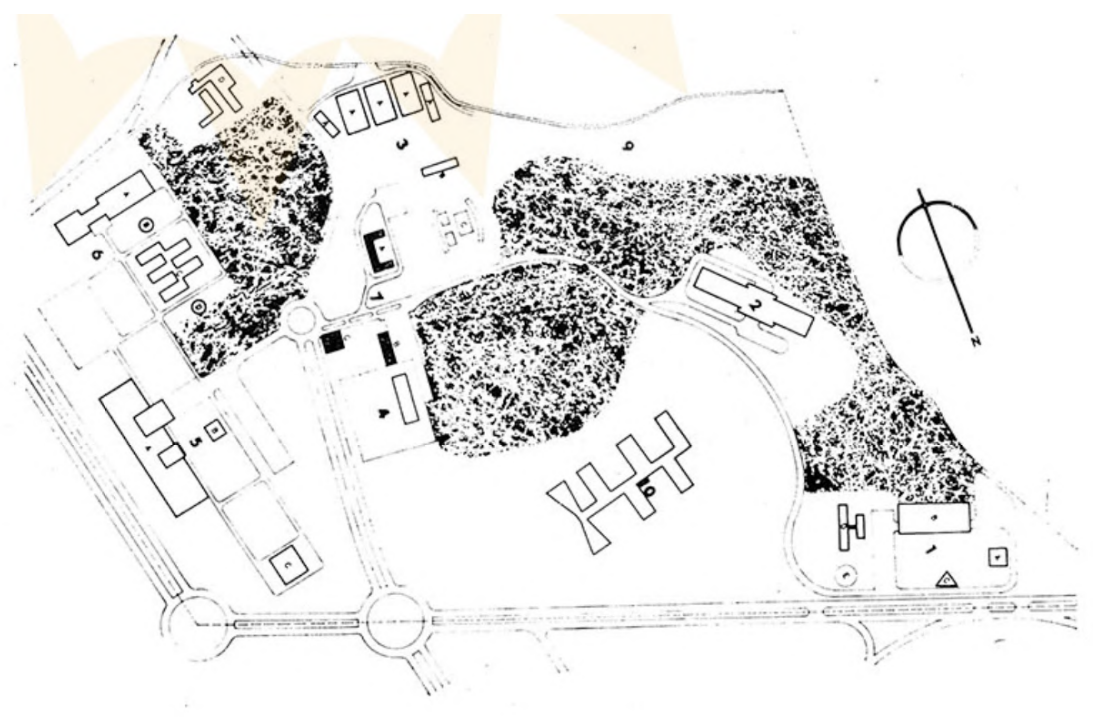

Figura 81: Plano geral de 1965 para o Instituto Butantan. Fonte: Revista Acrópole, 1966, ano 28, n 331, p. 31.

Ao mesmo tempo que elabora novos projetos, o plano urbanístico mantém o edifício do museu projetado por Abelardo de Souza para o Plano de 1963, assim como a esplanada do setor de pesquisa que permanece desde o Plano de 1961 apenas com alterações pontuais. Embora prevaleça a modernidade sobre o conjunto tradicional, o plano elaborado entre 1965 e 1966 esboça uma tentativa de acomodação das novas estruturas diante do núcleo formado pelos edifícios históricos. Estes esforços de conciliação, já ensaiados em 1963 aparecem, desta vez, de forma menos conflituosa, expressando a consolidação da importância histórica e arquitetônica dos edifícios existentes.

Em suma, o Plano de 1965 e 1966 será a última experiência de planejamento moderno total do Instituto Butantan. A partir desta data, prevalece uma acomodação das intenções modernizadoras, quando os arquitetos passam a projetar sob as demandas exclusivas da instituição, pautando alterações e projetos mais pontuais, que não mais objetivam a transformação integral do campus do Butantan. 


\subsubsection{Edifício da produção ${ }^{78}$}

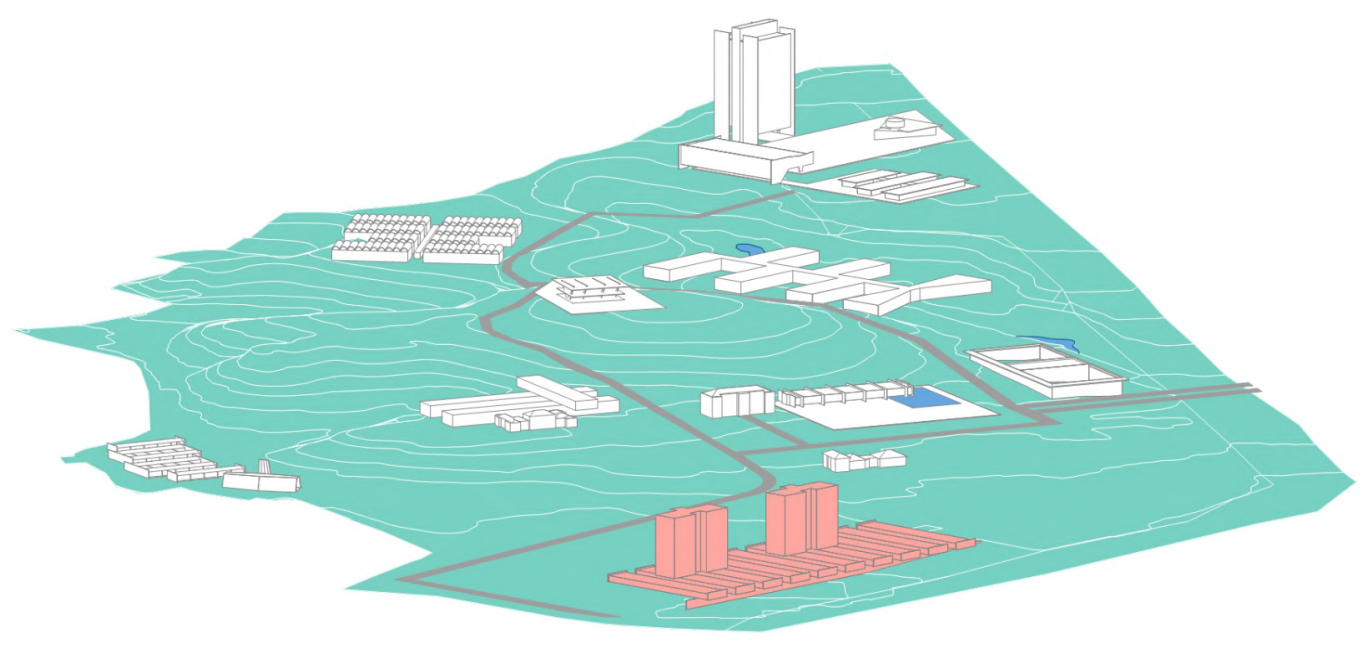

Figura 82: Situação do Edifício da Produção no Plano Geral de 1963. Fonte: desenho nosso.

O conjunto de edifícios do Instituto Butantan denominados de "Produção", são destinados à indústria de produtos biológicos, o que vem provocar um programa bastante complexo e uma consequente dependência íntima do partido a adotar ao programa elaborado. Esta precisão é primordial para um Instituto que se transforma e que deve suprir o Estado de São Paulo, talvez o país todo, de produtos biológicos de alto custo e responsabilidade de produção. (Revista Acrópole, 1966, ano 28, n³31, p. 32)

O plano para a execução de um edifício para o setor da produção é um dos primeiros projetos anunciados para o Instituto Butantan, logo no início do Plano de Ação. Após a visita do Governador Carvalho Pinto em 1959, o Instituto apresenta um projeto para a construção de quatro novos edifícios, entre estes o que seria destinado à Produção Industrial (Relatório Anual Ibu, 1959, fl.03). A necessidade de ampliação da produção de soros e vacinas tornou-se uma questão central para o desenvolvimento institucional, sobretudo, durante a década de 1940 e início de 1950, quando o diretor Eduardo Vaz (1947-1951) passa a priorizar a produção como setor principal e integrado ao setor científico e de pesquisas (IBAÑEZ, WEN, FERNANDES, 2005, p.133).

78 Para mais informações sobre os documentos referentes ao projeto, consultar a ficha 01 do inventário (subcapítulo 2.3). 
Deste modo, os projetos para os novos edifícios da produção aparecem em todos os planos urbanísticos desenvolvidos entre 1959 e 1966 e, consequentemente, apresentam inúmeras alterações, revisões e localizações distintas no campus do Instituto. Ainda sem uma definição de sua arquitetura, o edifício da produção aparece nos estudos de Rubens Carneiro Vianna em 1959 e, já um pouco mais desenvolvido, no Plano de 1961, mas ainda sem uma definição consolidada. Inclusive, este estudo apresenta uma implantação bastante interessante para o edifício, que é composto por diversos pavilhões sobrepostos perpendicularmente, conformando um extenso e único conjunto para a produção e os serviços. Sua localização, no mesmo plano de 1961, está em uma posição de destaque na paisagem, indicando uma atividade primordial do Instituto.

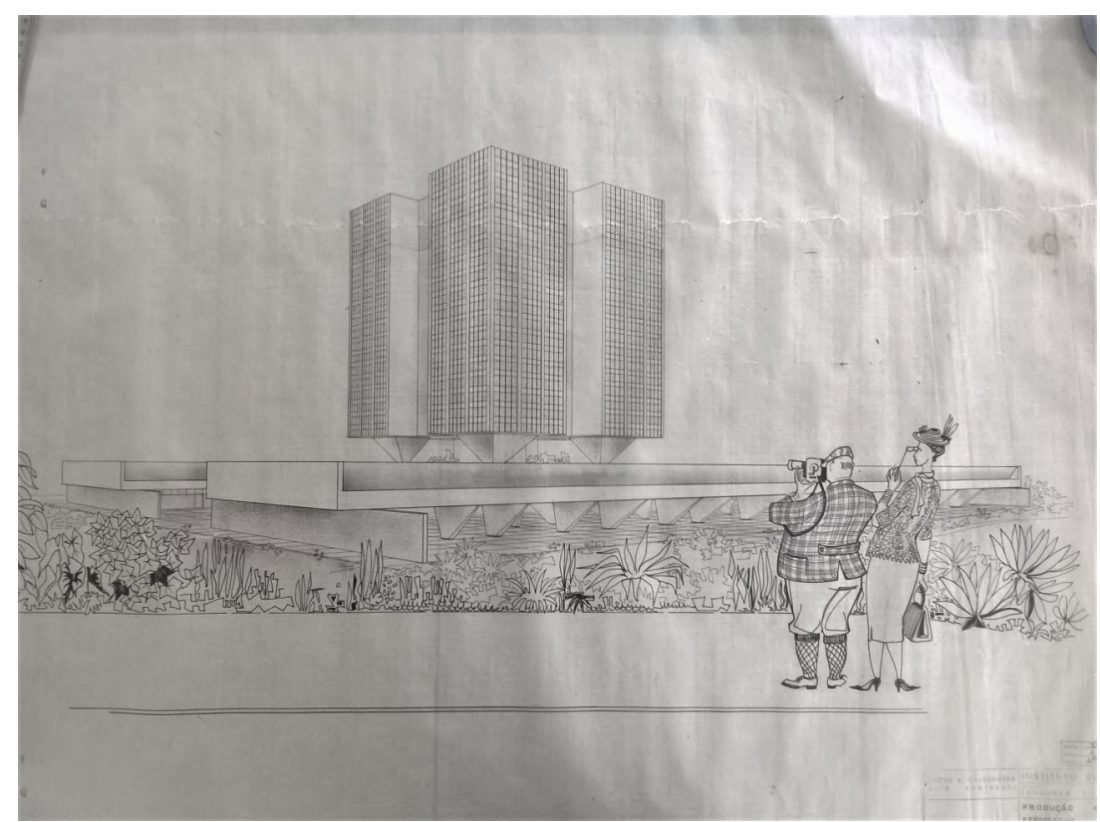

Figura 83: Perspectiva da primeira proposta dos arquitetos Jacob Goldemberg e Luiz Contrucci para o conjunto da produção, 1962. Fonte: prancha 32.18, Centro de Memória/IB

A produção recebe uma arquitetura definitiva com os projetos gestados a partir de 1962, do arquiteto Jacob Goldemberg, e do engenheiro arquiteto Luiz Contrucci (Figura 84), aparecendo no Plano de 1963. Segundo Goldemberg, arquiteto formado em 1960 pela antiga Faculdade Nacional de Arquitetura, no Rio de Janeiro, a atuação com Luiz Contrucci, engenheiro arquiteto formado em 1950 pela Escola Politécnica, se 
deu por definição do próprio Escritório Técnico de Construção da Cidade Universitária. Assim, de forma diferente da implantação do conjunto no Plano de 1961, os arquitetos propõem uma separação do programa, projetando edifícios distintos para os serviços e a produção. Deste modo, o edifício da produção é constituído por pavilhões, denominados "unidades padrão", situados perpendicularmente à Avenida da Universidade e sobrepostos por torres espaçadas de pelo menos 10 ou 12 andares, que receberiam laboratórios, administração e gerenciamento das atividades produtivas.

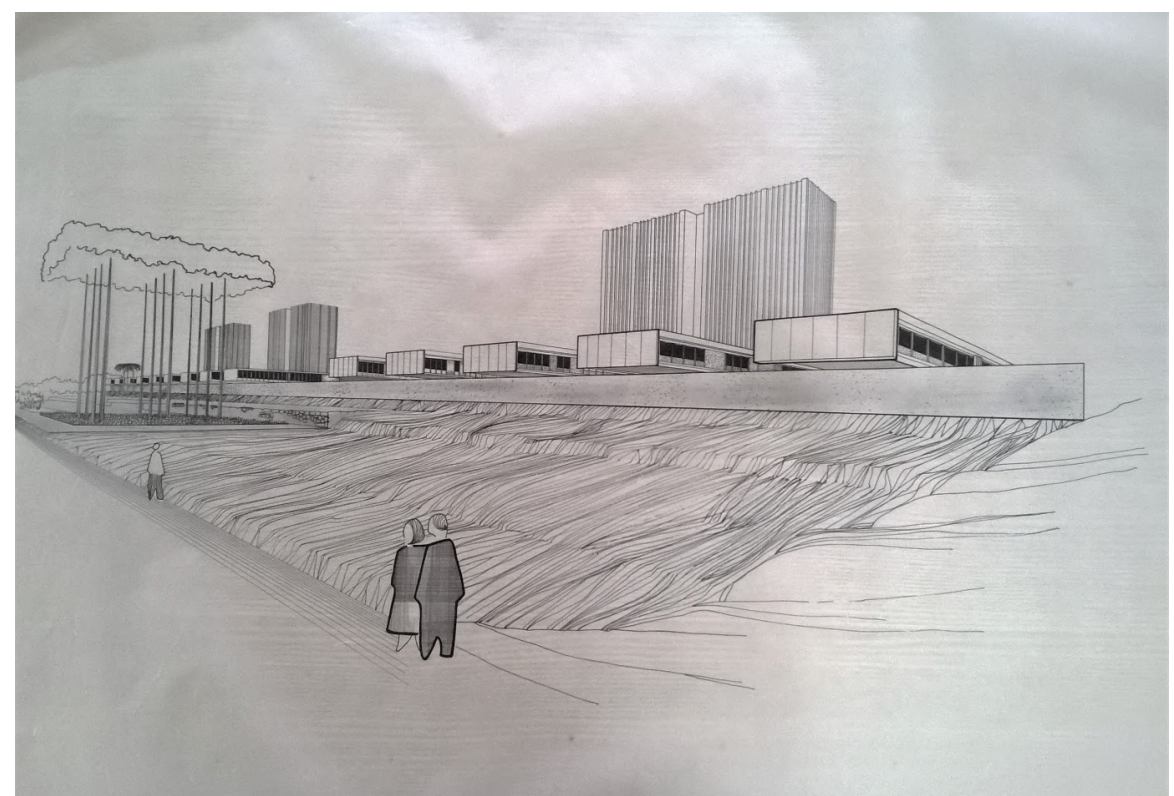

Figura 84: Perspectiva da segunda proposta para o edifício da produção visto a partir da Avenida da Universidade, arquitetos Luiz Contrucci e Jacob Goldemberg, 1963. Fonte: prancha 36.16, Centro de Memória/IB.

Em suma, o projeto parte da ideia de serialização da arquitetura, pensado para uma expansão ilimitada, de acordo com o desenvolvimento do Instituto e da necessidade de ampliação das atividades. Esta intenção é evidenciada na perspectiva do conjunto, cujos pavilhões se estendem até desaparecerem no horizonte (Figura 85). Deste modo, o conjunto poderia ser expandido a partir do módulo da "unidade padrão" ao longo de toda a extensão da Avenida da Universidade, até o limite da área do Instituto com a USP, na Avenida Prof. Lineu Prestes. A partir deste projeto dos arquitetos Jacob Goldemberg e Luiz Contrucci, as demais revisões e alterações vão 
manter esta característica da modulação, que também aparece em projetos para outros edifícios no período.

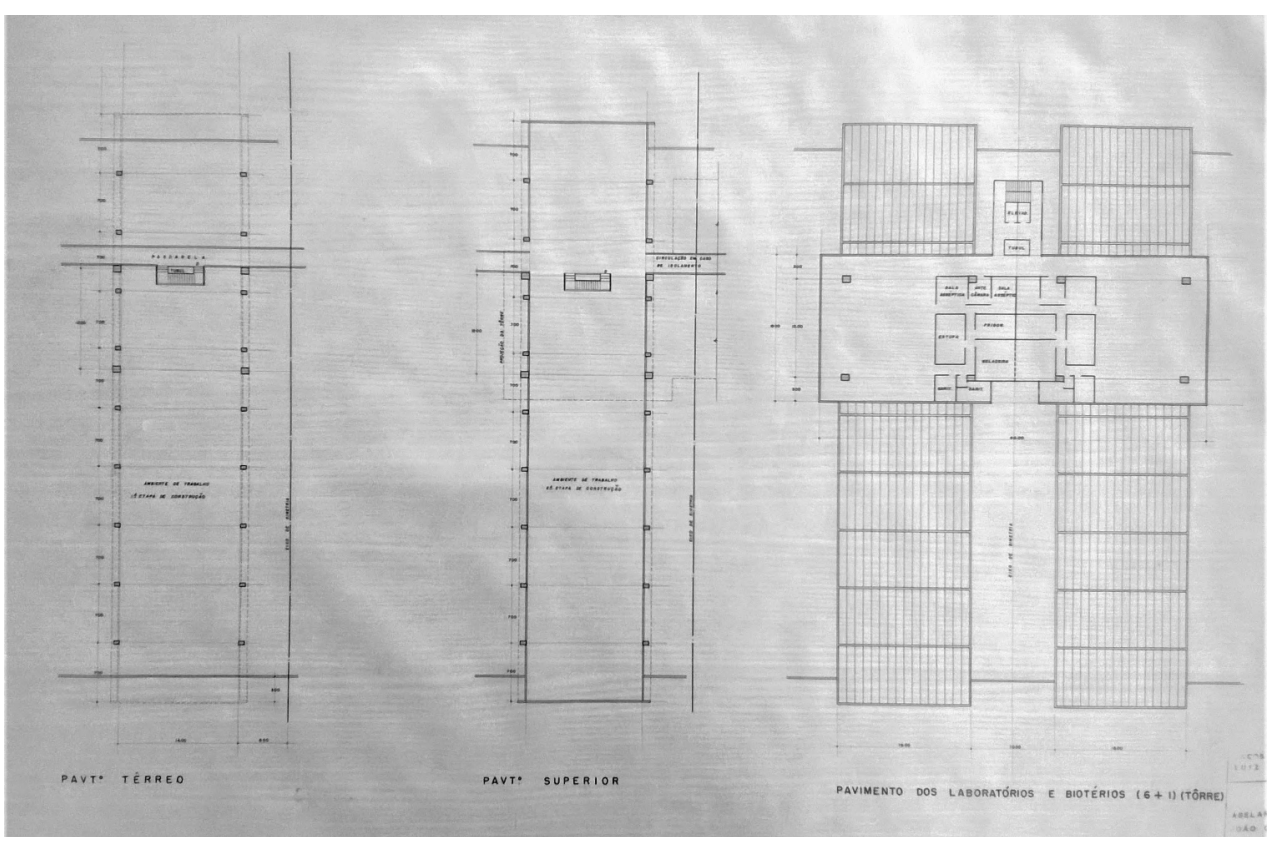

Figura 85: Planta do 1ํ e 2o pavimentos e da torre da "unidades padrão", módulos que poderiam ser replicados de modo ilimitado, 1963. Fonte: prancha 37.06, Centro de Memória/IB.

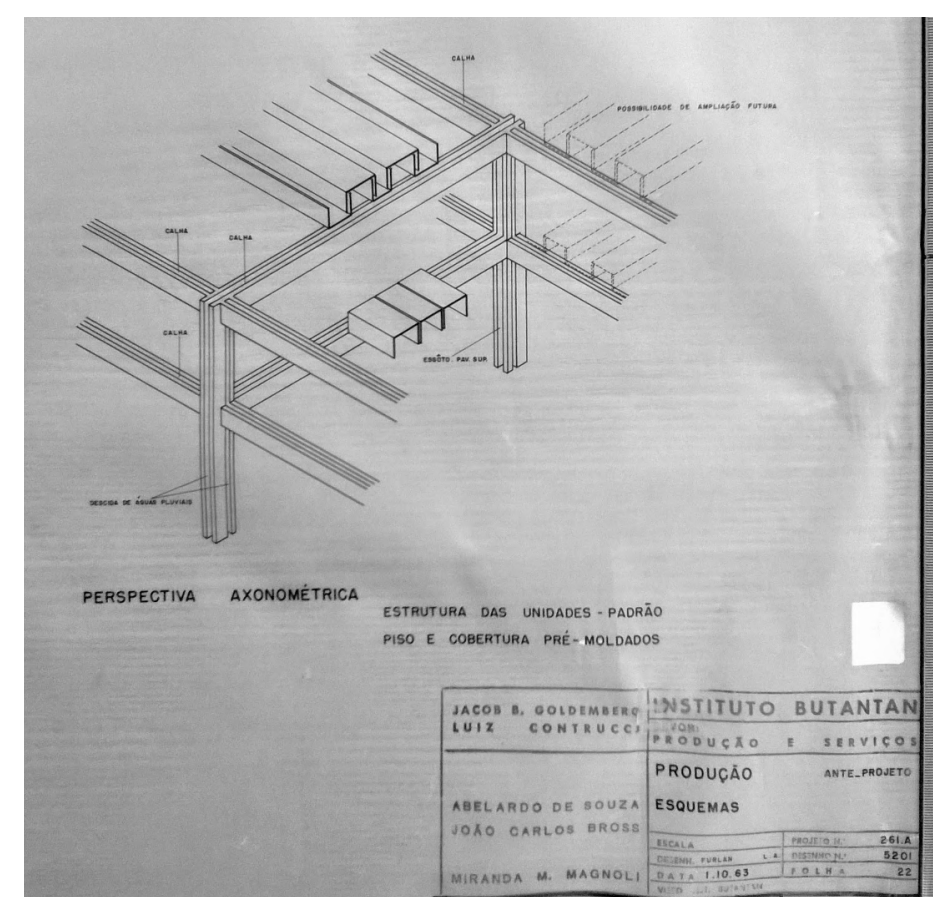

Figura 86: detalhe do e.squema de montagem dos módulos das "unidades padrão", que podiam ser replicadas e cuja estrutura e componentes eram todos modulados, 1963. Fonte: prancha 32.16, Centro de Memória/IB. 

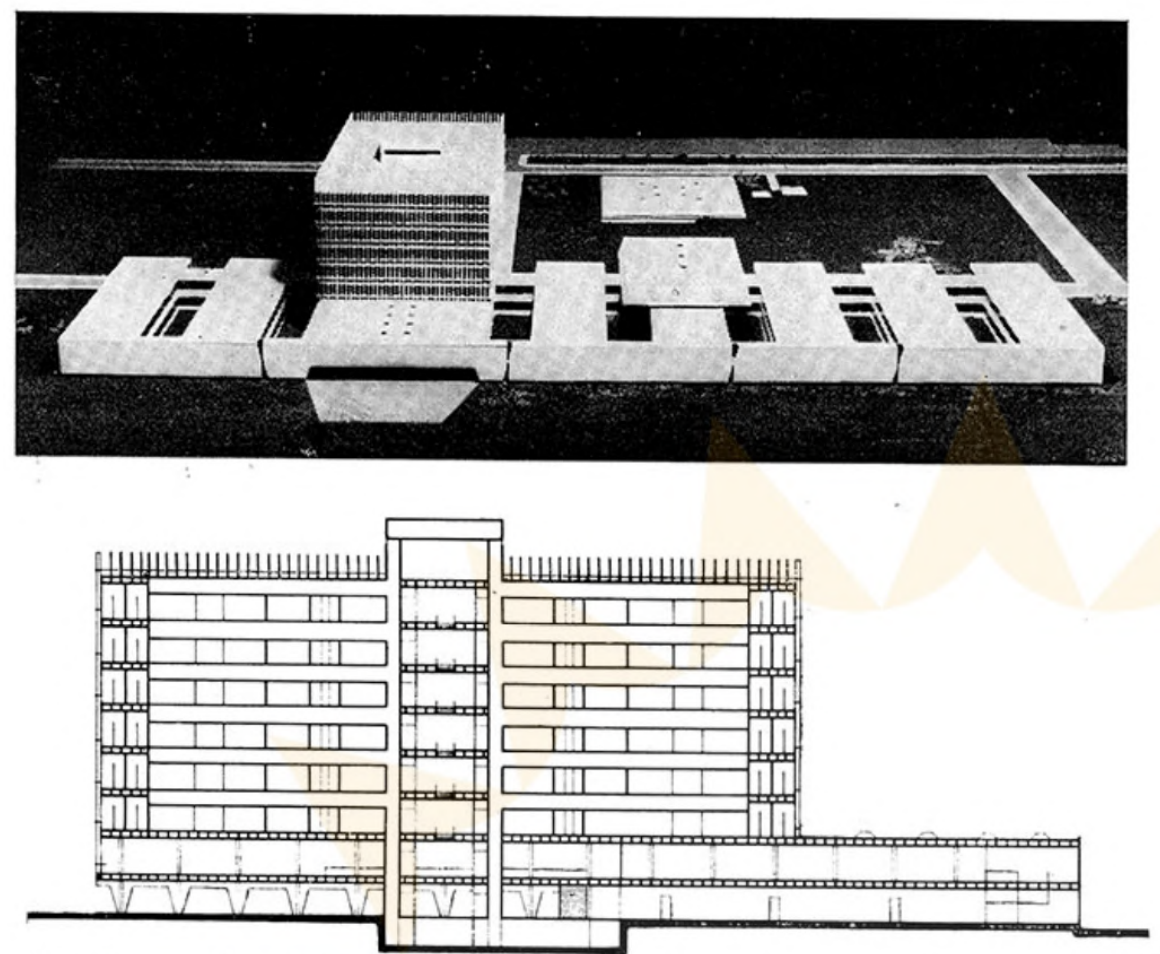

Corte transversal passando pelos dutos de instalaçōes do bloco principal

Figura 87: Maquete e corte do edifício da produção dos arquitetos Osmar Mammini e Carlos Henriqeu Heck, 1966. Fonte: Revista Acrópole, 1966, ano 28, n 331, p. 32.

Além do conjunto principal, formado pelas "unidades padrão" e pelas torres de laboratórios, existe um segundo grupo de edifícios anexos interligados por passarelas, onde estão localizados os espaços de apoio à atividade principal, como restaurante para funcionários, vestiários, carga e descarga de materiais e insumos, e almoxarifado. Neste sentido, a racionalização dos elementos componentes e estruturais do projeto, também se estende ao planejamento das atividades e da rotina do trabalho de produção, demonstrando, por parte da arquitetura, um profundo esforço de organização do funcionamento de um programa tão específico.

Embora não tenha sido construído, o projeto elaborado pelos dois arquitetos em 1962, adaptado e desenvolvido em 1963, estabeleceu as bases de uma outra proposta para o edifício da produção, concebida por Osmar Mammini e Carlos Henrique Heck nos anos seguintes em que passaram atuar no Instituto. No geral, esta segunda proposta é bastante parecida, mantendo a padronização e a localização do 
conjunto, a modulação das estruturas e espaços, e o gabarito da edificação. Contudo, a organização do edifício a partir da "unidade padrão", dá lugar a um edifício mais estanque, que permite a expansão mas conforma um elemento único desde a sua concepção. Assim, a construção por elementos pré-fabricados, indicada no projeto de Goldemberg e Contrucci, é substituída pelo concreto armado moldado em obra, com projeto estrutural do engenheiro José Carlos de Figueiredo Ferraz.

\subsubsection{Pavilhão de serviços ${ }^{79}$}

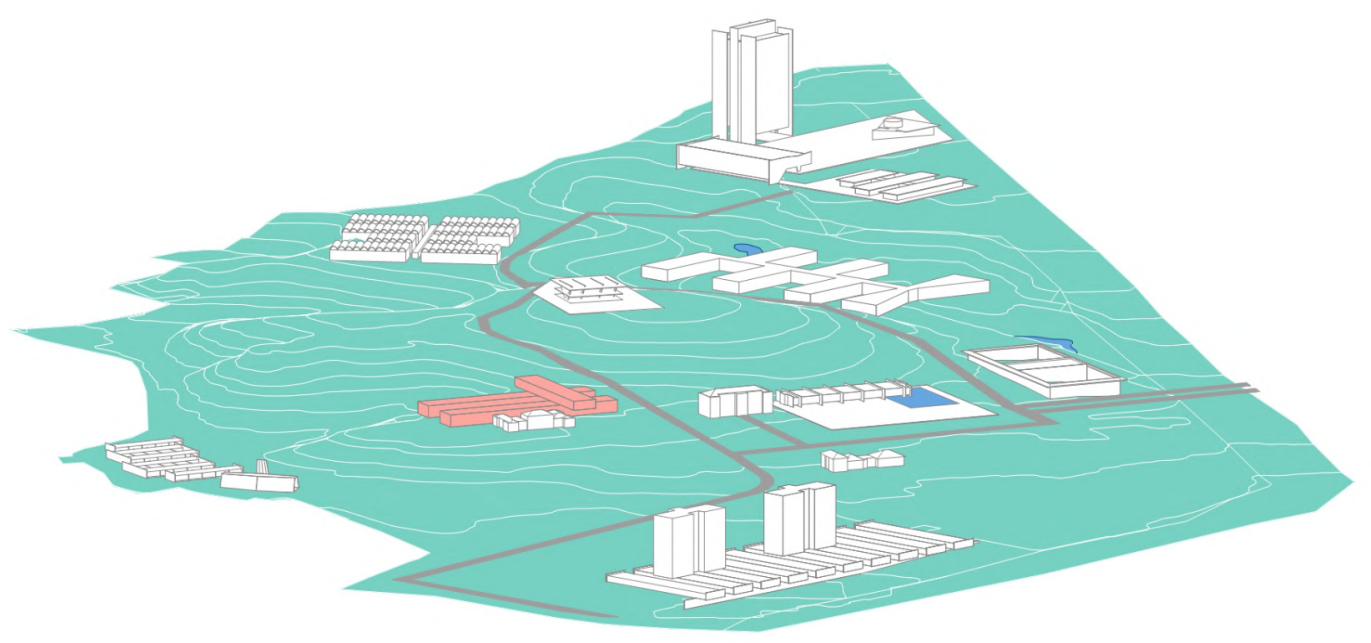

Figura 88: Situação do Edifício de Serviços no Plano Geral de 1963. Fonte: desenho nosso.

A existência de um departamento de serviços está relacionada às necessidades de otimização e organização dos espaços e trabalhos de apoio às atividades principais, em decorrência do crescimento da Instituição. Em uma instituição de pesquisa e produção imunobiológica, esta área é responsável por uma série de funções, reunindo almoxarifados, recepção de materiais, depósitos, controle, garagens, oficinas e todos os serviços auxiliares necessários ao funcionamento dos demais setores, como

79 Para mais informações sobre os documentos referentes ao projeto, consultar a ficha 15 do inventário (subcapítulo 2.3). 
manutenção e limpeza, além dos espaços destinados à administração das equipes e das próprias atividades.

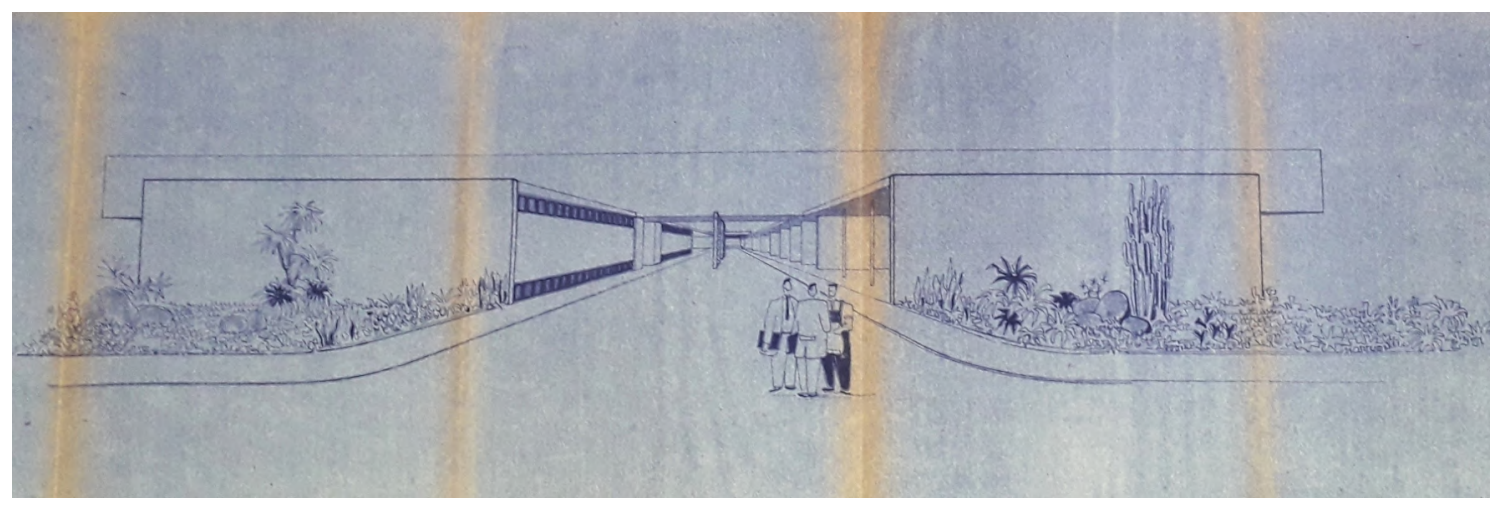

Figura 89: Perspectiva da fachada principal do Edifício de Serviços, 1962. Fonte: Fl.36-Anteprojeto-Serviços, Biblioteca FAU USP.

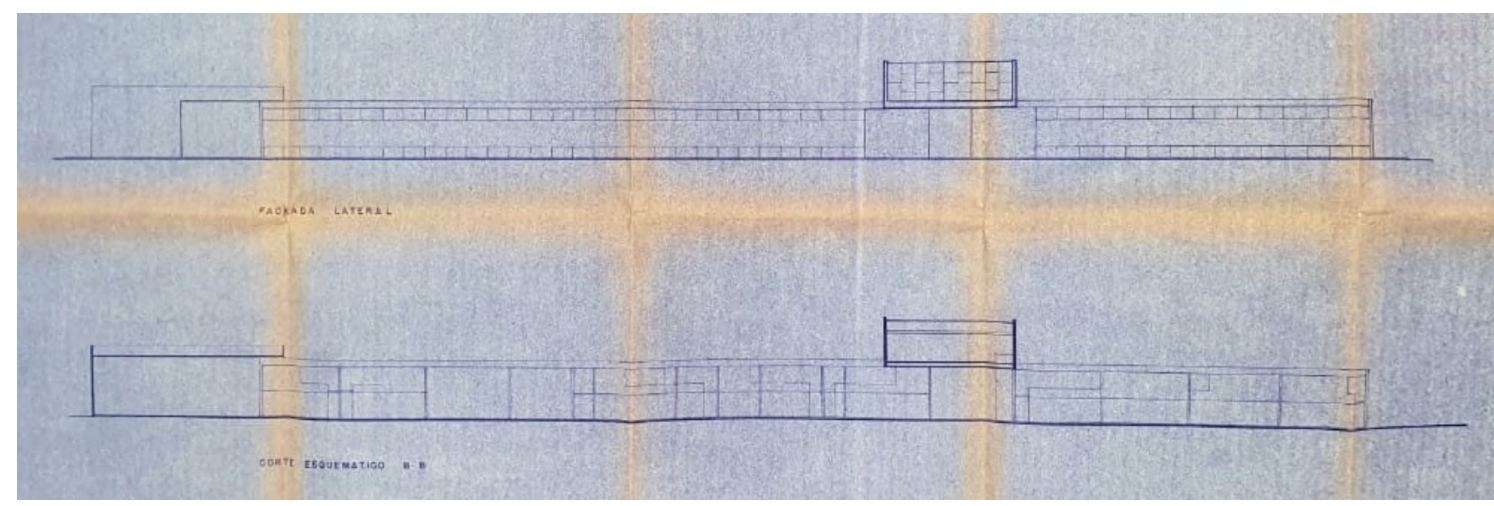

Figura 90: Fachada lateral e corte do Edifício de Serviços, 1962. Fonte: Fl.37-Anteprojeto- Serviços- Cortes e Fachadas, Biblioteca FAU USP.

Deste modo, o setor da produção geralmente está vinculado aos serviços, pela sua magnitude e centralidade nas atividades desempenhadas pelo Instituto. A produção de soros e vacinas concentra parte significativa dos trabalhadores, equipamentos específicos e edifícios consideravelmente maiores do que, por exemplo, as atividades de pesquisa. Da mesma forma, é preciso um rigoroso mecanismo de controle recebimento e armazenamento de insumos e materiais, além de uma rigorosa organização para a distribuição dos produtos. São atributos de uma fábrica, com particularidades ainda mais complexas, na qual o apoio dos serviços é constante, principalmente nos casos em que a produção não pode ser interrompida, funcionando diuturnamente. ${ }^{80}$

80 Há muitos casos em que a produção de imunobiológicos não é interrompida, funcionando em turnos nos quais equipes de trabalhadores se revezam e as equipes de apoio ficam à disposição para 
A primeira aparição de um edifício voltado para tal finalidade é no Plano de 1961, onde se prevê a construção de um conjunto único para produção e serviços. Nos anos seguintes, os serviços do Butantan ganham um projeto independente, mas sempre situado em local próximo da produção, pela sua característica complementar. Provavelmente, a interdependência entre os dois setores deve ter contribuído para que os mesmos arquitetos projetassem, tanto o edifício da produção quanto o de serviços. Assim, Jacob Goldemberg e Luiz Contrucci, responsáveis pelo desenvolvimento do primeiro, também projetam o segundo, ambos a partir de 1962.

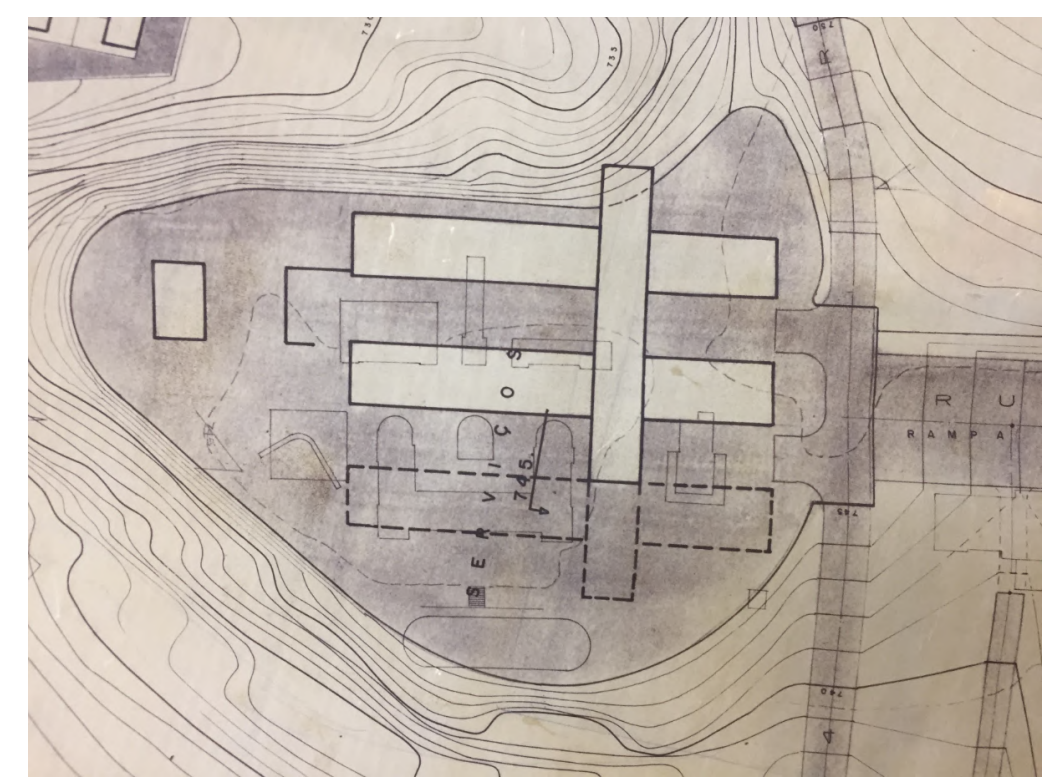

Figura 91: Implantação do Edifício de Serviços no Plano de 1963 com a projeção de expansão do conjunto sobre o Edifício Vital Brazil. Fonte: prancha 21.10, Centro de Memória/IB.

Enquanto a produção, com vimos, ocupou a região próxima da Avenida da Universidade, os serviços do Instituto Butantan seriam implantados em uma região mais central do campus, onde se encontra o Edifício Vital Brazil. A escolha pela localização não é muito evidente, visto que a implantação dos pavilhões de serviços acabava por rivalizar com o importante edifício histórico construído em 1914, na atuação pioneira de Vital Brazil, fundador do Instituto. Contudo, é possível imaginar que a escolha tenha se dado pela localização que, ao mesmo tempo que mantém o 
setor de serviços próximo da produção, condição imprescindível, também o posiciona em uma região central e, portanto, de fácil acesso aos demais setores. De algum modo, corresponde ao critério exposto no Plano Geral de 1963, de minimizar a movimentação de terra. Em um terreno acidentado como o do bairro do Butantã, a escolha pelo platô, no qual está localizado o conjunto da Cocheira-enfermaria, de 1901, logo atrás do Edifício Vital Brazil, condiz com a intenção de se reduzir a interferência no terreno, podendo ter contribuído para a escolha do local.

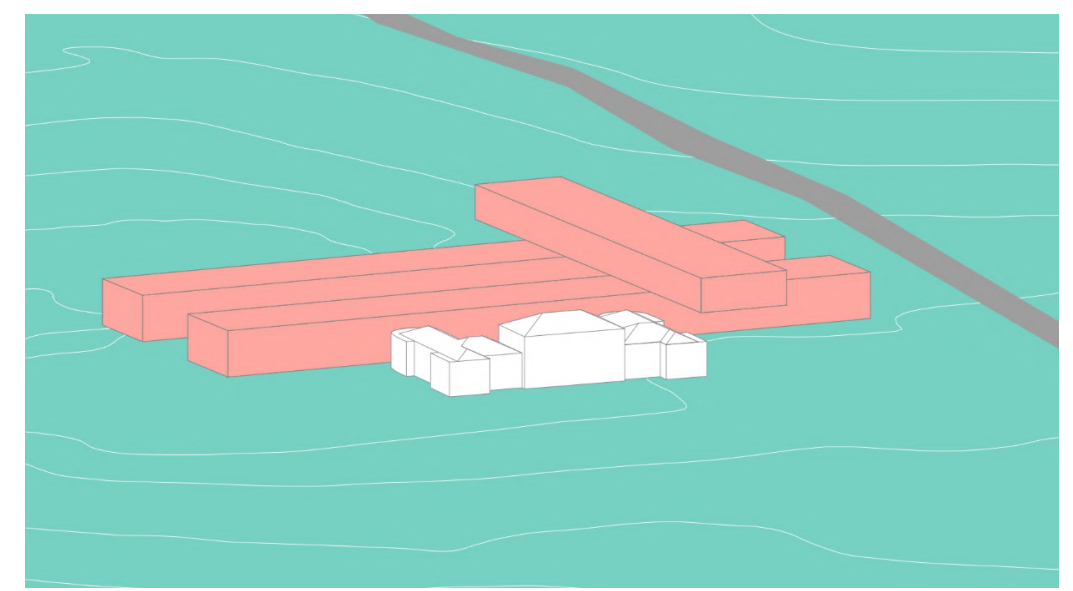

Figura 92: Modelo digital reproduzindo a volumetria do Edifício de Serviços (em destaque) diante do Edifício Vital Brazil. Fonte: desenho nosso.

Para um conjunto formado por pavilhões de cerca de 100 metros, reduzir a interferência na topografia parece algo desafiador, na medida em que seus blocos e o programa do projeto são pouco compatíveis com terrenos acidentados. Assim, o novo prédio se sobrepõe ao conjunto da cocheira, que precisariam ser demolidas, se projetando ao histórico edifício Vital Brazil. No Plano de 1963 para o Instituto Butantan, há uma indicação de expansão do edifício de serviços, que passaria a ocupar o local onde está o prédio histórico de 1914, que guarda uma dimensão simbólica para a Instituição.

Esta possibilidade de ampliação, é uma característica comum aos projetos do período e, também, dos edifícios projetados por Goldemberg e Contrucci. O conjunto de serviços que, inicialmente, seria formado por três blocos principais, sendo o terceiro 
perpendicular e apoiado sobre os demais, poderia expandir suas instalações ao ser acrescido por um quarto bloco.

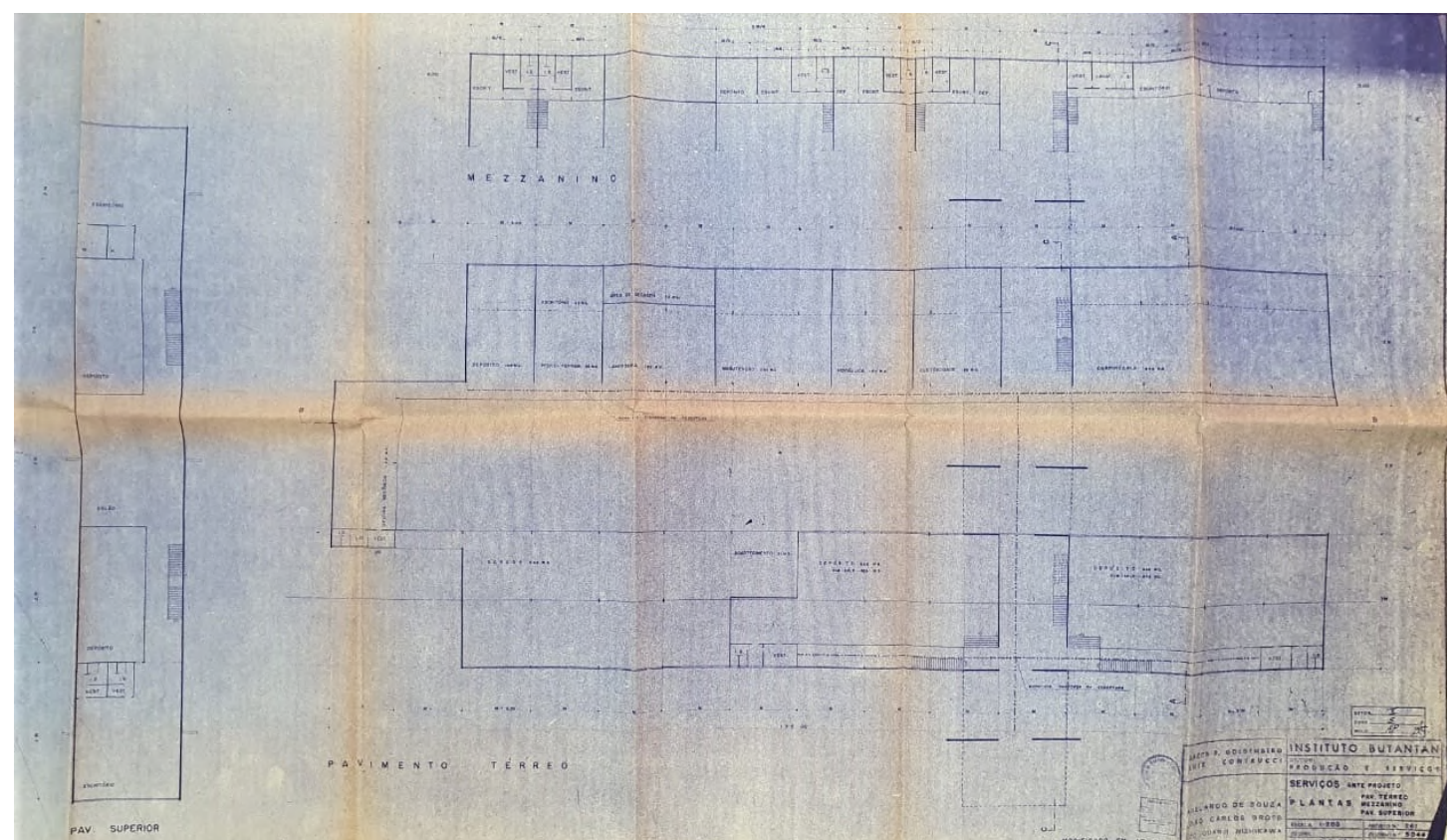

Figura 93: Planta do pavimento térreo, do mezanino e do pavimento superior do Edifício de Serviços, 1962. Fonte: Fl.39-Anteprojeto- Serviços- Pavimento Térreo, Mezzanino e Pavimento Superior, Biblioteca FAU USP.

Em suma, o projeto é formado por dois pavilhões paralelos com térreo e mezanino, nos quais se encontram garagens, depósitos e serviços gerais. Estes blocos são sobrepostos por um terceiro pavilhão perpendicular a eles e em balanço, no qual se encontram os escritórios da administração. A disposição dos blocos é planejada para favorecer a circulação dos veículos no interior do conjunto e o acesso destes às garagens e oficinas. Neste sentido há uma clara separação entre espaços servidores e servidos, e o edifício parece reproduzir, em pequena escala, um ambiente urbano de hierarquias viárias bem definidas, no qual podem ser identificadas as ruas, as quadras, os passeios dos pedestres e os edifícios. 


\subsubsection{Conjunto ou Núcleo Residencial ${ }^{81}$}

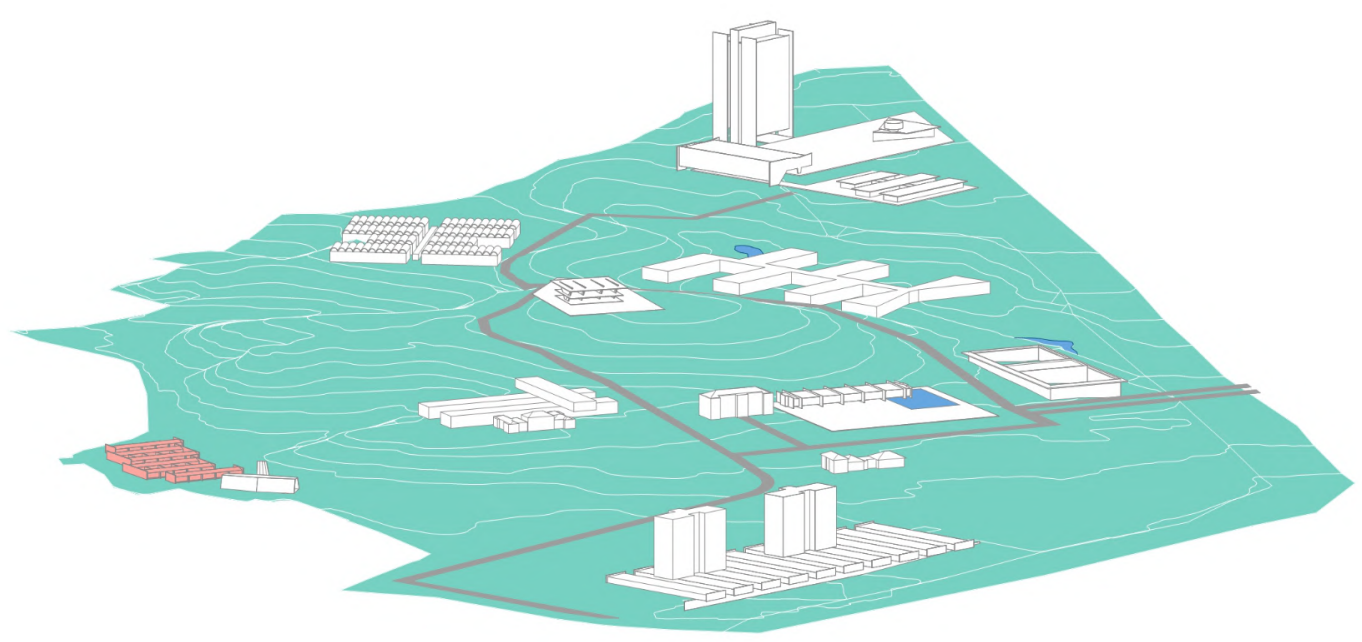

Figura 94: Situação do Conjunto Residencial no Plano Geral de 1963. Fonte: desenho nosso.

Para introduzir a análise do conjunto residencial, vamos pontuar algumas questões relevantes. Sempre existiram moradias na área onde se encontra o Instituto Butantan. Se expandirmos o nosso recorte temporal, e territorial, veremos que a região do bairro do Butantã preserva resquícios de habitações rurais do período colonial, como a casa bandeirista, onde se encontra hoje um museu municipal. No século XX, com a urbanização promovida pela Companhia City, o bairro se afirmou pela sua característica residencial.

Esta vocação residencial do bairro, foi impulsionada pela implantação do Instituto Butantan, nas primeiras décadas do século XX e, mais tarde, pela implantação do campus da Universidade de São Paulo. Assim, tornou-se comum que estudantes e professores da Universidade passassem a morar nas redondezas do campus, o que fez com que, ao menos desde a década de 1950, arquitetos modernos, alguns professores da FAU USP, projetassem residências para professores da Universidade. O mesmo acontecia para pesquisadores do Instituto Butantan que, diante da distância do

81 Para mais informações sobre os documentos referentes ao projeto, consultar a ficha 02 do inventário (subcapítulo 2.3). 
Instituto das regiões mais centrais da cidade, optaram por se estabelecer no bairro, mantendo a proximidade com o trabalho e a qualidade de vida nem sempre encontrada nas regiões mais adensadas da cidade. Em 1956, um casal de pesquisadores do Instituto Butantan construiu uma casa no bairro: Olga Bohomoletz Henriques e Sebastião Baeta Henriques, ${ }^{82}$ que dão nome à Casa Baeta, importante projeto residencial de João Batista Vilanova Artigas e Carlos Cascaldi. Neste período, outros importantes projetos residenciais modernos foram executados no bairro: a Residência Boris Fausto de Sérgio Ferro, projetada em 1961, as casas "gêmeas" de Paulo Mendes da Rocha em 1964, a Residência Juarez Brandão, de Flávio Império e Rodrigo Lefévre em 1968, a famosa residência Dino Zamataro, formada por uma grande abóbada, também projetada por Lefévre dois anos depois. Ainda podemos citar projetos residências de Joaquim Guedes e Abrahão Sanovicz, sem mencionar os projetos mais contemporâneos. ${ }^{83}$

Não obstante, por muito tempo o campus do Instituto Butantan vigorou como residência para muitos de seus servidores. A construção de uma casa para o diretor do Instituto e sua família, idealizada pelo diretor Afrânio do Amaral (1928-1938), projetada por Mauro Álvaro e concluída em 1931, consumou-se como a grande arquitetura residencial do Instituto em suas primeiras décadas de existência. $O$ edifício onde hoje estão instalados os escritórios da diretoria, nomeado "Casa de Afrânio do Amaral" em 2018, é formado por dois pavimentos, garagem e uma piscina. A construção da residência foi defendida como solução para a longa distância percorrida

82 Os médicos Olga Bohomoletz Henriques e Sebastião Baeta Henriques, foram cientistas do Instituto entre 1944 e 1964, quando são submetidos a um inquérito em razão de suas convicções políticas e afastados de seus cargos públicos pelo regime civil-militar. Após longo tempo no exílio, retornaram ao Instituto na década de 1980, até serem aposentados compulsoriamente. A aproximação do casal com Vilanova Artigas deve ter ocorrido no ambiente do PCB, ao qual os cientistas eram filiados, assim como o arquiteto. Apesar da perseguição política, tornaram-se profissionais renomados e que contribuíram definitivamente para o desenvolvimento das áreas em que trabalharam no Instituto, cujo reconhecimento tem sido retomado por investigações recentes feitas pelos pesquisadores do Centro de Memória e do Laboratório de História da Ciência do Instituto Butantan.

83 O projeto "Arquivo Arq" tem um interessante levantamento da arquitetura moderna na cidade e no estado de São Paulo, onde é possível localizar os projetos catalogados em um mapa. Ver: www.arquivo.arq.br 
diariamente entre o Instituto e a cidade. De fato, a questão do acesso atravessou décadas, inclusive, até a chegada do sistema de metrô ao bairro na última década.
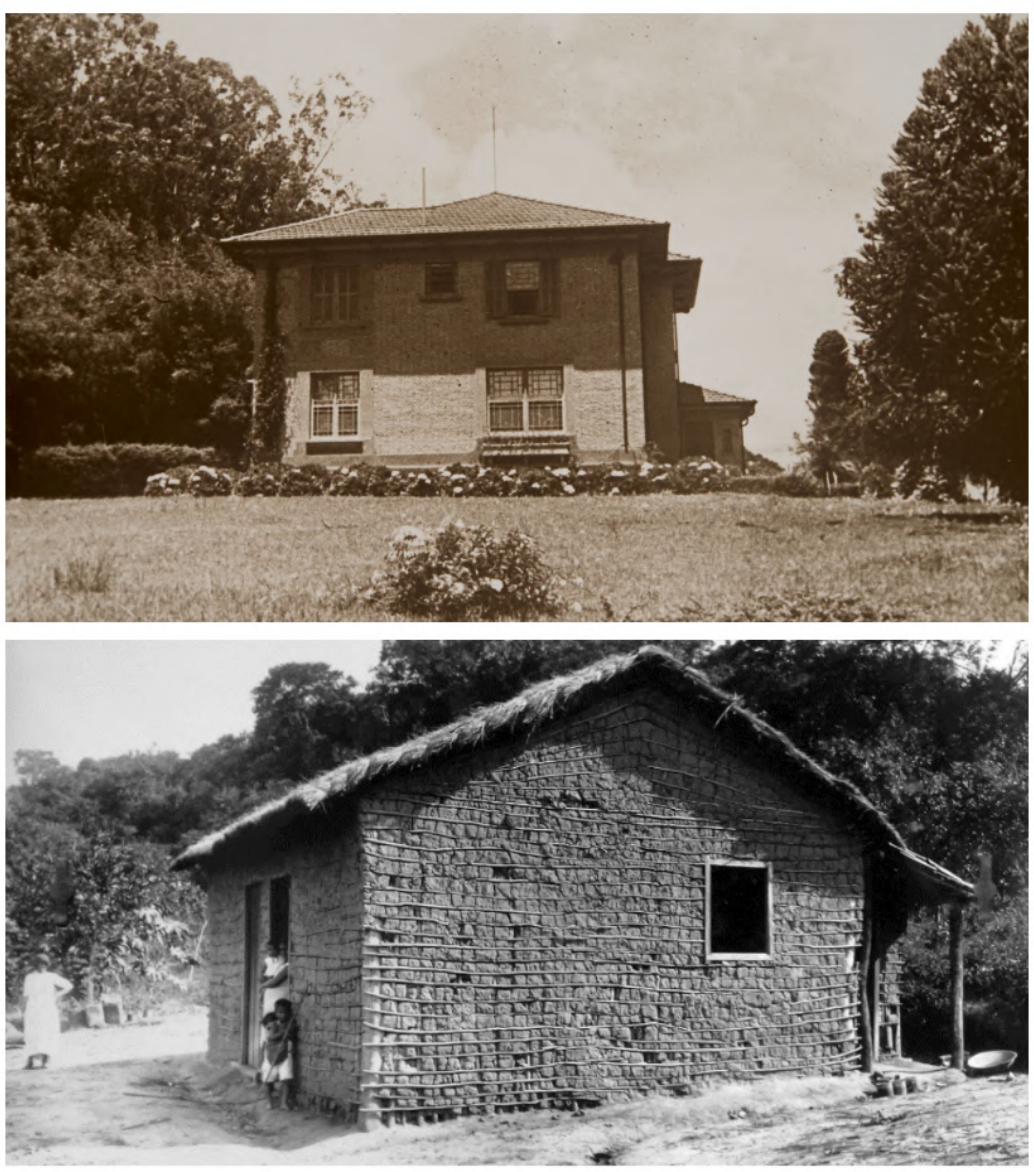

Figura 95: Residências no Instituto nas primeiras décadas: acima a residência para a família do diretor, construída pelo então diretor Afrânio do Amaral na década de 1930 e, abaixo, uma das casas de funcionários da fazenda que existiram até a década de 1920. Fonte:IB_ICO_009374 e Relatório Anual de 1929, Centro de Memória/IB.

O campus do Instituto Butantan sempre abrigou, além dos usos relacionados ao trabalho científico, diversas residências ou mesmo partes de edifícios utilizadas para moradia. Isso se deve a alguns motivos principais: a distância entre o campus e a área urbana de São Paulo no início do século XX, somada à dificuldade de transporte, fazia com que a opção por morar no próprio Instituto fosse vantajosa para seus funcionários, especialmente diante do entusiasmo da equipe científica com a nascente instituição; além disso, a própria natureza do terreno e das atividades nele desempenhadas (pesquisa e produção científica, plantio, colheita, criação de animais), exigia a permanência de funcionários que as monitorassem em tempo integral; também foi sempre comum a necessidade de alojar visitantes internacionais (autoridades ou pesquisadores) que podiam permanecer por várias semanas ou meses para desenvolver seus trabalhos; por fim, muitos moradores da antiga fazenda permaneceram em casas no campus durante as primeiras décadas do Instituto. (SÁ, 2019,p.213) 
Contudo, apesar das construções de vulto desempenhadas neste período, aos trabalhadores comuns restaram as casas mais simples, de perfil rural e dispersas pela enorme área do Instituto (Figura 95). ${ }^{84}$ Deste 1925 se manifestava a necessidade de acomodação dos funcionários na área do campus ou em locais próximos. Para isso, foi proposto o loteamento de uma área pouco utilizada do Instituto, cujos lotes seriam vendidos aos funcionários para que construíssem as próprias casas (Relatório Anual, 1925, p. 8). Nas décadas seguintes, são desenvolvidos projetos para residências de funcionários, divididas pela hierarquia funcional dos servidores. Apesar da necessidade antiga, o Instituto permaneceu até a década de 1950 sem que nenhum destes planos fosse integralmente executado.

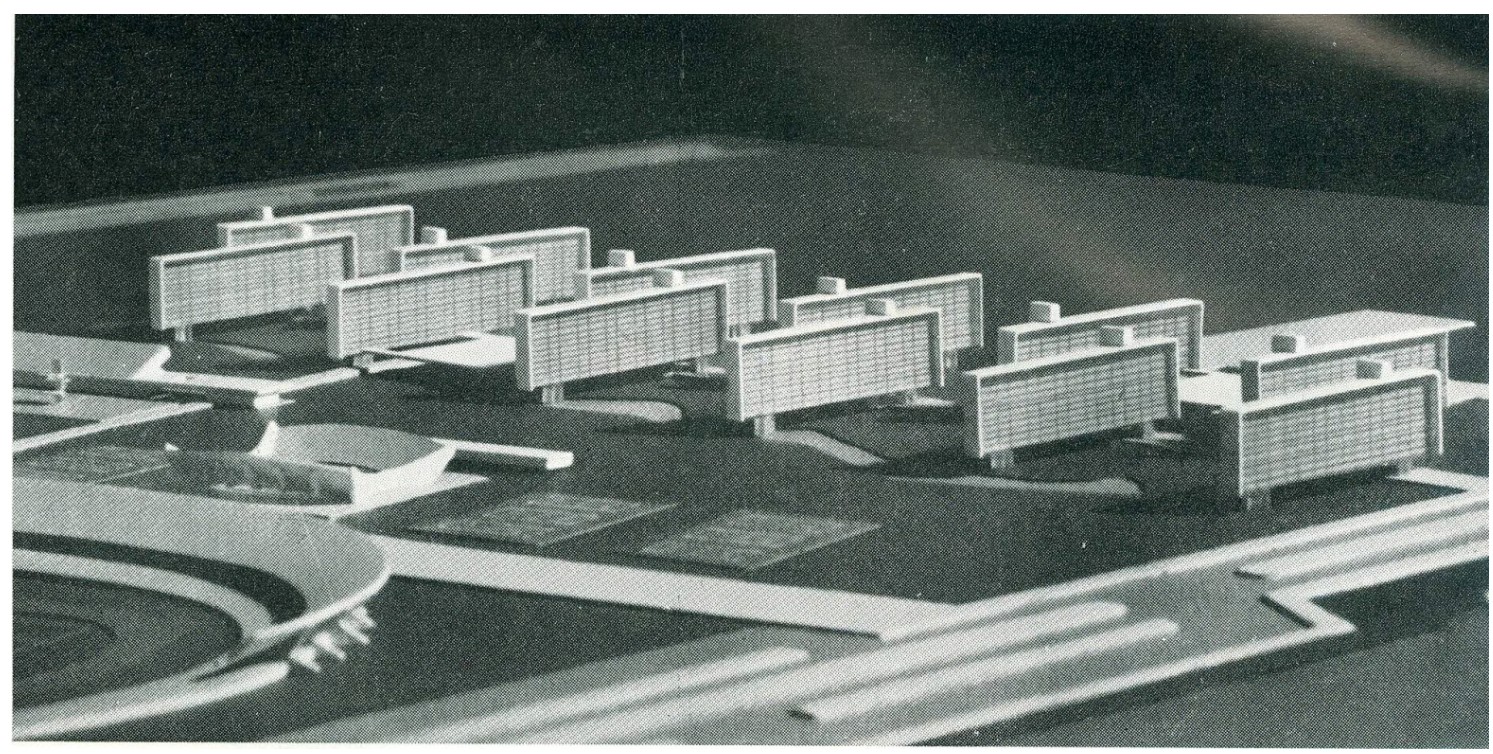

Figura 96: Maquete do conjunto residencial da USP, do arquiteto Eduardo Keneese de Mello, 1961. Fonte: Revista América, ano 7, no2, 1962, sem página.

O projeto para a construção de residências no campus é retomado no período do Plano de Ação. A proposta de um setor residencial é contemplada já no primeiro ano, em 1959, pelos estudos de Rubens Carneiro Vianna, que situa uma vila residencial em local próximo à Cidade Universitária, no entrocamento da Linha Adutora de Cotia, onde está a Avenida Professor Lineu Prestes, com a Avenida da Universidade (Figura 73). Em 1961, os arquitetos Leo Quanji Nishikawa e Luiz Contrucci apontam a situação problemática das habitações existentes, dispersas pelo Instituto e desprovidas de 84 Em sua dissertação, Anderson de Sá (2019) apresenta alguns destes edifícios rurais existentes na Fazenda Butantan. 
condições mínimas de higiene. No plano proposto, situam o conjunto de residências a ser construído em local próximo à entrada da Cidade Universitária, ainda sem a definição de sua arquitetura.

A arquitetura do conjunto é iniciada em 1962 pelo arquiteto Mário Rosa Soares, que trabalhava para o Fundo de Construção da Cidade Universitária. Neste projeto, o conjunto é novamente remanejado, passando para a entrada do Instituto pela Avenida Vital Brazil, como aparece no Plano de 1963 e onde se encontra atualmente. Sua construção tem início no ano seguinte e, ao que tudo indica, é concluída em 1964. No Relatório Anual de 1961 (fl.04), em ocasião da ratificação do convênio entre FCCUASO e Instituto Butantan, é mencionada a previsão de construção de cem residências "com acesso independente para a via pública". Destas foram construídas cerca de cinquenta unidades, sendo o único projeto executado pelo PAGE na Instituição.

O Conjunto Residencial do Instituto Butantan se vincula a uma categoria de edifícios habitacionais diferente das residências unifamiliares que caracterizaram o bairro do Butantã até meados do século. Como habitação moderna, o Conjunto se define pelo propósito de massificação da habitação e pela possibilidade de reprodução e serialização das unidades habitacionais, diferente da casa da fazenda, vernacular, ou da casa do diretor, que constitui um edifício único no campus. No sentido da massificação da habitação, o Conjunto Residencial do Instituto se aproxima do Conjunto Residencial da USP (Figura 96) como um dos poucos edifícios habitacionais formados por unidades não individualizadas que foram construídos até este período na região. Viabilizados e construídos por meio do Plano de Ação, os dois projetos descrevem a preocupação dos arquitetos modernos com a disposição das habitações ao priorizar as condições ideais de ventilação e iluminação, e retificam a centralidade do programa habitacional para o Movimento Moderno. 


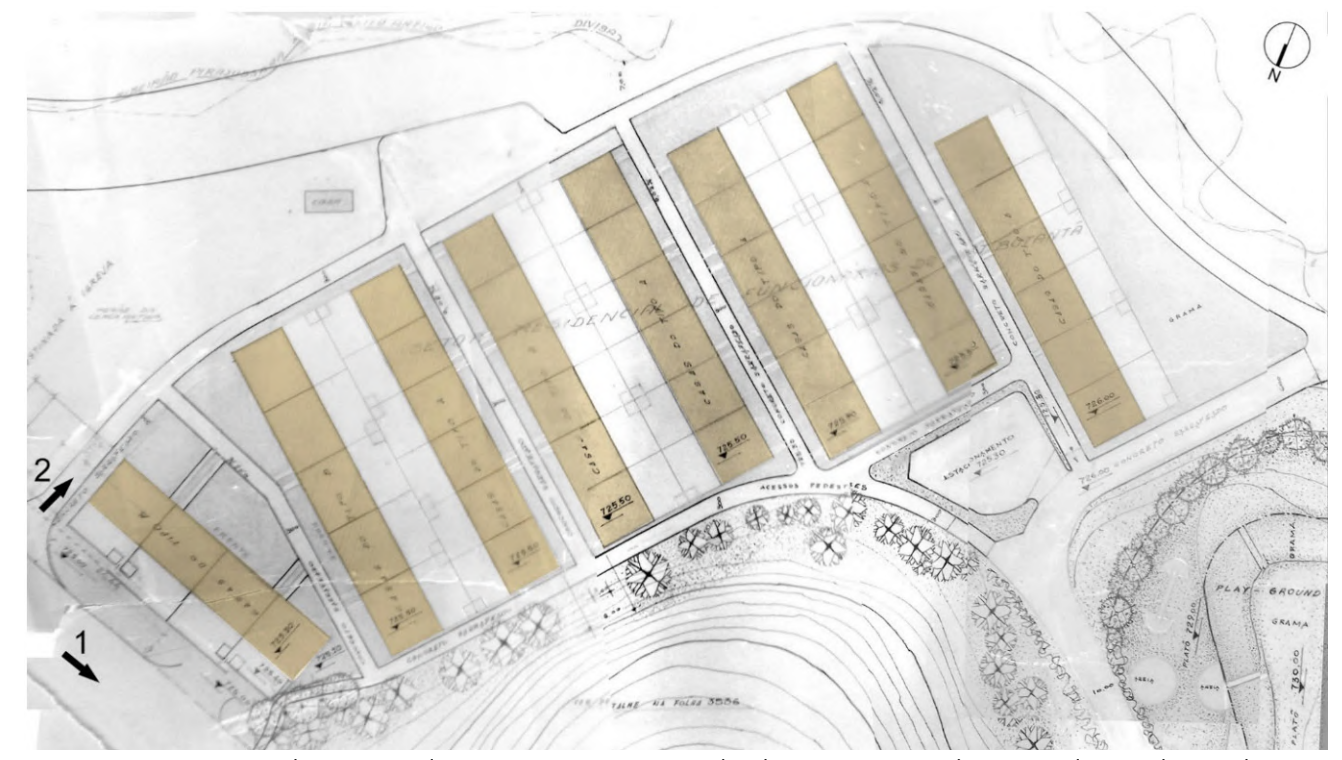

Figura 97: Implantação do conjunto na entrada do Instituto pela Avenida Vital Brazil, indicando a entrada independente (2) e o acesso principal ao Butantan (1). Fonte: prancha 49.02, Centro de Memória/IB, reproduzido da dissertação de Anderson de Sá (2019, p.215).

O núcleo de residências é formado por oito fileiras de unidades habitacionais geminadas, quase todas paralelas, com exceção da primeira que é alinhada à Avenida Vital Brazil, onde se encontra o acesso independente às casas. Os espaços entre as fileiras conformam as ruas e os pátios internos das unidades. É interessante notar que a solução adotada pelo arquiteto Mário Rosa Soares passa por dar um sentido unitário para as residências, em vez de optar por lotes separados e dotados de uma edificação isolada, sem conexão com o todo. Neste sentido, a proposta não deixa de fornecer um padrão para a construção em série de novas unidades habitacionais, algo que se encontra em outros projetos para o Instituto Butantan neste período.

Dentro da diversidade de soluções e linguagens modernas adotadas nos projetos para o Instituto Butantan e para a USP nestes anos, o conjunto de casas explora uma estética que está vinculada ao brutalismo da época: as paredes de tijolos aparentes, algumas delas sem aberturas, conformando empenas, telhados, caixas d'água e estruturas expostas, compondo e dando a forma do conjunto. Assim, apresenta elementos comuns aos edifícios brutalistas, em sua ênfase à estrutura e aos materiais, mas guardando certas especificidades: 
O sistema construtivo utiliza concreto armado, alvenaria, elementos de madeira e aço nos caixilhos, telhas de fibrocimento, entre outros itens acuradamente detalhados em projeto. Nesse sentido, ao adotar tijolos cerâmicos, peças de madeira aparente em beirais, entre outros detalhes, essas casas trazem elementos que as diferenciam das obras em concreto aparente da fase mais radical do Brutalismo Paulista (SÁ, 2019, p.219)

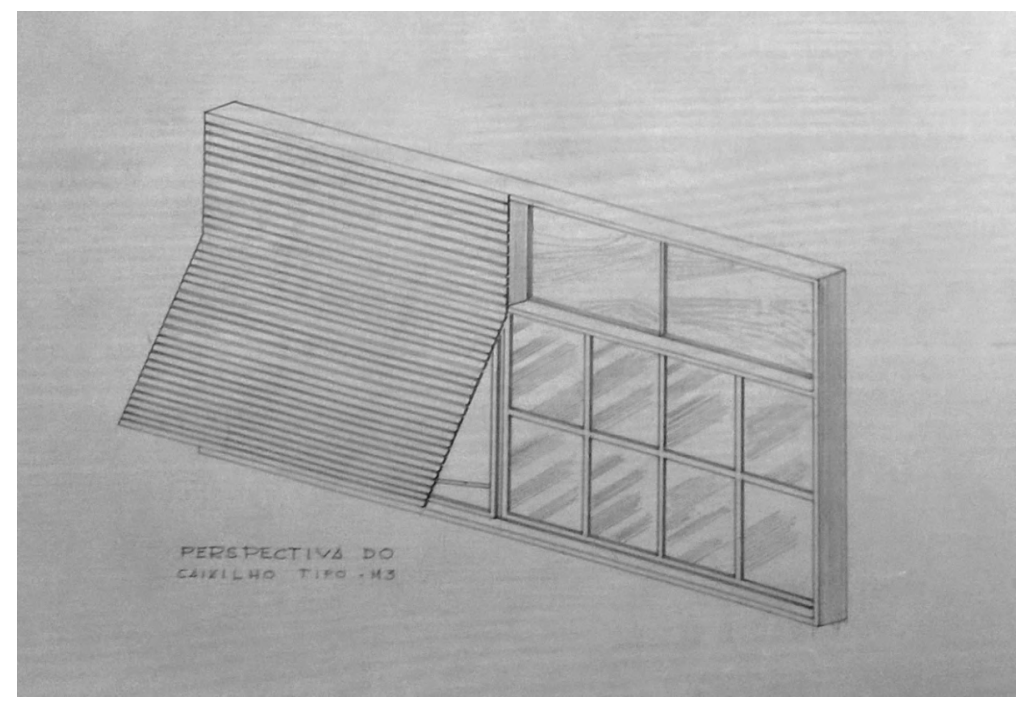

Figura 98: Detalhe de um caixilho de madeira projetado para as unidades residenciais. Fonte: prancha 46.24, Centro de Memória/IB.

O projeto de Mário Rosa Soares enfatiza um material menos utilizado nos projetos deste período, que chegam a ser usados em alguns outros edifícios construídos na Cidade Universitária mas, em menor medida, nos projetos para o Instituto Butantan até meados da década de 1960. Assim, as paredes de alvenaria aparente constituem o elemento definidor da forma do edifício, dando unidade ao conjunto e o identificando na paisagem, como é possível notar na Figura 101. Cumpre também uma função espacial: delimita o espaço do conjunto em suas laterais, conformando empenas cegas. Estas mesmas paredes organizam os espaços internos e delimitam a divisão das unidades que, vistas em planta, formam um interessante desenho de linhas paralelas intercaladas, onde estão dispostos os ambientes internos de cada unidade. Estas paredes de tijolos se estendem para além do espaço da casa, acompanhando o beiral e conferindo privacidade às residências e suas aberturas. 


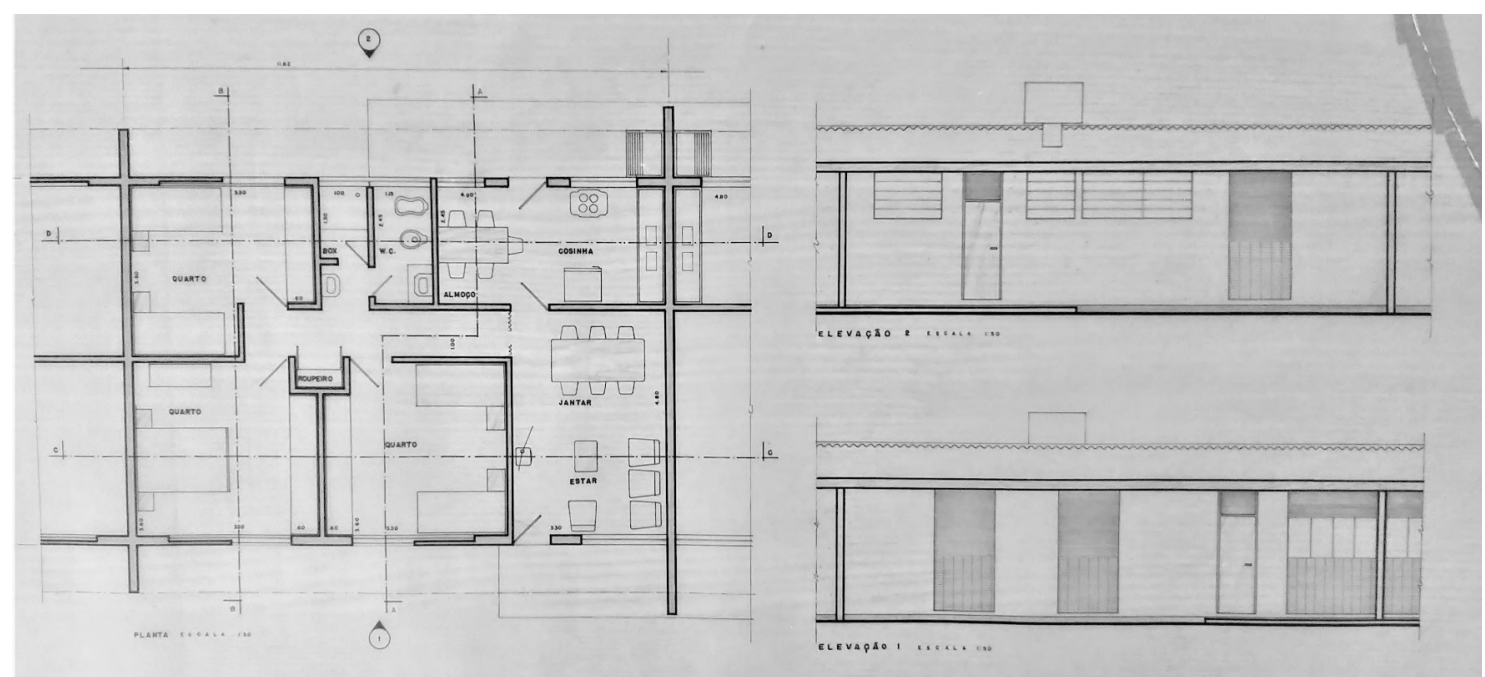

Figura 99: Planta e elevações de uma unidade do conjunto, 1963 Fonte: prancha 20.35, Centro de Memória/IB.

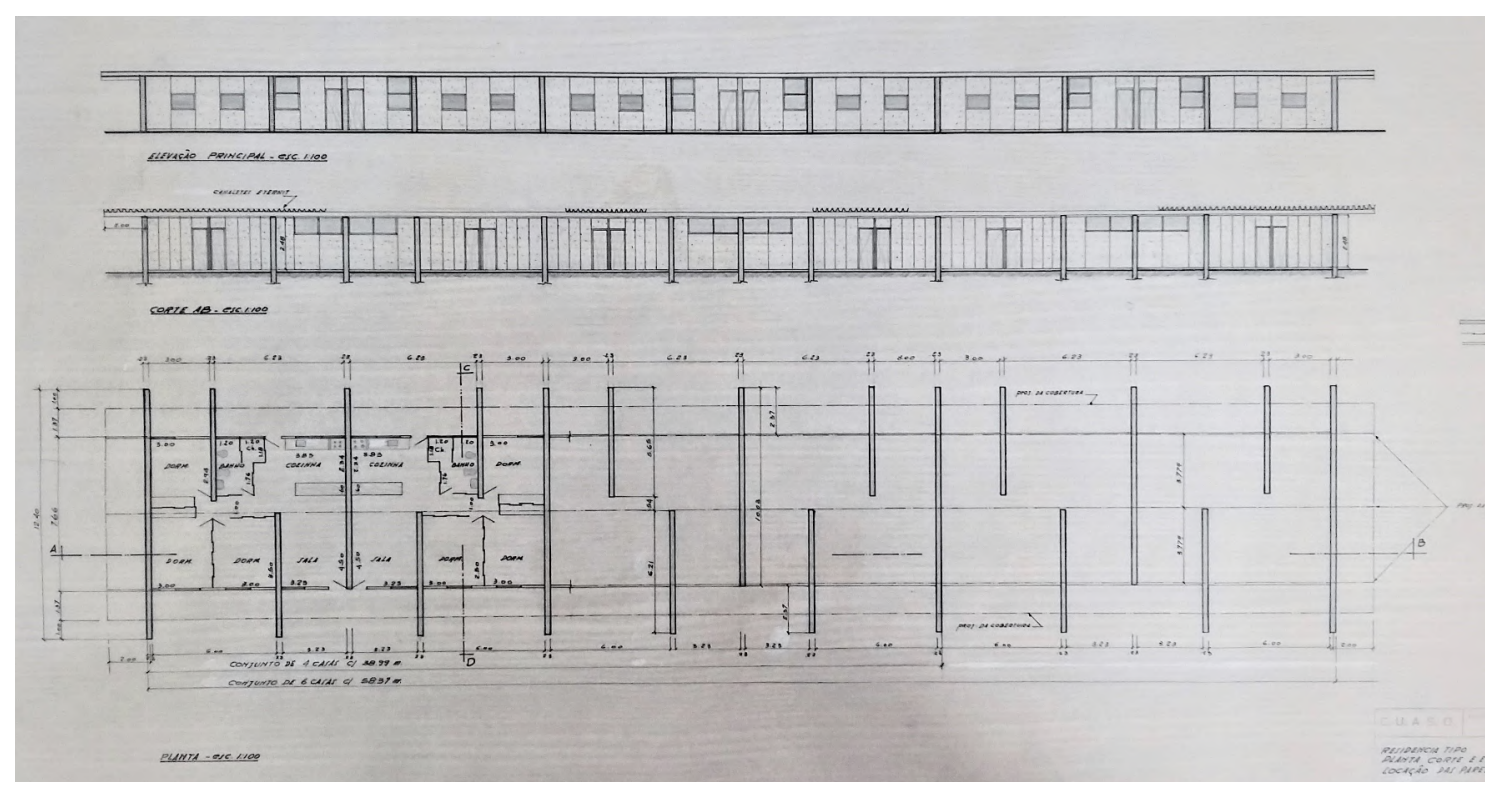

Figura 100: Fachada, corte e planta baixa de uma linha de casas do conjunto, 1963. Fonte: prancha 19.20, Centro de Memória/IB. 


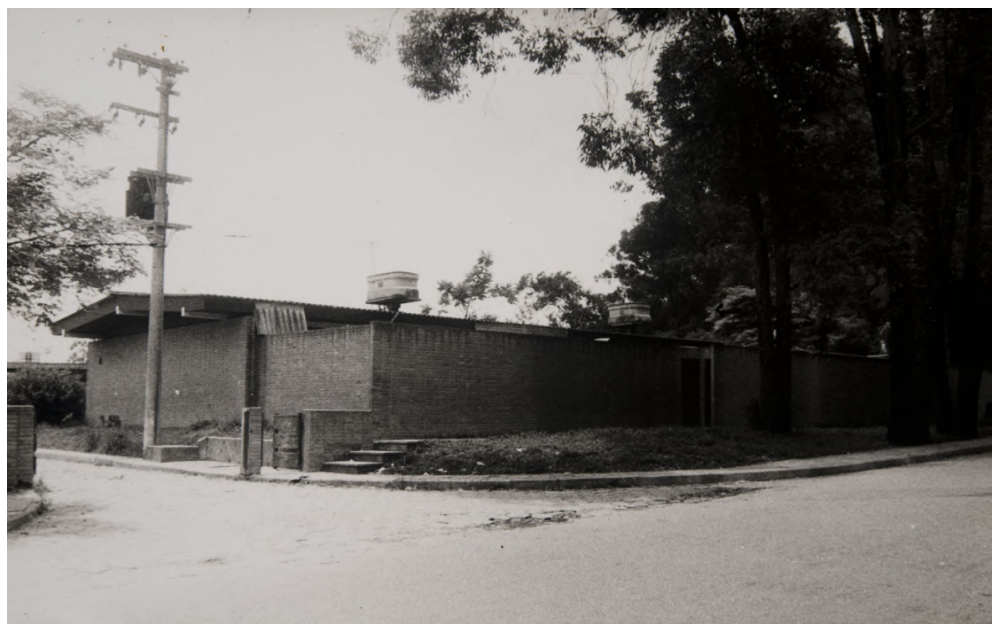

Figura 101: Vias e acessos de carros, anos 1970. Fonte: IB_ICO_008772, Centro de Memória/IB.

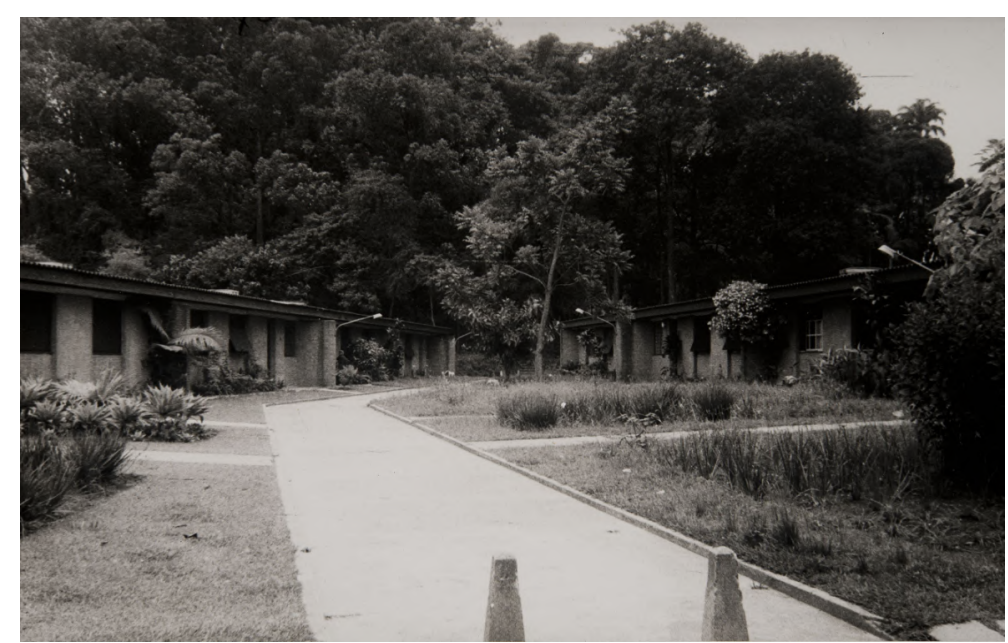

Figura 102: Paisagismo e espaços de circulação de pedestres na década de 1970. Fonte: IB_ICO_008773, Centro de Memória/IB.

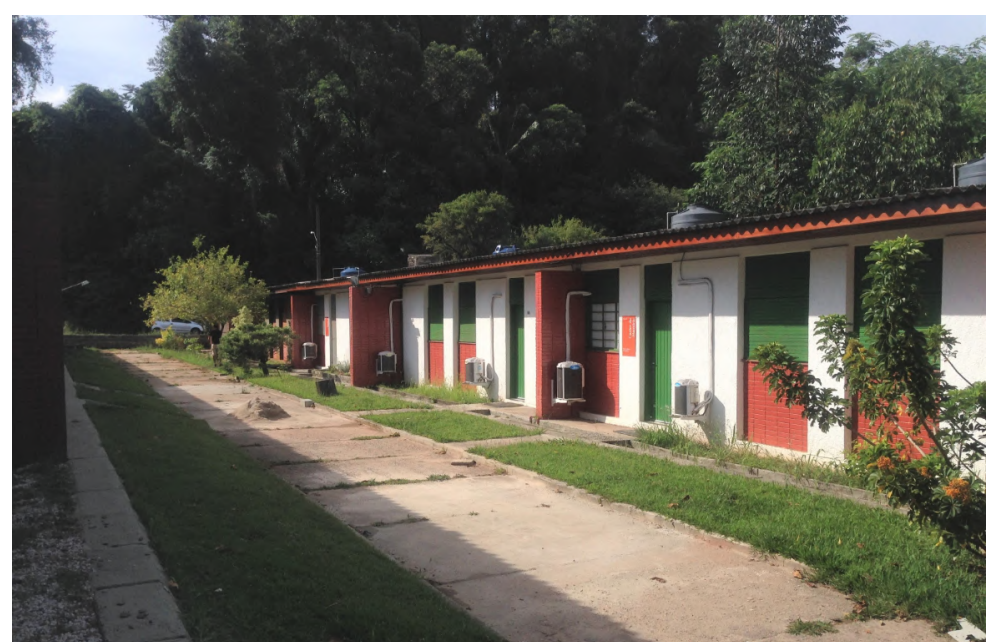

Figura 103: Fotografia das unidades reformadas que abrigam os arquivos do Centro de Memória desde 2019. Fonte: autor, dez. 2019. 
Após a conclusão das obras em 1964, outros planos continuam a ser desenvolvidos para o Núcleo Residencial. São feitos projetos de execução dos mobiliários das residências, em sua maioria, mas também relações de equipamentos domésticos necessários ao funcionamento das casas para os funcionários, detalhamento de caixilhos, divisórias e outros componentes de madeira. Em uma destas unidades concluídas, os arquitetos Osmar Antonio Mammini e Carlos Henrique Heck vão instalar um pequeno escritório, e passam a atuar nestes últimos projetos do conjunto, desenvolvendo em 1966 um centro social (Figura 104) e de lazer para os moradores do núcleo residencial, que não chegou a ser construído.

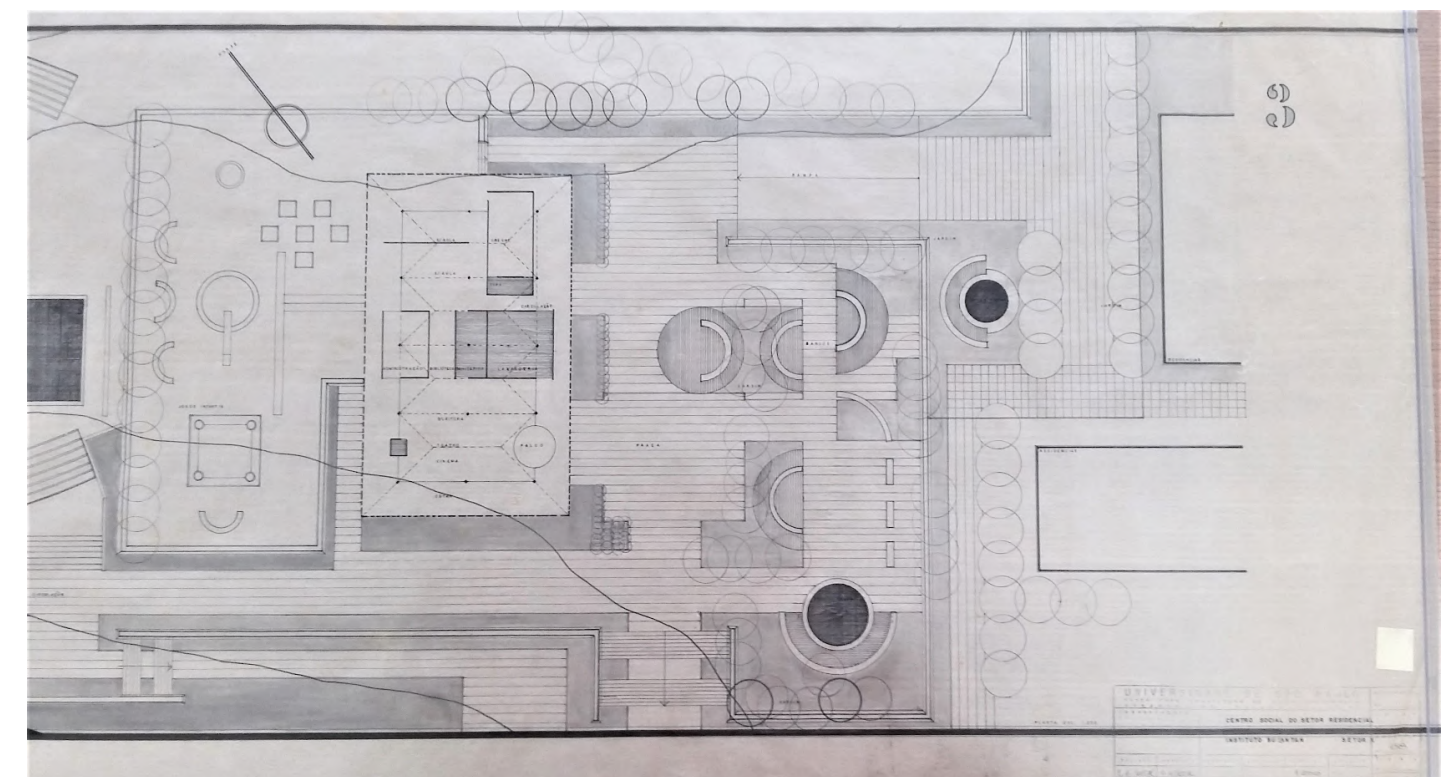

Figura 104: Projeto para o Centro Social do Conjunto Residencial, arquitetos Osmar Mammini e Carlos Henrique Heck, 1965. A proposta previa uma grande praça situada próxima às residências, com um edifício centralizado que se caracterizava por uma grande cobertura para abrigar atividades diversas, contendo sala de cinema e leitura, biblioteca, sala de aula, creche, lavanderia e administração. Fonte: prancha: 19.16, Centro de Memória/IB.

Atualmente, a histórica função residencial deixou de fazer parte do Instituto Butantan. Até recentemente, permaneciam alguns poucos moradores antigos no conjunto residencial, enquanto algumas unidades têm sido reformadas e ocupadas por departamentos e laboratórios do Instituto, como os arquivos e administração do Centro de Memória e o Laboratório de História da Ciência (Figura 103). De todo modo, a maior parte das casas continuam desocupadas e em processo de deterioração, sem 
que exista um plano definido para a sua recuperação e restauro, ou sequer um plano de destinação dos seus espaços para outras atividades.

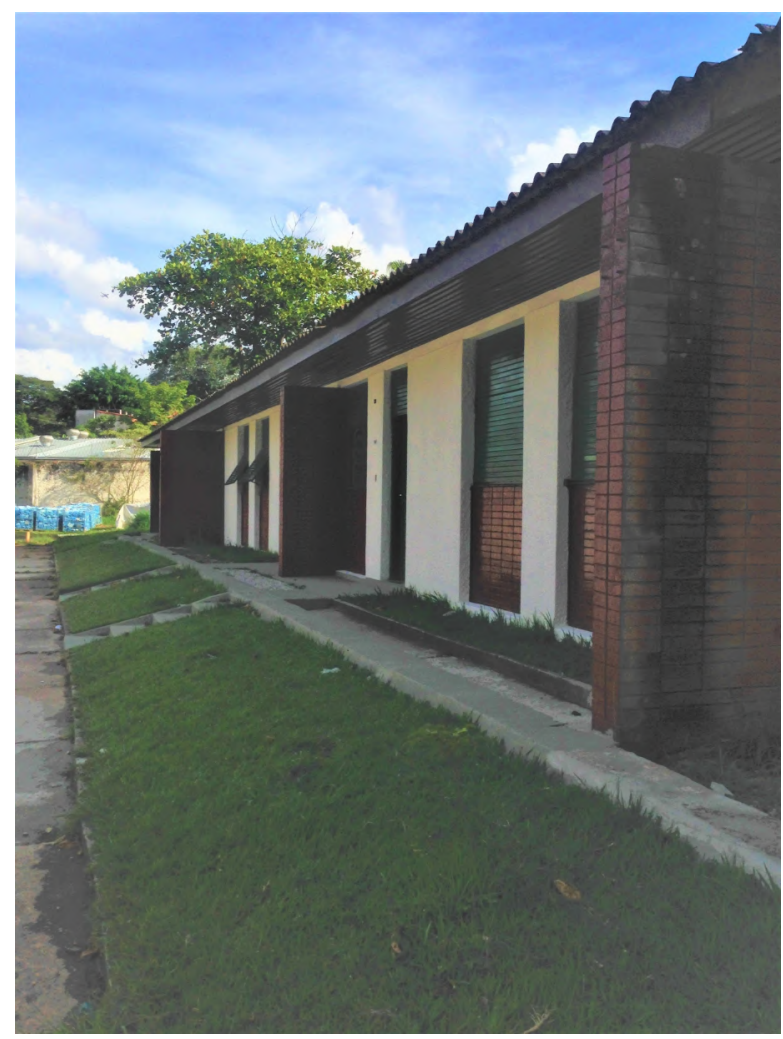

Figura 105: Imagem de uma fileira de casas parcialmente reformadas. É possível notar a unidade formada pelos muros de alvenaria aparente, que avançam para além do espaços das unidades, e o beiral dos telhados. Fonte: autor, dez. 2019

A única proposta discutida recentemente pela instituição, é a possibilidade de demolição do conjunto para dar lugar a um estacionamento, que serviria a um novo edifício para os laboratórios, conforme apresentado em seu Plano Diretor de 2016. Como colocou Anderson de Sá (2019, p.222), ${ }^{85}$ apesar de estar em risco, a preservação de parte do conjunto ainda é possível, mesmo que sejam desfigurados os seus aspectos urbanísticos.

85 O autor apresenta em seu trabalho uma importante análise do Núcleo Residencial e de sua preservação, que buscamos complementar com outras questões trazidas por esta pesquisa. Para mais informações sobre o edifício recomendamos a leitura da sua dissertação, referenciada neste trabalho. 


\subsubsection{Edifício de Pesquisa ${ }^{86}$}

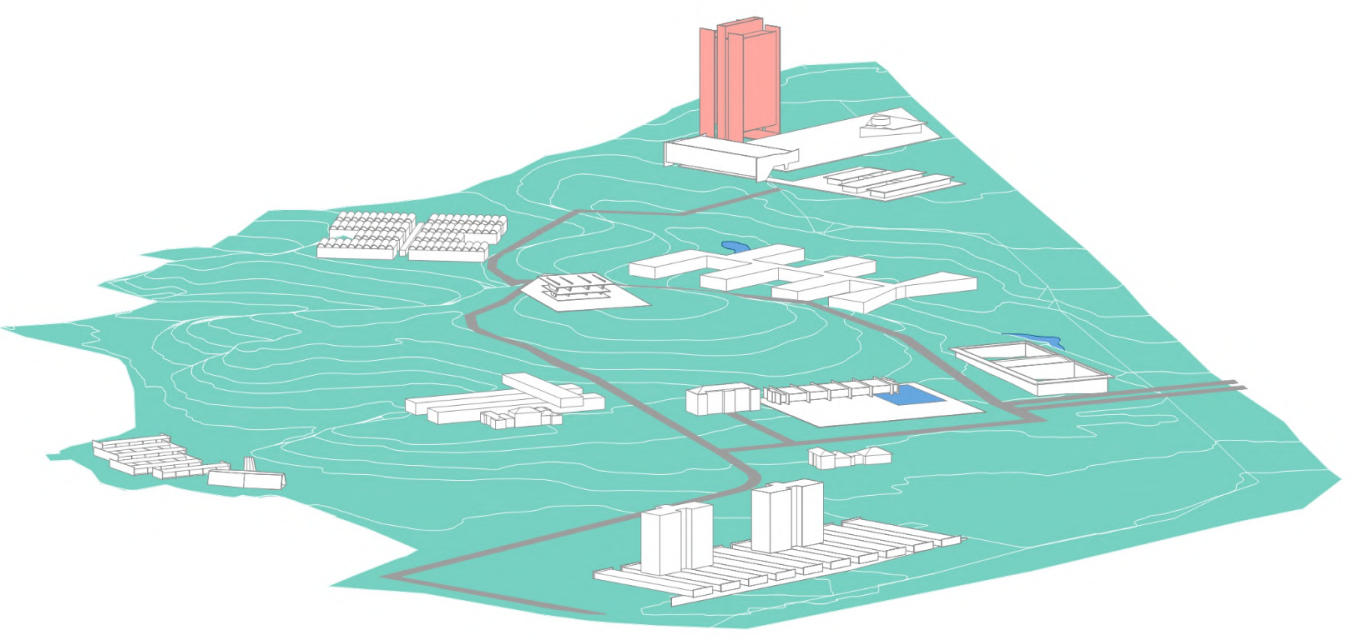

Figura 106: Situação do Edifício de Pesquisa no Plano Geral de 1963. Fonte: desenho nosso.

Formando parte do conjunto de edifícios destinados aos serviços do Butantan, a Tôrre de Pesquisa destaca-se como marco vertical da composição urbanística.

A solução vertical não foi só escolhida por imposição plástica, mas principalmente pela sua perfeita adaptação às necessidades funcionais dos serviços a que está destinada, cujas atividades são pesquisas científicas nos diversos ramos ligados à biologia.

A análise do programa levou à solução vertical que apresenta uma série de vantagens sôbre a solução horizontal, como seja a diminuição das distâncias, a menor extensão das instalações elétricas, hidráulicas e outras. A concentração das circulações, assegura tranquilidade e o isolamento necessário à pesquisa. (Revista Acrópole, 1966, ano 28, n³31, p. 38)

Ao final da década de 1950, o bairro do Butantã já constituía parte da cidade de São Paulo. Não se tratava mais de um território afastado, uma fazenda distante do centro, como aquela cujo Instituto Butantan iniciou sua trajetória no início do século XX. Apesar disso, o processo de verticalização que começava a se manifestar em determinados pontos da cidade ainda não era a realidade do bairro que, até hoje, resiste a tal investida. Deste modo, causa surpresa a proposta elaborada pelo arquiteto

86 Para mais informações sobre os documentos referentes ao projeto, consultar a ficha 03 do inventário (subcapítulo 2.3). 
Rubens Carneiro Viana, no ano de 1961, para o novo edifício de pesquisa do Instituto Butantan: uma torre de mais de vinte andares contrastando não somente com a situação local, de edifícios históricos e de baixo gabarito, mas com o próprio contexto de baixo adensamento do bairro, no qual predominavam residências unifamiliares.

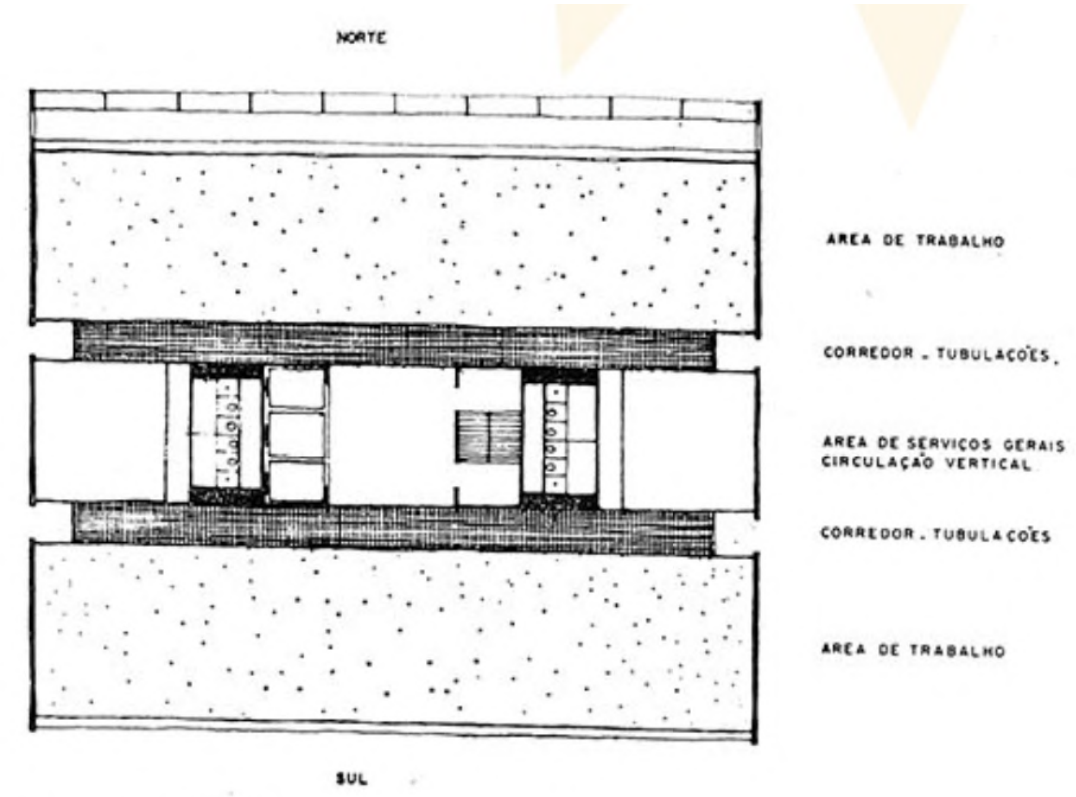

Esquema de instalaçōes e circulação

Figura 107: Partes que compõem o pavimento tipo do edifício: áreas de trabalho nas fachadas norte e sul, separadas por um bloco de circulação e serviços, por onde passam todas as infraestruturas, 1961. Fonte: Revista Acrópole, 1966, ano 28, n³31, p. 38.

Justificando o partido tomado, o texto que descreve o projeto na Revista Acrópole de 1966 ( $n^{\circ}$ 331, p. 38), defendia que a solução vertical adotada ia além de uma escolha formal e estética mas se relacionava a uma questão funcional e programática, que estava amparada na natureza do programa. Sendo um edifício voltado para os laboratórios de pesquisa, no qual trabalhariam cientistas e onde se previa a instalação de equipamentos, a verticalização se apresentava como solução mais adequada à organização das instalações e da circulação interna do edifício, na medida em que o acesso aos pavimentos se daria por elevadores.

Verticalizando o programa, a área a ser construída torna-se praticamente ilimitada, não estando condicionada à distância entre os laboratórios, algo comum em 
edifícios horizontais deste tipo, cujas distâncias são percorridas a pé, resultando em corredores extensos e pouco funcionais. A opção pela torre, também está relacionada à atividade de pesquisa, que requer tranquilidade e isolamento adequados ao ambiente de trabalho. Além disto, acrescenta-se a disposição do edifício no terreno, em um dos pontos mais altos do campus, com vista para toda a região do rio Pinheiros e, mais ao fundo, do centro de São Paulo.

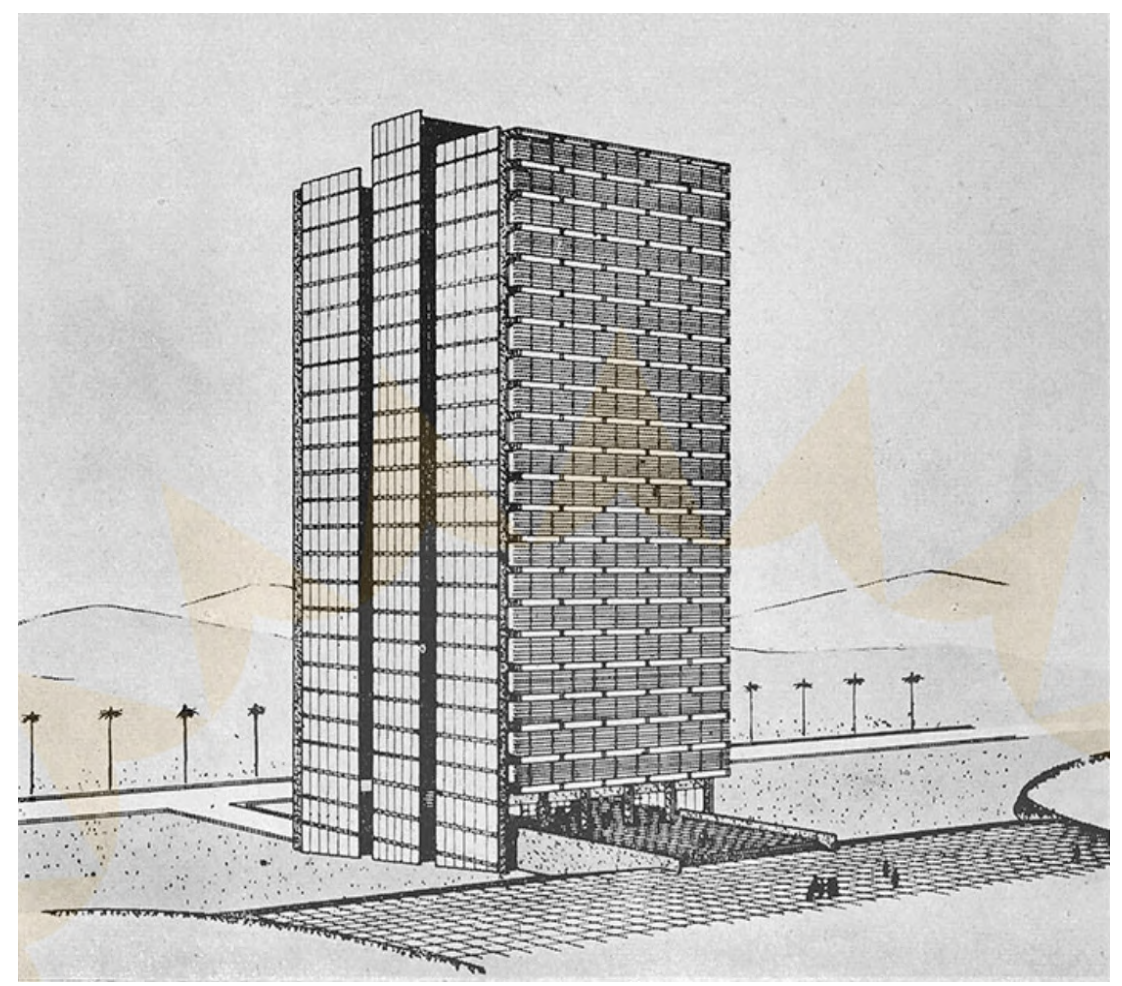

Figura 108: Perspectiva do Edifício de Pesquisa situado em uma esplanada dedicada ao setor de pesquisas do Instituto Butantan, em um dos pontos mais altos do terreno, 1961. Fonte: Revista Acrópole, 1966, ano 28, n³31, p. 38.

Estas características remontam ao centro de pesquisa projetado por Louis Kahn, que comentamos no primeiro capítulo deste trabalho. O Salk Institute, contemporâneo dos projetos modernos para o Instituto Butantan, tem na dimensão do isolamento e reclusão de seus espaços para a pesquisa uma característica central, que é potencializada pelas aberturas do edifício que se voltam para a paisagem do oceano pacífico. Perspectiva, paisagem, isolamento e racionalização dos espaços servidos e servidores, são características presentes no projeto do edifício para o Instituto Butantan em São Paulo. 


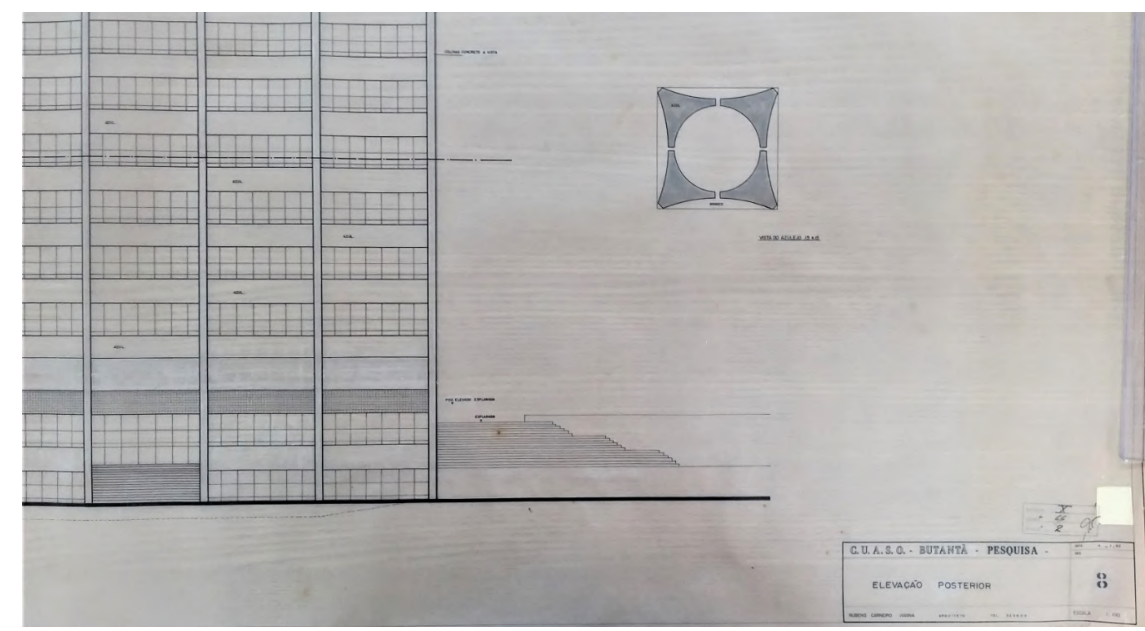

Figura 109: Prancha de projeto detalhando a fachada composta por azulejos, 1962. Fonte: prancha: 19.05, Centro de Memória/IB.

Guardada a particularidade da verticalização em relação ao Salk Institute, o Edifício de Pesquisas de Rubens Carneiro Vianna se volta para a paisagem através de grandes panos de vidro, cuja perspectiva é direcionada pelas empenas cegas de concreto que delimitam a forma do edifício. A preponderância do concreto armado que confere um claro vínculo do edifício ao brutalismo da época, coexiste com outros artifícios e materiais muito presentes na arquitetura moderna brasileira.

A composição plástica de volume caracteriza o destino da obra e é expressão funcional de seus interiores.

Grandes janelas abrindo ao sul, separadas por panos de azulejos e ritmadas pelos elementos estruturais, se opõem à fachada norte, protegida por quebra-sóis horizontais. Essas duas fachadas abertas contrastam com as empenas laterais fechadas, sulcadas ùnicamente pela iluminação dos corredores. (Revista Acrópole, 1966, ano 28, n³31, p. 38)

Nas fachadas abertas do edifício, Rubens Carneiro Vianna adota duas soluções reconhecidas e amplamente associadas à arquitetura brasileira: os brises e o azulejo. Infelizmente, não há uma perspectiva da fachada azulejada do edifício, mas é possível imaginar a interessante composição resultante da união entre os elementos estruturais em concreto aparente, os azulejos e os grandes panos de vidro. Em uma das pranchas do projeto (Figura 109) são indicadas as áreas azulejadas do edifício, nas faixas formadas pelo guarda-corpo logo abaixo das janelas, e define-se o modelo do 
azulejo: de fundo branco com o desenho na cor azul e tamanho de 15 por 15 centímetros.

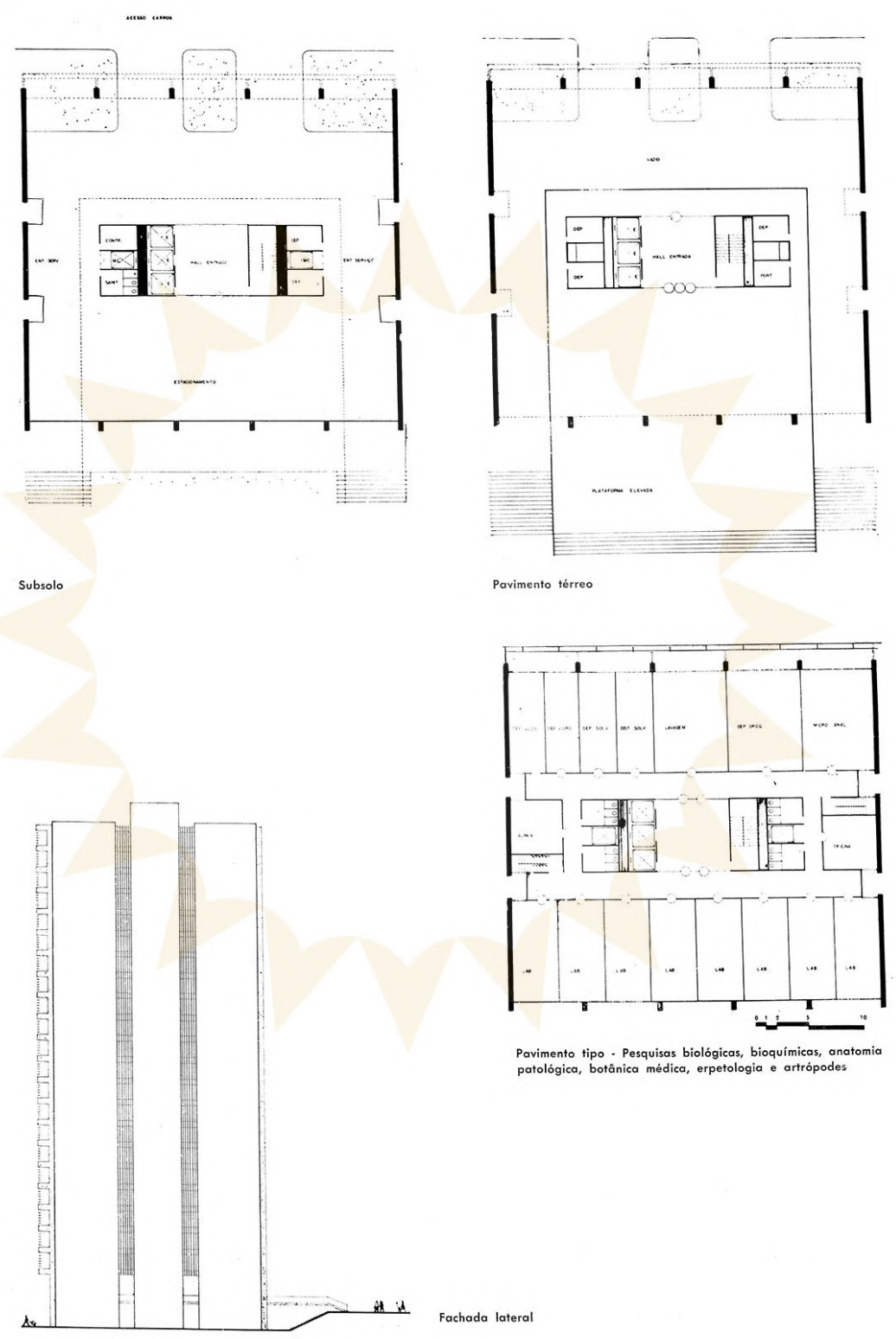

Figura 110: Página da Revista Acrópole, apresentando a planta do subsolo, pavimento térreo, pavimento tipo, e fachada lateral. Fonte: Revista Acrópole, 1966, ano 28, nº 331, p. 39.

Além dos mais de vinte andares de laboratórios, o edifício teria no andar térreo um amplo saguão de recepção, através do qual seriam acessados os elevadores que se situam no ponto médio da planta, desempenhando uma dupla função: de circulação e de sustentação das lajes neste ponto central. A maior parte dos demais apoios são 
periféricos, empenas nas fachadas leste e oeste, e pilares nas fachadas norte e sul, liberando os espaços internos aos laboratórios e espaços de trabalho. O térreo do edifício se abre para uma grande esplanada, uma espécie de praça seca, onde estão o Edifício de Vírus e Genética e o Prédio da Biblioteca e Auditórios.

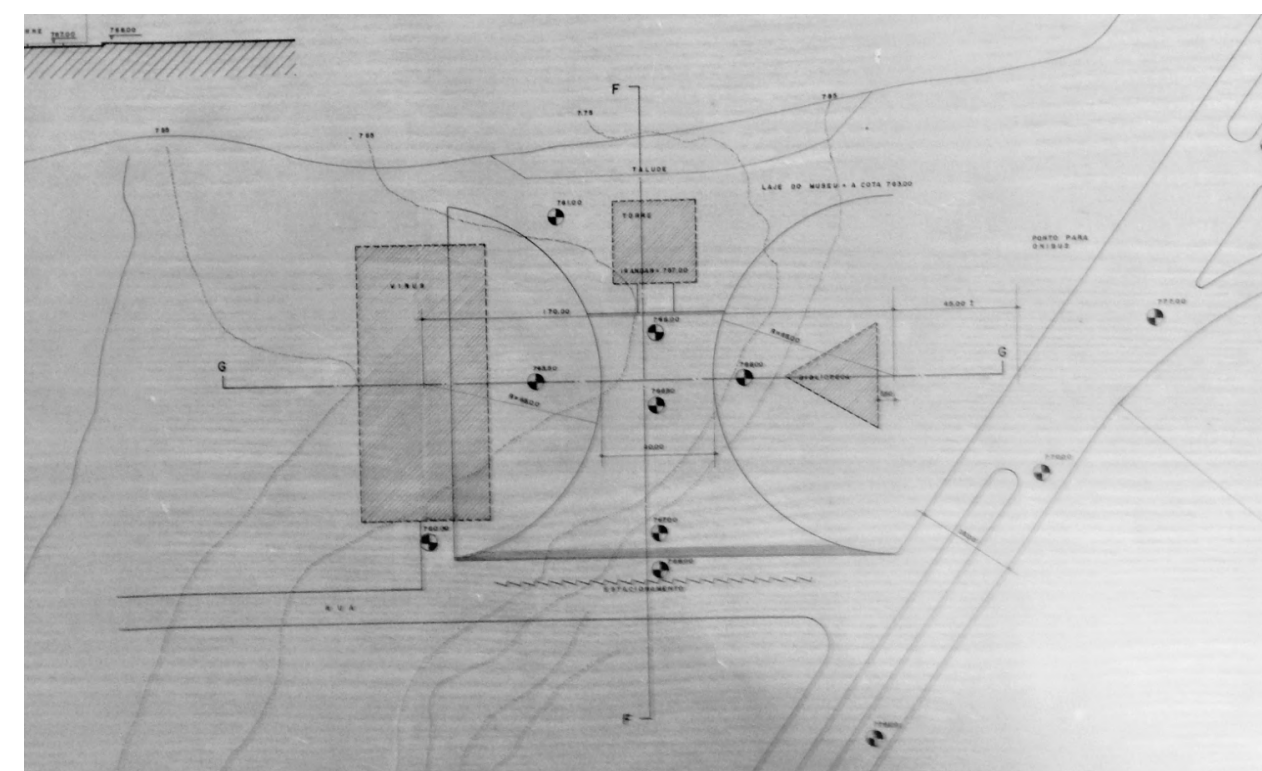

Figura 111: Disposição dos edifícios na esplanada do Setor de Pesquisa, plano do arquiteto Jorge Wilheim, 1962. Fonte: prancha 49.12, Centro de Memória/IB.

Os três edifícios projetados que conformam a esplanada (Figura 111), permanecem em todos os planos urbanísticos de 1961 até 1965, com pontuais alterações. A praça contém uma dimensão de monumentalidade, pelo espaçamento e a escala dos edifícios, com destaque para o Edifício de Pesquisa que, ao mesmo tempo, comporta uma dimensão simbólica, que privilegia a pesquisa como um dos pilares do Instituto. Neste sentido, embora não haja uma referência explícita por parte de Rubens Carneiro Vianna, que enfatiza os propósitos racionais do projeto, o edifício ocupa o lugar de um monumento para a Instituição, tanto pela sua altura, quanto pela sua localização em destaque no campus do Instituto Butantan e da USP. 


\subsubsection{Edifício de Vírus e Genética ${ }^{87}$}

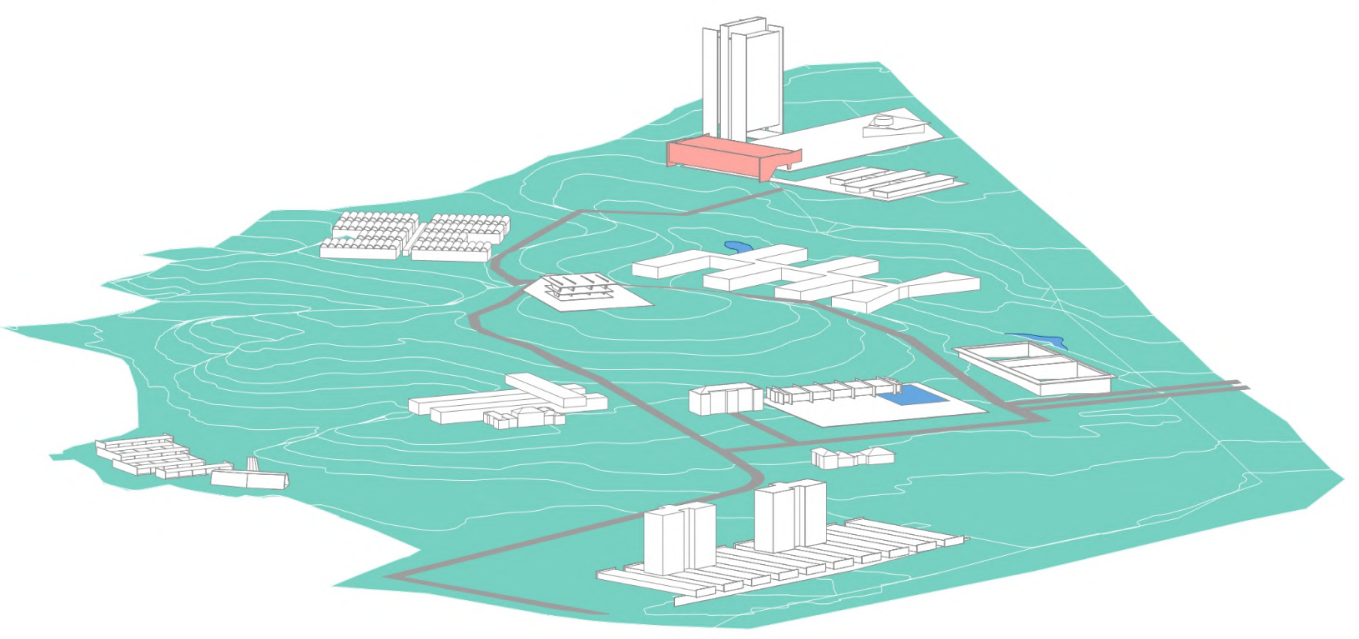

Figura 112: Situação do Edifício de Vírus e Genética no Plano Geral de 1963. Fonte: desenho nosso.

Êste edifício forma parte do conjunto de pesquisa do Butantan situando-se numa esplanada que abrigará a Tôrre de Pesquisa e o Auditório do Conjunto.

Sob uma única cobertura, de estrutura em concreto protendido, abrigou-se dois edifícios distintos: O departamento de vírus que ocupa quatro pavimentos e o departamento de genética, que ocupa um único pavimento. (Revista Acrópole, 1966, ano 28, n³31, p. 36)

O Edifício de Vírus e Genética é um dos projetos mais interessantes do conjunto projetado para o campus do Instituto Butantan. De autoria do arquiteto Maurício Tuck Schneider em 1961, o edifício parte de princípios adotados por alguns arquitetos da época que se tornaram amplamente reconhecidos e reproduzidos. Neste sentido, se nos projetos da época, feitos para o Instituto Butantan e também para a Cidade Universitária, prevalece uma grande diversidade de linguagens e soluções, emprestadas e desenvolvidas do repertório moderno, neste caso, a associação com o edifício da FAU USP, de Vilanova Artigas e Carlos Cascaldi é inevitável.

Assim como a FAU USP, podemos acrescentar o projeto do arquiteto Eduardo Corona para o prédio dos Departamentos de História e Geografia, da FFLCH, e alguns

87 Para mais informações sobre os documentos referentes ao projeto, consultar a ficha 04 do inventário (subcapítulo 2.3). 
projetos não construídos para o setor das humanas, como o Departamento de Sociologia, de Paulo Mendes da Rocha, da mesma Faculdade, e o de Geologia, de Pedro Paulo de Mello Saraiva. Edifícios projetados nos primeiros anos da década de 1960, cuja característica fundamental é a do grande vão, que conforma generosos espaços internos semipúblicos. Basicamente, se caracteriza pela delimitação das fachadas do edifício por empenas ou planos semiabertos por vidro e brises, geralmente elevados do solo e se utilizando da topografia para conformar uma ampla cobertura e uma espécie de praça interna.

Existe uma extensa literatura que discute tais aspectos, geralmente associados a arquitetura moderna paulista, dos grandes vãos e dos edifícios elevados do solo que, em certa medida, reproduzem um ambiente urbano através de sua arquitetura. $\mathrm{O}$ uso desta estratégia de projeto foi ensaiada e desenvolvida por Vilanova Artigas e outros arquitetos, sobretudo, durante o período do Convênio Escolar em São Paulo, adquirindo uma nova escala com Plano de Ação e a construção dos edifícios da Cidade Universitária, cujo edifício da FAU USP tornou-se a obra mais reconhecida do arquiteto. Neste sentido, o edifício escolar tornou-se, por excelência, a tipologia mais associada a esta solução, que ainda hoje aparece em boa parte dos projetos educacionais.

A característica do grande vão se tornou tão importante para a arquitetura moderna brasileira, que acabou por distingui-la da arquitetura brutalista internacional, praticada em diversas partes do mundo na segunda metade do século XX. Ao mesmo tempo, a incompreensão da sua importância e função para o edifício, resultou em algumas críticas descabidas, como se o espaço criado pelo projeto fosse um desperdício de área construída. Em 1966, após a inauguração do Edifício de História e Geografia da USP, o arquiteto Eduardo Corona, autor do projeto, rebateu as críticas feitas no Jornal "O Estado de São Paulo" e "Jornal da Tarde":

[...] O fato, porém, que me causa maior espécie é o de chamarem o pátio interno de área perdida, ou pelo menos, o de interpretarem uma área destinada à conversa dos intervalos de aula, ao abrigo na espera dos horários, às exposições, à interligação das atividades normais com as extracurriculares, como tal. [...] um pátio coberto, apenas pelo prolongamento 
das coberturas das duas alas de salas de aulas, translúcido, concorrendo para a unidade arquitetônica. Não há, portanto, espaço perdido. (Revista Acrópole, 1966, ano 28, n³31, p. 18)

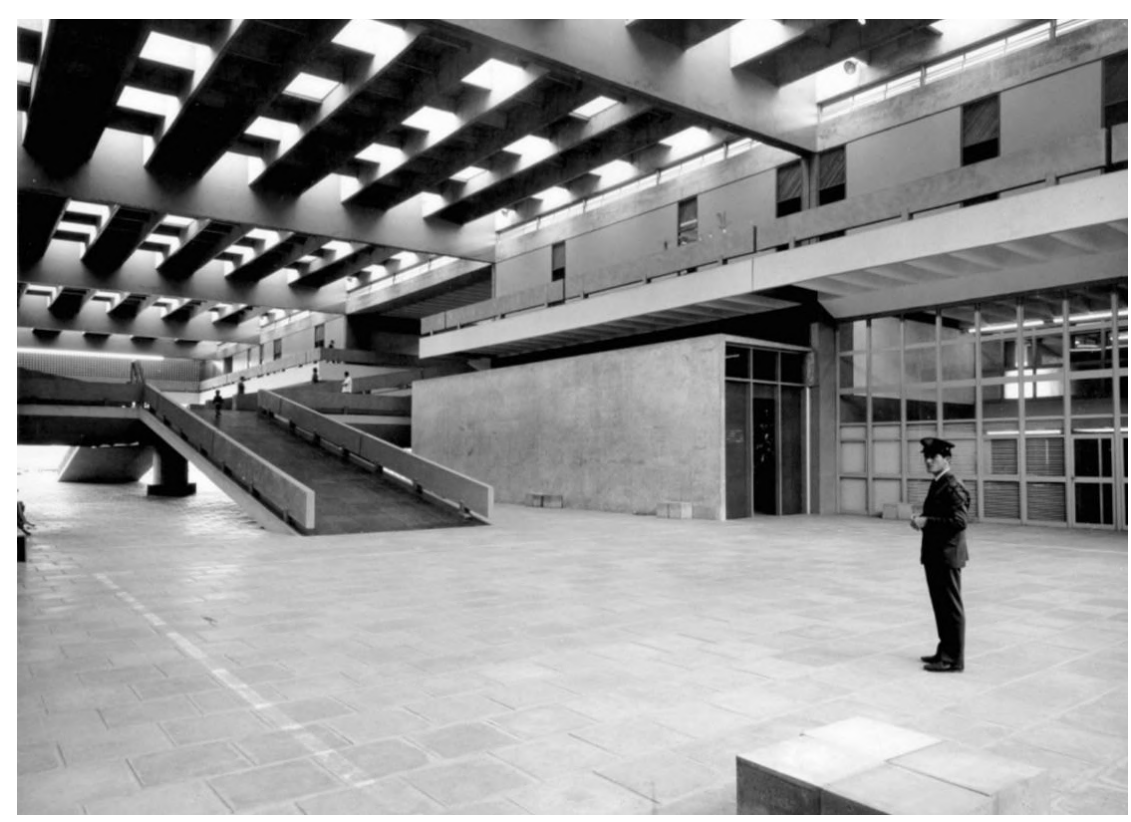

Figura 113: Vão e rampas internas do edifício de História e Geografia da USP, projeto do arquiteto Eduardo Corona em 1961. Fonte: Arquivo COESF.

Disponível em: ww.arquivo.arq.br/projetos/faculdade-de-historia-e-geografiada-usp. Acesso em: 16/03/2021.

Os usos do pátio coberto, elencados por Corona, são amplamente condizentes com as atividades desempenhadas em um edifício escolar, de ensino, pesquisa e extensão, cujo convívio é elemento fundamental do ambiente universitário. Por estas razões, nos projetos feitos pelo PAGE, este uso é predominante nos edifícios escolares e menos comuns em outras tipologias. O Fórum de Avaré, projetado por Paulo Mendes da Rocha e João de Gennaro em 1962, adota este artifício de modo distinto, mas com o mesmo propósito apresentado por Fábio Penteado para o Fórum de Araras de 1959, que se apoia na dimensão pública de um edifício de justiça.

Contudo, é provável que o projeto para o Edifício de Vírus e Genética de Maurício Tuck Schneider, desenvolvido em 1961 para o campus do Instituto Butantan, seja um dos poucos edifícios de laboratórios de pesquisa a adotar esta característica. A escolha do arquiteto está relacionada, principalmente, com a racionalização dos fluxos e da circulação interna e, também, com a qualidade dos espaços de pesquisa. 


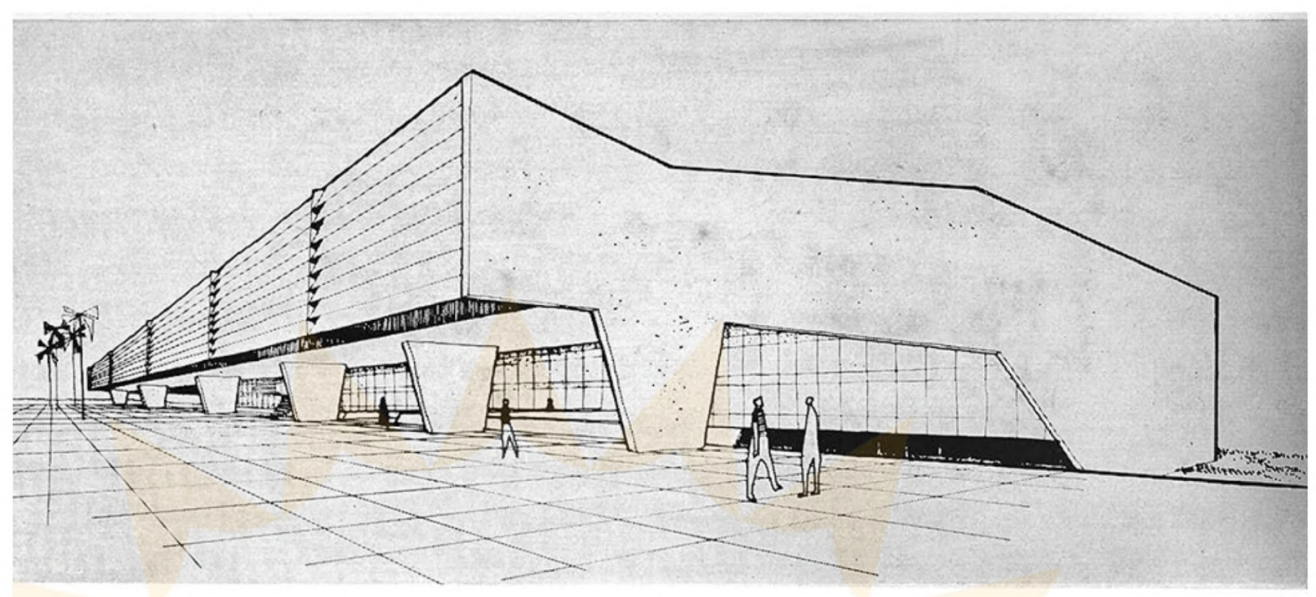

Figura 114: Perspectiva do Edifício de Vírus e Genética, do arquiteto Maurício Tuck Schneider, 1961. Fonte: Revista Acrópole, 1966, ano 28, n³31, p. 36.

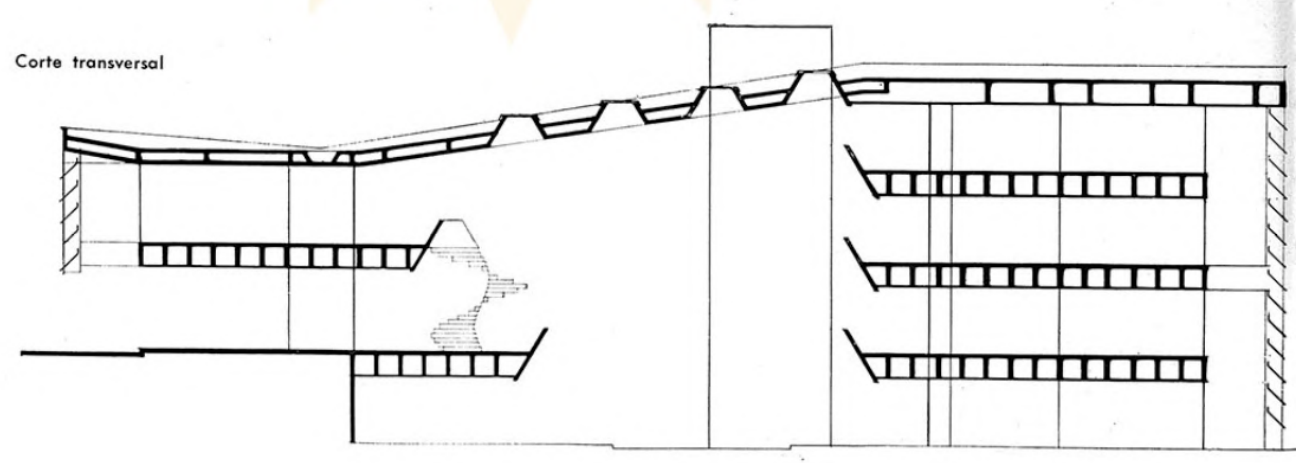

Figura 115: Corte do Edifício de Vírus e Genética, com o bloco de genética e esplanada à esquerda, e departamento de vírus à direita. Arquiteto Maurício Tuck Schneider, 1961. Fonte: Revista Acrópole, 1966, ano 28, n³31, p. 36.

Desta forma, o "vazio" conformado pelos dois blocos do edifício, dispostos sob uma cobertura única, é atravessado por uma rua no nível do subsolo, por onde podem circular os veículos que acessam os espaços de preparo de material e biotério de animais, configurando um ambiente de apoio aos laboratórios. Este eixo de circulação, serve como recepção e distribuição de produtos e animais, sem que seja necessário o acesso pelo nível térreo, onde está a esplanda. 


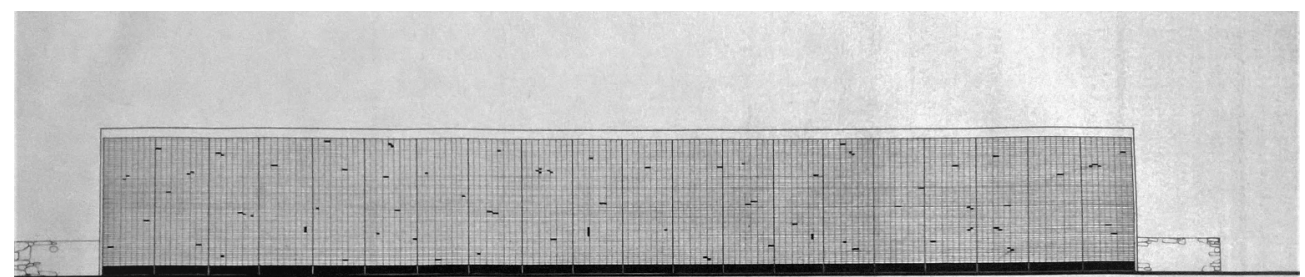

fachadA LEste

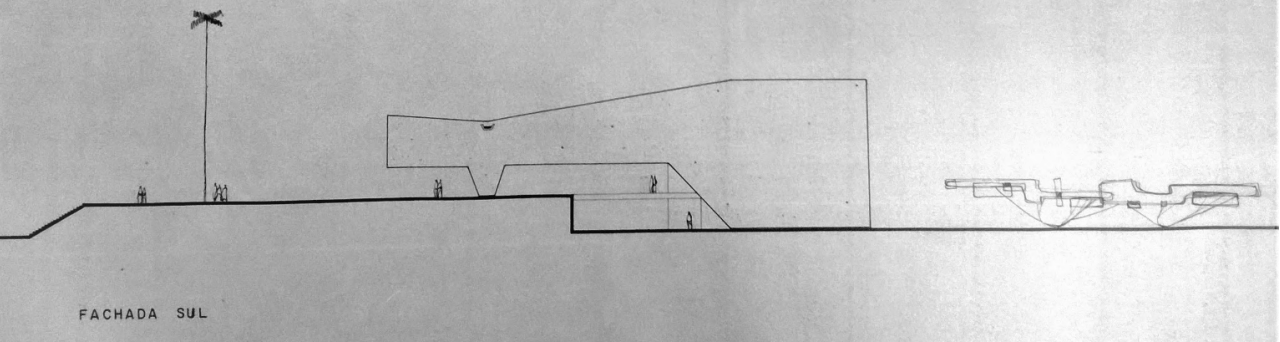

Figura 116: Fachadas leste e sul do Edifício de Vírus e Genética, 1961. Fonte: prancha 42.17, Centro de Memória/IB.

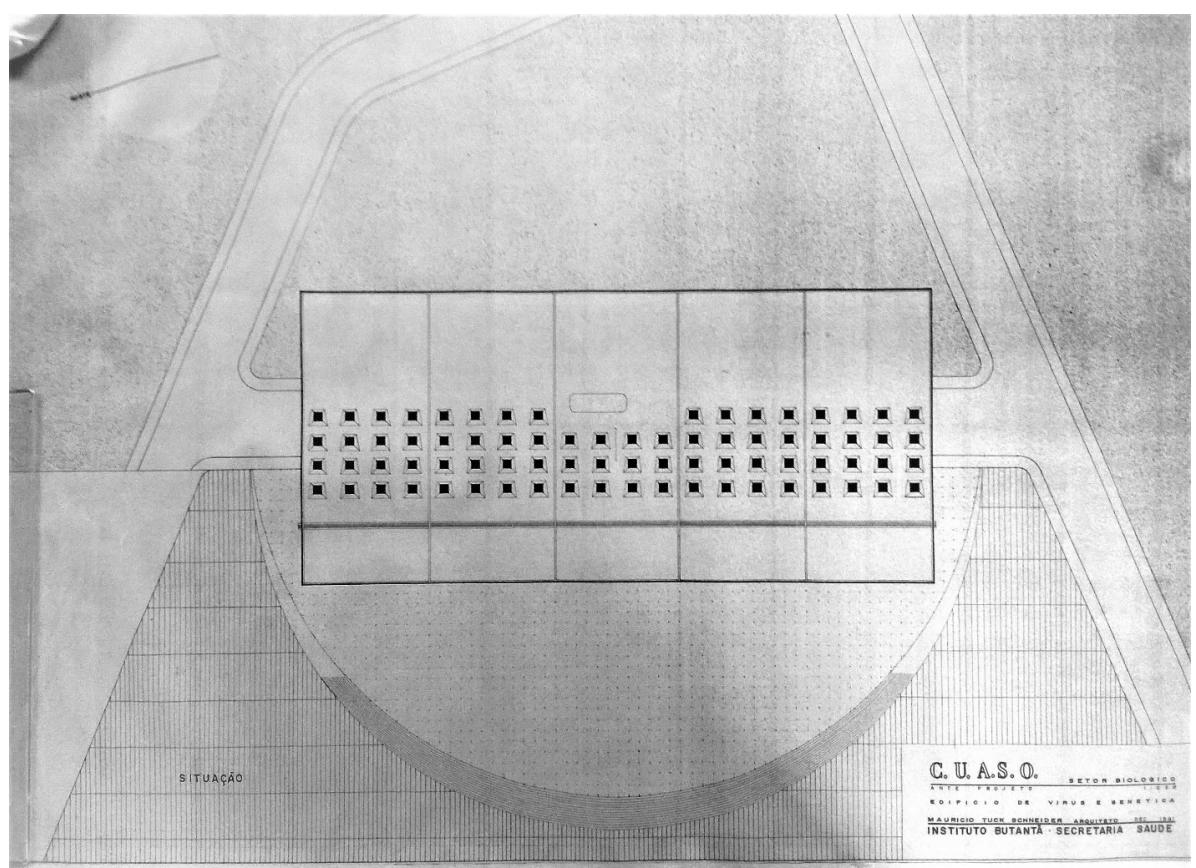

Figura 117: Implantação do Edifício na esplanada do Setor de Pesquisa, onde é possível identificar a rua de aceso ao prédio e a cobertura formada por domus, 1961. Fonte: prancha 42.13, Centro de Memória/IB. 


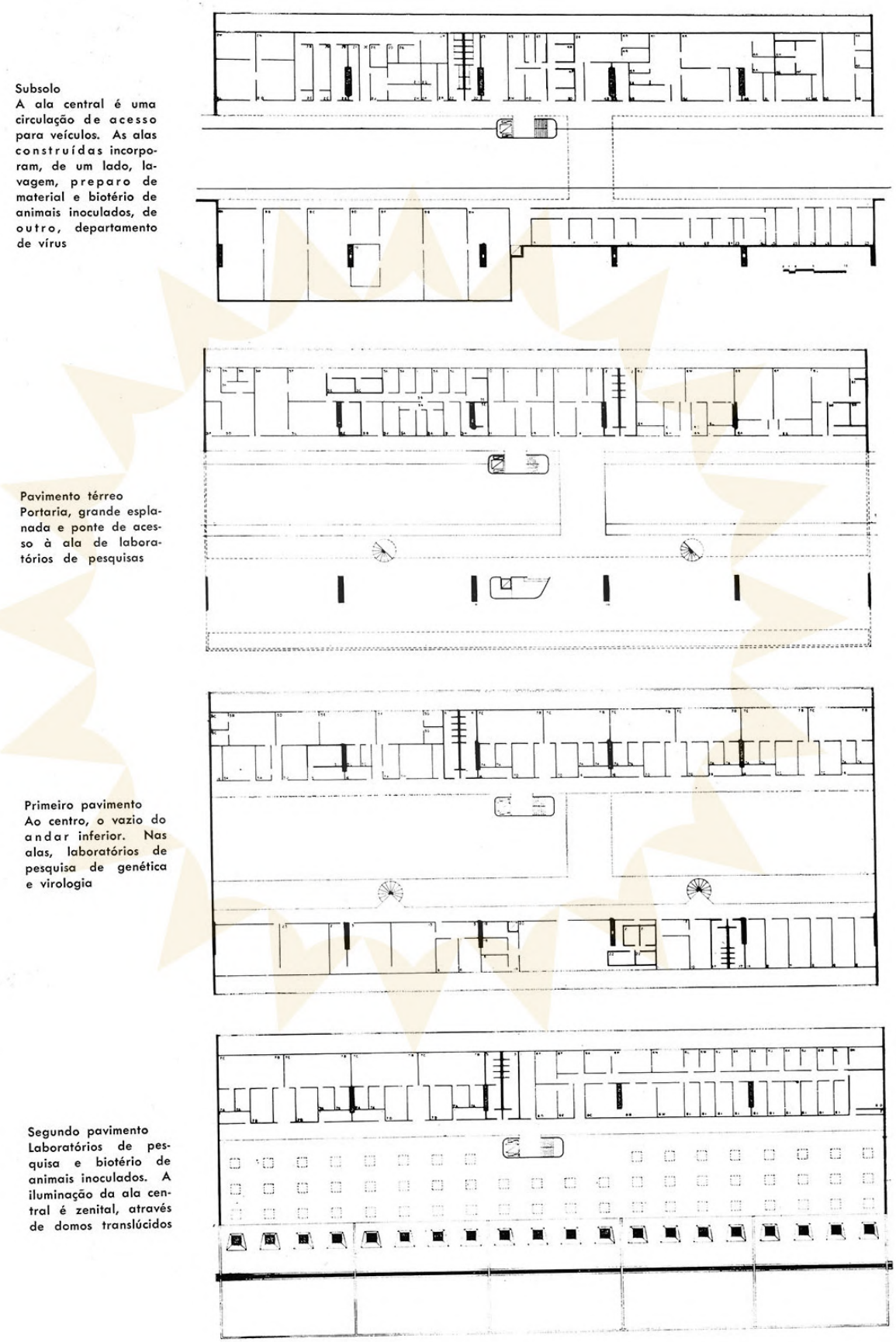

Figura 118: Planta dos pavimentos do Edifício de Vírus e Genética. No terceiro pavimento, a cobertura de domus é inclinada e se conecta ao nível inferior. Arquiteto Maurício Tuck Schneider, 1961. Fonte: Revista Acrópole, 1966, ano 28, n³31, p. 37. 
No andar térreo, o edifício se abre para esplanada do Setor de Pesquisas (Figura 114), onde estão a torre de Pesquisa e o Prédio do Auditório e Biblioteca. A partir deste pavimento, os blocos dos dois departamentos são conectados por uma passarela em cada nível e, verticalmente, por um conjunto de escadas e elevadores. Dentre estes elementos de circulação vertical, se destacam duas escadas em concreto armado de tipo "caracol", que interligam o nível da esplanada ao andar superior, distribuindo a circulação por todo o edifício. O sistema construtivo define estes espaços a partir das grandes empenas de concreto armado, que se apoiam em pilares trapezoidais no nível da esplanada e tocam o chão ao nível do subsolo na fachada oposta. Nas empenas, pilar e viga constituem um único elemento.

O pátio conformado pelo edifício, permite aberturas duplas para as salas e laboratórios, que se voltam, tanto para as fachadas leste e oeste, protegidas por um sistema de brises, quanto para o espaço interno que é iluminado por um sistema de domus, onde a estão os eixos de circulação. Neste sentido, o acesso pela esplanada permite a leitura de todo o ambiente interno do edifício, sendo facilmente identificados os espaços e usos correspondentes aos departamentos que se abrem para o espaço coletivo interno (Figura 114).

Embora o pátio interno do Edifício de Vírus e Genética se explique por motivos de racionalização dos espaços de circulação e de infraestrutura, no sentido dos espaços servidos e servidores, como vimos em outros projetos para o Instituto, há um caráter didático e democrático na proposta de abertura dos seus espaços internos que é compatível com os anseios da arquitetura no ambiente da sociedade brasileira deste período. Neste ponto, sem correr o risco do exagero, podemos afirmar que há uma aproximação com os pressupostos dos edifícios de justiça e edifícios escolares projetados pelos arquitetos do Plano de Ação.

A ideia de que à arquitetura cabia o papel de formação dos cidadãos para a vida moderna e em sociedade, uma função pedagógica desempenhada pelo próprio edifício (COSTA, 2015, p.175-176), é parte fundante da concepção dos edifícios escolares projetados no Convênio Escolar e no Plano de Ação. Os fóruns e edifícios de justiça 
produzidos pelo Plano de Ação por todo o Estado de São Paulo, correspondem aos anseios destes arquitetos de ruptura com as antigas e monumentais tipologias dos prédios de justiça (CORDIDO, 2007, p.225), subvertendo a ordem hierárquica que regem tais espaços.

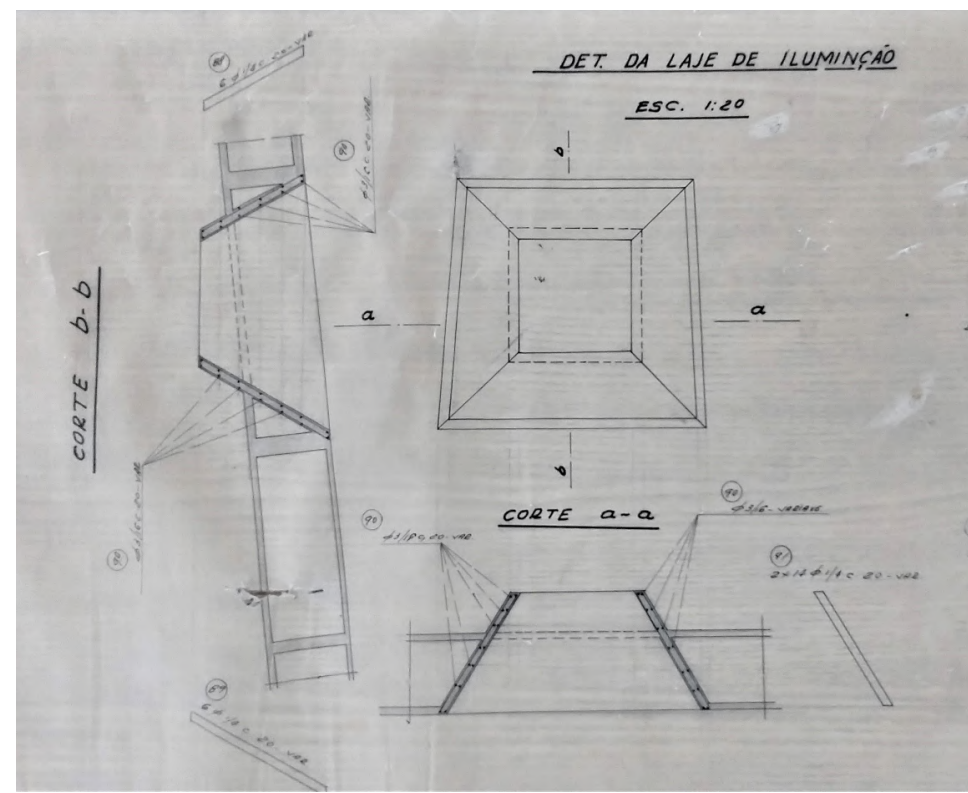

Figura 119:Detalhe do sistema de domus e iluminação na laje da cobertura, Engenheiro Roberto Rossi Zuccolo,1962. Fonte: prancha 15.02, Centro de Memória/IB.

Assim, a grande cobertura que forma os espaços semipúblicos iluminados a partir de aberturas zenitais, a articulação dos níveis por rampas e passarelas, as aberturas envidraçadas constituem um vocabulário arquitetônico que enfatiza, de forma radical, o caráter público e a dimensão coletiva destes edifícios modernos. Em parte, a irreverência destes projetos explicam as posteriores tentativas de supressão e controle destes espaços levadas, a cabo por seus administradores, que frequentemente resultaram no cercamento dos espaços e praças cobertas. ${ }^{88}$

É possível imaginar no projeto de Maurício Tuck Schneider o propósito de abertura dos espaços fechados e enclausurados do ambiente da pesquisa, uma busca pela transparência destas atividades que possibilitaria a aproximação das pessoas comuns com o universo científico, num esforço didático de democratização do espaço

88 No caso dos edifícios de justiça, há também a questão da ocorrência de atentados e outras perturbações cujo controle é dificultado em espaços deste tipo, como ponderou Cordido (2007, p.227-228). 
e do conhecimento. Na esplanada que conforma o Setor de Pesquisa do Instituto, a Torre de Pesquisas se abre no nível térreo, mas somente o Edifício de Vírus e Genética cria uma grande cobertura para o espaço externo, revelando o seu interior para os que nele se abrigam.

Embora tal constatação possa parecer demasiadamente simbólica e, até mesmo subjetiva, o propósito de democratização e difusão da ciência constitui para o Instituto Butantan, assim como para outras Instituições deste porte, como a Fiocruz, um esteio fundamental de suas atividades. ${ }^{89}$ Nos planos elaborados para o campus do Instituto em 1961 e 1963, já se previa um setor turístico com um programa voltado ao público que visita a Instituição desde as suas primeiras décadas.

89 Atualmente, o Instituto abriga três museus com esta finalidade, sendo um deles, o Museu de Microbiologia, inaugurado em 2002, voltado especificamente para ações educativas e a promoção da ciência entre jovens estudantes. 


\subsubsection{Edifício da Administração ${ }^{90}$}

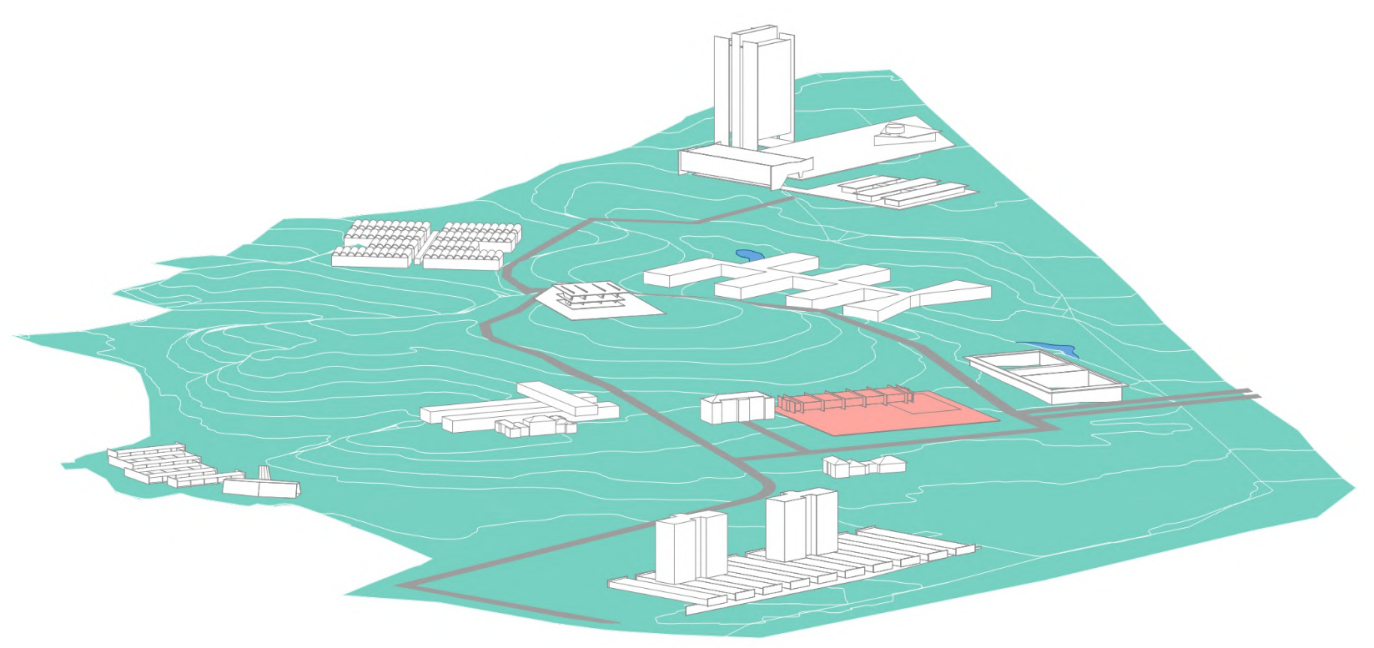

Figura 120: Situação do Prédio da Administração no Plano Geral de 1963. Fonte: desenho nosso.

O Edifício da Administração foi implantado sôbre uma ampla praça. O programa solicitava áreas destinadas à superintendência, administração e serviços gerais afetos ao diretor administrativo.

O bloco arquitetônico se identifica com a área circundante, atentadas suas dimensões e tratamento paisagístico. Foi criada uma estrutura de grandes pórticos apoiados sôbre o "platô", projetados sôbre um amplo espelho d'água.

[...] A estrutura é definida por um conjunto de grandes pórticos balanceados e intercalados por pórticos menores, e interligados por quatro vigas: duas superiores e duas inferiores, estas diretamente apoiadas sobre os pilares. (Revista Acrópole, 1966, ano 28, n³31, p. 40)

Implantado em uma região central do campus do Instituto Butantan, onde se encontram a maior parte dos edifícios do núcleo histórico, o Edifício da Administração se destaca justamente pela localização, aparecendo como elemento articulador dos espaços no Plano de 1963. Isto se deve pela sua posição privilegiada, disposto logo na entrada pela Cidade Universitária, no prolongamento da Avenida Professor Luciano Gualberto, por onde se daria o principal acesso ao Instituto.

90 Para mais informações sobre os documentos referentes ao projeto, consultar a ficha 12 do inventário (subcapítulo 2.3). 


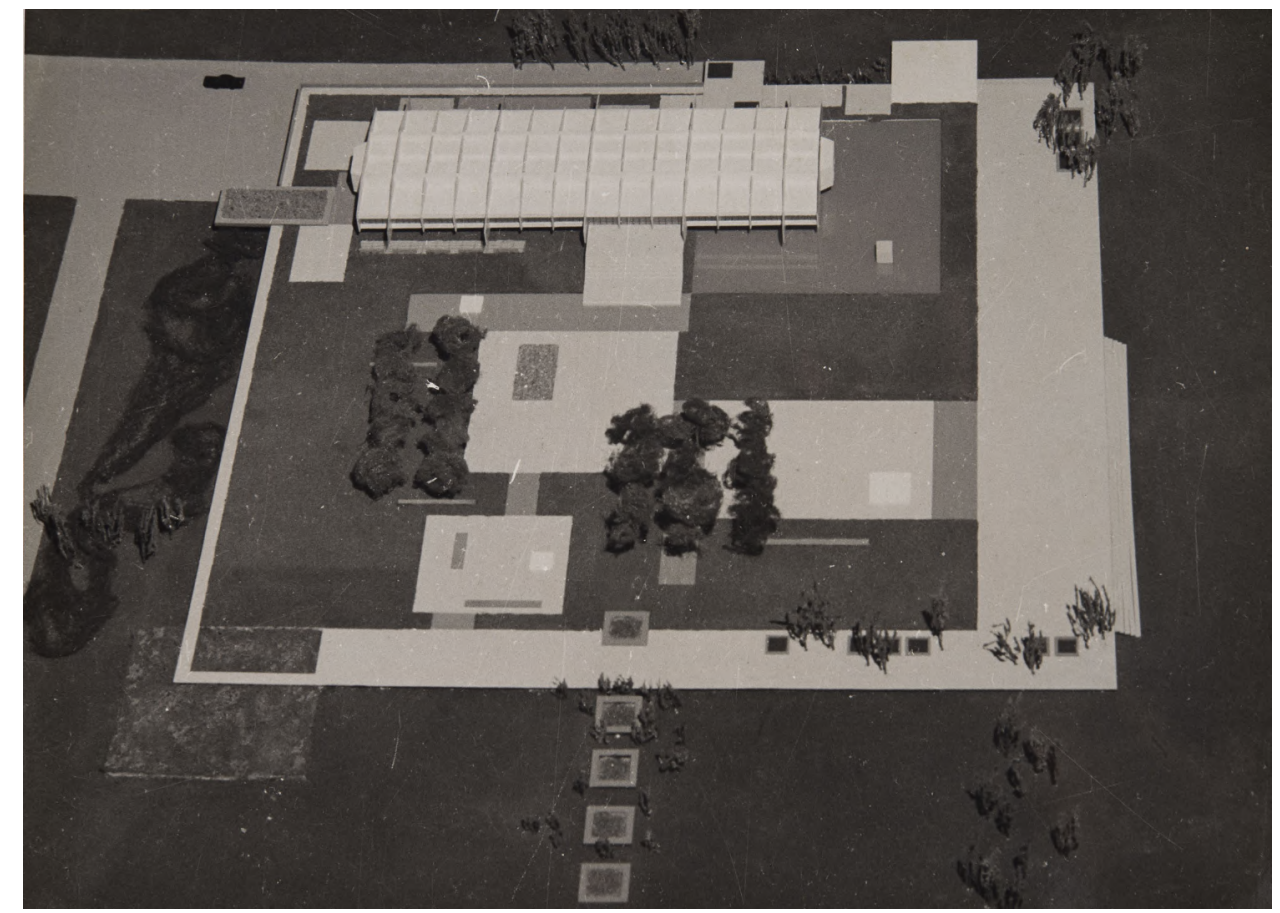

Figura 121: Maquete do Edifício Administrativo do Instituto Butantan, arquiteto João Carlos Bross, 1962. Fonte: IB_ICO_009098, Centro de Memória/IB.

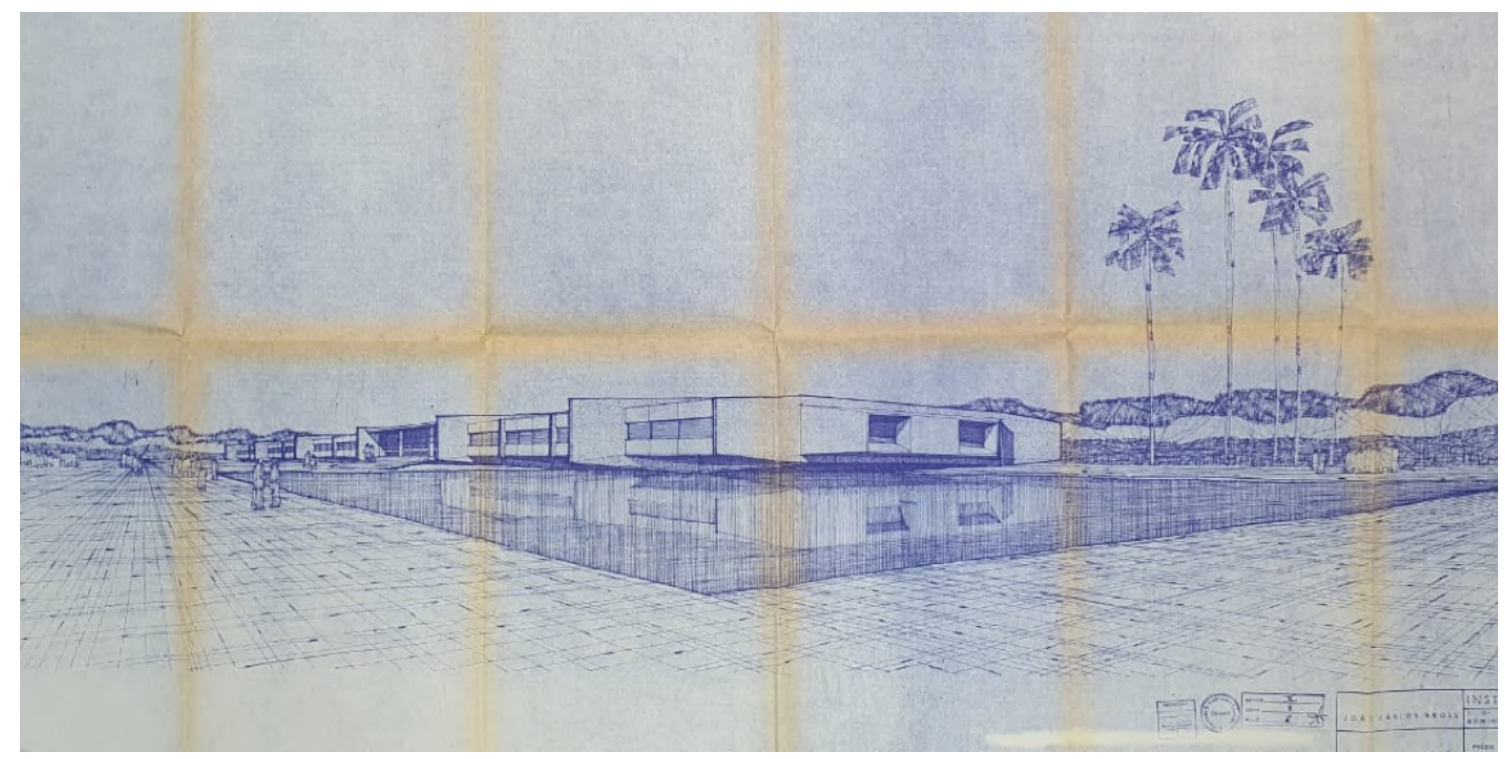

Figura 122: Perspectiva do edifício a partir da praça e do espelho d'água, 1962. Fonte: Fl.26-Administração e Hospital- Prédio da Administração- Perspectiva. , Biblioteca FAU USP. 

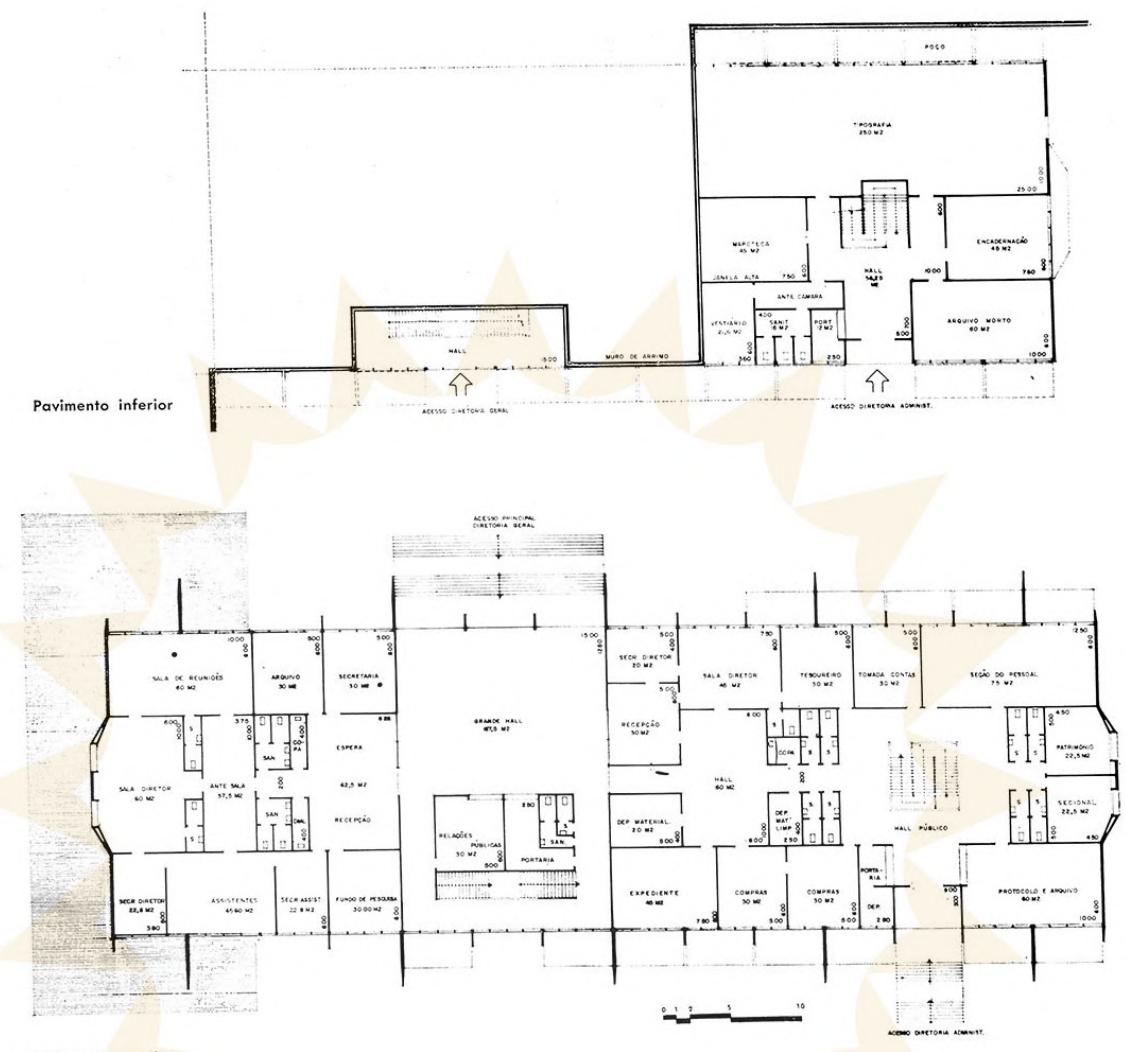

Pavimento superior

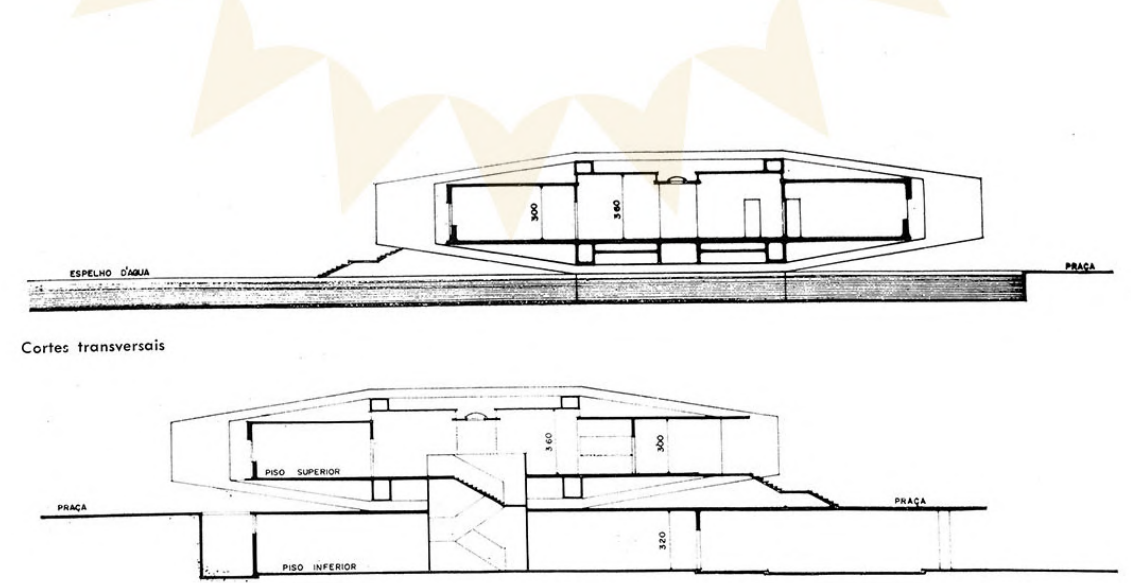

Figura 123: Plantas e cortes do Edifício da Administração, arquiteto João Carlos Bross, 1962. Fonte: Revista Acrópole, 1966, ano 28, n³31, p. 41. 
Projetado pelo arquiteto João Carlos Bross, nascido no Rio de Janeiro e formado alguns anos antes, em 1956, pela Universidade Mackenzie de São Paulo, o edifício compõe uma grande praça situada entre três dos principais edifícios históricos do Instituto: o Prédio Novo (1945), o Pavilhão Lemos Monteiro (década de 1920), (ambos representados na figura 119) e a Casa do Diretor (1931). Embora estejam entre os maiores edifícios do conjunto histórico, com exceção da Casa do Diretor, os dois prédios localizados próximo a praça se dissolvem diante da nova escala, imposta pela arquitetura moderna dos novos projetos.

A dimensão e posição da praça decorre, justamente, da necessidade de um espaço central para o campus, advinda com espalhamento dos edifícios por toda a área do Instituto. Assim, a praça administrativa substitui a centralidade anteriormente existente, que era dada pelo próprio conjunto original de edifícios e pelo eixo principal do campus que os conectava, atual Rua Roberto Kok. Ao mesmo tempo, sua configuração também é decorrência da adaptação do Plano Geral de 1961, que previa a construção de duas grandes praças: uma monumental, na entrada do Instituto pela Avenida da Universidade e uma Praça Cívica, onde estaria concentrado o setor de turismo e seus edifícios, como o museu histórico e um museu geral. Neste aspecto, pode-se afirmar que a praça presente no Plano de 1963, corresponde a uma praça cívico administrativa, pela sua característica de sede da administração e pela sua importância como referência urbanística.

O edifício, por sua vez, é caracterizado por um extenso pavilhão que chega a atravessar quase toda a extensão da praça e se projeta sobre um espelho d'água, sem tocar diretamente o solo, uma vez que os pilares são recuados de modo a produzir tal efeito de "flutuação" do bloco principal. Esta configuração faz com que o projeto se desdobre em três níveis: um piso inferior semienterrado, a praça como nível intermediário, e o bloco principal, acima desta. O acesso principal se dá por uma escadaria no nível da praça e o acesso secundário pelo subsolo, por uma via situada na parte posterior do conjunto. No pavimento inferior, estão localizados os arquivos, mapoteca, tipografia e vestiários. No volume principal, estão todos os setores 
administrativos, divididos em duas alas. Ao lado direito da planta estão as salas de compra, pessoal, contas, expediente, protocolo e arquivo, patrimônio, etc. Ao lado esquerdo da planta, projetando-se sobre o espelho d'água, estão todas os espaços relacionados à diretoria e a sala do diretor.

A estrutura em concreto armado, que faz "flutuar" o bloco principal sobre a praça, é constituída por uma série de pórticos conectados por vigas que atravessam toda a extensão maior do prédio. Pelo projeto, não é possível constatar onde se situam e quantos são os pilares em que se apoia o sistema de vigas e pórticos. Todavia, os cortes do projeto (Figura 123) indicam a linha das vigas inferiores como eixo dos pilares. A estrutura também define as aberturas e ventilação do edifício. Os vãos formados pela estrutura de pórticos recebem a caixilharia das salas situadas nas extremidades, enquanto os domus instalados na laje da cobertura iluminam os ambientes situados no miolo do bloco. 


\subsubsection{Edifício do Museu ${ }^{91}$}

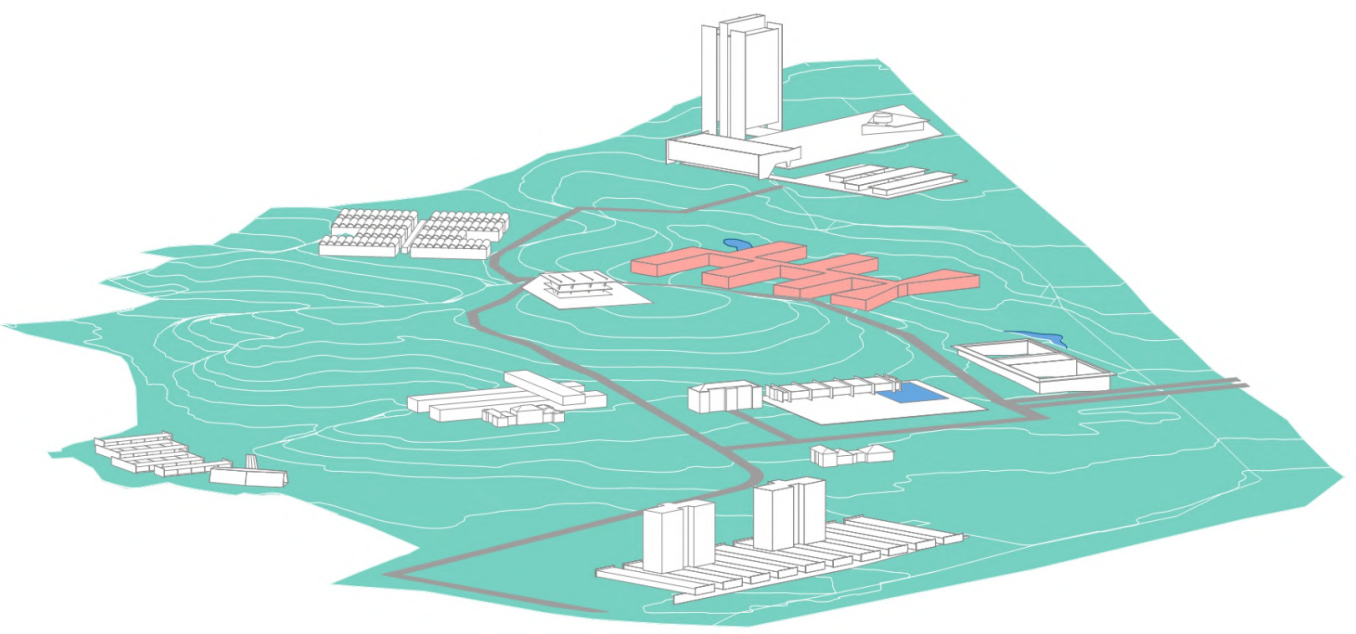

Figura 124: Situação do Museu no Plano Geral de 1963. Fonte: desenho nosso.

Muito antes da chegada do Plano de Ação, se manifestava a necessidade de formação de um museu para o Instituto que, no primeiro ano do Governo de Carvalho Pinto, já acumulava quase seis décadas de história. Inicialmente, o plano concebia um "museu geral", que não estava diretamente relacionado à história institucional, mas às atividades desempenhadas pelo Instituto, que atraiam quantidades cada vez mais significativas de visitantes, apesar da localização de difícil acesso do campus do Butantan.

O aumento de sua notoriedade concedeu à Instituição um lugar no imaginário coletivo por meio de sua associação às serpentes. ${ }^{92}$ Tal imagem não se limitou à população paulistana, na medida em que o Butantan era um centro de recepção de animais peçonhentos capturados por toda parte e responsável pela produção de soros antiofídicos enviados para todo o Brasil. Na cidade de São Paulo, o seu isolamento das áreas urbanizadas e a reduzida compreensão de suas atividades, despertavam a

91 Para mais informações sobre os documentos referentes ao projeto, consultar a ficha 13 do inventário (subcapítulo 2.3).

92 Esta associação está presente inclusive na arquitetura de um dos seus edifícios. Na fachada do Prédio Central estão representadas duas serpentes, na qual uma delas, a Muçurana, se alimenta da outra. A imagem foi muito adotada como representação da atuação do Instituto na pesquisa sobre o ofidismo. 
curiosidade das pessoas, em especial dos visitantes estrangeiros que constantemente perguntavam curiosos aos habitantes locais sobre a Snake Farm, ${ }^{93}$ entusiasmados para conhecer de perto o famoso instituto de pesquisa e os animais expostos ao público em seu serpentário.

A notável divulgação feita por Afrânio do Amaral, em sua segunda passagem pela direção (1928-1938), por meio de seus vínculos profissionais e com instituições de outros países, e através da contratação de pesquisadores estrangeiros (IBAÑEZ, WEN, FERNANDES, 2005, p.130), contribuiu para o aumento da fama internacional do Instituto. Deste modo, eram comuns as visitas feitas por cientistas, personalidades de todo tipo, políticos e chefes de estado como, por exemplo, Theodore Roosvelt em 1913, ou o Rei Leopoldo da Bélgica em 1962 que, nesta data, retornava ao Instituto depois de visitá-lo quando criança (Relatório Anual, 1962, fl.03). O Relatório Anual do Instituto de 1959 (fl.03) classifica o movimento turístico daquele ano como "dos mais intensos", com a visita diplomática da Duquesa de Kent e a Princesa Alexandra da Inglaterra "acompanhadas pelo Senhor Governador Carvalho Pinto e o Senhor Secretário da Saúde e Assistência Social, Fause Carlos".

Na década de 1940, encarregado pelo Diretor Eduardo Vaz (1947-1951) a organizar um plano para um museu provisório e para um futuro museu definitivo do Instituto, o cientista alemão e funcionário do Butantan Wolfgang Büecherl, mencionou que, segundo seus cálculos, o Instituto recebia entre 10 e 12 mil visitantes ao mês, entre brasileiros e estrangeiros (Doc. 1460.1, Inst. Bardi, 1949, p.04).

O lugar escolhido para as instalações provisórias do museu é a Residência do Diretor, construída em 1931 por Afrânio do Amaral. Em 1956 as peças da coleção do museu são colocadas para exposição no térreo da casa, constituindo o museu provisório. Dois anos depois, em 1958, o espaço recebia cerca de 150 a 200 visitantes por dia e já se manifestava o desejo de instalar o futuro museu do instituto no então

93 Segundo uma das filhas do diretor Afrânio do Amaral (1928-1938), que viveu na casa construída pelo pai no Instituto durante a década de 1930, os estrangeiros referiam-se ao Butantan como "Snake Farm". Depoimento dado em entrevista feita pelo autor e pela historiadora e diretora do Centro de Memória Dra. Suzana Fernandes, em janeiro de 2018. 
prédio da cocheira (Relatório Anual, 1958, fl.60). Neste período, a arquiteta Lina Bo Bardi chegou a desenvolver um projeto para as instalações do Museu no Prédio da Cocheira.

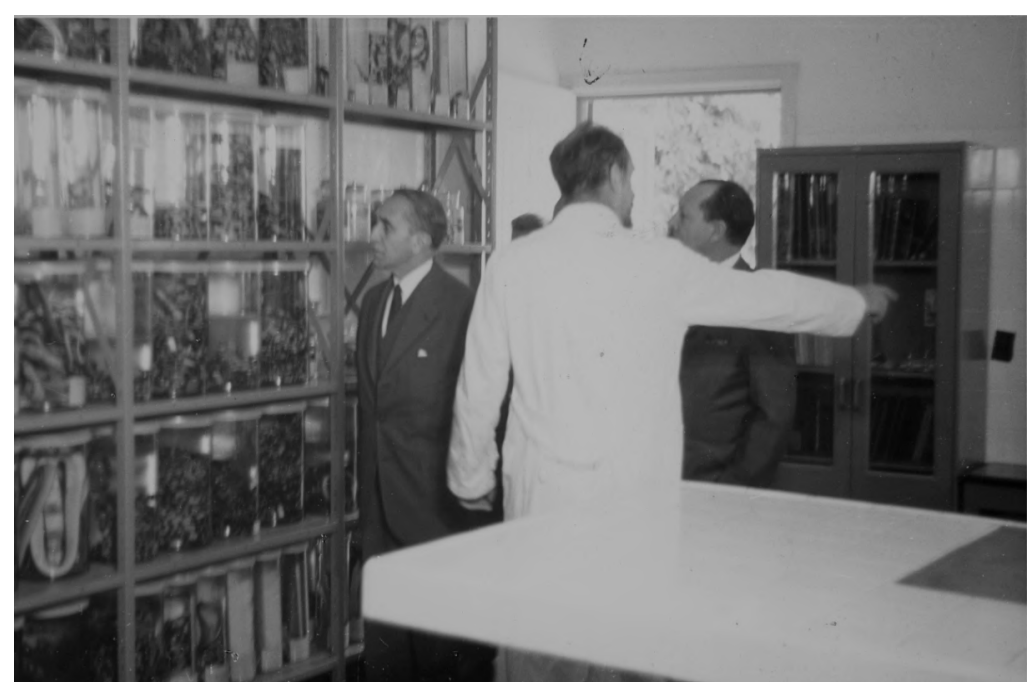

Figura 125: Visita do Governador Carvalho Pinto (primeiro à esquerda) ao Instituto Butantan em 1959. Fonte:IB_ICO_010050, Centro de Memória/IB.

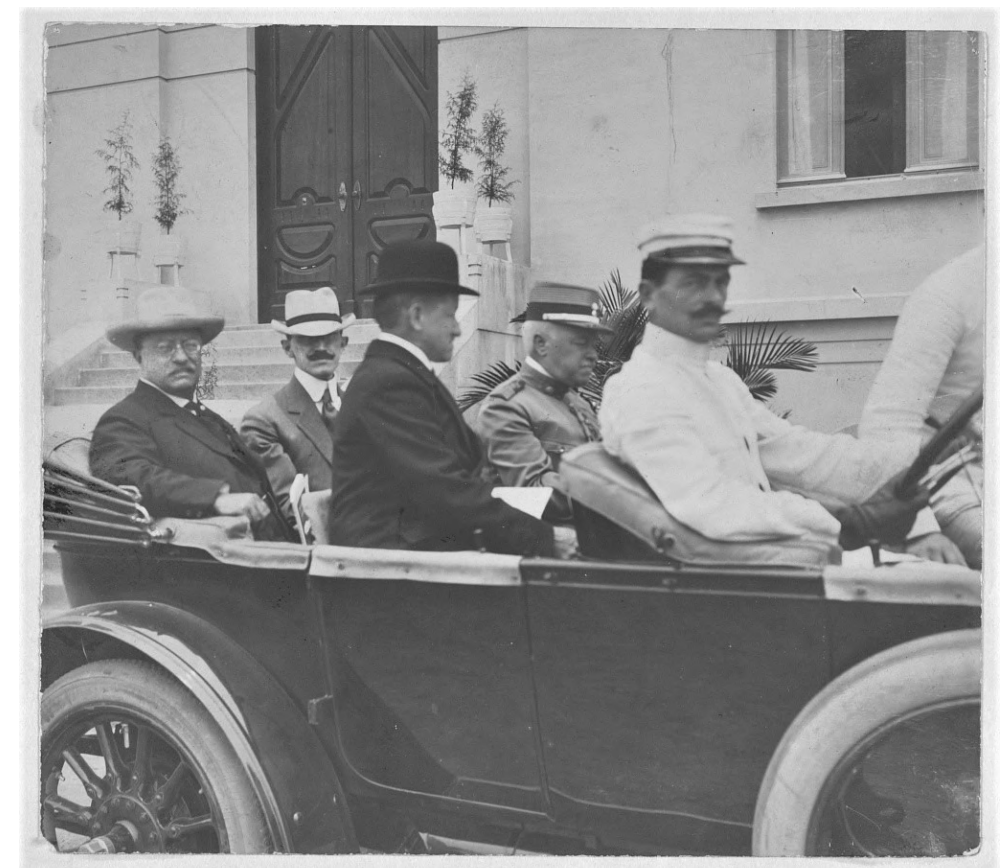

Figura 126: Visita de Theodore Roosevelt (primeiro à esquerda) acompanhado pelo Secretário do Interior Altino Arantes (no banco ao lado) ao Instituto Butantan em 1913. Ao fundo, Edifício Vital Brazil inaugurado em 1914. Fonte: Biblioteca do Congresso dos EUA. 
Contudo, os planos para o tão esperado museu do instituto são revistos e ampliados a partir de 1959, com a chegada do Plano de Ação do Governo do Estado. No Plano Geral de 1961, são indicadas duas localizações: o museu histórico a ser instalado no já escolhido Prédio da Cocheira e um museu geral com frente para a praça cívica prevista no plano. No ano de 1962, a partir da reformulação do plano anterior, é finalmente projetado um edifício para o museu a ser implantado em outra localização, como previsto no plano seguinte, de 1963.

O projeto do futuro museu foi dado ao arquiteto Abelardo de Souza, profissional formado em 1932 na ENBA, experiente e reconhecido no ambiente da arquitetura paulista, tendo sido vice-presidente do IAB de São Paulo, atuando no projeto para a sede do órgão de classe em 1947, entre outros importantes projetos executados na cidade, como o Edifício Três Marias na Avenida Paulista, em 1952, e o Edifício das Nações Unidas de 1953. Foi professor da FAU USP durante a década de 1960, tendo trabalhado com Miranda Magnoli, quem colaborou com o arquiteto como professora-assistente em seus primeiros anos como docente da Faculdade. Neste sentido, apesar das imprecisões quanto a autoria dos projetos, tudo indica que a arquiteta tenha atuado com Abelardo de Souza no projeto para o Museu do Butantan em 1962.

O edifício chama a atenção pelo tamanho, sendo um dos mais extensos projetados no Plano de 1963 e possuindo aproximadamente cerca de 200 metros no sentido mais longo (Figura 124). Justamente neste sentido há um grande eixo de circulação que organiza e distribui o programa e os respectivos acessos aos blocos de exposição, com pé direito duplo e mezanino, com altura final de cerca de 7 metros. A horizontalidade e disposição do conjunto de blocos, que são intercalados por grandes áreas abertas, parece ter como objetivo diluir a enorme área construída do edifício no ambiente natural, criando espaços de permanência, ajardinados e onde estão dispostos os cobris e serpentários para a apreciação dos visitantes.

A intenção de se criar espaços de convivência entre os pavilhões, que estejam conectados com a natureza e com os animais preservados pela instituição, 
desempenha o objetivo de expandir o programa para além dos ambientes fechados que, geralmente, caracterizam os espaços museais. Deste modo, o paisagismo desempenha um papel fundamental na apropriação dos espaços externos, onde estão os serpentários e onde existe um curso d'água sobre o qual repousa o edifício, ao passo que as generosas rampas de acesso convidam o público a adentrar o espaço.

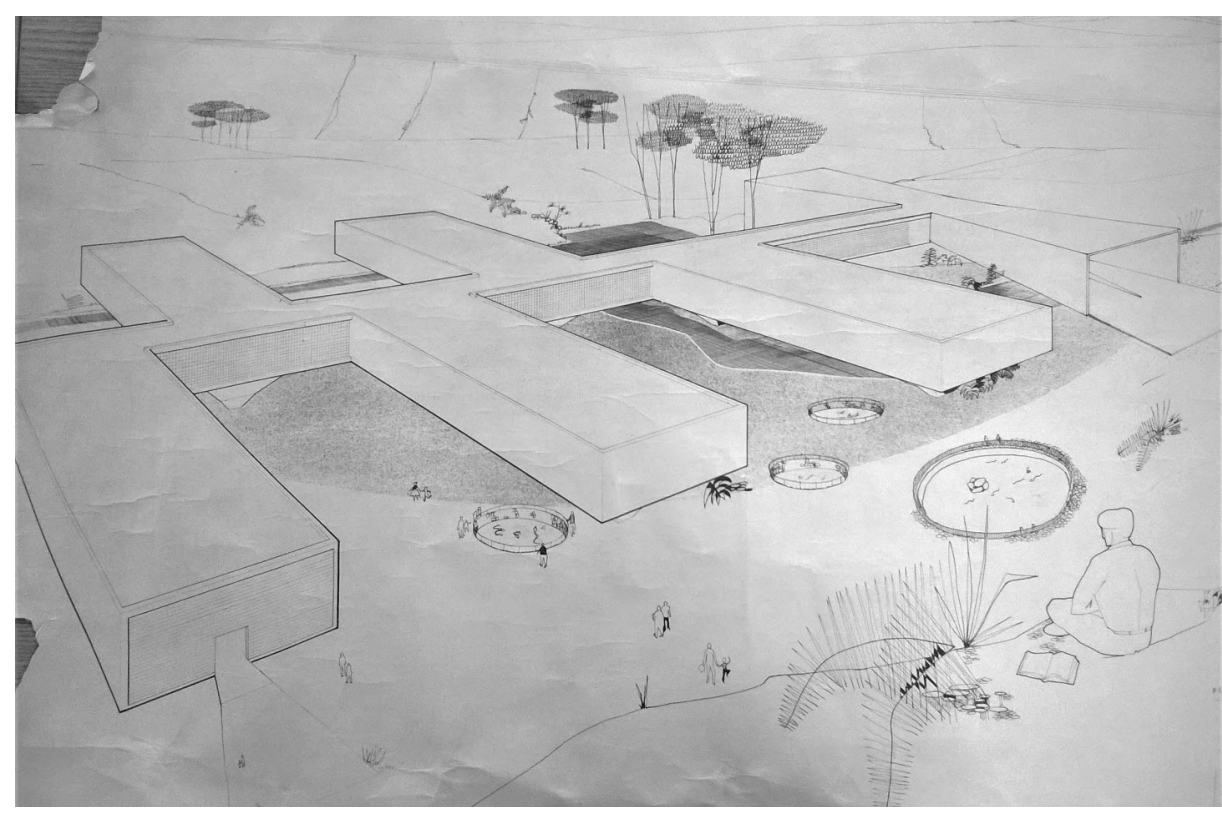

Figura 127: Perspectiva do Museu a ser construído sobre um curso d'água existente no campus do Instituto, mostrando a relação com a paisagem e a disposição dos serpentários externos abertos ao público. Fonte: prancha 55.10, Centro de Memória/IB.

O edifício reproduz a disposição do programa em blocos e pavilhões modulados, como no Edifício da Produção, de Jacob Goldemberg e Luiz Contrucci, ou no Biotério de 1962, cujo projeto também é de autoria do arquiteto Abelardo de Souza, produzido no mesmo ano. No Biotério, a cobertura abobadada e os espaços entre os blocos servem à ventilação e iluminação dos ambientes, enquanto no Museu, a mesma estratégia conforma espaços de convívio e cria aberturas para o lago resultante do curso d'água sobre os quais está implantado o edifício. Desta forma, o conjunto dos pavilhões parece flutuar sobre o terreno, sem que estejam claros os pontos de apoio ou a definição da estrutura (Figura 124). Uma segunda perspectiva do projeto, avança na definição do sistema estrutural, que seria concebido por pórticos executados, ao que parece, em concreto armado, elevando os volumes sobre o 
terreno, enquanto as rampas de acesso alcançam o chão nas extremidades dos blocos.

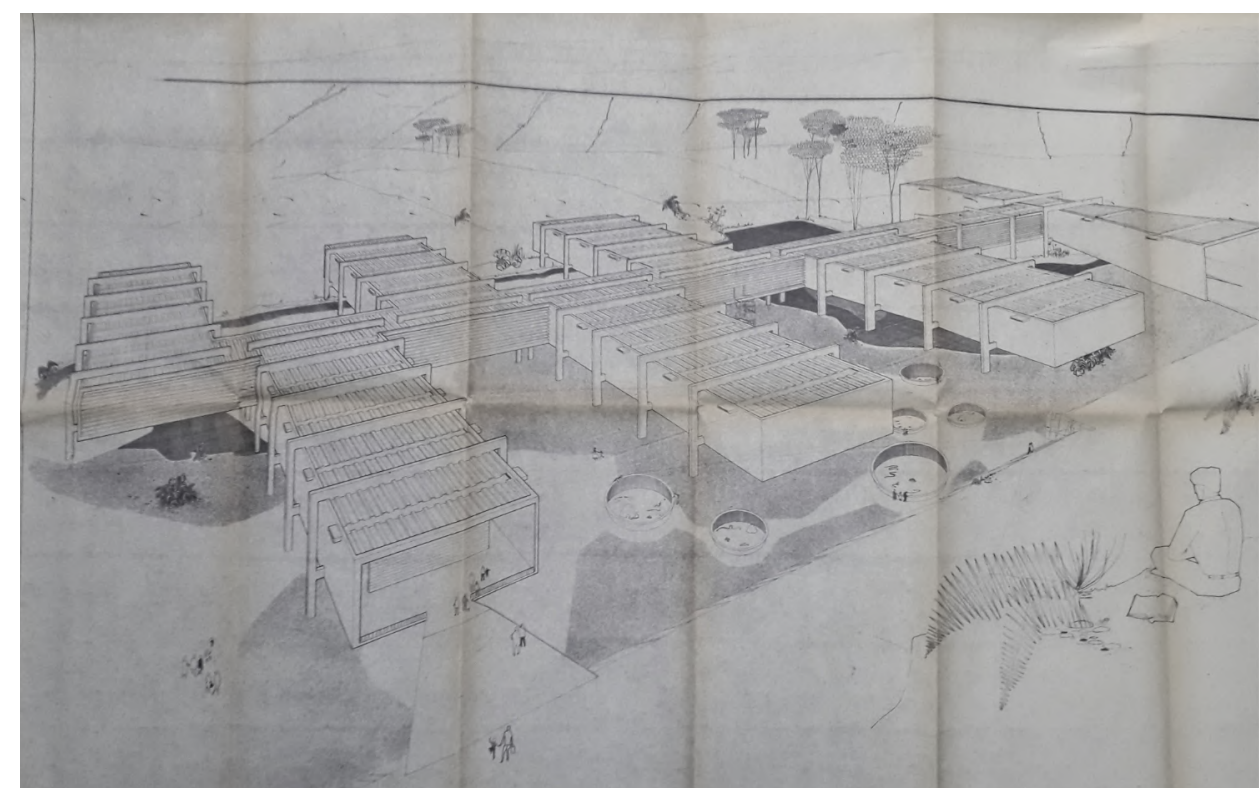

Figura 128: Perspectiva do Museu com a definição das estruturas de sustentação dos volumes que compõem o edifício, 1962. Fonte: Fl.13-Museu- Anteprojeto - Perspectiva, Biblioteca FAU USP.

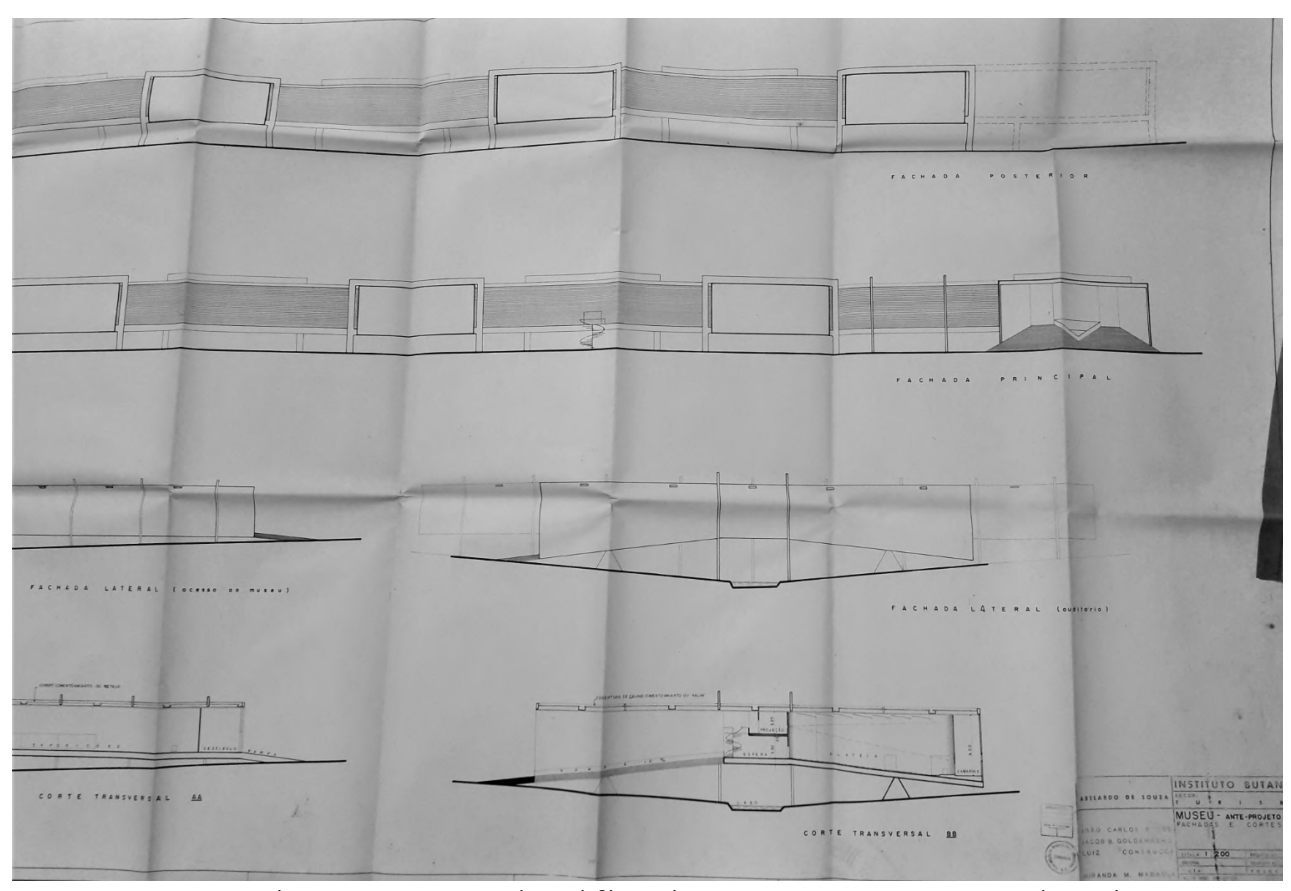

Figura 129: Elevação e cortes do edifício do Museu com a projeção dos pórticos estruturais, 1962. Fonte: FI.12-Museu- Cortes e Fachadas, Biblioteca FAU USP. 
O fato é que os poucos desenhos existentes sobre o projeto do Museu não avançam a uma maior definição de suas características. O programa limita-se a um bloco de acesso ao conjunto, e outro bloco de acesso ao auditório nas extremidades do edifício, enquanto nos blocos intermediários estariam os espaços expositivos com térreo e mezanino, com fachadas cegas e interior iluminado por aberturas zenitais. $\mathrm{O}$ eixo de circulação seria o único ambiente com aberturas laterais em vidro, sobre as quais seriam instalados brises ou elementos vazados, também não especificados.

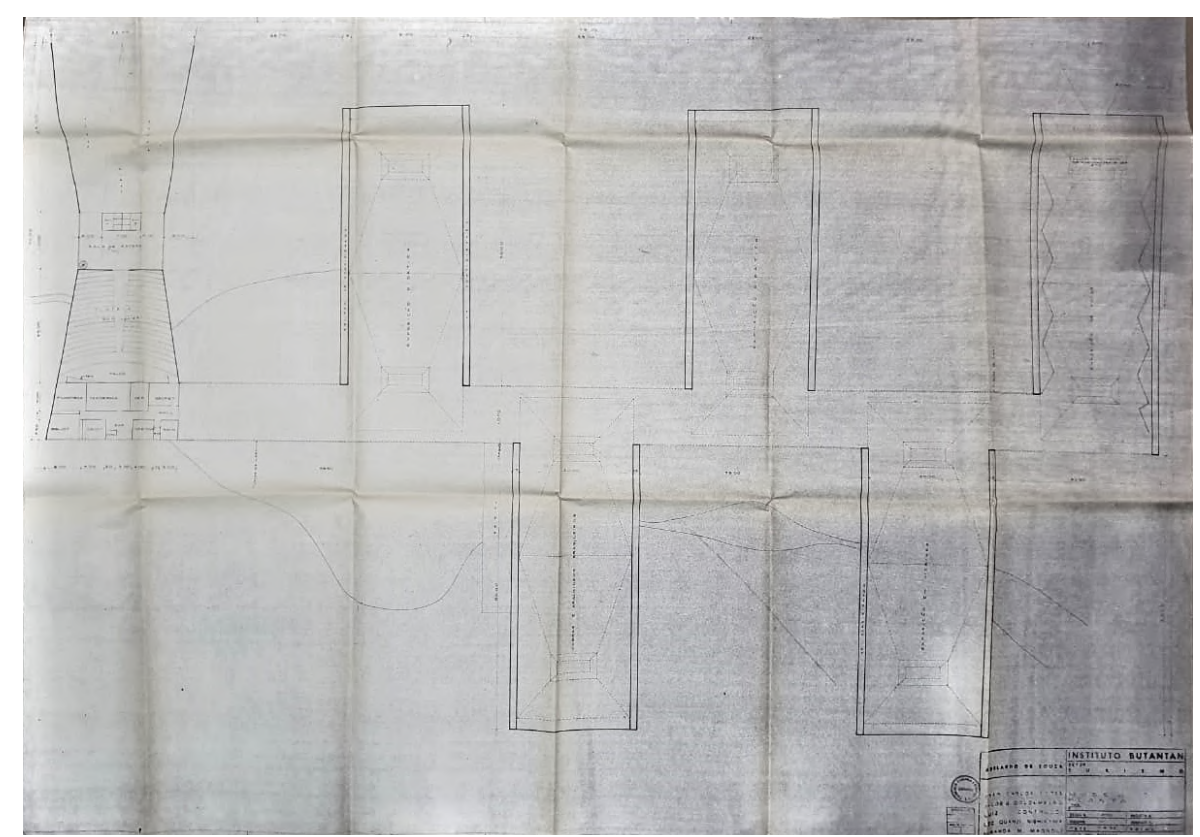

Figura 130: Planta baixa do Museu sem a planta dos mezaninos e pouco legível, 1962. Fonte: Fl.16-Museu-Anteprojeto- Planta do Museu e Auditório, Biblioteca FAU USP.

A única planta encontrada está pouco legível e também não avança nas características do projeto. Apesar do pouco desenvolvimento do sistema construtivo e estrutural, a planta existente parece indicar uma alternativa à proposta dos pórticos estruturais que elevam os blocos do edifício. Assim, é provável que a solução estrutural da primeira versão do projeto (Figura 127), marcada pelos volumes puros e que não tocam o solo, seja possível pela função estrutural das paredes laterais, como enormes vigas de 7 metros de altura que sustentam os blocos a partir do eixo de circulação até as pontas que tocam o chão, onde estão os acessos de pedestres, como é indicado na planta do Museu (Figura 130). 
No que pese o pouco detalhamento do projeto de Abelardo de Souza, que provavelmente teve o seu trabalho limitado ao anteprojeto feito no ano de 1962, a proposta para o Museu condensa, em um único edifício, as dimensões urbanas pretendidas para o Setor de Turismo do Instituto Butantan no Plano de 1961, que estaria disperso por uma praça e dois museus.

Ao concentrar o programa em um edifício desta extensão, é possível que se pretendesse regular a circulação dos visitantes, separando o setor turístico dos espaços de produção e pesquisa, de natureza mais controlada. Em suma, o ganho principal desta proposta está na relação com a natureza e com a paisagem, acomodando o edifício a uma condição topográfica mais reclusa, e dispondo-o abaixo do nível médio do terreno. Por sua vez, o prédio combina uma certa liberdade formal na disposição dos blocos com um desenho funcional, criando vãos e espaços ajardinados abertos, como se fossem praças descobertas, sem o recurso à grande cobertura presente em muitos de seus pares modernos. 

Capítulo 3. Disputas Institucionais

de Planejamento 


\subsection{Da euforia desenvolvimentista à crise do projeto moderno}

Durante os anos desenvolvimentistas, ligada a Brasília e às esperanças do socialismo, havia maturado a consciência do sentido coletivista da produção arquitetônica. Ora, para quem pensara na construção racional e barata, em grande escala, no interior de um movimento de democratização nacional, para quem pensara no labirinto das implicações econômicos políticos entre tecnologia e imperialismo, o projeto para uma casa burguesa é inevitavelmente um anticlímax. (SCHWARZ, 1978, p.79)

Com o golpe de estado e o início do regime militar no Brasil a partir de 1964, coloca-se uma enorme barreira para o que se acreditava ser o caminho natural das forças produtivas no país. Comentando a arquitetura produzida nestes primeiros anos de ditadura, o crítico literário Roberto Schwarz (1978) aponta a contradição existente entre o projeto avançado desenhado pelos arquitetos e a realidade a qual esta arquitetura se aplicava. Em outras palavras, para aqueles arquitetos progressistas que acreditavam, ao menos até a década de 1960, estarem desenvolvendo os espaços de uma nova sociedade, apartada a concepção revolucionária da arquitetura, restou a aplicação de seus conceitos na construção de encomendas privadas, de casas burguesas (SCHWARZ, 1978, p.79-80).

Contudo, apesar de separada a arquitetura de sua dimensão política, o fato é que os arquitetos modernos em São Paulo continuarão, mesmo após a perseguição político ideológica imposta pelo regime, a projetar equipamentos públicos para o Estado, sobretudo nos anos $1970 .{ }^{94}$ De todo modo, nos primeiros anos do regime, a intensa produção cultural ensaiada nos anos anteriores ao golpe de 1964, de intenção democrática e universalizante, foi afastada de seu potencial popular e social, se restringindo a uma classe média intelectualizada, que podia consumir esta arquitetura como objeto de ostentação, símbolo da revolução que não ocorreu (SCHWARZ, 1978, p.79). A questão da função social da arquitetura, cujos arquitetos paulistas assumiram como prerrogativa de seus projetos, desloca-se e perde sentido nestes anos, gestando

94 Ainda nos anos 1960, por exemplo, Vilanova Artigas vai projetar, com Fábio Penteado e Paulo Mendes da Rocha, o conjunto residencial Zezinho Magalhães, cujo projeto se torna o centro de um debate sobre o papel da arquitetura diante do autoritarismo do regime e da suspensão da democracia. 
o impasse moral que terão de enfrentar nos anos seguintes. ${ }^{95}$

Escancarada pelo acirramento da perseguição imposta pelo regime através do Ato Institucional número 5, a questão social da arquitetura já era elemento constitutivo das críticas aplicadas à arquitetura moderna brasileira a partir de 1950. Estas críticas eram, evidentemente, endereçadas aos arquitetos cariocas e especialmente à Oscar Niemeyer, acusado pela aproximação de sua arquitetura com o mecenato estatal e pelo excessivo apelo formal de suas obras. Em duas visitas à São Paulo no início dos anos 1950, Max Bill vai embasar as críticas ao mestre da arquitetura carioca, fazendo ressoar pelos lados paulistas a crítica ao desvio da função social da arquitetura.

Com a construção de Brasília as disputas se intensificam e à Max Bill, somam-se as críticas feitas por outros arquitetos e historiadores europeus reunidos em ocasião do Congresso Internacional dos Críticos de Arte, na cidade de Brasília, em 1959. ${ }^{96}$ Em São Paulo estas críticas são incorporadas à narrativa dos arquitetos paulistas, cujo embasamento é fornecido pelo próprio Plano de Ação do Governo de Carvalho Pinto. Colocando-se frente a hegemonia da arquitetura carioca na construção de Brasília através do Plano de Metas, serão enfatizados os investimentos sociais e ao caráter humanístico intrínseco ao plano governamental de São Paulo, em referência à sua filiação ao movimento Économie et Humanisme criada por Louis Joseph Lebret (CAMARGO, 2019, p.09). Deste modo, o aspecto bruto, a estrutura e a materialidade exposta dos projetos do modernismo paulista, serão enfaticamente destacados como evidências da responsabilidade social do arquiteto, assim como os grandes vãos e o caráter coletivo destes edifícios. Estes elementos são parte constituinte de um projeto de reposicionamento paulista no quadro do desenvolvimento brasileiro, ao qual a arquitetura emprestava uma função simbólica, materializada nos edifícios da Cidade Universitária.

95 Apartada de sua pretensão social a arquitetura paulista vai se configurar, durante as décadas de 1970 e 1980, como forma arquitetônica reproduzida a esmo, descolada de sua origem compromissada com a sociedade. Este período também gestou os impasses do fórum de 1968 da FAU USP, quando se torna claro que o projeto de desenvolvimento nacional em que acreditavam os arquitetos progressistas havia sido dilacerado pelo autoritarismo do regime militar.

96 São eles: Giulio Carlo Argan, Nikolaus Pevsner e Bruno Zevi, opondo-se aos comentários de Sigfried Giedion sobre Brasília. 


\section{Capítulo 3. Disputas institucionais de planejamento}

Estes elementos, que configuram o emaranhado de narrativas e embates que se fez em torno da arquitetura moderna brasileira neste momento e que não se restringiu, nem pode ser reduzida, à disputa interna entre arquitetos cariocas e paulistas, tendo participação direta de personagens estrangeiros aguçados pela centralidade que a arquitetura brasileira passava a ocupar, contribuem para situar o quadro da arquitetura em São Paulo naquele momento, exprimindo um ponto de virada para esta história nos idos de 1960.

O PAGE, que tem início no ponto máximo desta trajetória, marcada pela construção da Nova Capital do país, seria, talvez, o último impulso governamental que despertou nos arquitetos o otimismo de uma produção social e politicamente engajada. Mais do que isto, a intensa e avançada produção destes profissionais ao longo da década de 1950 e nos primeiros anos de 1960, descrevem um ambiente que transborda os limites da arquitetura e se generalizava por todas as instâncias da sociedade brasileira, que se traduz no otimismo e pela expectativa de que, como disseram Fernando Novais e João Cardoso de Mello (1999, p.560), "faltava dar uns poucos passos para nos tornarmos uma nação moderna". Compartilhando a mesma perspectiva, Carlos Martins descreve que a arquitetura brasileira dos anos 1950, que pode ser compreendida no período democrático de 1945 à 1964, constituiu um dos elementos deste ambiente de intensa efervescência política e cultural, que foi capaz de subverter a lógica da produção da cultura que determinava a condição periférica da sociedade brasileira:

[...] Alguém já disse que os anos 1950 foram o último momento em que o Brasil acreditou na possibilidade de "dar certo". Neste momento o país se deu conta de que na arquitetura, como na cultura, não há primeiro, segundo ou terceiro mundos. A arquitetura brasileira não era periférica a nada, como sua música também não era.

[...] A utopia dos arquitetos foi a da possibilidade de construir outro país. (MARTINS, 2010, p.161-162).

Ato contínuo, a abrupta e inesperada reconfiguração da conjuntura política 
ocasionada pelos acontecimentos de 1964, passa por modificar a trajetória do desenvolvimento nacional em curso até aquele momento, subvertendo as bases do projeto nacional democrático e popular, cujos arquitetos estavam a projetar em suas obras pretensamente coletivas, indutoras de uma nova sociabilidade, características incontestavelmente presentes e fundantes dos projetos do Plano de Ação. A suspensão da democracia veio a abalar as bases deste projeto moderno para o país.

Retomando Roberto Schwarz (1978, p.62-63), que ao final da década de 1960 buscava refletir sobre o panorama cultural diante da conjuntura que havia tomado o país, os dois momentos marcados por 1964 e 1968 atingiram de forma complementar a intensa produção cultural do início da década. Primeiro, tratou de cortar os laços que mantinham a ligação entre intelectualidade e o povo, ou "as massas", que faziam deste projeto, um projeto nacional e popular. Contudo, o governo de Castelo Branco não tratou, num primeiro momento, de liquidar estas ideias, se limitando a cortar suas raízes que o viabilizavam como projeto para o país. $\mathrm{O}$ que se fez, foi restringir os espaços de produção cultural e intelectual a eles mesmos, sem que pudessem ser disseminados. Isto fez com que a circulação de um ideário de esquerda se mantivesse em seus círculos restritos: na produção artística de modo geral, no tetro e no cinema, no jornalismo e na arquitetura, a produção é feita "para consumo próprio".

A manutenção relativa e restrita destes círculos, não inibiu o florescimento de uma cultura pujante, de qualidade notável e até mesmo dominante, que produziu obras magníficas, mas preteridas e deslocadas do projeto universalizante do período democrático. No caso da arquitetura, a pretensão dos arquitetos em desenhar a habitação coletiva foi se reduzindo, nos primeiros anos do regime, à casa burguesa, encomendada por outros intelectuais e colegas de partido. 1968 representa, segundo Schwarz, a supressão deste espaço de circulação de ideias que, embora controlado, se expandia a ponto de não haver outra produção cultural que pudesse contrapô-la, pois:

[...] em 68, quando o estudante e o público dos melhores filmes, do melhor teatro, da melhor música e dos melhores livros já constitui massa politicamente perigosa, será necessário trocar ou censurar os professores, os encenadores, os escritores, os músicos, os livros, os editores, 
E prossegue, apontando a reação posta em prática pelo regime:

- noutras palavras, será necessário liquidar a própria cultura viva do momento. $O$ governo já deu vários passos neste sentido, e não se sabe quantos mais dará. Em matéria de destroçar universidades, o seu acervo já é considerável: Brasília, S. Paulo e Rio, as três maiores do país. (Ibid. p.63)

Em suma, a reação conservadora ao ambiente de otimismo com o desenvolvimento do país na década de 1950, rapidamente removeu as esquerdas do espaço político solapando um projeto nacional e democrático, mas que muito pouco havia de revolucionário. ${ }^{97}$ Esta reação foi de encontro aos espaços de produção e de circulação de ideias, as redações, aos teatros, aos eventos e manifestações musicais, contra a parte politizada da arquitetura e setores acadêmicos. Alvos desta escalada autoritária, membros das universidades foram submetidos a inquéritos militares, expulsos e exilados. Na FAU USP, Vilanova Artigas e Abelardo Riedy de Souza são indiciados em 1964 e, em decorrência do Al-5, Artigas aposentado compulsoriamente em 1969, com Jon Andoni Vergareche Maitrejean e Paulo Mendes da Rocha. O mesmo acontece em outras unidades com nomes como Florestan Fernandes, Caio Prado Júnior, Elza Berquó, Paul Singer, Emília Viotti e Isaias Raw, médico e professor que viria a ser diretor do Instituto Butantan entre 1991 e 1997.

Nós arquitetos, por vezes lemos e ouvimos sobre o transcorrer desta história, sobre o fórum de 1968 da FAUUSP, sobre a prisão dos professores Rodrigo Brotero Lefèvre e Sérgio Ferro em 1970, sobre o retorno de Artigas à USP em 1984. Sabemos também, que o edifício projetado por Artigas na Cidade Universitária, no ambiente promissor dos primeiros anos da década, é concluído e inaugurado no auge da ditadura, em um contexto completamente distinto. O PAGE, que teve início neste período, se completou às vésperas do golpe, legando, ao menos no que se refere à arquitetura e ao planejamento, espaços projetados para uma sociedade que não se realizou.

97 Conhecemos as posições da grande parte dos partidos e organizações de esquerda naquele momento, a exemplo do PCB, cujo projeto era pautado pela união com a burguesia nacional, mais com vistas à superação do atraso brasileiro e combate ao imperialismo, do que por um projeto efetivamente revolucionário. Neste sentido, Roberto Schwartz afirma que, em 64, o povo "assistiu passivamente à troca de governos" (p.61). 


\subsubsection{Mudanças no planejamento da Cidade Universitária}

Resultado de um pacto social, como fora o Plano de Ação, no qual conviveram e atuaram profissionais e intelectuais progressistas de diversos posicionamentos e filiações políticas. Plínio de Arruda Sampaio, responsável pela coordenação do Plano e um dos nomes próximos ao Governador Carvalho Pinto, fez parte da Juventude Universitária Católica, assim como o arquiteto Francisco Witaker, que também integrou o grupo de planejamento do PAGE, no qual trabalharam outros muitos profissionais como os economistas Diogo Adolpho Nunes Gaspar, identificado por Plínio Sampaio como um Keynesiano (CORDIDO, 2007, p.304), e Antônio Delfim Netto, que viria a ser ministro durante o regime militar e signatário do Al-5. Além, é claro, dos arquitetos contratados por meio do IAB-SP, em articulação feita por Vilanova Artigas, membro do PCB.

Mais do que uma filiação, a influência exercida pelas $\operatorname{SAGMACS}^{98}$ e pelo Movimento Economia e Humanismo, fundado pelo Padre dominicano francês LouisJoseph Lebret, vem a reafirmar um viés progressista e, sobretudo, reformista do planejamento, que estava amparado pelo vínculo da economia ao bem-estar humano e social. Embora tenha sido fundamental a relação de alguns dos profissionais que atuaram na formulação do PAGE, com o Movimento de Lebret, como Francisco Witaker e Celso Lamparelli, além do próprio Plínio de Arruda Sampaio, que estabeleceu contato com Lebret por meio da JUC, o Plano do Governo de Carvalho Pinto se caracterizou pela coexistência de posicionamentos diversos por parte de seus atores:

Apesar da extensão dos princípios econômicos humanísticos na sua formulação, o PAGE abrigou certa heterogeneidade de idéias por meio dos participantes do Grupo de Planejamento. No conjunto de orientações, as melhorias das condições de vida responderiam a ações ordenadas através do Plano de Governo, no qual o desenvolvimento e o progresso de cada região deveria se ajustar a uma evolução do bem-estar social, porém dentro da

98 A Sociedade para Análise Gráfica e Mecanografia Aplicada aos Complexos Sociais (SAGMACS), como comentamos no capítulo 2.1 desta dissertação, foi uma instituição fundada pelo padre francês em São Paulo no ano de 1947, com escritórios em outras cidades do país. Tinha como base a teoria do Movimento de Economia e Humanismo e atuava no campo do urbanismo e do planejamento desenvolvendo estudos e atividades de consultoria, tendo formado diversos profissionais que se vincularam ao Movimento iniciado por Lebret. A atuação de Lebret acabou recebendo retaliações por parte da Igreja Católica e a SAGMACS foi interrompida com o golpe de 1964. 
perspectiva "moderada", afinada com o pensamento político de Carvalho Pinto. (CORDIDO, 2007, p.51)

Diante desta conjunção política, a pergunta que fazemos é a seguinte: como pôde um plano de abrangência regional, com impacto e pretensões nacionais, agregar interesses e grupos tão distintos?

Em que pese o caráter reformador do Plano, e o progressismo de alguns de seus proponentes, a "perspectiva moderada" conferia um equilíbrio que estava alinhado à própria figura de Carvalho Pinto. Nesta ocasião, a coexistência de posicionamentos e ideias distintas puderam ser articuladas em torno de um objetivo comum, que se pautava pelo interesse nacionalista, no sentido de conquista da autonomia político-institucional e do desenvolvimento nacional, ao mesmo tempo em que se justificava pelo caráter reformador e keynesiano, que evidenciava a necessidade de reformas que reparassem problemas sociais e econômicos latentes, que poderiam agravar crises já existentes.

Neste contexto, o caráter moderado e reformista do Plano de Ação, baseado em uma concepção do Estado como agente do desenvolvimento capitalista, não constituiu um entrave ao campo da esquerda brasileira. Na década de 1950 , a posição do PCB, colocado novamente na clandestinidade desde 1947, passou a se inclinar à resolução das contradições internas e superação do atraso nacional através das reformas estruturais encampando, para isto, uma ampla coalizão de forças entre "o proletariado, os camponeses, a pequena burguesia e a burguesia nacional" (GORENDER, 1987, p.30). Esta posição do partido, que buscou se diferenciar dos ataques udenistas ao governo, que culminaram com o suicido de Vargas em 1954, e em apoio ao Governo de Juscelino Kubitschek, buscava fortalecer um setor nacionalista da política brasileira, com vistas a alcançar a etapa nacional e democrática da chamada revolução brasileira, tema muito debatido pelos intelectuais brasileiros até meados do século XX.

Em suma, em resposta à questão anteriormente colocada, parece haver uma notável convergência entre a posição desta esquerda brasileira com o projeto de 
desenvolvimento estabelecido pelo $\mathrm{PAGE}^{99}$ o que possibilitou tal coesão ideológica do Plano.

Comentamos, no início deste capítulo, que a arquitetura moderna brasileira passou por um momento de revisão crítica durante o seu auge na década de 1950. A crítica ferrenha de Max Bill e de outros críticos estrangeiros, destinada às mais importantes obras da arquitetura brasileira, sobretudo as de Oscar Niemeyer, apontava um descompasso entre os anseios sociais e o apelo formal desta arquitetura, ${ }^{100}$ culminando com a resposta de Oscar Niemeyer na Revista Módulo em 1955. Como se sabe, esta querela teve grande repercussão em São Paulo, que ganhava espaço e notoriedade como centro do debate e da produção da arte e da arquitetura brasileira nesta época.

A arquitetura do Plano de Ação está em sintonia com estes acontecimentos, políticos e culturais da década de 1950. A doutrina humanística de Lebret era rebatida no planejamento, assim como a questão social da arquitetura e o pensamento político dos arquitetos se desdobravam na concepção dos edifícios, produzindo arquiteturas que tensionaram os limites entre o espaço construído e a transformação da sociedade; aspectos latentes nos fóruns, nos edifícios escolares e, por extensão, no planejamento da Cidade Universitária da USP.

No que se refere à conceituação do planejamento para a construção do principal campus da Universidade de São Paulo, a transposição das faculdades dispersas pela cidade correspondeu aos critérios de organização dos departamentos em setores. Isto possibilitou que as unidades fossem agrupadas e dispostas em um ambiente de integração, favorável ao convívio entre os diversos campos do

99 O conservador, mas nacionalista Carlos Alberto de Carvalho Pinto, antes de se tornar governador, encampou uma disputa com a Companhia Elétrica Light, empresa estrangeira que fornecia os serviços em São Paulo, o que fez, segundo Plínio Sampaio, com que ele compreendesse a existência do imperialismo. (CORDIDO, 2007, p.48). Inserido no setor de infraestrutura, os investimentos em energia corresponderam a cerca de $10 \%$ do total dos investimentos feitos pelo Plano de Ação.

100 A crítica ao possível descompromisso social da arquitetura brasileira neste período, pôde ser confrontada a partir dos estudos sobre o Convênio Escolar em São Paulo e sobre a habitação social no Brasil, demonstrando que o recorte analisado por Max Bill estava limitado aos edifícios internacionalmente reconhecidos. Ver: Carlos Alberto Ferreira Martins (1987 e 2010). 
conhecimento. Este aspecto também estava presente no plano para a construção de espaços de convivência da comunidade universitária, de um centro esportivo e de habitações estudantis que deveriam alocar os moradores em apartamentos coletivos, em detrimento de sua individualização (Revista América, 1962, sem página). A cidade Universitária constituiria a grande realização da cultura arquitetônica de seu tempo:

Em reuniões semanais, com a presença do ilustre Professor Anhaia Mello, Diretor da Faculdade de Arquitetura e Urbanismo, e contando sempre com a presença do Professor Ulhôa Cintra, Magnífico Reitor da Universidade de São Paulo, foi conseguida a unidade necessária ao planejamento, que transfomará, estamos convictos, a Cidade Universitária "Armando de Salles Oliveira" na maior demonstração da cultura arquitetônica dos tempos atuais, sem os formalismos e os luxos condenáveis que vimos percebendo e sentindo nas realizações da arquitetura mundial contemporânea. ${ }^{101}$ (Revista América, 1962, sem página)

A universidade é uma das primeiras instituições afetadas com a transformação da conjuntura política do país a partir de 1964. Logo após o golpe têm início uma série de alterações e subversões dos espaços recém-construídos pelo Plano de Ação. O Conjunto Residencial da USP (CRUSP), projeto do arquiteto Eduardo Kneese de Mello em 1961, cujos amplos espaços entre os edifícios priorizavam a convivência entre os seus moradores, passou por alterações tendo um de seus blocos demolido e, a partir de 1968 , com o endurecimento do regime, os estudantes que moravam no conjunto foram expulsos (CABRAL, 2009, p.04).

A construção da Cidade Universitária, que havia sido impulsionada e concretizada pelo Plano de Ação em 1959, no democrático e eufórico ambiente da década, tem seus primeiros edifícios construídos nos anos iniciais da década de 1960, com algumas das obras concluídas durante o regime civil-militar, quando abdica-se dos demais projetos desenvolvidos em favor de uma reorganização do planejamento. A proposta original de constituição do campus em setores que proporcionavam o convívio e a integração, foi suprimida com o advento do regime. Segundo o Engenheiro Savério Orlandi, um dos profissionais responsáveis pelo planejamento da Universidade junto do arquiteto Paulo de Camargo e Almeida:

101 Fala conferida ao arquiteto Paulo Camargo de Almeida, responsável pelo planejamento da Cidade Universitária Armando de Salles Oliveira, junto do engenheiro Savério Andrea Felice Orlandi. 
Foram cerca de quatro anos de muito trabalho, até que fomos impedidos de continuar as obras pois o modelo que estávamos desenvolvendo foi considerado socialista. O projeto acabou sendo mutilado. (SMIRNE, 2017)

Apesar da multiplicidade de profissionais que trabalharam no planejamento, e desenvolvimento do Plano de Ação e nos projetos das edificações, a forma que tomavam estes novos espaços não condizia com o projeto conservador do regime. Mais do que a forma, a existência de espaços que propiciavam a reunião e a sociabilização dos individuos, tornou-se alvo do governo a partir de 1968 , sobretudo no âmbito universitário, como vimos em Schwarz (1978, p.63), onde se encontram espaços de produção de cultural.

Um destes espaços era o setor 3 da Cidade Universitária, definido no planejamento como o "Setor de Ciências Políticas, Sociais e Humanas" que, pelas características do projeto, ficou conhecido como "Corredor das Humanas". Neste setor seriam alocados os edifícios dos "Departamentos de História e Geografia, Letras, Geologia, Paleontologia, Mineralogia e Petrografia, de Sociologia e Antropologia, de Matemática e Estatística, e finalmente a Faculdade de Arquitetura" (Revista América, 1962, sem página). Alinhados aproximadamente na ordem descrita, o conjunto de edificações formaria um amplo eixo localizado na parte central do campus, constituindo um grande espaço de encontro e que interligava os setores da Universidade, características acentuadas pela arquitetura de seus edifícios. Por exemplo, o primeiro a ser construído, o Edifício de História e Geografia:

Este edifício foi concebido para desempenhar um papel decisivo na conceituação que o grupo de arquitetos adotou para o planejamento das construções na USP. Assim como a FAU, no outro extremo deste setor de $1 \mathrm{~km}$ de extensão, todos os prédios intermediários - de outros arquitetos e não construídos - tinham o mesmo princípio: espaços internos generosos, para se interligarem através de ruas e caminhos, ampliando assim as possibilidades de um convívio universitário. (XAVIER, LEMOS e CORONA, 1983, p. 63).

Como indicado pelos três autores, entre eles Eduardo Corona, autor do projeto do edifício de História e Geografia, somente este e o Edifício da FAU de Vilanova Artigas e Carlos Cascaldi foram construídos, dentre os propostos para o "Corredor das Humanas". Em comum, estes projetos tinham a estrutura, os espaços internos e a ideia 
da grande cobertura que conforma espaços de permanência entre as suas principais características. Como se fosse uma praça pública, estes espaços sempre serviram à reunião e ao convívio dos alunos e da comunidade em eventos acadêmicos, exposições e congressos, assim como em manifestações políticas de todo tipo.

Assim como o edifício de justiça que não tem porta e cujo acesso se dá por uma praça, como nos fóruns construídos pelo Plano de Ação, os edifícios da Cidade Universitária constituíam espaços que enfatizavam o caráter coletivo e público da Universidade. Com a mudança de planejamento, boa parte dos projetos que não haviam sido inciados, foram substituídos por novos modelos, em sua maioria construídos por estruturas modulares, de pequenos vãos e espaços restritos às salas de aula e corredores.

Os espaços de convívio e integração, que materializavam a sociedade brasileira em construção, foram consumados no ambiente de acirramento do regime, o que logo nos primeiros anos acelerou a transferência de muitas das unidades da USP para o campus do Butantã, cujo afastamento do centro da cidade acabava por isolar os estudantes. O Plano de Ação, que produziu obras emblemáticas da arquitetura brasileira e singulares do ambiente da arquitetura paulista naqueles anos, em que pese seu traço conservador, teve justamente no caráter democrático a forma como se organizou e se viabilizou na sociedade, como um grande arranjo social habilmente elaborado pelos seus atores. Para ilustrar este arranjo, retomamos outra passagem de Roberto Schwarz:

[...] O símbolo desta salada está nas grandes festas de então, registradas por Glauber Rocha em Terra em Transe, onde fraternizavam as mulheres do grande capital, o samba, o grande capital ele mesmo, a diplomacia dos países socialistas, os militares progressistas, católicos e padres de esquerda, intelectuais do Partido, poetas torrenciais, patriotas em geral, uns em traje de rigor, outros em blue jeans. (SCHWARZ, 1978, p.65-66) 


\subsubsection{Desventuras modernas no Instituto Butantan}

No início deste terceiro capítulo, buscamos fazer uma aproximação com o contexto político e cultural do país na década de 1950. Trata-se de um tema caro à história brasileira, no campo da cultura, da política e da democracia, e que tem sido frequentemente retomado diante da conjuntura crítica na qual vivemos, como se a história contemporânea do Brasil estivesse determinada por ciclos de euforia nacional e tragédia política. Para a arquitetura brasileira, são os anos de uma produção inigualável, fruto da consolidação da profissão no ambiente democrático, gestando espaços de debate de onde surgiram as acaloradas discussões sobre a prática profissional. Assim, apontavam os arquitetos paulistas as contradições da obra de Niemeyer presente, por exemplo, na crítica de Sérgio Ferro aos canteiros de Brasília, que começava a expor o terreno pouco sólido sobre o qual era construída a modernização do país.

Antes do início desta pesquisa, entre 2016 e 2017, durante o primeiro contato com os documentos destes projetos feitos para o campus do Instituto Butantan, e ainda sem a certeza de sua relação com o PAGE e a Cidade Universitária, nos perguntávamos sobre a não construção destes edifícios, que permaneceram desconhecidos e ausentes da paisagem construída do Instituto. A proximidade com a Universidade de São Paulo suscitava a comparação entre os dois espaços em relação a construção dos projetos modernos. Ao mesmo tempo, todo o ambiente favorável, do debate e da produção da arquitetura moderna no Brasil durante a década de 1950, nos direcionou para a mesma pergunta (LUCCA NETO, 2016): diante da dimensão alcançada pela arquitetura moderna no Brasil e pelo Plano de Ação em São Paulo, apesar da construção da Cidade Universitária e dos inúmeros projetos desenvolvidos, por que praticamente nenhuma estrutura moderna foi de fato construída no Instituto Butantan até meados da década de 1960 ?

O ano de 1964 apareceu como uma segunda interrogação a esta pergunta, na medida em que os projetos desenvolvidos para o campus da USP foram desestimulados ou passaram por alterações com a mudança do planejamento. A 
despeito da proximidade com a Cidade Universitária e a organização do planejamento a partir do mesmo órgão, o FCCUASO, o Instituto Butantan guardou certas particularidades a respeito do desenvolvimento destes projetos. Deste modo, apesar do impacto com a transformação do ambiente político pelo golpe de 1964, a mudança do modelo de planejamento iniciado pelo PAGE, se explica por fatores diversos e complementares. Por exemplo, a não continuidade do governo de Carvalho Pinto, que não conseguiu eleger seu sucessor nas eleições de 1962, assim como por fatores endógenos, que se explicam pelos elementos internos à organização institucional, no caso da USP e do Instituto Butantan.

O fato é que, em 1959, o Plano de Carvalho Pinto foi exaltado pelo então diretor Flávio Ribeiro da Fonseca (1956-1963), como oportunidade de modernização que viria a impulsionar, de forma inédita, o desenvolvimento institucional:

No decurso do corrente ano teve a atual direção do Instituto Butantan ocasião de perceber se terem reunido as condições essenciais para situar o Butantan em posição de realizar um avanço excepcional em prazo também excepcionalmente curto. Desconhecer esta oportunidade significaria perder uma ocasião tão favorável como outra até hoje não se apresentou, em 60 anos de existência do Instituto. (Relatório Anual, 1959, fl.06)

E acrescenta, em tons elogiosos, ao final do documento:

Não se deixe de assinalar que só um gesto arrojado, como o do atual Plano de Ação do Govêrno, permitiria o emprego de tão vultuosa dotação nas próximas construções a serem feitas no Butantan, instituição que ficará dotada de possibilidades realmente extraordinárias em relação às atuais, multiplicando o seu potencial de produção técnica e científica. (Ibid., fl.09)

O que se segue a partir do anúncio do PAGE em 1959, como vimos, são acontecimentos que vão minando a perspectiva de modernização atrelada à ampliação da autonomia institucional, transformando as manifestações entusiasmadas em declarações de receio, apelos à preservação territorial e protestos quanto ao decreto de 1941, que destinou a maior parte da Fazenda Butantan ao campus da Cidade Universitária. Assim, em 1961, é firmado o convênio com o FCCUASO, no qual ficam expostas as condições para o planejamento conjunto dos campi, o que acelera o projeto dos novos edifícios e do Plano Geral para o Instituto.

Segundo o Relatório Anual do ano de 1961 (fl.04), a entrega das obras do 
Instituto ao FCCUASO, surgiu por determinação do próprio governador, cujo corpo técnico e os trabalhos em andamento, deveriam contribuir para acelerar os demais, ainda em fase inicial, que eram desenvolvidos no campus do Instituto Butantan. Entre 1959 e 1963, os documentos institucionais revelam uma certa frequência de visitas feitas pelo Governador ao Instituto, sempre mencionando a questão das obras e novos projetos a cargo do Plano de Ação.

O ano de 1961 é um marco desta história. Como vimos em relação aos planos desenvolvidos no período, até esta data os projetos urbanísticos e de intervenção passaram por uma notável radicalização, prevendo a demolição generalizada de edifícios históricos e a dispersão do programa, concentrado no núcleo de edifícios históricos, para toda a área do campus. Também neste momento, são produzidos inúmeros projetos de novos edifícios em um pequeno intervalo de tempo, constituindo um grande esforço para a execução das obras no prazo do Plano de Ação e em consonância com o andamento da construção da Cidade Universitária.

A partir deste episódio, culminando com o Plano de 1963, prevalece uma acomodação em relação aos planos urbanísticos, que passam a contemplar a preservação de determinados sítios históricos, como o que é conformado pelo eixo viário central, onde estão localizados os principais edifícios do núcleo histórico do Instituto Butantan. A partir de 1963, poucos novos edifícios são projetados, enquanto os que haviam sido desenvolvidos até esta data começam a passar por alterações e revisões.

No Relatório Anual de 1964, encerrado o Plano de Ação e com o Butantan sob a direção de Aristides Vallejo-Freire (1963-1966), menciona-se um dos possíveis motivos para o atraso das obras e a não construção dos edifícios, face à situação crítica das instalações existentes:

A renovação das instalações é urgente, pois não há espaço para qualquer aumento de atividades, sendo inadiáveis as construções programadas em colaboração com o Fundo para Construção da Cidade Universitária e que não foram executadas de forma mais ativa por falta de entrega dos recursos previstos nos orçamentos de 1964. (Relatório Anual, 1964, fl.03-04) 
Com este registro, acrescenta-se mais um motivo, ou hipótese, para a não realização integral do projeto moderno no campus do Instituto que, com a mudança do planejamento e da governança do estado, não teria recebido os recursos dispostos pelo Plano de Ação alguns anos antes. Contudo, sem deixar que a hipótese da limitação dos recursos prevaleça, o mesmo documento, mais uma vez, menciona a perda de território para a Universidade de São Paulo, ao citar as obras necessárias à Fazenda São Joaquim, para onde se deslocou parte das atividades do Instituto, depois da cessão da Fazenda Butantan em 1941:

[...] A aquisição de vários lotes de cavalos para produção de soros está exigindo a imediata construção de baias para, no mínimo, 500 animais, o que não pode ser mais adiado, posto que a mortalidade de cavalos usados para imunização tem sido elevadíssima, tendo em vista as precárias condições da Fazenda São Joaquim, que não conta com qualquer proteção aos animais que, mesmos doentes, permanecem ao relento, desde que os serviços de veterinária tiveram de ser transferidos para aquela Fazenda, devido à ocupação de grande área pertencente ao Instituto pela Cidade Universitária. (Relatório Anual, 1964, fl.05)

Embora tenhamos inciado este tópico com a pergunta sobre a razão da não construção destes projetos modernos, em que pese a conjuntura eufórica com a modernização e a arquitetura brasileira no período, não parece haver uma resposta conclusiva. Mesmo assim, após alguns anos observando e avaliando estes projetos, a indagação permanece e alguns aspectos podem ser levantados.

A mudança de governo em 1963 impactou decisivamente o Plano de Ação, na medida em que sua dimensão e escala de implantação eram bastante ousadas para o período de um governo, embora muito tenha sido feito em tão curto período. Deste modo, apesar da proposta de um segundo Plano de Ação para o período seguinte de governo, Carvalho Pinto não conseguiu fazer o seu sucessor, sendo eleito o candidato da oposição Adhemar Pereira de Barros (CORDIDO, 2007, p.52).

Ainda que pesem as características do planejamento da Cidade Universitária que, como salientamos, entram em conflito com as intenções do governo militar em 
1964 e 1968, a mudança do governo estadual, já em 1963, também contribuiu para a alteração do planejamento vigente. Neste sentido, na medida em que o planejamento do Instituto Butantan estava a cargo do FCCUASO desde 1961, a mudança das diretrizes para o campus da USP impactam diretamente o campus do Instituto.

Ao que indicam os documentos e os projetos feitos no período, a mudança de governos e de planejamento, assim como a intermitência de recursos com o fim do Plano de Ação, podem explicar, em alguns aspectos, o reduzido sucesso do plano moderno em um ambiente nacional tão propício para a sua realização.

A partir de 1959, o Plano de Ação se apresenta ao Instituto Butantan como oportunidade de atingir um desenvolvimento inigualável em sua história, que não somente resolveria os problemas estruturais que obstruíam a sua expansão, mas o colocaria em um outro patamar como centro de pesquisa. Paradoxalmente, esta possibilidade colocaria o Butantan em uma posição de dependência à USP, uma instituição ainda maior e que ganhava força naqueles anos, na contramão dos esforços pela autonomia institucional (IBAÑEZ, WEN e FERNANDES, 2005) observados desde a direção de Afrânio do Amaral (1928-1938).

Manifestada nos primeiros anos, a euforia com o desenvolvimento cede lugar ao ceticismo com o projeto moderno, não somente pela radicalidade de sua arquitetura, mas pela submissão ao planejamento feito por um corpo de profissionais estranhos aos espaços institucionais. 


\subsection{Desdobramentos do Plano de Ação no Instituto Butantan}

Desenvolvidos quase duas dezenas de projetos para novos edifícios, dos quais apenas o Conjunto Residencial foi construído, além de quatro diferentes planos urbanísticos no período que vai até 1965 , sem que nenhum fosse definitivamente implantado, mesmo que parcialmente, o principal legado do planejamento do Instituto Butantan durante o Plano de Ação foi o convênio com o Fundo de Construção da Cidade Universitária. ${ }^{102}$ Consumado em 1961, o convênio durou duas décadas, permanecendo até o ano de 1981 em ocasião do processo de tombamento e patrimonialização do conjunto arquitetônico do Instituto pelo Condephaat.

Na periodização de sua história institucional, proposta por Nelson Ibañez, Fan Hui Wen e Suzana Cesar Gouveia Fernandes (2005, p.135-136), o período que vai de 1951 à 1982 é caracterizado por uma "inércia institucional” e pela direção exercida por lideranças internas. Na falta de uma política de ciência e tecnologia voltada à saúde, a sobrevivência do Instituto era angariada por meio de apoios do governo do estado, ou através da vinculação a projetos nacionais. Quanto ao planejamento, o recorte proposto para entre 1961 e 1981 por Anderson de Sá (2019, p.248-249), foi caracterizado pela ênfase aos projetos para o setor da produção, pela delimitação do núcleo histórico constituído pelos edifícios das primeiras décadas do século $\mathrm{XX}$, da coordenação dos projetos pelo FCCUASO e de predominância de uma linguagem arquitetônica alinhada ao brutalismo paulista, mas que buscava se adaptar "às preexistências do campus, a essa altura já historicizado". Neste sentido, há uma conscientização da importância histórica destes edifícios, que passam por alterações que buscam manter as características originais:

\footnotetext{
Mas devido às sucessivas perdas de área sofridas pelo Instituto, intensificouse nessa época a consciência de defesa de seu território, levando a ações de efetiva ocupação urbanística e paisagística das áreas até então ociosas, e também a levantamentos do patrimônio cultural edificado que culminariam no tombamento do Instituto em 1981. (SÁ, 2019, p.249)
}

Considerada a trajetória do Plano de Ação no Instituto Butantan, que se 
caracterizou pelas sucessivas tentativas de implantação de um projeto moderno, exógeno ao campus, frustradas por condições institucionais específicas, em um momento de suscetibilidade e inércia da instituição, é possível afirmar que a radicalidade com a qual o PAGE se apresenta, induz ao Instituto uma resposta conservadora, voltada à manutenção de seus espaços. Assim, volta-se para a preservação de sua história manifestada através de seus imponentes edifícios.

\subsubsection{O PLADI de Ademar de Barros}

Encerrado em 1963, o Governo de Carlos Alberto de Carvalho Pinto é substituído por Adhemar de Barros, candidato eleito no ano anterior pelo Partido Social Progressista, o PSP, derrotando Jânio Quadros, do PTN, ex-presidente do Brasil que havia renunciado em 1961, e o udenista José Bonifácio Coutinho Nogueira, empresário que foi Secretário da Agricultura e candidato à sucessão do governo apoiado pelo PDC de Carvalho Pinto.

Apesar da interrupção deste grupo político no poder, que havia se formado em torno de Carvalho Pinto, o Plano de Ação obteve um significativo sucesso e popularidade pela capacidade com que produziu equipamentos públicos por todo o estado. Estes equipamentos difundiam uma arquitetura avançada e desconhecida da população, tanto pela sua modernidade quanto pela nova linguagem, literalmente, construída pelos arquitetos que atuaram no plano. Neste sentido, no âmbito da arquitetura esteve, talvez, o maior alcance e impacto do PAGE, difundindo um novo ideário moderno da arquitetura brasileira, sendo responsável por transformar a orientação de obras públicas pelo Estado paulista, que permanecia vinculada, sobretudo, a uma produção não moderna (BUZZAR, CAMARGO e CORDIDO, 2016, p.23). ${ }^{103}$

103 Um aspecto interessante desta mudança advinda com o Plano de Ação em relação ao funcionamento padrão do DOP em São Paulo, é que os grandes e mais importantes edifícios feitos pelo órgão do Estado tinham seus projetos encomendados à profissionais contratados, como Mário Whately, Francisco Pinotti e o escritório Severo e Vilares, sendo que os demais edifícios eram, geralmente, construídos a partir de projetos padrão, como os fóruns do interior do estado (BUZZAR, CAMARGO e CORDIDO, 2016, p.6-7). Com o PAGE, é possível dizer que há uma democratização da arquitetura, não 


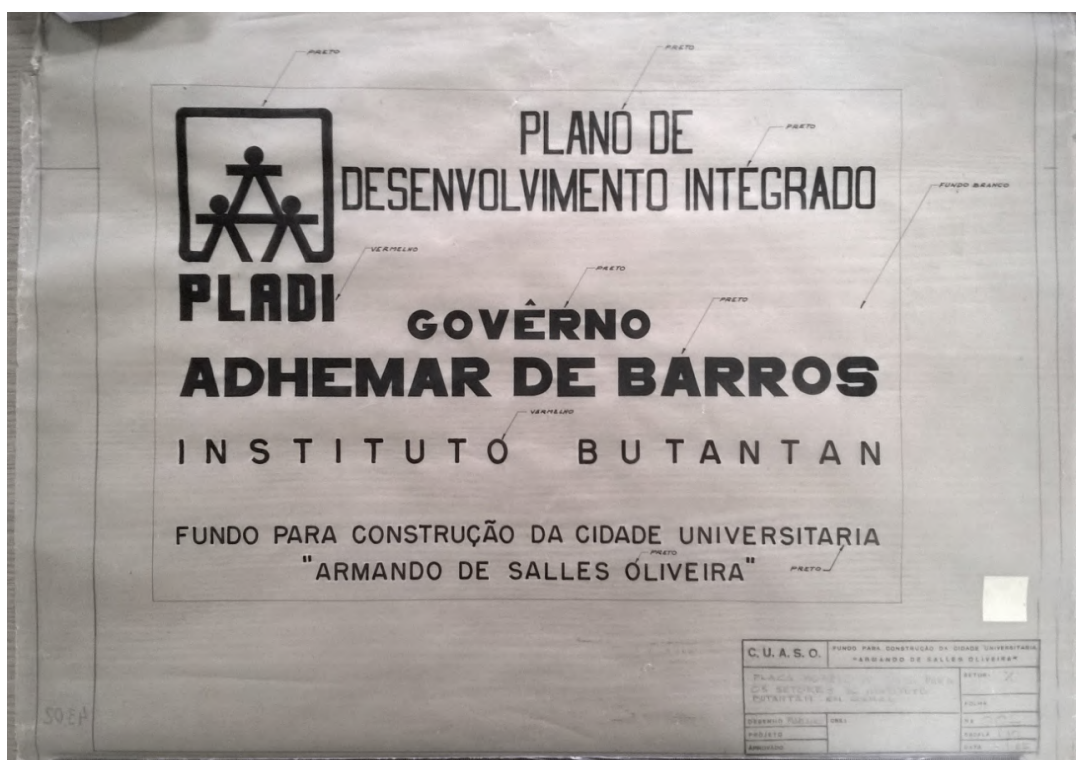

Figura 131: Projeto para placa de obra do Instituto Butantan com referência ao Plano de Desenvolvimento Integrado (PLADI), do governo de Adhemar de Barros, 1965. Fonte: prancha 43.02, Centro de Memória/IB.

Esta transformação da cultura construtiva advinda com o Plano de Ação, no ambiente de enorme sucesso da arquitetura moderna brasileira, fez com que a arquitetura praticada durante o governo de Carvalho Pinto não fosse um mero aspecto de uma política provisória de planejamento. Com o seu Plano de Desenvolvimento Integrado, Adhemar de Barros busca dar ao seu governo o aspecto modernizador deflagrado por Carvalho Pinto. Assim, obras feitas no período anterior e novas obras anunciadas estiveram associadas ao seu governo, pautando-se pelo mesmo caráter desenvolvimentista, executando obras rodoviárias, hidrelétricas e hospitais, mas sem grande ênfase na arquitetura. Eleito para governar entre 1963 e 1967, seu governo foi interrompido em 1966 com o seu afastamento pelo regime militar do general Castelo Branco.

No Instituto Butantan, o Plano de Ademar de Barros não parece ter alcançado tanta repercussão quanto o seu antecessor, embora seja mencionado em alguns documentos do período. Nos relatórios anuais não são mencionadas possíveis visitas

havendo distinção entre projetos mais ou menos importantes, mesmo que alguns projetos tenham sido oferecidos, ou reservados, para determinados arquitetos. O que importa, é que todos os edifícios tinham sua relevância dentro do Plano, a ponto de pequenas cidades do interior receberem projetos pensados para seus contextos, com características próprias e que se tornaram edifícios paradigmáticos da arquitetura brasileira. 
feitas pelo governador, algo comum na história da instituição, apenas a necessidade de avanço nas obras e falta de recursos que seriam destinados a este fim (Relatório Anual, 1964, fl.03-04). Enquadrado no setor de investimentos destinados à área da saúde, o Plano direcionava ao Instituto, em seu item 3, recursos para a "construção de novos laboratórios, biotérios, cocheiras, serpentários, nos terrenos e fazendas do Instituto Butantã" (PLADI, 1964, p.500). Não sabemos se estes investimentos foram feitos mas, ao que indica o Relatório do Instituto no ano de 1964, não foram entregues os recursos que haviam sido previstos no orçamento daquele ano.

Sob convênio com o FCCUASO desde 1961, para o planejamento e execução de obras, o Instituto Butantan concluiu alguns projetos neste período, como o seu Conjunto Residencial, além de alguns edifícios para o setor da produção e serviços, como veremos a seguir, cujos projetos haviam sido iniciados no Plano de Ação. Diferentemente deste, a participação do PLADI no Butantan parece ter sido substancialmente tímida, sem grandes menções ou participação direta nos projetos e obras que, por sua vez, representam menos uma obra do governo de Ademar de Barros do que uma decorrência do trabalho desenvolvido desde os primeiros anos do governo anterior.

\subsubsection{O escritório de projetos do Instituto Butantan e os edifícios modulares em consonância com a Cidade Universitária}

Após o longo período de desenvolvimento de projetos para o Instituto Butantan, datados desde o primeiro anúncio de novos edifícios em 1959, no final do ano de 1964 é instalado, no campus do Butantan, um escritório para atender exclusivamente às demandas do Instituto por novos espaços e das obras em andamento. Em dezembro daquele ano, os profissionais contratados pelo Fundo de Construção da Cidade Universitária se instalam em uma das casas recém-construídas do Conjunto Residencial, e passam a atuar nos projetos para o Instituto, sobretudo na revisão e desenvolvimento dos edifícios da produção e de serviços. 
Denominado como "Divisão de Projetos" do FCCUASO, o escritório local atenderia às necessidades específicas do Instituto Butantan de construção de novos espaços, que pouco haviam avançado até aquele ano, assim como direcionava o corpo técnico do FCCUASO que atuava em diversas frentes da Cidade Universitária em construção. O número de profissionais trabalhando no escritório sempre foi bastante reduzido, contando com dois ou três arquitetos e o mesmo número de desenhistas, sendo que alguns destes se revezavam com os projetos e obras do campus da USP, que aconteciam simultaneamente. Os documentos referentes ao período de 1964 à 1965 (Relatório Anual, 1965, fl.11) indicam a contratação de um arquiteto e um desenhista, enquanto, dois anos depois, em dezembro de 1966, assinam um documento do escritório de projetos os arquitetos Osmar Antonio Mammini e Carlos Henrique Heck, além do engenheiro Francisco Mariano de Souza Costa.

Os nomes dos três profissionais aparecem na maior parte dos projetos feitos no período, com destaque para Osmar Antonio Mammini, arquiteto formado em 1959 pela Universidade Presbiteriana Mackenzie, em São Paulo, foi contratado pelo FCCUASO e logo em seguida alocado no Instituto Butantan para auxiliar no desenvolvimento e implementação dos projetos já realizados. Mammini trabalhou no Instituto até o início da década de 1980, período no qual também atuou na construção da Cidade Universitária, nos projetos para a Faculdade de Odontologia, de Medicina Veterinária e o Hospital Universitário. No Butantan, projetou a última versão do edifício da produção, que foi parcialmente executada, desenvolveu os projetos do Conjunto Residencial projetado por Mário Rosa Soares, o Museu em 1966 e a réplica da cocheira da Fazenda Butantan em 1981, além do Edifício do Biotério de Criação e o Plano Geral de 1966.

O Biotério e o Plano de 1966 foram feitos em conjunto com Carlos Henrique Heck, arquiteto que havia se formado recentemente pela FAU USP, em 1964. Segundo o próprio Heck, em depoimento (MAMMINI, HECK, 2017, p.165), sua atuação no Instituto Butantan teve início em 1966, quando começou a trabalhar com Osmar Mammini no escritório instalado em uma das "casinhas" do Conjunto Residencial. 
Segundo o arquiteto (Ibid., p.166), sua atuação no Instituto se deu no contexto da revisão dos projetos desenvolvidos anteriormente, trabalhando em um novo projeto para o Edifício da Produção e para o Edifício do Biotério. Instalados em uma das casas do Conjunto Residencial, os arquitetos produziram, além dos projetos institucionais, trabalhos solicitados pelos funcionários do Instituto, moradores do Conjunto, quando desenvolveram um centro de convivência a pedido dos moradores.

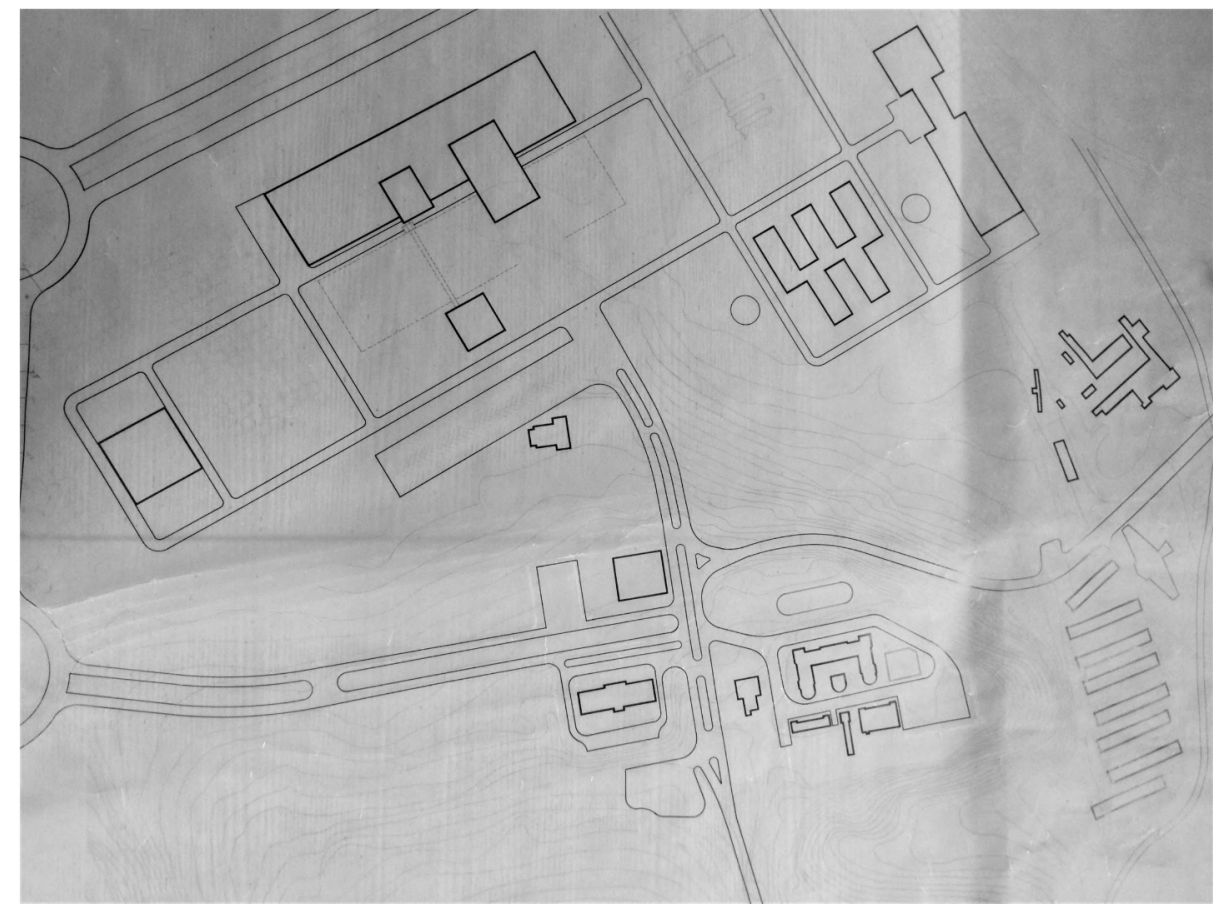

Figura 132: Plano de 1965 para o Instituto Butantan: abaixo está o conjunto de edifícios históricos preservados e na parte superior da prancha estão os edifícios do setor da produção que foram parcialmente construídos. No canto inferior direito estão as fileiras do Conjunto Residencial. Fonte: prancha 52.01, Centro de Memória/IB.

Embora Mammini tenha permanecido no Instituto por quase duas décadas, a passagem de Heck foi mais curta, durando até o ano de 1969. Neste período, o arquiteto se engajou na luta contra o regime militar, foi preso e conseguiu se exilar na Inglaterra, onde trabalhou como arquiteto e depois como professor na França.

Se muito pouco foi construído, pra não dizer quase nada, em relação a quantidade de projetos desenvolvidos e arquitetos que atuaram no Instituto a partir do Plano de Ação, os profissionais que constituíram um escritório interno a partir de 1964, ainda que submetido ao FCCUASO e vinculado ao planejamento da USP, puderam 
realizar algumas obras ensaiadas há anos para o campus, principalmente para o setor da produção. Desta forma, ainda que muitos destes projetos, inclusive os que foram feitos por iniciativa dos próprios arquitetos, como o centro social dos moradores, não tenham sido executados, foram construídos alguns pavilhões da produção, edifícios para os serviços e almoxarifados, um restaurante, um prédio de lavanderia, a reforma da cocheira central para a instalação de um museu e a reconstituição de um antigo edifício utilizado nas origens do Instituto, além de projetos de detalhamento e execução do Conjunto Residencial.

Alguns destes edifícios foram parcial ou integralmente demolidos, outros sofreram alterações e descaracterizações. Por exemplo, o conjunto de edifícios construídos para os almoxarifados e serviços gerais do Instituto, era formado por extensos pavilhões interligados e de tipologias variadas. Estes espaços abrigavam desde almoxarifados e escritórios, até galpões com pé-direito duplo e amplas aberturas para acesso de veículos, além de serviços em geral como oficinas de manutenção, sendo possível que algumas atividades diretamente relacionadas à produção também tenham sido realizadas nestes espaços.

Observando o Plano de 1965 (Figura 132) e as imagens dos edifícios em construção (Figura 133), é possível identificar cinco pavilhões construídos, cada um com cerca de 50 metros de extensão, sendo um bloco de escritórios a frente e os demais destinados aos serviços, almoxarifados e depósitos. Apenas o bloco de escritórios e metade do segundo bloco foram preservados, os demais foram demolidos na década de 2010 para a construção de uma nova fábrica de vacinas. Os primeiros projetos para os pavilhões de serviços e almoxarifados datam de 1965 , com as obras sendo inciadas logo em seguida e, provavelmente, concluídas até o final da década. Neste mesmo período, foram construídos mais dois edifícios, também projetados pelos profissionais do escritório instalado no Instituto Butantan desde o final de 1964. 

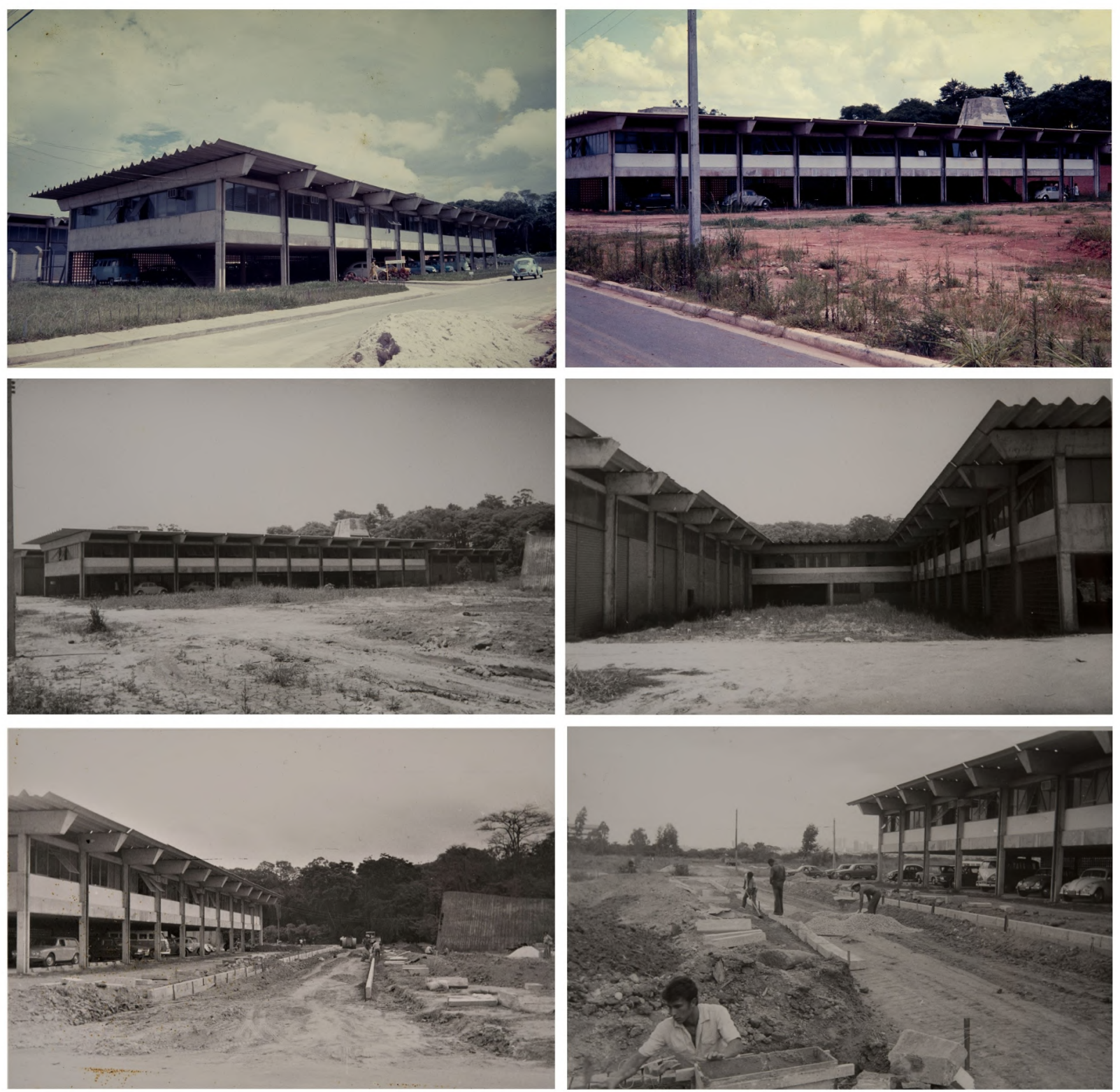

Figura 133: Fotografias do edifício de almoxarifado e serviços do Butantan, no qual atuaram Osmar Mammini e Carlos Henrique Heck. As duas primeiras imagens são do edifício concluído, provavelmente da década de 1970, e as demais são do edifício em fase final de construção, na segunda metade da década de 1960. Fonte: IB_ICO_000160, IB_ICO_000161, IB_ICO_008573, IB_ICO_008581, IB_ICO_008576, IB_ICO_008555, Centro de Memória do IBu. 
Próximo ao edifício do almoxarifado, foi executado um pavilhão ainda maior para a produção de soros e vacinas, que permanece até hoje apesar de ter sido amplamente descaracterizado. Sua arquitetura se assemelhava aos pavilhões de serviços e almoxarifados pela materialidade, com o fechamento em tijolos aparentes, estrutura pré-fabricada de concreto e a telha da cobertura também aparente, com janelas altas entre as paredes e as vigas da cobertura. Enquanto o primeiro era formado por cinco pavilhões com cerca de 50 metros de extensão, interligados e dispostos de forma alternada, os dois pavilhões que formavam o conjunto da produção têm, somados, mais de 150 metros de extensão. O resultado é um edifício cuja fachada é marcada pela estrutura de vãos idênticos, preenchidos pela alvenaria, constituindo dois enormes blocos horizontais (Figura 134).

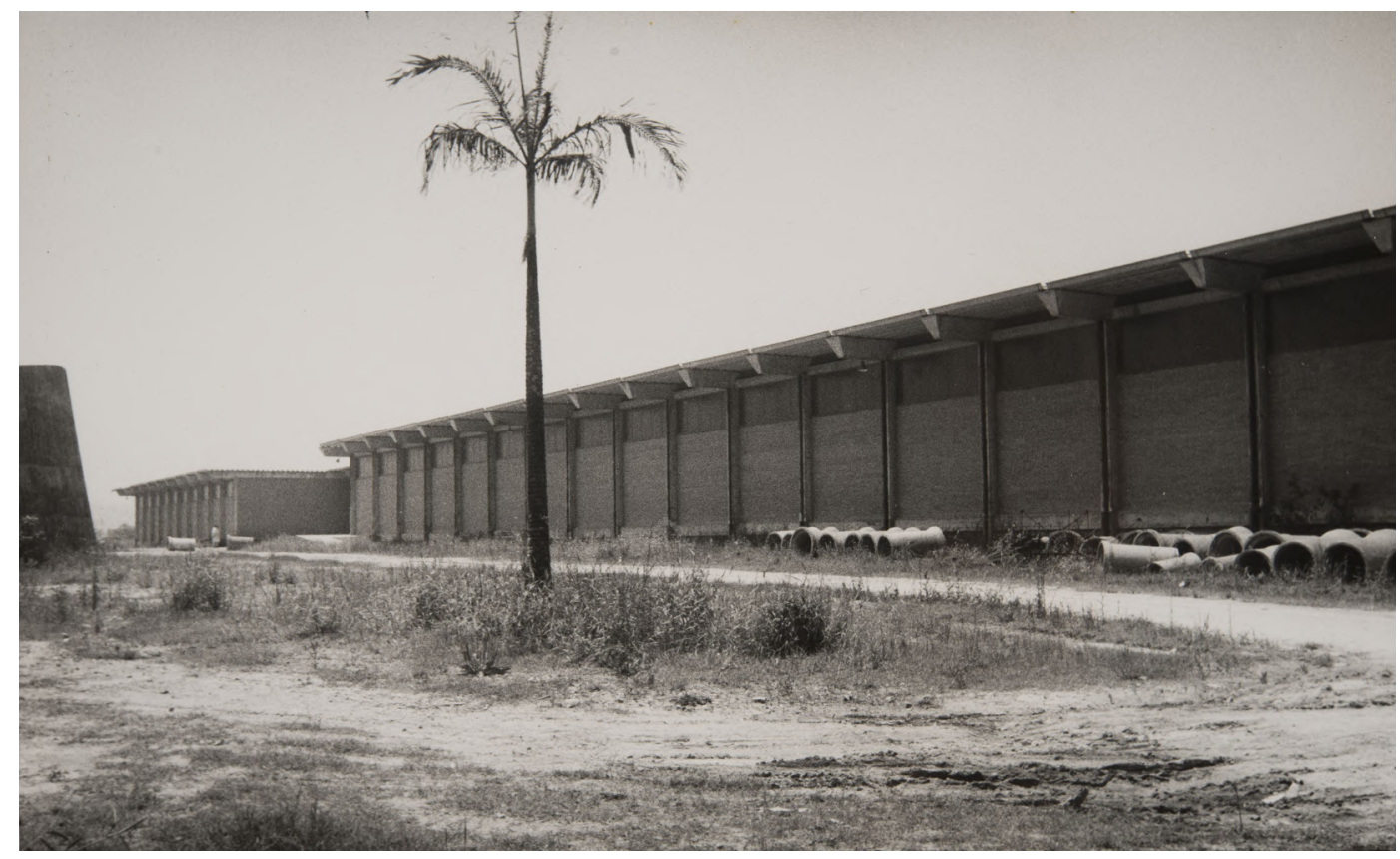

Figura 134: Fotografia de edifícios para a produção executados pelo FCCUASO após convênio estabelecido com o IBu. Autor desconhecido, provavelmente de 1968. Fonte: IB_ICO_008595,

Centro de Memória do IBu.

Atualmente, o edifício encontra-se destituído de sua principal característica: seu aspecto bruto, caracterizado pela exposição dos materiais e dos elementos estruturais, foi apagado pelas reformas e atualizações feitas no setor da produção ao longo dos anos, com a instalação de anexos, ampliações e novos materiais que ocultaram as fachadas originais dos edifícios. 

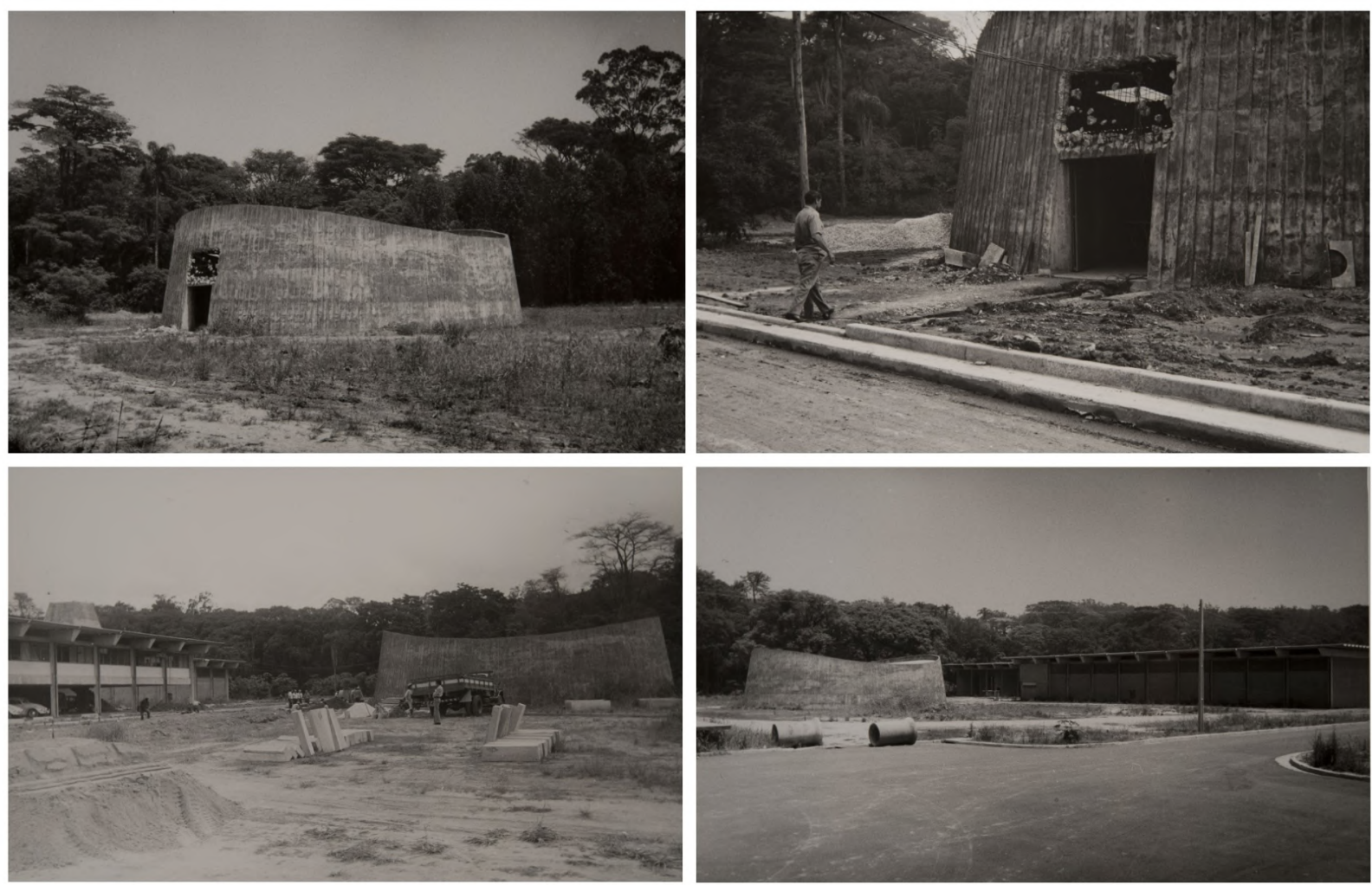

Figura 135: Edifícios "gêmeos” para as lavanderias e depósito, projeto do escritório do Instituto Butantan, sem data. Fonte: IB_ICO_008570, IB_ICO_008607, IB_ICO_008571, IB_ICO_008572, Centro de Memória/ IB.

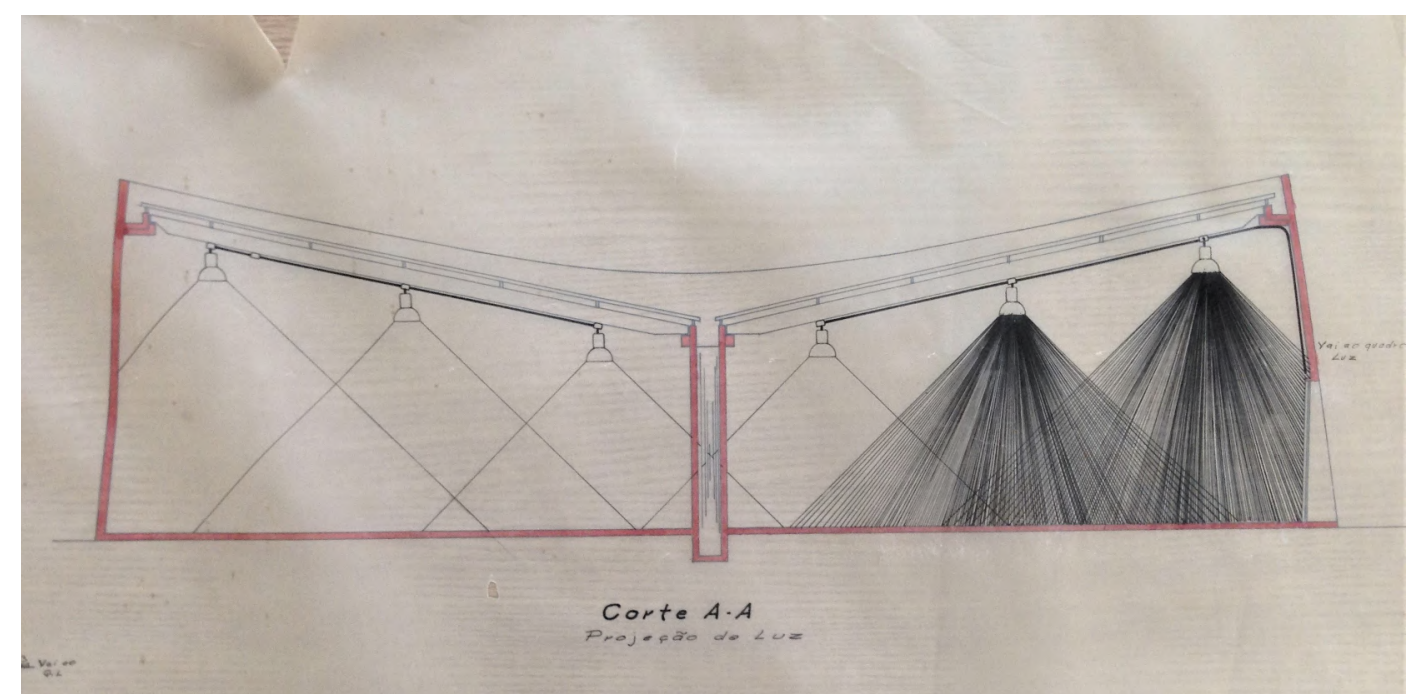

Figura 136: Corte do edifício para a lavanderia e depósito para estudo da iluminação interna, 1966. Fonte: prancha 50.16, Centro de Memória/ IB. 
Um terceiro prédio foi construído neste setor, formando um conjunto com os outros dois edifícios voltados à produção e serviços, como havia sido definido pelo planejamento setorizado do campus, proposto desde os primeiros anos do Plano de Ação. Trata-se, na verdade, de dois edifícios gêmeos, posicionados um em cada ponta do Prédio dos Almoxarifados e Serviços, e entre este e o pavilhão da Produção (Figuras 135 e 136), projetado para abrigar uma lavanderia e um depósito de produtos inflamáveis. Em formato cilíndrico, os dois prédios foram construídos em concreto armado, cobertos por duas telhas em "V" embutidas nas paredes que se alongam nas partes mais altas da cobertura, onde se encontram domus para iluminação interna. As fôrmas de concretagem das paredes imprimem no edifício um aspecto bruto, destacando a sua materialidade e o seu formato que se distingue dos pavilhões construídos em estrutura pré-fabricada.

Os projetos dos dois edifícios coincidem com o dos pavilhões, datam a partir de 1965 e a construção é iniciada em conjunto com os demais, como é possível observar pelas fotografias que registraram as obras, sendo concluídos até o final da década de 1960. Também a partir de 1965, são executadas reformas em edifícios existentes, como a adaptação da Cocheira Central para a instalação do atual Museu Biológico, no qual participou ativamente o arquiteto Osmar Mammini.

Após este primeiro conjunto de edifícios construídos, a atuação do escritório permanece na segunda década do convênio com o FCCUASO, sem contar com a participação de Carlos Henrique Heck desde 1969. Nos anos 1970, é construído um novo edifício para o setor da produção e um restaurante para os funcionários e visitantes do Instituto. O primeiro abriga atualmente a produção de Vacinas Anaeróbicas e foi construído próximo aos edifícios da produção e serviços. Não foram encontrados os projetos deste edifício e são poucas e imprecisas as menções à sua construção nos documentos institucionais, contudo foram preservadas fotografias de sua execução (Figura 137).

São dois pavilhões idênticos cujo sistema construtivo é bastante simples: inicialmente é feita uma grande estrutura em concreto armado que, ao mesmo tempo, 
define a forma do edifício, restando os fechamentos em alvenaria que, neste caso, foram rebocadas. Por fim, são feitas as instalações e colocados os caixilhos nos vãos definidos pela estrutura. As fotografias da época demonstram as etapas da construção, registrando um edifício acabado e o outro em fase de execução da estrutura (Figura 137).
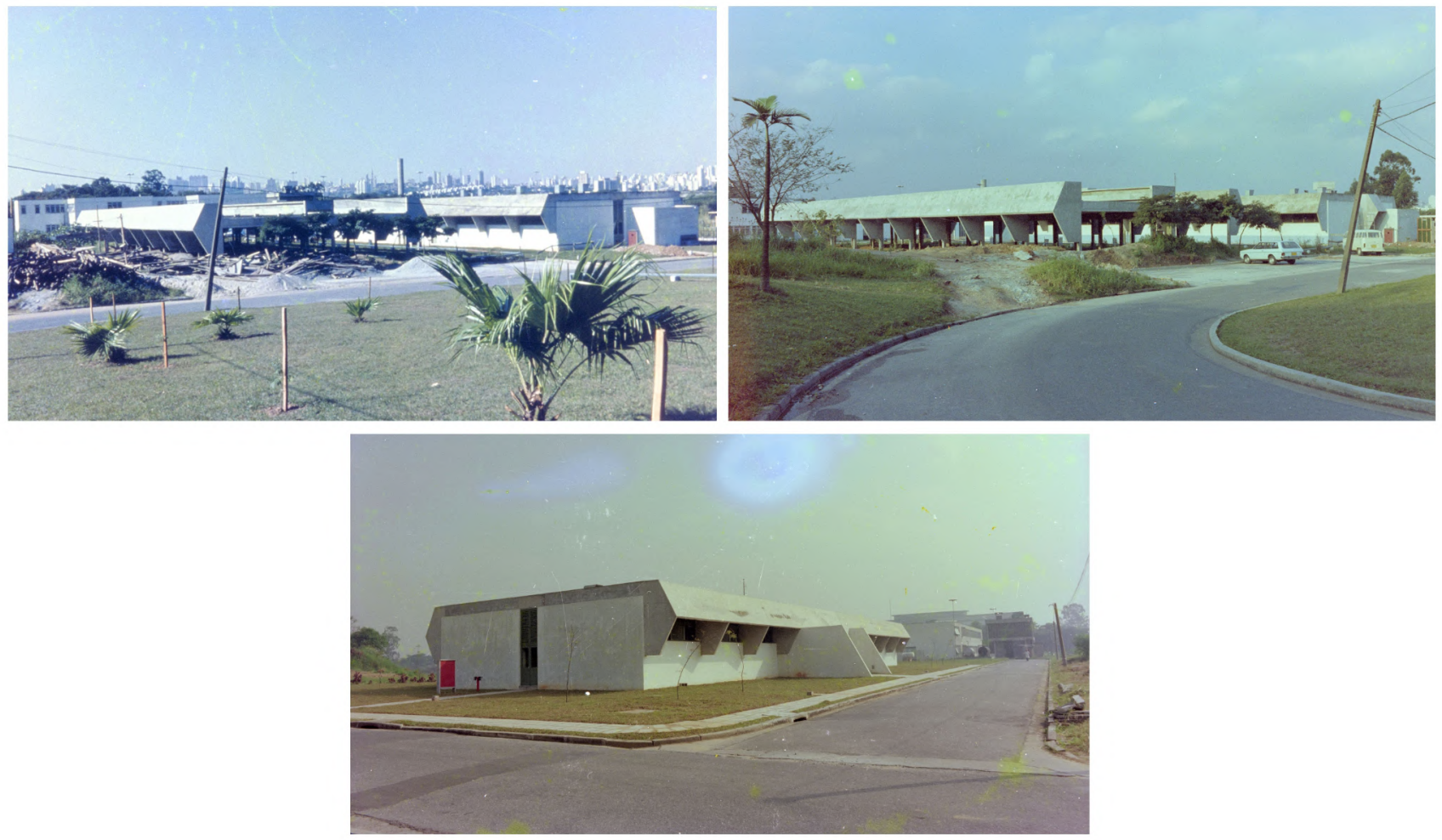

Figura 137: Construção dos pavilhões no setor da produção, hoje prédio das "Vacinas Anaeróbicas", década de 1970. Fonte: IB_ICO_003158, IB_ICO_003274, IB_ICO_003155, Centro de Memória/IB.
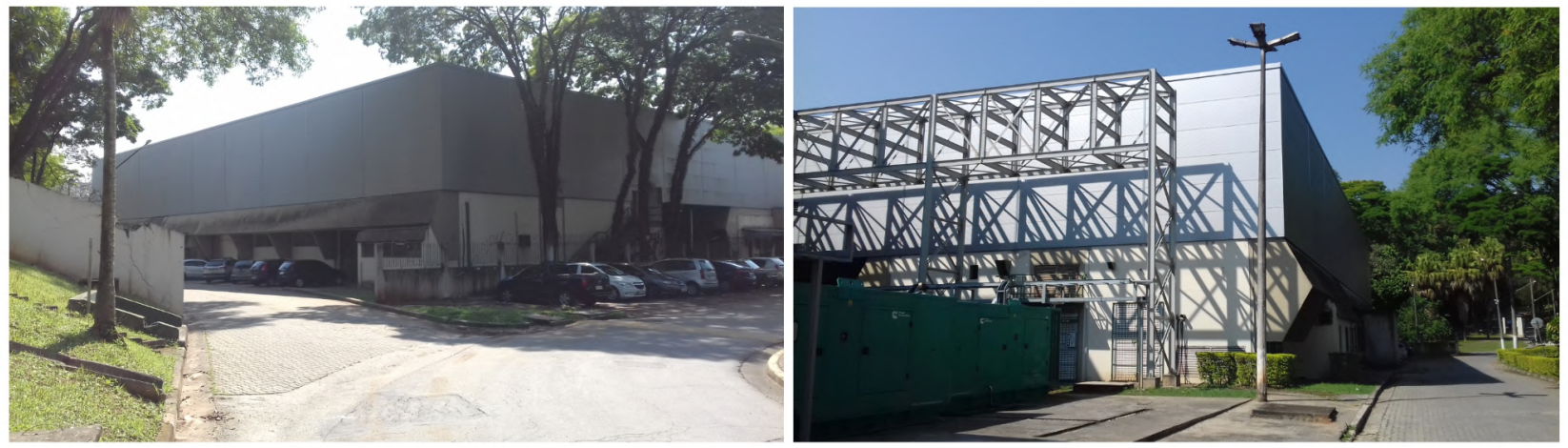

Figura 138: Atual situação do edifício após reformas de ampliação, 2017. Fonte: imagens cedidas por Anderson Luiz Félix de Sá. 
Os dois pavilhões ainda permanecem no Instituto, mas com alterações profundas que o tornaram quase irreconhecível (Figura 8). Os dois edifícios térreos foram acrescidos de um outro pavimento construído em estrutura metálica, acima da estrutura de concreto que caracterizavam os dois edifícios, então transformados em um bloco único. Ainda é possível identificar os beirais em concreto que fazem parte da estrutura original, assim como as alvenarias revestidas e as aberturas dos caixilhos, contudo, a caixa conformada pelo segundo andar ganha destaque no conjunto.
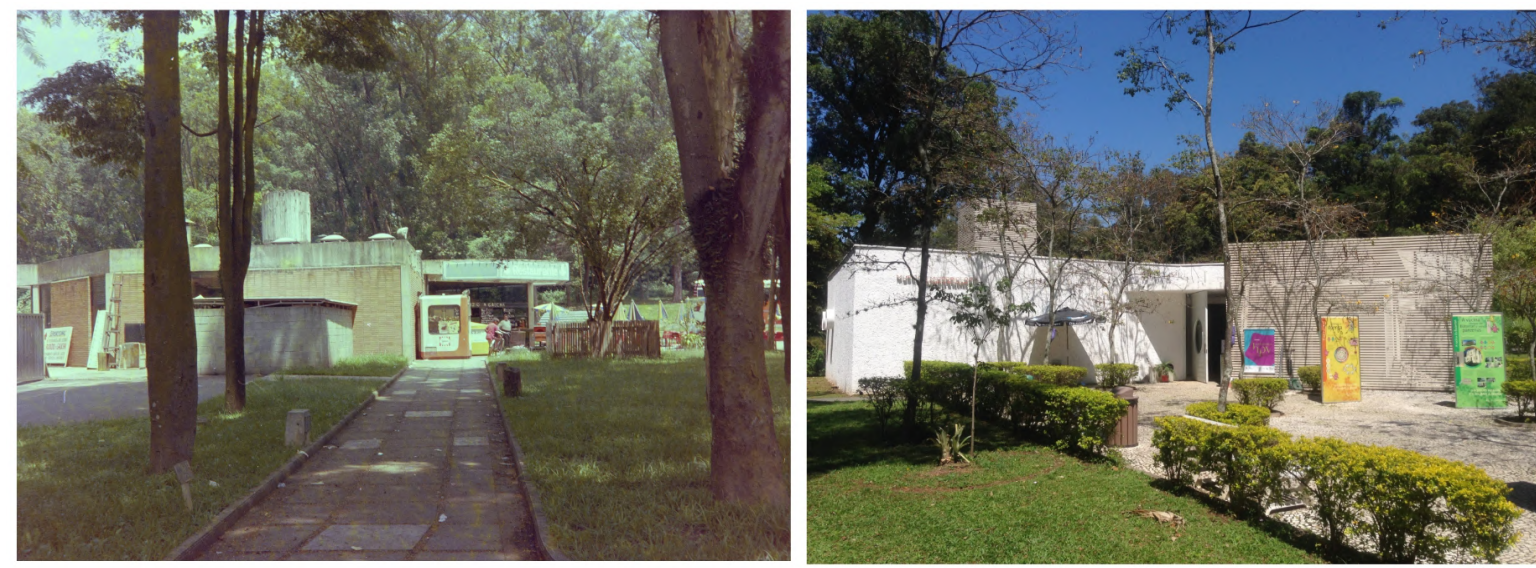

Figura 139: Foto do antigo restaurante nos anos 1980 e imagem de 2018 do atual uso do prédio como Museu de Microbiologia. Fonte: IB_ICO_003091, Centro de Memória/IB e foto do autor, 2018.

Estas transformações dos edifícios construídos entre as décadas de 1960 e 1970 foram feitas, em sua maioria, nas últimas duas ou três décadas, principalmente a partir dos anos 2000. O edifício do restaurante (Figura 139), construído entre 1977 e 1978, passou por uma mudança significativa para abrigar o Museu de Microbiologia inaugurado em 2002. O edifício é a única construção deste período, com exceção dos projetos de reforma, que foi executada na região onde se encontram os prédios do conjunto histórico do Instituto e não no setor da produção, onde esteve concentrada a maior parte das obras realizadas durante o convênio com o FCCUASO.

Como os demais, o prédio do restaurante tem como principais características a iluminação por domus, estrutura em concreto armado com fechamento em alvenaria, ambos aparentes, assim como a caixa d'água do edifício. Restaram poucas informações sobre o antigo prédio, algumas fotografias e o projeto de reforma feito mais recentemente pelo arquiteto Marcio Kogan para a sua conversão em Museu. 

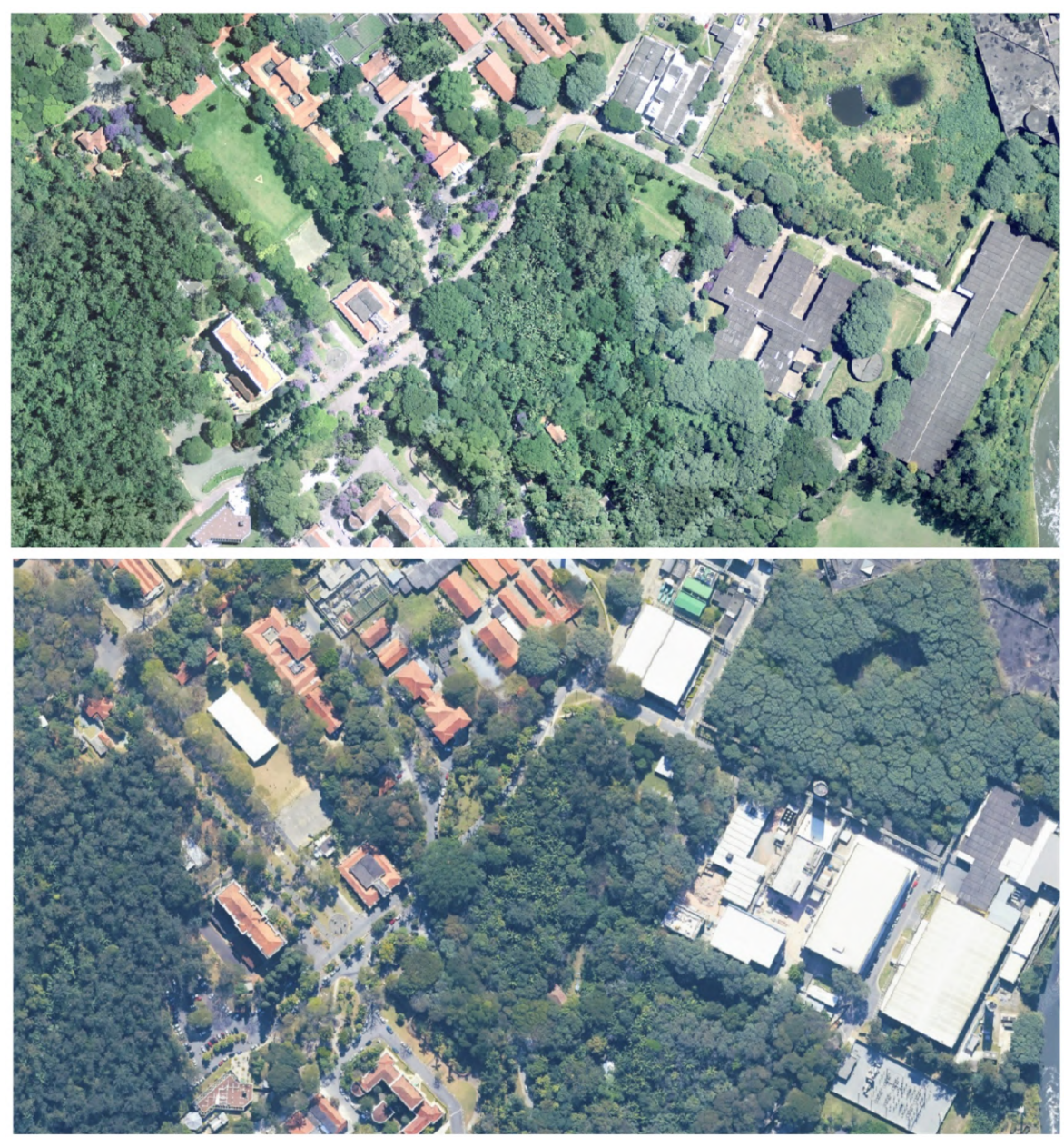

Figura 140: Imagens aéreas de 2004 e 2017, onde é possível ver as alterações e demolições recentes feitas no conjunto. A partir do rio Pirajussara Mirim, à direita, estão o pavilhão da produção (alterado), o primeiro prédio circular (demolido), o conjunto dos almoxarifados e serviços (parcialmente demolido), o segundo prédio circular gêmeo (demolido) entre as árvores. Na mesma rua está o edifício de vacinas anaeróbicas (alterado). No canto esquerdo da imagem é possível identificar as coberturas de telha cerâmica dos edifícios históricos do Instituto e, o último edifício do canto inferior esquerdo, o edifício do restaurante transformado em Museu de Microbiologia. Fonte: Geosampa, 2004 e 2017.

Além do Conjunto Residencial, único projeto executado durante o Plano de Ação, estas são as principais obras construídas através do convênio com o FCCUASO (1961-1981), que somente puderam ser realizadas com a organização de um escritório interno e de uma equipe voltada integralmente aos projetos do Instituto Butantan e supervisionada pela direção. Embora tenha alcançado relativo sucesso no que se refere aos edifícios construídos, esta cessão do planejamento ao controle do Instituto não 
ocorreu sem conflitos e adversidades, formalizadas em acusações endereçadas ao Fundo de Construção por atrasos no andamento das obras.

Em outro aspecto, esta soberania sobre o próprio planejamento, que passa a ser exercido pelos integrantes do Instituto, está limitada pelo corpo técnico e sua relação com a construção da Cidade Universitária. Em outras palavras, os médicos e cientistas que dirigem a instituição podem planejar, mas não podem fazer a arquitetura, o que está reservado aos profissionais que atuam sob as diretrizes do planejamento do FCCUASO. Neste sentido, os edifícios projetados e construídos para o Instituto, neste período, estão em consonância com as construções feitas no campus da USP após o fim do Plano de Ação que, em sua maioria passam a ser feitas em estrutura pré-fabricada e modulada. Esta mudança, dos projetos que priorizavam os grandes vãos e a integração para os edifícios modulados e pré-fabricados, é visível em boa parte dos projetos feitos para o Instituto até os anos 1970.

\subsection{O Museu de Lina Bo Bardi}

Passadas mais de seis décadas da fundação do Instituto, a construção de um museu definitivo no prédio da Cocheira Central, em 1965, veio a sanar a condição provisória do museu instalado no térreo da casa do diretor em 1957. A escolha do prédio para o museu institucional era algo pensado pela diretoria desde a década anterior e considerado nos estudos e planos urbanísticos produzidos durante o Plano de Ação. ${ }^{104}$ Sua transformação em museu é, também, algo que está relacionado ao decreto de 1941, na medida em que parte da antiga Fazenda era utilizada como pasto dos animais mantidos pelo Instituto para a produção de soros e vacinas. Em seguida, os animais foram transferidos para a Fazenda São Joaquim ${ }^{105}$ e o edifício passou a abrigar a cavalaria militar, até ser novamente esvaziado e perder o seu uso (FERRAZ, 1993).

104 O Plano Geral de 1961, dos arquitetos Leo Quanji Nishikawa e Sergio Atrigliano, indicava o Prédio da Cocheira como o único elemento preexistente a ser preservado, pela relevância de sua arquitetura, para a instalação de um museu histórico.

$105 \mathrm{~A}$ fazenda São Joaquim está localizada, aproximadamente, à $50 \mathrm{~km}$ do Instituto Butantan, no município de Araçariguama. Foi destinada ao Instituto Butantan como compensação ao decreto de 1941 do Governo do Estado. 


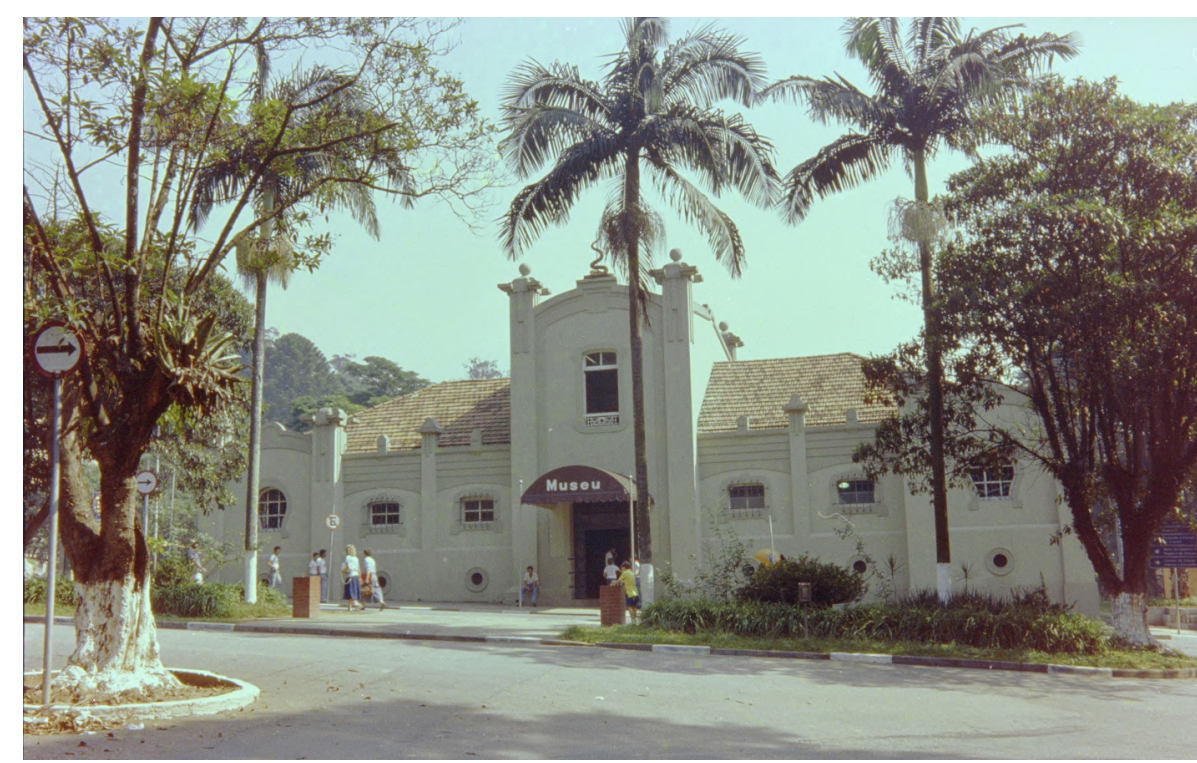

Figura 141: Fotografia da fachada principal do Museu Biológico, década de 1980. Fonte: IB_ICO_003107, Centro de Memória/IB.

Parte do conjunto dos primeiros prédios institucionais, o edifício projetado pelo engenheiro arquiteto Mauro Álvaro de Souza Camargo e construído na década de 1910, após a transferência dos animais permaneceu sem uso definido até os anos 1960, salvando-se da demolição generalizada proposta no Plano de 1961, durante o PAGE. O edifício, como conhecemos, hoje abriga o Museu Biológico, cujo projeto e as obras de reforma foram iniciados em 1965 até a conclusão no ano seguinte, com objetivo de sediar o I Simpósio Internacional de Venenos Animais. Com a aproximação do evento, os trabalhos da Divisão de Projetos do Instituto Butantan foram deslocados para o canteiro de obras do novo Museu:

Nêste mês (Junho de 1966) e no seguinte, o escritório passa a funcionar no Museu, organizando o espaço e equipamento adquirido para o Simpósio, desenhando painéis de animais peçonhentos, expondo projetos e maquetes, bem como tôda correspondência, trabalhos e publicações de Vital Brazil.

Por esse trabalho foi o Fundo para Construção da Cidade Universitária elogiado em missiva do Diretor do Instituto e Presidente do Simpósio. (Relatório Anual, 1966, fl.23)

O projeto liderado pelo arquiteto Osmar Mammini, que ficou a cargo da reforma, tinha como objetivo transformar o edifício formado por um pátio interno e contornado por cavalariças em um museu com auditório. A solução adotada foi criar uma cobertura para o pátio onde seria instalado o auditório, enquanto o museu se 
desenvolve no seu entorno, no lugar das antigas cavalariças, formando um circuito expositivo que se encerra no acesso principal do edifício. Sobre a execução do projeto, o arquiteto comentou a recepção do museu em ocasião do evento sediado:

\begin{abstract}
Aconteceu logo que eu entrei no Instituto, eles só tinham construído a vila dos operários, né, então quiseram fazer esse simpósio internacional, então eu transformei a estrebaria num auditório cercado por um museu, inclusive com vitrines, vamos dizer assim, de animais peçonhentos; que, no caso, eram mais cobras do que outra coisa para o pessoal ver e até que deu certo, porque não teve falha nenhuma: os estrangeiros que vieram ficaram encantados. (MAMMINI e HECK, 2016,p.
\end{abstract}

No início da década de 2000, o Museu passou por reformas de manutenção e atualização de seus espaços, principalmente do seu projeto museográfico (ver Capítulo 1, Figuras 22 e 23). A organização interna do edifico permaneceu, contudo, definida pela reforma de 1965, que alterou profundamente sua tipologia ao cobrir o pátio para a instalação de um auditório. Com exceção da fachada, as características originais da antiga cocheira foram amplamente alteradas.

O projeto de reforma feito em 1965 e executado as vésperas do evento internacional, não foi a única proposta pensada para a transformação do edifício em museu. No período em que o prédio histórico permaneceu desocupado, entre as décadas de 1950 e 1960, a arquiteta Lina Bo Bardi chegou a desenvolver uma proposta distinta da que foi executada, cuja data de desenvolvimento do projeto é imprecisa. Os desenhos feitos pela arquiteta datam de 1965, porém, os documentos relativos ao período no Instituto Butantan não mencionam o projeto, enquanto uma carta enviada à Lina em 1958 por Luiz Augusto Ribeiro do Valle, diretor do Instituto entre 1966 e 1967, agradece os serviços por ela prestados ao Butantan. 


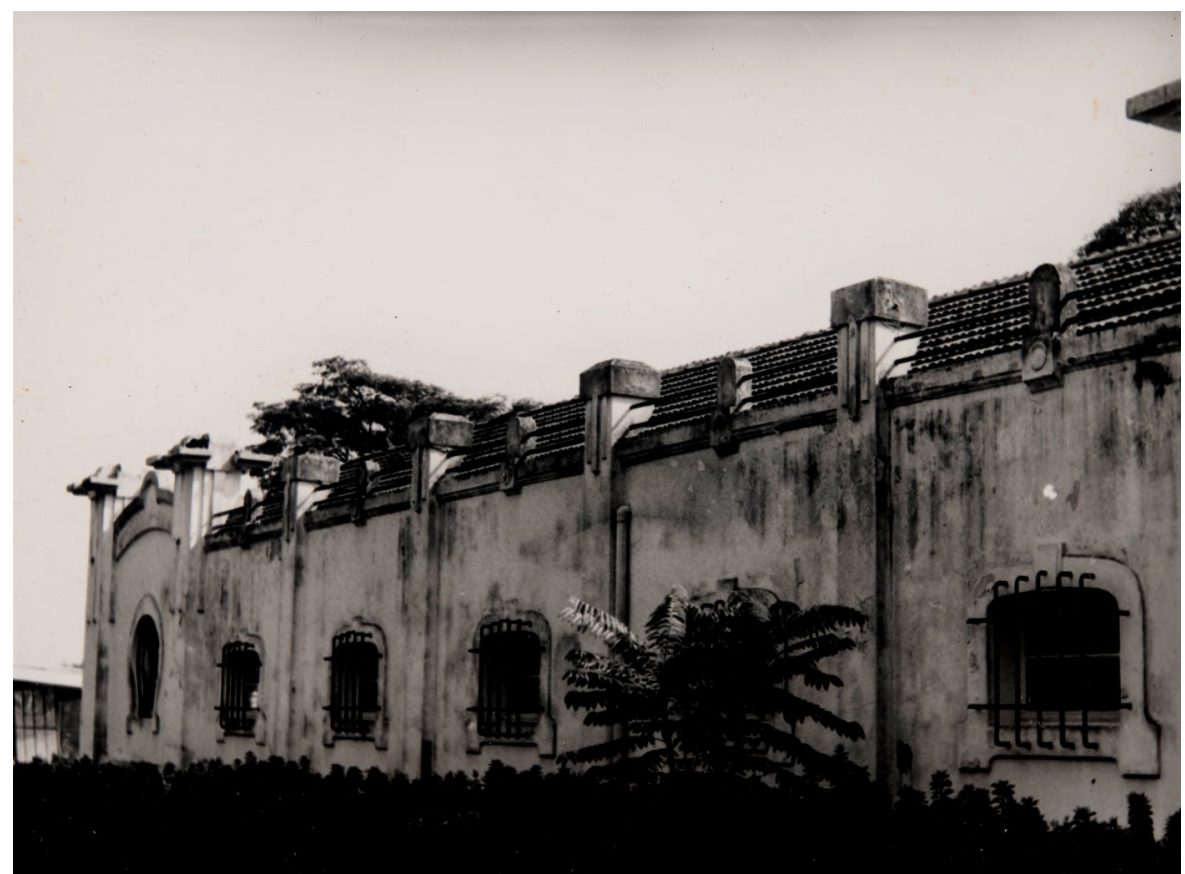

Figura 142: Fotografia da fachada lateral da Cocheira Central antes da reforma de 1965. Fonte: IB_ICO_009319, Centro de Memória do IB.

Uma série de conjecturas podem surgir a partir desta imprecisão da data de um projeto que aparece como mais uma arquitetura não construída no Instituto Butantan. ${ }^{106}$ Todavia, dois documentos parecem ser imprescindíveis para situar a atuação de Lina Bo Bardi no projeto para o Instituto. Nos parece que a carta de 1958 (Documento 01.0462.03, 1958, Instituto Bardi), enviada por Ribeiro do Valle, está relacionada ao início das obras de reforma do museu que é mencionada nos documentos institucionais do mesmo ano (Relatório Anual, 1958, fl.60).

Em hipótese, visto que a intenção de se construir um museu no local era há alguns anos demonstrada pela diretoria, é possível que a arquiteta tenha sido convidada nos anos finais de 1950, período em que o pesquisador Wolfgang Bücherl esteve encarregado do plano de reforma para a organização do Museu, desde a direção de Eduardo Vaz (1947-1951). A inconstância do plano para o museu durante as

$106 \mathrm{~A}$ impossibilidade de se precisar uma data torna difícil avaliar a dimensão deste projeto para o planejamento do Instituto. Por exemplo, se é possível que a proposta de Lina Bo Bardi tenha sido preterida pelo projeto executado em 1965, feito por Osmar Mammini no escritório do Instituto. Também não permite que se estabeleça uma relação com a atuação do PAGE no Butantan, por exemplo, se o convite feito a arquiteta foi anterior, ou se partiu de uma reação da diretoria movida pela insatisfação com as propostas do Plano, cujo projeto do Museu feito por Abelardo de Souza propunha algo completamente distinto (ver capítulo 2, item 2.5.8). 
diretorias que sucederam Eduardo Vaz, ${ }^{107}$ culminaram com a sua suspensão por Flávio Ribeiro da Fonseca (1956-1963), às vésperas ou já na vigência do Plano de Ação, quando são anunciados vultuosos investimentos para novos edifícios. Nesta conjuntura, é possível que a proposta tenha sido levada em paralelo com os projetos do PAGE até 1965 , visto que o Instituto mantinha contato com ela desde a década anterior. Segundo a própria Lina:

\begin{abstract}
Alguns cientistas do Instituto Butantã queriam fazer um museu popular para apresentar o trabalho da instituição, especialmente aqueles ligados às aranhas, aos insetos pequenos e também às cobras. Aí me chamaram e eu comecei a fazer o estudo. Mas não havia dinheiro, como de costume. Teríamos conseguido fazer o museu num dos pavilhões 'art nouveau', lá no jardim do Instituto, muito bonito. Mas o governador, parece-me Jânio Quadros, instalou ali uma cavalaria militar. Aí o museu foi esquecido. Depois eles fizeram uma coisa decente, mas não era do porte das nossas ilusões. (FERRAZ, 1993, p.174)
\end{abstract}

Comentando esta passagem, Anderson de Sá (2019, p.154), também reconhece a incompatibilidade da datação, que conflita entre o citado período de governo de Jânio Quadros (1955-1959) e a data conferida aos estudos da arquiteta. De todo modo, apontada esta discordância, sem postularmos conclusões definitivas, é importante analisar a proposta da arquiteta, diante do projeto realmente executado.

A diferença fundamental entre os estudos feitos por Lina Bo Bardi e o projeto executado para o Museu pelo escritório do Instituto Butantan em 1965, está no uso destinado ao pátio interno do prédio. Enquanto no plano de reforma executado o pátio foi coberto para abrigar um auditório, numa estratégia que acabou alterando drasticamente a configuração original do edifício histórico, o espaço imaginado por Lina seria o ambiente principal e articulador do programa do Museu. Lina previu para o pátio da Cocheira a reprodução do habitat dos animais expostos no Museu, concebendo uma espécie de lago retangular ao centro, sob o qual se estenderiam passarelas para a circulação dos visitantes. O espaço aberto deveria constituir um

107 Ao final desta diretoria, Wolfgang Bücherl descreveu a inconstância do projeto durante as diretorias posteriores (Anexo do documento 1461.1, Instituto Bardi). Dorival da Fonseca Ribeiro (19531-1953) deu início às obras reunindo 1,5 milhão de cruzeiros para este fim; Afrânio do Amaral (1953-1956) quis reformular o projeto "ele mesmo"; Flávio Ribeiro da Fonseca (1956-1963) não deu continuidade ao projeto. 


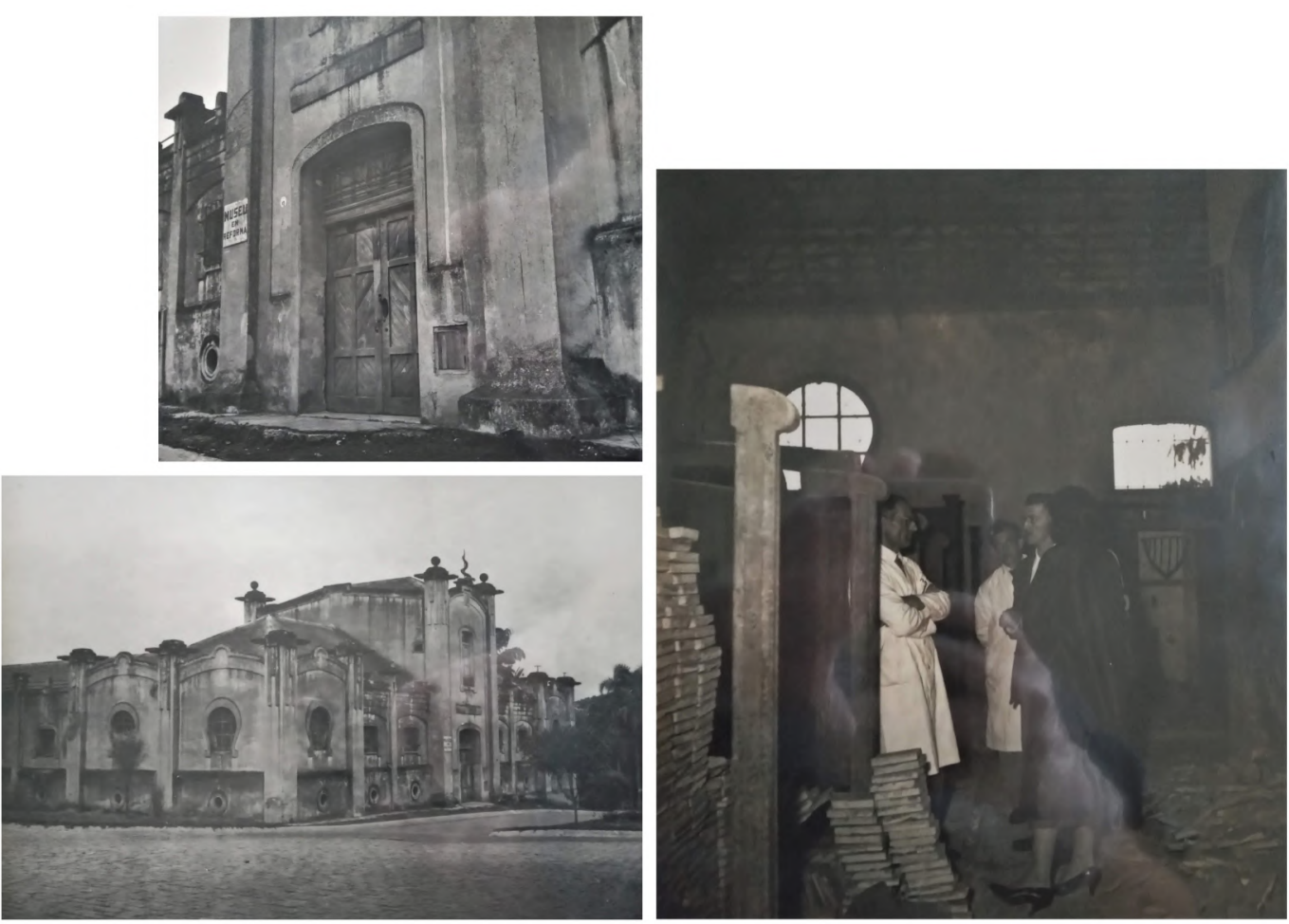

Figura 144: Fotografias da cocheira central e da arquiteta Lina Bo Bardi em visita ao edifício, sem data. Fonte: Acervo do Instituto Bardi.
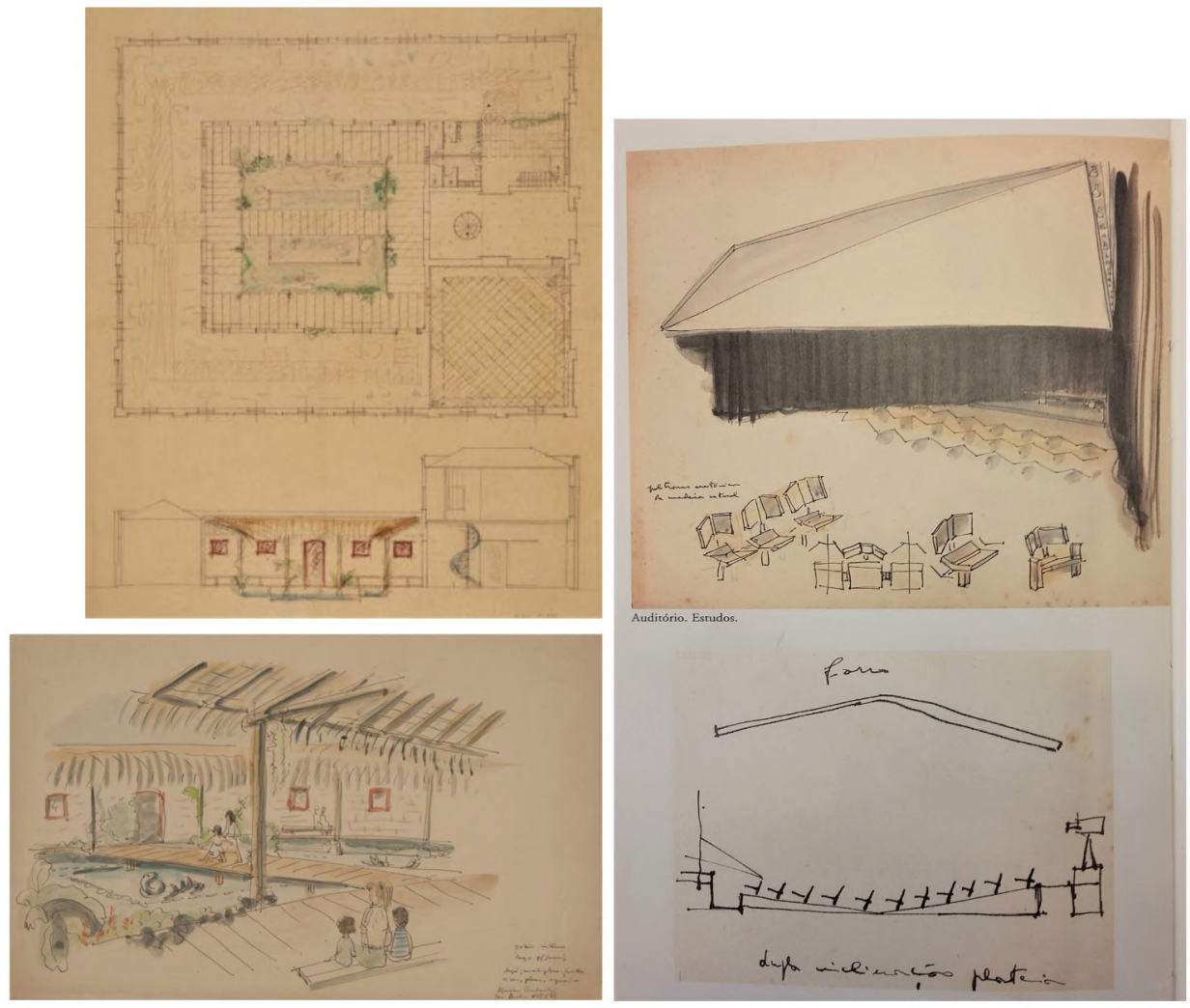

Figura 143: Desenhos de Lina Bo Bardi para o Museu: planta e corte, vista do pátio interno, vista e detalhe do auditório, 1965. Fonte: FERRAZ, 1993, p.176, 177 e 178. 
diorama, que emulasse cenas do ambiente natural e da fauna brasileira. Nas anotações feitas pela arquiteta no próprio desenho: "plantas, árvores secas, pedras, areia, terra, animais empalhados, piso: cimento com pedras roladas, parede: tijolos à vista com caiação, tábuas e sapé na varanda e na exposição [...]" (Figura 143).

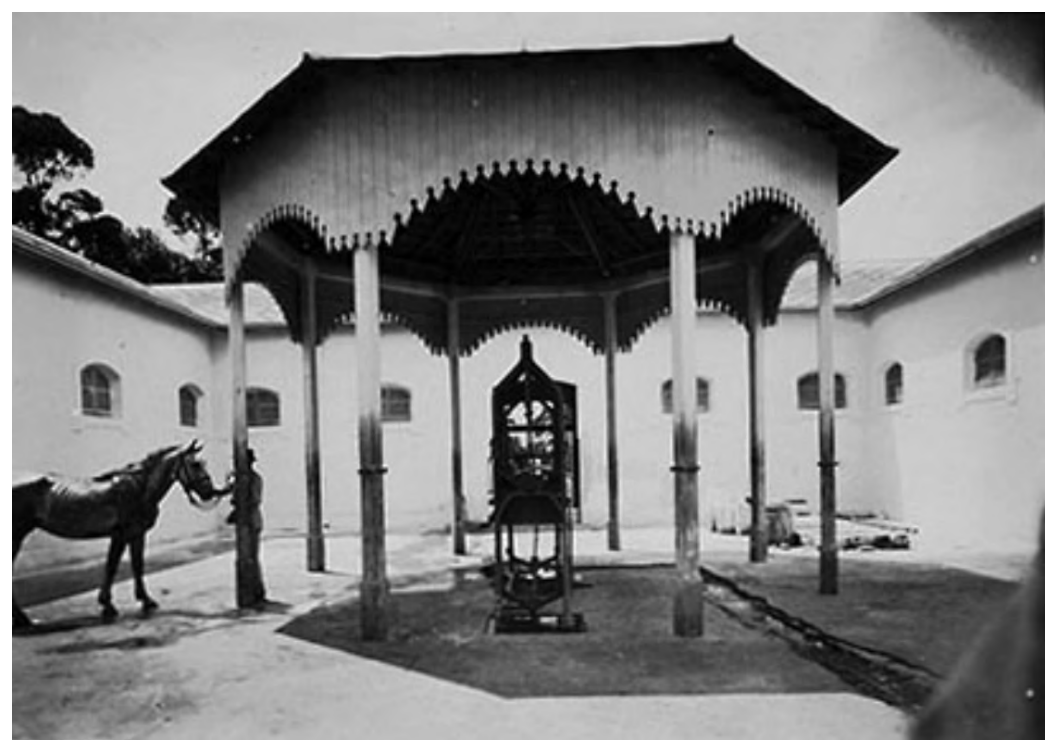

Figura 145: Pátio da Cocheira Central na década de 1920. Fonte:

IB_ICO_010256, Centro de Memória/IB.

No perímetro entre a área central e o espaço expositivo, onde ficavam os estábulos dos animais, seria alocada uma varanda feita de sapé, contornando todo o ambiente externo e voltada para os dioramas no pátio. A cobertura da varanda criaria lugares de permanência e o seu material se distinguiria das paredes preexistentes, cujos tijolos seriam deixados à vista e pintados de branco.

Os espaços internos do Museu abrigariam as áreas expositivas, cujas ilustrações sugerem a exibição dos animais em caixas transparentes, sobrepostas e acomodadas livremente pelo espaço (Figura 146). Por sua vez, o auditório ocuparia o térreo de uma das alas laterais do bloco de acesso ao edifício, ao lado esquerdo da entrada principal. Apropriando-se da melhor forma do espaço limitado para tal uso, as fileiras e o palco estariam em uma posição de 45 graus em relação às paredes, enquanto os assentos desenhados pela arquiteta seriam feitos em madeira natural, que nos remete às que foram feitas para o teatro do Sesc Pompéia. 


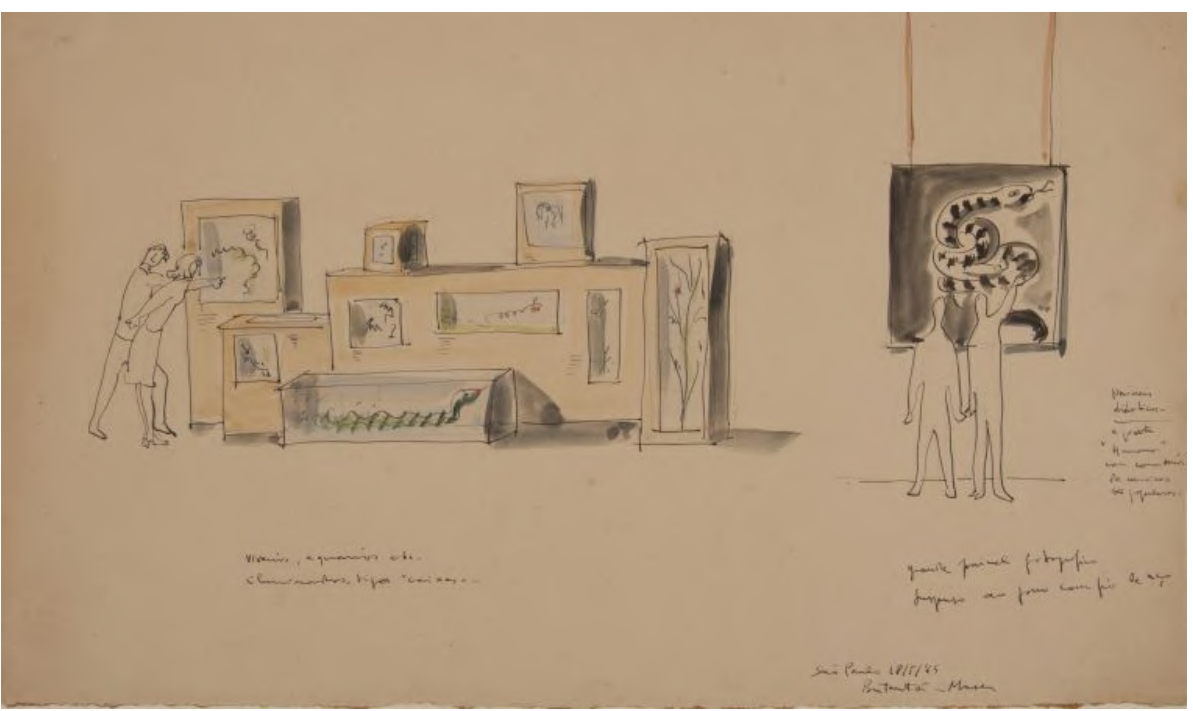

Figura 146: Ilustração dos expositores e do espaço interno do Museu no projeto de Lina Bo Bardi, 1965. Fonte: 069ARQd0003, Acervo do Instituto Bardi.

O projeto configuraria um espaço completamente distinto do que foi executado e permanece até hoje como Museu Biológico, assim como enriquece o acervo de projetos não construídos, que foram feitos para o Instituto Butantan neste breve período. Sobretudo, o contato dos pesquisadores do Instituto com a arquiteta, registrado pela carta de 1958 , demonstra uma iniciativa interna para o planejamento dos espaços do campus, cuja escolha e necessidades partem dos membros diretores do Instituto. Em 1959, estes projetos internos vão se deparar com o vertiginoso plano governamental de Carvalho Pinto, complexificando as disputas institucionais que já se faziam em torno do planejamento.

\subsection{Das disputas institucionais ao processo de tombamento}

Nas décadas de 1960 e 1970, o Instituto Butantan se consolidou como produtor de soros e vacinas para a saúde pública brasileira, atingindo o protagonismo nas campanhas nacionais de vacinação responsáveis pelo controle e erradicação de diversas doenças. Com o processo de desnacionalização da indústria farmacêutica, a produção pública ganhou destaque e o êxito do Instituto nestes episódios de vacinação o alçaram à condição de órgão essencial para a autossuficiência nacional na produção de imunobiológicos (TEIXEIRA, 2006, p.121). 
Do ponto de vista institucional, vitórias alcançadas em sua área de atuação também contribuíram para o fortalecimento de uma narrativa de mitificação do Instituto e de seus principais personagens, algo recorrente em instituições deste tipo, como identificaram os historiadores Jaime Larry Benchimol e Luiz Antonio Teixeira (1993). Histórias de superação, de enfrentamento das adversidades em sua trajetória, contribuíram para a coesão do Butantan em suas primeiras décadas, diante do desafio da consolidação institucional em um contexto de instabilidade e competição acirrada com outros centros de pesquisa e produção na área da saúde. Como vimos, o espaço construído de seu campus de pesquisa também desempenhou papel importante para a formação de uma narrativa própria que, inclusive, pudesse diferenciá-lo de outras inúmeras instituições do mesmo tipo que surgiam no final do século XIX.

\begin{abstract}
Nessa narrativa, o espaço construído desempenha um papel importante ao constituir sua materialização. Enquanto no Rio era Oswaldo Cruz o líder fundador, sendo a Fazenda de Manguinhos o locus, e o engenheiro-arquiteto Luiz Moraes Jr. o projetista dessa epopeia através de obras como o Pavilhão Mourisco e a Cavalariça, entre outros, em São Paulo foi Vital Brazil, na Fazenda Butantan, o personagem heroico. Aqui, quanto à arquitetura, parece ter havido diversos profissionais atuantes, seja do Departamento de Obras do Estado, seja com particulares contratados, como é o caso de Andrigo. Mas, pelo número de obras projetadas nesses primeiros anos, pode-se dizer que o arquiteto que desempenhou aqui um papel como o de Moraes no Rio foi o engenheiro-arquiteto Mauro Álvaro de Souza Camargo. (SÁ, 2019, p.54)
\end{abstract}

Esta narrativa é sempre renovada e acrescida de elementos que exaltam os triunfos institucionais. Este fator foi importante para a sobrevivência do pequeno laboratório instalado na Fazenda Butantan no final do século XIX, sob a direção de Vital Brazil, quando foi capaz de debelar o surto de peste bubônica em Santos. De certo modo, este aspecto pode ser presenciado diante da conjuntura atual, na qual a pandemia de Covid-19 acirrou as narrativas políticas e colocou novamente o Instituto Butantan no centro das atenções nacionais. Os grandes desafios retornam para mais uma vez legitimar sua relevância e centralidade, além de reafirmar e renovar a própria narrativa construída pela instituição.

Retornando aos anos 1960, a questão do planejamento do seu campus, parte fundamental e constituinte desta narrativa, aparece como mais um percalço a ser 
superado. Inicialmente aceita - até mesmo comemorada durante o anúncio do PAGE -, a construção da Cidade Universitária seguida pelo convênio com o FCCUASO foram percebidos como uma ameaça à sua autonomia territorial, que mais uma vez viria a tolher seus espaços como ocorreu em 1941. As intenções radicalizadas de substituição dos edifícios históricos por arquiteturas modernas, cujo planejamento ficava a cargo de arquitetos alheios à política e ao funcionamento interno do Instituto, foram o estopim de uma escalada pela preservação do conjunto que conferia identidade ao Butantan, passando a ser compreendido como patrimônio histórico.

\subsubsection{A escalada das disputas e o recurso ao passado}

A escalada destes embates tem como origem a insatisfação com os rumos do planejamento do campus do Instituto Butantan nas duas décadas do convênio com o FCCUASO, principalmente no que se refere à preservação do território Institucional, cujos limites foram sendo gradativamente redesenhados durante a construção da Cidade Universitária. Após a realização dos primeiros projetos feitos pelo convênio, construídos a partir da segunda metade da década de 1960, além do Conjunto Residencial, concluído nos anos anteriores, na década de 1970 os novos projetos e obras vão se tornando mais reduzidos. Os investimentos passaram a se concentrar no setor da produção, enquanto obras de reforma dos edifícios existentes e construções pontuais, como o prédio para o restaurante, se localizaram na região do núcleo de edifícios históricos do Instituto.

Dois eventos ocorridos na década de 1970 foram importantes para o acirramento das relações entre Instituto e a Universidade, no que se refere à delimitação dos respectivos territórios definidos pelo decreto de 1941, que desmembrou a então Fazenda Butantan. Em 1977, por meio de um novo decreto, seriam destinados cerca de $60.000 \mathrm{~m}^{2}$ da área do Butantan para a Secretaria de Obras e Meio Ambiente (Relatório Anual, 1978, fl.04), montante revisto e diminuído após esforços da diretoria do Instituto. Esta área seria destinada à instalação da Fundação 
Faria Lima, onde hoje se encontra a Fundação SEADE, cujo acesso se dá pela Avenida Prof. Lineu Prestes, na Cidade Universitária. A localização é muito próxima do local onde foi projetada a esplanada do setor de pesquisas do Instituto, prevista nos Planos de 1961 e 1963, feitos sob o Plano de Ação do Governo do Estado, onde seriam construídos os prédios de Pesquisa, Vírus e Genética e Auditório e Biblioteca (ver capítulo 2.5).

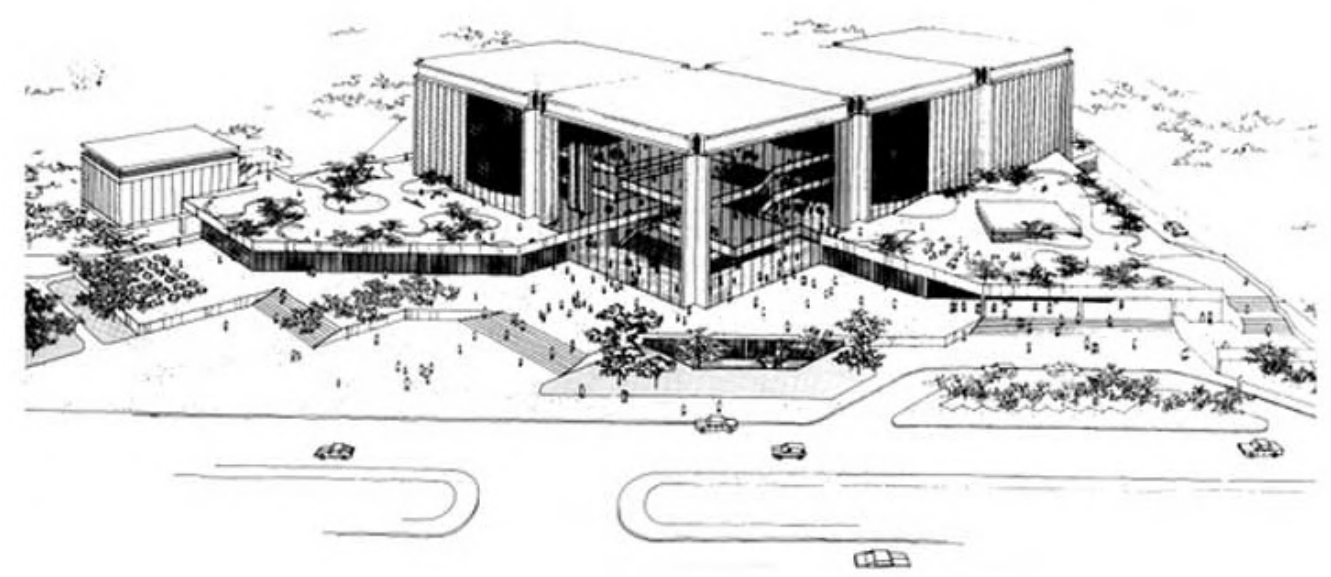

Figura 147: Perspectiva do projeto de Jorge Wilheim pra o Centro Estadual de Cultura e Civismo, no qual participaram Rosa Kliass, Renina Katz e Sílvio Sawaya, 1973. Somente as esplanadas vistas na imagem foram construídas. Fonte: Site de divulgação da obra de Jorge Wilheim, disponível: http://www.jorgewilheim.com.br/legado/Projeto/visualizar/1474. Acesso em: 01. Abr. 2021

A esplanada, assim como o prédio do Auditório e Biblioteca, eram projetos de 1961 do arquiteto Jorge Wilheim, responsável pelo planejamento do Setor Biológico da Cidade Universitária e que estabelecia relação importante com a esplanada do Instituto. Em 1973, Wilheim projetou um grande edifício para o Centro Estadual de Cultura e Civismo (Figura 147), localizado na Avenida da Universidade, principal via de acesso ao campus da USP e que faz limite com o Instituto Butantan em quase toda a sua extensão. O edifício teria frente para a Avenida, em área de propriedade do Instituto, próximo de onde se encontra o setor da produção.

O projeto de cerca de $70.000 \mathrm{~m} 2$ foi parcialmente construído, o que não deixou de significar uma enorme estrutura construída em seu território mas alheia ao Instituto. Posteriormente, passou a abrigar o Paço das Artes e somente foi retomado 
em 2018, quando a USP cedeu o espaço e foram feitas reformas para a instalação do centro administrativo do Instituto Butantan.

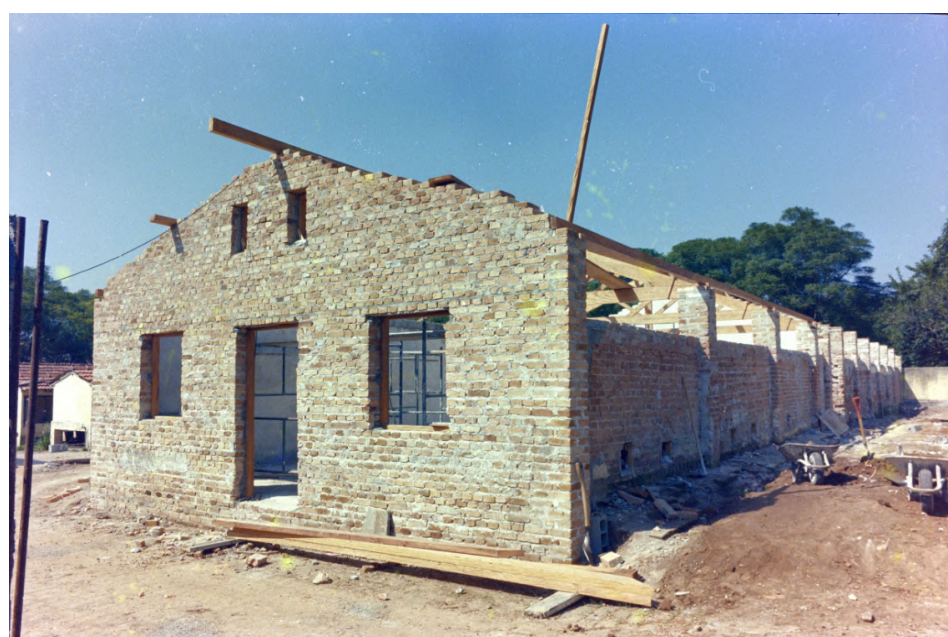

Figura 148: Construção da réplica do antigo laboratório e estábulo, 1980. Fonte: IB_ICO_003176, Centro de Memória/IB.

Segundo Henrique Moisés Canter, diretor da Divisão Cultural à época, os dois episódios nos quais o Instituto Butantan foi obrigado a ceder, por mais uma vez em sua história, parte da área de seu campus, somados a outros fatores como a comemoração dos 80 da instituição, fizeram com que a necessidade de preservação do seu patrimônio ganhasse ainda mais importância:

Aproximava-se a data em que o Instituto Butantan comemoraria os seus 80 anos, presenciara-se nos últimos anos a sucessiva perda de área em seu campus (Fundação Faria Lima e Centro Cultural/USP), motivando-se então a necessidade de preservar o seu patrimônio físico e cultural através de seu tombamento (14/09/81) e de comemorar a data, realizando-se obras e inúmeros procedimentos de natureza científico-culturais. (CANTER, 2005, p.65)

Neste contexto, diante da comemoração de seus 80 anos de fundação, o recurso a um passado mítico serviu como mecanismo de conservação do seu patrimônio, ao que era visto como um longo processo de espoliação que durava desde 1941. A descoberta de vestígios de um antigo edifício da Fazenda Butantan, no qual Vital Brazil teria instalado o seu primeiro laboratório para a produção de soro, serviu como elemento de resgate da história institucional, motivando a reconstituição do antigo edifício pra a instalação de um Museu Histórico, o segundo museu do Instituto, 
desde a reforma da Cocheira Central em 1965.

Com este intuito foi reconstruído um antigo prédio rural de características simples, formado por um pequeno pavilhão de cobertura em telha de barro e treliças de madeira. Fez-se uma réplica com base nos vestígios encontrados e depoimentos de antigos funcionários, cujo projeto e execução ficou a cargo do arquiteto Osmar Mammini, da divisão de projetos do FCCUASO no Instituto Butantan. Segundo o arquiteto, o edifício foi praticamente todo reconstruído, visto que muito pouco havia restado da construção original:

E nós fizemos piso novo, tudo novo, porque só tinha um pedaço de muro desse tamanho, não tinha mais nada. E nós pegamos tijolos antigos, madeira antiga para fazer o telhado, tudo, sabe, para tentar reconstruir o mais próximo da realidade. (MAMMINI e HECK, 2016, p.155)

Originalmente, o edifício abrigou funções diversas nos primeiros anos do Instituto até ser demolido em 1928, restando o piso e as fundações que foram encontrados durante serviços de demolição executados nos anos finais de 1970 . Em 1981, optou-se por construir uma réplica exata do antigo edifício conferido à atuação pioneira de Vital Brazil, no qual foram adotadas estratégias controversas e que pouco se aproximavam de um processo de restauro como havia sido anunciado. ${ }^{108}$ De todo modo, este episódio contribuiu para a contratação de profissionais e para o desenvolvimento da pesquisa histórica no Instituto Butantan, ${ }^{109}$ o que era desempenhado pelos próprios pesquisadores, que produziram estudos sobre a história da Instituição.

\subsubsection{Tombamento e o fim do convênio com a USP}

As frequentes investidas recebidas contra o seu território, despertaram a comunidade e a direção do Instituto Butantan para a preservação do conjunto

108 No capítulo 2.3.19. Museu Histórico, Anderson de Sá (2019) faz uma análise detalhada da reconstrução do edifício e das estratégias adotadas pelos seus idealizadores à época, cujo prédio foi anunciado como fruto de um processo de restauro.

109 A partir deste episódio, inúmeros historiadores e pesquisadores passaram pelo Instituto, muitos ligados à Universidade de São Paulo. Hoje o Butantan conta com os profissionais do Centro de Memória e do Laboratório de História da Ciência, além da própria equipe do Museu Histórico. 
edificado do seu campus. Neste ponto, a iniciativa de reconstrução do antigo edifício conferido aos trabalhos iniciais de Vital Brazil, se inseria em um esforço pela patrimonialização, não somente do conjunto das edificações, mas do território que configura o campus do Instituto. Ao mesmo tempo, foram levadas a cabo estratégias de ocupação do seu território para além do núcleo edificado, com a expansão das áreas verdes que ocupam a maior parte do campus.

Assim, em 1980 foi oficializado o pedido de tombamento ao Condephaat, decretado em 14 de Setembro do ano seguinte, quando das comemorações dos 80 anos do Instituto Butantan. Justificado pela relevância histórica do conjunto arquitetônico, o processo de tombamento foi, sobretudo, motivado pela necessidade de autopreservação do patrimônio institucional, constantemente ameaçado por interesses externos, manifestos em projetos da Universidade de São Paulo e do Governo do Estado, para as áreas do campus.

Embora o convênio com o FCCUASO para o planejamento tenha permanecido até 1985, o tombamento do Instituto em 1981, acabou por encerrar o período dos grandes projetos de modernização do campus do Instituto, que já desaceleravam desde o final da década de 1960. A partir do tombamento, o instituto voltou-se definitivamente para a preservação de seus espaços, atravessando uma grave crise financeira nos anos 1980, que limitou consideravelmente os investimentos para a restauração e manutenção dos edifícios históricos.

Em consequência do novo patamar atingido pelo conjunto arquitetônico, chancelado pelo órgão estadual de preservação e não mais somente caracterizado como um grupo de edifícios evocados pela sua simbologia institucional, o campus passou a ser cada vez mais compreendido como patrimônio cultural e o Instituto Butantan também como centro de pesquisa, divulgação e promoção da cultura e da ciência, para além da sua função original de pesquisa científica e produção de fármacos. Esta nova condição de patrimônio, atrelada às iniciativas institucionais voltadas à pesquisa histórica, à manutenção de museus institucionais, à formação de arquivos, laboratórios e grupos de pesquisa, consolidou o Instituto como importante 
centro de cultura na cidade de São Paulo.

\subsubsection{A questão do moderno como patrimônio}

O advento do Plano de Ação em São Paulo, que transformou a cultura construtiva e arquitetônica do Estado (BUZZAR, CAMARGO, CORDIDO, 2016), embora não tenha se desenvolvido plenamente nos projetos feitos para o Instituto Butantan, foi decisivo para a valorização do seu patrimônio arquitetônico e para a conformação do campus como patrimônio cultural. Em paralelo a este processo de valorização do patrimônio histórico vinculado à arquitetura, se estabeleceu uma relação de hostilidade com o planejamento moderno, cujos poucos edifícios construídos no campus durante o PAGE e o convênio com a USP foram desconsiderados como patrimônio no processo de tombamento.

É importante notar que naquela época, em 1981, embora estes fossem edifícios contemporâneos, que acumulavam pouco mais de uma década de história, alguns até menos do que isso, a questão da arquitetura moderna como patrimônio já aparecia como objeto de debate no campo disciplinar, sendo que, no mesmo ano, o Condephaat tombava o Edifício da FAU USP ${ }^{110}$, inaugurado em 1969 e resultado do mesmo contexto proporcionado pelo Plano de Ação, que produziu projetos modernos para o Instituto Butantan.

Embora o caso da FAU USP seja uma exceção pela sua importante relevância como exemplar da arquitetura deste período, a arquitetura moderna no Instituto Butantan, principalmente esta arquitetura de matriz brutalista, parece não ter sensibilizado os seus dirigentes no sentido de sua preservação. Por diversas vezes após concluído o processo de tombamento do seu conjunto arquitetônico, desde o início da década de 1980 até os anos recentes, as obras modernas construídas entre as décadas de 1960 e 1970, foram constantemente alteradas, descaracterizadas e, muitas delas, demolidas. Como vimos neste Capítulo 3 (subcapítulo 3.2.2), pouco restou do conjunto 
de edifícios construídos na segunda metade da década de 1960 para o setor da produção, permanecendo um dos cinco pavilhões originais do Prédio dos Almoxarifados e Serviços, e os demais edifícios do setor descaracterizados ou demolidos. Por sua vez, o Conjunto Residencial do arquiteto Mário Rosa Soares, único projeto construído do período do Plano de Ação, é mantido praticamente sem uso e em rápido processo de deterioração, enquanto planos para a sua demolição são frequentemente cogitados. O caso do Prédio do Restaurante, um dos exemplares modernos e de linguagem associada à arquitetura brutalista, construído entre 1977 e 1978, representa bem esta relação conturbada da modernidade como patrimônio. Em 2001, a convite do ex-diretor Isaias Raw (1991-1997), o arquiteto Marcio Kogan desenvolveu um projeto para a transformação do Prédio do Restaurante em Museu de Microbiologia, que ocultou as suas características originais marcadas pela exposição dos materiais e elementos construtivos, encobertos no projeto pela adição de novos elementos à estrutura existente (LUCCA NETO, 2019). ${ }^{111}$

Estas arquiteturas modernas, tornaram-se o resquício de um momento no qual o conjunto de edifícios existentes, realmente entendidos como patrimônio histórico, foi colocado em risco pela execução de um projeto de modernização externo ao Instituto e que extrapolava os seus limites, mas que tinha nele uma de suas frentes de atuação. Esta percepção foi se aprofundando na medida em que eram desenvolvidos os projetos do Plano de Ação e avançava a construção da Cidade Universitária. Conforme o depoimento do arquiteto Osmar Mammini:

[...] Quando me mandaram para o Butantan, o diretor do Instituto, já falecido, era o Aristides Vallejo Freire. Ele acha que aqueles projetos que tinham para o Instituto eram todos, vamos dizer assim, mais para a ascensão dos arquitetos do que para promover o Instituto, propriamente. Então ele não os quis, ele preferiu fazer tudo novo. (MAMMINI e HECK, 2016, p.148)

A mesma percepção parece ser compartilhada pelo arquiteto Carlos Henrique Heck, que trabalhou com Mammini no escritório do FCCUASO no Instituto:

[...] Eu tenho, uma vaga memória..., portanto, quando eu fui participar dessa equipe, alguns projetos em função do tempo em que foram feitos e na atualização depois de alguns anos (estes) já não satisfaziam tanto a direção

111 Ver Apêndice I desta dissertação. 
do Butantan. (Ibid., p.165)

Ao fim, a ideia de que os projetos de modernização correspondiam à interesses externos expôs a disparidade entre as intenções dos arquitetos do Plano e os interesses institucionais, consolidando o entendimento de que a arquitetura que, de fato, representava a história institucional e deveria ser preservada era a dos edifícios históricos das primeiras décadas.

Com o passar dos anos, pouco se fez para a preservação dos edifícios modernos construídos a partir dos anos 1960 e foi se ampliando a noção de que estes exemplares eram elementos conflitantes com a paisagem histórica e tradicional que se pretendia valorizar. Apesar da existência do pequeno prédio da recepção de animais de 1952, de Hélio Duarte e Ernst Mange, cuja matriz corbusiana e da arquitetura carioca é bastante presente, o modernismo não conseguiu penetrar e se consolidar no campus do Instituto Butantan. Não fosse o trabalho de resgate e preservação dos documentos do Plano de Ação, pouco restaria deste episódio da arquitetura moderna, cujos poucos exemplares construídos correm risco de desaparecimento.

Ao longo dos últimos quarenta anos, desde o seu tombamento em 1981, o campus do Instituto Butantan recebeu, e continua a receber, novos projetos e planos de intervenção, convivendo com a necessidade de preservação dos edifícios e da paisagem do núcleo histórico. Estes planos, manifestados por atores diversos: diretores, membros do governo ou órgãos de estado, agentes empresariais e, se pudermos adotar a separação entre arte e poder de Argan (2005), produzidos por um corpo técnico próprio, por meio de concursos de projeto ou por escritórios de arquitetura convidados, expressam embates políticos e visões múltiplas sobre o planejamento do Instituto, cujo futuro de seus espaços permanece em disputa e em produção. 
Conclusão 


\section{Conclusão}

Ao longo do século XX, o Instituto Butantan pôde se desenvolver e se tornar uma das mais importantes instituições científicas e de pesquisa do mundo e principal produtor de imunobiológicos do Brasil, responsável por grande parte das vacinas do Programa Nacional de Imunização. Sua trajetória está entrelaçada à história brasileira e do desenvolvimento científico nacional, cuja a atuação precursora, na produção de soros e vacinas, o tornou presente no cotidiano das pessoas, contribuindo para a sua popularização e para a construção de um lugar privilegiado no imaginário social, fortemente vinculado ao trabalho pioneiro de Vital Brazil com serpentes.

Parte fundamental desta trajetória, o seu campus de produção e pesquisa, com seus imponentes edifícios históricos, ajudou a imprimir uma imagem para a tradicional instituição, que se vincula às conquistas de seus pesquisadores e ao progresso da ciência. Ao mesmo tempo, a história de seus espaços está relacionada ao desenvolvimento do bairro do Butantã, no qual o Instituto desempenhou um papel importante para ocupação inicial da região, e ao campus da Universidade de São Paulo, com o qual a Instituição estabeleceu uma relação intensa, que dura a maior parte de seus 120 anos de existência.

Esta relação está presente na colaboração institucional e no intercâmbio científico, em projetos conjuntos na área da saúde e na intensa circulação de pesquisadores e profissionais, que, ao longo de suas carreiras, atuaram em ambas as instituições. Contudo, esta profícua relação, que legou a formação conjunta de inúmeros profissionais e que está presente no sucesso dos trabalhos científicos, não se estende ao espaço construído. Do ponto de vista do planejamento, a relação entre Instituto Butantan e Universidade de São Paulo foi, também, marcada pela circulação profissional mas, sobretudo, pela relação de convivência estabelecida em 1941, quando a maior parte da Fazenda Butantan foi cedida para a construção da Cidade Universitária. Esta coexistência territorial, nem sempre harmoniosa, pode ser observada na conformação atual dos dois campi, cujos muros e portões delimitam os espaços das duas instituições, preservando-se muito pouco da proposta de integração 
entre institutos e faculdades, presente nos planos para a implantação da Cidade Universitária, sobretudo a partir do Plano de Ação em 1959.

Decisivo para esta atual configuração, o Plano de Ação do Governo do Estado de São Paulo, durante o governo de Carlos Alberto de Carvalho Pinto, de 1959 até 1963, foi responsável pela implantação da Cidade Universitária da USP e se estendeu ao Instituto Butantan, propondo a modernização do seu campus formado por edifícios históricos, datados das primeiras décadas do século XX. Recebido com entusiasmo pela direção do Instituto à época, o Plano foi visto como oportunidade inédita para a sua expansão e consolidação, que permitiria a afirmação do Butantan no quadro do seu reconhecimento e dimensão internacional, alcançados nas décadas anteriores.

Inserido no ambiente do pós-guerra, no contexto das políticas econômicas keynesianas dos países centrais, o Plano de Ação é parte das políticas desenvolvimentistas e de reforma verificadas em diversos países latino-americanos e que almejavam ampliar o desenvolvimento, não somente econômico, de modo a prevenir novas crises, como as que impactaram o mundo na primeira metade do século $X X$, assim como possibilitar a inserção e uma certa emancipação nacional dos países ditos não desenvolvidos na economia global. No Brasil, o Plano de Ação, assim como outros planos e políticas de desenvolvimento, se insere no ambiente democrático após o fim do Estado Novo, no qual se colocam as lutas políticas pela ampliação de direitos e reformas sociais. Nesta conjuntura, o Plano de Carvalho Pinto vai se caracterizar pelo forte investimento no desenvolvimento humano e social, através da construção de equipamentos públicos, convergindo com os anseios de muitos arquitetos paulistas em relação ao compromisso com a função social da arquitetura. Ao mesmo tempo, o Plano extrapolou os limites regionais, inserindo o estado de São Paulo no quadro do desenvolvimento nacional, anos após o revés político representado pelo Varguismo.

Considerados estes pretensiosos objetivos a serem realizados no breve período de um único governo, o Plano de Ação obteve enorme sucesso na medida em que foi capaz de proporcionar o desenvolvimento do interior do estado, reposicionando São Paulo, política e economicamente, na dinâmica nacional, consolidando e 
impulsionando a Universidade de São Paulo, além de transformar a cultura arquitetônica do estado através da construção de obras únicas, que desenvolveram uma linguagem própria e um projeto de modernização que se colocava diante do Plano de Metas e da construção de Brasília.

Nesta correlação com a arquitetura e os arquitetos da Nova Capital, as arquiteturas do Plano de Ação em São Paulo, foram identificadas pela literatura como uma linguagem local do modernismo brasileiro, distinta, ou inovadora em relação à consagrada obra de Oscar Niemeyer, até os anos de 1950. Esta alteridade da arquitetura moderna do Plano de Ação, que, por certas vezes, é vista como uma linguagem homogênea, se caracterizou por uma notável pluralidade de composições, elementos, formas e soluções arquitetônicas, amparadas pela diversidade de arquitetos que atuaram na produção de, ao menos, mil edifícios projetados e inúmeros construídos. Esta pluralidade arquitetônica, também é verificada nos projetos para o Instituto Butantan, para o qual foram desenvolvidos quase duas dezenas de novos edifícios modernos e quatro planos urbanísticos, somente no período que vai até 1966, embora apenas um destes tenha sido construído no campus.

Em que pese as poucas obras realizadas, o Plano de Ação legou ao Instituto Butantan um convênio de mais de duas décadas com o Fundo de Construção para a Cidade Universitária, iniciado em 1961 por determinação do governador Carvalho Pinto, para que se desse maior agilidade à execução dos novos projetos. Esta condição despertou o receio quanto a perda da soberania institucional, almejada desde a atuação pioneira de Vital Brazil no início do século, articulando esforços de emancipação do então Instituto Serumtherapico, em relação ao Instituto Bacteriológico.

Do mesmo modo, a construção da Cidade Universitária e os projetos de reformulação do campus do Instituto Butantan, fizeram emergir a preocupação quanto ao desmantelamento do conjunto de edifícios históricos que definiam a imagem e história da Instituição. A partir de meados da década de 1970, o Instituto recorre ao tombamento do seu conjunto arquitetônico pelo Condephaat que, em 1981, 
reconhece o valor histórico e arquitetônico do conjunto edificado do campus para São Paulo. Responsável pelo planejamento e execução das obras do campus do Instituto até 1985, o Escritório Técnico do Fundo de Construção chegou a construir alguns edifícios importantes entre as décadas de 1960 e 1970, mas renunciando ao planejamento integrado com a Cidade Universitária que havia sido proposto nos planos de 1961 e 1963.

Nesta conjuntura, o episódio do Plano de Ação no Instituto Butantan pode ser entendido, por um lado, como uma frente frustrada, que diante da resistência interna ao planejamento feito por arquitetos modernos, vinculados a um órgão alheio aos interesses da direção do Instituto, foi impossibilitado de reproduzir o sucesso do plano observado em praticamente todas as frentes de atuação pelo estado. Contudo, embora não se traduza diretamente na transformação dos espaços do campus, os projetos do Plano de Ação acabaram por definir a sua conformação atual, marcada pela ênfase aos edifícios históricos na paisagem, cuja existência havia sido ameaçada pelos projetos de modernização.

Pouco perceptíveis na paisagem atual do campus, estes aspectos do planejamento moderno do Plano de Ação, que desencadearam os esforços pela preservação do conjunto histórico, somente puderam ser resgatados e revistos através da documentação guardada pelo Centro de Memória do Instituto Butantan. Neste sentido, a disparidade entre a paisagem construída do campus e os projetos modernos identificados no acervo, reafirmam o triunfo do planejamento institucional sobre as propostas modernizadoras que, de diversas formas, foram (e continuam) sendo apagadas da paisagem oficial ou relegadas à condição de edifícios secundários, não relacionados à história institucional. Na contramão desta percepção arraigada ao planejamento, que sobressai destas disputas no início da década de 1980, podemos afirmar que estas arquiteturas modernas são parte constituinte da história do conjunto arquitetônico do Instituto Butantan, tão importantes quanto as construções institucionais feitas nas primeiras décadas, que realmente são valorizadas pelas políticas de preservação. 
Decisivo para o longo processo que culminou com a patrimonialização do conjunto edificado na década de 1980 , a reação desencadeada ao planejamento moderno feito a partir pelo Plano de Ação, acabou por definir a integração restrita e a permeabilidade limitada entre os campi do Instituto Butantan e da Universidade de São Paulo, apesar do significativo fluxo de pessoas e visitantes que cotidianamente transitam por estes espaços. Neste sentido, na medida em que se acelera o desenvolvimento da região, durante o século $X X$, o Instituto se volta para a preservação de seus espaços, buscando a manutenção de sua autonomia no contexto de disputa pelo território em processo de urbanização. 
Apêndices, Anexo e Bibliografia 
Apêndice I: Manifestação do contemporâneo no conjunto arquitetônico do Instituto Butantan ${ }^{112}$

Inaugurado no ano de 2002, o Museu de Microbiologia é o terceiro edifício do Instituto construído com a finalidade de abrigar um programa de caráter cultural e museológico, ${ }^{113}$ sucedendo a reforma do antigo edifício da cocheira central em 1965, construído em 1920, para a implantação do Museu Biológico e a construção do Museu Histórico em $1981 .^{114}$

A construção destes primeiros museus se insere, ainda na década de 1950, no quadro do constante aumento da preocupação da direção quanto a necessidade de um museu institucional para o conjunto, que se realizará somente em 1965 com o Museu Biológico. A partir dos anos de 1950 o conjunto do Butantan consolidava um grande interesse turístico em razão da fama internacional adquirida pelo Instituto até aquele momento. Deste modo, os projetos elaborados neste período, principalmente os planos urbanísticos modernos de 1959 a 1963, passam a considerar a implantação de grandes setores turísticos, que agregavam museus, espaços de lazer e de promoção da cultura e da ciência.

Já na virada do século, em um contexto político e econômico marcado pela retração dos investimentos públicos, o $\mathrm{MMB}$ surge como uma intervenção mais modesta, idealizado em razão das comemorações do centenário do Instituto (19012001) e pensado como um Museu destinado à promoção da ciência e com o objetivo de estimular o interesse científico do público mais jovem, especialmente de estudantes e professores de ensino médio (GRUZMAN, 2012, p. 144).

112 Análise do projeto para o Museu de Microbiologia presente no artigo apresentado no XXIII Congresso ARQUISUR, "A Produção da Cidade Contemporânea no Cone Sul", realizado na cidade de Belo Horizonte/MG entre 02 e 04 de outubro de 2019. Ver LUCCA NETO (2019). Texto completo disponível em: $\quad$ https://proceedings.science/arquisur-2019/papers/manifestacao-do-contemporaneo-noconjunto-arquitetonico-do-instituto-butantan-o-museu-de-microbiologia-de-marcio-kogan?lang=ptbr

113 Além do Museu de Saúde Pública Emílio Ribas, situado fora do parque do Instituto Butantan, localizado na região do Bom Retiro, centro de São Paulo, que, portanto, não constitui parte do conjunto arquitetônico tombado em 1981.

114 Um dos projetos para o Museu Biológico em 1965 é de autoria da arquiteta Lina Bo Bardi, não construído e substituído pelo atual projeto dos arquitetos do FCCUASO instalados no Instituto à época. O Museu Histórico foi, por sua vez, reconstituído em 1981 a partir de ruínas encontradas de um antigo estábulo dos primórdios do Instituto e idealizado em razão do tombamento pelo Condephaat no mesmo ano. 
Na paisagem do conjunto o $\mathrm{MMB}$ ocupa uma cota mais alta em relação aos demais museus do Parque e próximo à grandes edifícios como o Edifício Vital Brazil (1914) e o Prédio Novo (1945), ao mesmo tempo, está parcialmente ocultado pela vegetação densa que o circunda e por sua posição deslocada do principal eixo turístico e de circulação do campus, às costas para os principais edifícios (figura 149). Esta situação contribui para a presença modesta e quase imperceptível do Museu na paisagem do conjunto, reforçada pela sobriedade da intervenção proposta pelo projeto.
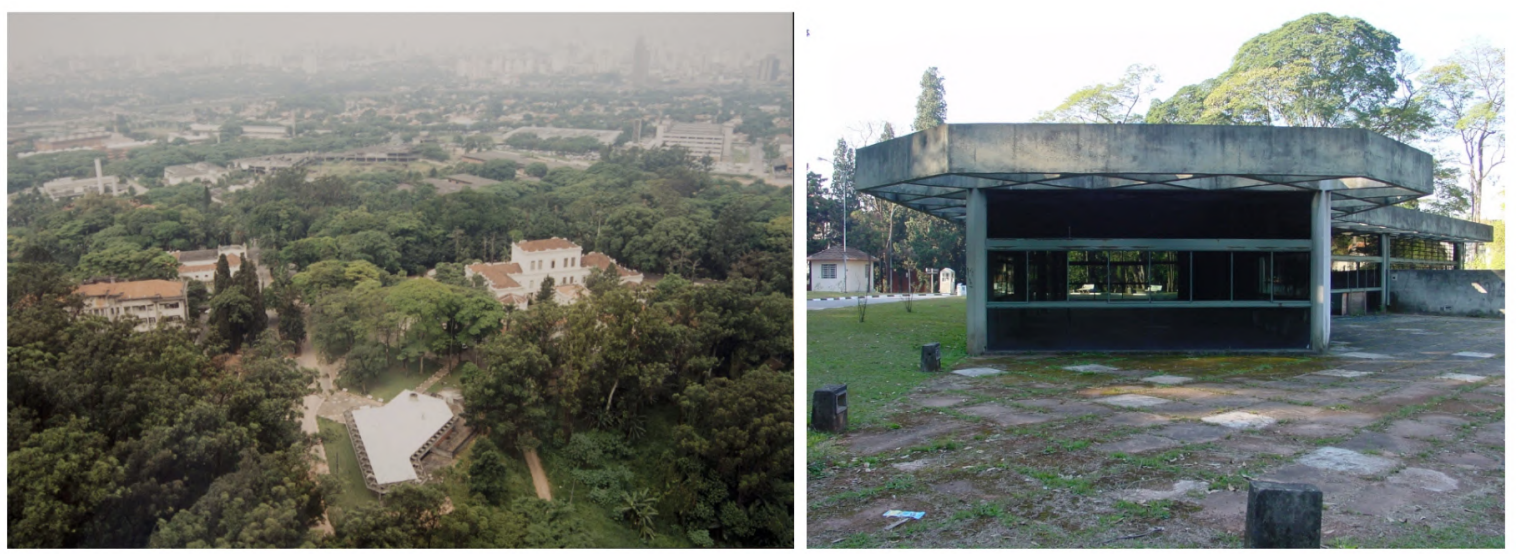

Figura 149: Fotografia aérea localizando o antigo restaurante recuado entre o Prédio Novo e o Edifício Vital Brazil e imagem do edifício antes da intervenção, sem data. Fonte: Centro de Memória/IB e MK27.

Apesar das restrições impostas pela sua implantação em um edifício preexistente, o programa do museu está organizado em cinco setores: recepção, salão principal, laboratório didático, auditório e, por fim, a chamada Praça dos Cientistas (BOCEWICZ, 2019, p.08), configurando um espaço de permanência e acesso ao edifício. $^{115}$

São poucos os documentos disponíveis sobre o projeto que permitem uma compreensão mais apurada da relação entre o antigo edifício preexistente e o projeto proposto pelo arquiteto Marcio Kogan em 2001. No entanto, dada as características estruturais do edifício modernista, organizado por pilares e vigas em concreto armado independentes da alvenaria, é provável que o procedimento de reorganização da planta para o novo programa não tenha se apresentado como o maior obstáculo. 
Parece indiscutível que o grande desafio do projeto tenha sido, de fato, a reformulação formal e material do edifício.

Tirando proveito dos vãos estabelecidos pela estrutura, o projeto divide-se em dois principais setores: um que chamaremos de técnico e que compreende laboratório, auditório, banheiros e a bilheteria; e o setor expositivo, no qual está o salão de exposições (figura 150). O espaço do salão é definido por uma grande mesa central recebendo a chamada exposição de longa duração que "aborda aspectos da história da microbiologia por meio de uma sequência de painéis" como descreve Carla Gruzman (2012, p.149). Além de objeto expositor, a mesa é o elemento que define e organiza os fluxos do setor expositivo, conformando um espaço de circulação que começa pela entrada principal e encaminha os visitantes por um circuito no seu entorno. Todo o espaço da exposição está envolto por um fechamento em vidro e por uma pele de madeira externa que, por sua vez, nos direciona para outro aspecto do projeto.

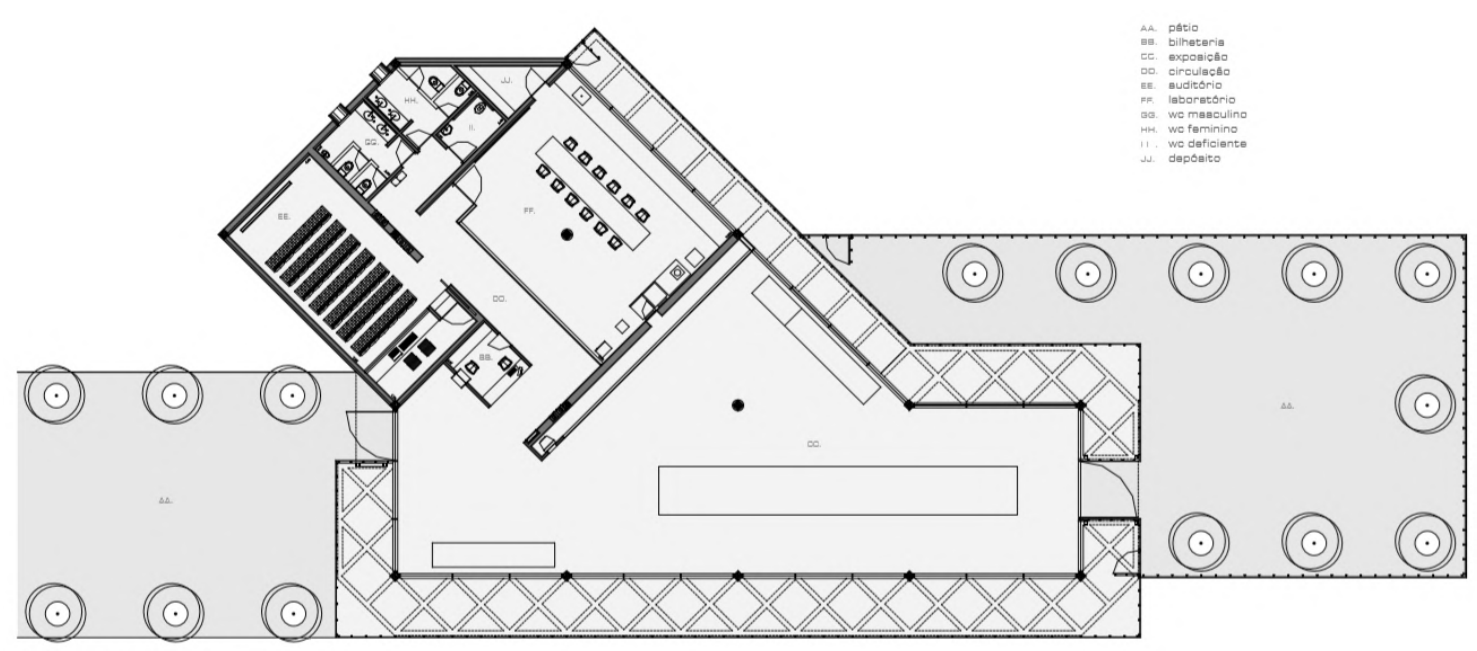

Figura 150: Planta térrea do Museu de Microbiologia, com pequenas variações em relação a atual praça externa construída. Fonte: projeto cedido pelo MK27.

Entre 1999 e 2001 o Arquiteto Marcio Kogan projetou, em conjunto com sua equipe, a residência Gama Issa, também localizada na cidade de São Paulo. Na apresentação disponível no site do escritório um breve texto descreve conceitualmente o projeto da nova casa como quem escreve o roteiro de um filme, seus protagonistas? $\mathrm{O}$ cliente, o arquiteto e personagens de seu cotidiano de projeto. ${ }^{116}$ 
No texto, que começa como uma cena de um filme e descreve o programa do projeto, aparecem algumas referências: a poltrona Ball de Eero Aarnio, os anos 60, o Minimalismo, o filme "Meu Tio" de Jacques Tati. Este último ganha destaque, dividindo o protagonismo com as imagens do projeto. São caras as referências cinematográficas para Kogan que produziu diversos curtas entre os anos 1970 e 1980 e o filme Fogo e Paixão de 1988, dirigidos com o também arquiteto Isay Weinfeld.
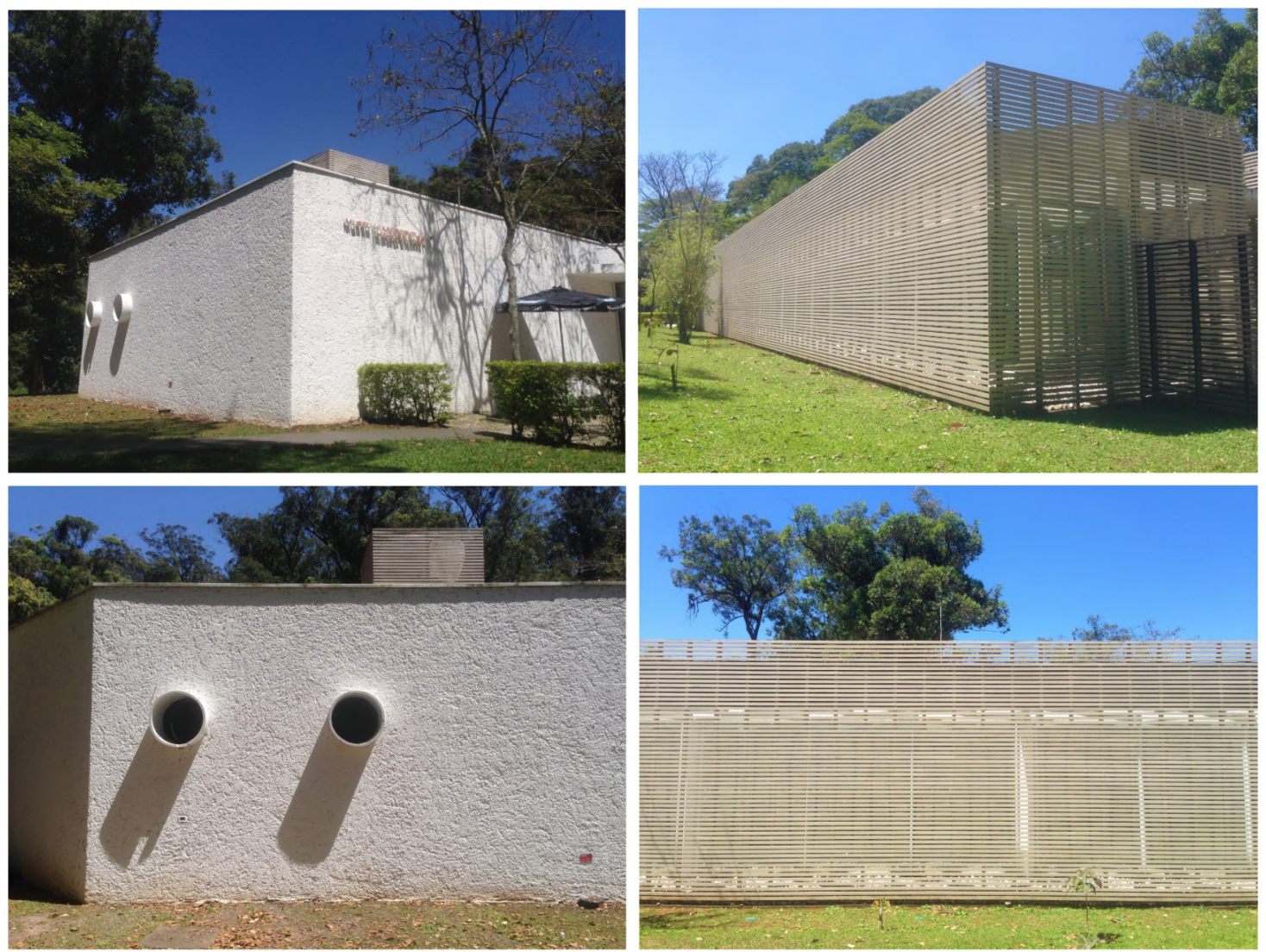

Figura 151: Fotografias do Museu de Microbiologia do Instituto Butantan, respectivamente: volume à esquerda da entrada principal, volume à direita, fachadas laterais. 2018. Fonte: fotografia do autor, Setembro de 2018.

No Museu para o Instituto Butantan dois volumes compõem o edifício definidos pelo programa: o volume branco, fechado e maciço, um outro permeável, envolto pelo ripado de madeira controlando a luz incidente nas fachadas envidraçadas. Uma pele que envolve o edifício moderno e atualiza sua linguagem. Contemporâneo à casa Gama Issa, iniciado em 2001, o MMB apresenta fortes semelhanças formais com a casa concluída naquele ano: volumes brancos e puros, minimalistas, janelas circulares, elementos que evocam a modernidade cômica dos filmes de Tati (figura 151). 
Além de Mon Uncle (1958) o cineasta francês Jacques Tati produziu filmes como Playtime (1967), uma sátira à modernização acelerada do mundo e crítica ao ponto de chegada deste processo, da massificação do consumo, da padronização e do ambiente genérico das cidades modernas. Nitidamente, a relação existente entre a arquitetura de Kogan e o cinema, como duas atividades que permeiam a trajetória do arquiteto, se dá, também e de forma ambivalente, com a tradição moderna da arquitetura brasileira.

Em muitos aspectos esta herança moderna parece, nos debates mais localizados em São Paulo, definir a condição de grande parte dos arquitetos a partir dos anos 1980. A evidente crise do modernismo arquitetônico brasileiro que, ao menos até a década de 1960, parecia inverter a balança da arquitetura com os países centrais, abriu precedentes para uma disputa nos anos 1990 entre seguir, ou não, uma tradição moderna consolidada no país nas décadas anteriores.

Assim, dividiam-se os arquitetos entre os que acreditavam na permanência da modernidade e os que buscavam outras referências para seus projetos, por vezes, voltando-se à produção dos países centrais na busca por um modelo. O historicismo e o revivalismo pós-modernos parecem, no entanto, não terem alcançado vida-longa num país de tradição moderna tão enraizada, na outra ponta, os defensores de uma vertente modernista também foram recebidos com ressalvas. Nada simbolizou tão bem essa disputa quanto o concurso para o Pavilhão Brasileiro na Exposição Universal de Sevilha em 1992, resultando o famoso artigo "deu em vão" publicado por Hugo Segawa (1991) comentando o projeto vencedor, de Angelo Bucci e Alvaro Putoni, que teria incorporado de forma acrítica os cânones do modernismo paulista.

O problema, no entanto, era o fato de que, nos anos 90 , a experimentação criativa -defendida por Artigas, anos antes, para justificar a sobrevida de seu projeto arquitetônico de cunho político e social, mesmo depois de combalido pela impossibilidade de estender as "benesses" da industrialização da construção em concreto armado para a toda a população -havia se transformado, também, numa espécie de "redenção" para a iminente "perda" de identidade arquitetônica brasileira, em face à indistinta absorção de signos historicistas de cunho pós-modernista pelos brasileiros, naquele momento.

Entretanto, apenas parcialmente, essa noção pode ser aqui utilizada, pois, apesar da ideia de retomada do trabalho dos precursores transparecer no discurso projetual desse grupo de arquitetos, ela padece em atualizar seu conteúdo, porque, ao fugir de uma compilação dos historicismos que 
estavam em voga no plano internacional, o projeto vencedor, talvez reproduza, nos próprios termos da pós-modernidade, uma estetização da chamada "arquitetura paulista". (FIORIN, 2012, p.124-125)

Neste ponto a arquitetura produzida por Marcio Kogan na virada do milênio, incluso o projeto do $\mathrm{MMB}$, parece se relacionar com o modernismo arquitetônico brasileiro de modo relativamente distinto. Enquanto os arquitetos que retomaram o modernismo paulista na Exposição de 1992 o fazem como manifesto, como reação ou resposta à absorção indiscriminada de símbolos arquitetônicos dos países centrais - do historicismo ao high tech - os projetos de Kogan se inserem numa postura ambivalente. Remetem à linguagem moderna mas parecem fazê-lo como nos filmes de Tati.

A adoção desta estratégia permite fazer com que, na transformação de um espaço marcadamente moderno, não haja dúvida, por exemplo, quanto ao encapsulamento do edifício preexistente como modo de atingir uma expressão contemporânea com referências ao moderno, um modernismo atualizado e, por vezes, atemporal ou deslocado no tempo. Assim, como no caso do Museu de Microbiologia, apesar da clara referência a uma linguagem moderna que será a tônica dos projetos do MK27 ao longo de sua trajetória, não há, conciliação com a modernidade real do antigo edifício de materialidade aparente.

Esta correlação entre moderno e contemporâneo, fortemente presente no Museu, recria uma "modernidade leve" (FOSTER, 2017, p.88) ${ }^{117}$ como recurso a uma racionalidade de cunho modernista mas ausente dos materiais brutos, disfarçando os resquícios materiais da antiga construção mesmo que o espaço conformado por esta ainda esteja presente. O artifício da "pele" contemporânea como superfície mais importante que a estrutura parece representar um atributo fundamental do MMB, resta saber, neste caso, até que ponto se assume o risco da fetichização e ofuscamento de seu conteúdo.

A retomada histórica ensaiada neste artigo apresenta algumas noções importantes para tratar do projeto do Museu. A primeira refere-se a correlação do 
atual edifício com outro construído no último quartel do século XX. Não somente correlação mas uma coexistência que parte de um procedimento de projeto que age sobre uma estrutura preexistente, não há demolição, há uma adoção da estrutura antiga e uma adaptação basicamente material, uma atualização da imagem do antigo.

O conceito de mimese constituiu o suporte de toda a história da arte e da arquitetura, ao menos até os dois últimos séculos, quando foi radicalmente apartado da arte pelas vanguardas modernas através da aposta na abstração como nova forma de expressão em um mundo em transformação intensa (MONTANER, 1999, p.9-10). A crise da modernidade parece ter readmitido o recurso à mimese tendo, agora, também, a própria arquitetura moderna como referência. ${ }^{118}$ Vimos que no Brasil o enraizamento da modernidade permitiu a retomada de alguns de seus aspectos por uma nova geração de arquitetos diante do crítico impasse delineado ao final do último século. Instaura-se um movimento paradoxal: a busca rumo ao novo, que ainda não sabemos no que se constituirá, com referências ao moderno que não mais existe a não ser como história.

Como vimos, tal situação parece estar no âmago do projeto do $\mathrm{MMB}$ ao se referenciar a uma modernidade talvez idealizada, ao passo que suprime o moderno real e existente. Na perspectiva de uma análise histórica possível, tal operação configura a permanência do edifício modernista ao longo dos anos adentrando o novo século com uma nova roupagem dada pela introdução de novos materiais no projeto do Arquiteto Marcio Kogan. Até que ponto esta operação busca apagar os resquícios do antigo é um ponto a ser discutido, basta, por enquanto, afirmar a relevância destes aspectos: a relação do Museu com a história do conjunto do Butantan e a permanência do antigo edifício moderno, mesmo que invisível a primeira vista.

Se aos aspectos expostos no parágrafo anterior cabem nuances e maiores discussões a segunda noção a ser destacada é, sem dúvida, mais taxativa e unânime. Apesar da pretensa discrição que caracteriza o edifício, da simplicidade e modéstia própria de sua escala, não há dúvida de que o $\mathrm{MMB}$ corresponde à arquitetura de maior relevância do conjunto arquitetônico do Instituto Butantan desde os grandes 
projetos das primeiras décadas, passando pelas tentativas modernas dos anos 1960, até o século XXI.

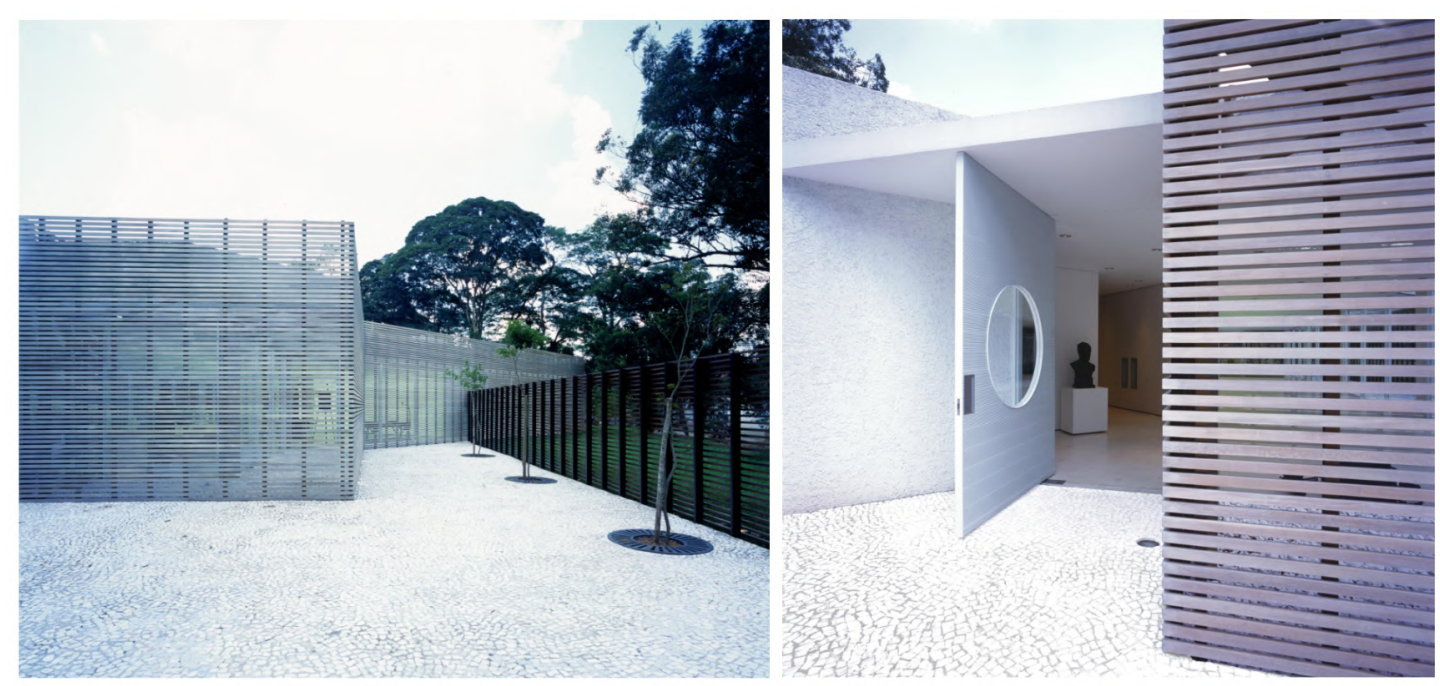

Figura 152: Imagens da praça posterior e da entrada do edifício do Museu de Microbiologia. Fonte: imagens cedidas pelo escritório MK27.

O Museu projetado por Marcio Kogan no ano de 2001 a convite do diretor Isaías Raw é representativo de uma tentativa de atualização e inserção na contemporaneidade de uma instituição tradicional que se tornava centenária no mesmo ano da concepção do projeto. Mesmo que os imponentes edifícios construídos nas primeiras décadas do século XX constituam a imagem do Instituto e revelem a sua importância como patrimônio histórico e cultural da cidade de São Paulo, o peso deste passado acabou, em parte, por tolher os esforços por novos espaços condizentes com as também novas necessidades que surgiam, subtraindo a arquitetura dos novos projetos executados nas últimas décadas.

Ainda que pesem as amarras impostas à periferia, num mundo globalizado e marcado pelo encolhimento do planejamento num sentido público, que outrora marcou o modernismo brasileiro, os esforços de proposição de espaços contemporâneos na periferia representam um potencial de renovação da disciplina. As restrições impostas pelo orçamento e pela preexistência no caso do Museu de Microbiologia descrevem uma crise que, ainda assim, produziu o edifício de maior relevância do centenário conjunto arquitetônico do Instituto Butantan nas últimas décadas, materializando a manifestação do contemporâneo num espaço consolidado e tradicional, no qual nem os planos modernos conseguiram se enraizar. 


\section{Apêndice II: entrevista com o Arquiteto Jacob Goldemberg ${ }^{119}$}

\section{Apresentação}

Formado em 1959 pela Faculdade Nacional de Arquitetura no Rio de Janeiro, então capital federal até a inauguração de Brasília no ano seguinte, o arquiteto Jacob Goldemberg teve, logo em seus primeiros anos de profissão, a oportunidade de atuar em um plano de enorme impacto para o desenvolvimento do estado de São Paulo, no qual os arquitetos urbanistas tiveram um papel central e destacado. Trabalhando em uma das principais frentes do Plano de Ação do Governo do Estado, no planejamento da Cidade Universitária da USP e do Instituto Butantan, Goldemberg participou de diversos projetos para o campus do Instituto de saúde e pesquisa entre 1961 e 1964.

Esta pesquisa identificou ao menos oito projetos para o Instituto Butantan cuja a autoria é conferida ao grupo formado pelo arquiteto junto de outros cinco profissionais: Abelardo de Souza, João Carlos Broos, Léo Quanji Nishikawa, Miranda Magnoli e Luiz Contrucci. Estes arquitetos se dividiram para a realização dos seguintes projetos: o Edifício da Produção, Edifício da Administração, Hospital, Restaurante, Macacário, Biotério, o Museu do Instituto Butantan e um Plano Geral para o zoneamento do campus da instituição. Assim como muitos outros projetos desenvolvidos pelo Plano de Ação em todo o estado, os edifícios e planos para o campus de pesquisa e produção do Instituto Butantan não foram executados, restando a lacuna histórica deste episódio da arquitetura moderna em São Paulo.

Esta entrevista teve como objetivo retomar esta história a partir da perspectiva de um dos atores que trabalhou diretamente nestes projetos de modernização. Buscamos assim compreender questões como o contexto da formação profissional do arquiteto, de sua atuação no Plano de Ação, as relações que estabeleceu com outros profissionais naquele momento, o cenário da arquitetura brasileira diante da construção de Brasília e sua perspectiva sobre os projetos que ajudou a desenvolver. 


\section{Entrevista $^{120}$}

Luiz: Jacob, pra começar eu queria pedir para que você se apresentasse, contando um pouco da sua trajetória profissional, como você foi estudar arquitetura, em que ano se formou.

Jacob: Eu me formei em 1959, na Faculdade Nacional de Arquitetura da Universidade do Brasil, Rio de Janeiro. E eu consegui na ocasião, uma nomeação pra trabalhar em Brasília, com Lucio Costa, na implantação de Brasília mesmo, da Capital, que estava no início. Aí, demorou pra sair essa nomeação e eu fui à Brasília para tentar ver o que acontecia. Estava acontecendo, existia o negócio. Aí cheguei lá, passei dois, três dias lá, não consegui descobrir. Voltei por São Paulo...conversei com um primo que tenho em São Paulo, que na ocasião administrava o Teatro de Arena, estava fazendo uma reforma. Um teatro que ficou muito importante na época da Bossa Nova, da implantação... eram os anos Juscelino né, uns anos de Brasil que nunca mais teve igual. E aí eu conversei com ele e fiquei de voltar lá pra tratar do assunto, ajudá-lo, como arquiteto e voltei para o Rio, tentei falar novamente com o presidente, não eu, mas a pessoa que tratava disso pra mim, e não foi possível fazer outra nomeação, disse que uma outra não era possível e tal, lamentava, aí eu resolvi ir pra São Paulo.

Luiz: E você ainda era estudante, ou já havia se formado? Foi em 1959?

Jacob: Foi em 1959. Eu cheguei a ir pra São Paulo em... final de 1950, ano de 1961.

Luiz: E essa oportunidade de trabalhar em Brasília...

Jacob: Se perdeu.

Luiz: Mas foi logo em 1959? Logo no início, quando tinha acabado de se formar?

Jacob: Quando eu... eu tinha um emprego público. Quando eu vi como é que estava São Paulo, eu passei por aí e falei com o meu primo e tal, eu disse: vou pra lá. São Paulo... no Rio não tinha nada. Quer dizer, não tinha nada, era muito difícil, recém120 Nota do entrevistado: O uso repetido da palavra "negócio", no meu falar, é um cacoete verbal, não se referindo a uma ação comercial ou mercantil, e, sim, a Trabalho, Compromisso, Atividade, Projeto, Objeto e outros que tais. 
formado. Aí peguei as trouxas, fui pra São Paulo, deixei a mulher e a filha com três meses, aqui, voltava todo fim de semana, depois. Mas aí fui pra São Paulo e... pra fazer esse trabalho e consegui um emprego no escritório do Jorge Wilheim, era um escritório muito bom, participava-se da nata dos arquitetos da época, e trabalhei lá por bastante tempo. Depois... trabalhava lá, abri um escritório meu, meio expediente, pra tentar coisas, comecei a fuçar, conseguia uma coisinha aqui outra ali, aí começou aquela luta...

Luiz: e era em São Paulo? O Escritório que você começou era em São Paulo?

Jacob: Já estava em São Paulo, rua Major Sertório. E era também o centro boêmio de São Paulo. Tinha uma casa lá e convênio com o barman da boate do lado, servia bebidas e etc., por cima do muro. E era um lugar muito bacana, foi uma época muito bonita, muito boa e a gente frequentava, por ocasião, o IAB, almoçava todo dia no $I A B$, e onde estavam os melhores arquitetos da época, gente jovem e alguns veteranos, lógico. Era um momento, um período muito bom, pra você se desenvolver, porque era outro tipo de, vamos dizer, de comportamento dos arquitetos. Eram arquitetos que se discutia, se falava, se debatia, modos de pensar a arquitetura. Tinha uma corrente é... que era orgânica, arquitetura orgânica, Frank Lloyd Wright e [inaudível], e outros que eram os racionalistas, funcionalistas, Le Corbusier, Louis Kahn e etc. e tal.

E esse era o papo, era dividido, a arquitetura tinha uma casa em... tinha duas correntes, eram os arquitetos da USP e os arquitetos do... Mackenzie não é? Mackenzie, eram duas... é o tal negócio não é, você nunca encontra unanimidade, então cada um puxava a brasa pra sua sardinha, era o melhor, o outro não era e... nos estagiários eu via também, tinha diferença de como era o pessoal. Pro nosso jeito aqui do Rio de Janeiro, o pessoal da USP era muito melhor de lidar, de tratar, de conversar, já o pessoal do Mackenzie era muito mais eficiente, mais certinho, entende? A USP já tinha, assim, um "toquezinho" mais carioca.

Luiz: e tinham outros arquitetos, de outros lugares do país, além dos arquitetos do Rio de Janeiro? 
Jacob: Não, não. Aquilo começou no período do, como é o nome do governador?

Luiz: A partir de 1959 é o Carvalho Pinto.

Jacob: Isso, desse plano do Carvalho Pinto, é que começaram a, vieram arquitetos do Rio pra lá. Porque... eu fui pra lá [São Paulo] quando soube disso, porque o Plano do Carvalho Pinto, não sei se eu estou me adiantando...

Luiz: Não, fique à vontade.

Jacob: Então, eu fiquei aí [São Paulo] até 1966. Eu fiz depois um escritório grande de arquitetura e construção, construímos algumas coisas depois compramos uma marcenaria muito grande, pra atender aos meus projetos, casas que eu fiz toda a parte de mobiliário. Depois em 1966, resolvi voltar para o Rio de Janeiro... esse período, o que atraiu na ocasião eram essas coisas desse plano do Carvalho Pinto.

Luiz: Que era uma oportunidade de atuar em um grande plano.

Jacob: Era difícil trabalho, lá [no Plano de Ação em São Paulo] eles estavam distribuído projetos de casas de agricultura, escolas, tinham mais algumas coisas unidades de saúde, e aí até conseguir esta do Butantan, que foi um caso, assim, diferente, era uma outra maneira de se conseguir.

Luiz: A gente vai entrar neste assunto mas, aproveitando que o senhor está dando um panorama...

Jacob: Pode esquecer do "senhor".

Luiz: [risos] Tudo bem. Então, aproveitando que você está dando um panorama sobre a sua trajetória nestes anos, eu fiquei muito curioso pra lhe perguntar sobre... imagino que você tenha iniciado a sua formação em arquitetura nos anos da construção de Brasília e você acabou se formando antes da inauguração. A minha pergunta é: o que era isso, isso teve alguma relevância pra você e pra sua geração? Foi algo mais marginal do que podemos imaginar hoje? O que significava pra você, para os seus colegas de faculdade, estudantes de arquitetura, a construção da nova capital do país naquele momento? 
Jacob: Tudo. Era tudo. Porque, a época no Brasil, essa época do Juscelino, era uma época de entusiasmo, de esperança, era um país crescendo, começou a indústria automobilística, e Brasília, o trabalho em Brasília era um negócio sensacional. Era um país, realmente crescendo. Era o Plano do Juscelino, era 50 anos em 5, foi o período dele, Brasília era tudo. Haviam discussões enormes... é que na época, os arquitetos discutiam, realmente, a arquitetura. Realmente, [discutiam] arquitetos, discutiam a arquitetura de determinado arquiteto, de outros... Todo mundo trabalhava a partir do segundo ano da faculdade, todo mundo correndo atrás de estágio, era uma época que as vezes você arranjava... vamos dizer, por uma questão política ou de amizade, pra conseguir trabalhar em determinados escritórios de determinados arquitetos de qualidade, reconhecidos pela gente e, muita vezes, de graça. Aí que era uma formação mesmo, entende, mais até, ou muito mais forte do que a própria faculdade.

Então, era um negócio sensacional. Por exemplo, era assunto do seu dia a dia, da sua vida, o desenvolvimento do país, e de Brasília, que significava tudo. 0 acompanhamento, as discussões, Niemeyer, não Niemeyer, enfim, aquela questão de sempre, todo mundo. Lá em São Paulo tinha o Artigas, tinha gente que adorava o Artigas, tinha gente que destetava o Artigas e, entende? Na verdade você tinha ídolos, você tinha gurus, você tinha caminhos, você tinha... não era uma situação como a que nós chegamos hoje, sei lá, quarenta anos depois você tem embate, você tem briga entre as pessoas, você não tem discussão, nada disso tem. Então isso era muito importante, concursos que a gente participou, um negócio sensacional e, vamos dizer assim que pulsava, a vida profissional, você era arquiteto, antes de mais nada, era uma maneira de ser. Não sei se eu respondi a tua pergunta [risos].

Luiz: Claro, claro, respondeu.

Jacob: Um clima sensacional.

Luiz: E a arquitetura naquele momento, por exemplo, a arquitetura de Brasília, pra você pessoalmente, o que significava naquele momento em que você estava iniciando a sua carreira?

Jacob: Você estava assistindo à criação de uma cidade. Você podia ter questões sobre aquilo, questões a discutir, questões filosóficas, da dificuldade de você criar uma 
cidade do nada, criar ela pronta, certamente teria dificuldades, a partir de que não estava criada a partir de gente, que formava um núcleo, e sim construía uma cidade e botava gente lá dentro. Era uma cidade, capital administrativa, uma cidade administrativa, com uma finalidade, um projeto, entende? Então, sempre achei um negócio muito bem feito, muito bem bolado, e a gente acompanhou, eu acompanhei o próprio concurso de Brasília, um concurso internacional. Foi também um negócio muito discutido, muita briga.

Luiz: E você estava no começo da faculdade de arquitetura nestes anos? Durante o concurso.

Jacob: Eu entrei em 1955.

Luiz: Exatamente o ano do concurso.

Jacob: pois é, entende? Acompanhamos aquilo, estudamos aquilo, e tinha outros grandes projetos daí de São Paulo também, era um negócio assim. Enfim, você vibrava, na verdade era um tempo vibrante. Você vibrava com a arquitetura, com as coisas que você fazia, as coisas que você via, que você discutia, entende? Aquilo tinha um valor intrínseco, quer dizer, fazia parte da sua formação e ajudava a sua formação.

Luiz: Você falou que naquele momento, quando você estava em São Paulo, que era um momento muito propício para os debates, e que começavam a surgir, o $\mathrm{s}$ arquitetos se organizavam em correntes, ideias, existiam os mestres, enter aspas, os arquitetos que eram mais destacados, você citou o Artigas. Você chegou a se inserir nesse debate, se posicionando diante ou escolhendo algumas dessas correntes...

Jacob: Não, eu vinha já com a minha formação. Eu estagiei, primeiro eu estudei muito, toda a arquitetura na faculdade, não só trabalhos, parte de livros e debates e todas essas coisas. Depois daí, eu nunca deixei de ser considerado um carioca [risos], não era muito inserido nos grupos. Sempre houve essa relação de carioca e paulista. Em outras coisas e nisso também tinha, ele era o carioca. Mas as pessoas, você conhecia muita gente, praticamente todo dia encontrava no $I A B$, nos almoços, todo mundo almoçava lá e, tinha grupos conhecidos, mas não assim de participar desse tipo coisa, eu ouvia debates dava os meus palpites, tudo numa boa. 
Luiz: E você chegou a se filiar a alguma corrente, entre aspas, a seguir algum tipo de arquitetura daquele momento?

Jacob: Não, eu sempre fui... a minha formação toda foi a partir da arquitetura de Corbusier, é... mais Corbusier, Louis Kahn, realmente os caras que eu achava muito... embora admirasse tremendamente outros né? Alvar Aalto, o próprio Wright, ${ }^{121}$ eu estudei bastante a arquitetura dele, entende, não fazia muito o meu gênero, eu não sentia muito. Sentia mais essa arquitetura das estruturas, das grandes estruturas, dos volumes, o espaço, a luz. Principalmente, a gente entendia o ser humano, entende? Isso era, vamos dizer, como eu pensava a coisa, e como a maioria, grande parte pensava assim. Claro que depois isso foi evoluindo, na própria (cidade de) São Paulo começou a aparecer as galerias de lojas, teve um boom de galerias de lojas e foi indo, para os grandes edifícios, grandes shoppings, um negócio assim, que foi subindo até o que é hoje, no mundo todo né, aconteceu aquilo.

Luiz: Nesse momento, você já comentou um pouco sobre isso, mas eu queria saber mais nesse início, logo depois da sua formação, como que você foi trabalhar no Instituto Butantan? Foi por esse ambiente que você vivia no IAB? Como que você chegou a trabalhar nesses projetos?

Jacob: Eu soube da coisa por conversa, eu tinha um primo que era arquiteto, também conhecia outros, na convivência do $I A B$, outros arquitetos que a gente conversava, fazia essa amizade. Aí eu soube como é que era, que o Carvalho Pinto, este Plano, estava distribuindo isto, e começou esta distribuição através do IAB. Logicamente, os melhores projetos foram distribuídos pela diretoria, os mais integrados na "patota", mas distribuíram, tinha muita coisa, muita coisa. Aí eu fui ver como é que eu podia entra nisso, quem podia me colocar nisso daí. Aí um velho método, tradicional, que funciona até hoje, eu cheguei a um parente, que tinha uma boa relação com um vereador, um sujeito muito legal, aí eu falei com ele o que eu queria. Eu queria o quê? Eu queria arranjar um projeto, ser contratado por um projeto, como contratavam pra todo mundo. Eu queria um também, mas como? Por que eu? Aí eles disseram tudo bem, vamos tratar disso, ele fez... o método tradicional, marcou 
uma reunião lá no Butantan, como parlamentar que queria conhecer o trabalho e tal. Foi lá, me levando a tiracolo. Então teve uma reunião, com o diretor, não me lembro quem era.

Luiz: E era diretor do Instituto?

Jacob: É... acho que era do escritório técnico.

Luiz: Tá.

Jacob: E aí conversou, o cara mostrou o Instituto. Aquele negócio de política. Tem que agradar o político, o político tem que agradar o Instituto, enfim. Ele me apresentou, disse que gostaria muito se eu pudesse participar dessa obra, dessas coisas todas. Aí passou algum tempo, se não me engano, eu falei, ele voltou a ligar pra lá, enfim. Num determinado momento eu fui convocado, e era pro escritório do Butantan ${ }^{122}$. Só que, não era mais um projeto para mim, era um projeto para várias pessoas. Era o Butantan, era grande, tinha muitas coisas a projetar.

Luiz: Muitos setores não é?

Jacob: Então eles reuniram, talvez, várias pessoas que também tinham seus vereadores [risos], seus modos de chegar lá e contrataram esse grupo. Cada um com uma obra definida, mas era um grupo só. Não havia nada entre si, então juntou "fulano", "beltrano", "ciclano" e tal, que eles deviam estar tendo pressão para contratar, então pega isso aqui e bota essa turma lá e a gente resolve um problema.

Luiz: E você chegou a trabalhar no Butantan, então, através do escritório técnico da Cidade Universitária?

Jacob: sim, certamente, porque se sabia que o Butantan era independente, naquele tempo só se sabia que o Butantan fazia soro antiofídico, só se sabia disso [risos]. Butantan era só negócio de cobra. E eles contrataram... tua pergunta foi qual especificamente?

Luiz: eu queria chegar na seguinte questão: provavelmente vocês foram contratados de diversas formas pelo escritório técnico da Cidade Universitária, é o que 
eu estou imaginando. Aí, como distribuíram os arquitetos para atuar em cada área, cada setor, foi uma escolha interna deles?

Jacob: Eu acho que foi deles.

Luiz: Provavelmente eles reuniram o grupo de arquitetos e ofereceram os projetos pra vocês.

Jacob: Eu não me lembro se a distribuição já veio deles, ou se nós fomos apresentados e nos reunimos para nós definirmos entre nós quem ia fazer o que, e tinha o coordenador. Eu me lembro, se não me engano, que eles faziam o pagamento, eram parcelas, e que depois eram distribuídas, não me lembro como é que era isso, disso eu não me lembro exatamente, dessa parte burocrática, administrativa eu não me lembro exatamente como é que era. Então, essa equipe era um, dois três, quatro, cinco. Deixa eu ver se eu tenho...

Luiz: Eu tenho alguns nomes aqui.

Jacob: Ficamos cinco. Canta aí os nomes. Tem um que eu não tenho certeza.

Luiz: São nomes que eu levantei pelos projetos que encontrei. O seu nome aparecia na maioria das vezes junto do nome do Abelardo de Souza...

Jacob: Sim.

Luiz: Da Miranda Magnoli, que era arquiteta paisagista se não me engano.

Jacob: Isso.

Luiz: Deixa eu olhar todos os nomes porque são vários projetos.

Jacob: Eu me lembro de cinco.

Luiz: O Luiz Contrucci.

Jacob: Esse trabalhava junto comigo. Em dois projetos.

Luiz: E o Léo Quanji Nishikawa.

Jacob: Isso aí, esse era o... ele pegou a parte de urbanização e coordenação. Ele ficou coordenando o grupo. O contato maior era ele com o escritório técnico.

Luiz: E ele, nesse grupo o Abelardo de Souza era o arquiteto mais experiente? 
Jacob: Era, ele é um veterano, um veterano da época do, formado pela Belas Artes aqui do Rio. Ele era o "top".

Luiz: E vocês eram todos de uma idade próxima?

Jacob: Não, próxima não.

Luiz: Não, digo, próxima entre vocês: o Luiz o Léo, a...

Jacob: Olha, o Léo era muito novo, o Japonês, ele era bem novo, era da nossa idade. O Abelardo era veterano, já era um nome na arquitetura brasileira. Ele é um dos autores do prédio do IAB.

Luiz: Sim.

Jacob: A Miranda era paisagista e foi sócia dele, tinha um escritório com ele. Eu e o Luiz Cotrucci, o Contrucci também era veterano, era mais velho, ele era do interior de São Paulo, nascido em... tinha projetos no interior de São Paulo, mais residenciais e coisas assim. Mas era bem mais velho, podia ser perto do Abelardo. O Léo ficou com a coordenação e urbanismo, urbanização da área. O Abelardo fez o Museu...

Luiz: Museu do Instituto Butantan.

Jacob: O projeto todo que a gente tinha era esse, era esse conjunto todo. Uma área pertencia à Cidade Universitária, onde tinha a urbanização dessa área, pra nela instalar um Museu, com paisagismo, o Setor de Produção e o Setor de Serviços Gerais, esses dois ficaram comigo e com o Luiz Contrucci.

Luiz: O nome de vocês aparece na maior parte das pranchas, só que não tem uma distinção de quem é o responsável, vocês atuaram juntos em todos esses projetos?

Jacob: Não, as vezes a gente tinha reuniões, porque tinha essa coordenação, coordenação e urbanização da área. E o projeto do Museu foi feito no escritório do Abelardo, projeto do Setor de Produção e Serviços Gerais foi feito no meu escritório e do Contrucci. Miranda, se não me engano, na época já era associada ao Abelardo, acho que já estavam num escritório, juntos. Entende, era assim, acho que pegaram os compromissos que eles tinham que fazer e juntaram, não houve uma reunião de uma 
equipe por questão de unidade, pra você ver que tinha altas idades e poucas idades. Aí a distribuição foi feita.

Luiz: Entendi. Eu fiquei imaginando que, nos registros que encontrei, nos relatórios do Instituto Butantan, parece que teve um concurso em 1961, pro desenvolvimento do plano diretor, de um plano de urbanização pro Instituto Butantan. O nome do Léo Quanji Nishikawa aparece nesses projetos.

Jacob: Bom, provavelmente ele veio antes, teria participado, conseguido isso daí.

Luiz: Pois é, parece que foi um concurso, então... eu acredito que a proposta dele foi a escolhida.

Jacob: Então eles devem ter juntado Abelardo, Miranda, eu e o Contrucci, pra participar depois do desenvolvimento desse..

Luiz: Dos projetos.

Jacob: Dos projetos, entende? O Léo desenvolveu esse que ele ganhou. Estou admitindo que seja isso, eu não lembrava dessa história de concurso. Então depois lá, provavelmente a gente deve ter discutido, ter sido apresentado ao Léo, e juntado o grupo todo, ele desenvolvia essa parte e os outros desenvolviam os prédios em si.

Luiz: Imagino que deve ter sido isso. Então não existia alguém que liderava os projetos, os projetos foram cedidos para grupos, pra você e pro Luiz [Contrucci], pro Abelardo, é isso? Os projetos foram divididos.

Jacob: Eles devem ter colocado isso, Abelardo e Miranda, eu e o Contrucci. Nós é que resolvemos lá dentro.

Luiz: Entendi, essa era a minha pergunta. Entre vocês, vocês dividiram entre vocês?

Jacob: Isso aí.

Luiz: É que a autoria... Autoria não mas a prancha dos projetos aparece com o nome de todos vocês. É porque, pra fins... pra efeitos burocráticos os responsáveis pelos projetos eram todos, mas entre vocês, vocês separaram é... pode dizer. 
Jacob: Esses detalhes é que eu não vou, não me lembro como é que era, porque quem cuidava disso, essa relação com o escritório técnico era o Léo.

Luiz: Eu levantei alguns projetos, em que aparecem os nomes que você comentou: o seu nome, do Abelardo, da Miranda, do Léo e do Luiz. Eu queria falar dos projetos né, queria que você comentasse o que você se lembra. Os projetos nos quais esses nomes aparecem são: o Edifício da Produção, do Setor da Produção, que você comentou que participou...

Jacob: Esse foi o que eu mais trabalhei nele.

Luiz: O Plano Geral para o zoneamento do campus que, provavelmente...

Jacob: É do Léo.

Luiz: É o do Léo, que ele desenvolveu. Mas também aparecem, ainda o Edifício da Produção, o Edifício da Administração, o Hospital, um restaurante, um biotério pra animais e um macacário.

Jacob: Esse eu não me lembro. Não me lembro realmente. Eu me lembro deste que eu estou te dizendo que, conosco tinha, eu tinha até algum tempo o desenho, o Setor de Produção, esse eu me lembro bem e o Serviços Gerais. Não sei se é o que chamam de administração, é um bloco baixo e comprido.

Luiz: É, eu imagino que os serviços gerais sejam... Um edifício que está relacionado com o edifício da produção.

Jacob: Não, produção eram uns blocos...

Luiz: Uns pavilhões não é?

Jacob: Eram uns blocos verticais muito grandes, não sei, três ou quatro blocos, eu me lembro da perspectiva que a gente fez.

Luiz: Eu tenho a perspectiva, posso mostrar.

Jacob: Me mostre.

Luiz: Tenho alguns projetos aqui que eu gostaria de te mostrar, então acho que a gente pode começar por isso. Aparece pra você [a imagem do projeto]?

Jacob: Sim. 
Luiz: Esse é o projeto para o Museu $^{123}$ que você tinha comentado, Museu do Instituto Butantan. Acredito que seja do Abelardo.

Jacob: Não, o projeto do Abelardo era, tinha um canal no meio do terreno. Esse eu me lembro bem dele. Tinha um canal no meio do terreno com duas encostas, acho que até, não sei se escavavam mais, aprofundavam mais o canal, mas era assim tinha um arco, ou dois arcos de concreto que se apoiavam nas duas margens inclinadas e sobre isso tinha um bloco comprido. Não era esse [que está sendo apresentado].

Luiz: E era um museu esse edifício.

Jacob: Esse que eu estou falando era um museu. Esse aí [que está sendo apresentado] está com o nosso nome?

Luiz: Está com o nome de vocês, "perspectiva do Museu, Abelardo de Souza...". O João Carlos Bross também aparece, você se lembra dele?

Jacob: Pode ser, o Bross, eu conheci o Bross muito, é capaz de ele estar aí sim. Eu não me lembro dele, o nome dele está aí nessa relação?

Luiz: Está, ele está nessa relação, neste projeto aparece e em outros também.

Jacob: Pode ser que sim. Eu me lembro do Bross, conheci bem ele, pode ser que isso aí seja do Bross sim.

Luiz: E ele atuou nessa... ele participou junto do grupo de vocês então?

Jacob: Pode ser que sim, eu não lembrava dele como... eu me lembro destes cinco.

Luiz: Aqui tem uma variação desse projeto do Museu, que me parece um pouco mais detalhado, a diferença aqui é que ele apresenta estes arcos estruturais. E os autores também são os mesmos. Esse aqui [outra imagem] é um Plano.

Jacob: Aí eu não estou vendo... acho que não estou vendo, do Abelardo. O que eu me lembro era isso, inclusive o seguinte, esse que eu digo nosso, que eram dois prédios, eu me lembro que o da produção eram verticais, bem altos e... os de serviços gerais eram quase que um prédio secundário, tipo de colocar, sei lá, caminhões, serviços do campus, era de grande importância.

1230 projeto completo pode ser visto no item 2.5 .8 desta dissertação. 
Luiz: Esse edifício dos Serviços eram pavilhões também não é? Volumes horizontais.

Jacob: Qual, o da Produção?

Luiz: Não, dos Serviços.

Jacob: Serviços Gerais era baixinho, se não me engano era um pavimento só, se não me engano.

Luiz: E o da Produção era uma série de edifícios altos.

Jacob: Bem altos.

Luiz: Mas eram vários, não só um.

Jacob: Eram vários, porque tinham todos os laboratórios. Esse eu me lembro mais porque era muito difícil o negócio, porque eram laboratórios especiais, especializados. Na ocasião tive até que comprar livros sobre isso, livros americanos sobre laboratório, tive muito isso. Tive muito contato com um diretor do... não sei se chamava diretor médico, ou diretor de produção, mas é o que me apresentou, era o chefão mesmo.

Luiz: Era do Instituto Butantan?

Jacob: Do Instituto. Digamos que seria o diretor operacional, o diretor geral. ${ }^{124}$ Ele me encaminhou a todos os médicos, todos os médicos dos vários setores de produção, pra eu ter um entendimento com eles, ter um survey, ${ }^{125}$ sobre o que era, o que eles precisavam, o que o Butantan queria. Uma trabalheira do "cão". Pra cada setor, cada, o que eles precisavam, que isso tudo seria planejado no geral e detalhado. Eu me lembro de fazer isso, demorou bastante tempo, aí depois voltei a falar com esse diretor, me lembro do desespero dele. Eu mostrei, conversei com ele [sobre] o que a gente tinha chegado, o que eu tinha, vamos dizer, colhido, quais eram os instrumentos que eu tinha pra projetar a coisa. E ele ficou desesperado, dizia "não é possível, esses caras estão te pedindo tudo o que eles precisam hoje, eles têm que pedir para daqui os próximos quinze anos".

124 É provável que se refira à Aristides Valejjo-Freire, responsável pela relação com os arquitetos e engenheiros do FCCUASO para os projetos do Instituto Butantan e seu diretor entre 1963 e 1966. 125 Termo em inglês que significa questionário. 
Luiz: E ele estava se referindo a quem?

Jacob: De modo geral, os diretores de produção eram incapazes, não tinham traquejo para visualizar, a produção, eu tenho isso e tal mas, sei lá eu preciso, isso aqui vai ampliar. Eu não vou construir uma coisa pra trabalhar só hoje, vai demorar, vai levar sei lá, quanto? Dez anos, quinze anos, então, sei lá, eu tenho aqui, dez salas de produção, eu tenho que projetar que eu vou precisar de quinze vinte, que isso aí vai aumentar. Era um projeto, ele não queria ter um prédio pra traduzir o que ele precisava naquele momento. Naquele momento ele já tinha e era insuficiente entendeu? O cara ficou desesperado, aí a gente bolava uma solução, não me lembro o que era, pra dar uma ampliação no negócio, isso eu me lembro que era um negócio grande.

Luiz: Tem mais alguns projetos aqui, eu vou tentar encontrar este projeto que você tinha falado do Museu que o Abelardo de Souza fez, vou ver se encontro uma referência dessa descrição. Essa aqui [imagem] é uma perspectiva da administração.

Jacob: Pode ser, era bem o desenho do Bross, o desenho eu estou reconhecendo.

Luiz: Do Bross? É, esse tem o nome do Bross também.

Jacob: Ele era muito bom.

Luiz: Inclusive o nome dele aparece em destaque no carimbo. Eu acredito que ele tenha desenvolvido esse projeto então não é.

Jacob: Eu posso te dizer o seguinte, aconteceu isso de agente ter o projeto pronto já, a gente sair e serem contratados outros arquitetos. A gente soube, não em detalhes mas soube disso.

Luiz: Mas o Bross trabalhou nesse período, junto com vocês.

Jacob: Pode ser, você está dizendo mas eu não lembrava.

Luiz: Eu imagino que o Bross é desse período, realmente outros arquitetos trabalharam mas depois do Plano de Ação. Mas nesse período, a partir de 1961 e 1962, os projetos do Bross são dessa data. Mas aí tem outros projetos de outros arquitetos em 1964 e 1965. Eu queria aproveitar que a gente está falando sobre os projetos e mostrar mais algumas imagens, porque eu fique interessado sobre o que o senhor 
falou sobre o prédio da produção e, você comentou que foi o que você mais trabalhou, que eram as torres...

Jacob: Eu sei que eram mais de uma, eu me lembro da perspectiva que, essa eu tinha trazido de São Paulo.

Luiz: Tem uma imagem aqui. Esse projeto aparece o seu nome e o do Luiz [Contrucci], que é do conjunto da produção.

Jacob: É isso aí.

Luiz: Você se lembra? É esse mesmo?

Jacob: É isso aí, esse mesmo. Esses bonequinhos é o que eu fazia [risos]. Era a minha característica. Agora, [a imagem] está em negativo não é? Era isso aí, esses bloquinhos e aquelas torres.

Luiz: E a ideia é que ele pudesse se expandir, os pavilhões podiam ser construídos conforme as necessidades. Imagino que seja isso não é?

Jacob: Eram módulos. Eu não me lembro exatamente, o que era o que exatamente. Mas você vê que tem aqui, lá atrás tem mais dois [torres de laboratórios do conjunto], tem esses aí na frente, uma coisa assim.

Luiz: Deixa eu ver se encontro mais alguma aqui. É que eu levantei tanto material que preciso procurar aqui, nas pastas, conforme você vai falando eu vou lembrando dos projetos também. É porque tem uma variação desses projetos, que eu acho interessante.

Jacob: Variação?

Luiz: É, não sei dizer se são edifícios da produção também. Este projeto você chegou a ver, você se lembra dele? O Edifício de Vírus e Genética.

Jacob: Não.

Luiz: Do arquiteto Maurício Tuck Schneider?

Jacob: Lembro dele, mas ele não fazia parte deste grupo não. 
Luiz: E o Jorge Wilheim, ele aparece também como autor de alguns projetos nesse período, em 1961. Inclusive ele fez um projeto para uma Biblioteca do Butantan e ele fez um plano de urbanização.

Jacob: Pode ser, porque isso aí, depois, seguiu por muito tempo. Ele foi secretário de urbanismo de São Paulo, então... Tá vendo esse Luiz Carlos Anthony (arquiteto), que está aqui do lado [imagem dos projetos da Cidade Universitária na Revista América, 1962]. Esse Luiz Carlos Anthony foi meu colega de científico, antigo científico, aqui no Rio de Janeiro. Antes de ser arquiteto, eu já conhecia ele, depois ele foi pra São Paulo.

Luiz: Eu consegui levantar na pesquisa, dois planos de urbanização e setorização da Cidade Universitária, um deles, o primeiro, é do Jorge Wilheim, o segundo, agora com a nossa conversa está mais claro, é o do Léo Quanji Nishikawa, quando é feito o concurso. Então esse setor aqui, o primeiro setor foi feito pelo Jorge Wilheim, mas depois os projetos foram sendo alterados. ${ }^{126}$

Jacob: Aqui, Anatomia [prédio da Cidade Universitária na Revista América, 1962] do Julinho Neves [arquiteto Júlio José Franco Neves], esse cara era importante na época, era novo. Tudo da nossa faixa de idade.

Luiz: O Rubens Carneiro Viana, você se lembra dele?

Jacob: Não.

Luiz: Ele projeto esse edifício também [Prédio de Pesquisa do Instituto Butantan], que faz parte do Plano do Léo Nishikawa.

Jacob: Esse não. Eu acho que o negócio, não sei se teve antes, certamente depois, eles deve ter acrescentado outros projetos ou já existiam outros projetos.

Luiz: Vou espelhar só mais uma imagem aqui, pra gente poder...

Jacob: Eu estou me divertindo, pode ficar aí o dia inteiro.

Luiz: Que bom [risos], eu estou me divertindo também, descobrindo um monte de coisas. Este aqui [imagem do projeto] é um dos projetos do hospital, ${ }^{127}$ uma 126 Nos referimos ao Setor Biológico da USP que englobava a esplanada do setor de pesquisas do Instituto Butantan, projetados por Jorge Wilheim em 1961. 1270 projeto pode ser encontrado nas fichas do inventário de projetos desta dissertação, item 2.3.2. 
perspectiva, está o João Carlos Bross, o Abelardo de Souza e você também, seu nome também aparece no projeto.

Jacob: É, então o Bross fez parte disso.

Luiz: Mas eu consegui entender melhor agora, com os seus comentários, que dentro dessa equipe alguns ficaram responsáveis por uns projetos, outros desenvolveram outros.

Jacob: Exatamente. Pode ser assim, porque o Bross eu conheci bem ele, depois a gente cruzou quando eu vim embora pra cá [Rio de janeiro], porque ele fez muito, ficou quase como um especialista em hospitais, e eu fiz muito hospital aqui no Rio de Janeiro e eu já conhecia ele. Pode ser que foi dessa época. Você está reavivando de onde eu conhecia ele. Ele deve ter participado disso sim.

Luiz: Isso aqui [imagem] são detalhes do plano geral de urbanização, do Léo Nishikawa, ${ }^{128}$ que é assinado por ele e se não me engano pelo Luiz Contrucci. ${ }^{129}$ Se eu não me engano. Mas o que eu queria lhe mostrar, aqui o Museu, novamente. Você acha que esse projeto do Museu não se refere ao que você se lembrava? Porque tem um eixo de ligação, mas não é exatamente esse, era outra coisa, que você tinha em mente?

Jacob: Não, eu estou sendo franco, eu lembro desse [que havia falado], é um que ficou marcado.

Luiz: Eu vou tentar encontrar esse projeto.

Jacob: Não vou jurar pra você, que eu não vi um outro projeto do Abelardo de museu e ficou gravado pra mim como museu do Abelardo e estar achando que é aí [no Instituto Butantan]. Documentação eu não tenho nenhuma, lembrança do prédio eu tenho lembrança, pra descrever a você como é que era. ${ }^{130}$

Luiz: Mas este museu [imagem] você não se lembra dele, desse prédio? 
Jacob: O que eu me lembro de museu eu liguei aí [no Instituto Butantan], porque o contato com o Abelardo, que eu tive, foi mais aí. Não vou jurar par você, mas as vezes você fica procurando uma coisa que pode não existir.

Luiz: Este [imagem do projeto do Edifício da Produção] está assinado por você também, o seu nome e o do Luiz [Contrucci] estão em destaque. É a mesma lógica não é? Aqui está uma perspectiva um pouco mais detalhada, mas são essas torres [que definem o projeto] não é?

Jacob: Pode ser sim. Pra te dizer o seguinte, isso pode ser. Esses bonecos [desenhados] nunca seriam feitos por mim. Porque, a gente... na época se faziam coisas, você ajudava e tudo. Pra você ter uma ideia, eu tinha um escritório associado com outro rapaz e nós fizemos um concurso da Assembleia Legislativa aí de São Paulo, essa que foi feita aí no Ibirapuera, e nosso projeto era um projeto totalmente diferente, realmente um negócio, não é porque você está na minha presença, mas muito bom e avançado. E tinha no meio uma praça, no meio do projeto tinha uma praça e a gente criou como sendo uma ágora grega, onde os parlamentares encontrariam com os eleitores, com o povo e tudo. $E$, na verdade, o que eles menos queriam era se encontrar como o povo porque eles seriam linchados. No meio tinha um grande, na perspectiva era um prédio redondo, e essa grande praça em um cilindro no ar. Tinha uma grande escultura, uma queda d'água, um negócio muito bonito. E essa perspectiva foi feita pra gente pelo Paulo Mendes da Rocha, que era amigo e tal, na época ele era bem mais jovem que hoje. Então, ele é quem desenhou aquilo, porque ele desenhava maravilhosamente bem. Então, as pessoas eram mais colegas do que qualquer outra coisa. Esse desenho [imagem] eu não sei quem é que fez, mas pode ser [que ele tenha feito] essa perspectiva também.

Luiz: Então, não necessariamente vocês faziam todos os desenhos.

Jacob: Não, você ajudava. Eu te mostrei, aquele bonequinho ridículo [de uma das perspectivas do Prédio da Produção] era meu [risos]. Eu conseguia fazer aquele bonequinho, o desenho era meu, era o que eu fazia. Isso aqui [imagem] eu não fazia, isso não era meu não, alguém que fez pra gente.

Luiz: Mas a ideia do projeto era essa [das torres e pavilhões]. 
Jacob: Era essa.

Luiz: O projeto é o mesmo.

Jacob: Esse pode ser uma outra visão daquele lá.

Luiz: Aqui tem uma outra, as variações [do projeto para o Edifício da Produção] que eu tinha comentado são essas. Tem uma variação de torres e aqui uma torre única.

Jacob: Você vê que tem os mesmos bonecos [escala humana do desenho] não é? Só junta as duas torres praticamente.

Luiz: Você acha que essa variação pode ser já um trabalho de outro arquiteto em cima do seu projeto? Porque o seu nome está na prancha, você é o autor do projeto, mas essas variações talvez tenham sido de outros arquitetos ou você acha que acompanhou essas alterações.

Jacob: Não sei, a recordação que eu tenho mais é daquele outro. Então o desenho que eu tinha, que eu trouxe. Esse não é um desenho que pra mim é estranho não, pode ter sido também. Eu não me lembro como é que foi, era feito tudo a mão, vegetal, nanquim e gilete. Imagina o que era isso [risos].

Luiz: Eu nem consigo imaginar.

Jacob: É eu sei.

Luiz: Eu peguei a fase do computador. Eu queria te perguntar mais algumas coisas. Você tinha relação, você conversava com a direção do Instituto, tinha um responsável lá dentro...

Jacob: Não, a única coisa que eu tive foi, que eu me lembro, que eu tive mais contato, me lembro até o nome dele, Vallejo-Freire, que era um diretor, era um cara muito inteligente, muito mesmo. Um cara que, assim, conhecia o negócio...

Luiz: E vocês reportavam os seus projetos a ele?

Jacob: Eu conversei com ele, fui conversar com ele sobre essa necessidade do, desse survey, de tomar todo conhecimento que afinal, de laboratório de produção, eu não entendia nada. Eu tinha que entender o que era, o que precisava, como é que 
funcionava, o que eles imaginavam. Precisa saber o que eles imaginavam e entender como é que funcionava pra poder projetar o que eles precisavam.

Luiz: E aí vocês projetavam e apresentavam, geralmente, para ele, pro VallejoFreire?

Jacob: Ele é com quem eu tive o contato todo, inicial, ele me apresentou aos vários responsáveis por setores da produção. Então eu visitei aquilo lá, fiz todo o levantamento do que precisava e comprei esses livros sobre projeto de laboratórios, a maioria americanos, uns calhamaços de coisas, porque o que eu precisava ver eram os espaços e como é que funcionavam. Aí, depois, eu entrei em contato com ele pra apresentar, pra discutir, se era aquilo que eles precisavam, pra depois transformar aquilo em espaço.

Luiz: Você comentou dos livros de projeto que eram americanos, a maior parte, e você comentou, no começo da nossa conversa, sobre o Louis Kahn, que você tinha conhecimento do trabalho dele.

Jacob: De quem?

Luiz: O Louis Kahn, o arquiteto americano. ${ }^{131}$ Vocês tinham conhecimento da orba dele nesse momento, ele já era reconhecido no Brasil?

Jacob: Ele era dos menos reconhecidos.

Luiz: Porque naquela época ele estava fazendo... ele não era tão famoso, ele estava fazendo os maiores projetos dele nos anos 1950 e 1960.

Jacob: Primeiro, ele era mais velho. E ele nunca foi reconhecido, entende? Vamos dizer, reconhecido não, foi reconhecido mas nunca foi famoso. Têm prédios nos Estados Unidos, fabulosos e na índia, também tem prédios fabulosos e ele era uma figura complicada, não era um Corbusier. Corbusier era uma vedete, sabia se promover, sabia aparecer, essas coisas. E ele tinha uma vida complicada, o Louis Kahn. Pra começar tinha três famílias, três mulheres com filho, morando na mesma cidade, próximo um dos outros. Situações assim em que ele era complicado, era mal visto, por 
problemas pessoais. Então, não fazia parte, assim, do establishment. Mas a arquitetura dele era incrível.

Luiz: e nessa época ele projetou edifícios de pesquisa, de saúde.

Jacob: Isso, era incrível porque ao criar a estrutura ele já estava criando tudo.

Luiz: E nos projetos que você fez, principalmente no edifício da produção, tem algo disso, essas ideias aparecem no projeto, de alguma forma?

Jacob: Eu só consegui desenvolver alguma coisa nessa área... porque isso não era muito aceito. Artigas fazia, depois Paulo Mendes, também fazia. Eu tentei, nesse concurso da Assembleia Legislativa, era nesse esquema, tanto que foi um projeto que não ganhou, mas foi um dos mais comentados no meio da arquitetura, que era um negócio totalmente diferente. E, aqui no Rio eu fiz um projeto, esse eu executei, que é uma residência toda em concreto aparente. Isso nunca foi muito aceito aqui, principalmente. E outra coisa que eu fiz muito aqui foram projetos específicos, para clientes específicos, por exemplo, fiz muito pro exército. Eram quartéis, escolas, parte das instalações deles, hospitais, fiz uma garagem, e essa foi a última obra que eu fiz pra eles, foi construída dentro dessa linha. Todas eram muito específicas e o cliente não podia chegar em um determinado padrão de arquitetura e impor, porque o cliente tinha já muito cristalizado o que era usar subterfúgios pra conseguir vender qualquer coisa.

Luiz: E no Instituto Butantan vocês tinham uma liberdade de criação grande? Liberdade de projeto?

Jacob: Foi isso que foi feito aí. Eles não entraram nisso. Nunca houve uma rejeição aos projetos, que eu me lembre. Agora, aí tem muitos projetos que eu nem tive conhecimento, dos que você estava mostrando. Me lembro desse grupo só. Agora estou admitindo que o Bross fazia parte, quando eu vi o desenho que você mostrou do Hospital. Que ele depois vem desenvolver, num futuro, quase que uma especialização em hospital no Brasil.

Luiz: Mas esses projetos eram bem aceitos, pela direção do Instituto, o ValejjoFreire com quem você tinha contato. Eu pergunto isso porque, uma coisa que eu 
reparei é que esses projetos, aí eu acho que tem a ver um pouco com o plano de urbanização, de implantação desses edifícios, que foram planejados pra serem construídos exatamente no mesmo local em que existiam prédios antigos da Instituição. Por exemplo, o Prédio de Serviços está projetado onde hoje existe um prédio bastante antigo do Butantan [Edifício Vital Brazil], que foi construído em 1914. Uma das coisas que me chamaram a atenção nesses projetos é que eles previam a demolição de alguns edifícios antigos, de boa parte dos edifícios antigos. Inclusive, o plano do Léo Nishikawa previa a demolição de bastante coisa, de uma parte enorme do conjunto existente no Butantan. Então, eu queria perguntar se você se lembra dessas questões, se isso apareceu pra você quando foi projetar o Edifício da Produção. Por exemplo, olhando o plano, o Edifício da Produção estava numa região, numa área do terreno que não era ocupada, mas o Edifício de Serviços, está exatamente no mesmo ponto de um prédio histórico [Edifício Vital Brazil]. Você se lembra destas questões, isso apareceu pra você?

Jacob: Não, não. A gente tinha, quando eu fiz o projeto, eu me lembro que a gente tinha dentro de um plano geral uma área que seria... bom, aqui vai ser projetado isto, aqui vai ser o Prédio da Produção. Eu tinha o terreno, só, não havia essa...

Luiz: Essa preexistência.

Jacob: Essa situação. Porque, nessas coisas, principalmente no Brasil é assim, muda a administração muda tudo não é? Não há uma sequência, ou seja, ninguém bota azeitona na empada do vizinho [risos]. O cara faz algo novo, tudo bem, ou não faz. Sempre aconteceu isso. Então, possivelmente pode ter deixado de ser feita alguma coisa em algum lugar que tinha um prédio, porque alguém achou que aquele prédio tinha de ficar, porque ele achava alguma coisa sobre o assunto.

Luiz: Talvez, eu imagino, alguns edifícios, ou boa parte dos edifícios não foram construídos porque... Por causa desse conflito, ou não?

Jacob: Eu acho, esses conflitos sempre tiveram, sempre aconteceram, não são estranhos... Ter esses problemas. Então, você ter um prédio... planos não serem levados até o final, serem modificados no meio, por razões não explícitas. Mudou porque alguém resolveu mudar. 
A falta de planejamento é um problema bem brasileiro. Então, você faz um plano, que é aprovado, que foi definido, estudado, teoricamente, com razões e estudos sérios, faz o plano e, depois, antes deste plano se completar, você já modifica por razões que não sejam justificáveis. Por quê você mudou? Porque eu acho que deve ser diferente. Eu já tive estes problemas, de alguma maneira. Eu fiz um grande projeto para a Petrobras na Bahia uma vez, e aí é questão também de planejamento, que era um, eu não me lembro exatamente qual era a função, mas era um projeto muito grande da Petrobras. Esse projeto foi feito todo, prontinho, desenvolvido, ficou perfeito. Tudo bem, entregue, recebido, pago, tal e depois, de acordo com o que eles queriam, quer dizer, o programa era da Petrobras, era de quem fez o planejamento todo. Aí nos soubemos que foi abandonado, por quê? Porque a demolição do que existia, as consequências e o custo da demolição eram inviáveis. Então, os planos não são muito... é uma coisa que você tem que seguir pro desenvolvimento do, sei lá, da região, do país, aquilo tem a ver com esse plano, mas você muda porque mudou, resolveu mudar.

Luiz: Eu fico pensando que no plano de Léo Nishikawa ele deixa um pouco, não sei se era a intenção dele mas acredito que tenha pensado nisso, ele deixa um pouco evidente uma proposta de demolição mesmo, de alguns edifícios antigos. Então, ele inclusive desenha estes edifícios antigos e aponta quais deveriam ser retirados, demolidos segundo o plano dele. Eu acho que no seu caso, como você fez o projeto do Edifício da Produção, ele está em uma região, numa área não construída, mas o Edifício de Serviços ele está em uma área onde existe um edifício até hoje. Então, por isso eu queria saber se você presenciou algo desse tipo.

Jacob: Não, não, até porque a produção, qualquer daqueles projetos que estão ali, que você mostrou, o resultado deles, o volume deles, é o resultado das áreas e dos espaços que eram necessários. Então, vamos dizer, uma das razões daquilo é o terreno que a gente tinha, pra ter adotado aquela solução. Aquilo não seria um simples partido estético, vamos fazer assim com duas torres porque fica bacana, era a solução, era assim que a gente pensava. O partido era esse em função do que você precisava e em função do que você tinha. 
Luiz: Sim.

Jacob: Então, esse negócio dos serviços estar ali, em cima de demolição, é porque aquilo era contado, o terreno devia já considerar isso, e não com um prédio que foi projetado e viu-se que tinha um edifício.

Luiz: Sim, eu acho que isso foi planejado, fazia parte do planejamento.

Jacob: Se isso existisse você poderia fazer com que, como já foi feito, você construir um prédio em cima do outro, se aquilo tivesse que ser preservado, assim, a grosso modo, entendeu? Um partido, se na ocasião existisse, um prédio que deveria ser preservado, que não poderia ser demolido, você iria fazer, sei lá, inventava qualquer coisa disso.

Luiz: Essas condições de preservação, do patrimônio, elas ainda não eram muito claras pro Instituto também, porque o conjunto do Instituto, hoje é tombado, mas foi tombado só em 1981. Então nos anos 1960 isso não era necessariamente uma questão, manter ou não aqueles edifícios... Eu imagino que a questão ali era criar estrutura pro desenvolvimento do Instituto, que realmente existia uma escassez de espaços pra expansão.

Jacob: O Instituto já era ali não é.

Luiz: Desde 1901.

Jacob: E esses prédios eram em área da Universidade, não?

Luiz: Eles eram [estavam] em área do Instituto, porque o Instituto se instalou ali em 1900, a Universidade foi fundada em 1934 e nos anos 1940 começaram a construir a Universidade em parte da área que era do Instituto. Só que é só em 1959 que a cidade começa a ser construída por causa do Plano do Governo Carvalho Pinto, mas originalmente toda aquela área da Universidade era do Instituto.

Jacob: Era do Instituto né.

Luiz: O Instituto cede uma parte para a construção da Cidade Universitária.

Jacob: Política. 
Luiz: Pois é, era uma área excelente pra criação da Universidade. E o que eu estou percebendo com a pesquisa é que existe um certo conflito ali, com o Instituto porque o planejamento do Butantan passa, nesses anos 1950 e 1960, a ser responsabilidade da Universidade não é. Porque quem tinha o corpo técnico de arquitetos e engenheiros era a Universidade, do Escritório Técnico.

Jacob: Pois é, era o Escritório Técnico. Porque aqui no Rio também tinha o escritório técnico da universidade, onde eu fiz o projeto... Você me perguntou agora estou me lembrando, eu fiz um auditório aqui pra Escola de Engenharia, também assim... Modernidades.

Luiz: Fica no campus principal? Na Ilha do Fundão ${ }^{132}$ não é?

Jacob: Eu fiz ali dois projetos, era um auditório muito grande pra, inclusive, aulas, e era no princípio, quando se começava a usar a informática, nem bem informática, não tinha computação, ainda era na época do fax e outras coisas do gênero, projeção, coisas bem inciais. E fiz mais um, também na Universidade [Federal do Rio de Janeiro], na Praia Vermelha, um outro prédio, esse não foi construído.

E esses planejamentos que a gente está falando não é o que comanda o desenvolvimento dessas coisas, não aí, mas de modo geral, os projetos que eu fiz, mutia coisa que não é feita porque resolveu mudar, mudou porque quis, o novo diretor acha diferente, então não vai ter e ele não vai fazer o que o outro fez.

Luiz: Jacob, eu acho que fiz todas as perguntas que gostaria de fazer há algum tempo e não imaginava que teria essas respostas. Eu agradeço muito pela conversa.

Jacob: Isso aí era, na verdade, meio picotado, solta uma coisa aqui, aqui outra, porque a época era mais ou menos assim também. Era uma época muito vibrante, muito, sei lá, as pessoas se davam mais, haviam os arquitetos, uma comunidade de arquitetos. Embora disputassem trabalho, embora houvesse uma série de coisas em relação a concursos e todas estas coisas que existem, mas era um outro padrão, um outro nível de convivência não é. Mas estamos aí, se quiser mais coisas, qualquer outra coisa, a qualquer momento.

132 Campus da Universidade Federal do Rio de Janeiro, na cidade do Rio de Janeiro. 


\section{Anexo: Carta de Luiz Augusto Ribeiro do Valle à Lina Bo Bardi ${ }^{133}$}

Instituto Butantan, 22 de dezembro de 1958.

Tem esta por objetivo agradecer a valiosa colaboração que V.S. tão gentilmente tem prestado a este Instituto.

Agora, quando se processam as obras de reforma do prédio destinado a abrigar o futuro museu deste Instituto, a sua cooperação se torna ainda mais necessária, a fim de que se possa esta instituição dispor de um departamento de educação e divulgação, a cargo do Dr. Wolfgang Bücherl, realmente à altura de sua tradição científica e dentro de suas funções precípuas no campo da Saúde Pública.

Prevaleço-me do ensejo para apresentar a V.S. os protestos de minha distinta consideração e elevado apreço.

Dr. Luiz Ribeiro Augusto do Valle 


\section{Referências Bibliográficas}

ALVES, André Augusto de Almeida. Arquitetura escolar paulista 1959 - 1962: o PAGE, o IPESP e os arquitetos modernos paulistas. 2008. Tese de Doutorado em História e Fundamentos da Arquitetura e do Urbanismo - FAU USP, São Paulo, 2008.

ARGAN, Giulio Carlo. História da arte como história da cidade. São Paulo, Martins Fontes, 2005.

BOCEWICZ, Ana Carolina Dias. Avaliação de protótipos expositivos do Museu de Microbiologia do Instituto Butantan. (Monografia de Conclusão do Curso de Especialização História, Museologia e Divulgação da Ciência e Saúde do Instituto Butantan). São Paulo, 2019

BRUAND, Yves. Arquitetura contemporânea no Brasil. São Paulo, Perspectiva, 1981.

BUZZAR, Miguel Antonio (coord.) e ali. Difusão da arquitetura moderna no Brasil - O patrimônio arquitetônico criado pelo Plano de Ação do Governo Carvalho Pinto (1959-1963). Relatório do projeto de pesquisa referente ao Edital do convênio Condephaat/ Fapesp, processo 2011/51108-0. São Paulo, 2015.

. CAMARGO, Mônica Junqueira de. CORDIDO, Maria Tereza Regina Leme de Barros. et al. Arquitetura moderna no Estado de São Paulo: difusão e dimensão social através de equipamentos públicos produzidos pelo Plano de Ação do Governo Carvalho Pinto - PAGE (1959-1963). São Paulo, Cultura Acadêmica, 2016. p. 101-110. In: SALCEDO, Rosío Fernández Baca; BENINCASA, Vladimir; CHAMMA, Paula Valéria Coiado; FARIA, Obede Borges, orgs. Reabilitação do patrimônio arquitetônico e edificado e sua dimensão cotidiana, São Paulo: Cultura Acadêmica, 2016.

CORDIDO, Maria T. R. L. de Barros. SIMONI, Lucia N. A arquitetura moderna produzida a partir do plano de ação do governo Carvalho PintoPage - (1959/1963). Artigo, Revista arq.urb, n.14, USJT. 2015.

_. João Batista Vilanova Artigas: elementos para a compreensão de um caminho da arquitetura brasileira, 1938-1967. São Paulo, UNESP, SENAC, 2014.

. CAMARGO, Mônica Junqueira de. CORDIDO, Maria Tereza Regina Leme de Barros. Os significados da mudança de paradigma arquitetônico advindo com o Plano de Ação de Governo de Estado/SP (PAGE) na gestão Carvalho Pinto (1959-1963). Recife, 2016. s.p., Seminário Docomomo Brasil(11.: 2016: Recife).. Anais: O campo ampliado do movimento moderno, Recife, 2016. 


\section{Apêndices, Anexo e Bibliografia}

BENCHIMOL, Jaime Larry; TEIXEIRA, Luiz Antonio. Cobras e lagartos e outros bichos: uma história comparada dos Institutos Oswaldo Cruz e Butantan. Rio de Janeiro: UFRJ, 1993.

CABRAL, Neyde A. Joppert. A recuperação do Crusp. Coord. São Paulo, Coesf USP, 2009. Disponível em: https://bit.ly/357Z3f2. Acesso em: 16 abr.2021.

. A Universidade de São Paulo: modelos e projetos. São Paulo, Edusp, 2018.

CAMARGO, Mônica Junqueira de. Artigas e a Escola Paulista. Revista arq.urb, n. 14, p. 135-155, 16 dez. 2015.

- Escola Paulista, Escola Carioca. Algumas considerações. Salvador, 2019. Seminário Docomomo Brasil (13.: 2016: Salvador). Anais: Arquitetura moderna brasileira. 25 anos do Docomomo Brasil. Todos os mundos, um só mundo. Salvador, 2019.

. História: o edifício da FAU-USP e o PAGE. São Paulo, Editora da Cidade, 2016. p. 164-169. In: Barossi, Antonio Carlos, org. O edifício da FAU-USP de Vilanova Artigas, São Paulo: Editora da Cidade, 2016.

_. Inventário dos bens culturais relativos ao Plano de Ação do Governo Carvalho Pinto. Revista CPC, [S. I.], n. esp21, p. 164-203, 2016. Disponível em: http://www.revistas.usp.br/cpc/article/view/111965. Acesso em: 12 out. 2020.

CANTER, Henrique Moisés. Museu Histórico: origem e memória. Cadernos de História da Ciência, São Paulo, v. 1, n. 1, pp.63-74, 2005.

CONTIER, Felipe de Araujo. O edifício da Faculdade de Arquitetura e Urbanismo na cidade universitária: projeto e construção da Escola de Vilanova Artigas. 2015. Tese de Doutorado em Teoria e História da Arquitetura e do Urbanismo - Instituto de Arquitetura e Urbanismo, Universidade de São Paulo, São Carlos, 2015.

CORDIDO, Maria Tereza Regina Leme de Barros. Arquitetura forense do Estado de São Paulo: produção moderna, antecedentes e significados. Dissertação de Mestrado em Teoria e História da Arquitetura e do Urbanismo - EESC-USP, São Carlos, 2007.

COSTA, Angélica Irene da. As obras escolares do Plano de Ação do Governo do Estado (PAGE): a educação em novas formas. Tese de Doutorado em Teoria e História da Arquitetura e do Urbanismo - IAU-USP, São Carlos, 2014. 
FERNANDES, Suzana Cesar Gouveia. O Instituto Butantan de 1928 a 1947: uma visão sóciocultural de sua organização interna. 2008. Tese de Doutorado - FFLCH-USP, São Paulo, 2008.

FERRAZ, Marcelo Carvalho. Arquitetura em vão? Sobre exposição da arquitetura brasileira em Matosinhos, Portugal. Resenhas Online, São Paulo, ano 18, n. 205.04, Vitruvius, jan. 2019. Disponível em: https://www.vitruvius.com.br/revistas/read/resenhasonline/18.205/7231. Acesso em: 28 de Maio de 2020.

_. Lina Bo Bardi. São Paulo: Instituto Lina Bo e P. M. Bardi, 1993.

FIORIN, Evandro. O projeto para o pavilhão brasileiro na expo'92 em Sevilha e a chamada Arquitetura Paulista. Noviembre 2012. Universidad de Sevilla. Disponível em: https://repositorio.unesp.br/handle/11449/73719?show=full. Acesso 16 abr.2021.

FOSTER, Hal. O complexo arte-arquitetura. São Paulo: Ubu Editora, 2017.

GORELIK, Adrián. Das vanguardas a Brasília: cultura urbana e arquitetura na América Latina. Belo Horizonte, Editora UFMG, 2005.

GORENDER, Jacob. Combate nas trevas: a esquerda brasileira: das ilusões perdidas à luta armada. 2. ed. São Paulo, Ática, 1987.

GRUZMAN, Carla. Educação, Ciência e Saúde no Museu: uma análise enunciativo-discursiva da exposição do Museu de Microbiologia do Instituto Butantan. Tese (doutorado) Universidade de São Paulo, São Paulo, 2012.

GUERRA, Abílio. Construção de um campo historiográfico. São Paulo, Romano Guerra, 2010. p. 11-22 In: Textos fundamentais sobre história da arquitetura moderna brasileira - parte 1. São Paulo: Romano Guerra Editora, 2010.

HARTOG, François. Regimes de historicidade. Presentismo e experiências do tempo. Belo Horizonte: Autêntica, 2013.

HOBSBAWM, Eric John. Era dos extremos: o breve século XX, 1914-1991. 2. ed. São Paulo, Companhia das Letras, 1995.

IAB/SP, Instituto de Arquitetos do Brasil. Por uma Rede de Acervos de Arquitetura e Urbanismo. Carta aberta. Drops, São Paulo, ano 21, n. 156.04, Vitruvius, set. 2020. Disponível em: https://vitruvius.com.br/revistas/read/drops/20.156/7883. Acesso em: 23 de Dezembro de 2020. 
IBAÑEZ, Nelson; WEN, Fan Hui; FERNANDES, Suzana C. G. Instituto Butantan: história institucional. Desenho metodológico para uma periodização preliminar. Cadernos de História da Ciência. São Paulo, v. 1, n. 1, pp.115-144, 2005.

LE GOFF, Jacques. História e memória. Campinas, Editora da UNICAMP, 1990.

LUCCA NETO, Luiz de. Apontamentos para a questão da modernidade no Instituto Butantan. Cadernos de História da Ciência, v. 12, n. 2, 2016. p. 55-72.

. Manifestação do contemporâneo no conjunto arquitetônico do Instituto Butantan: o Museu de Microbiologia de Marcio Kogan. In: Assoiciación de Escuelas Y Facultades Publicas de Arquitectura de América del Sur, 2019, Belo Horizonte. Anais eletrônicos. Campinas, Galoá, 2019. Disponível em: <https://proceedings.science/arquisur-2019/papers/manifestacao-docontemporaneo-no-conjunto-arquitetonico-do-instituto-butantan--o-museu-de-microbiologiade-marcio-kogan?lang=pt-br>. Acesso em: 16 abr. 2021.

. Estado, desenvolvimento e arquitetura moderna no âmbito do Plano de Ação (1959-1963). In: X Congresso de História Econômica da Universidade de São Paulo, 2019, São Paulo. Anais do X Congresso de História Econômica. São Paulo: DH-USP, 2019. Disponível em: http://congressohistoriaeconomica.fflch.usp.br/x-congresso-anais-digitais. Acesso em: 17 abr. 2021.

MAMMINI, Osmar Antonio; HECK, Carlos Henrique. O Fundo de Construção da Cidade Universitária e o Instituto Butantan Entrevistas com os arquitetos Osmar Antonio Mammini e Carlos Henrique Heck. Cadernos de História da Ciência, v. 12, n. 2, 2016. pp. 137-181.

MARTINS, C. A. F. Identidade nacional e Estado no projeto modernista. Modernidade Estado e tradição. In: Arquitetura e Estado no Brasil elementos para uma investigação sobre a constituição do discurso moderno no Brasil: a obra de Lucio Costa 1924-1952. 1988. Dissertação de mestrado - FFLCH, USP, 1988.

. Identidade nacional e Estado no projeto modernista. Modernidade, Estado e tradição. In: GUERRA, Abilio. (Org.). Textos fundamentais sobre história da arquitetura moderna brasileira Parte 1. São Paulo: Romano Guerra Editora, 2010.

MONTANER, Josep Maria. La modernidad superada: arquitectura, arte y pensamiento del siglo XX. 3. ed. Barcelona, Gili, 1999.

MONTEIRO, Paulo H. N. (org.). Guia de arquitetura Butantan. São Paulo, Instituto Butantan: 
Centro de Desenvolvimento Cultural, 2017.

NOVAIS, Fernando Antonio e MELLO, João C. de. Capitalismo tardio e sociabilidade moderna. In SCHWARCZ, Lilia K. M. (org.). História da Vida Privada no Brasil: contrastes da intimidade contemporânea. São Paulo: Companhia das Letras, 1998.

PALERMO, Nicolás Sica. As arquiteturas do tempo de Louis I. Kahn. Arquitextos, São Paulo, ano 06, n. 069.08, Vitruvius, fev. 2006. Disponível em: https://vitruvius.com.br/revistas/read/arquitextos/06.069/382. Acesso em: 25 de Janeiro de 2021.

ROLDAN, Dinalva Derenzo. Um ideário urbano em desenvolvimento: A experiência de LouisJoseph Lebret em São Paulo de 1947 a 1958. 2012. Dissertação - Faculdade de Arquitetura e Urbanismo, Universidade de São Paulo, São Paulo, 2012.

ROSSI, Aldo. A arquitetura da cidade. São Paulo, Martins Fontes, 2001.

SÁ, Anderson Luiz Félix de. Preservação do patrimônio arquitetônico no Instituto Butantan. Dissertação (Mestrado em História e Fundamentos da Arquitetura e do Urbanismo) - Faculdade de Arquitetura e Urbanismo, Universidade de São Paulo, São Paulo, 2019.

SCHWARZ, Roberto. Cultura e política, 1964-1969. In: O pai de família e outros estudos. Rio de Janeiro: Paz e Terra, 1978.

SCULLY, Vincent. Jehová en el Olimpo. Louis Kahn y el final del Movimiento Moderno. In: SAINZ, Jorge (ed.), Louis I. Kahn, Monografias de Architectura \& Vivienda. Madrid, ES, Arquitectura Viva, 2001.

SEGAWA, Hugo Massaki. Pavilhão do Brasil em Sevilha: deu em vão. Projeto (São Paulo), São Paulo, v. 138, p. 34-39, 1991.

SEVCENKO, Nicolau. A Revolta da Vacina: mentes insanas em corpos rebeldes. São Paulo, Cosac Naify, 2010.

. Orfeu extático na metrópole: São Paulo, sociedade e cultura nos frementes anos 20. São Paulo, Companhia das Letras, 1992

SIMONE, Sergio de. A casa de Afrânio do Amaral. Cadernos de História da Ciência. São Paulo, 2021. No prelo. 


\section{Apêndices, Anexo e Bibliografia}

SMIRNE, Diego. C. Planejador da Cidade Universitária tem ideias também para o Brasil. São Paulo, Jornal da USP, 2017. Disponível em: https://jornal.usp.br/universidade/planejador-dacidade-universitaria-tem-ideias-tambem-para-o-brasil/. Acesso em: 20 mar. 2021.

TEIXEIRA, Luiz Antonio. A trajetória do Instituto Butantan: pesquisa e produção de imunobiológicos para a saúde pública. Revista Brasileira de Inovação, Campinas, SP, v. 15, n. 1, p. 165-173, 2016.

Disponível

em https://periodicos.sbu.unicamp.br/ojs/index.php/rbi/article/view/8649124. Acesso em: 20 fev. 2021.

Pesquisa biomédica e produção de imunobiológicos em São Paulo: um duelo entre o público e o privado. Cadernos de História da Ciência, São Paulo, v. 2, n. 1, p.125-123, 2006. Disponível em: https://ojs.butantan.gov.br/index.php/chcib/article/view/252/238. Acesso em: 20 fev. 2021.

TELLES, Sophia. A arquitetura modernista: um espaço sem lugar. São Paulo, Romano Guerra, 2010. p. 279-297. In: Guerra, Abilio (Org.). Textos fundamentais sobre história da arquitetura moderna brasileira - parte 1. São Paulo: Romano Guerra Editora, 2010.

VENTURI, Robert. Complexidade e contradição em arquitetura. São Paulo, Martins Fontes, 2004.

VIANA, Claudio Muniz. Da Concepção ao projeto de execução: a gênese documental dos arquivos de arquitetura. Ponto de Acesso, Salvador, v.9, n.2,p. 123-155, 2015. Disponível em: https://periodicos.ufba.br/index.php/revistaici/article/view/8328. Acesso em: 16 abr. 2021.

XAVIER, Alberto; LEMOS, Carlos; CORONA, Eduardo. Arquitetura Moderna Paulistana. São Paulo: Editora Pini, 1983. 


\section{Fontes Primárias}

Acervo de fotografias do Centro de Memória, anos 1901 a 2017.

Arquivo pessoal dos diretores do Instituto Butantan, Centro de Memória.

Acervo de projetos da Biblioteca da FAU USP.

Acervo de documentos do Instituto Bardi.

Arquivo do Estado de São Paulo.

Acervo da SEF USP.

Acervo do Jornal O Estado de São Paulo.

Arquivo COESF.

Acervo de fotografias da Biblioteca do Congresso dos Estados Unidos da América.

Acervo de Projetos do arquiteto Jorge Wilheim.

CAPH, Centro de Apoio à Pesquisa em História "Sérgio Buarque de Holanda", FFLCH USP.

Departamento de arquivo e documentação, Fiocruz, COC.

Desenhos técnicos e mapas do acervo cartográfico do Centro de Memória, 1901 a 2010.

Desenhos e fotografias do escritório de arquitetura MK27, São Paulo.

Mapas do Instituto Geográfico e Cartográfico do Estado de São Paulo.

Relatórios Anuais do Instituto Butantan, anos 1901 a 2002.

Mapas da Seção Técnica de Geoinformação e Produção de Bases Digitais da FAU USP.

\section{Depoimentos}

Adriana Mortara - historiadora, diretora do Museu Histórico do Instituto Butantan.

Henrique Moisés Canter - ex-diretor da divisão de desenvolvimento cultural do Instituto

Butantan, in memoriam.

Jacob Goldemberg - arquiteto, desenvolveu projetos para o Instituto Butantan por meio do FCCUASO no início da década de 1960.

Sérgio de Simone - arquiteto e pesquisador do Laboratório de História da Ciência do Instituto Butantan.

Suzana Gouveia Fernandes - historiadora, diretora do Núcleo de Documentação do Instituto Butantan. 


\section{Periódicos}

Jornal O Estado de São Paulo, São Paulo

Jornal da USP, São Paulo

Revista Acrópole, São Paulo

Revista América, São Paulo

Revista Cadernos de História da Ciência, Instituto Butantan, São Paulo.

Revista Drops, Vitruvius, São Paulo

Revista FAPESP

Revista Pós, FAUUSP, São Paulo.

Revista Projeto, São Paulo

Revista Resenhas Online, Vitruvius, São Paulo

Sites consultados (Janeiro de 2019 até Março de 2021)

Arquivo Arq: https://arquivo.arq.br

Arquitetura Brutalista: http://www.arquiteturabrutalista.com.br

Acervo Jorge Wilheim: https://www.jorgewilheim.com.br

Fiocruz: https://portal.fiocruz.br

Instituto Butantan: https://www.butantan.gov.br

Instituto Bardi: http://institutobardi.com.br

Geosampa: http://geosampa.prefeitura.sp.gov.br

MK27: http://studiomk27.com.br

Patrimônio Belga no Brasil: https://belgianclub.com.br

Vitruvius: https://vitruvius.com.br 

